Florida International University

FIU Digital Commons

FIU Electronic Theses and Dissertations

University Graduate School

$11-3-2011$

\title{
The Role of Neighborhood Organizations in the Production of Gentrifiable Urban Space: The Case of Wynwood, Miami's Puerto Rican Barrio
}

Marcos Feldman

Florida International University, mfeld001@fiu.edu

DOI: $10.25148 /$ etd.FI11120917

Follow this and additional works at: https://digitalcommons.fiu.edu/etd

\section{Recommended Citation}

Feldman, Marcos, "The Role of Neighborhood Organizations in the Production of Gentrifiable Urban Space: The Case of Wynwood, Miami's Puerto Rican Barrio" (2011). FIU Electronic Theses and Dissertations. 540.

https://digitalcommons.fiu.edu/etd/540

This work is brought to you for free and open access by the University Graduate School at FIU Digital Commons. It has been accepted for inclusion in FIU Electronic Theses and Dissertations by an authorized administrator of FIU Digital Commons. For more information, please contact dcc@fiu.edu. 


\section{FLORIDA INTERNATIONAL UNIVERSITY \\ Miami, Florida}

\section{THE ROLE OF NEIGHBORHOOD ORGANIZATIONS IN THE PRODUCTION OF GENTRIFIABLE URBAN SPACE: THE CASE OF WYNWOOD, MIAMI'S PUERTO RICAN BARRIO}

A dissertation submitted in partial fulfillment of the requirements for the degree of DOCTOR OF PHILOSOPHY

in COMPARATIVE SOCIOLOGY

by

Marcos Feldman 
To: Dean Kenneth G. Furton

College of Arts and Sciences

This dissertation, written by Marcos Feldman, and entitled The Role of Neighborhood Organizations in the Production of Gentrifiable Urban Space: The Case of Wynwood, Miami's Puerto Rican Barrio, having been approved in respect to style and intellectual content, is referred to you for judgment.

We have read this dissertation and recommend that it be approved.

$\begin{array}{r}\text { Bruce Nissen } \\ \hline \text { Patricia Price } \\ \hline \text { Richard Tardanico } \\ \hline \text { Alex Stepick, Major Professor }\end{array}$

Date of Defense: November 3, 2011

The dissertation of Marcos Feldman is approved.

Dean Kenneth G. Furton

College of Arts and Sciences

Dean Lakshmi N. Reddi

University Graduate School

Florida International University, 2011 
(C) Copyright 2011 by Marcos Feldman

All rights reserved. 


\section{ACKNOWLEDGMENTS}

Many individuals and organizations contributed in various ways to this research. Most fundamentally, this project would not have been possible without the people who participated in my field research, either as respondents, informants or by providing access to archives and records. I am deeply grateful to all of them but a few stand out. The staff of the City of Miami's Clerk's Office was helpful in facilitating my access to historical city archives. Former City of Miami Mayor Maurice Ferre was instrumental in connecting me with respondents who were active in the neighborhood decades ago. I am grateful to the many colleagues, collaborators and friends in Miami's social justice movement who shared their time, thoughts and work space.

Crucial support and access to field research settings has been provided over the years by the Research Institute on Social and Economic Policy within the Center for Labor Research and Studies at Florida International University. Thanks to everyone who has made the Labor Center a great place to work. Thanks to the faculty and staff of the Global and Sociocultural Studies Department and especially the members of my doctoral committee. Special thanks to Bruce Nissen, who recruited me to RISEP and has been a friend and fountain of knowledge since we met. Bruce has in many ways inspired me to focus my research on the injustices faced daily by people in their workplaces and communities. Alex and Carol Stepick have not only been mentors, supervisors, collaborators and careful editors throughout my time at RISEP and FIU, but they also became a second family to me in Miami, most notably by giving me a home when I've needed one. 
Although it goes without saying that I owe perhaps everything to my family in Chicago, I have to officially thank my mother for transcribing several interviews. I am extremely grateful to Melissa for the unwavering emotional support and meticulous editing of earlier versions of the manuscript.

Finally, this manuscript was made possible by the Florida International University Dissertation Year Fellowship in 2011. 


\begin{abstract}
OF THE DISSERTATION
THE ROLE OF NEIGHBORHOOD ORGANIZATIONS IN THE PRODUCTION OF

GENTRIFIABLE URBAN SPACE: THE CASE OF WYNWOOD, MIAMI'S PUERTO

RICAN BARRIO

by
\end{abstract}

Marcos Feldman

Florida International University, 2011

Miami, Florida

Professor Alex Stepick, Major Professor

Partnerships between government and community-based actors and organizations are considered the hallmark of contemporary governance arrangements for the revitalization and gentrification of economically distressed, inner city areas. This dissertation uses historical, narrative analysis and ethnographic methods to examine the formation, evolution and operation of community-based governance partnerships in the production of gentrifable urban space in the Wynwood neighborhood of Miami, FL between 1970 and 2010. This research is based on more than four years of participant observation, 60 in-depth interviews with respondents recruited through a purposive snowball sample, review of secondary and archival sources, and descriptive, statistical and GIS analysis.

This study examines how different organizations formed in the neighborhood since the 1970s have facilitated the recent gentrification of Wynwood. It reveals specifically how partnerships between neighborhood-based government agencies, nonprofit organizations and real estate developers were constructed to be exclusionary 
and lead to inequitable economic development outcomes for Wynwood residents. The key factors conditioning these inequalities include both the rationalities of action of the organizations involved and the historical contexts in which their leaders' thinking and actions were shaped. The historical contexts included the ethnic politics of organizational funding in the 1970s and the "entrepreneurial" turn of community-based economic development and Miami urban politics since the 1980s. Over time neighborhood organizations adopted highly pragmatic rationalities and repertoires of action. By the 2000s when Wynwood experienced unprecedented investment and redevelopment, the pragmatism of community-based organizations led them to become junior partners in governance arrangements and neighborhood activists were unable to directly challenge the inequitable processes and outcomes of gentrification. 


\section{TABLE OF CONTENTS}

CHAPTER

PAGE

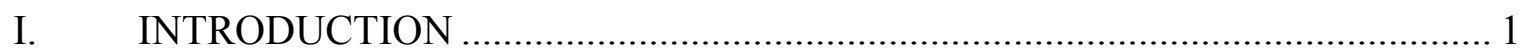

The Problem of Unopposed Gentrification ................................................................ 3

Contentious Politics, Neighborhood Organizations and Governing

Arrangements 7

Social Movement Theory ........................................................................ 8

Organizations and Governmentality ........................................................ 10

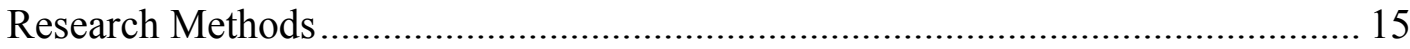

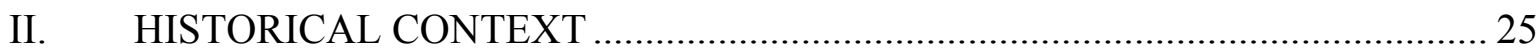

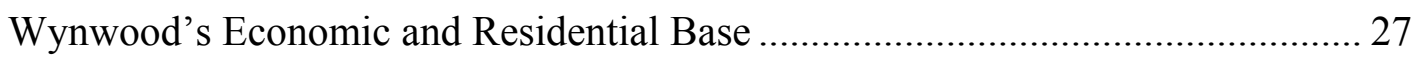

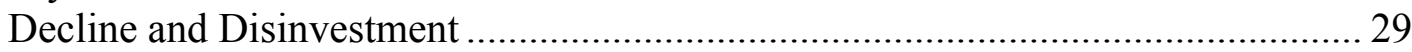

Territorial Stigmatization in Miami's Cold War Context...........................................35

The "Science" of Slum Clearance.................................................................. 41

III. THE MAKING OF PUERTO RICAN WYNWOOD …………………………......56

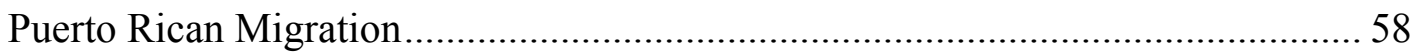

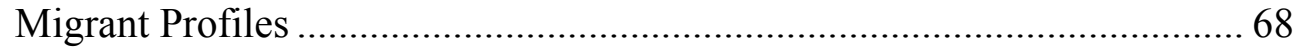

The Ethnic Politics of U.S. Community Development............................................ 70

Wynwood's Puerto Rican “Awakening” .............................................................. 76

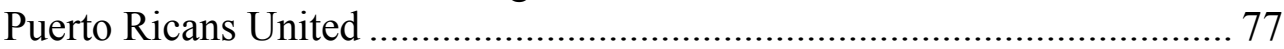

Bureaucratic Enfranchisement and Internal Fissures.................................. 90

The Broader Puerto Rican "Community”................................................................ 94

IV. THE "SPATIAL FIX" OF URBAN REDEVELOPMENT .....................100

The 1979 Garment District and 1990 Safe Neighborhood Plans............................102

The Emergence of Community Development Corporations .....................................114

Community Development Corporations in Wynwood ............................... 118

Faith-Based Activism against Disinvestment and "Blight"...................................... 134

The Creation of the City of Miami Voting Districts................................................139

V. RATIONALITIES OF COMMUNITY-BASED ACTION..................................... 143

Community-Based Planning for the "Reality" of Gentrification.............................. 146

The Broader Political Climate of "Irresistible" Development ..................................172

VI. CASE STUDIES OF “UNSTOPPABLE” GENTRIFICATION ………………..... 188

Case 1: The Midtown Miami Project................................................................. 189

Planning for the Florida East Coast Railway Corridor ................................ 194

The Governing Partnerships to Build Midtown ........................................... 199

Discourses of Neighborhood, Community and Development ....................2214

Case 2: Rise of the Wynwood Art District ...........................................................224

The "Miami Model" of Arts Entrepreneurship .........................................2236 
Art in the Arms of Real Estate Power..................................................240

Creating the Scene: Artist Lofts and Artsy Parties ................................. 244

The Teamwork of Neighborhood Redevelopment .................................228

Pressures of Exclusion and Displacement ..............................................286

Case 3: The Campaign to Take Back Roberto Clemente Park ............................296

Wynwood's Community Center: Island of Decay in Seas of Renewal .....298

Neighborhood Organizing as part of Social Movement-Building.............325

Discussion: Neighborhood, Social Movements and Gentrification...........336

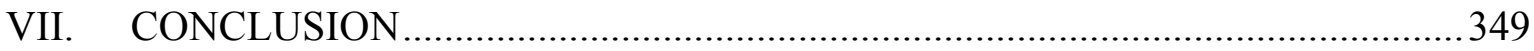

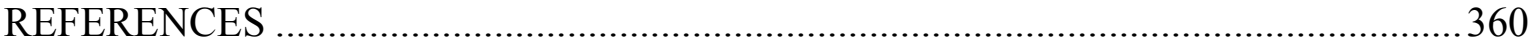

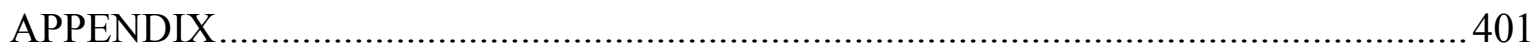

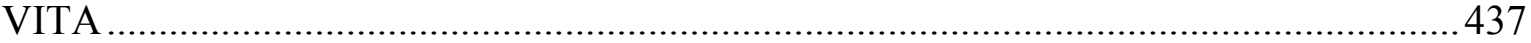




\section{LIST OF TABLES}

TABLE

PAGE

3.1: Number and Percent of Persons of Puerto Rican Origin .59

3.2: Puerto Ricans as a Share of the Total Population of Selected Census Tracts, Miami-Dade County and Central City, 1970-2000

3.3: Puerto Ricans in Selected Central City Tracts as a Share of Total Puerto

Ricans, City of Miami and Miami-Dade County, 1970-2000 64

3.4: Community Development Block Grant Funding Allocation to Wynwood and City of Miami Overall, 1975-1982

4.1: Change in Total Housing Units in Wynwood Census Tracts, 1970-2000

4.2: Change in Total Population in Wynwood Census Tracts, 1970-2000

6.1: Change in the Median Gross Rent in the Design District, South Beach and

Wynwood, 1990-2000 


\section{LIST OF FIGURES}

FIGURE

PAGE

1.1: Images of Major Construction Transforming Wynwood in 2006 3

1.2: Map of Wynwood, Major Inner City Neighborhoods, the City of Miami and Miami-Dade County 15

2.1: Wynwood Districts and Age of Built Structures 26

2.2: Map of Concentrations of Puerto Rican, Non-Hispanic Black and ForeignBorn Residents, Miami-Dade County Census Tracts, 1970

2.3: Image from a 1957 Miami Daily News cover story on the "Puerto Rican Problem" 36

2.4: Aerial View of Wynwood Catholic Parish Bisected by Interstate 95. .48

2.5: Map of the Percent of Persons with Incomes below the Federal Poverty Line, Selected Race/Ethnic Groups, Miami-Dade County, 1970 53

2.6: Map of Poverty Rate in 1970 for Selected Race/Ethnic Groups and Poverty Rate Change, 1970-1980, Miami-Dade County

3.1: Map of the Population of Puerto Rican Origin, Miami-Dade County Census Tracts, 1970

3.2: Map of the Change in Persons of Puerto Rican Origin, Miami-Dade County Census Tracts, 1970-2000 .66

3.3: Share of Community Development Block Grant Funding by City of Miami Target Areas, 1975-1982

4.1: Map of the Wynwood Garment District surrounded by Inner City Areas. 105

4.2: Map of Proposed "Street Improvements" in the Garment District Redevelopment Plan

4.3: Map of Proposed Vehicular Access Restrictions in the Wynwood Safe Neighborhood Plan

4.4: Views of Street Closures along NW 22 Street.

4.5: Map of Wynwood Community Development Target Area and Neighborhoods 126 
4.6: Image of the Failed Wynwood Free Trade Zone Site, 2010.

4.7: Boundaries of the City of Miami Commission Districts and Wynwood

5.1: Proposed San Juan Plaza and Actual Development of the Site as a Parking

Lot in 2008.

5.2: Diagram of Wynwood's Historic Buildings

5.3: Images of Historic Bungalow Homes in Wynwood

5.4: Map of the Change in the Median Price of Single Family Homes in Census Block Groups, Wynwood and Vicinity, 2000-2005

6.1: Aerial View of Midtown Miami Site, Before and After Redevelopment.

6.2: Boundaries of the FEC Corridor Study Area

6.3: Photo of a Gathering of Friends at the Neighborhood Bodega.

6.4: Image of Homes Belonging to Marta's Family .....

6.5: Image of a Typical Wynwood Warehouse Converted into an Art Gallery

6.6: Map of Galleries, Studios, Private Collections and Venues in the Wynwood Art District, 2003. 226

6.7: Image of Fortification Surrounding the Rubell Residence next to their Wynwood Warehouse. .230

6.8: Image of the Colorful Wall Fortifying an Art Gallery Located on a Residential Street in Wynwood.....

6.9: Map of Major Art District Property Owners and Selected Community Organizations and Government Agencies

6.10: Image of the Former "Terminal Fabrics" Factory Converted to Residential Lofts

6.11: Image of Cornerstone Experiential Art Scene in 2007 250

6.12: Images of "Safe Parking" Sign and Pedestrian Traffic during a Typical Wynwood Art Walk .253 
6.13: Image of the London Police Graffiti Crew Painting a Wall as part of the 2010 Primary Flight Project

6.14: Map of the Wynwood Café District Boundaries as of February, 2011 .258

6.15: Image of one of the Private Security Vehicles within the Wynwood Arts District Patrol 268

6:16: Image of a Construction Site with a "No Hiring" Sign in Wynwood 273

6.17: Image of the Argentinean-Owned Beauty Salon below a New Artist Studio 276

6.18: Image of the Boricua Café, one of the few remaining Puerto Rican Cafeterias in Wynwood

6.19: Images of Vacant Lot where Housing was demolished by Levine. 281

6.20: Image of Message on the Wall of an Art Gallery that reads, "Remember that u're not doing it for money".

6.21: Image of a New 10-story Condo Loft Building built in 2007 two blocks from Marta's House

6.22: Map of the Social Justice Center's location in Liberty City and near Wynwood

6.23: Image of the Social Justice Center's Anti-Gentrification Poster 304

6.24: Image of the Clemente Park Community Center, Condemned and Closed, with Midtown Condo Building in the Background. 306

6.25: Image of Protests Convening in Front of the Mayors Hotel during the "March on the Mayors Conference" 


\section{LIST OF ACRONYMS}

$\begin{array}{ll}\text { ADO Activists in Defense of Overtown } \\ \text { BWCC } & \text { Biscayne-Wynwood Chamber of Commerce }\end{array}$

CAA Community Action Agency

CAMACOL Cámara de Comercio Latina (Latin Chamber of Commerce)

CBO Community Based Organization

CBP Community-Based Policing

CCSA Christian Community Service Agency

CDA Community Development Act

CDBG Community Development Block Grant

CDC Community Development Corporation

CETA Comprehensive Employment Training Act

CRB Community Relations Board

CRP Community Renewal Program

FBAC Faith Based Activist Coalition

FCO Ford Fund for Community Organizing

FRS Federal Revenue Sharing

FTZ Free Trade Zone

HEW U.S. Department of Health, Education and Welfare

HUD U.S. Department of Housing and Urban Development

LUGO Latinos Unidos Grassroots Organization

ODP Organización Democrática Puertorriqueña (Puerto Rican Democrats)

OEO Office of Economic Opportunity 


$\begin{array}{ll}\text { OSJ } & \text { Old San Juan Management } \\ \text { PRCC } & \text { Puerto Rican Child Care } \\ \text { PRES } & \text { Puerto Rican Educational Services } \\ \text { PROC } & \text { Puerto Rican Opportunity Center } \\ \text { PRU } & \text { Puertorriqueños Unidos (Puerto Ricans United) } \\ \text { NAC } & \text { Nonprofit Art Complex } \\ \text { RTTC } & \text { Right to the City Alliance } \\ \text { SBOC } & \text { Small Business Opportunity Center } \\ \text { SJC } & \text { Social Justice Center } \\ \text { WADA } & \text { Wynwood Art District Association } \\ \text { WEDC } & \text { Wynwood Economic Development Corporation }\end{array}$




\section{INTRODUCTION}

I approached the exit ramp for North Miami Avenue on my way to inspect an apartment for rent during the summer of 2006 in Wynwood, known as Miami's Puerto Rican barrio since at least the 1950s. The view south from the airport expressway revealed a neighborhood in the midst of an unprecedented physical upheaval. The seemingly abandoned and decaying industrial warehouses visible from the highway were wrapped in graffiti murals, billboards advertising the neighborhoods' edgy and artistic entrepreneurs. Beyond the 20 foot high piles of debris filling the construction staging grounds that lined the base of the highway at Wynwood's northern edge, a sign hanging from the wall of one of the ubiquitous boxy warehouses asked, "Need Space in Wynwood?" I leaned forward in the driver's seat to see the top of the Midtown Miami condo and shopping complex under construction, rising 34 stories above single-story bodegas and cafeterias where residents buy groceries and socialize. The four lane avenue had been reduced to two - one in each direction - as the city upgraded the street infrastructure simultaneously with the construction of the Midtown complex which stretched seven-by-two city blocks. Traffic crawled through the dust clouds.

One of the oldest neighborhoods in the City of Miami, where half of the nearly 5,500 residents lived in households that earned no more than $\$ 13,813$ in annual income in 2000, Wynwood was in the throes of rampant gentrification at the height of one of the largest real estate bubbles in the history of Florida. In addition to the Midtown complex that was under construction, Wynwood had become home to a burgeoning Art District. On one block houses were crumbling while on the next I found a newly built art gallery fortified by steel walls and security cameras. The contradictions of gentrification were 
everywhere, the most pronounced of which was the destruction of the Roberto Clemente Park Community Center, condemned and closed for years because of termite damage during the investment boom. Although an activist campaign arose to force the reconstruction of the Community Center, I learned over the course of living in Wynwood and studying its' community politics that gentrification was and continues to advance without organized opposition.

In this research I examine not only the processes of the gentrification of Wynwood and its impacts on residents during the last five years, but also, through historical and narrative analysis, how gentrification was produced to be uncontested. With respect to the latter, I focus on the role of community-based organizations in shaping Wynwood's community politics since the 1970s, with special attention to the inter-organizational partnerships and conflicts that developed in the context of recent gentrification processes. My research is not only relevant to other neighborhoods and cities to the extent that gentrification has become a "global urban strategy" (Smith 2002), but it also fills an empirical gap in our understanding of the micro-politics of neighborhood change as new community-based governing arrangements flourish under the aegis of an ever-changing and locally contingent neoliberal urbanism (Ruben and Maskovsky 2008; Addie 2009; Peck, Theodore and Brenner 2009). While the patterns in urban governing arrangements that are uncovered here are likely to be found in other cases of gentrification in the U.S., the Miami context may also point to the future of regions of the world characterized by similar dynamics - rapid growth fueled by speculative investment and high immigration and transience (Portes and Stepick 1993; Nijman 2011). 


\section{Figure 1.1: Images of Major Construction Transforming Wynwood in 2006}

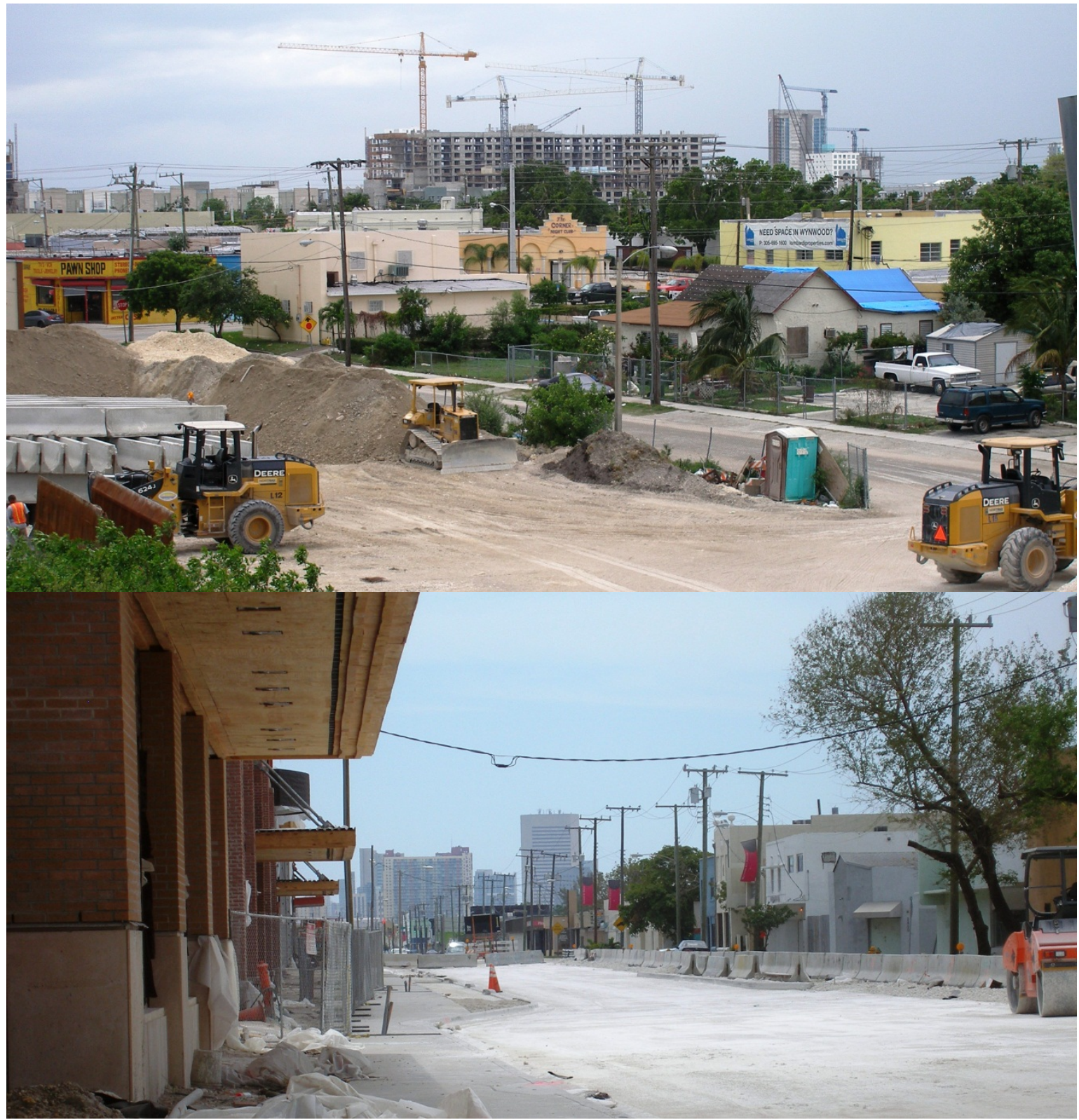

Source: Photos by author, June, 2006. Images of a construction staging ground for the Midtown complex, visible in the distance (top), and a view of the reconstruction of N. Miami Avenue between Midtown and residential Wynwood (bottom).

\section{The Problem of Unopposed Gentrification}

Despite decades of debate over the definition of gentrification (e.g., Smith and

Williams 1986; Bridge 1995; Boddy and Lampert 2002; Lees, Slater and Wyly 2008), 
many analysts have settled on Hackworth's (2002, p. 815) more expansive notion of "the production of space for progressively more affluent users." Innumerable quantitative and qualitative case studies, meta-analyses, and philosophical and theoretical treatises have demonstrated that gentrification has become a "global urban strategy" for re-capitalizing disinvested inner cities through state and corporate strategies of urban redevelopment (Lefebvre 1976; Smith 2002; Swyngedouw and Kaïka 2003; Atkinson and Bridge 2005; Lees, Slater and Wyly 2008). The voluminous studies of gentrification have made clear that gentrified space is produced through the political machinations linking the real estate and "symbolic" or cultural economies (e.g., Zukin 1989) as well as through the demographic growth and changing lifestyles of the "new" middle-classes (e.g., Bridge 2007).

The processes and outcomes of this re-urbanization are also filtered through political contests over urban space. Case studies of the politics of gentrification explain how neighborhood resistance to gentrification sometimes forces modifications or "renegotiations" in the way space is produced or otherwise describes how resistance is circumvented (e.g., Castells 1983; Robinson 1995; Smith 1996; Betancur 2002). Yet, political variation is treated theoretically as the inevitable local "noise" generated by the

\footnotetext{
${ }^{1}$ Some analysts have argued that direct displacement of one class by another is the necessary condition of gentrification and, moreover, they are careful to distinguish the particularities of the gentrifier class from other forces shaping "frontier" inner city landscapes, such as commercial investment or public works projects (Boddy and Lampert 2002; Davidson and Lees 2005). Nevertheless, more critical analysts have effectively responded that despite the diverse forms and processes through which new development occurs, such projects "are appearing both in reaction to and to stimulate further demand from a specific class of resident - the middle-class consumer. The middle classes are the gentri-part of the word, and they are moving into new-build residential developments - built on formerly working-class industrial space [for example] — which are off limits to the working classes. Furthermore... such developments have acted like beachheads from which the tentacles of gentrification have slowly stretched into the adjacent neighborhoods" (Slater 2006, p. 745). In the latter view, gentrification occurs whether or not the lower income residents were displaced decades ago and are no longer visible in the vicinity, or whether the gentry are arriving now or later (see Lees, Slater and Wyly 2008).
} 
contradictions of uneven urban development but which does little to alter the outcomes in terms of the distribution of the costs and benefits of growth.

While the general availability of capital for the secondary (real estate) circuit may govern in cyclical fashion the overall intensity of activity in the real estate sector, it cannot explain the specific form which development takes. Sociospatial patterns of development are explained by the actions of growth coalitions and networks along with the negotiations and conflicts involving those groups and other class fractions. This is frequently played out as a clash between pro growth and no growth ideologies; however, most often the property sector works unopposed-and for this reason it constitutes the leading edge of the Late Capitalist production of space.

(Gottdiener 1994, p. 227)

Given the substantial costs borne unevenly across social groups and especially by the city's poorest workers, how can we explain the absence of "negotiations and conflicts" in most cases of gentrification beyond observing that "most often the property sector works unopposed"? City dwellers are neither oblivious to the inequality inherent to urban redevelopment nor numb to the pain of losing control over their community space. Moreover, as gentrification becomes increasingly common and widespread globally, how is this global urban makeover implemented to be mostly unopposed? Are socio-spatial politics at the neighborhood and city level structured to pre-empt the possibility of oppositional movements or practices in urban space?

Research on the possibilities of resisting gentrification has focused on the structural challenges, particularly as many scholars have lamented the decline in antigentrification activism since the 1980s (Wilson and Grammenos 2000; Hackworth and Smith 2001; Lees, Slater and Wyly 2008). As Lees, Slater and Wyly (2008, p. 249) summarize, "resistance has diminished due to the twin factors of (1) continued working- 
class displacement robbing a city of activists, and (2) the authoritarian (neoliberal) governance of urban places making challenges to gentrification extremely difficult to launch." There is little empirical research on the extent and effect of the first factor, which has elsewhere been termed "political displacement" (Gibbs-Knotts and Haspel 2006; Martin 2007). Indeed, critical analysts have become alarmed at the "gentrification of gentrification research" and lack of attention paid to the issue of displacement (Slater 2006, 2008, 2010; Smith 2008; Wacquant 2008).

While the displacement of potential activists in the form of existing residents may be a crucial factor undermining potential resistance, the fact remains that in many if not most cases gentrification proceeds largely uncontested, even as it displaces existing residents (sometimes callously, as I will show later). Several studies in recent years have documented the frustration and bitterness of residents coping with the seemingly unstoppable forces and impacts of neighborhood change (e.g., Martin 2007; Cahill 2006, 2007; DeSena 2006; Boyd 2008; Sullivan and Shaw 2011), while fewer have noted residents' ambivalence toward or embrace of gentrification (e.g., Freeman 2006). The lack of resistance to gentrification has contributed to vigorous debates over whether gentrification is helpful or harmful to the poor (see e.g., Vigdor 2002; International Journal of Urban and Regional Research 2008, v.32, no.1). Whereas few areas have histories of anti-gentrification activism, such as those in San Francisco or New York (Robinson 1995; Smith 1996), all cases of gentrification experience in some form the "neoliberal governance of urban places" that makes resistance "difficult to launch" (Lees, Slater and Wyly 2008, p. 249). 
Focusing on a case where resistance to gentrification never existed or, at best, emerged late and ineffectually, this project seeks to incorporate the production of political thinking and action as part of the production of gentrifiable urban space, rather than a reactive "clash" of different growth ideologies and class fractions. My research traces a "history of the present" (Barry, Osborne and Rose 1996) in a gentrifying neighborhood to understand how over decades an "apparatus" (Foucault 1977, 1979a; see also Deleuze 1992; Rabinow and Rose 2003; Huxley 2008) of governance ideologies and techniques were used to produce gentrifiable urban space and shape its attendant sociospatial politics. Marginal urban spaces were made governable through such techniques, not merely by setting the stage for gentrification in terms of public subsidies to revitalize housing and infrastructure, but actively working to produce the socio-political conditions for "unopposed" real estate development. Accounting for but going beyond the strategic actions of growth-oriented urban regimes (Jonas and Wilson 1999), this research examines how residents' political engagement with urban growth processes is affected by government policies and practices as well as structured through a network of nongovernmental organizations and institutions.

\section{Contentious Politics, Neighborhood Organizations and Governance}

Theoretical approaches from three different subject areas are relevant to understanding the work and role of community organizations in the governing arrangements of neighborhood gentrification and offer useful concepts for examining the problem of unopposed gentrification. While social movement theory sheds light on the emergence, form and evolution of organized political action, research in organizational 
sociology and Foucauldian approaches to power emphasize the role of organizations as mediators of the relationship between residents and broader structural forces in society. I describe the key concepts from the respective fields of research and then discuss how I seek to apply their inter-related insights to the case of Wynwood's community politics.

\section{Social Movement Theory}

Three sets of social movement (SM) concepts are useful for explaining how and why collective action against prevailing patterns of urban development and specifically gentrification have not developed in Wynwood: those relating to political opportunities, mobilizing structures and framing processes (McAdam, McCarthy and Zald 1996, pp. 320). (1) Political opportunities refer to "changes in the institutional structure or informal

power relations of a given... political system" (p. 3). Although the concept is typically applied to national political systems in line with the focus of much SM research on broad-based social movements, political opportunity structures (POS) can be found at all levels of social organization, including cities and neighborhoods. The relative openness of a political system to change is thought to be shaped not only by the nature of access to formal political channels (e.g., single majority vs. proportional electoral systems), but also by the stability of the "broad set of elite alignments that typically undergird a polity," the "presence of elite allies" and propensity for government repression (p. 10).

(2) Mobilizing structures are "those collective vehicles, informal as well as formal, through which people mobilize and engage in collective action" (p. 3). Mobilizing structures may be informal groupings such as friendship networks within a 
neighborhood (and the informal public or private spaces that contain them, such as neighborhood parks or cafeterias) or more formal arrangements such as homeowner associations, churches or professional activist organizations. These structures are crucial as a basis for the organization and mobilization of resources to carry out collective action for a given cause. In the case of professional organizations, external resources may also change the form and behavior of the mobilizing structures.

(3) Framing processes have to do with the "shared meanings and definitions that people bring to their situation" and how these frames mediate "between [political] opportunity, organization and action" (p. 5). Snow and Benford $(1988,1992)$ delineate three functions of collective action frames (see Martin's [2003] use of their typology). They are motivational in defining the community that acts collectively; diagnostic in specifying the problem and its cause; and frames provide a prognosis in clarifying the means to solve the problem through collective action. Framing is a particularly salient concept for analyzing collective action in response to gentrification, as gentrification involves a complex, politically diffuse set of processes which conspire to mystify residents' perception of the problem and possibly solutions (Henig 1982; Cordova 1991; Martin 2007). Since gentrification is felt by residents as a place-bound problem, it is useful to consider whether and how residents espouse a place-based, collective identity (e.g., Martin 2003; Martin 2007) in addition to whether and how they individually and/or collectively interpret gentrification, and what course of action, if any, is prescribed.

The three social movement concepts of political opportunities, mobilizing structures and framing processes are interactive and interdependent in locally contingent ways. As McAdam, McCarthy and Zald (1996, p. 8) put it, "no matter how momentous a 
change appears in retrospect, it only becomes an 'opportunity' when defined as such by a group of actors sufficiently well organized to act on this shared definition of the situation.” Moreover, political opportunities, mobilizing structures and framing processes within the same set of social movement actors may differ across diverse scales of political action, including national, state and local.

While SM concepts help to reveal the dynamics that shape organizational and collective action in relation to gentrification, they are not as useful in explaining the lack of organizational action. SM theories may reveal that collective action in response to gentrification did not emerge because of inadequate mobilizing structures or framing processes, or because of a political context not conducive to challenging urban development processes. These forces are theorized in binary terms (present/absent) without sufficient attention to how they operate on as well as through organizations to shape the thinking and action of organizational leaders and members who live in the neighborhood. The object of SM theories are "collectives" and, as such, are not equipped with finer grained tools for examining how the subjectivities and practices of the individuals within those collectives both affect and are affected by the political opportunities, mobilizing structures and framing processes. Such finer grained tools are especially important for studying the absence of collective action over time as opposed to the usual subject of SM researchers - the emergence and evolution of social movements. For the former concepts I turn to recent work in organizational sociology as well as the Foucauldian approach to the development of political subjectivities and the adoption and implementation of a particular mentalities of governing. 


\section{Organizations and Governmentality}

McQuarrie and Marwell (2009, p. 256) argue that formal organizations are too often "treated as derivative rather than productive of urban social life," calling for more attention to the ways that organizations "mediate the relationship between system-level institutions - such as the state and the economy - and urban communities and neighborhoods." The perspective draws from structuration theory (Giddens 1991), focusing on the flexible, relational functioning of organizations, both among each other (in the network) and as "meso level” mediators (McQuarrie and Marwell 2009). Also relevant to understanding the role of neighborhood organizations in the governing arrangements of gentrification are the insights of the notion of "governmentality" (Foucault 1979a; Foucault et al. 1991), which "refers to the rationalities and mentalities of governance as well as the range of tactics and strategies that produce social order" through "a set of apparatuses operating across distances of time and space" (Fairbanks 2007, p. 112). For Foucault (1977, p. 10), the apparatus is a "heterogeneous grouping composing discourses, institutions, architectural arrangements, policy decisions, laws, administrative measures, scientific statements, philosophic, moral and philanthropic propositions." "As a relational entity that links these various components, a governing apparatus effects a "disciplinary normalization" on urban space not merely by codifying norms as laws, but also through spatial practices (see also e.g., Lefebvre 1976; Merry 2001) and the "mediating" functions that are the focus of McQuarrie and Marwell's (2009) organizational sociology. Inherent to both of these approaches is the perspective

\footnotetext{
${ }^{2}$ McQuarrie's (2010, p. 239) definition of "governance arrangement" is similar, albeit perhaps not as expansive: "By governance 'arrangement' I mean a lash-up of organizations, practices, institutional logics, technologies, metrics and objects that collectively produce a given outcome."
} 
that power is productive. ${ }^{3}$ But the Foucauldian concepts go beyond structural

configurations to consider the rationalities that permeate entire networks and governing arrangements and also, crucially, approach the subject of governance as a historical process (Rabinow and Rose 2003; Crampton and Elden 2007).

I highlight these concepts to draw attention to some of the key elements of community-based governance involved in producing gentrification: the relationship between ideas, techniques and organizations, the evolution of these formations through different political contexts, and normalizing effects on urban space. The governing arrangements that have shaped gentrification in Wynwood link key ideas to spatial practices: the notion of crime prevention through environmental design is mobilized through the architecture of redevelopment planning and projects (see Garland 2001; Herbert and Brown 2006); the concept of the frontier, rooted in Wynwood's history of “territorial stigmatization" (Wacquant 2007), disinvestment and deprivation, underpinned a period of punitive spatial discipline which was key to the growth of the Art District in the early 2000s. Moreover, the variegated governing arrangements that have facilitated the growth of the Art District and the creation of the Midtown complex were made possible by the ideology of "community" self-governance that for decades has supported the decentralization of policymaking and service provision through nonprofit organizations. In this way, "governance takes place through rather than despite civil

\footnotetext{
${ }^{3}$ In Discipline and Punish (1977, p. 194), Foucault explains: "The individual is no doubt the fictitious atom of an 'ideological' representation of society; but he is also a reality fabricated by this specific technology of power that I have called 'discipline.' We must cease once and for all to describe the effects of power in negative terms: it 'excludes', it 'represses', it 'censors', it 'abstracts', it 'masks', it 'conceals'. In fact, power produces: it produces reality; it produces domains of objects and rituals of truth. The individual and the knowledge that may be gained of him belong to this production". Although my focus is not specifically on the formation of individual subjectivities, this productive notion of power is useful to keep in mind when considering the role of organizations as relational intermediaries between residents and broader urban political processes.
} 
liberties" (Fairbanks 2007, p. 112) as freedom is redefined under the imperatives of the entrepreneurial city. As I will show in the case of Wynwood, the embrace of decentralized governance produces highly malleable, unaccountable political spaces that reproduce and sometimes exacerbate inequalities in the name of community participation.

While a static snapshot of the governing arrangements reveals the inequalities inherent to gentrification processes in Wynwood, it does not adequately explain the lack of organized opposition and the propensity of community-based organizations to become supporters and facilitators of the neighborhood's redevelopment and gentrification. This role is grounded in the historical constitution of community politics through the experiences, successes and failures, partnerships and conflicts that have shaped those organizations. Many of Wynwood's Puerto Rican organizations were created through the "ethnic politics" of "collective consumption" characteristic of the 1970s in Miami and elsewhere (Castells 1983; Fainstein 1987). In the 1980s and 90s, the rationalities and practices of these organizations and their leaders evolved with the turn toward "entrepreneurial" community development, declining government support and intensified inner city disinvestment (Eisinger 1988; Harvey 1989; Swanstrom 1999). The bureaucratic enfranchisement of Puerto Rican activists turned their political energies inward, led to conflicts and divisions, and gradually eroded the capacity of these organizations to produce a politics of neighborhood defense. Faith-based activism emerged to defend Wynwood against disinvestment and environmental degradation; however, through the church's pragmatic political orientation and territorial rationality of service, redevelopment was construed as a "reality" that could not be changed. By the turn of the $21^{\text {st }}$ Century, Puerto Rican organizations had been stripped entirely of their 
activist politics and limited to the provision of social services. Thus Wynwood's community-based organizational representatives were amenable to the partnerships of urban redevelopment espoused by the "gentlefication" discourse of developers, arts entrepreneurs and city officials.

Although the governance arrangements of gentrification and the historical formation of Puerto Rican community politics are the principal themes I address in this research, I also examine examples of strategic choices by social justice activists to not campaign against gentrification. The evolution of social movement-building into flexible network formations is considered crucial in order to overcome the fragmentation and “post-political” ethos of decentralized, community governance (DeFilippis, Fisher and Shragge 2010; Benner and Pastor 2011; Macleod 2011). However, as with the governing arrangements of gentrification, the various episodes of activism that I examine reveal tensions in the networked, relational and scalar formations through which social justice is pursued. These tensions are especially pronounced in the case of gentrification, the complexities of which seem to require the creation of broad regional, state and national alliances and strategies, as well as intensive, neighborhood-based political organizing, particularly in the context of the hyper-entrepreneurial governance arrangements in Miami that I discuss below. 


\section{Figure 1.2: Map of Wynwood, Major Inner City Neighborhoods, the City of Miami and Miami-Dade County}

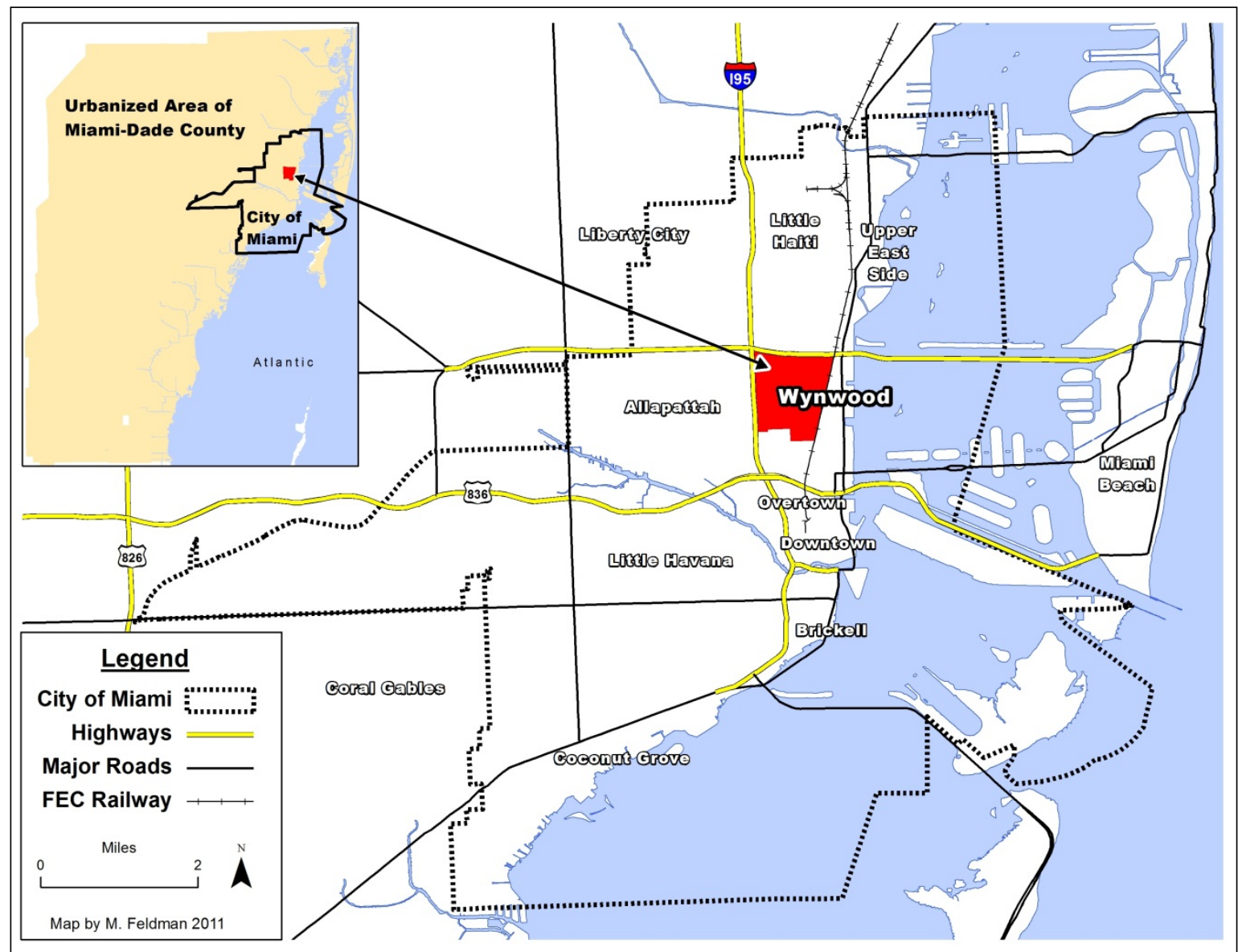

\section{Research Methods}

In this research I use a mix of qualitative research methods and approach my subject as a "history of the present," in the Foucauldian sense of drawing analytically on history to explain a contemporary phenomenon. The notion of a "history of the present" emphasizes the difference between "a past" that is "merely that which precedes the present" as opposed to historical layers that are productive, interacting with and shaping the present and future (Keith 2009, p. 77). Historical study of urban politics typically uses 
narrative analysis, with its focus on "the organization of contemporaneous actions and happenings in a chronological, sequential order 'that gives meaning to and explains each of its elements and is, at the same time, constituted by them"' (Griffin 1993, p. 1097; quoted in Gotham and Staples 1996, p. 483). In these ways, narrative analysis seeks to be "temporal" and "conjunctural," establishing the relations between events and social forces over time, but also "holistic," accounting for the various inter-related contexts shaping events - economic, political, cultural (see Schutt 1999, p. 334-5).

Between 2006 and 2008, when I lived in Wynwood, and thereafter as I returned to do field research through 2011, I conducted participant observation in a variety of settings. Most of the time, two basic guiding themes directed me to appropriate sites and events in Wynwood, and led to informants and interview respondents: (1) processes of gentrification and (2) political meetings and events (that is, formal "Politics," in the sense of relations with or through government). These two themes frequently overlapped but not always. Moreover, this intentionality of field research was more pronounced after I moved out of the neighborhood and particularly during 2010 and 2011, when I followed up with individuals I had previously met in order to interview them. At that point, I had a deeper understanding of the neighborhood's history, having read newspaper archives, government documents and other sources. I deliberately returned to interviewees who were in some way involved in the politics of the neighborhood, either the processes of gentrification or the previous eras of political action starting with the 1970s.

I should note that it was challenging to talk to residents about the politics of gentrification because there had not been much formal, organized political activity in relation to gentrification (such as community meetings). Few residents were highly 
informed about political changes taking place to facilitate gentrification, beyond seeing the new buildings, consumers, traffic and other manifestations of the redevelopment. Still, people talked about changes in their neighborhood. I observed this perhaps most intensely at the place where I lived for two years, an 8-unit apartment building on $32^{\text {nd }}$ Street wedged between the Nonprofit Arts Complex (see Chapters 6 and 7) and a low-rise pubic housing project that face a middle school named after a Puerto Rican independence philosopher. Indeed, I was the landlord's first "professional" tenant, as he proclaimed, and as it turned out, the most stable one. My neighbors came and went. The three who I was friendliest with were all evicted at some point, including one of who I later interviewed about his experiences in the building. In fact, more residents were evicted than moved on their own accord during my time there, though this did not seem to be the result of an overly punitive landlord, as several neighbors were allowed to fall three or four months behind on rent before being evicted. In these and a myriad of other ways, I learned about how people experienced gentrification and the different pressures associated with the intensity of urban development taking place in Miami in 2006 and 2007. By 2008, before I left, I also observed the onset of the recession and rising unemployment in the neighborhood, evident not only in evictions but before then, as neighbors asked to borrow my electricity or fill up jugs of water to bathe their kids.

Beyond the life in my building, I spent time eating, drinking, shopping, doing laundry, playing soccer and doing other activities in and around the neighborhood. Partly because of problems with my car, I made it a point to use my bicycle both around the neighborhood and also from Wynwood to the university where I worked, located almost on the extreme opposite end of the county. For one period of about six months, I walked, 
biked and rode the bus to get everything I needed and to get around the city. Most of these personal experiences, including living on $32^{\text {nd }}$ Street and living without a car, are beyond the scope of the cases of gentrification and governance I examine in this dissertation. But I mention them because I believe they shaped my sense of space and time, and made me more sensitive to the way people in Wynwood, especially low-income people who depend on public transit, experience the city and how their movements may be shaped by the transformation of the built environment. This sense of how residents navigate urban space turned out to be quite relevant to my analysis of the physical interventions of redevelopment planning in Chapter 4.

While I lived in Wynwood I also witnessed the creation of an activist campaign to urge the city to reconstruct a community center that had fallen into disrepair. The campaign is one of the cases in Chapter 6 . The campaign was led by an activist organization with which I have had a close relationship for several years, particularly those years. Throughout this research was facilitated by my role as a Research Associate at the Research Institute on Social and Economic Policy (RISEP), before which I was a research intern at the aforementioned activist organization a few years before living in Wynwood. During Wynwood's community center campaign, I assisted as a translator at some neighborhood meetings. Since 2004, I have worked with this organization in several other ways. While my relationship means that most of the activist or politically active residents I spoke with are or were associated with this organization, it also happens that this organization has recruited its members from the ranks of the most politically active residents in Wynwood. There simply are no other activist organizations in 
Wynwood; and, as I will explain in Chapter 6, this organization is not really from Wynwood.

Also, while I lived there and to a lesser extent thereafter, I participated in the processes of gentrification as a consumer (of gentrified urban space). I got to know some local artists and participated in the social spaces they produced, including art festivals. I ate and drank in some of the new, more expensive restaurants that started cropping up. Much of this experience speaks for itself as part of the case study of the creation of the Art District, also in Chapter 6.

By 2011, I had completed more than 60 in-depth interviews with individuals who are linked in different ways to the governance arrangements that have shaped Wynwood's gentrification: current and former residents; organizational staff and directors; police officers; current and former city officials and neighborhood-level administrators; other professionals involved in the neighborhood's redevelopment planning; artists and people involved in the arts businesses; neighborhood merchants and property owners; real estate developers; and the most influential of the Puerto Rican community leaders and activists who were involved in Wynwood at different times since the 1970s. The identities of all research respondents and their organizations, except for those speaking in their capacity as public officials, are kept confidential and given pseudonyms in this dissertation. I recruited interview respondents through a purposive snowball sample that I began to construct in the spring of 2010. My own experience as a resident of the neighborhood helped me to recruit informants, including the managers of the most popular small businesses. Beyond that, my earliest key informants were the directors and staff members of nonprofit service organizations, community organizers 
with whom I already had working relationships, the former City of Miami Mayor Maurice Ferre, and my own relatives who live in Wynwood. This last point merits some elaboration, but I am limited by the promise of confidentiality to this person as with the vast majority of the human subjects in this research. My family ties in Wynwood introduce bias in this research not because of how my relationship to the respondent shaped her statements and testimony to be different from what would have been provided to an unrelated researcher. Rather, I believe that another researcher simply may not have made contact with this person who is not involved in any public aspects of community politics. In this way, while the trust facilitated through family ties was important to obtaining access to this person's deeply felt concerns, more important was the ability to make this connection in the first place. I ultimately met other residents with similar feelings and views.

In addition to the qualitative methods describe above, this study employs descriptive, statistical and Geographic Information System (GIS) analysis, and draws on a variety of secondary, archival sources. For statistical and GIS analysis I relied on: the U.S. Census Bureau; the Neighborhood Change Database produced by Geolytics, Inc., accessible at the Florida International University (FIU) library; a GIS shape file containing property sales and land use records purchased in 2005 from the Miami-Dade County Property Appraiser; and other GIS shape files available on the server of the FIU GIS laboratory and from the U.S. Census Bureau Web site. I used this information to examine basic descriptive statistics of changes in population, housing units, property prices, and other shifts that contextualize the transformations that have taken place in Wynwood. 
The archives I draw on include articles from major national and various local newspapers and magazines, transcripts of City of Miami Commission meetings and other public records (clerk's reports, memorandums, discussion items, as well as some MiamiDade County records, where relevant), in addition to scholarly and online sources. In citations I refer to City of Miami Commission transcripts as MCC and Miami-Dade County Commission documents as MDCC. The Global NewsBank digital database contains full text articles from major national and most local Miami newspapers dating back to 1982. I researched articles older than 1982 from major local sources, primarily The Miami Herald and The Miami Daily News, using the FIU microfilm system. The City of Miami's legislative records are available online since 2003; beyond that, I spend several hours a week over a two-month period at the City Clerk's office, where I was provided access to digital, searchable archives of commission minutes dating back to the city's inception in 1896, available only on their office computers. Other important records, such as City of Miami plans and research reports, were accessed at the FIU reference library or obtained through the personal archives of some of my respondents who participated in the preparation of these documents. Although I took photographs of all of the settings that I describe below, I sometimes use and cite Google Street View images instead of my own because they capture a view that I missed and has since changed.

I reviewed hundreds of pages of transcripts of the City of Miami commission meetings to help construct the narrative history of the politics of community-based organization funding, which formed most of the basis of the relationship between Wynwood's Puerto Rican activists and City Hall since the 1970s. Reading this history 
helped me focus on key moments that are exemplary of the different phases in the evolution of Wynwood's relationship with City Hall, as well as the relationships among the various neighborhood organizations and leaders. I also sought to balance the accounts in the commission transcripts against the testimony of the former organizational leaders and city officials with whom I spoke, as well the newspaper articles. Finally, from my review of these records and documents from other sources noted above, I focused on a few major redevelopment planning efforts that affected the built environment in Wynwood and which were in themselves important episodes in the relation between neighborhood organizations and City Hall. I describe some of these cases in turn, as part of my description of the organization of the dissertation.

Chapter 2 traces some features of the history of Wynwood, including its inception as one of Miami's first middle-class suburbs and industrial districts, subsequent suburbanization and deindustrialization, early efforts at urban renewal and slum clearance, and related "territorial stigmatization" (Wacquant 2007) which set the stage for targeting Wynwood for redevelopment over the course of several decades. Chapter 3 examines the history of the creation of "Puerto Rican Wynwood," first by tracing the popular narrative of migration to Southeast Florida and to Wynwood and the hardships experienced by Puerto Ricans and then through the narratives about the emergence and evolution of the ethnic politics of community development funding in which many of the still-existing neighborhood nonprofit organizations were founded. In particular, I draw from interviews, city commission transcripts and newspaper articles to examine narratives of community empowerment, achievement, conflict and bureaucratic enfranchisement. 
Chapter 4 examines examples of the shift in Wynwood's community politics in the context of entrepreneurial policymaking that sought to effect a "spatial fix" in the built environment's profitability: (1) major redevelopment planning efforts, such as the 1979 Garment District Redevelopment Plan and the 1990 Wynwood Safe Neighborhoods Plan; (2) the emergence of community development corporations (CDCs), and their role in a failed attempt to create a Free Trade Zone in the "redeveloped" section of the Garment District in the 1990s; (3) the emergence of faith-based activism and its participation with and immersion in the entrepreneurial ethos of community development.

Chapter 5 takes stock of the institutional history and layers of Wynwood's community politics. I examine the rationalities of the different organizational actors with respect to urban development politics at this crucial turning point to the $21^{\text {st }}$ Century, in the context of a growing real estate bubble in Miami. The analysis, which is grounded in a case study of the first "community-based" Master Plan created in 1996 to envision the future of the neighborhood, focuses on the discourse and practices of various community and organizational leaders involved. This section also reviews the thinking and actions of some leaders in relation to the politics of the broader development boom in Miami during this period. Specifically, I examine a campaign to reform a proposed, county-wide inclusionary zoning policy in Miami in order to achieve a more equitable distribution of affordable housing.

Chapter 6 focuses on three cases revealing different, inter-related sets of governing arrangements that shaped urban development politics in Wynwood between 2000 and 2010: (1) The creation of the Midtown Miami residential and commercial 
complex; (2) the creation and growth of the Art District and; (3) the campaign to rebuild the community center at Roberto Clemente Park, which was also viewed by activists as a way to reclaim community territory from the forces that encroached on it. In each of these cases I trace the political narrative, and examine the formation and functioning of the governing arrangements, the rationalities of action inherent to different actors involved, and residents' engagement in the formal and informal politics of the production of space. I close this chapter with discussion of the relational qualities of social movement-building in South Florida and the implications for social justice in the gentrifying city.

Although my dissertation describes the thinking of action of various individuals and organizational actors, my intention is not to critique any single person or organization. Instead, I aim to understand gentrification and specifically why and how gentrification has advanced so easily in Wynwood. Rather than focusing on any individual or organization, in this dissertation I examine the rather diffused, yet effective forces that have facilitated gentrification. Moreover, the relevance of the cases analyzed in any one chapter to the recent gentrification of Wynwood cannot be understood in isolation from the larger history of Wynwood's community politics presented in the rest of the chapters. 


\section{HISTORICAL CONTEXT}

Little has been documented on the history of Wynwood. Most oldtime residents say the name was probably chosen by real estate investors Josiah Chaille and Hugh Anderson. They took out the first plat in Wynwood on January 7, 1917, and chose the name Wyndwood Park for their subdivision. Josiah Chaille was a native of Tennessee who moved to Miami from Ocala, Florida, in 1896. He owned a five-and-dime store on the corner of Flagler Street and Miami Avenue until shortly before 1920, when he went into real estate.

- Elliot Rodriguez, The Miami News (1979)

The area known as Wynwood became part of the City of Miami in 1913 through

an annexation vote that expanded the city's boundaries north and south along the bay

(City of Miami 1955). Located immediately west of Florida East Coast (FEC) rail yard stretching from $29^{\text {th }}$ to $36^{\text {th }}$ streets along N. Miami Avenue, the subdivisions historically platted as "Wyndwood Park" and "St. James Park" comprise the residential core of present day Wynwood (MCC 3/15/1917). ${ }^{4}$ By the 1920s, when the Florida (and especially South Florida) land boom led to the creation of several cities including Miami Beach and Miami Shores, among others, the Wynwood area had developed homes and

\footnotetext{
${ }^{4}$ In the historic meeting minutes of the City of Miami Commission Wyndwood and Wynwood alternated in use in reference to the neighborhood, although sources suggest that the neighborhood has always been known as Wynwood (see Rodriguez 1979), including several interview respondents who lived or worked in the area before 1960. In the 1974 meeting where Wyndwood Park was renamed Roberto Clemente Park, residents, elected officials and government staff refer to Wynwood as the neighborhood. Wyndwood continued to appear in legal references (e.g., Wyndwood Sewer and Highway Improvement Districts) until 1991, when the Cuban-American City Mayor paused the meeting to clarify: "It's Wyndwood Highway improvement. Is that the same as Wynwood? [Y] ou might want to take the 'd' off. It might confuse everything" (MCC 1/10/1991) This was the last time Wyndwood appeared in legal references to the area. Several respondents including current and former residents believed that the long-standing Latinization of the neighborhood, particularly after 1960, led to the acceptance of the more Latinized pronunciation, Weenwood, and Wyndwood lost the "d".
} 
apartment buildings mostly for middle-class or wealthy families. ${ }^{5}$ The architectural styles that developed in Wynwood as in other historic city neighborhoods (e.g., Riverside) during the 1920s and 1930s ranged from functional "two-flat" apartment buildings to single-family homes built in the craftsman bungalow and mission styles (WMP 1996). It was one of Miami's earliest suburbs.

Figure 2.1: Wynwood Districts and Age of Built Structures

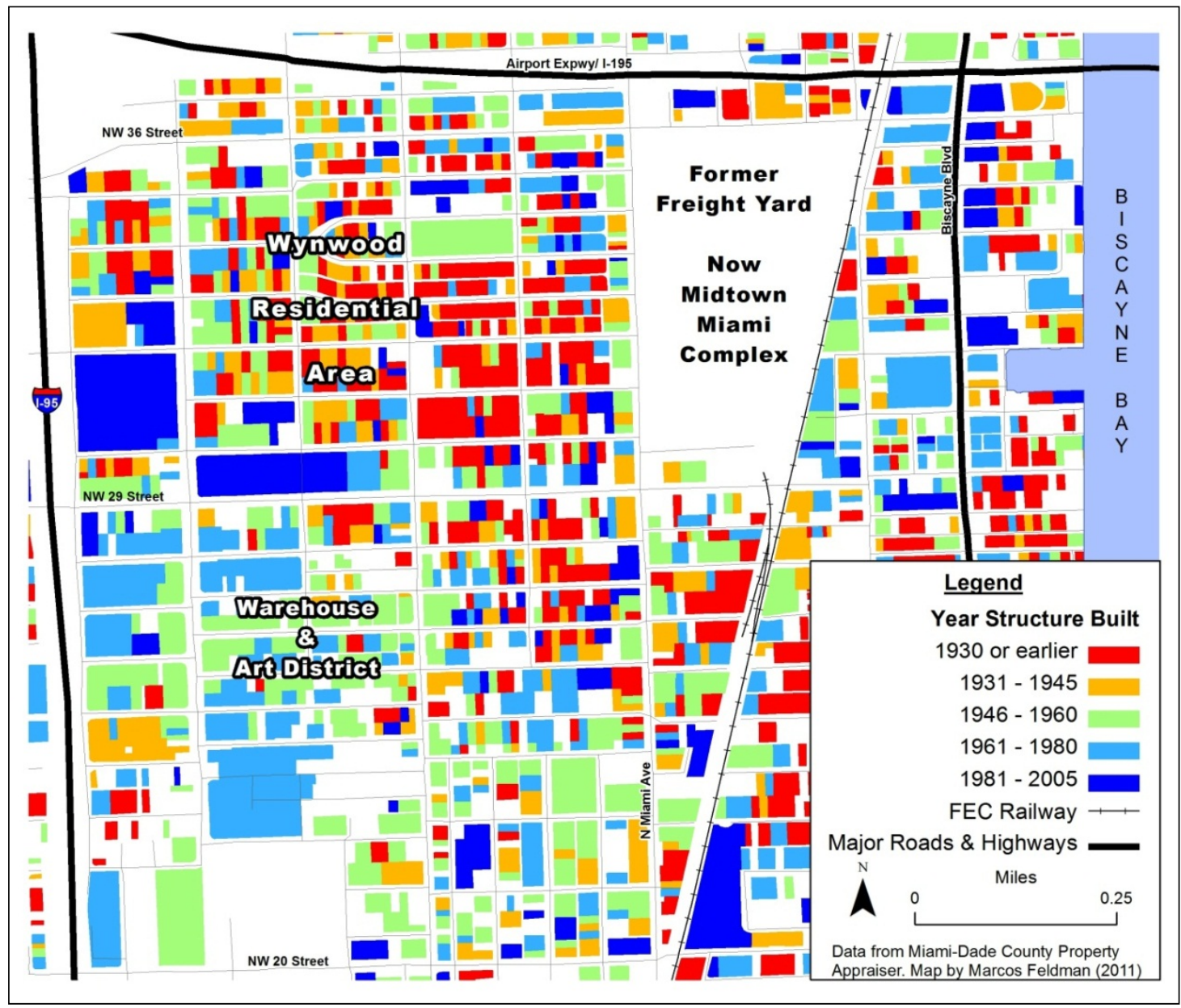

5 This is at least how "Wynwood Park" was represented in real estate ads and in the "society" section of The Miami News during the 1920s. Marriage announcements revealed the occupations of newlyweds who built bungalow homes in Wynwood, such as a man who owned a small realty company and another who worked as an architect (issues from 5/11/1921, 7/10/1923). The quality of the housing relative to other neighborhoods is evident from the real estate ads in The Miami News during this period (e.g., issues from 10/25/1921, 4/1/1921, 9/1/1927). 
Wynwood's Economic and Residential Base

Wynwood's economic base was comprised historically of the emerging manufacturing sector mostly south of $29^{\text {th }}$ Street and the residential area to the north inhabited by a variety of professionals, technicians and skilled craftsmen, policemen and school teachers, owners of small business supported by the nearby Florida East Coast rail workers as well as area residents, and others. South of $29^{\text {th }}$ Street and particularly $25^{\text {th }}$ Street, south of the emerging Garment District, were low-cost apartments that housed African-Americans being pushed out of the downtown area and later, particularly after 1940, a growing number of Puerto Rican migrants.

Rodriguez (1982) wrote that "the 1920s boom years saw the first signs of what was to become the Garment District," noting that in 1926 Coca-Cola built a giant bottling plant along $29^{\text {th }}$ Street and soon after a large orange juice plant was built on NW 27 th Street and 2nd Avenue. In the post-WWII period the southern section of Wynwood developed into a cluster of light industrial warehouses, mostly for garment and shoe manufacturing. ${ }^{6}$ As the industry expanded during the 1930s and 1940s, the largest

\footnotetext{
${ }^{6}$ The garment as well as shoe manufacturing industry in Miami had its origins in the early decades of the $20^{\text {th }}$ century. The emergence of Southeast Florida's winter vacation locales such as Palm Beach in the 1900-1920 period and particularly Miami Beach during the 1910s and 20s made South Florida a key consumer market for spotting the latest "summer" fashion trends as styles were experimented during the South Florida winters and then released during the northern summers (see Clemente 2007). South Florida's development in this regard led Jewish and other garment manufacturers to build sewing factories or, after retiring, lend their expertise to emerging garment manufacturers in Miami. Jews were disproportionately represented as owners and managers in the apparel industries of New York City (garment manufacturing and retailing) during the first half of the $20^{\text {th }}$ century but still found their opportunities limited because of anti-semitism and stiff competition in the nation's largest garment manufacturing center. South Florida represented not only a new and expanding frontier in which to become established, but after the real estate bust that underpinned the Great Depression in the late 1920s, restrictive covenants in Miami's real estate market were lifted to allow the economy to recover more easily and Jews gained access to and became major players in South Florida's real estate markets and industries. The Jewish population in Miami Dade County grew from 7,000 in 1940 to 47,000 in 1950 to 119,000 in 1960 (Clemente 2007, p. 48).
} 
manufacturers (who came to dominate the Miami Manufacturers Guild formed in the 1940s) consolidated the smaller firms and new, larger factories were built on relatively affordable land near the rail lines and storage depots, primarily in Wynwood during the 1940s but eventually to other neighborhoods located near the FEC railway and its eastwest extensions (e.g., the Little River Industrial District and in Hialeah) (Clemente 2007; Shell-Weiss 2009). ${ }^{7}$ Sewing and later cutting and design factories were established throughout the southern part of the neighborhood between $20^{\text {th }}$ and $29^{\text {th }}$ streets and between North Miami and NW $5^{\text {th }}$ avenues (see Figure 2.1 for orientation). The southern section became known as the Garment District, and later also the Fashion District when retail operations were added particularly in the northwestern section (City of Miami 1979). Most of the structures in the western half of the Garment District, where a majority of the warehouses and a few former manufacturers are still located (albeit operating different types of businesses), were built in the 1940s and 1950s, considered the height of Miami's status in the national garment industry (City of Miami 1979; Clemente 2007). By 1951, there were more than 251 garment factories in the City of

\footnotetext{
${ }^{7}$ According to Clemente (2007), the rapid growth of the apparel industry in South Florida in the post World War II decades is due especially to five factors: (1) Clothing manufacturing was well suited to Miami because "with no need for smokestacks or waste dumps, manufacturing facilities could be easily hidden from leisure-seeking tourists" (Clemente 2007, p. 45). (2) The mass immigration of Jews and later Latinas to South Florida contributed to the abundance of a particular skill sets needed in the garment industry. (3) Miami's role as a fashion trendsetter led to its growth as a manufacturing center. It was more cost efficient to manufacture the clothing in the same place they were being sold (at least initially, before Miami's industry went "global") but it was also convenient that manufacturers and retailers knew each other from regional trade associations and came to trust one another, instead of buying clothes made in New York or California or elsewhere. (4) As a new site for manufacturing, Miami was not bound by the same traditions as northern or even other southern manufacturers whose designers, for example, took off the month of August and did not resume to resortwear lines until mid-September, putting them at a competitive disadvantage relative to Miami factories. Moreover, as the globalization of consumption expanded after World War II, Miami found itself better positioned to sell clothing to Latin American tourists and consumers, many of whose summer seasons were the opposite of the United States (Ibid). (5) The success of the leisure and sportswear industry in Miami also hinged on the use of technology and the growing popularity of synthetic fabrics, such as rayon, embraced and championed by Miami manufacturers.
} 
Miami employing more than 5,000 workers (Shell-Weiss 2009), and the largest

concentration were operating in Wynwood's Garment District (City of Miami 1979).

These patterns were affirmed by the testimony of a former manufacturer, Harold, whose experiences were typical of the Jewish families that moved from New York to Miami to set up garment factories. In 1946 when Harold's ${ }^{8}$ father opened his business manufacturing children's clothes in Wynwood - two years after he moved his family from New York for health reasons - it was one of the first and largest of a growing number of garment factories in the area. ${ }^{9}$ By 1954 when his father built a 20,000 square foot warehouse in the heart of the Garment District and he employed upwards of 200 workers, Harold estimates there were about 100 garment factories of various sizes in the area.

\section{Decline and Disinvestment}

Miami's garment industry expanded in the 1960s despite the growth of international competition facilitated by the accelerating globalization across many sectors of the national economy (Feagin and Smith 1987; Grosfoguel 2003; Clemente 2007). The arrival of cheap, mostly female labor resulting from the massive influx of Cuban exiles

\footnotetext{
${ }^{8}$ I interviewed Harold in his Wynwood office, November, 2010, with his colleague in real estate, Michael, a self-described "Jewban" (Cuban Jew) and also former garment manufacturer in the 1960s. Harold worked for and eventually took over the family garment business after 1973 when his father died. In 1987 he sold his business and went into real estate and still operates out of his Wynwood office. Michael, along with two other realtors who were licensed through Harold's realty company, closed and sold their garment businesses in the 1980s.

${ }^{9}$ This is supported by the assertion in the City of Miami's 1979 Garment Center Redevelopment Plan (p. 5) that "by 1940 the majority of the apparel manufacturers in Dade County were located within the area which was becoming known as the Garment Center." Clemente (2007, p. 140) writes that by 1940 the Manufacturers Guild in Miami, to which Harold's family business eventually belonged, "included 20 large producers" and an unknown number of smaller, "home-work" producers.
} 
allowed Miami's apparel manufacturing to persist in spite of the pressures of cheap, foreign imports (City of Miami 1979). ${ }^{10}$ Shell-Weiss (2009, p. 179-181) describes how in a period of two years (1959-1961) many garment factories in Wynwood closed shop to avoid and divide unionization efforts that were intensifying since the mid-1950s, only to re-open in Hialeah where they could hire entirely Cuban workforces, reflecting and perhaps creating a major difference in the employment prospects and socio-economic mobility of Cubans compared to the mostly Puerto Rican and African-American residents of the Wynwood Garment District area. ${ }^{11}$ Cubans increasingly suburbanized while most Blacks and Puerto Ricans remained in the deteriorating social and physical environments of inner city neighborhoods (Winsberg 1979; see also Figure 2.2, below).

By the 1970s, recently arrived Cuban women in the garment trades were increasingly unionized (albeit by then mostly located in Hialeah) at the same time as the garment industry was shrinking (City of Miami 1979; Nissen and Grenier 2001; ShellWeiss 2009). Many factories underwent restructuring to speed production and cut costs, but such strategies were frequently undermined by direct (labor organizing) or indirect (slow-downs) resistance from workers (Grenier and Stepick 2002), and ultimately could not prevent the gradual dispersal of many of the manufacturing components of the

\footnotetext{
${ }^{10}$ The number of workers in the needle trades increased from around 1,000 in 1947 to 7,000 by the end of the 1950s, and would triple in the 1960s (Clemente 2007; Shell-Weiss 2009), largely due to the transformation of the seasonal Cuban labor migrations into a permanent, year-round workforce after the Cuban Revolution of 1959.

${ }^{11}$ In the 1960s and 70s recent Cuban immigrants were willing to accept lower wages than existing workers (Shell-Weiss 2009, p. 179-181). The perceptions and realities of Cubans' employment prospects compared to non-Cubans in Miami has been written about extensively (Grenier and Stepick 1992; Portes and Stepick 1993; Dunn 1997; Croucher 1999; Grenier and Castro 2001; Shell-Weiss 2009). Most analysts agree such inequalities result from the use by industrialists and policymakers of one vulnerable population to exploit several others. Nevertheless, the perception of Cubans "leaping over" other groups has been a point of significant tension in Miami's inter-ethnic relations (Ibid).
} 
garment industry to other countries, particularly in the last three decades (1980-2010). In Miami-Dade County, the number of apparel manufacturing firms declined from a historical high of 702 in 1977 to 634 in 1982, and shrunk an additional 17 percent (down to 526) by 1997 (U.S. Census Bureau, County Business Patterns). In the Wynwood Garment District there were 99 manufacturing firms in 1974 (down from 112 a year earlier) (Polk \& Co., 1976), about 60 of which were apparel factories (City of Miami 1979). In 1997 only 35 apparel manufacturers remained, more than two-thirds of which employed fewer than 10 people (U.S. Census Bureau, Zip Code Business Patterns). The decline of apparel manufacturing would have a negative impact on inner city residents' economic well-being since, according to City Planning research, "in 1960, 51 percent of the city's apparel industry workers lived in the City of Miami” (City of Miami 1967, p. 21). Deindustrialization combined with other processes in the formation of inner city ghettoes.

Following the economic recession of the early 1970s poverty increased in Miami, residential and commercial suburbanization accelerated, and low-income, inner city neighborhoods became increasingly isolated and segregated by race and income (Winsberg 1979, 1983a, 1983b; Aguirre, Schwirian and La Greca 1980; Boswell and Cruz-Báez. 1997; Woodlieff 2006; Ganapti and Frank 2008). By the 1980s Wynwood was one of the poorest neighborhoods in one of the poorest cities in the country. About 66 percent of the neighborhood's residents had incomes below 150 percent of the federal poverty level (U.S. Census 1980) and 16 to 20 percent of eligible workers were unemployed (Balmaseda 1982). Rising class and racial/ethnic inequality in Miami combined with policy brutality contributed to violent inner city protests in the 1980s that 
accelerated the exodus of people and businesses from Wynwood. Two major "race riots" shook inner city neighborhoods and a smaller riot took place in Wynwood in 1990 (Feldstein-Soto 1990). In less than two decades the Garment District lost almost 60 percent of its clothing manufacturers (Hernandez 1984; McCarthy 1985a) while its warehouses were converted to mostly Korean-owned wholesale businesses catering to Latin American buyers (Proscio 1992). Puerto Rican residents with the financial means left the neighborhood, moving to other parts of Miami-Dade County, to Broward County or abandoned South Florida altogether (Ovalle 2004b). Wynwood's population base diversified even further, drawing new immigrants from Central America, Haiti and other islands in the West Indies, and became home to a growing number of African-Americans.

The accelerated economic decline and disinvestment that characterized the late 1970s and 1980s in Wynwood was also when policymakers and "place entrepreneurs" began to envision the revitalization of inner city neighborhoods through a variety of "cultural policy" techniques in which the decline of urban space as a locus for economic production would give way to the use and creation of urban place as a consumable product (see Harvey 1989; Gottdiener 1994). Historic preservation emerged as a mechanism for renovating and gentrifying districts in the 1980s, particularly in South Beach and Coconut Grove (Kranish 1982; Sala and Easton 1987; Mesa 1990), where entrepreneurial strategies were also under way to create and promote arts and heritage districts. In Little Havana, Calle Ocho was increasingly envisioned as a site where ethnic tourism and Latin cultural events would bring people "back to the city" (Menendez 1994a, 1994b; Feldman and Jolivet, forthcoming). But before entrepreneurial strategies blossomed for revitalizing inner city neighborhoods (which I will discuss in subsequent 
chapters), the federal and local state intervened with slum clearance and highway construction to clear the land so that new possibilities could emerge.

However, such clearance and redevelopment required first what Wacquant (2007) calls "territorial stigmatization" of inner city neighborhoods. These are the "discourses of vilification [which] proliferate and agglomerate about [poor neighborhoods], 'from below', in the ordinary interactions of daily life, as well as 'from above', in the journalistic, political and bureaucratic (and even scientific) fields" (p. 67). Moreover, such discourses are not mere expressions or representations, but legitimize public and private remedial interventions. Once a place is stigmatized, "it is easy for the authorities to justify special measures, deviating from both law and custom, which can have the effect - if not the intention - of destabilizing and further marginalizing their occupants, subjecting them to the dictates of the deregulated labour [and land] market, and rendering them invisible or driving them out of a coveted space" (Ibid, p. 69). As I explore below, stigmatization and even self-stigmatization cast a particular shadow over the neighborhood and provided the justification and basis for unequal redevelopment in the future. 
Figure 2.2: Map of Concentrations of Puerto Rican, Non-Hispanic Black and Foreign-Born Residents, Miami-Dade County, 1970 ${ }^{12}$

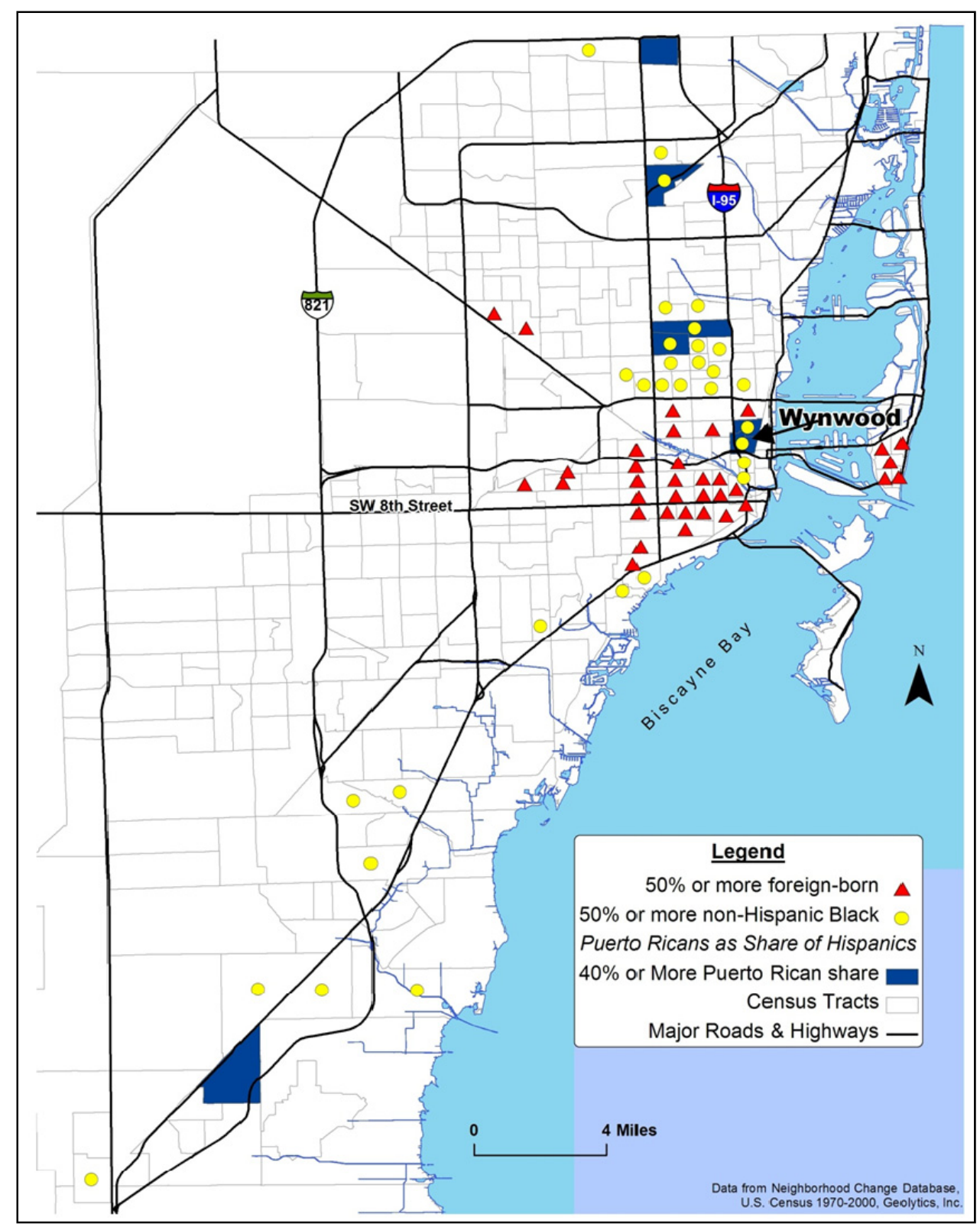

\footnotetext{
${ }^{12}$ Miami has always had foreign born residents but their high concentration in certain Census Tracts by 1970 reflects the rapid influx and spatial segregation of Cubans (Winsberg 1979, 1983). Although the greatest number of Puerto Ricans in the County resided in and around Wynwood, the map depicts four other clusters of Puerto Rican residents in 1970. The southwestern area of Miami-Dade County is where Puerto Rican migrant farm workers originally settled in the decades following World War II. The other clusters are in the north-central corridor of Miami-Dade County, inhabited mostly by African-Americans and also containing large concentrations of public housing. As U.S. citizens, many low-income Puerto Ricans were immediately eligible for housing assistance and came to live in these areas. Still others were steered to these neighborhoods through the racist processes of redlining that limited Puerto Ricans affordable housing options (see Shell-Weiss [2009] and news articles cited below).
} 


\section{Territorial Stigmatization in Miami's Cold War Context}

Through the networks of Puerto Ricans (discussed in Chapter 3), Wynwood became known to both islanders and Miamians as a Puerto Rican place, albeit often in negative terms. Although residents had a more positive perception of the neighborhood prior to the 1980s, negative stigmas were created and perpetuated by government officials (often parroted and disseminated by the media) since the advent of slum clearance and renewal policies in the 1950s and 60s. In 1952, a Miami Daily News cover page article (reprinted in Puerto Rico's El Mundo) referred to the southern section of Wynwood as "a Puerto Rican Slum in Miami," featuring a picture of an apartment house on $25^{\text {th }}$ Street and N. Miami Avenue where 50 migrant workers lived and which the reporter described as "worse than in the central district for blacks." Throughout the 1950s, newspapers drew attention not only to housing conditions in Puerto Rican Wynwood but also to crimes committed by Puerto Ricans (mostly outside of Miami) and their involvement and militancy in unionization campaigns in Miami and elsewhere (notably in Puerto Rico). ${ }^{13}$ During this period the neighborhood came under increasing police scrutiny, with Miami's police chief referring to the area as "one of the greatest crime threats" in the city, claiming that "crimes of violence recorded for Puerto Ricans are greatly out of proportion to their numbers," despite evidence to the contrary (ShellWeiss 2009, p. 154). There were no major newspaper reports of gangs or any other kind of violence in Wynwood during the 1950s and 60s. Instead, the chief's concerns were

\footnotetext{
${ }^{13}$ In addition to Shell-Weiss' (2009, Chapters 5 and 6) review of articles, see articles in the St. Petersburg Times (May 13, 1952), Sarasota-Herald Tribune (March 4, 1955), Daytona Beach Morning Journal (August 8, 1958) and the Miami Daily News (Roberts 1954a, 1954b, 1954c, 1954d, 1954e; December 1, 1956; Colbert 1957a, 1957b, 1957c, 1957d).
} 
with Puerto Ricans' alleged tendency to "congregate in groups," "make obscene remarks at women," and claim not to understand English (Ibid).

Figure 2.3: Image from a 1957 Miami Daily News cover story on the "Puerto Rican Problem"

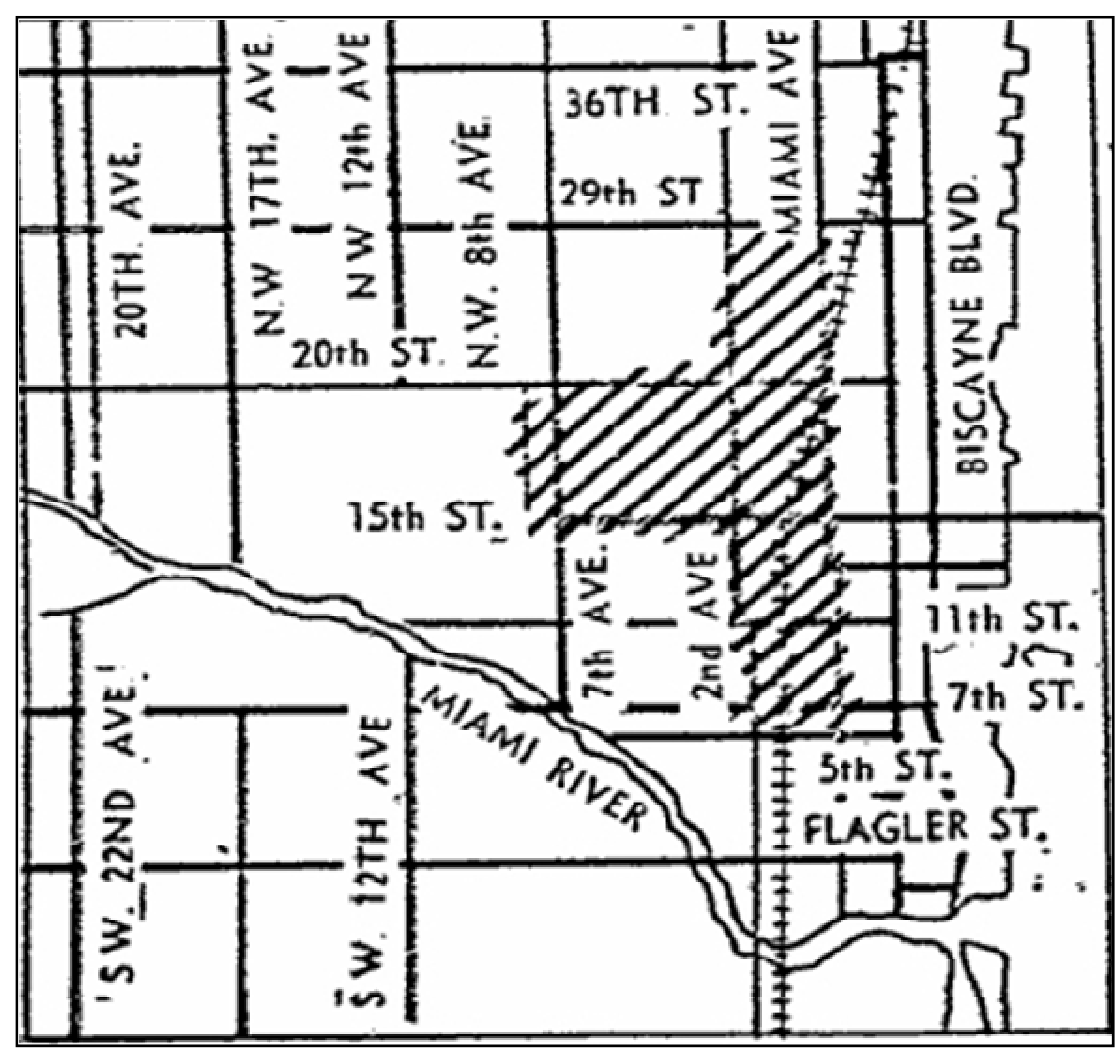

Image caption: "Colony extending north: Much of this area is a slum." Source: Colbert, Haines. 1957. Puerto Ricans in Miami: A Debatable Issue. Miami Daily News, April 22, Cover.

Despite the negative perception of Wynwood by outsiders (e.g. the police, reporters), my Puerto Rican interview respondents remember the 1950s through the 1970s in Wynwood as good and "tranquil" times, particularly compared to their assessment of the 1980s and 1990s, considered the area's worst years. Those who lived in Wynwood in the 1950s noted the potential for violence, evident from the presence of 
"Latino, Anglo and Italian gangs" in a neighborhood of "mostly Rednecks - the old Anglo-Saxon southerners," according to Felipe, although he couldn't recall any major conflicts. There were also Black gangs as Larry pointed out, "[NW] Second Avenue was the differentiation point of the black American at the time... so we needed not to go over west, because that was their territory and they didn't come into our territory." Most respondents agreed that the 1980s marked a turning point. As Marta put it, "in 1980 it already got bad here. You know a lot people came from different places ${ }^{14}$ and it got pretty bad. There were a lot of delinquents, many things that we still have, lots of drugs too." Like Miami's representation in the media more generally, satirical hyperbole is not uncommon in Wynwood, such as Carlos' exclamation that "the neighborhood was wild. That was a Vietnam there. They would steal your socks without taking your shoes off!" Yet, Carlos' son pointed out that "Wynwood, for all its vices... still had that quality of a real neighborhood," where Puerto Rican social networks functioned as a "village" for watching over children and neighbors.

The concentration of Puerto Ricans throughout low-income and particularly near African-American neighborhoods in the post-war decades, and the stigmatization of these areas by a variety of sources, set the stage for future policy interventions that would play an important role in shaping the built environment of these neighborhoods as well as residents' capacity to engage these interventions and shape their own neighborhood. As Mohl (1995, 2001a), Shell-Weiss (2009), Connolly $(2006,2009)$ have analyzed elsewhere, in post-war Miami highway construction, zoning and building code

\footnotetext{
${ }^{14}$ She was referring to the Cuban "Marielitos" and Haitian "boat people" in 1980 (see Portes and Stepick 1985).
} 
enforcement, and other legal and discursive mechanisms were created and used to disperse and control African-Americans to the extent they interfered with industrialists' profits or business plans. Downtown expansion compelled "urban renewal" and "slum clearance" but these plans were also complicated by a combination of political and economic forces throughout the Cold War climate. Fiscal conservatism wrapped in anticommunism limited the extent and quality of replacement housing ${ }^{15}$ while slumlords lobbied to protect their (dis)investments. ${ }^{16}$ Finally, as the civil rights movement grew nationally and locally and was gradually absorbed into policy and planning mechanisms, a particular science of government emerged to justify slum clearance in increasingly humane and economic (or "progressive") terms that concealed the racist and classist foundations of urban planning and redevelopment. ${ }^{17}$ Refashioned into a progressive discourse of economic prosperity for all, suburbanization and expressway construction

\footnotetext{
${ }^{15}$ During the 1950 s, police, civic and political leaders at state and local levels repeatedly sought to associate communism with ethnic groups, "progressive" policies and even "tolerant" attitudes toward poverty (as I demonstrate in the case of Puerto Ricans' living and working spaces). Slum clearance itself was not challenged, but conservatives opposed providing relocation assistance to displaced Black residents. "One of the best ways to get rid of communism," argued senate challenger George Smathers during the 1950 Florida Democratic Party, "is by getting rid of our slums." Meanwhile, in Miami, protesters took to the streets with signs that read "Can you afford to pay somebody else's rent?" and "Are the Communists for public housing? You bet they are!" (Shell-Weiss 2009, p. 136-137). The result was that slum clearance remained unfinished (to the dismay of White, Black and Hispanic urban renewal advocates) until the federal highway construction plans were rerouted through Miami's low-income and predominantly Black neighborhoods (Mohl 1995).

${ }^{16}$ Indeed, the debate over Black housing was essentially one had between different segments of White real estate interests (Mohl 1995, 2001a; Shell-Weiss 2009). While slum clearance and renewal was promoted by downtown elites, those who most forcefully resisted slum clearance in Coconut Grove and Overtown were the White owners of slum housing, evident from their "the unhappy jeers of the landlords" at various public hearings (The Miami News, 1961, p. 10A). As I discus below, the coalition to protect Black homeowners was heavily dependent on the advocacy and lobbying of Elizabeth Virrick, a White activist from Coconut Grove (Mohl 1995, 2001b; Shell-Weiss 2009).

${ }^{17}$ Analysts have noted the lack of militant Black leadership in Miami (Mohl 1990, 2001b) and suggested that the potential radicalization of the civil rights movement and coalition building between different ethnic groups (e.g., Blacks, Jews, Puerto Ricans and other Latinos) was interrupted or short-circuited by Cuban immigration in the 1960s (Mohl 1999; Shell-Weiss 2009).
} 
destroyed the resource base of inner city neighborhoods while urban renewal and slum clearance served the downtown-based, White civic and business elite who were virtually unopposed (Mohl 2001a 2001b, 2004).

Shell-Weiss (2009) documents how as the number of Puerto Ricans grew in Miami and became increasingly involved in garment industry unionization campaigns, "the initially positive attitude ${ }^{18}$ about this community shifted dramatically" (p. 144-145). In a 1949 article entitled, "Miami Chosen Center of Latin Red Network" and a series of articles in subsequent years, the Miami Daily News highlighted the role of union organizing among the city's Latino garment workers-heavily Puerto Rican —in shifting the "center of subversion in the United States... from California to Miami" (Crouch 1949, p. 1A). Thanks in part to union organizing which sought to build class alliances across racial lines, Wynwood became known (accurately or not) for its heterogeneous racial composition — in particular, the perceived propensity of low-income Latinos, mostly Puerto Ricans in the 1950s (but later other Hispanics), to live near and among African-Americans. ${ }^{19}$ Although expressed in terms of fears of "mixed racial stock" ${ }^{20}$ and the potential for inter-racial alliances that could challenge the black-white segregation system, Shell-Weiss (2009) reveals how the actual threat was the potential for class-based

\footnotetext{
${ }^{18}$ Shell-Weiss is referring to positive attitudes about the wealthy Puerto Rican families that settled in South in the early 1940s.

${ }^{19}$ Researchers in New York have noted the propensity of Puerto Ricans, compared to Whites, Hispanics and most other immigrant groups, to live spatially closer to African-Americans (Massey and Bitterman 1985; Galster and Santiago 1994; Freeman 1999), without explaining how the concentration of Puerto Ricans in inner city "ghettoes" was largely a result of racial discrimination in housing markets (Grosfoguel 2003; Davila 2004).

${ }^{20}$ These fears were expressed, on the one hand, by the Police and "pro-segregationists" in Miami during the 1950s. But resentment was also expressed by African-Americans who perceived that Spanish language allowed darker-skinned Latinos to "pass" as non-Black and were therefore accorded better treatment (ShellWeiss 2009, p. 155).
} 
alliances and conflict that challenged industrialists' capacity to exploit workers by dividing them along ethnic lines. For example, during a major International Ladies Garment Workers Union (ILGWU) campaign in 1955, the union distributed fliers with a photo of a factory owner's Miami Beach home shown above a photo of Wynwood apartment houses, "emphasizing shared living conditions among workers and locating the labor dispute in Miami's neighborhoods" (Ibid, p. 166). Beyond the assessment that such tactics temporarily but "effectively united workers across ethnic lines,"21 they also reflected the reality of an urban space (a location) occupied by marginalized U.S. citizens, from which some form of resistant, alternative urban as well as workplace politics might emerge.

The 1950s was a period of incipient stigmatization of a neighborhood constructed as one of Miami's first middle-class suburbs. As will become increasingly clear from subsequent analyses of city politics and planning processes, Wynwood's relatively heterogeneous socio-spatial composition made it the target of a variety of remedial interventions and governance techniques during the latter half of the $20^{\text {th }}$ century. Although there has been no explicit policy objective or political discourse to "break up" the mixing, so to speak, there is a clear drive in subsequent decades toward a social and physical homogenization—“disciplinary normalization” (Foucault 1977, 2009)—of the area in the name of security and social control; to harden the edges at which difference and contact occur, and "segregate uses" (in typical urban planning parlance). As the economic base of the neighborhood declined and civil rights activism made official race

${ }^{21}$ In Shell-Weiss' account (e.g., p. 165-168) industrialists ultimately prevailed by either relocating their operations or, in a few notorious cases, "by bringing in all Puerto Rican 'scabs'." This led many Anglo- and African-American workers to "worry that Puerto Ricans would 'take away' their jobs ," and to claims that "Latinos were 'bad union people' or were 'clanninsh'." 
domination increasingly untenable, a "scientific basis for slum clearance" emerged with increasing legitimacy. A variety of governance techniques were implemented until Wynwood could be considered a "clean canvas" for redevelopment— processes which took several decades.

\section{The "Science" of Slum Clearance}

As U.S. cities suburbanized in the post-war period, urban renewal planning and implementation were set in motion by the 1949 and 1954 U.S. Housing Acts, through which the federal government required and helped to finance slum clearance, including the planning research needed to legitimize such interventions. The primary aim of urban renewal in the 1950s was demolition and clearance of central city "slum" housing to enhance the downtown business environment while linking it more efficiently with the suburban professional classes; but an equally important outcome (particularly in the view

of local elites) was the displacement and dispersal of "problem" populations surrounding downtowns, particularly poor Black residents (Harvey 1973; Mollenkopf 1975; Molotch 1976; Fainstein and Fainstein 1978; Castells 1983). But since this task was complicated by increasing resistance and militancy from community organizations in the 1960 s, a variety of services and programs to "manage" urban renewal were also devised and implemented (Ibid). Funding and institutional support for such programs "suffered from an unusual degree of temporal inconsistency" and thus "public housing, urban renewal, below-market-interest-rate subsidies, Model Cities-each has come and gone, leaving unfunded plans and half-finished projects in its wake" (Fainstein and Fainstein 1978, p. 135). Nevertheless, through these programs a science of urban governance was born and 
gave rise to a wide variety of implementation techniques ${ }^{22}$ that sought to make urban space, and its resident populations, more governable in order to "secure" the inner city for higher investment returns (Harvey 1975, 1989; Gottdiener 1994). Research was important for legitimizing these interventions. The production of scientific knowledge about the inner city not only lent geo-statistical precision to renewal activities but also presented a veil of accountability.

By the 1960s Wynwood, like other inner city "slums," came under increased scrutiny by public planning boards, government research agencies, zoning and building departments, and policy-makers. Whereas Miami-Dade County's (1949) first research report serving as "the scientific basis for slum clearance" focused on the "two principal blighted areas" of Overtown and Coconut Grove, in the 1960s the newly created Dade County Welfare Planning Council carried out a series of research reports (1963-1967) resulting in a "complete inventory" of the City of Miami's "social and physical problem areas" (Sterne 1965, p. 2) - which included Wynwood. Deemed the basis of "a longrange program for elimination of the City's blighted areas," the series of five reports marked the initiation of the County's Community Renewal Program (CRP) which identified not only priority areas for clearance but also the corresponding social and economic "needs" of residents (City of Miami 1967). The University of Miami sociologist, Sterne (1965), made the case for the integration and management of residents. Given the complex factors causing extreme poverty, for urban renewal to be successful:

\footnotetext{
${ }^{22}$ This includes not only governing by force but also production and facilitation of self-management through "public-private partnerships" that integrate "citizen participation" (see e.g., Foucault 1979a, 1982; Rabinow and Rose 2003; Jessop 2007).
} 
[C]onsideration... must be given not only to buildings and other physical elements, but also to the underlying cultural and social matrix. The urban dweller himself... needs attention. If the urban dweller is economically productive and socially well adjusted, he is an asset to the city. If he is poor, or a problem to himself and to others, he makes his neighborhood less desirable. The maladjustments of this type of person are called 'social problems.' (Ibid, p. 4$)^{23}$

Another section of the analysis brought the urban dweller into closer focus by asking:

Are problems concentrated in certain minority groups? For example, are the Negroes or the Cubans special problems? It was deemed desirable to determine to what extent these groups required specific social assistance and to what extent they located in the City's slum areas. The same question might be asked about the Puerto Ricans; however, their number is relatively small and, also, they are mixed with native whites in certain areas. These factors make it very difficult to validly separate the Puerto Ricans. (Ibid, pp. 37-38)

Sterne's research targeted the geographic areas in which different ethnic groups lived, particularly "the Negroes who had the highest problem scores" compared to "the Cuban population [which] had few social problems." Puerto Ricans could not be singled out statistically for social problems, though their spatial mixing with Whites in certain neighborhoods was carefully noted. Stern's research served as the basis for city officials to "target areas" 24 for remedial intervention, determined by a formula which counted the number and measured the correlation of a variety "social problem" cases ${ }^{25}$ within subsections of Census Tracts, deemed Analysis Districts. Of hundreds of districts identified

\footnotetext{
${ }^{23}$ The footnote to this section of the introduction reveals that "the statement just made reflects- - with the substitution of 'Miami' for Liverpool - the wording in a report printed in England. Miami shares problems with metropolitan areas the world over."

${ }^{24}$ In the city's renewal plan the term Target Area is used as a noun, not as a verb the way I do here.

${ }^{25}$ The following "problems" were included: Illegitimate births (a proxy for "Fatherless Families"), Aid to Dependent Children (Federal Welfare), Aid to the Disabled, County Welfare Cases, Syphilis, Old Age Assistance, Tuberculosis, Aid to the Blind, Infant Mortalities, Adult Arrests, Juvenile Arrests, School Drop Outs.
} 
as having some extent of "problems," the study designated 13 as Target Areas in need of further study and specialized planning, two of which were within the southern sections of Wynwood (p. 64). The Wynwood Target Areas were given "problem scores" of "middle" and "low to high," due to the "mix" of "low level of social problems" with "high level of physical problems." The report further described the neighborhood's problem areas:

[Wynwood Area 1:] Residential uses [mixed] with institutional and commercial. Housing is largely deteriorated. Definite transitional area with regard to hospitalcomplex expansion.

[Wynwood Area 2:] Older Latin area. Has many diverse uses ranging from single family dwellings to light manufacturing and a railroad yard. Area is bordered and bisected by heavily traveled streets and the North-South Expressway cuts through the Western end. Considerable deterioration of both residential and nonresidential uses.

"As with other parts of the total Community Renewal Program," concluded Sterne (p. 68), the 1965 Social Problem Areas study "will actually mark only the beginning of a concerted effort to meet needs and problems of people and their City." Indeed, the series of reports marked the beginning of the construction of a "scientific" rationality of government for implementing physical redevelopment of the inner city. In the context of increasing tensions between industrialists and workers, natives and immigrants, white and non-white residents, this emerging "spatial governmentality" (see Merry 2001; Huxley 2007) claimed "to develop greater depth and understanding of social conditions and needs of people and their neighborhoods, so that urban renewal action projects can be more sensitively applied to particular areas" (Sterne 1965, p. 67).

However, the mandate for research, planning and "sensitivity" came from the federal government, which was facing growing challenges to urban renewal from 
residents in cities such as San Francisco and New York. No such sensitivity was needed or actually applied in Miami, since there was no organized, mass opposition to slum cleraance or expressway construction during the 1950s or 1960s (Mohl 2001b, 2004; Shell-Weiss 2009). ${ }^{26}$ Leaders of Black communities, which were the most affected by urban renewal, were sharply divided on questions of slum clearance and public housing (Shell-Weiss 2009, 135-138), ${ }^{27}$ and this helped the White business and civic elite to opreate relatively uncontested well into the 1970s (see Mohl 2001b, 2004). Since Miami's expressways were built relatively early (1964-69), without delays, and because amendments to urban renewal reequiring greater local participation and oversight kicked in after inner city homes had been demolished, most affected residents (especially Black residents) received little more than 24 hours notice to clear out and received no relocation

\footnotetext{
${ }^{26}$ During the 1950s, the Coconut Grove "housing reformers" Elizabeth Virrick and Rev. Theodore Gibson advocacy of slum clearance and public housing, supported crucially by a coalition of "progressive" Whites among the civic elite (including major newspaper editors), was opposed only by slumlords and the politicians they supported (a majority on the Miami City Commission), which likened such government intervention to communism (Mohl 1995, 2001b; Shell-Weiss 2009). But by the 1960s real estate interests realized they stood to gain from subsidized redevelopment and instead focused on using the occasion to build new Black housing and "blockbust" White neighborhoods in outlying areas. Local control of urban renewal by real estate entrepreneurs ensured that replacement public housing and social services were limited so as to allow the private sector a virtual monopoly on displaced families' housing needs (Ibid). This situation was exacerbated when expressway construction began in 1965. Virrick was forced to reverse her advocacy of slum clearance, realizing it had been manipulated by slumlords, and "throughout the expressway-building era [she] was a lonely... voice speaking out on the necessity of linking highway construction with public housing and relocation programs" (Mohl 2001b, p. 31).

${ }^{27}$ According to Shell-Weiss (2009, p. 135-138), the Grove's Black Bahamians had higher rates of homeownership and therefore tended to prefer slum clearance policies, while Overtown leaders more often opposed demolition but were resigned to accepting the status quo of downtown expansion and Black dispersal. Miami's civil rights movement was relatively small and peaceful compared to other parts of the country (see e.g., Piven and Cloward 1979; Castells 1983; Fainstein and Fainstein 1985). While some local stakeholders and analysts argue it was marginalized and deflated by its coincidence with the mass inmigration of Cuban political refugees after 1959 (Portes and Stepick 1993; Shell-Weiss 2009), others have noted limitations inherent to civil rights leadership in Miami and attempts to build an interracial alliance between Jews and Black prior to 1959 (Mohl 1999).
} 
assistance other than a redirection to what Mohl (1995) termed "the second ghetto" (Ibid). ${ }^{28}$

There is evidence that urban renewal and expressway construction negatively impacted several inner city neighborhood in addition to Overtown, which is typically cited as the neighborhood that was "destroyed" by the routing of Interstate 95 (see Dluhy, Reveall and Wong 2002; Connolly 2006). Mostly white, working-class neighborhoods such as Allapattah, Buena Vista and Wynwood lost hundreds of homes and important commercial corridors and neighbrohood institutions during the 1960s.

Respondents described NW $7^{\text {th }}$ Avenue, between $20^{\text {th }}$ and $36^{\text {th }}$ streets, as Wynwood and Allapattah's “downtown” area, home to one of Miami's oldest movie houses (the Strand Theater), a roller rink and a variety of successful stores and restaurants. ${ }^{29}$ A recent Miami Herald retrospective wrote that "Seventh Avenue once brimmed with civic importance" (De Vise 2004, p. 1B). A respondent who was born and raised in Wynwood during the 1950s recalled that "the highway just changed everything... we had NW $5^{\text {th }}$ and $6^{\text {th }}$ avenues and [I-95] went right down through the

\footnotetext{
${ }^{28}$ By the time the south extention of Interstate- 95 had broken ground, meetings were just taking place to plan for how to provide social services to displaced families (Blanchard 1966). "What has taken years and a complexity of social conditions to build up," said the Housing Agency director about the needs of displaced families, "will take years and a coordination of social effort to begin to rectify" (Ibid, p. 4A, emphasis added). Three years later the same Housing Agency director was criticizing the County Commissions' delay tactics (Robertson 1969). Indeed, by 1970, the Model City program, which was the largest of the local urban renewal "social programs" meant to help displaced families, was so mired in delays by bureacratic gatekeepers at County Hall that the Chair of the Model City Governing Board (also City of Miami Vice Mayor), Athalie Range, along with several other members resigned in protest (Blanchard 1970). Not until community development funding in the 1970s would more effective service programs be implemented, nearly a decade after more than 10,000 Black families were displaced by urban renewal and expressway construction (City of Miami 1967).

${ }^{29}$ Interviews with three male respondents who grew up in Wynwood during the 1950s and early 1960s: a half-Cuban/half-Puerto Rican-American born in New York, a Cuban-American who moved with his family when he was less than a year old, and an Anglo-American who was born and raised there (whose wife also contributed to the interview but had only lived in the neighborhood for 2 years).
} 
middle and took $7^{\text {th }}$ Avenue with them. [They] took housing, of course, for the right-ofway, and people that we had known for years... moved out when they built 95." Another respondent noted that, in retrospect, he can understand why his parents moved out of the area in the early 1960s: "I-95 and [Expressway] 836 were in the process of completion. It seems that once 95 was completed, things began to decline in Wynwood." A 1964 Miami News article about a long-time neighborhood bakery deemed "a notable institution which elected to stay," lamented that "when the expressway intruded, several commercial landmarks disappeared" (Ash 1964, p. 15). The owners of the bakery estimated that expressways' construction "cost close to 800 customers" (Ibid). In an interview with Fernando, the priest of a Catholic Church based in Wynwood and Allapattah-one of the Miami's largest and an neighborhood important institution — he used the design of the parish system to illustrate how the expressway "killed the parish and the neighborhood":

Consider how... the parish faces the expressway. It doesn't make sense. It was built in $1959 \ldots$ when the [expressway] was not the in the middle of the neighborhood. Inserting the expressway, well, then the neighborhood of Wynwood was separated from the parish. Wynwood was left constrained between the expressway and the railroad tracks. If you notice, there is no connection between Wynwood and Edgewater [the eastern bayfront neighborhood], only through 36 or $29^{\text {th }}$ streets. In short, [Wynwood] was converted into a ghetto. 


\section{Figure 2.4: Aerial View of Wynwood Catholic Parish Bisected by Interstate 95}

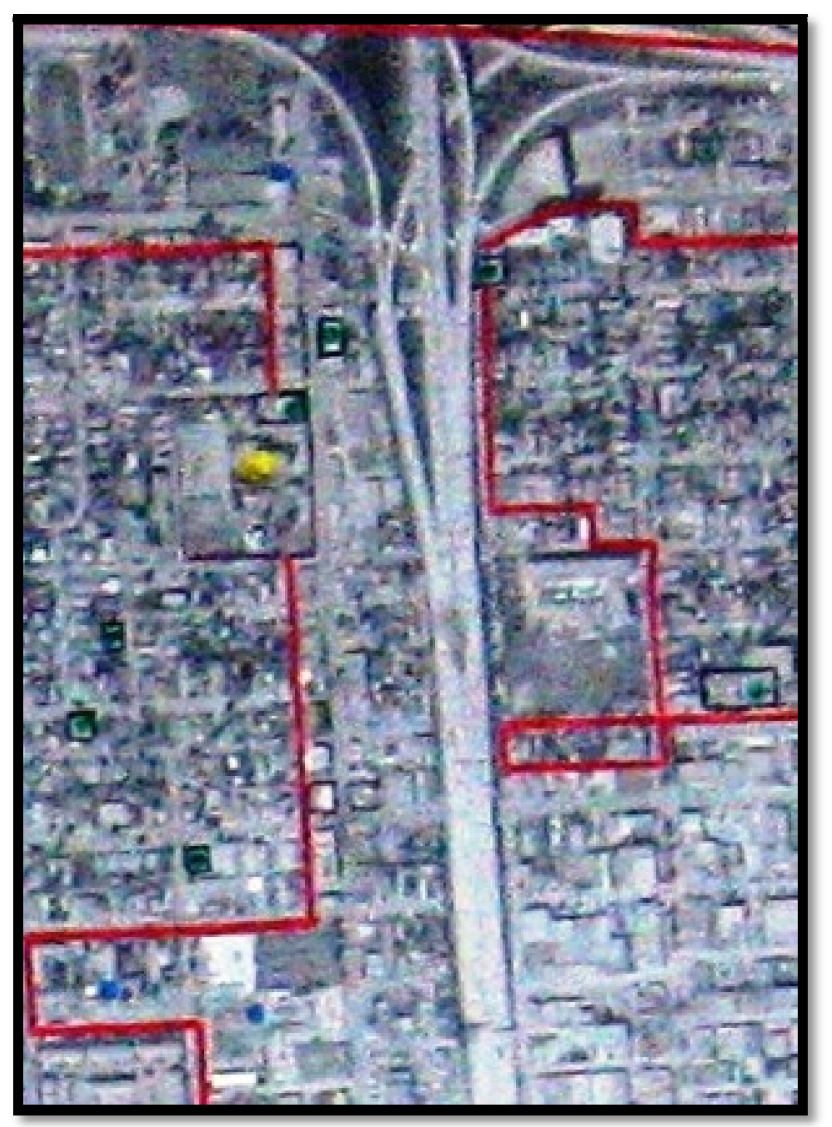

Source: Authors' photo of the priests' aerial images of a portion of the Wynwood Catholic Parish, taken during our interview. The yellow pushpin is the main church facing the expressway which divides the parish base, outlined in red.

As the expressways were built, ${ }^{30}$ the Dade County Welfare Planning Council was completing the series of research reports that would initiate and serve as the empirical

\footnotetext{
${ }^{30}$ The Airport Expressway that cut from the northwest corner of Wynwood across Allapattah and west to the Airport was completed in 1964 (Ash 1964), while the southern extension of Interstate 95 into the City of Miami began construction in the Lemon City area (now Liberty City and Little Haiti) in the latter half of 1964 (Nellius 1964). By January, 1965, all of the housing demolition required for the segment of Interstate 95 routed through Overtown, Wynwood and Allapattah was complete and some sections of the expressway were under construction in these areas (Hale 1965). Among the last segments of the Interstate system built in the City of Miami, the Midtown Interchange (between the north-south and east-west expressways) and the southernmost sections routed through Overtown were built between 1966 and 1968 and occupied a six block section of the northwest corner of Wynwood (The Miami News, 1967; Williams 1967; Dluhy, Revell and Wong 2002; Mohl 2004).
} 
basis for the City of Miami Community Renewal Program, described above. Using data from Sterne's (1965) survey, the Planning Council's final research report (City of Miami 1967) compared neighborhood-level statistics from 1960 and 1965. In Census Tract 26, the northern and wealthiest section of Wynwood, single family home values decreased between 11 and 20 percent, one of the highest rates in the City (Map 35, p. 48). The population decreased in only five City of Miami Census Tracts (Map 1, p. 3), three of which comprised Overtown and southeastern corner of Allapattah, through which Interstate 95 was built. During the same period (1960-1965), the population-perhousehold increased in only four inner city Census Tracts: three $(19.01,19.03,19.04)$ in southeast Liberty City, where most displaced Overtown residents were relocated; and Census Tract 28 which comprises the southern and (at the time) Puerto Rican half of Wynwood, bordering Overtown. Since urban renewal only funded the construction of "about one low-rent unit for every six displaced families" and most new units were more expensive than those demolished (Hartman 1964, 1971; Columbia Law Review, 1966), clearing slums to make way for the expressways may have led to increasing population densities in nearby and already crowded, low-income districts such as Wynwood (Sterne 1965). However, it is not clear whether these data reveal the initial impacts of highway construction or whether highway construction merely coincided with these patterns, possibly but not necessarily contributing to them.

Nevertheless, research on the impact of highway construction has argued that urban renewal destroyed inner city neighborhoods (see Hirsch and Mohl 1993; Mohl 1995). In their research on Overtown business patterns during the period when the highway was built through the neighborhood, Dluhy, Revell and Wong (2002) found that 
the number of businesses dropped by 23 percent from 1966 to 1967, the largest singleyear decline in the neighborhood's history. Other research focused on the displacement of residents and the lack of relocation assistance and replacement housing provided (e.g., Hartman 1964, 1971; Downs 1970). "Given the realities of the low-income housing market," wrote Hartman (1964, p. 278), "for many families, relocation [means] no more than keeping one step ahead of the bulldozer."

In many parts of the country, urban renewal also led to the construction of highrise public housing projects that would later be condemned for their "concentrating" effects on poverty, crime, and the resulting socio-economic isolation of poor communities (Massey and Denton 1993; Wilson 1996). However, in Miami public housing construction was both more limited and designed for lower-density occupancy, thanks largely to elected officials' "commitment" to "free enterprise" (Mohl 1995, 2001a) or, put differently, to conserving local real estate investors' monopoly on slum housing. While the concentration and isolation of poverty in Miami’s inner city neighborhoods nonetheless increased (Boswell and Cruz-Baez 1997; Dluhy, Revell and Wong 2002), poverty and low-income housing also became more dispersed (City of Miami 1967; Winsberg 1983) owing in large part to the availability of outlying tracts of land controlled by blockbusting real estate investors (George and Petersen 1988; Mohl 1995, 2001a, 2004). ${ }^{31}$ The somewhat unique historical combination of both high poverty and dispersed

\footnotetext{
${ }^{31}$ A crucial result of these historic processes is that while a large share of low-income neighborhoods (land acreage) is covered by public housing, the overall number of units are fewer, leading Miami to have a comparably smaller share of subsidized units within its overall housing stock and comparably higher rates of housing cost-burden, overcrowding and other hardship (on cost-burden see e.g., Feldman 2007). According to data from the Universoty of Florida's Shimberg Center for Affordable Housing (Shimberg 2007), public housing (project-based Section 8) and units subsidized by rental vouchers, not including housing financed by local municipalities, represent only 6.2 percent of Miami-Dade's rental housing
} 
poverty $^{32}$ reflects the region's economic dependence on tourism and real estate- - that is, many low-wage workers are needed to service the economy but should be housed as far from the view of investors and consumers as possible (Nijman 2011).

Viewed over a longer time frame, urban renewal and expressway construction in Wynwood may be interpreted as the primary mechanisms for creating the "spatial fix" needed by investors to eventually revitalize the area (Harvey 1985, 1989; Smith 1996; Weber et al. 2006). Although typically conceptualized in terms of its economic function (Ibid), the spatial fix is also social and political as the removal of residents reduces the possibility of neighborhood opposition to future redevelopment proposals and projects (Gibbs-Knotts and Haspel 2006; Martin 2007). Incipient stigmatization, uncontested urban renewal and the lack (or insignificance) of poor people's social movements exacerbated the socio-spatial dispersion of Miami's low-income communities (see Maps below), further weakening the possibility of collective action for social change. To the extent that by the 1970s, at the height of urban activism elsewhere in the country, attempts were being made at interracial urban social movements (Castells 1983; Mantler 2008), ${ }^{33}$ in Miami limited interacial efforts either within unions (as noted above in ShellWeiss 2009, pp. 165-168) or within the frame of civil rights activism (Mohl 1999) did not

market. Although there is no database that provides directly comparable statistics, the figures in a recent UCLA research report (Kucheva 2011) reveal that in cities such as New York, Chicago and Los Angeles (the report does not include Miami), project-based public housing and rental vouchers comprise between 14 and 17 percent of those cities rental markets.

\footnotetext{
${ }^{32}$ This was unique during the immediate postwar period, perhaps making Miami a forerunner to later federal policy developments (discussed below).

${ }^{33}$ These and other analysts (Fainstein and Fainstein 1985; Fainstein and Hirst 1994) nevertheless found that interracial urban social movements were largely unsuccessful in their aims and fragmented by the late 1970 s and especially the 1980s, in relation to their increasing "enfranchisement" under community development programs. Nevertheless, some have argued that they left an institutional legacy for future interracial organizing (Castells 1983; Mantler 2008).
} 
survive into the 1960s. Urban renewal policies were not soley responsible for this outcome, since the diseprsion of African-American and Afro-Caribbean communities in Miami had begun during the 1930s (Mohl 1995; Dluhy, Revell and Wong 2002) and because pockets of poverty had to some extent always been dispersed throughout the region (George 1978). (Cuban migration, as I will discuss later, also affected the possibility of social movement-building among Miami's poorest residents.) But during the 1960s and 1970s, urban renewal accelerated low income residents' displacement from the urban core, thus initating a decades-long process of removing them as physical and potentially political obstacles to redevelopment. The resulting spatial and political fragmentation facilitated the downtown business elites' control of urban redevelopment in the postwar period. Ironically, the only constituent group that has been effective in stopping redevelopment projects has been activists in the Overtown neighborhood who sued on numerous occasions to halt public plans and projects on the basis of the historical injustices sufferred without the payment of any reparations (Dluhy, Revell and Wong 2002).

Urban renewal and public housing "met their effective demise in the 1970s" because of "the inability of either to significantly counter the decay of the nation's older urban areas" (Judd 1988, p. 275), which is putting it midly. However, local real estate interests and downtown elites manipulated postwar urban renewal and highway construction in such a way that these programs destroyed inner city neighbrohoods and made poverty worse in nearby neighborhoods that were not "cleared." Indeed, such neighbrohoods became the target of future strategies referred to as the "second wave" of 
subsidized redevelopment and refashioned as "community development" (Stoecker 1997;

Hackworth 2001; Smith 2002; Gotham 2005). 
Figure 2.5: Map of the Percent of Persons with Incomes below the Federal Poverty Line, Selected Race/Ethnic Groups, Miami-Dade County, 1970

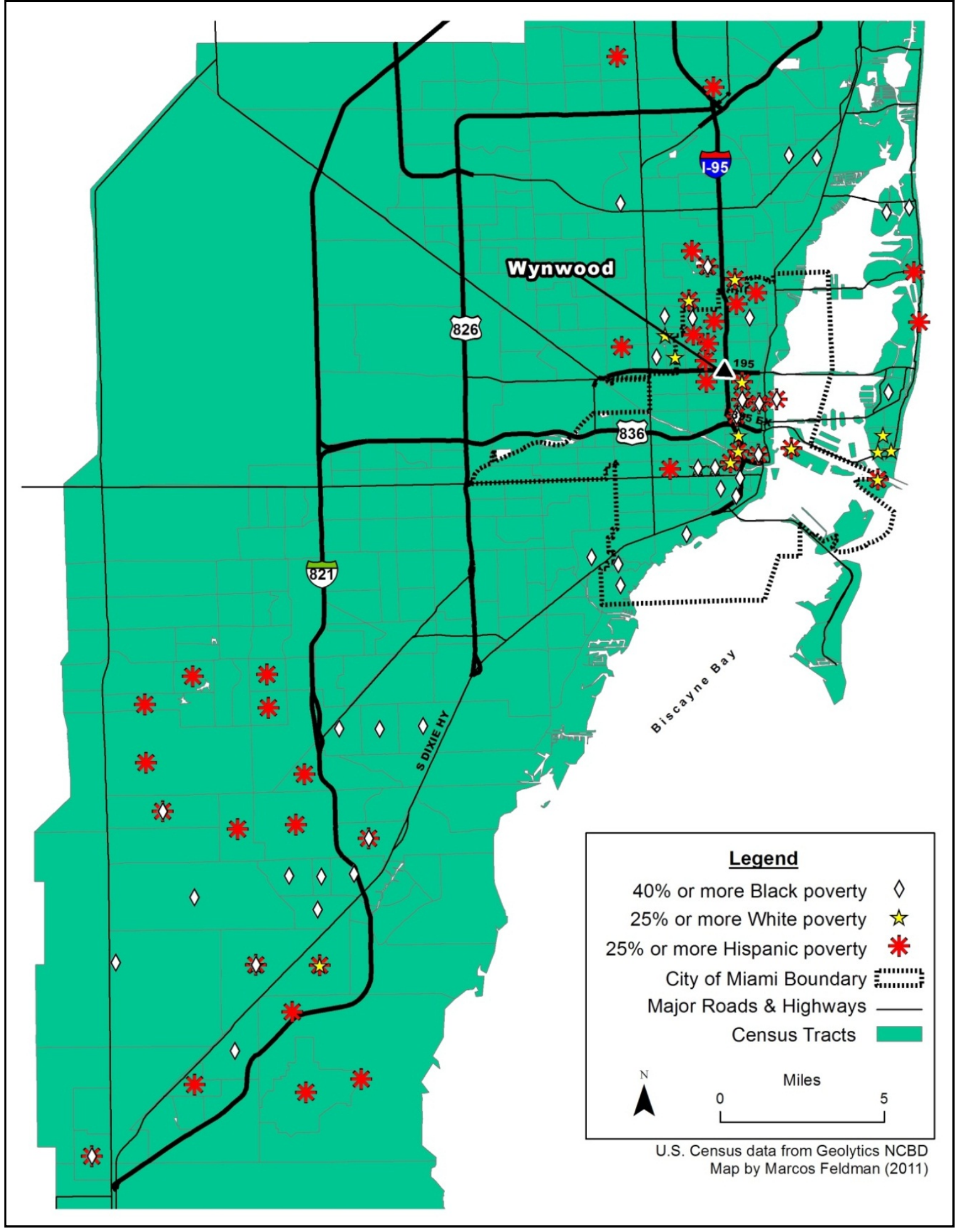


Figure 2.6: Map of Poverty Rate in 1970 for Selected Race/Ethnic Groups and Poverty Rate Change, 1970-1980, Miami-Dade County

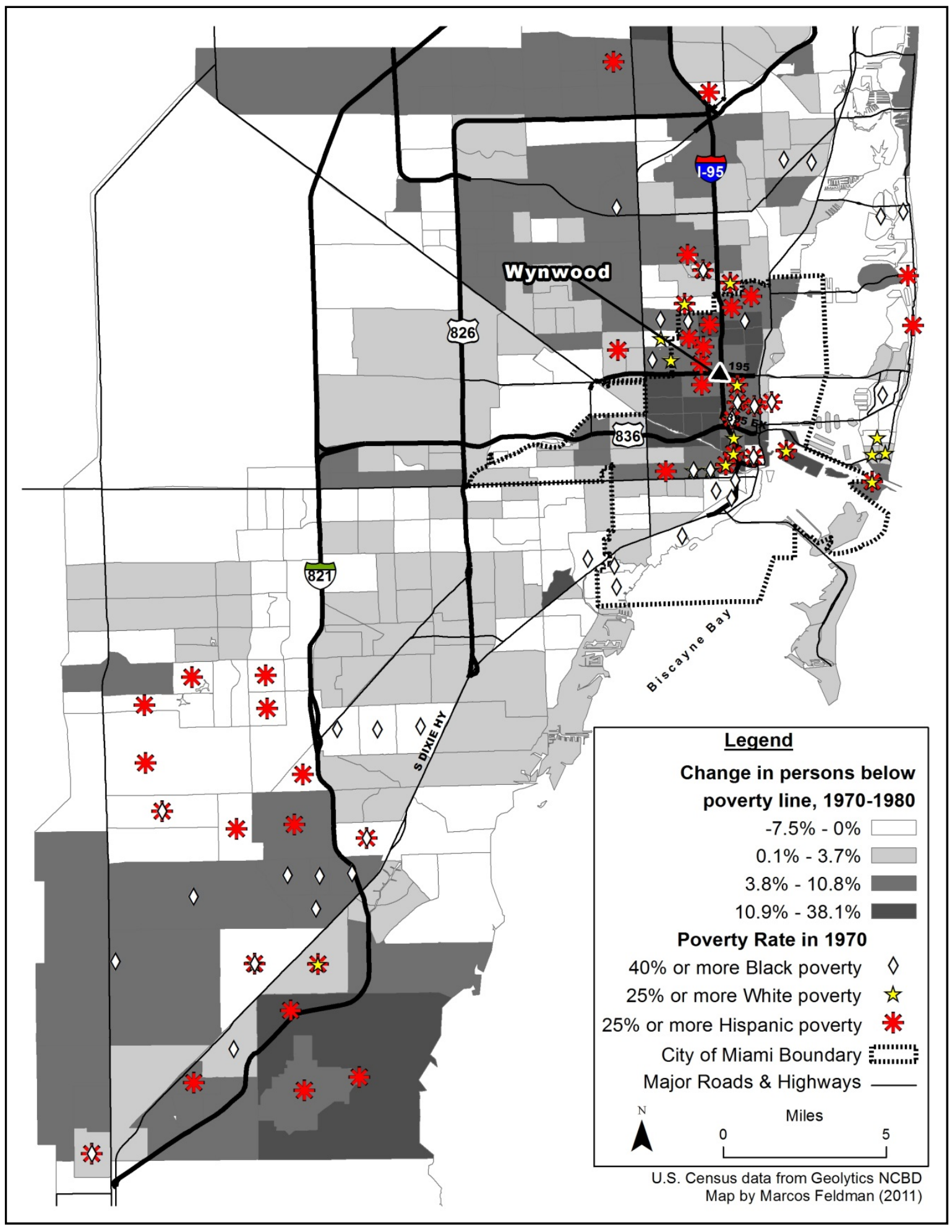




\section{THE MAKING OF PUERTO RICAN WYNWOOD}

Urban renewal, the interstate highway system and suburbanization in conjunction with the deindustrialization of U.S. cities cemented the economic decline of many inner city neighborhoods (Massey and Denton 1993; Mohl 1995; Wilson 1996). As the federal government intervened by underwriting these processes, inner city residents organized to demand political representation, basic services and greater control over their neighborhoods (Castells 1983; Fainstein, Fainstein and Armistead 1983). Some of the community organizations that emerged to challenge the existing urban political system made advances in terms of social services and limited political representation for the poorest residents, but their "bureaucratic enfranchisement" (Fainstein, Fainstein and Armistead 1983) also fragmented their leadership and constituencies by co-opting moderate activists toward narrower objectives and excluding the most radical (Piven and Cloward 1979; Castells 1983). In many cases, as neighborhood decline later turned to gentrification and "community development" took an increasingly entrepreneurial turn, co-opted organizations evolved into Community Development Corporations (CDCs) and worked to revitalize their neighborhoods in the absence of "community control," paving the way for unequal redevelopment and investment by larger, wealthier companies (Logan and Molotch 1987; Bockmeyer 2003; DeFilippis 2004; Newman 2004; Kirkpatrick 2007).

The following describes the emergence of community organizations in Wynwood through the activism of Puerto Rican leaders in the 1970s. As with ethnic- and race-based civil-rights era movements in other U.S. cities (Mollenkopf 1975; Castells 1983), as well as the mobilization of Puerto Ricans in places like Chicago and New York (Padilla 1987; 
Melendez 2003), racism and segregation, extreme poverty and political exclusion (despite their U.S. citizenship) were the basis for Puerto Rican mobilization in Wynwood in the late 1960s.

As Castells (1983) pointed out in the case of Chicanos in San Francisco's Mission District, the crucial catalyst to community organization in the late 1960 s was service funding - especially, but not exclusively, from the government. The organization of Puerto Rican activists in Wynwood was at first made possible by neighborhood organizing supported by religious institutions. In the climate of the civil rights era, the neighborhood's Puerto Rican leaders demanded government funding for services on the basis of ethnic and racial discrimination. The program funding that was conceded led to the formation of Puerto Rican service agencies and by the mid-1970s, Puerto Rican mobilization had been channeled into these programs, funding for which was controlled by Miami City Hall. As happened across the U.S. (Fainstein, Fainstein and Armistead 1982), "bureaucratic enfranchisement" redirected conflict inward, among the residents and leaders. What started as a somewhat united cadre of activists - Puertorriqueños Unidos - over time revealed fissures, as leaders shed their militancy and narrowed their objectives; one leader became a wealthy real estate investor, while some newcomers with Puerto Rican credentials sought power at the helm of service programs.

As subsequent chapters will make clear, the organizations established by these activists would eventually help to facilitate gentrification - not only because they were powerless and even reluctant to oppose it or implement alternatives; but also because toward the turn of the 21st Century the decentralized and privatized governance of gentrification incorporated the Puerto Rican leadership as junior partners. 
What follows is not an exhaustive history but draws on a few key examples involving the most influential leaders and organizations. In discussing the conflict between different individuals or groups, my objective is not to uncover the reasons for conflict, as the impact of organizational enfranchisement on poor people's movement has been dealt with in greater detail elsewhere (e.g., Piven and Cloward 1979; Castells 1983). Instead, I aim to lay the foundation for understanding the legacy of political engagement left by key leaders and organizations during the 1970s, while the longer-term impacts of this legacy will be examined in subsequent chatpers. Before turning to the rise and evolution of the Puerto Rican community organizations, I describe how Puerto Ricans came to live in Wynwood and provide a social and geographic profile of the neighborhood.

\section{Puerto Rican Migration}

While the number of Puerto Ricans has increased rapidly in the last three decades throughout the State of Florida, particularly in Central and South Florida, in the City of Miami their presence peaked around 1980, representing 4 percent of the city's population (Table 3.1). Although in the table below I rely on U.S. Census Tract enumerations compiled in the Neighborhood Change Database (NCBD), it is well-known that the Census underestimates the Puerto Rican population (Duany 1992, 2000; Rodriguez and Monserrat 2000). ${ }^{34}$

\footnotetext{
${ }^{34}$ The extent of the undercount was greatest in 1970 due to incompetence and insensitivity on the part of the Census Bureau (U.S. Civil Rights Commission 1974) as well as the socio-cultural context shaping Puerto Ricans' responsiveness to the census questionnaires (Duany 1992, 2000; Rodriguez and Monserrat 2000). Duany's (1992) review of and own ethnographic research among Puerto Ricans in the U.S. and on the island found that among Puerto Ricans who do not respond or respond partially
} 
The experiences of Puerto Ricans in Miami have differed somewhat from that of their counterparts in the major northeastern cities. ${ }^{35}$ Florida has the second-largest concentration of Puerto Ricans in the U.S. outside of New York, mostly concentrated in three major metropolitan areas: Orlando-Kissimmee-Sanford, Miami-Ft.

Lauderdale, and Tampa-St. Petersburg (Duany and Matos-Rodriguez 2006). MiamiDade County has the second largest number of Puerto Ricans in Florida behind Orlando, but like the rest of Florida's Puerto Ricans, those in Miami tend to have higher levels of education and income compared to elsewhere in the U.S. (Duany and Matos-Rodriguez 2006). Long before Orlando's emergence as a major Puerto Rican destination in the 1990s, Miami's urban, suburban and rural areas were where many Puerto Ricans settled.

or "inaccurately" to Census surveys, the main reasons have to do with distrust and self-protection: In subsequent research (Duany 2000) he also emphasized how resistance to U.S. ethnic and racial categories caused some Puerto Ricans to classify themselves as "other" and/or "American," in order to emphasize their U.S. citizenship. In Miami, awareness of the undercount led to complaints that Puerto Ricans were "invisible" (Colbert 1957a) and "the forgotten minority" (Cruz 1974). Cited in newspaper articles, estimates of the number of Puerto Ricans by government agencies and community activists ranged from 20,000 county-wide in the 1950's (Colbert 1957a) to 30,000 in 1970 (Cruz 1974) to between 60,000 and 100,000 in 1980 (Roberts 1981). In 1974, a neighborhood social worker surmised that Puerto Ricans "just tell census workers they are American citizens and do not identify themselves further, any more than an American would feel he has to say he is from Massachusetts" (Cruz 1974, p. 1A).

${ }^{35}$ Puerto Rican labor migration flows to the U.S. mainland were created by federal trade, immigration and national security policies in order to both help industrialize the island and to fill labor shortages in manufacturing and agricultural areas across the country (Caban 1994; Grosfoguel 2003). By the 1960s, Puerto Rican men also worked as unskilled factory operatives and menial help in hotels and restaurants while women were employed as domestics and as seamstresses in the garment industry (Maldonado 1979; Bonilla and Campos 1981). Puerto Ricans low position in the U.S. division of labor was facilitated by their legal migrant status and reinforced by the absence of federal aid and lack of attention given to their poor living and working conditions (Bonilla and Campos 1981; Portes and Rumbaut 1990). 
Table 3.1: Number and Percent of Persons of Puerto Rican Origin

\begin{tabular}{|l|c|c|c|c|}
\hline Geography & 1970 & 1980 & 1990 & 2000 \\
\hline \multirow{2}{*}{ City of Miami } & 6,589 & 12,181 & 11,154 & 10,280 \\
& $(2 \%)$ & $(4 \%)$ & $(3 \%)$ & $(3 \%)$ \\
\hline \multirow{2}{*}{ Miami-Dade County } & $\begin{array}{c}(7,429 \\
(1 \%)\end{array}$ & $\begin{array}{c}45,808 \\
(3 \%)\end{array}$ & $\begin{array}{c}68,634 \\
(4 \%)\end{array}$ & $\begin{array}{c}80,305 \\
(4 \%)\end{array}$ \\
\hline \multirow{2}{*}{ Florida } & 31,600 & 98,780 & 241,563 & 478,698 \\
& $(1 \%)$ & $(1 \%)$ & $(2 \%)$ & $(3 \%)$ \\
\hline
\end{tabular}

Source: Geolytics, Inc., Neighborhood Change Database, 1970-2000, U.S. Census Bureau, Hispanic Origin Tables

Florida's earliest Puerto Ricans were wealthy families and agricultural business owners who settled in Miami in the 1940s (Duany and Matos 2006; Shell-Weiss 2009), including the family of former City of Miami Mayor Maurice Ferre. The first mass migration of Puerto Ricans to Florida was part of the contract farm worker program sponsored by the Migration Division of Puerto Rico's Department of Labor in the 1950s, and supported by the U.S. Federal government (Maldonado 1979). During the 1950s, Miami formed part of the national agricultural labor circuit, which, particularly during the winters, brought thousands of Puerto Rican as well as other Latin American and Caribbean migrant workers to Southern Dade County to harvest vegetables during the Winter (Duany and Matos 2006; Shell-Weiss 2009). Puerto Ricans' citizenship facilitated their shift into other job sectors in the region, including the growing retail service and apparel manufacturing sectors in the cities of Miami and Miami Beach. According to my interview respondents, affordable rents and proximity to these jobs drew workers to Wynwood. Growth in this small community during the 1950s and 60s was also fueled by Puerto Ricans migrating from the northeastern U.S. and from the island looking for work in Miami's growing service sectors. The growing concentration of Puerto Ricans in 
Wynwood led to the area becoming known as Little San Juan, and in 1973 Wyndwood Park in the heart of the neighborhood was renamed Roberto Clemente Park, after a famous Puerto Rican baseball player.

Although my interview respondents and a few newspaper articles indicate that there were many Puerto Ricans in Wynwood by the 1950s, there is no neighborhood level Census data to confirm precisely how many were living there prior to 1970 . Remaining mindful of the undercount problems noted above, I examine Census Tract enumerations for Hispanics of Puerto Rican Origin since the year 1970. Table 3.2 below reports the number and share of Puerto Ricans in the central city tracts where they were most concentrated from 1970 to 2000 . Table 3.3 examines their concentration in these central tracts as compared to Puerto Ricans in the rest of the City of Miami and Miami-Dade County. Figure 3.1 depicts the distribution of Puerto Ricans throughout the county in 1970 and Figure 3.2 reveals the change in this distribution between 1970 and 2000.

Two basic patterns are clear. (1) Puerto Ricans' share of the population of these central city tracts, particularly the single tract comprising the northern half of Wynwood, peaked in 1980. (2) While these central city tracts had the highest concentration of Puerto Ricans in 1970, the Puerto Rican population was and has increasingly become dispersed throughout the Central City and the County. In the two tracts that comprise Wynwood there were 1,236 Puerto Ricans, only one-fifth of the Central City's Puerto Rican population in 1970. The height of Puerto Ricans' concentration in Wynwood was in 1980, when Census counts reported that almost one-third of the residents in census tract 26 (Wynwood's northern half) were of Puerto Rican origin (Table 3.2). This single tract is the area now considered "Little San Juan." There were 2,577 Puerto Ricans in the six 
central city tracts where they were most concentrated in 1970 (Table 3.2), comprising the contemporary boundaries of Wynwood, Allapattah, Edgewater and Buena Vista (also known as the Design District and southern edge of Little Haiti). These six tracts accounted for about 39 percent of the Puerto Rican population in the City of Miami and about 15 percent of the county-wide total (Table 3.3). Moreover, these tracts' share of the central city- and county-wide Puerto Rican population has progressively declined since 1970.

There is no neighborhood level data on the socio-economic characteristics of Puerto Ricans in Wynwood. My field research experiences revealed that many of Wynwood's Puerto Ricans worked in the retail service sector or as agricultural laborers when they migrated to Miami in the 1950 through 70s. Less clear is the extent to which neighborhood residents and specifically Puerto Ricans found jobs in the nearby Garment District before the industry declined in the 1980s. Shell-Weiss (2009, p. 144) estimates that similar to New York and New Jersey, where most of Miami's manufacturers had relocated from (and brought their ethnic hiring practices), at least one-third of the garment manufacturing workforce in Miami around 1950 must have been comprised of Puerto Ricans; Cuban-Americans, ${ }^{36}$ African-American and Black West Indians made up the rest. ${ }^{37}$ Despite the lack of statistical information, it seems likely that during the 1950 s

\footnotetext{
${ }^{36}$ Shell-Weiss' used the term "Cuban-Americans" to identify those Cubans who had lived and worked in the U.S. for several years as opposed to seasonal Cuban workers or those who arrived after the 1959 revolution and considered their stay temporary.

${ }^{37}$ Discussed below, Shell-Weiss's (2009, pp. 158-165) analysis of the International Ladies Garment Workers' Union (ILGWU) records reveals organizing and protest activity that involved Puerto Ricans, Cuban-Americans and African-Americans.
} 
some of the Puerto Ricans in Wynwood, where most of Miami's Puerto Ricans were concentrated, were working in the apparel factories nearby.

I interviewed ${ }^{38}$ two former garment manufacturers who recalled that their workforce during the 1960s and 1970s was mostly "Cubans and Blacks." Of another eight interview respondents who lived in Wynwood during or since the 1950's (6 Puerto Ricans, 1 Cuban-American and 1 born in the U.S. to Cuban and Puerto Rican parents), ${ }^{39}$ two Puerto Ricans were career seamstresses. The other four Puerto Rican respondents ${ }^{40}$ (one of whom is married to one of the seamstresses) could not identify or recall any other Puerto Ricans working in the garment industry during the 1950 or 1960 s, although most opined that some Puerto Ricans held these occupations. These respondents offered the explanation that the Wynwood garment factories had closed and relocated so long ago (citing the 1970s at the latest) that they either could not recall or that this job sector had largely disappeared from the neighborhood by the time they arrived.

Instead, my interview respondents (including other more recent Puerto Rican migrants and Wynwood residents) and other evidence ${ }^{41}$ suggest that most of the Puerto Ricans who moved to South Florida before 1970 were former farm workers who found work in the service sector as dishwashers, janitors, cooks, bakers, laundry workers, construction laborers or gardeners. Many of the Puerto Ricans who migrated to the South Florida during the 1950s and 60s initially worked as agricultural laborers-either in

\footnotetext{
${ }^{38}$ Both Jewish - one from Cuba and the other from New York and who, respectively, operated in Miami since the early 1950's and mid-1960's.

${ }^{39}$ Among the Puerto Rican respondents were two married couples.

${ }^{40}$ The U.S.-born respondent of Puerto Rican and Cuban parentage self-identified as a "half Puerto Rican American".

${ }^{41}$ See Maldonado (1979), Grosfoguel (2003), Duany and Matos-Rodriguez (2006).
} 
southern Dade County (Homestead) or in the northeastern U.S. (e.g., Pennsylvania, New York) before moving to Miami. Many others worked in manufacturing and service industries of the northeast before migrating south. A history of labor recruitment dating back to at least World War I and intensifying in the post World War II era established formal and informal migration networks that led to the creation of places like New York's Spanish Harlem (Maldonado 1979; Portes and Grosfoguel 1994) as well as Wynwood. For many of Miami's Puerto Ricans, harsh conditions in the agricultural "labor camps" ${ }^{42}$ and their status as US citizens prompted them to seek work in the growing service economies of the cities of Miami and Miami Beach in the 1950 and 60s.

\footnotetext{
${ }^{42}$ A series of newspaper articles exposed the illegal recruitment and exploitation of Puerto Rican farm workers in Miami and Florida during the 1950s (Roberts 1954a, 1954b, 1954d, 1954e). In 1974, at the request of local community leaders concerned about ongoing abuses, the Miami Regional Office of the Migration Division of the Puerto Rico Department of Labor was created to study the living and working conditions of Puerto Ricans (OGPRUS 2006). The Miami office existed until 1984 and documented abuses dating back to 1961 .
} 
Table 3.2: Puerto Ricans as a Share of the Total Population of Selected Census Tracts, Miami-Dade County and Central City, 1970-2000

\begin{tabular}{|c|c|c|c|c|c|c|c|c|c|c|c|c|c|}
\hline \multirow[b]{2}{*}{ Neighborhood } & \multirow{2}{*}{$\begin{array}{l}\text { Census } \\
\text { Tract }\end{array}$} & \multicolumn{3}{|c|}{1970} & \multicolumn{3}{|c|}{1980} & \multirow{2}{*}{$\begin{array}{c}1990 \\
\text { PR }\end{array}$} & \multirow[b]{2}{*}{ Total } & \multirow[b]{2}{*}{$\%$} & \multirow{2}{*}{$\begin{array}{c}2000 \\
\text { PR }\end{array}$} & \multirow[b]{2}{*}{ Total } & \multirow[b]{2}{*}{$\%$} \\
\hline & & PR & Total & $\%$ & PR & Total & $\%$ & & & & & & \\
\hline Buena Vista E. & 2201 & 298 & 4,198 & $7 \%$ & 265 & 5,461 & $5 \%$ & 177 & 5,688 & $3 \%$ & 106 & 4641 & $2 \%$ \\
\hline Vista W. & $80 ?$ & 404 & 6,511 & $6 \%$ & 492 & 7,641 & $6 \%$ & 405 & & $6 \%$ & 369 & & $6 \%$ \\
\hline Alla & 500 & 301 & 8,134 & $4 \%$ & 1,318 & 8,707 & $15 \%$ & 738 & 8, & $9 \%$ & 780 & 11,542 & $7 \%$ \\
\hline Edge & 2702 & 338 & 4,012 & $8 \%$ & 410 & 2,816 & $15 \%$ & 198 & 1,894 & $10 \%$ & 92 & 1,453 & $6 \%$ \\
\hline Wynwood N & 00 & 837 & 5,173 & $16 \%$ & 1,513 & 4,862 & $31 \%$ & 1,214 & 4,530 & $27 \%$ & 779 & 4,175 & $19 \%$ \\
\hline Wynwood S. & 2800 & 399 & 3,156 & $13 \%$ & 256 & 2,265 & $11 \%$ & 346 & 1,767 & $20 \%$ & 164 & 1,293 & $13 \%$ \\
\hline \multicolumn{2}{|c|}{6 Central City Tracts: } & 2,577 & $31,184^{*}$ & $8 \%$ & 4,254 & $31,752 *$ & $13 \%$ & 3,078 & $28,940^{*}$ & $11 \%$ & 2,290 & $28,984 *$ & $8 \%$ \\
\hline
\end{tabular}

* Total for six census tracts

Note: Selected Census Tracts with the largest concentrations (more than 250) of Puerto Rican residents in 1970.

Source: Geolytics, Inc. ,Neighborhood Change Database, 1970-2000, U.S. Census Bureau

Table 3.3: Puerto Ricans in Selected Central City Census Tracts as a Share of Total Puerto Ricans, City of Miami and Miami-Dade County, 1970-2000

\begin{tabular}{|c|c|c|c|c|c|c|c|c|c|c|c|c|}
\hline & \multicolumn{3}{|c|}{1970} & \multicolumn{3}{|c|}{1980} & \multicolumn{3}{|c|}{1990} & \multicolumn{3}{|c|}{2000} \\
\hline & No. & $\begin{array}{l}\text { Pct. of } \\
\text { City }\end{array}$ & $\begin{array}{l}\text { Pct. of } \\
\text { County }\end{array}$ & No. & $\begin{array}{l}\text { Pct. of } \\
\text { City }\end{array}$ & $\begin{array}{l}\text { Pct. of } \\
\text { County }\end{array}$ & No. & $\begin{array}{l}\text { Pct. of } \\
\text { City }\end{array}$ & $\begin{array}{l}\text { Pct. of } \\
\text { County }\end{array}$ & No. & $\begin{array}{l}\text { Pct. of } \\
\text { City }\end{array}$ & $\begin{array}{l}\text { Pct. of } \\
\text { County }\end{array}$ \\
\hline $\begin{array}{l}6 \text { Central } \\
\text { City Tracts }\end{array}$ & 2577 & $39 \%$ & $15 \%$ & 4254 & $35 \%$ & $9 \%$ & 3078 & $28 \%$ & $4 \%$ & 2290 & $22 \%$ & $3 \%$ \\
\hline $\begin{array}{l}\text { Rest of } \\
\text { Central City }\end{array}$ & 4,012 & $61 \%$ & $23 \%$ & 7,927 & $65 \%$ & $17 \%$ & 8,076 & $72 \%$ & $12 \%$ & 7,990 & $78 \%$ & $10 \%$ \\
\hline $\begin{array}{l}\text { Rest of } \\
\text { County }\end{array}$ & 10,840 & & $62 \%$ & 33,627 & & $73 \%$ & 57,480 & & $84 \%$ & 70,025 & & $87 \%$ \\
\hline
\end{tabular}

Note: Selected Central City Tracts are those with the largest concentrations (more than 250) of Puerto Rican residents in 1970.

Source: Geolytics, Inc. ,Neighborhood Change Database, 1970-2000, U.S. Census Bureau. 
Figure 3.1: Map of Persons of Puerto Rican Origin, Miami-Dade County, 1970

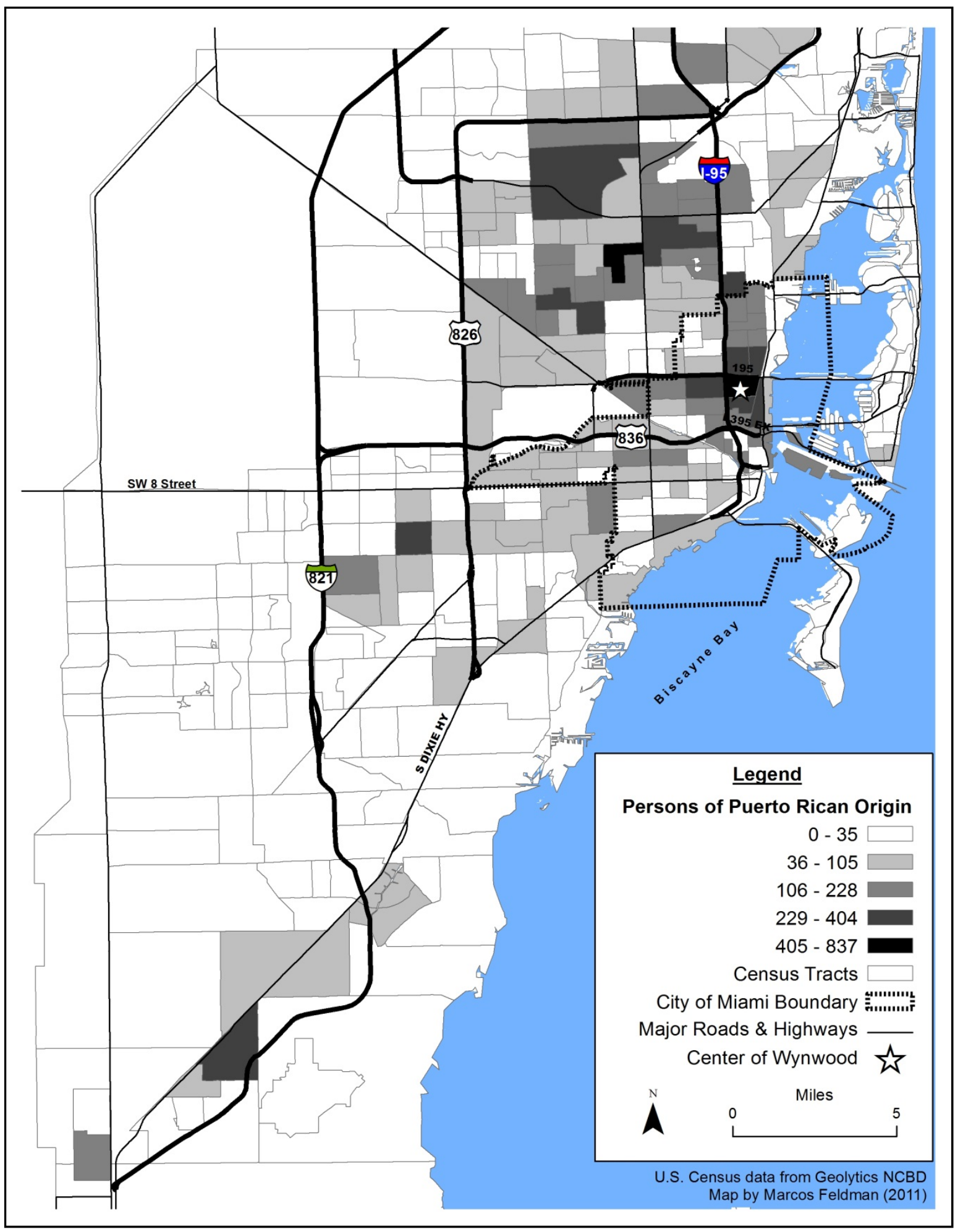


Figure 3.2: Map of the Change in Persons of Puerto Rican Origin, Miami-Dade County, 1970-2000

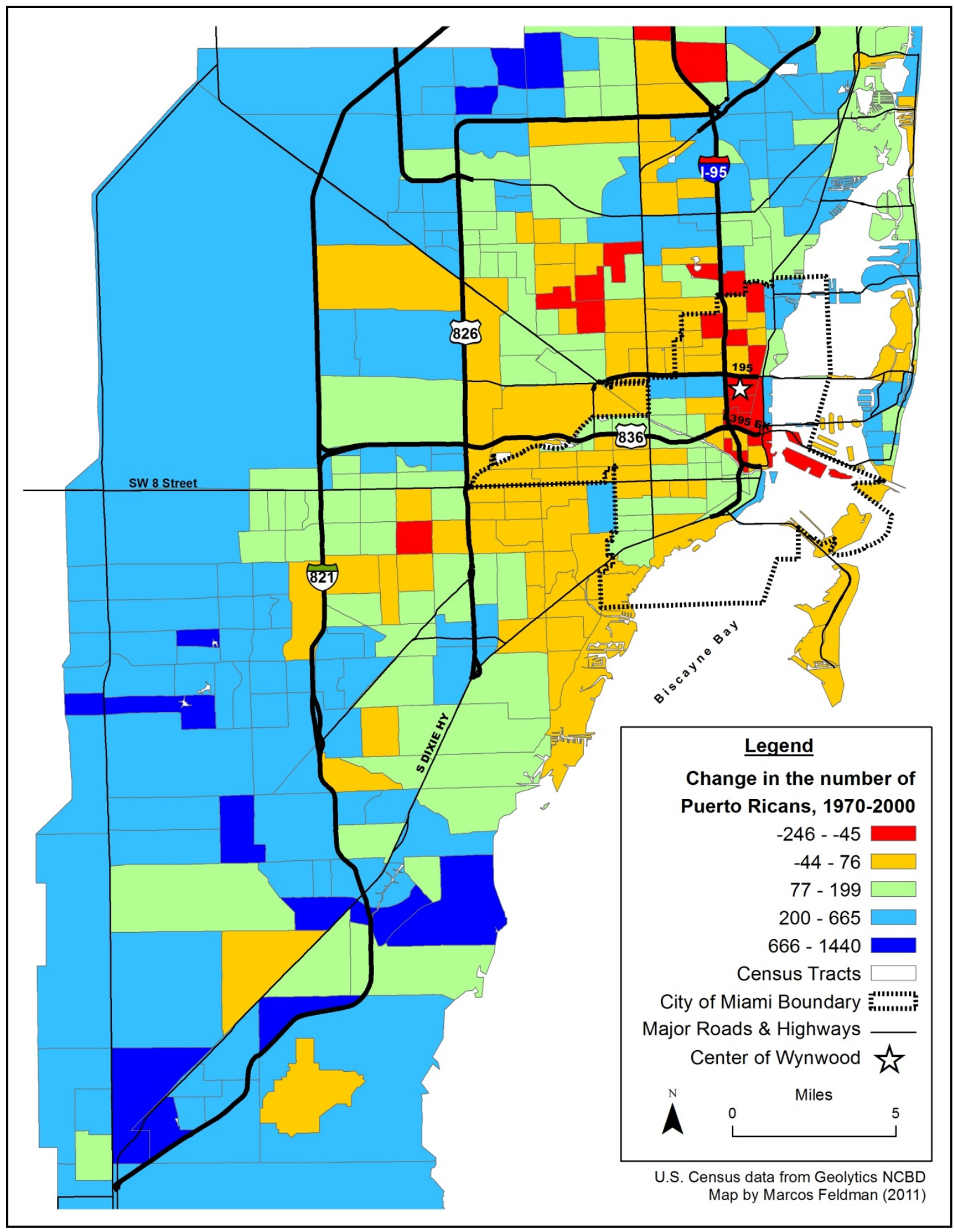




\section{$\underline{\text { Migrant Profiles }}$}

Wilfredo ${ }^{43}$ migrated to Homestead in Southern Miami-Dade County from his rural town near Arecibo, Puerto Rico in 1962, where he grew up among sugar cane cutters. When he was 26 he joined one of the "va y viene" (come and go) circuits that have characterized the lives of many Puerto Ricans (Duany 2002). After three years of working in fields in Homestead he moved to the City of Miami to look for work in restaurants which he heard about from other Puerto Ricans living in the vicinity of Wynwood. He recalled that this work was "better" because it offered "more money, [was] cleaner, and not as sad as working in the fields." He moved to the eastern edge of Wynwood (the boundaries of which were then thought to extend east to the Biscayne Bay shoreline), found work as a busboy in a small restaurant on Biscayne Boulevard, and enjoyed living and working in an area where Puerto Ricans socialized in cafes, on the street and in their front yards and porches. Within a couple of years he was training as a baker at a different restaurant closer to his apartment in Wynwood, where he remained for 12 years and became the head baker. It was working in the bakery where he met his next landlord and future wife, Serena, who was from the central mountainous region of Atuado, Puerto Rico, and who also migrated to Miami in 1962. By the 1970s when the two met in the bakery, Serena was a sewing machine operator (producing wigs) in a Jewish-owned factory in Wynwood's Garment District. She eventually supervised other garment workers, mostly Cubans, Haitians and African-Americans, while Wilfredo shifted into construction work in the 1980s and, after Hurricane Andrew in 1992, opened a roofing business.

\footnotetext{
${ }^{43}$ Interview in Spanish with Wilfredo and Serena in their Wynwood home, January 14, 2011.
} 
Carlos and Maria, ${ }^{44}$ who both grew up in the same small village near Camuy, Puerto Rico, settled together in Wynwood in 1960. Carlos first migrated to the U.S. in 1956, recruited by his uncle to work on Pennsylvania farms picking cabbage, tomato, parsley and other crops. When the harvest ended he returned to Puerto Rico and the following year decided to follow a different uncle to Miami, where he moved in with a Puerto Rican family living on $11^{\text {th }}$ Street near NE $2^{\text {nd }}$ Avenue, in the uncertain edges between Wynwood and Overtown, a historic African-American neighborhood. Through his uncle, he immediately found a job at the Algiers hotel on Miami Beach "grabando discos," a Puerto Rican “Spanglish" term for washing dishes (see Miller 1978).

Throughout the late 1950s Carlos moved between Miami and Camuy, brought his brother to live with him and married and brought Maria to live together with his aunt and uncle, only for her to return to Puerto Rico the next year when she became pregnant. In 1960, after their first daughter was born, Maria returned to Miami and they settled in a two bedroom apartment on $25^{\text {th }}$ Street for $\$ 50$ in monthly rent. The va y viene continued as each of their children was born and spent their first 4-6 months on Puerto Rican soil. As the 1960s advanced and their children were born, the couple also brought Maria's grandmother to live with them as well as several of their younger siblings who settled in Wynwood apartments. Carlos took several of his brothers to work with him in Miami Beach hotels. After all her children were in school, in the late 1960s Maria took her first job at a large laundry service a block from home and eventually worked as an assistant in the offices and cafeteria at Buena Vista Elementary, the neighborhood school. Their

\footnotetext{
${ }^{44}$ Interview in Spanish with Carlos and Maria at their home, December 8, 2010, and phone interview in English with their son, Carlos Jr., who lives in Washington D.C., December 27, 2010.
} 
youngest children attended Buena Vista briefly during the early 1960s before racial integration caused them to transfer to formerly all-black schools near Overtown. In the 1970s they participated in a religious after-school program affiliated with the nearby Wynwood Catholic Church (Cantero 1976; Rodriguez 1979). Like Carlos and Maria, their three children grew to become leaders in Wynwood, particularly their only son, Carlitos.

Born in Utuado, Puerto Rico, Felipe arrived in Miami in 1953 when he was 7 years old. His father's first experience in the U.S. had been as a migrant worker in 1948, when he spent the northern sowing and harvest seasons on farms in Connecticut and Massachusetts and during the winter moved south to work the fields in Homestead in southern Miami-Dade County. After spending the next season back home in Puerto Rico, his father returned to South Florida in the summer of 1949 and worked as a busboy in a Miami Beach hotel and the following year as a waiter. He worked this way until he saved enough to move his large family to Miami in 1953, a few children at a time. The family's first apartment was on $23^{\text {rd }}$ Street in Wynwood, in the heart of the Garment District, and later on $36^{\text {th }}$ Street, near where intersecting interstate highways (I-95 and I-195) were built. In the 1960s Felipe's father became a City of Miami groundskeeper at Wyndwood Park. Like Carlos and Maria's children, Felipe attended neighborhood schools before they integrated. Before he graduated from college, in 1969, he bought his first business in Wynwood, a Puerto Rican restaurant and bar. After college he opened several additional businesses in the neighborhood and eventually became one of the neighborhood's largest property owners. As I will discuss in greater detail later, despite moving in 1969 from 
Wynwood to a north Miami suburb, his status as a successful entrepreneur made him an important community leader and neighborhood representative in public affairs.

Of an older generation, Elsa ${ }^{45}$ was born in Puerto Rico in 1909 but lived briefly in Santiago, Cuba, as a child before migrating with her mother after World War I to Brooklyn, New York. There she finished high school and gained her first work experience. By the 1930s she was a seamstress in a Manhattan garment factory, a job she held for nearly 20 years and during which time she married and divorced an Italian man before remarrying a Puerto Rican taxi driver. In 1951, Elsa sold her Brooklyn apartment and relocated with her husband to Miami. After a series of moves between different apartment houses in the vicinity of Wynwood, in 1957 they bought a small house on $34^{\text {th }}$ Street where they lived out the remainder of their lives. Her husband worked as a mechanic in Miami before his health deteriorated in the 1980s, while she transitioned from her first job in a senior center lunchroom to a better paying job developing photographs in a nearby laboratory, which she held for more than 20 years. However, Elsa was best known for her community service and activism, which I will discuss later. Thinking back to her first years in Wynwood, Elsa recalled how the neighborhood was "mostly Americans" and a few Cubans, and listed the occupations of her closest neighbors: a lawyer, a water heater mechanic, the principal of Buena Vista Elementary, the owner of a hardware and paint store, the neighborhood pharmacist—-all Americans around here, there were no Puerto Ricans. We were the first that invaded this [area].” Although Elsa was joking, many local authorities and residents came to view the Puerto Rican influx as an invasion (see chapter 2).

\footnotetext{
${ }^{45}$ Interview with Elsa in her home, November 19, 2010, in English and Spanish.
} 
Puerto Ricans were stigmatized by newspaper coverage in the 1950s but received little attention in the 1960s, in the midst of the Cuban influx and the dramatic transformation of inner city neighborhoods through urban renewal discussed in Chapter 2. By the 1970s, Puerto Ricans had become the largest "minority" group in Wynwood, replacing the out-moving middle-class families of Anglo-Americans and Cuban exiles. Wynwood also became home to many other low-income immigrants, including Dominicans, Cubans, Haitians and Central Americans, and continued to serve as a "springboard" for many on their way to other neighborhoods. But as a small, inner city neighborhood with high rates of poverty and no single ethnic or racial group as a super majority, Wynwood was relatively ignored in the urban political arena until the "awakening" of the Puerto Ricans (Inclan 1972a). Their entry into local politics was shaped by U.S urban policy and specifically the emerging and evolving "community development" system.

\section{The Ethnic Politics of U.S. Community Development}

Unlike most Western European countries, urban renewal policy in the United States has always emphasized decenralization and devolution of authority to localities and this has led, with few exceptions, to partnership with (if not total control by) nongovernmental organizations and private companies in the delivery of social services and affordable housing (Fainstein and Fainstein 1978, 1985). As noted above and has been well documented elsewhere (e.g., Judd 1988), partnerships with the private sector led the original urban renewal programs to emphasize demolition and clearance, at the expense of low-income housing construction, relocation assistance and comprehensive social 
services. These failures and the political pressures created by grassroots mobilization across the country gave rise to "Federal Activism," evident most notably in civil rights legislation and anti-poverty programs, particularly the Economic Opportunity Act of 1964 enacted as part of the broader "War on Poverty."

The 1960s federal "War on Poverty" created the Office of Economic Opportunity (OEO) and a new vehicle for community planning and activism in localities, the Community Action Agency (CAA). The mission of the CAA was resident empowerment to improve local conditions, shaped by the central principle of the Community Action Program (responsible for oversight of the CAAs) of "maximum feasible participation" of community members in local politics (Judd 1988, p. 317). Community Action Agencies distributed funds to local community-based organizations (CBOs), although the first rounds of this funding (1965-66) supported relatively few organizations because the federal program's initial focus on maximum participation was implemented as a "demonstration project" (Fainstein 1987; Judd 1988). The War on Poverty programs were as much a response to the pressures of the civil rights movement as reflective of the need of the Democratic Party to increase voter turnout in low-income, black communities (Judd 1988; DeFilippis 2004). These programs were also a key shift in the political opportunity structure of federalism, which, by introducing new resources and mobilizing structures, affected the "collective action repertoire" of community-based activists and organizations (McAdam 1999; Bockmeyer 2003).

While the impact of CAAs on political mobilization varied greatly across cities, by 1967, their explicitly political agenda (in several major cities, CAAs had become vehicles for militant, community-based activism) was "sufficiently threatening or 
persuasive to precipitate [another] change in national urban policy" (Fainstein 1987, p. 328). New federal legislation changed the nature of government-funded community organizations from political organizing (reinterpreting the "maximum feasible participation" clause) to social service and economic development activities, facilitating the program's rapid expansion into the 1970s (Judd 1988, pp. $316-321) .{ }^{46}$ Under Nixon's "New Federalism" in the 1970s, the OEO was terminated and the CAA program shifted into the newly created Community Services Administration. This shift marked the beginning of a "new urban policy" created through a series of initiatives during the Nixon administration (Stoecker 1997; Reed Jr. 1999; Defilippis 2004; Newman and Lake 2006), including the transformation of federal grant programs into general revenue sharing and block grants for states and cities. This gave local policymakers control of the funds, rapidly eroding the direct link between the federal government and urban $\mathrm{CBO}$ stakeholders (Defilippis 2004; Newman and Lake 2006).

Federal Revenue Sharing (FRS) granted local officials considerable spending discretion and, in most large cities, the majority of funds went to essential services (e.g., fire, police), and basic infrastructure maintenance, while typically less than one-third of funds were devoted to social services for low-income residents (Judd 1988, pp. 340-344). The Housing and Community Development Act of 1974 (CDA) blended the Republican Party's interest in decentralizing urban policy with Democrats' efforts to increase funding

\footnotetext{
${ }^{46}$ The number of CBO's nearly doubled from 650 funded in 1965 to 1,100 in 1967 (Ibid, p. 317). The shift in priorities began through the passage of the Special Impact Program amendment to the OEO in 1966 and was furthered by the supplemental Federal Community Self-Determination Act in 1969 (note the "selfhelp" language). The other component of the shift towards entrepreneurial community development occurred through the Model Cities Program, designed "to place the control over antipoverty [and] neighborhood development policies back into the hands of city governments - and explicitly away from the hands of communities" (DeFilippis 2004, p. 42).
} 
for social services and, especially, subsidized housing. The resulting CDA also consolidated numerous categorical grant programs into a single block grant to local governments. Like FRS, Community Development Block Grants (CDBG) could be spent on a variety of basic urban needs and services, but the CDA funding was targeted to lowincome neighborhoods ("Target Areas"), defined through planning research also funded by the program. A final piece of legislation worth mentioning because of its relevance to Wynwood during the 1970s was the Comprehensive Employment Training Act (CETA), which expanded the payrolls of local government in part to administer CDBG and FRS funded programs.

During the 1970s, funding for CBOs — especially FRS, CDBG, and CETAshaped the political environment in which Wynwood was constituted as a Puerto Rican place. These programs created a political constituency in the community development sector which would structure neighborhood residents' engagement with the broader urban political arena for years to come. By the 1980s, national urban policy would change again, intensifying the entrepreneurial turn in community development practice, introducing new political opportunities, resources and mobilizing structures and further shaping activists ways of thinking and acting. Bockmeyer (2003, p. 177) summarizes the cumulative impact of federal policy shifts and specifically CDBG funding for both service and, later, housing development organizations in the community-based sector:

Decentralization together with a lack of administrative coordination - as found in the United States - can be expected to multiply the points of access for citizens. At the same time, fragmentation discourages protest movement activism - which would be more symptomatic of centralized and repressive regimes - and instead produces cooperative or assimilative behavior (Kriesi, 1995). As a result, American devolution produces a centrifugal effect on organizers, in a fragmenting, "let a thousand flowers bloom approach" (Dreier, 1998, p. 115). The 
emergent repertoire includes the expansion of service delivery groups, while lacking social movement mobilization. Community activists are challenged to make use of dispersed access points in a collective effort. Both dispersed policy making and grant distribution shape the collective action frame... As non-profit groups increasingly implement programs, federalism becomes a complex web... in which to affect policy and its implementation, advocates must access multiple points, influence public and private sector actors, and stay ahead of the ever changing relationships between sectors.

Along with African-Americans in Overtown and Liberty City (Mohl 1999), Puerto Ricans in Wynwood were the first to respond to and benefit from the shift in federalism encouraging maximum participation and empowerment of residents in the late 1960s and early 1970s. Yet, this political opportunity closed quickly and Wynwood's leaders were integrated to the funding systems of nonprofit service provision, resulting in the "lacking social movement mobilization" noted by Bockmeyer (2003, p. 177). The following section describes the development and change of these structural influences on collective action in Wynwood as well as the internal conditions of the Puerto Rican community in Miami that contributed to its fragmentation and weakened potential for social movement activism.

Wynwood's Puerto Rican “Awakening”

The 1970s in Wynwood were defined by Puerto Rican leaders' "awakening" (Inclan 1972a) to political opportunities to obtain social services for the neighborhood's “forgotten" residents (Ousley 1993a). Through the politics of CBO funding, these individuals created lasting organizations through which future generations of Puerto Rican leaders would be employed and that engaged residents in local politics. In the following decades the leadership would become less Puerto Rican, reflecting the growing 
diversity of the neighborhood's residents. But the 1970s generation of Puerto Rican leaders made possible the symbolic constitution of the neighborhood as a Puerto Rican place. Morevoer, the rise of this Puerto Rican leadership and its evolution over time also reflected the impact of federal urban policymaking and local implementation. By the 1980s, when the urban agenda of the federal government was nearly eliminated, space was created (out of need and/or opportunity) for non-government funded organizations to help fill the void of shrinking social services and to mobilize residents politically.

\section{$\underline{\text { Puerto Ricans United }}$}

Prior to 1968, in Wynwood there were no social service agencies based in the neighborhood and virtually no grassroots efforts to obtain political representation or social services for neighbrohood residents. ${ }^{47}$ In 1968 an office of the Christian Community Service Agency (CCSA), an interdenominational organization funded through a network of local and national churches,${ }^{48}$ was established in Wynwood with an open-ended mission to help residents (Inclan 1972a). Although the CCSA was founded in 1965 to serve residents throughout Miami-Dade County, the organization was immediately overwhelmed by the needs of Cuban exiles arriving on the "Freedom Flights" and refugee resettlement became its primary function (Glass 1967; Johnson-King 1969). By the late 1960s, however, CCSA shifted away from this work and "back to" its mission of helping local "minority" groups, according to its director (Johnson-King 1969,

\footnotetext{
${ }^{47}$ Sporadic interventions by state and local prosecutors on behalf of Puerto Rican migrant workers occurred in response to complaints and newspaper coverage of the poor condition of their housing, but there were no systematic or sustained organizing efforts these or other injustices in Wynwood.

${ }^{48}$ Although the CCSA received federal anti-poverty funding for its county-wide services (particularly Cuban refugee resettlement), it is not clear whether any federal funding supported the work in Wynwood.
} 
p.10A). The faith-based organization opened branches in different neighborhoods, including Liberty City and Wynwood, where its work evolved into organizing the poorest residents to address different injustices they faced. ${ }^{49}$

In Wynwood, the CCSA's work began as a one-man operation under Jose Molina, a priest and former radio talk show host from Honduras (Inclan 1972a; Brownstein 1980; Hancock 1992). Molina rented a cheap apartment in Wynwood but practically lived out of his car during his first year of knocking on residents' doors, getting to know their troubles and needs, and helping them obtain different kinds of services on a case by case basis (Ibid). Activists and leaders from the 1970s as well as newspaper accounts (Inclan 1972a; Brownstein 1980; Hancock 1992) credit Molina with catalyzing organizational and political action in the neighborhood. ${ }^{50} \mathrm{He}$ trained some vocal residents and service workers on how to organize inside the community and in relation to local government. Molina and other CCSA staff were able to sustain their initial organizing efforts well into the 1970s through the Wynwood Community Project, funded by the United Methodist Church from 1972 to 1974 (The Voice 1971; Cruz 1974; Brownstein 1980). ${ }^{51}$ From 1968 to 1969 , the Honduran was instrumental in organizing 12 neighborhood leaders into a group that became known as Puertorriqueños Unidos [Puerto Ricans United, PRU], also dubbed the "12 apostles" by some neighborhood residents.

\footnotetext{
${ }^{49}$ In Liberty City, for example, CCSA "social workers" helped to organize a tenant union and initiate a rent strike against slumlords (Ash 1967).

${ }^{50}$ The neighborhoods primary spokesperson in the 1970s, Rodrigo, described below, credited Molina with advancing his political and professional development as well as that of other Puerto Ricans in Wynwood. "He was my mentor. He was the cause of it all. Many people give me credit for the things that happened, but he was the one behind [everything we achieved]."

${ }^{51}$ Archives of the United Methodist Church, Race and Religion Commission, Minority Self-Determination Grants: Wynwood Community Project, 1972-1974.
} 
Under the guidance of Molina, by 1972 the PRU led by its main spokesperson and President, Rodrigo, began routinely mobilizing hundreds of Wynwood residents, mostly Puerto Ricans, and campaigning at City and County Hall and through the local newspaper for more attention, services and control over resources (Inclan 1972a, 1973a, 1973b; Handros 1973; Cruz 1974). Although Wynwoods' Puerto Rican leaders spoke out on a number of issues - the deterioration of Wyndwood Park, the need for bilingual education (an issue ultimately addressed by Cubans), the unintended hazards of school desegregation (e.g., children having to cross different neighborhoods to get to school), the lack of Puerto Rican representation in government agencies, the need for small business loans (Inclan 1972a, 1973a, 1973b; Handros 1973; Cruz 1974)—- they were confronted with a local City and County government which had total control over the kinds of programs that could be funded and the fact that the Puerto Rican vote within the City of Miami was numerically insignificant. On the one hand, their inability to challenge funding decisions politically meant that by the mid-1970s the PRU leaders' actions were shaped by the "citizen participation" processes through which funding priorities were effectively manipulated by city officials. On the other hand, realizing this, they also increasingly focused on mobilizing Puerto Rican voters through the Organizacion Democratica Puertorriqueña (or Puerto Rican Democrats, ODP).

As the story goes, Rodrigo grew up so poor in Mayaguez, Puerto Rico, that he had to stuff newspapers in his shoes to cover the holes. Before moving to Miami in 1963, Rodrigo spent the 1950s in between New York, Puerto Rico and serving in the U.S. Marines, during which time he also took some college courses. In Miami, as he recalled, "I dedicated myself to study and fight." For a few years, he worked in retail stores and 
later as an officer in a juvenile justice center, before returning to college and ultimately earned a masters degree in guidance counseling, in addition to various certifications in medical services. His involvement in Wynwood began not as a resident but as a counselor in a neighborhood school, Buena Vista Elementary, in the late 1960s. "I found so much need, I started to take kids from school in my car to Jackson Memorial Hospital and to the different places where they needed services, and that's [how] I started to get recognized by the community." Recognition by community members led to Rodrigo's designation as President of the PRU. He also became the primary (but not the only) spokesperson for the neighborhood in governmental affairs.

In 1972 Miami-Dade County's Community Relations Board (CRB, comprised mostly of public officials and civic and business leaders) held a series of public meetings to gather resident input on priorities for spending money from different federal and local programs (Inclan 1972b). One of the programs for which proposals were solicited was the U.S. Department of Health, Education and Welfare's (HEW) Public Service Grants, which went directly to community organizations but were vetted through local authorities. The timing of the solicitation was crucial. Under President Nixon, federal urban funding was shifting from categorical social purpose grants to federal revenue sharing and eventually, consolidated block grants. The last year that local organizations could be funded directly was $1973,{ }^{52}$ although by then Nixon had given local mayors "a coveted veto power" over federal grant applications (Judd 1988, p. 344).

\footnotetext{
${ }^{52}$ Some of this direct funding was transformed into special categorical programs, such as funding for nonprofit health clinics. But after 1972, local authorities would always have some role to play in the relationship between community organizations and federal funding programs.
} 
An outcome of the first meeting (held at The Miami Herald building), where Wynwood was represented by the PRU leaders and another "30 or 40 Puerto Ricans" from the neighborhood, ${ }^{53}$ was the formation of a loose-knit network of Latino leaders, including Cubans in Little Havana, Mexicans in Homestead and the PRU leadership (Inclan 1973b). ${ }^{54}$ Rodrigo recalled that at the meeting "all the local universities and everybody else was there, and they wanted the money to do research. I stood up and said, 'No, you're not going to do that. We're tired of being studied. What we really need is action!" In an attempt to structure the process, federal HEW officials at the meeting asked the cohort of Latinos to organize their respective national groups - Cubans, Puerto Ricans and Mexicans - into a 15-member coalition with even ethnic representation and to make a specific proposal from each group after consulting with neighborhood residents. The United Way of Miami, which served as fiscal agent for some federal programs, hosted subsequent CRB meetings to help evaluate and recommend one specific proposal from each group, as well as sponsor their travel to Atlanta to present their proposal to the HEW.

In Wynwood, meetings took place in the living rooms of PRU leaders, particularly Carlos, ${ }^{55}$ who organized the neighborhood's Puerto Rican Little League and

\footnotetext{
${ }^{53}$ According to Rodrigo, not all of the PRU leaders or their supporters lived in Wynwood. Several lowincome, politically active Puerto Ricans lived in Homstead as well as the Larchmont Gardens public housing project in what is now known as the northern edge of the Little Haiti neighborhood. Larchmont Gardens was in notoriously bad condition (Florida Grand Jury 1985; Miami Herald 1998) and was eventually privatized and redeveloped into condominiums (Miami-Dade County 2006).

${ }^{54}$ According to former PRU leaders, the link between the Puerto Ricans and other Hispanic groups in political work was the ODP, which worked with Cubans in local and state electoral campaigns and had been involved in efforts to help Mexican and Puerto Rican farm workers in Homestead.

${ }^{55}$ Carlos Jr. recalled how during his this period of his childhood, "our house was a hotbed of social [activism]... it was always very active. Folks coming in and out of it all the time, the Rodrigo's of the
} 
was heavily involved in the ODP. A consensus was reached to request funds to start a community-based Health Clinic. The United Way sent the "Dade Delegation" to Atlanta where a two-page proposal and oral presentation by the Puerto Rican Group of Five ${ }^{56}$ won approval for $\$ 145,000$ for the first year of the clinic's operation. But the funds would not be disbursed without a more detailed plan and the group would have to return to Atlanta within a few months to make a final presentation. After consulting with Puerto Rican associates in New York "since they're so advanced in [Puerto Rican] community issues," Rodrigo decided it was too expensive to rely on outsiders and instead "a group of four at my house," including a Puerto Rican architect who worked for free, “ended up writing the project without knowing anything about clinics." The second trip to Atlanta was supported by a neighborhood fundraiser, "a pesetita y a peso" (a penny here, a dollar there), so that neighborhood residents could join the Group of Five. The project's final approval not only founded a Puerto Rican-named health clinic and resulted in "the biggest celebtation you can imagine in Wynwood," but by "beginning to do what we did, then we became recognized as the Puerto Rican neighborhood."

More precisely, what they did led to a shift in perception both within and from outside the neighborhood. The naming of a major Puerto Rican institution in Wynwood represented a shift from the negative stigmas perpetuated in local newspapers about the neighborhood and Puerto Ricans during previous decades (e.g., El Mundo 1952, 1957; Reynolds 1953; Colbert 1957a). Wynwood was still known for poverty and slum

world or Felipe's, and the [founding] directors of the ODP. You know, they came because my father was a community organizer."

${ }^{56}$ The Puerto Rican Group of Five was more socio-economically diverse than the PRU's leadership, according to Rodrigo, reflecting the need to incorporate Puerto Ricans with professional skills to assist with the presentation. 
housing, but the area's problems were framed in increasingly sympathetic terms (Cruz 1974). Newspaper coverage of Puerto Rican symbols and cultural events in the 1970s added a positive and prideful association (The Miami News 1970; Inclan 1972a, 1976) and the neighborhood's problems were framed as "improving" through the help of social service agencies (Handros 1973; Inclan 1973a, 1973b; Rodriguez 1979).

Between 1973 and 1977, several non-profit organizations and government agencies were created in Wynwood, most of which continue to exist as the symbolic and institutional representations of Puerto Ricans' accomplishments in the neighborhood. Wyndwood Park was renovated with funds from the 1972 issue of the City's "Parks for People" Bonds and renamed Roberto Clemente Park after the famous Puerto Rican baseball player. Its inaugeration was a major event attended by the governor of Puerto Rico, Clemente's widow and son, state and local politicians and hundreds of residents. The Holy Cross Episcopal Church hosted several of Wynwood's first social service agencies. A non-profit day care center was created and housed there until it became an independent agency, Puerto Rican Child Care, Inc. (PRCC) and grew into one of the largest in the County. A lunchroom for the elderly was also established in the church. The lunchroom grew into a center for recreation and other services known as Ancianos del Encanto ("Charming" or "Enchanting" Elderly). Other agencies established during this period included a legal services branch, a "Puerto Rican mental health unit" for drug abuse counseling, and a "Puerto Rican Opportunity Center" for job training and placement services. Approved in 1975 and developed in multiple phases, in 1979 a Cityand County-funded "neighborhood service center" was inaugurated in the heart of the neighborhood to house social services for youth and elderly, and serve as a recreational 
and meeting hall for other organizations. It was named the Eugenio Maria De Hostos Center, after the Puerto Rican philosopher and independence advocate. Neighborhood seniors continue to congregate there daily to play dominos and eat lunch.

Although not "activist" in their orientation, privately-funded, faith-based organizations serving Wynwood's Puerto Ricans also emerged during this period. In 1964, just as the exodus of Anglo-American residents from the Wynwood-Allapattah area was accelerating due to expressway construction and deteriorating conditions, the Wynwood Catholic parish located there instituted the practice of neighborhood missions not only to serve the area's growing number of "Spanish-speaking" residents who "find themselves separated from their duties as Catholics" but also to reverse the decline in attendance at parish churches (The Voice 1964, p. 21). The mission system created satellite centers of religious practice throughout the neighborhood, closer to residents. The first mission, attended by 250 new Spanish-speaking ${ }^{57}$ parishoners-likely to be a mix of Cubans, Puerto Ricans and some Dominicans - took place on an empty lot in the Allapattah area. As the initial influx of Cubans increasingly moved to Miami’s suburbs, mission activities and other church services were located in the Puerto Rican sections of Wynwood. In 1970 the Centro Catolico San Juan de Puerto Rico (The Centro) was founded by Miami Archbishop Coleman Carroll "as a recognition of the specific cultural and spiritual needs of Puerto Ricans living in Miami, especially in the Wynwood community [of the] Catholic parish" (The Voice 1975, p. 2). A group of Ecuadorian nuns known as Las Hermanas Marianitas lived above a floor abve the Centro and ran an after-

\footnotetext{
${ }^{57}$ In the Miami Archdiocese' Spanish-language monthly newspaper (titled, The Voice En Español, and later, La Voz Catolica), the national origin of the Spanish-speaking parishioners is not identified in issues published in the 1960s. They are referred to as Spanish-speaking or Latin.
} 
school recreation center in addition to providing religious and cultural education, and vocational training such as sewing classes (Pena 1974, p. 2). Of the 200 Hispanic children attending the Center in 1975, about 130 were Puerto Ricans and most of the rest were Cuban (The Voice 1975, p. 2). The Centro helped cultivate "cultural pride" among the neighborhood's Puerto Ricans during the 1970s (Ibid). Particularly before the creation of the De Hostos community center, the Centro San Juan hosted festivities such as the the patriotic celebrations (known as the fiestas patronales) of St. John the Apostle, the patron saint of Puerto Rico, attended by thousands of neighborhood families as well as the PRU leaders (some of whose children attended the Centro). As I will delve into later, the Centro's closure ${ }^{58}$ in the 1980 s amidst increasing violence and declining attendance became cause for the revival of the parish mission work under new leadership, with a clear focus on political action to "take back" the neighborhood.

Aside from faith-based initiatives and the Puerto Rican health clinic, which were funded mostly by private sources (e.g., the Archdiocese and the Wynwood Catholic Church) and federal agencies, respectively, the rest of Wynwood's service organizations were created and maintained by lobbying at City Hall for community devleopment funding. ${ }^{59}$ Rodrigo's leadership in the creation of the Puerto Rican Health Clinic made him an important spokesperson for the neighborhood at City Hall.

\footnotetext{
${ }^{58}$ It re-opened in Opa-Locka, an African-American controlled municipality in the northwest of MiamiDade County, where it still operates and serves that city's growing Latin-American population, including Puerto Ricans.

${ }^{59}$ The largest sources of funding for most of these organizations was Federal Revenue Sharing (1972-1987) and Community Development Block Grants (created in 1974). Elected officials voted on the funding recommendations of Community Development staff at the City Manager's office, who received input from Community Action Agency (CAA) Advisory Boards comprised of neighborhood residents.
} 
After we started to accuse the whole world of discrimination [against Puerto Ricans], then [the City and County] started to bring the government programs with greater emphasis to Wynwood... at the beginning of the 1970s. [And later there were other] programs which they gave to me but since I didn't want to be a "poverty pimp"... I passed the programs to Christian Community Service [Agency] and they established them. So from a neighborhood that didn't have a single program, in the year after the Health Clinic [1975] we got like six or seven other programs, to help the neighborhood.

Other PRU leaders were important in early initiatives such as renovating and renaming the park and obtaining funding for the senior center. In addition to Carlos (profiled earlier), who was active in the ODP and managed youth athletic programs in the neighborhood, Benny and Felipe were influential not only as volunteer lobbyists for social service funding but also in electoral mobilization and economic development initiatives. Benny arrived from New York in 1970 as an AFL-CIO ${ }^{60}$ representative and became known as one of the most aggressive of Wynwood's activists, along with Rodrigo. Unlike Rodrigo, however, Benny lived in the neighborhood and through his daily presence was involved in development issues affecting the built environment. $\mathrm{He}$ was a member of the Community Action Agency's (CAA) Advisory Board in 1972-73 and eventually became board chairman for the Target Area containing Wynwood. Having helped to establish many of the neighobrhood's service organizations, Benny served on several of their advisory boards. In the 1980s, as urban policy took an entrepreneurial turn, Benny helped found the Wynwood Chamber of Commerce and was until his death in 1983, the founding director of a Wynwood-specific Community Development Corporation, created to support physical redevelopment initiatives in the area.

\footnotetext{
${ }^{60}$ American Federal of Labor and Congress of Industrial Organizations is the largest federation of unions in the United States.
} 
A product of Wynwood, by the 1970s Felipe was an accomplished businessman (accountant and realtor, among other interests), gradually accumulating investment ventures and properties in the area as well as becoming a campaign manager for city, county and state politicians. Felipe was a founding director or board member of several of the neighborhood's organizations: the Puerto Rican health clinic, Puerto Rican Lions Club, the Roberto Clemente baseball league, the Puerto Rican Opportunity Center, and later in the 1980s, the Wynwood Community Economic Development Corporation. After the creation of the health clinic, Rodrigo and Felipe were appointed to the Advisory Board of the City of Miami's Parks for People Bond program (in 1973 Felipe was Chair for the Park district containing Wynwood), which allocated almost $\$ 150,000$ for the renovation of Wyndwood Park and \$1.8 million for parks in surrounding neighborhoods (mainly Overtown and Edgewater). ${ }^{61}$

Felipe later served on the City of Miami's Audit Advisory Board and the Police Crime Prevention Council. Through his involvement in the ODP, he eventually became an independent campaign consultant who helped local, state and national political candidates mobilize the Puerto Rican vote. Throughout the 1970s he was a campaign coordinator for City Mayor Maurice Ferre and in 1984 he founded the Puerto Rican Democrats for Reagan. By also participating and leading in political initiatives that were broader than Wynwood, Felipe and Rodrigo became well-known throughout the City and County. This enabled them, at least during a few occassions in the 1970s, to collaborate

\footnotetext{
${ }^{61}$ Two years later Rodrigo, acting as chairman of the Parks Advisory Board for the central district, including Wynwood and Overtown, actually rescinded \$25,000 from Wynwood's allocations to help a struggling park in Overtown (MCC 3/12/75).
} 
with other Latinos, which at the time seemed an effective strategy for increasing the political clout of Hispanics. $^{62}$

Felipe described his involvement in Wynwood and his role in the PRU in the following ways, starting with a description of the business he established in the early 1970s in the neighborhood's main commercial corridor:

Not [only] accounting, a service agency where you could go to if you had a problem... We used to solve the community's problems. That's how I got involved; I used to be a social service agency for profit. I mean, I would charge nominal fees, but I would charge something.

The relationships forged through the service agency not only contributed to Felipe's ability to support political action but also served him as a real estate investor since 1975, when he began steadily acquiring properties throughout the neighborhood. By learning about and helping his clients ${ }^{63}$ through their personal and financial difficulties, "they offered me the first opportunity of buying."

I had money. I knew the community. I know people with money. Politicians need money and support to get elected. So Rodrigo initiated with the idea- 'Who do we go to? Let's go to City of Miami Commission and talk to commissioner soand-so,' who I helped get elected because I ran his campaign for Wynwood. I

\footnotetext{
${ }^{62}$ In the 1970s, Cubans in Miami claimed to be facing discrimination from the Anglo-American power structure and were not yet solidly Republican (an eventual turn which alienated Puerto Ricans and some other Hispanics). In these ways they had more in common with other Latino leaders in the 1970s. While it is not clear whether the coalitional strategy of Latinos worked, Black Miamians' frustration over their declining share of City resources relative to Latinos was cited by community leaders as a cause of the 1980 riots (Porter and Dunn 1984; Portes and Stepick1993).

${ }^{63}$ It is interesting to note that diverse sectors of the neighborhood were linked, albeit loosely and informally, to the PRU network through Felipe. On the one hand, he gave legal advice and sold houses to neighborhood drug dealers who had money to invest. "[Then] on the other line, the City Mayor: 'Freddie, I need your support, let's go to lunch.' I played both sides." As Felipe's son recalled not only from growing up in the area but also working for and eventually managing his fathers' business: "These guys [drug dealers] were philanthropists, too. You'd be surprised. Those guys would come and give out turkeys and all kinds of crazy things... they'd be part of the community because they were [there] from the beginning."
} 
knew the politicians... I had one thing - that I was working on my own, for myself, I was not working for the government agency. So I had a little more leeway and a little more pull than most people, because politicians needed somebody that can get the votes out and somebody that can get money to organize the campaign.

By 1980 Felipe was a wealthy man and built a home in an expensive bayfront suburb -- on a lot purchased from his friend, Rodrigo. Indeed, as each separately explained to me, the two formed a close friendship and crucial partnership during the 1970s - Felipe as an accomplished businessman trusted by city officials to keep an eye on different neighborhood agencies' finances; and Rodrigo as the more militant activist.

Rodrigo, Felipe, and Benny were not the only Puerto Ricans who comprised the PRU but they were the most influential. ${ }^{64}$ Each took on leadership roles through governing boards and advisory committees, as organizational directors or through grassroots organizing to rally support for specific initiatives. Less-known Puerto Ricans within the PRU (recall there were 12 at the onset) were also brought onto some boards and advisory committees by the leaders but their roles were mostly limited to linking the main leaders to grassroots support as well as personifying the needs of low-income residents in strategic ways. ${ }^{65}$

\footnotetext{
${ }^{64}$ Carlos led voter registration and turnout drives and was well-known through his networks in the neighborhood, at church and the baseball league. But aside from his involvement in the ODP and as an initial member of the Health Clinic's board, he was not involved in the administrative affairs of non-profit or government agencies and did not speak at public meetings. Later I will describe how his son became active in public affairs.

${ }^{65}$ Other founding PRU members include Braulio, Maritza and Tony. Rodrigo recalled that Braulio was a neighborhood resident and founding PRU member. He was also a patient at the Puerto Rican Health Clinic and a clinic board member loyal to Rodrigo during bouts of infighting on the governing board. As he said to a reporter in 1991, "[Rodrigo] was picked as director from the start because he was the most capable. He was the loudmouth, the one who fought to get things done. I would give my head for him if I had to" (Viglucci 1991, p. 1A). Maritza was involved because her son was the victim of alleged police brutality (The Miami News, 1973, January 18). Tony, who lived in the area since the 1950's and also served on the
} 


\section{$\underline{\text { Bureaucratic Enfranchisement and Internal Fissures }}$}

The creation and growth of the new Puerto Rican service organizations also led to conflict, some of which I will describe in this section. It is not possible to reconstruct the entire history of the dissolution of the Puerto Rican leadership network in Wynwood over the years from my small sample of respondents. But I will focus on the tensions that surrounded the group's leader, Rodrigo, and the Puerto Rican health clinic, which grew rapidly ${ }^{66}$ and was prized as the first and foremost Puerto Rican community organization.

Less than a year after the clinic opened, during the winter of 1973-74, it was gripped in a power struggle between its board of directors and the executive director, Rodrigo, who was forced to resign (Inclan 1974a). Funding for the introduction of dental and X-ray services led to disagreements about hiring new personnel. Board members told reporters that Rodrigo was unresponsive to the board and was not attending budget meetings (Inclan 1974b), while Rodrigo claimed they were interfering with his work by pressuring him to hire their friends and relatives as administrative assistants. ${ }^{67}$ After a portion of Rodrigo's base of support in the neighborhood picketed the clinic for nearly two weeks, there was an intervention by federal funding authorities ${ }^{68}$ and a local civil court ruled Rodrigo's dismissal to be a breach of the board's by-laws. He was reinstated and his most outspoken critic, the chairman of the board, resigned.

\footnotetext{
founding health clinic board, continues to serve as a board member on the neighborhoods' Community Action Agency.

${ }^{66}$ From a budget of less than $\$ 200,000$ in 1973 , it grew to $\$ 500,000$ by 1983 and $\$ 2.7$ million in 1987 , when it served more than 60,000 patients a year.

${ }^{67}$ Interview with Rodrigo.

${ }^{68}$ They called for new elections.
} 
While this was only one of many similar power struggles at the clinic, Rodrigo noted it was the first time that Wynwood's Puerto Rican community had experienced such internal tension. 'Some people, when they realized they weren't going to be elected [to the board again], some of them retired. In one case, it was people from the neighborhood and the others [who left] were professionals." Similar episodes were repeated over the years at the clinic, sometimes pitting former PRU members or other Puerto Ricans against each other, and other times sparking conflict with other groups, such as Haitians.

In the late 1970s, a federal grant funded the crowded Clinic's expansion into a building a half-mile north of Wynwood, in the heart of Miami's Little Haiti neighborhood. Within two years, the clinic was again overwhelmed as its patient caseload nearly doubled, mostly from an increase in Haitian patients (Vaughan 1983). But the increasingly Haitian clients were treated by mostly Latino and Spanish-speaking health workers, especially among clerical staff, leading to misunderstandings in the stressed waiting room. Haitian community leaders protested their countrymen's underrepresentation in the clinic, as only one one of the 12 board members and three out of eight staff doctors were Haitian. But Rodrigo responded that they were "asking for too much, too soon," and argued that the real problem was the burgeoning caseload and resulting stress that affected all patients. After years of "accusing the whole world of discrimination" against Puerto Ricans, Rodrigo was in the position of defending himself against the same, and not only from Haitian critics. As he told The Miami Herald 
(Vaughan 1983, p. 20), "right now, the Puerto Rican community is accusing me of running a Haitian clinic." ${ }^{99}$

Not surprisingly, conflict was associated with stress. Each time the clinic underwent a major expansion in physical infrastructure or services, some form of power struggle ensued. "The biggest fight" erupted in the midst of the Clinic's celebrated but protracted move back to Wynwood from Little Haiti in the 1990s. Rodrigo took advantage of the opportunity to purchase a vacant and foreclosed six-story office building in 1987 but it took eight years and additional millions to overcome the the damage caused by internal discord, vandals and Hurricane Andrew (Roman 1988a; Viglucci 1991; Davis 1992; Maass 1993; Ojito 1995a, 1995b). The "melodrama" was exposed in the local newspapers (Viglucci 1991, p. 1A), including "two lengthy interviews salted with expletives and emotional outbursts" by Rodrigo, warring factions among the staff that resulted in the resignation of 10 admministrative and medical personnel, and allegations of bribery and embezzlement, among other things. The crux of the conflict was over control of the Clinic's expansion and specifically the selection of contractors, but tension had been building for years as a result of what critics called Rodrigo's dictatorial style. These allegations and conflicts notwithstanding, in 1995 the Clinic was inaugurated to a crowd of more than 300 and neighborhood residents wearing Puerto Rican T-shirts and waving flags.

\footnotetext{
${ }^{69}$ During my interview of Rodrigo, he asserted that he would never allow ethnic or racial discrimination in the clinic precisely because "we accused everyone of discrimination and so I made sure in the clinic there would not be discrimination. As with the employees, I brought people from all nationalities and we did something where, what we had said was happening to us, that nobody would accuse us of that." Moreover, Rodrigo reasoned that as Puerto Ricans were never a majority in the Wynwood, "It was always very mixed and we worked together. Whatever we [Puerto Ricans] achieved, we shared it with everyone else. And when the Haitians arrived in Miami and nobody served them, we were the first to open our doors and give services. The same when the Cuban balseros came. We opened our doors to everyone."
} 
Reflecting on these episodes, Rodrigo felt that "the biggest mistake I made was becoming director of the Health Clinic."

The person that's involved [in the community] and becomes leader, and then becomes director of the programs, loses part of that leadership because then the whole world wants to take away the reigns of what he's doing. That's when the fights started in the Puerto Rican community. People that I had placed [on the board] went against me!

Although such power struggles surely affect the relationships between former friends and the Puerto Rican leadership network, ${ }^{70}$ their significance is in that they reveal the transformation and absorption of activism into much narrower initiatives, reorienting the struggle inward, within the community, instead of against the government or other "outside" threats. The fundamental complaint of the PRU and Rodrigo, in particular, during the 1970s was that "the community" did not have control over what happened in the neighborhood. They were never able to substantially influence land-use decisions, particularly in the 1980s and 1990s as the scale of planned redevelopment grew larger (which I will examine in subsequent chatpers). As they grew older, more disillusioned and increasingly went their separate ways, they left behind organizations which continued to be useful, albeit to politicians and developers more than neighborhood residents, as I will show later in the context of gentrification.

\footnotetext{
${ }^{70}$ By 1979, Rodrigo admitted that the PRU had "gone by the wayside" (Rodriguez 1979, p. 2B). During the last major struglge that embroiled the clinic, some of the dissenters were part of the Puerto Rican leadership network from the 1970s. The most outspoken of Rodrigo's critics who resigned was married to the Puerto Rican woman who founded the Wynwood Day Care center in the local Church in the 1970s.
} 


\section{The Broader Puerto Rican "Community"}

Since the 1970s, both PRU leaders and other Puerto Ricans have tried to promote the sense of a Puerto Rican community in Miami, albeit in fragmented ways. Despite the significant concentration of low-income Puerto Ricans in Wynwood, even in the 1970s they made up at most one-third of the total Puerto Ricans spread throughout Miami-Dade County (and many in Broward and Palm Beach counties). Today Puerto Rican cultural events and activities are similarly spread throughout Southeast Florida and Wynwoods' leaders have no monopoly on the cultural symbols and practices of Puerto Rican-ness. This reflects the fact that, compared to large Puerto Rican populations in other parts of the country (e.g., New York, Chicago, even Orlando), Puerto Ricans in Miami and even those who grew up in Wynwood are more diverse socio-economically and more divided along class lines.

The PRU President, Rodrigo, asserted plainly that "since it was a poor neighborhood, the other middle-class Boricuas that lived outside of Wynwood felt offended that the neighborhood was identified as the Puerto Rican neighborhood.” The head priest of the Wynwood Catholic Church expressed a similar observation, recalling the controversy over the area's symbolic designation as "Old San Juan" (see also Roman 1987, 1988b).

When I arrived [in the early 1980s], they had declared the neighborhood "Old San Juan" and many Puerto Ricans were insulted because they wanted it to be called "little Vietnam" since it was full of drugs, violence; it was a neighborhood that gave a bad image to the Puerto Rican. The educated Puerto Rican, the wealthy 
Puerto Rican, didn't like to be associated, at least at that moment, with Wynwood. $^{71}$

While there are many Wynwood residents who chose to stay, there are also those who are "not coming back." Larry (whose mother was Puerto Rican), for example, is a successful businessman who grew up in Wynwood in the 1950s but moved out before its "worst years" and before the activism of the 1970s. He explained why he felt no solidarity with the neighborhood or its leaders, despite some fond childhood memories:

There's a distance [between me and the Puerto Rican leaders] ${ }^{72}$ and it was a different era. This was the slums. You made it out, right? You're not coming back! You know? Let me out of here, man! I can remember the City of Miami, Miami News at the time, doing an article on this area and showing my street, $24^{\text {th }}$ Street, as the slums, the Wynwood slums, and it was so fucking embarrassing that they're showing my street for Christ's sake! In the papers: The Puerto Rican Sluuums! [said in a higher pitch, imitating a newspaper boy announcing a headline] So I took that personally.

Many Wynwood residents who were part of the mobilization and activism of the 1970s also sensed that they were looked down on from "outside" of the neighborhood. Carlos remembers how "back then," before the neighborhood began to gentrify as an Arts District, “people didn't like to come to Wynwood... because it wasn't exactly - the area

\footnotetext{
${ }^{71}$ Although the priest was referring to middle-class Puerto Ricans outside of the neighborhood, there were apparently some neighborhood residents who also felt Wynwood would be more appropriately titled, "Little Vietnam," or at least they said so jokingly. According to a 1988 newspaper article (Roman 1988b, p. 1D): "First Angela DeLeon did a double take, then she laughed when she heard that her Wynwood neighborhood has been renamed Old San Juan. 'Old San Juan? It's better to call this Vietnam because this is so bad here,' said DeLeon, who has lived in Wynwood for 29 years." That residents as well as wealthier, non-residents of Wynwood should suggest that their neighborhood is really "a Vietnam" is evidently consistent with the internal and external stigmatization of other neighborhoods, such as Little Havana (Lowe and Saldivar 1983; Balsameda 1989). This is also consistent with scholarly research that finds that stigmatization by outsiders is eventually adopted by insiders (e.g., Wacquant 2007).

${ }^{72}$ Here he is also referring to a political distance. In his half-Cuban, half-Puerto Rican family there is many Republican voters, including Larry. This contrasts the typically Democratic voting patterns of Puerto Ricans.
} 
was mostly Puerto Rican, you understand? Like as we say, we came to be the Jibaros ${ }^{73}$ here [he laughs], as some have named us. But it's prideful for us, throughout all the years and how we've grown in Wynwood." The first Hispanic Mayor of Miami (1973-1985), a wealthy Puerto Rican, also emphasized the class divide among Puerto Ricans which, in his view, ensured that lower-income Puerto Ricans such as those in Wynwood would not receive a greater share of government or private sector resources.

All of these, mostly Puerto Rican and subsequently Cubans that were involved [in Wynwood], they had nothing to do with Wynwood or the [lower-income] Puerto Rican community or, you know, there was no social conscience of the wealthy, middle class, professional, Latino community in poor neighborhoods. It just didn't exist. Either here or in Puerto Rico. The [Puerto Rican] doctors that worked in Mercy Hospital and the people who owned the Pan American Bank ${ }^{74}$ and the other businesses didn't go to Wynwood. In other words, I was the only exception to that [laughing]. ${ }^{75}$ But there was a very large wealthy Puerto Rican community in Miami in the 50s. It was much larger than the Cuban community.

The institutions and governing arrangements established by these Puerto Rican activists would leave their mark on the community politics of Wynwood. They created community service organizations that became many residents' link to the political processes of the city. As Castells (1983) put it, issues of "collective consumption" dominated inner city politics in the 1970 s. As in other parts of the U.S. (Mollenkopf 1975; Castells 1983; Fainstein 1987; Judd 1988), the "ethnic politics" of collective

\footnotetext{
${ }^{73}$ Jibaro refers to the traditional Puerto Rican "hill people" or highland farm workers who lived in the interior of the island, but is also used pejoratively in a similar sense to the North American term, Hillbilly or Redneck. Carlos uses the term to indicate both feeling stigmatized and proud.

${ }^{74}$ Although there was no mention of the connection by long-time activists, in newspaper articles or other sources I reviewed, the Puerto Rican owners of Pan American bank may have donated to the Catholic Parish and other service agencies in Wynwood.

75 The former Mayor later admitted that he actually did very little to help Puerto Ricans in Wynwood, for reasons I will discuss below.
} 
consumption helped build up political constituencies and elect ethnic representatives; that is, community organizations were at least partners, perhaps no more than junior partners, in the larger governing arrangements of the city. While mobilization in Wynwood may have been initially effective, at least in obtaining funds, it was never strong enough to "elect its own" as Cubans and African-Americans did and, over time, even this initial ability to support the growth of service organizations weakened.

The creation of the Puerto Rican Health Clinic was a remarkable achievement and in addition to federal funding it received, in the first two years of the CDBG funding (1975, 1976), Wynwood's share of the total city's grant was 10 and 11 percent, respectively (Table 3.4). The relative increase in 1981 was largely the result of funding for the Garment District expansion in accordance with the 1979 Redevelopment Plan (discussed in Chapter 4). But by the 1980s, Wynwood settled into the role it would occupy thereafter within the city's collective consumption politics - that of being the neighborhood with the smallest share of CDBG funding. Having the smallest population of the CDBG Target Areas, this may not be surprising. However, for at least two years, Puerto Rican activists helped Wynwood to a larger slice of the pie. 
Table 3.4: Community Development Block Grant Funding Allocation to Wynwood and City of Miami Overall, 1975-1982

\begin{tabular}{|r|r|r|r|}
\hline Year & Wynwood & Share & City Total \\
\hline 1975 & $\$ 217,951$ & $10 \%$ & $\$ 2,270,852$ \\
\hline 1976 & $\$ 527,182$ & $11 \%$ & $\$ 4,911,559$ \\
\hline 1977 & $\$ 355,851$ & $4 \%$ & $\$ 8,763,410$ \\
\hline 1978 & $\$ 518,691$ & $5 \%$ & $\$ 9,628,937$ \\
\hline 1979 & $\$ 114,784$ & $1 \%$ & $\$ 9,271,297$ \\
\hline 1980 & $\$ 533,386$ & $6 \%$ & $\$ 9,106,258$ \\
\hline 1981 & $\$ 757,800$ & $12 \%$ & $\$ 6,210,954$ \\
\hline 1982 & $\$ 293,050$ & $4 \%$ & $\$ 7,181,000$ \\
\hline Total & $\$ 3,318,695$ & $6 \%$ & $\$ 57,344,267$ \\
\hline
\end{tabular}

Source: City of Miami Commission Records, City Clerk Archives

Figure 3.3: Share of Community Development Block Grant Funding by City of Miami Target Areas, 1975-1982

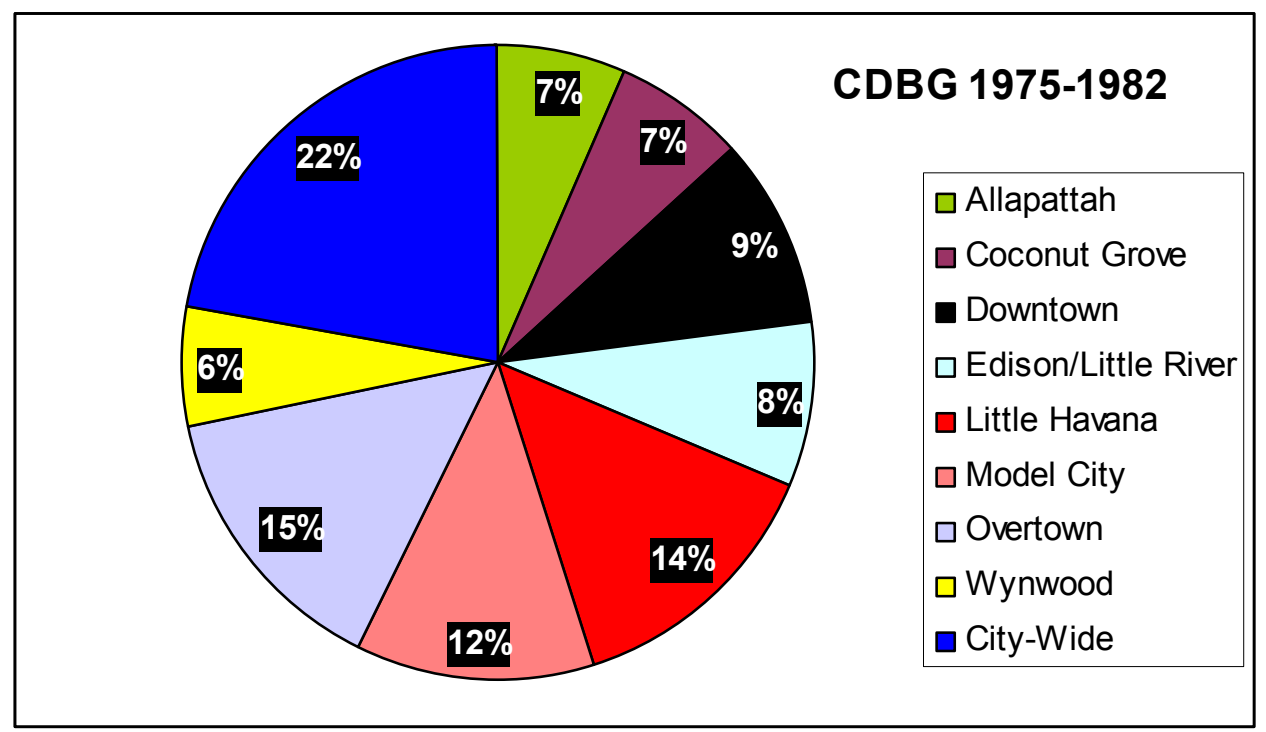

Note: City-wide is a category for funds spread across various sites, not the total for the city. Source: City of Miami Commission Records, City Clerk Archives

As will become clearer in the next chapter, the "ethnic politics" on which

Wynwood's mobilization was based - and on which Rodrigo in particular insisted - was not effective in fostering the Wynwood's inclusion in Miami city politics, beyond 
receiving its prescribed share of government-funded services. The Puerto Rican community in Miami was dispersed spatially and struggled to overcome internal class divisions. This political isolation was exacerbated by the internal divisions among the Wynwood Puerto Rican leadership, which endured well into the 1980s. Lacking an effective power base, the neighborhood continued to experience disinvestment and stigmatization, setting the stage for the "spatial fix" of slum clearance and policing interventions that would eventually make way for redevelopment and gentrification. As I will explore in the next chapter, in the 1980s and 1990s Wynwood's Puerto Rican organizations and leadership sought to develop the autonomous capacity to shape the economic development of the neighborhood. Although these efforts failed, by the 2000s the neighborhood's organizations would become useful partners within the unfolding governing arrangements of gentrification. 


\section{THE "SPATIAL FIX" OF URBAN REDEVELOPMENT}

As national CDBG funding increased to its 1978 peak, urban policy shifted from resident participation to service provision, drawing many activists in this direction as well. Activists were more likely to pursue service funding opportunities if their conceptualization and demands for "civil rights" and/or "welfare rights" were relatively narrow, focused on political inclusion and service provision, for example, instead of the broader objectives of "community control" which shaped the political agenda of some community organizations during the 1960s (Cloward and Piven 1975; Castells 1983; Cummings and Glaser 1985). Organizations that focused on community control had never developed in Wynwood. ${ }^{76}$ By the time Wynwood's organizations had developed in the late 1960s, battles had already been won in other parts of the country resulting in the creation of social service programs that local government agencies could offer activists as rewards. The more militant the activist, the more important the program they were given. By 1974, City and County Hall controlled the federal funding, further weakening neighborhood organizational autonomy and locking activists and public officials in ritualized, annual negotiations over funding terms and amounts. There is little evidence that activists in Wynwood sought anything more than basic services for poor residents, despite Rodrigo's regret:

\footnotetext{
${ }^{76}$ Nor did "community control" organizations - some of which eventually become Community Development Corporations (CDCs) - develop anywhere else in Miami until the 1980s (Von Hoffman 2001; Lowe 2004). Most of the early (1960s-70s) CDCs to develop did so in cities with strong, ideologicallydriven, social movement activism; whereas in Miami (as discussed in Chapter 2), the civil rights movement was, at its peak, a reform-oriented coalition of Blacks, Jews and other Whites focused on pragmatic objectives such as urban renewal relocation assistance and, ultimately, was largely ignored by elites preoccupied with the Cuban influx.
} 
I see that the programs that came to Wynwood and community development and all those programs from the government - they usually come with the intention [or stated purpose] of involving the community. And really they never allowed the community to develop what the community wanted, instead what they [the government] already had thought of beforehand. It's one of the things that I, in retrospect, can say - that those programs were controlled by the people that work in the city or the county [government], and they are the ones that decide. What the community says is really not taken into consideration.

As examples, Rodrigo pointed to the numerous occasions over the years in which Wynwood's organizational leaders advised city officials of their preferences for how to develop the FEC Railway property (the ultimate development of which I discuss in the next chapter).

We wanted to do other things there but it was not until the big money [developers] got to the neighborhood that the county and the city allowed it to be developed and to create multiple buildings [of high-rise condos] and that type of thing. In the $80 \mathrm{~s}$, we wanted to develop something else there, [we tried] through the city and through the county. We prepared ideas and presented them to the different community development groups that came [to the neighborhood]. We met every month... they [the advisory boards] would be assigned one or two or three million dollars, whatever, and we would tell them what we wanted to develop. But those often fell on deaf ears.

Some of the proposals that Rodrigo recalled sounded bizarre, such as the time "a Cuban man came with a proposal to build a tower like the one in Atlanta, very tall, like a tourist attraction... which many of the people [in Wynwood] were in favor of.",77 But he also cited more practical ideas, such as "lower scale apartments than what they have there now, but to be for the people of the community, the neighborhood, to move there."

\footnotetext{
${ }^{77}$ The 12-story steel tower topped with a golden flame - known as the Torch Tower - was built by an Atlanta real estate developer to memorialize the city's Olympic Games (Cress 1996).
} 
As I will examine in the next chapter, none of Wynwood's community-based development proposals - practical or otherwise - were taken into account when the FEC railway site was ultimately developed into expensive, high-rise condos and a commercial complex filled with upscale restaurants and national chain stores. Wynwood organizations never developed the capacity to implement physical development, despite the creation of Community Development Corporations (CDCs) to provide business services and to rehabilitate and build housing. Wynwood CDCs incapacity to build affected the thinking and practice of their leaders, shaping their roles as organizational intermediaries between neighborhood residents and the politics of urban development. In the case of Wynwood, CDCs would help facilitate gentrification not only because of their particular political rationalities but also because their lack of productivity contributed to the neighborhood's deterioration, helping to widen the "rent gap" and intensify the "spatial fix" of physical redevelopment needed to "revitalize" the area.

In the remainder of this chapter, I examine the main manifestations of both the "spatial fix" and the "entrepreneurial turn" of community development that eventually helped facilitate the area's gentrification: the 1979 Garment District Redevelopment Plan and the 1990 Safe Neighborhoods Plan for Wynwood; the formation of CDCs; and the emergence of faith-based activism to advocate for physical redevelopment initiatives.

\section{The 1979 Garment District and 1990 Safe Neighborhood Plans}

The City of Miami's 1979 Redevelopment Plan for “Garment/Fashion District" was the first major physical redevelopment initiative in Wynwood since the urban renewal and highway construction processes of the 1960s. This Wynwood-specific plan 
was set in motion by the city-wide research of real estate consultants Hunter Moss and Company (City of Miami 1976a), the basis for the City's Comprehensive Neighborhood Plan for $1976-86 .^{78}$ The premise of the Redevelopment Plan was established by the real estate research findings for Census Tract 28, which delineates the district (City of Miami 1976a, p. 26): "This tract will continue to follow a commercial direction which will work against any upgrading in the housing." 79 Although passed by the Miami City Commission in July 1979, implementation of the plan required a series of approvals by Miami-Dade County, which partnered in the redevelopment project.

The "primary objective" of the Redevelopment Plan was to demolish deteriorated housing in the section of the Warehouse District that overlapped with the Overtown Redevelopment Area (see Figure 4.1) in order to retain and expand industrial employment in this part of the city (City of Miami 1979, p. 8). The target area was described as having "developed during the 1920s, at which time a larger number of the wood frame structures were constructed. The area changed racially in the $1950 \mathrm{~s}$ as a

\footnotetext{
${ }^{78}$ The research and city-wide planning was mandated by the Florida Community Redevelopment Act of 1976, which enabled local governments to use community development funding for the purposes of extensive slum clearance and redevelopment. Incidentally, in the Florida International University library system, the City of Miami 1976-1986 Comprehensive Neighborhood Plan is available under the subject headings, "Neighborhood - Neighborhood planning - Gentrification" (see City of Miami 1976b, 1982).

${ }^{79}$ According to the city commissioned research (Ibid), "Census Tract 28 is predominantly made up of warehousing, wholesaling and light manufacturing with the residential in the form of Black walk-up apartments in poor condition and also deteriorating single-family and duplex dwellings. The occupants are primarily Blacks, Cubans and Puerto Ricans. There has been some upgrading in the appearance of the commercial structures with better than average warehouses and showrooms located along $5^{\text {th }}$ Avenue. This tract will continue to follow a commercial direction which will work against any upgrading in the housing." Census Tract 26, which encompasses the northern, predominantly residential section of Wynwood, was also described (Ibid, p. 24): "This tract has many diverse uses ranging from single-family dwellings to light manufacturing. It contains that large former freight yard of the F.E.C. Railroad containing 50 acres. It is little used today. The railroad has set a valuation on this of... just under $\$ 9,000,000$. As presently constituted this tract is as dismal as No. 25 to the west since its western boundary is bisected by I- 95 and is bordered by heavily travelled streets. However, a major redevelopment on the 50 acre FEC [rail]yards could represent a major thrust in doing something for this area that could have a ripple effect south into Census Tract 28 and 31."
} 
result of the expansion of the 'Central Negro District' at which time a number of large apartment structures were built (concrete monsters). ${ }^{, 80}$ More than 47 percent of the land uses in this area were residential even though a substantial number of housing units had been demolished by the time the plan was published (p. 8, 10): "Expansion of the Garment Center/Fashion District required the acquisition and demolition of approximately 280 occupied housing units (323 total units) south of NW $23^{\text {rd }}$ [and] 9 marginal business establishments on 14 acres of land for re-use as industrial property. Some 97 percent of these units," noted the plan, switching oddly into the present tense, "are in substandard condition [and] the vacancy rates are high, averaging over 10 percent."

Although later sections in the plan account for the exact location of the acquired and demolished units, the shifts in tense are confusing - how can demolished units be in substandard condition and vacant? The next paragraph, continuing in the more appropriate present tense, reported that "there are 45 single-family or duplex housing units in the Garment District north $23^{\text {rd }}$ Street, about 75 percent of which considered to be in substandard condition." ${ }^{, 81}$ Moreover, more than $\$ 1.8$ million or about 18 percent of the total budget for the redevelopment plan was set aside to provide relocation assistance to displaced residents (up to $\$ 4,000$ per family). None of the 10 area residents interviewed by a reporter a month before the redevelopment plan was approved and published had heard of the plan, although a community meeting had been scheduled for a week before

\footnotetext{
${ }^{80}$ Elizabeth Virrick, the housing reformer from the 1950s, was thought to have popularized the term "concrete monsters" through her advocacy of slum clearance (Mohl 2001b).

${ }^{81}$ Other than the 1979 plan, I found no public records (e.g., demolition permits, city commission records) to confirm the timing of the demolitions.
} 
its approval at City Hall to help residents obtain relocation assistance (Veciana 1979).

Although there were no organized protests at City Hall or elsewhere, ${ }^{82}$ a debate took

place in newspaper articles prior to the plan's approval. In response to the head city

planner's assurances that "we don't want to tear down any viable businesses in the area -

only marginal ones," the African-American owner of an auto repair shop retorted,

"What's a marginal business? They promise one thing and then they do another" (Sidlo

1979, p. 2b). When Rodrigo was asked about the plan, he complained that the majority of

the garment manufacturers did not hire residents from the neighborhood and the

manufacturers needed to participate more in job training and referral systems (such as the one run out of Rodrigo's Health Clinic) (Ibid). ${ }^{83}$

\footnotetext{
${ }^{82}$ When the plan was approved, two spokespersons from Overtown appeared to advocate that this neighborhoods' African-American residents be given the first right of refusal in purchasing some of the new homes that were planned to be built (although not for several years) in the vicinity as well as training for jobs in the garment industry (MCC 7/23/79).

${ }^{83}$ However, it was well-known that the mostly female labor force in the Miami garment factories earned very low wages (e.g., sewing machine operators), exacerbated by the irregular work schedule (Silva 1976a, 1976b; Moore 1981; Konicki 1982). A Puerto Rican nonprofit agency manager explained to me that he was not able to sustain a branch of a national jobs training program linked to Wynwood's garment industry in the late 1970s because "the garment industry was only minimum wage. We couldn't use those employers to satisfy the requirements [established by the national organization]." His wife, who worked at a welfare assistance agency in Wynwood, added that even though the pay was low and work unsteady, women might lose their welfare benefits by being employed. Moreover, "some of these women had to pay for baby sitters," which "even in the 70s, they paid around $\$ 50$ a week and that would take such a big chunk out whatever they earned that wasn't worth it for them to go to work [in the apparel factories]."
} 
Figure 4.1: Map of the Wynwood Garment District surrounded by Inner City Areas

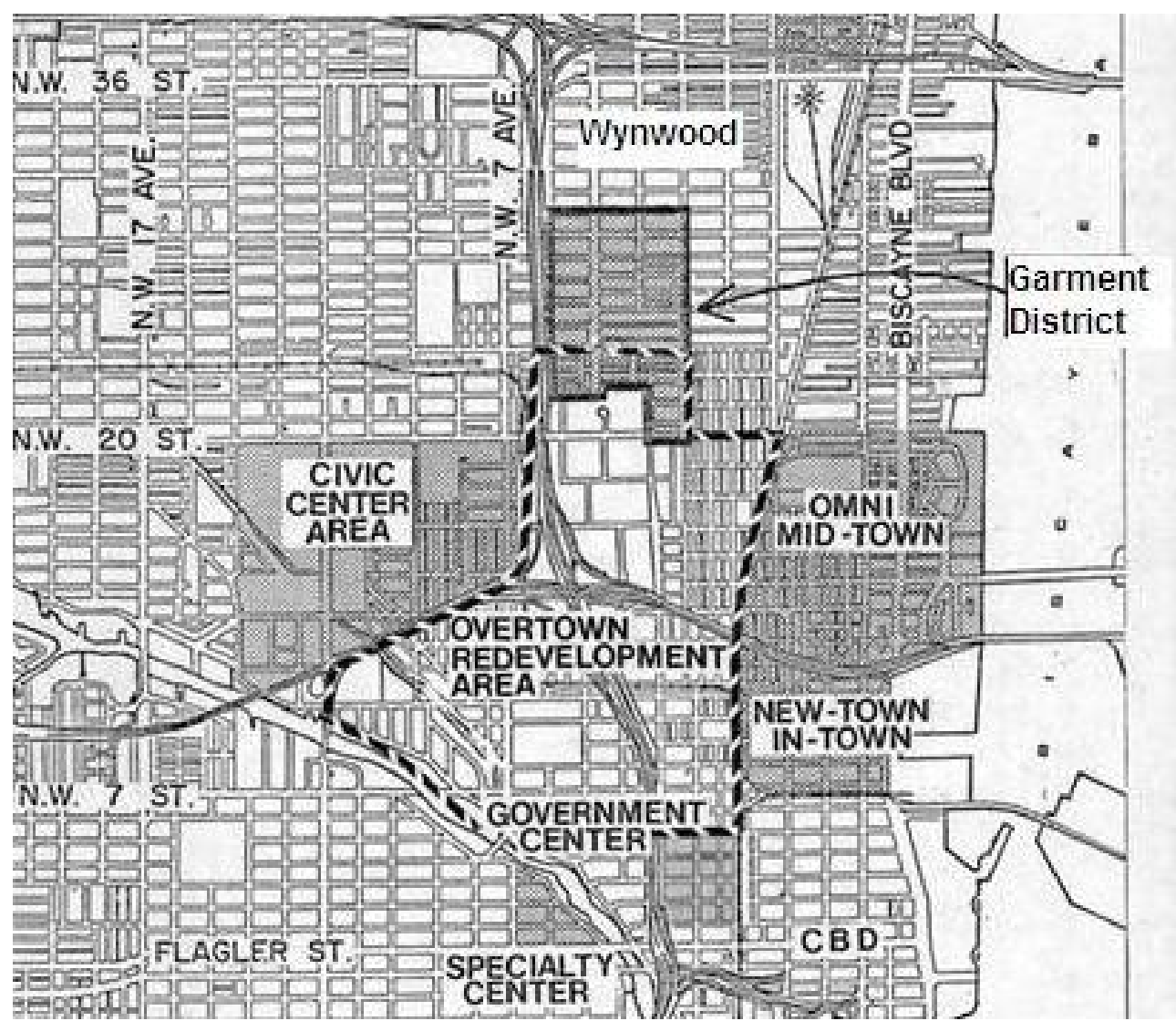

Source: 1979 Garment District Redevelopment Plan, City of Miami Planning Department (p. 6). The "Proposed Expansion Area" and "Future Redevelopment Area" are contained in the overlap between the Overtown and Garment District Redevelopment Areas.

The plan also outlined objectives to solve a variety of other problems: insufficient parking, inadequate loading facilities, poor access to the regional transportation system, inadequate street system, crime, and difficulty recruiting labor for manufacturing. Later I will discuss the job training and placement programs created in Wynwood, which became another source of conflict among Wynwood's Puerto Rican leadership. To address concerns about crime, vehicular access and inadequate street infrastructure, the plan called for a series of physical interventions, including not only housing demolition but 
also the installation of lighting and signage, and the construction of street closures and "landscape buffers." When combined with the creation of "vehicular access restrictions" (curbs, sidewalks and metal partitions to close streets) that largely comprised the 1990 Wynwood Safe Neighborhood Improvement District Plan, these interventions effectively enclosed and walled off the section south of $23^{\text {rd }}$ Street (the proposed expansion area) from the warehouse district to the north. The 1979 plan called for the closure of five north-south avenues and courts along $22^{\text {nd }}$ Street and the east-west $22^{\text {nd }}$ Terrace (see Figure 4.2). The following images depict these plans and a few examples of their implementation.

Figure 4.2: Map of Proposed "Street Improvements" in the Garment District Redevelopment Plan

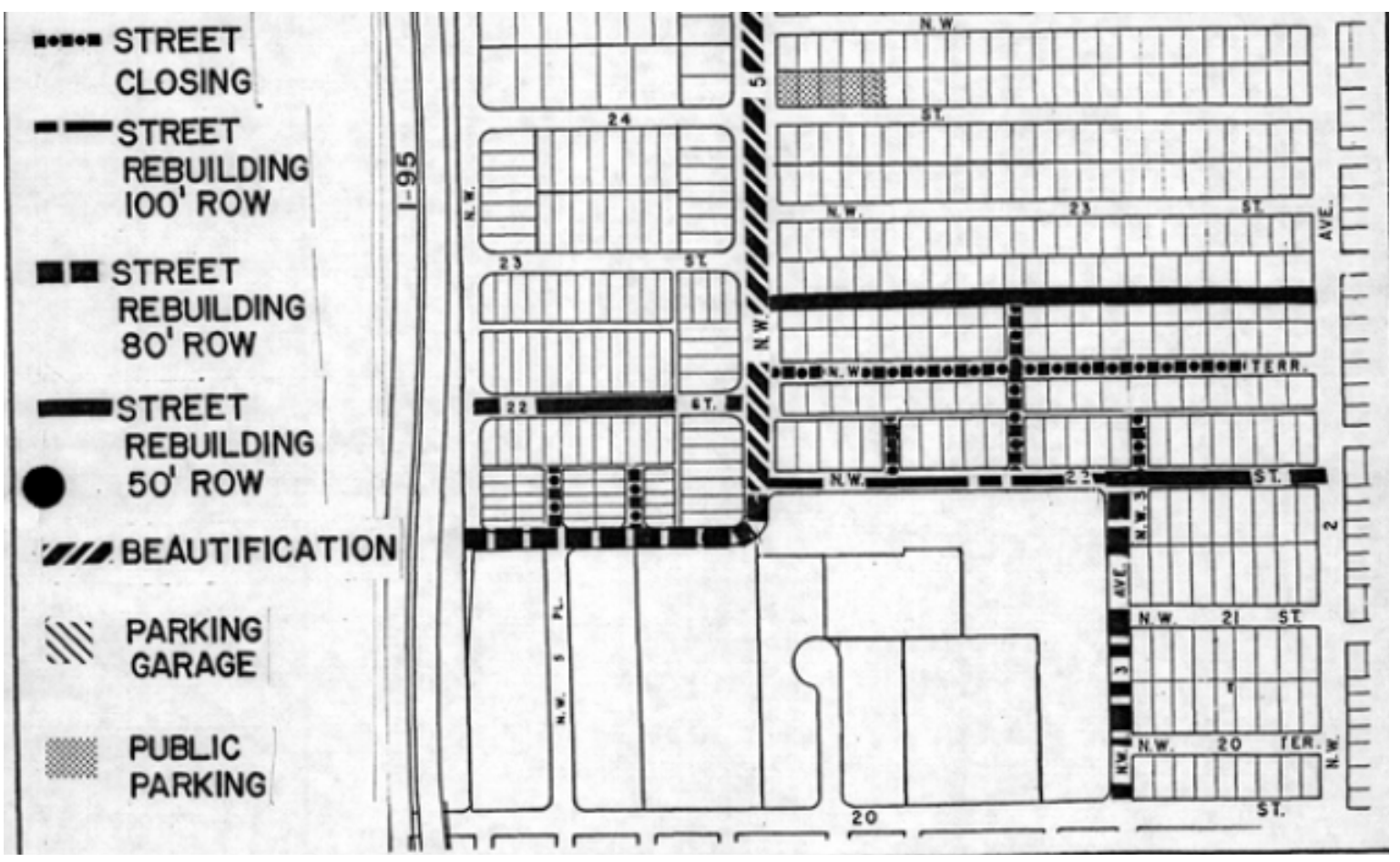

Source: 1979 Garment District Redevelopment Plan, City of Miami Planning Department (p. 17). Note that the northern solid black line marks the northern edge of the proposed expansion area. 
Figure 4.3: Map of Proposed Vehicular Access Restrictions in the Wynwood Safe Neighborhood Plan

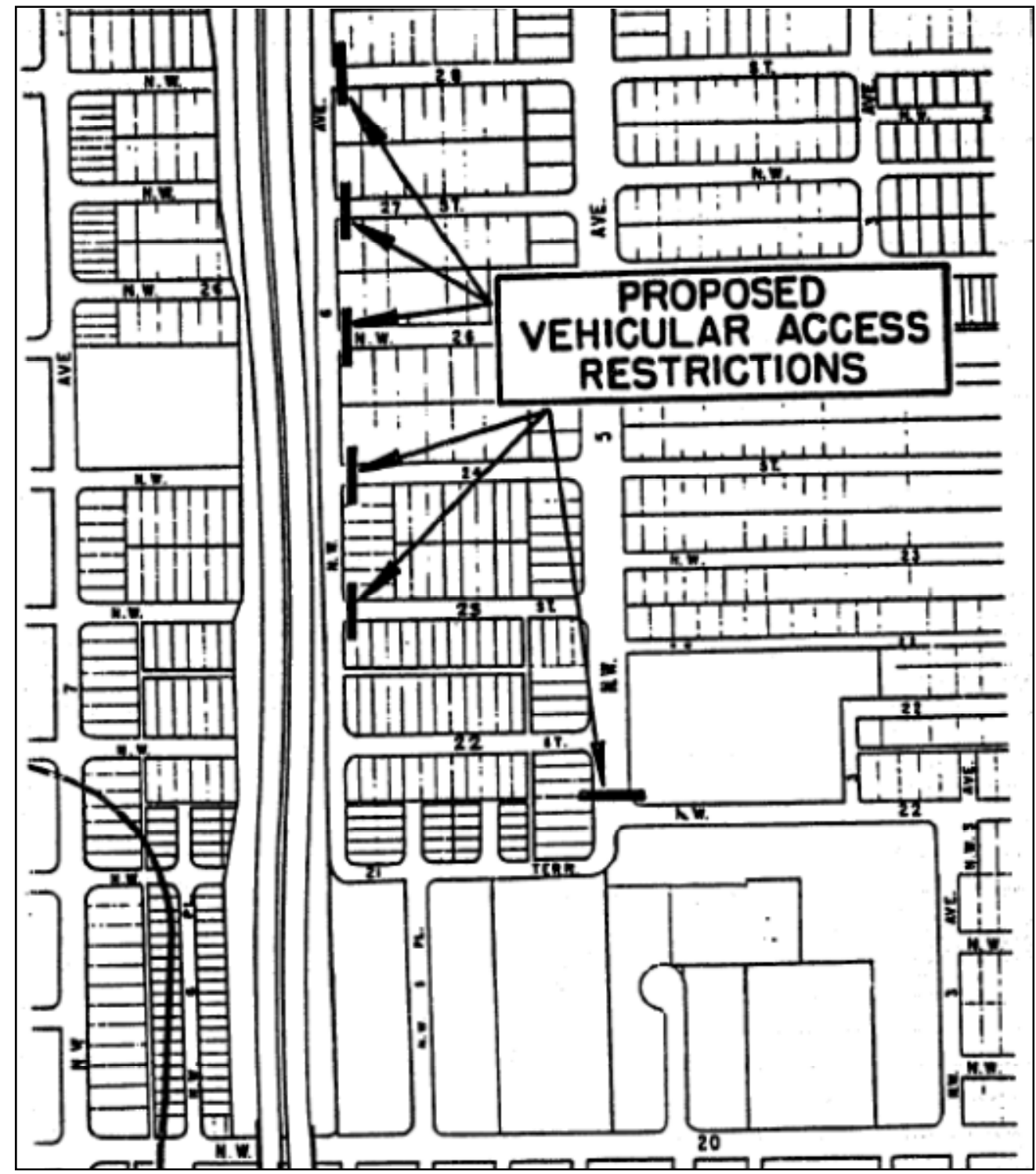

Source: 1990 Wynwood Safe Neighborhood Improvement District Plan, City of Miami Planning Department.

The only street closure actually built was at the southern tip of the Garment

District along NW $22^{\text {nd }}$ Avenue, completely closing off a low-income housing complex from the area to the north except for NW $6^{\text {th }}$ Avenue, next to the highway. Not shown 
here nor contained in any city planning documents, NW $3^{\text {rd }}$ Court that connects with $22^{\text {nd }}$ Lane was eventually closed as well (see $3^{\text {rd }}$ image, below). These may seem minor details. But the micro-geographies of segregation and enclosure created by the techniques of "crime prevention through environmental design" 84 shape the circulation of people in accordance with the security concerns of government and business elites and exacerbate the isolation of the poorest inner city residents (Davis 1992; Low 1997; Herbert and Brown 2006; Wacquant 2007). At the City Commission meeting where the 1990 Safe Neighborhood Plan was approved, district commissioner Miller Dawkins urged the city manager to complete the street closures regardless of delays in implementing other aspects of the plan, some of which required county and state approval (MCC 6/7/90).

I want you to give directions to close off that [avenue into a] cul-de-sac. We allowed the Design District to move [away] because we did not do enough to encourage them to stay. We got almost every business along $5^{\text {th }}$ Avenue [in the Garment District] rented [now] and if we do not work to make this area secure, where the people who are there with their businesses and their citizens ${ }^{85}$ who come there feel safe, they're going to move also. So now, let them [other city staff] go on and play with whatever they're playing with [county and state approval processes], that's fine. But I want you to come back at the next meeting and tell me how we - I don't care if it means closing off every entrance from 5 th [Avenue] and putting a cul-de-sac. So people, when they go in there, if you snatch a pocketbook you got to run back out and come by our police up at the corner. (emphasis added) But we have to do something to ensure the merchants... more than just moving parking meters so that the people can park free.

\footnotetext{
${ }^{84}$ This is how the resolution that approved the 1990 Safe Neighborhood Plan was worded: "to promote the concepts of crime prevention through environmental design" (City of Miami 1990; MCC 6/7/1990).

${ }^{85}$ This was an interesting word choice considering that the client base of the wholesale fashion district he is referring to were and still are mostly Latin American business owners who fly to Miami for a few days to buy merchandise in bulk. Very few stores in the district sell at retail prices or even open on the weekends, when Miami residents are more likely to shop (as they do in Allapattah's Fashion District nearby). The other reason why Dawkins word choice was interesting is because of how he (intentionally or not) links citizenship with shopping.
} 
By 1990, city officials spoke with a certain anxiety about the importance of the architecture of surveillance and security to the retention of business. Dawkins' unease was an ominous message just a few months before the Wynwood riots of December 1990. At the time of the 1979 Redevelopment Plan, however, City of Miami planners and their consultants were more optimistic; they expected the fashion apparel industry "to grow by 24 percent from 1976-1990 County-Wide and 15 percent within the City of Miami” (City of Miami 1979, p. 11). But by the early 1980s, the apparel industry began to decline, accelerated by the 1980 and 1982 riots in nearby neighborhoods. "That's really when we saw that we're going to have trouble bringing people back," said one linen store owner and former president of the district's merchants association (Hernandez 1984, p. 24). According to a City of Miami report, between 1976 and 1986 the number of garment factories within the City of Miami shrunk by 60 percent, representing about 2,000 jobs (Cosco 1986). ${ }^{86}$ United States Census data reveal that while the number of residents employed in manufacturing, transportation or public administration (the closest industrial category available) increased county-wide by nearly 9,000 between 1980 and 1990, within the City of Miami this category declined by more than 9,840 and in Census Tract 28 (encompassing the Garment District) by 244 (Geolytics NCDB) ${ }^{87}$ According to the Sun-Sentinel (Cosco 1986, p. 15B), "By the time the city had devised a redevelopment plan and acquired 13 acres in the area, the domestic garment industry was

\footnotetext{
${ }^{86}$ The former manufacturer I interviewed, Harold, recalled that in 1968 was the first time he walked into a Miami Department store "and saw a garment from Japan, which was the China of that time - had knocked off one of our garments at half the price. I said at the time, I told my Dad, that eventually the industry would disappear... By like 1980, 81, imports became more and more important, and then China got in the picture."

${ }^{87}$ The number of employed persons decreased by 891 during the decade in Census Tract 28, which is especially remarkable considering that the total population was 2,265 in 1980 and 1,767 in 1990.
} 
hit hard by cheaper imports.” Although apparel manufacturers were partially replaced by the growth in retail and wholesale clothing companies, these concentrated in the northwest section of the neighborhood around $5^{\text {th }}$ Avenue and were eventually controlled by small-scale, Korean merchants as many of the Jewish, Cuban and other Miami-based entrepreneurs moved out (Proscio 1992). The industrial decline seemed to further cement the area "becoming more and more like a ghetto," as the city's assistant director of community development described in 1986 (Cosco 1986, p. 15B).

Figure 4.4: Views of Street Closures Along NW 22 Street

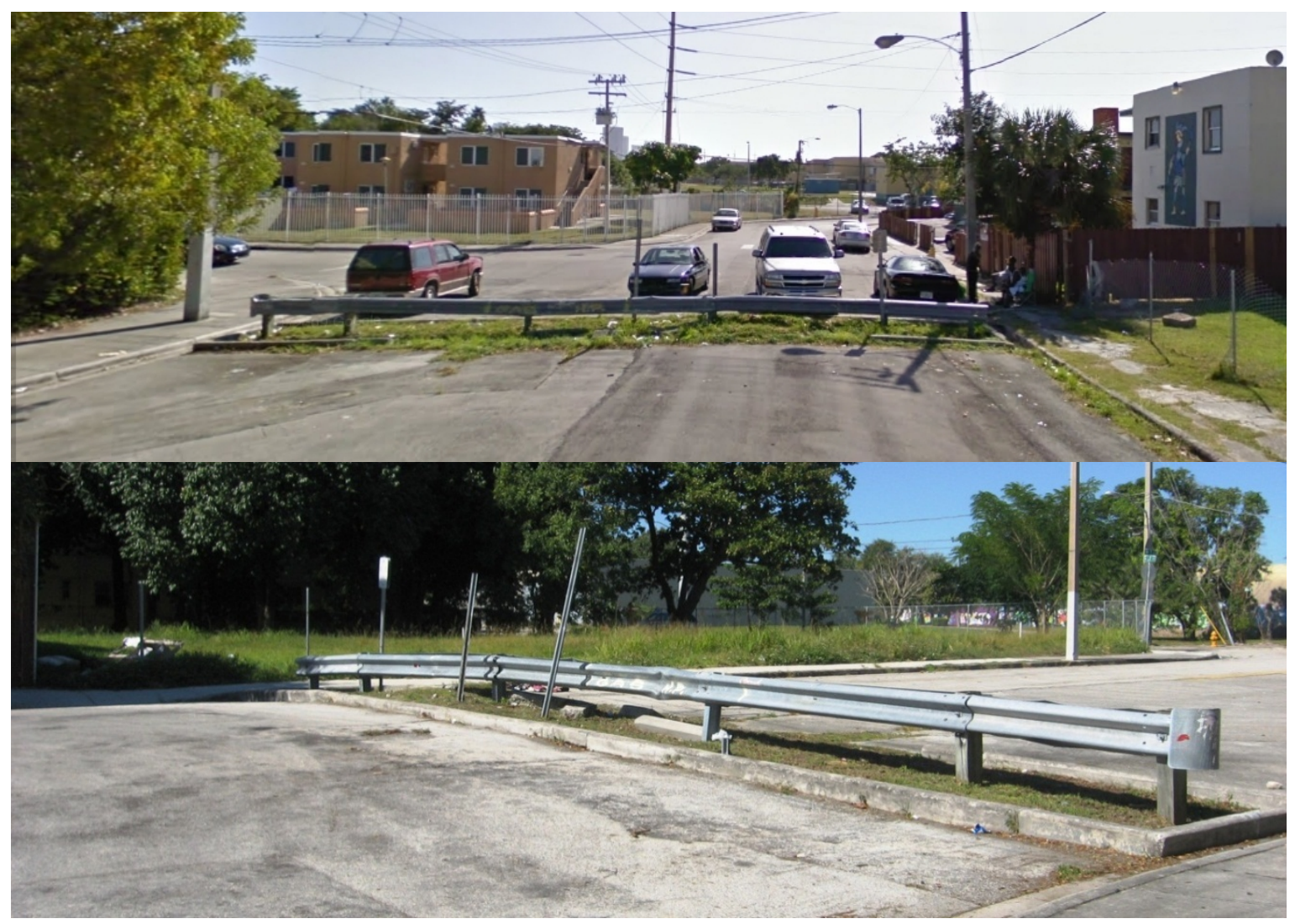




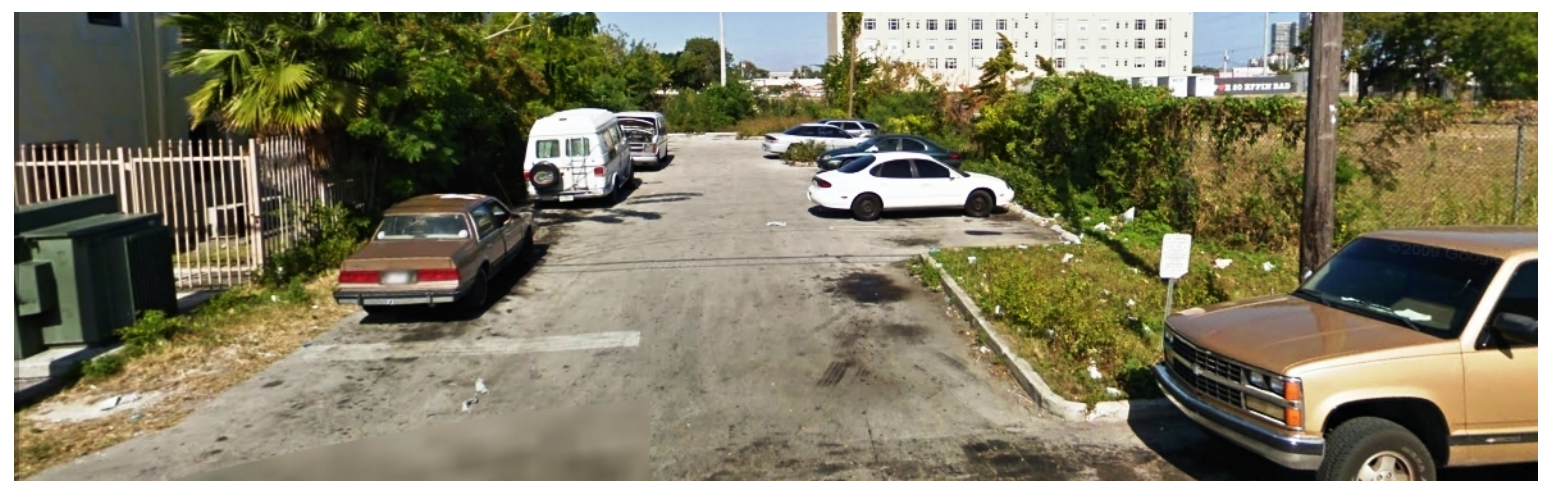

Source: The first and last are from Google Street View (2010) while the middle photo was taken by the author in December, 2010. In the last image, newly built artist lofts are visible in the distance, beyond the edge of what used to be NE $3^{\text {rd }}$ Court, now used as a parking lot for renters.

Although information on the actual number of homes demolished as a result of the 1979 Redevelopment Plan is not available (beyond the confusing past and present tense description in the plan), census tract data reveals that the total number of housing units in the Garment District (Census Tract 28) decreased by 189 between 1980 and 1990 (Table 4.1), eliminating more than one-fifth of the housing stock. Between 1970 and 2000 , the number of housing units decreased by about 550 in the southern part of Wynwood containing the Garment District. During these decades, the Garment District area lost more than four times as many units than did Wynwood's northern, more residential half (-130). The largest decrease in housing units throughout all of Wynwood occurred in the 1980s, owing not only to redevelopment planning and implementation but also to the emergence of faith-based activists who protested the condition of abandoned housing, as I will discuss below. 
Table 4.1: Change in Total Housing Units in Wynwood Census Tracts, 1970-2000

\begin{tabular}{|c|c|c|c|c|c|}
\hline $\begin{array}{c}\text { Wynwood } \\
\text { Area }\end{array}$ & 1970 & 1980 & 1990 & 2000 & $\begin{array}{c}\text { Change } \\
1970-2000\end{array}$ \\
\hline \multirow{2}{*}{$\begin{array}{c}\text { South } \\
\text { CT } 28 \\
\text { (Change) }\end{array}$} & 1,028 & 850 & 661 & 479 & \multirow{2}{*}{-549} \\
\hline & & -178 & -189 & -182 & \\
\hline \multirow{2}{*}{$\begin{array}{c}\text { North } \\
\text { CT } 26 \\
\text { (Change) }\end{array}$} & 1634 & 1677 & 1545 & 1504 & \multirow{2}{*}{-130} \\
\hline & & 43 & -132 & -41 & \\
\hline \multirow{2}{*}{$\begin{array}{l}\text { Wynwood } \\
\text { Overall } \\
\text { (Change) }\end{array}$} & 2662 & 2527 & 2206 & 1983 & \multirow{2}{*}{-679} \\
\hline & & -135 & -321 & -223 & \\
\hline
\end{tabular}

Source: U.S. Census Bureau and Geolytics, Inc. Neighborhood Change Database 1970-2000.

Land clearance and spatial controls were the main physical interventions planned and implemented in Wynwood in the 1980s and 1990s to achieve the "spatial fix" needed for future redevelopment. Beyond merely clearing land, these initiatives were concerned with controlling population flows, evident not only in the street closures but also because the majority of the buildings demolished had been occupied. Thus, the number of residents also declined (Table 4.2). In the southern part of Wynwood, the population declined by 891 in the 1970s, 494 in the 1980s and 474 in the 1990s. Over four decades, the entire neighborhood (south and north tracts combined) lost more than 34 percent of its population or almost 2,900 residents. 
Table 4.2: Change in Total Population in Wynwood Census Tracts, 1970-2000

\begin{tabular}{|c|c|c|c|c|c|}
\hline $\begin{array}{c}\text { Wynwood } \\
\text { Area }\end{array}$ & 1970 & 1980 & 1990 & 2000 & $\begin{array}{l}1970- \\
2000\end{array}$ \\
\hline \multirow{2}{*}{$\begin{array}{c}\text { South } \\
\text { CT } 28 \\
\text { (Change) }\end{array}$} & 3156 & 2265 & 1767 & 1293 & \multirow{2}{*}{-998} \\
\hline & & -891 & -498 & -474 & \\
\hline \multirow{2}{*}{$\begin{array}{c}\text { North } \\
\text { CT } 26 \\
\text { (Change) }\end{array}$} & 5173 & 4862 & 4530 & 4175 & \multirow{2}{*}{-1863} \\
\hline & & -311 & -332 & -355 & \\
\hline \multirow{2}{*}{$\begin{array}{l}\text { Wynwood } \\
\text { Overall } \\
\text { (Change) }\end{array}$} & 8329 & 7127 & 6297 & 5468 & \multirow{2}{*}{-2861} \\
\hline & & -1202 & -830 & -829 & \\
\hline
\end{tabular}

Source: U.S. Census Bureau and Geolytics, Inc.

Neighborhood Change Database 1970-2000.

\section{The Emergence of Community Development Corporations}

The period when housing was being demolished and jobs and people were leaving Wynwood was also when the Community Development Corporation (CDC) movement was blossoming nationally and locally. Designed as vehicles for the construction and rehabilitation of permanently affordable housing, CDCs were envisioned as a way to not only help "stabilize" a neighborhood's property market but, in some cities where gentrification had already begun in the 1970 s and early 1980 s, as a way to protect residents from displacement due to rising housing costs (e.g., Gaston and Kennedy 1987; Turner 1999; Levy, Comey and Padilla 2006). Some residents were protected from displacement in Miami Beach in the late 1980s and 1990s, where the Miami Beach CDC became an effective and nationally renowned developer of nonprofit-owned, affordable rental buildings (Donnelly 2005; Viegas 2005). ${ }^{88}$ Such a CDC never developed in

\footnotetext{
${ }^{88}$ I say partially because the gentrification of South Beach nevertheless displaced a large share of its' lowincome population (Ibid). CDC housing development is only part of a broader strategy needed to prevent gentrification-driven displacement.
} 
Wynwood even though faith-based activism, which at its peak was quite powerful within the City of Miami, supported the cause of affordable housing rehabilitation and development. CDCs in Wynwood were affected by the fragmentation of Wynwood's Puerto Rican leadership and the broader national and local political move toward private rather than public mechanisms for economic development.

The "entrepreneurial turn" of community development - part of the broader national shift toward "supply-side" economics since the 1970s (Eisinger 1988; DeFilippis 1999) - took shape in different ways across different local political contexts. Starting under Jimmy Carter in 1978, in the fourth year of the federal CDBG program and following the 1977 Community Reinvestment Act, community development funding was made available for community-based, physical development. By the 1980s "the rise of the entrepreneurial state" (Eisinger 1988) spawned a network of national foundations and state and regional intermediary organizations to support the work of local CDCs. Nationally, CDCs mostly focused on housing rehabilitation and construction. Although a few prominent CDCs existed throughout the U.S. in the 1970s, Miami's first three CDCs were established in 1980 in Liberty City, following the civil unrest in the historic African-American neighborhood (Von Hoffman 2001; Lowe 2006). ${ }^{89}$ Indeed, the emergence of CDCs revealed the salience of interethnic conflict in Miami's political climate. The state legislation and local policies and corporate alliances that funneled money to CDCs - particularly to the new African-American controlled CDCs - were responses intended to smooth interethnic relations in Miami (see Portes and Stepick

\footnotetext{
${ }^{89}$ The uprising that led to more than 1,000 arrests, $\$ 200$ million in property damage and 18 deaths, was catalyzed by the acquittal in 1980 of four white police officers for the fatal beating of an unarmed, black insurance agent (see Porter and Dunn 1984).
} 
1993, Chapter 8; Von Hoffman 2001, pp. 63-64). The Miami CDC movement of the 1980s and 90s exhibits extreme tendencies not only in terms of the politicization of CDC funding in the context of interethnic conflict, but is also extremely entrepreneurial in its ideology and practice.

The "highly politicized" nature of CDC funding in the context of interethnic competition meant that "in the course of transferring [some degree of] control of the city government from African-American to Cuban Americans" in the 1980s and particularly the 1990s, "deals were made by which CDCs that had not demonstrated an ability to carry out programs received long-term support" (Von Hoffman 2001, p. 66). Although this was generally consistent with national trends whereby the cultivation of "powerful political sponsors" (Ibid) meant that CDCs emerged "as practitioners of a new machine politics" (Marwell 2004, p. 278), ${ }^{90}$ Miami CDCs seem to have been especially unproductive. ${ }^{91}$ It is no coincidence that several of the City of Miami's current and past City Commissioners are or were leaders of the city's largest CDCs. ${ }^{92}$

\footnotetext{
${ }^{90}$ Although CDCs cannot engage directly in electoral politics, they generate neighborhood support bases through service provision and jobs, and in some cases directly through a "community organizing" branch of their work (e.g., Stoecker 1997; Marwell 2004).

${ }^{91}$ It is worth repeating the evidence that Von Hoffman (2001, p. 66) cites: "Surveying the landscape in 1993, Bratt and her colleagues found that few of the more than 20 nonprofit housing organizations in Miami had developed multifamily rental housing for more than four years, and these were primarily for the elderly (Bratt et al. 1995). By the late 1990s, 43 CDCs existed in the Miami-Dade County area, but only about a quarter of them were productive and at most 3 to 5 of them were in the top tier of CDCs across the country (Burnham 1999; Jones 1999; Martin 1999)." Also see the discussion in Stepick et al. (2003, pp. 6673) about the politics surrounding Miami’s African-American business development organizations.

${ }^{92}$ Current commissioner Willy Gort (who also had a spell during the 1990s) is president of the East Little Havana CDC. Former commissioner Angel Gonzalez directed the Allapattah Business Development Authority (ABDA, also a CDC). The latter commissioner was indicted on ethics charges for steering city contracts to his organization (Cenziper, Corral and Lebowitz 2007) and in the 1990s ABDA was found to have engaged illegally in electoral mobilization in support of former City Mayor Suarez and Commissioner Humberto Hernandez, both of whom were implicated in major corruption scandals (Hernandez was eventually convicted and imprisoned) (Garcia 1998; Viglucci 1998).
} 
A key finding of Von Hoffman's (2001) case study of community development in Miami was that $\mathrm{CDC}$ projects struggled because they followed an entrepreneurial approach instead of relying on foundation and government grants to the extent that is typical in other parts of the country. This was partly the result of a young CDC system: "Unlike other cities, Miami had never developed the proto-CDCs-neighborhood organizations that were formed to fight urban renewal and poverty and that then became interested in real estate development" (Von Hoffman 2001, p. 80). But in the 1980s when Miami's CDC support system was established in the form of technical assistance agencies and community foundations, it struggled for prominence because of competition from an alternative, entrepreneurial method of doing community development. ${ }^{93}$ The state of Florida's community development policies created in the 1980s emphasized small businesses loans with restrictive underwriting (making it difficult for CDCs to get loans) and established rules governing low-income housing tax credits which favor large development companies (Ibid, p. 65). Miami-Dade County's administration of community development funding also followed the entrepreneurial approach, for example, by typically distributing almost three-fourths of available grant monies to forprofit businesses and leaving more than $40 \mathrm{CDCs}$ to compete for the rest (Ibid, p. 66). In one case, a CDC in Liberty City failed because it consistently partnered with privatesector real estate developers, as "it adopted a strategy in keeping with the entrepreneurial

\footnotetext{
${ }^{93}$ The "traditional" CDC ideology differs from entrepreneurialism because according to the former, certain principles cannot be compromised to the profit motive, such as the location of development projects (in the neighborhood) and the permanent affordability of housing.
} 
ethos." "94 Albeit "weak," other CDCs made do within the existing community

development support system in Miami by relying on stronger political connections, scaling back their operations within the limited support system, and/or by virtue of operating in a smaller municipality where the political environment is more malleable and open (Von Hoffman 2001; see also Lowe 2004). ${ }^{95}$

\section{Community Development Corporations in Wynwood}

The problem that I had politically was that the Puerto Rican community in Wynwood expected from me to give preferential treatment to Wynwood. And there was no social, economic or any justification for them getting it other than their fair share. What was their fair share? It was never enough... They always wanted more. It's different [than other neighborhoods] because the fact is that they didn't get more. And the fact is that the Puerto Rican community never had any political clout. Never! [The Wynwood Puerto Rican leadership] was a very small, kind of, very ineffective, very insignificant... I mean, I went there because I felt an obligation to go there. Not because I had to go there. I didn't get elected there. My votes came from the Hispanic community [read: mostly CubanAmericans]... Then I got challenged from a Cuban-American in 1981 [and] at that point, I was [re]elected by the Black community.

- Former Miami City Mayor Maurice Ferre (1973-1985)

In Wynwood, although neither the service agencies nor the more development-

oriented CDCs managed by Puerto Ricans ever developed significant electoral clout, their

\footnotetext{
${ }^{94}$ Although the "weak" community development system and pro-entrepreneurial climate in Miami encouraged the CDC to operate like a for-profit business or at least partner with private companies, trained as a CDC executive, its' leaders made business mistakes that led to failed operations.

${ }^{95}$ The East Little Havana CDC, unlike the Liberty City case, was managed by a Cuban-American city commissioner and has had other influential Cuban-Americans on its Board of Directors. ELHCDC also focused on smaller-scale buildings intended for homeownership in addition to supporting small businesses, fitting with the entrepreneurial orientation of local policymaking and the prevailing housing development practice (as in the case of the Inclusionary Zoning policy I examine in Chapter 5, large-scale rental properties are the exclusive terrain of for-profit builders). The Opa Locka CDC has been effective along more "traditional" lines partly because it operates in the City of Opa Locka, where the political system was more malleable and public officials more supportive (indeed, the current OLCDC director is a former Opa Locka mayor), in addition to gaining some support from Miami-Dade County.
} 
leaders nevertheless behaved as if they were also political organizations, owing to the nature of the game in which all CDCs seemed to operate. While the first CDCs created in 1980-81 were Black organizations based in Liberty City and Overtown, by 1983 and 1984 Latino neighborhood leaders were funded to create similar organizations. ${ }^{96}$ The first CDC in Wynwood focused on business development and job training, and was born out of the complex and highly politicized series of events between 1980 and 1983 that included divisions among the neighborhood's Puerto Rican leadership, conflict between Puerto Ricans and Cubans from Little Havana, and the typical (for Miami) discursive conflicts between capitalist and socialist ideologies. This episode of ethnic and ideological friction was exemplary of the general pattern of internal and inter-ethnic conflict that characterized community development work in Wynwood throughout the 1980s and 90s.

The first public fissures between Puerto Rican organizational leaders became evident in 1980 when a Cuban-controlled nonprofit agency, the Small Business Opportunity Center (SBOC) based in Little Havana and housed in the offices of the Latin Chamber of Commerce (CAMACOL), was awarded monies from Wynwood's share of CDBG to implement a job training program there. The SBOC was selected because the Wynwood CDBG Advisory Board, chaired by Rodrigo, did not establish a quorum in its annual meeting to vote on a funding recommendation for 1981. Rodrigo appeared before the City Commission when the funding was awarded to SBOC to protest the decision but to no avail. Speaking in support of the SBOC was Benny, a Wynwood resident and

\footnotetext{
${ }^{96}$ In many cases, existing service agencies were funded to expand or shift their operations toward economic development.
} 
activist, who had apparently broken ranks with Rodrigo (MCC 6/26/80). Later, the SBOC hired and subsequently fired Manuel, one of Rodrigo's Puerto Rican associates from the Health Clinic, to help implement the new jobs program in Wynwood. After he was fired, Manuel, together with Rodrigo and another associate, Jorge, filed complaints with the city's legal department against the SBOC. They made a variety of allegations during the October 1980 deposition hearing (MCC 10/9/1980), but two are most relevant. Manuel claimed that he was hired as "a token" and that SBOC was being used as a cover for the Cuban-controlled CAMACOL to "infiltrate the Wynwood area." Second, Manuel testified that he was told "to back Benny for Chairman of the $\mathrm{CD}[\mathrm{BG}]$ Advisory Board [instead of Rodrigo]." ${ }^{97}$ As I discuss below, the Mayor eventually terminated the SBOC's program in Wynwood citing its lack of neighborhood support. The program funding was turned over to a new organization founded by Benny, who by then had been elected to the neighborhood's CDBG advisory board. For these reasons, explained Rodrigo, he regarded Benny as an "opportunist." Rodrigo lamented that by taking over the Puerto Rican Health Clinic he "lost the leadership factor" in the neighborhood. ${ }^{98}$

The other major split in Wynwood's Puerto Rican leadership occurred in the electoral arena. The leaders of the Organización Democrática Puertorriqueña (Puerto Rican Democrats or ODP), including Felipe, stopped working with Rodrigo to organize a Puerto Rican voting bloc in 1981 after Rodrigo decided not to support the incumbent

\footnotetext{
${ }^{97}$ The rest of the allegations had to do with the fact that the city-funded CAMACOL staff and board members were also employed by the city-funded SBOC, although the city attorney could not find any evidence that the Cubans had used their "position at one place to benefit the other," which would have constituted a conflict of interest.

${ }^{98}$ Felipe also regarded Benny as an opportunist, despite their temporary collaboration, and he was characterized as an aggressive, self-serving activist in newspaper articles (Feldstein-Soto 1983a, 1983b; Miami Herald 1983).
} 
Puerto Rican Mayor Ferre in his 1981 re-election campaign against Cuban Manolo Reyboso. The split between the ODP and Rodrigo not only divided the Puerto Rican vote in general but specifically within Wynwood, as one faction, including Benny and Felipe, followed the ODP and others were loyal to Rodrigo. ${ }^{99}$ Yet, by 1984, even Felipe abandoned the ODP to form a new organization, the Puerto Rican Democrats for Reagan, thus leaving the Democratic Party to support the President's re-election campaign in Florida.

Another notable case reveals the salience of both inter- and intra-group conflict in the politics of community-based organizations. Although the Puerto Rican Opportunity Center (PROC) established in 1976 was an "information and job referral" service (MCC 11/10/77), critics doubted whether it actually conducted job training or assisted neighborhood small businesses. Moreover, as it was housed in, and effectively managed by the leaders of the Puerto Rican Health Clinic (PROC was initially named after the clinic), it was seen as an extension of Rodrigo's role as a neighborhood representative. In the late 1970s, as Federal Revenue Sharing gave way to CDBG funding and local politicians had more discretion over community development monies, PROC funds were terminated and given to a national organization, Puerto Rican Education Services (PRES), which established itself in Wynwood in 1981. The Mayor explained his resolution singling out PROC for defunding during an October 1981 City Commission meeting (MCC 10/7/81):

As you know, we are funding the Puerto Rican [Health] Clinic $\$ 40,000$ a year. There are two things involved in this. One is, I think, substantive and the other is

\footnotetext{
${ }^{99}$ Interview with Rodrigo.
} 
something that is personal that I want to explain. The substantive issue is that the City of Miami has never dealt with funding of medical clinics. We were funding PROC, the Puerto Rican Organization for Community whatever it is, and they were involved in job training. Now all of a sudden PROC was a failure so it was faded out and absorbed [by the Health Clinic]. But instead of continuing to use that money for job training we ended up just because we wanted to placate the Puerto Rican community in Wynwood giving that money to the Puerto Rican [Health] Clinic. We are not in the business to do that. [Now] there is an organization called PRES... a national organization now in the Miami area [that] have been funded [by] the Federal government specifically for job training... As we go about cutting monies... the number one priority, after giving people hot meals, is job training.

After the Mayor's resolution was passed 4-1, with the dissenting African-American commissioner arguing that PROC should be given more time to reestablish job training or otherwise adjust, ${ }^{100}$ the Mayor went on to explain his more "personal" reason for defunding the agency (MCC 10/7/81).

I would like to now on the record, even though I didn't say it before because I didn't think it was germane to the vote and I didn't want to get into an emotional issue - that one of the of the members and evidently the political ideologue of the Puerto Rican Health Clinic, a gentlemen by the name of Font, F-O-N-T, Jorge Font, is the representative of the Puerto Rican Socialist Party in this community, and that the Puerto Rican Socialist Party is directly affiliated to Fidel Castro in Havana, Cuba, and is a bonafide member of the Communist International. And I would like for Mr. Font to clarify for this community how the Puerto Rican Socialist Party is functioning in Wynwood and in the rest of the Puerto Rican community. ${ }^{101}$

\footnotetext{
${ }^{100}$ Although the Mayor's surprise pocket item did not allow Rodrigo a chance to appear and defend his agencies' use of the funds, at the next city commission meeting Rodrigo argued that the reason he terminated the job training program was because another agency was established in the De Hostos Neighborhood Center (not PRES) to implement job training. Yet, he insisted on receiving the funding on the basis that the Mayors' actions were retaliatory against him for withdrawing political support during the last election. As it turns out, the Mayor's reasons may have been somewhat politically motivated, although not for lack of electoral support.

${ }^{101}$ Rodrigo explained to me that Jorge was indeed a socialist and one of the grandsons of Jorge Font Saldaña, a writer and politician close to former Puerto Rican Governor Luis Muñoz Marín (González 2008). The junior Font eventually moved back to island but never got involved in politics. He is not to be confused with the other grandson name Jorge (De Castro Font), who eventually became a Puerto Rican Senator, supporter of the island's commonwealth status and George Bush ally.
} 
Two months later, when Rodrigo appeared before the City Commission to protest the defunding of PROC, the Puerto Rican Mayor reiterated (MCC 12/10/81):

The PROC... started as a job opportunity and a job training [center] and in my opinion we have been derelict in the past couple of years when they got away from that because, in my personal opinion, [they] failed. And I think they failed because of the people that were involved and there is no question that some of the people involved that were being paid out of this were paying more attention to politics, both the politics of Miami and the politics of the Socialist Party of Puerto Rico which espouses independence of Puerto Rican, and I don't think it had anything to do with the well-being of the Puerto Rican and other community here and job training. PRES is a non-political, nationally recognized outfit.

He went on to argue that "poor people who need job training, they don't need politics and as far as I'm concerned that was an appropriate move [to defund PROC]."102 Speaking in support of funding for PRES was Benny, one of the original and key Puerto Rican leaders from Wynwood, who was by 1981 also on the governing board of PRES. Although Rodrigo later reflected that the Mayor employed "divide and conquer" tactics to avoid dealing with him, it seems more likely the Ferre was seeking to impress Cuban voters in an election year.

As noted above, the following year - in fact, only two months after Ferre was reelected - the Mayor terminated funding for the Wynwood-expansion of the Cubancontrolled SBOC and gave it to the new Wynwood Economic Development Corporation

\footnotetext{
${ }^{102}$ This time, the motion was introduced as part of a broader community development funding package by Cuban-American Commissioner (and Vice-Mayor) Carollo and seconded by Cuban-American Commissioner Perez, and passed by a 3-2 margin - the dissenting votes cast by African-American Commissioner Dawkins and Anglo-American Commissioner Plummer, the latter of which objected to other aspects of the package. Although Dawkins never explained his dissent, it was by his request that Rodrigo was invited to speak to the resolution, to no avail.
} 
(WEDC) formed by Benny, who thereafter served as Board Chairman (MCC 1/14/82). ${ }^{103}$ Later that year, Benny's first major undertaking with the WEDC was to obtain a $\$ 25,000$ city grant for the first annual Wynwood Community Festival (MCC 7/29/82) but the city's annual review of CDC contractors ranked the WEDC as the third-least productive organization (out of 10 studied), receiving a score of 54/100 (MCC 1/28/1983) that put it at risk of being defunded. To satisfy these concerns, in the following year Benny's WEDC joined forces with Felipe and a cohort from the wealthier Edgewater neighborhood to the east, including a Reverend and a merchants association, to form the Biscayne-Wynwood Chamber of Commerce (BWCC). They proposed to implement an emergency shelter and job training program with the support of many local businesses, which impressed the Mayor enough to initially recommend allocating \$275,000 (MCC 6/9/1983). ${ }^{104}$ Two months later, however, when faced with a competing proposal from the PROC (affiliated with Rodrigo and the Puerto Rican Health Clinic), the Mayor decided to amend the previous resolution and instead split the funding evenly between the two organizations (MCC 9/29/83). Felipe protested the decision, arguing that "we should have never been misled into believing that the Chamber of Commerce was granted this proposal," leading them to spend three months organizing the project under the presumption of a $\$ 275,000$ budget. Despite the obvious competition between the two

\footnotetext{
${ }^{103}$ Benny explained: "As you recall, about a year and a half ago I came before this Commission requesting that the monies allocated for the Wynwood Economic Development Program be given to the SBOC set up in Little Havana... One of the conditions that was [sic] set up at that time was that... I asked the Commissioners that until we come with a community organization, that there would be the agency to administer the funds. Now... that we have organized a community organization... we are asking for the transition from one organization to the other."

${ }^{104}$ The Mayor claims it was "one of the very first times that I have seen a business group... become involved in a serious community problem [training young men to help reduce crime]," and thereby there was "no way that I, as Mayor can turn my back on the attempt that is being made here" (MCC 9/29/1983).
} 
groups for funding, the Mayor voted for the split allocation on the condition "that both groups must work in tandem - I do not want separate, rival organizations... competing with each other for government funds on something that is essential for the well-being of the community" (Ibid).

Not surprisingly, a September 1983 Miami Herald article was titled, "Wynwood Needs United Leadership" (Morris 1983). While PROC and the WEDC-BWCC partnership competed for economic development funding, smaller groups also emerged to complicate and, ultimately, undermine the neighborhood's power. Also in 1983, a new activist to the neighborhood, Roxanne Rexach, founded Puerto Rican Charities, Inc. to train women on sewing machines, among other trades (Foote Jr. 1983). But within a year the Bronx-native, whose city funding proposal was not approved, disappeared with thousands of dollars in donations and down payments from neighborhood residents impressed by her "street skills" (Soto 1984). In December, 1983, Benny died of a heart attack during one of his "typical" heated discussions with the Mayor and Rodrigo over the distribution of funding for Wynwood groups (Miami Herald 1983; Gilbert 1984). ${ }^{105}$ The shelter project he wanted to build through the WEDC eventually became a public housing project for the elderly that was named after him.

Wynwood was left with a thoroughly fragmented leadership. The WEDC's replacement director resigned after only four months. The city soon defunded the agency (Colon 1984a), which remained inactive for almost four years until it was taken over by a new leader supported by Felipe (Roman 1987). Felipe and Rodrigo regrouped in order to reconstitute the WEDC as a stronger agency focused on Wynwood, and recruited its new

\footnotetext{
${ }^{105}$ Rodrigo's account is confirmed by newspaper articles.
} 
director, Bill, an educated Puerto Rican professional from New York. ${ }^{106}$ Still in 1987, newspaper reporters wrote that "residents speak of a fragmented Puerto Rican leadership and of too many small organizations that don't get together" (Roman 1987, p. 10). By 1989, the prior alliance between the Edgewater merchants and Wyndood leaders had also dissolved, as the WEDC and the new Edgewater Area Association competed for city funds (Roman 1989). This division was also important because it marked the redrawing of neigborhood lines between Wynwood and Edgewater, the latter of which had been considered part of Wynwood for decades (see CDBG map, Figure 4.5). ${ }^{107}$

\footnotetext{
${ }^{106}$ According to the accounts of Rodrigo and Felipe.

${ }^{107}$ As Edgewater gentrified, its' neighborohod associations and economic development organizations sought to implement different programs than those of Wynwood's Puerto Rican leaders. By 1993, for example, about \$200,000 of the Wynwood Target Area's \$2.1 million allocation was spent on Edgewaterbased programs (City of Miami 1996). Albeit small, such funding reflected the encroachment of new stakeholders in Wynwood's political terrain.
} 


\section{Figure 4.5: Map of Wynwood Community Development Target Area and Neighborhoods}

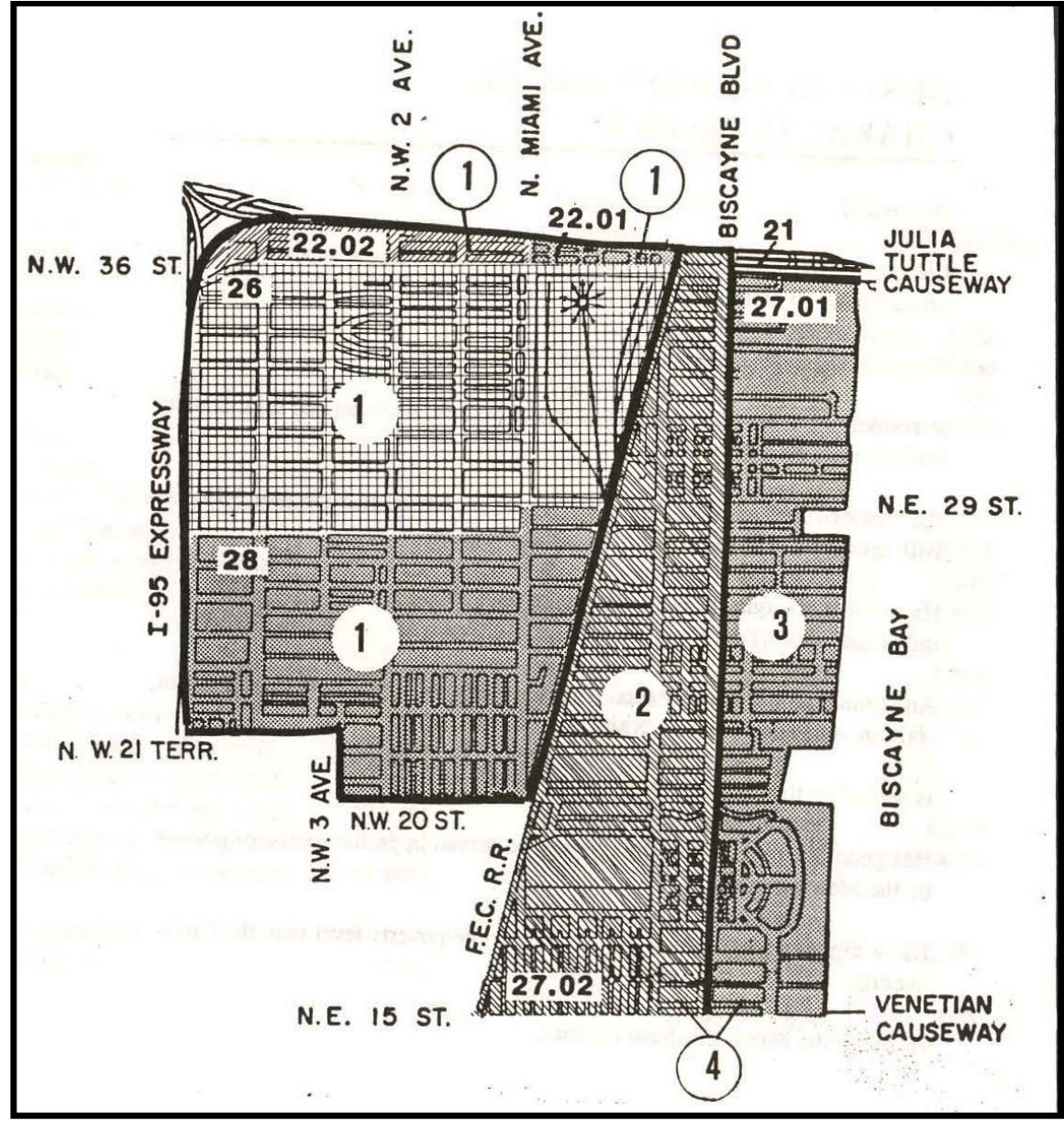

Source: From City of Miami's 1994-1996 Community Development Target Area report. In the legend, "Wynwood Neighborhoods" are numbered as following: (1) Wynwood, (2) Boulevard, (3) Egdewater, (4) Omni/Island. Note how the mostly Black low-income housing in the southwest corner of Wynwood - the Proposed Expansion Area in the 1979 Redevelopment Plan - is cropped out of the Wynwood's CD Target Area even though $\mathrm{CD}$ funds were used for some of the clearance.

By 1990 the thrust of the neighborhood's economic development intiatives was to directly address the conditions that limited real estate investment. Community initiatives became closely aligned to the political agenda for Wynwood established by government and business elites in the form of the 1979 Redevelopment Plan the 1990 Safe 
Neighborhood Plan, described earlier. Although the WEDC was tilting in this direction under Benny to the extent that he increasingly partnered with local businessmen, he was mainly interested in employment training for residents and low-income housing. His successor at the WEDC in 1984, although short-lived, already hinted at the potential shift in orientation, as his only undertaking was to publicly support the creation of the NonProfit Arts Complex, arguing that "besides giving prestige to the area, it will upgrade the neighborhood [and] you'll see traffic of new people (emphasis added) on the weekends" (Colon 1984b, p. 6). ${ }^{108}$ But it was only under new management in 1988, with one of Rodrigo's associates as board chairman and Felipe also in support, that the WEDC became a real estate development organization. Such an orientation was, after all, what CDCs were intended to adopt, even if in the Miami context they became extremely entrepreneurial. In this respect, compared to other Miami CDCs, the WEDC was somewhat late in its shift toward an explicitly entrepreneurial strategy. After briefly examining the WEDC's project in the 1990s, I will discuss how its failure made room for yet another group of new organizational leaders who formed CDCs in the mid-1990s.

Prior to 1990, the WEDC re-organized the wholesale clothing firms in the Garment District into a merchants association and sought a marketing strategy to change the perception of the area. The WEDC director successfully lobbied the City of Miami to provide visible signage to help direct tourists and shoppers from highway exists to the wholesale clothing district and to approve symbolic namesakes - for example, Fifth

\footnotetext{
${ }^{108}$ The establishment of the Arts Complex was funded in part by $\$ 200,000$ from Wynwood's CDBG allocation.
} 
Avenue became Fashion Avenue and the northern half of Wynwood became "Old San Juan."

The centerpiece of the new WEDC's work was an ambitious plan to establish a Free Trade Zone (FTZ) in the southwest corner of Wynwood, the city-owned site where housing had been cleared as part of the Garment District Redevelopment Plan. The Wynwood FTZ was also approved as part of the 1990 Wynwood Safe Neighborhoods Plan since, as the city manager put it, "that trade zone being a federal facility is required to have security, [then] that security will enhance the safety that [is] centered around that particular district” (MCC 6/7/1990). The FTZ was an extraordinarily large and protracted project initiated in 1990 that became mired in several legal disputes that were finally settled in 2005 , by which time the property was in foreclosure and surrounded by a burgeoning Art District (next chapter). Examining the details of the plan and the politics surrounding its failure are beyond the scope of my analysis; still, some key observations about the project reveal its consistency with the prevailing market ideology that had transformed community (re)development practices and fit into the plans of government and business elites (despite disagreements over the distribution of the profits). ${ }^{109}$

With approval and administrative support from the City of Miami and MiamiDade County, the WEDC applied for and received a Foreign Trade Zone designation from the federal government. The city then granted the WEDC the property title to the 13-acre site that had been cleared as part of the 1979 Garment District Redevelopment Plan, so that the WEDC could recruit private firms to develop a distribution facility at the

\footnotetext{
${ }^{109}$ In addition to sources cited, the following summary is based upon the authors review of a City Commission special hearing where attorneys explained the complexities of the pending litigation over the FTZ to commissioners (MCC 2/9/95) as well as newspaper articles (e.g., Ousley 1993b; Wilner 1999; Bussey 1996, 2003; Viglucci 2007), albeit with some simplification.
} 
site. The WEDC said it would require developers, contractors and tenants to train and hire local residents and charge them fees for use of the facility (where the import-export business would be tax free). These fees were expected to generate substantial proceeds for the WEDC, which planned to reinvest in community development initiatives. Both the city and the WEDC expected that the revenues from managing the free trade facility would be sufficient to allow the WEDC to operate independent of government funding. The WEDC established a private subsidiary corporation, Old San Juan Management, Inc. (OSJ), to act as its fiscal agent because the nonprofit entity was legally prohibited from managing the amount of money involved in the FTZ project. Old San Juan Management had the same board of directors and was to function only as a vehicle to funnel proceeds from the FTZ to specific WEDC community development initiatives.

The creation of this private entity alarmed city officials who in 1993 demanded the power to choose five of the WEDC's 12 board members. The remaining board members would be determined through neighborhood-based elections. Still, the FTZ and the WEDC's accountability to the neighorhood was called into question because the project's scale went far beyond the neighborhood, drawing on state and federal funding sources that did not permit Wynwood-specific training and hiring preferences, even though the WEDC had promised to use its leverage as project manager and relationships with contractors to provide exclusive opportunities to area residents. However, the protracted conflict and litigation apparently kept the board structure from developing. Records indicate that the only active board was comprised of three members: Chairman Gamaliel, an administrator at the Puerto Rican Health Clinic; Bill from WEDC; and Soraya of the Puerto Rican Child Care Center. Dozens of leaders and members of the 
Wynwood Catholic parish protested this at a City Commission hearing where their priest requested the following $(10 / 14 / 1993)$ :

There has to be some accountability with the [WECD] agency and they should answer to a higher authority, that being the City of Miami, since the Commission is elected by the people and to serve the people, that is to say, Wynwood. I would like to see the foreign trade zone serve the community and, in a special way, those who live in that area; and that all of the people who live in that area be assured some voice in the board of the Wynwood FTZ. ${ }^{110}$

Meanwhile, the Wynwood Puerto Rican leaders (Rodrigo, Felipe and Bill)

involved in the project accused the City Commission of trying to sabotage the FTZ, once they realized how lucrative it would be, by withdrawing funding and support for the WEDC to seek state and federal funding. The WEDC eventually sued the city for not "reasonably" cooperating as stipulated in earlier agreements to amend the property deed to repeal restrictions on private development. City officials, on the other hand, accused the WEDC of trying to enrich itself through a "sweetheart deal" without sharing the proceeds with the City. One commissioner in particular repeatedly lamented that the city had given away such a valuable piece of land without guaranteeing itself a greater share of the spoils. However, the WEDC prevailed in 2005 when a circuit court ruled that the city had unreasonably restrained the project's development by reneging on its commitments to amend the property deed and support the agency in seeking special federal and state loans (Jeffers 2005a). But by then the WEDC was bankrupt and its

\footnotetext{
${ }^{110}$ Rodrigo, who supported the WEDC FTZ project, later reflected that the Cuban priest was always distant from the pre-existing Puerto Rican organization leaders, seemingly uninterested in collaborating. Without pinpointing any specific groups, the priest noted during our interview that when he first arrived in Wynwood he found a variety of groups that he referred to as each made up of cuatro gatos, four cats, asking rhetorically: "but who is behind those four cats?" He contrasted other leadership to his own, noting that when his church fought for a cause they were supported by hundreds if not thousands. I will discuss this faith-based activism later in this chapter and the next.
} 
director had become a licensed realtor who had vanished from Wynwood's political scene.

Before the project was indefinitely caught up in litigation, the WEDC hired a developer to build the FTZ distribution facility (Figure 4.6), a major physical redevelopment project in itself. The resulting three-story building shell now divides the low-income housing complexes along NW $22^{\text {nd }}$ Street (previously segregated by street closures and landscapre buffers) from the warehouse district to the north. The FTZ was included as part of the 1990 Safe Neighborhood Plan as a rationale for the location and organization of the street closures.

Figure 4.6: Image of the Failed Wynwood Free Trade Zone Site, 2010

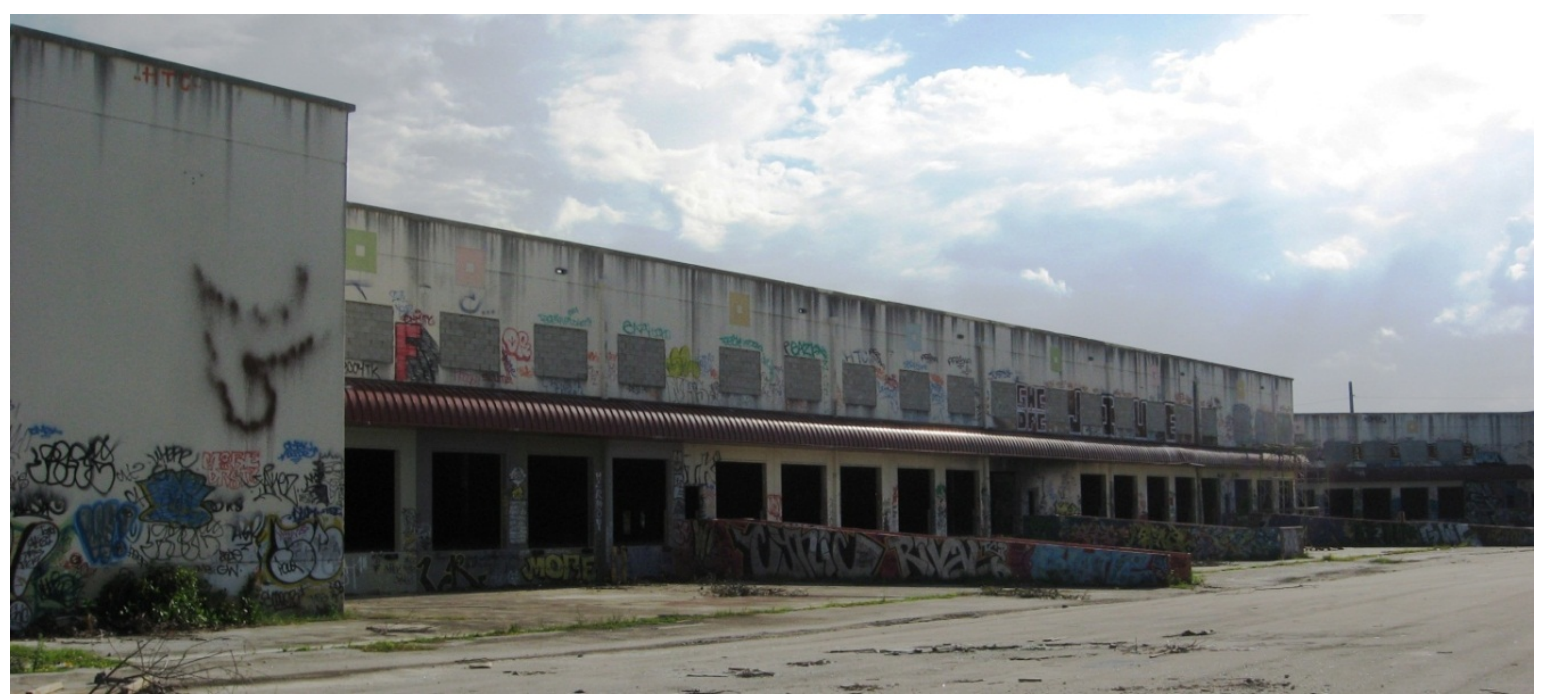

Source: Photo taken by author, September, 2010. In 2011 the site was purchased by an investment company that cleaned and leased it out as a film production site while plans are finalized to redevelop it into some kind of an artistic venue (Musibay 2011).

The project was unusually large for an organization like the WEDC and for a neighborhood with little political clout. From the outset, it seemed far beyond the scale at 
which Wywnood residents might be directly engaged. The lack of resident engagement led to questions from other neighborhood leaders and city officials about the project's accountability to Wynwood residents and city taxpayers. However, from the perspective of the WEDC director, "the problem" with the FTZ project "was [that] everyone wanted a piece of it" (Viglucci 2007, p. 1A). Ultimately, a county circuit judge found that "no justification for the city's action [to withrdaw support and funding] was reflected in the record," concluding that city officials were largely to blame for the FTZ's collapse (Ibid). The former city manager explained in an interview that the city erred in giving away the 13-acre site with so few strings attached (a point that was repeatedly brought up during City Commssion meetings in the 1990s).

The hyper-politicized nature of the project discouraged other organizational leaders who wanted to carry out community-based economic development from straying from the politically correct approach. Although many felt that that the FTZ was a promising project (Andrews 1991; Charles 1995a), the WEDC's struggle over the project was an example of how not to work with the City of Miami. Moreover, the project's failure further divided Wynwood's organizational leaders. The remaining, long-time Puerto Rican leaders, Rodrigo and Felipe, supported the WEDC. By 2000, these leaders retired and became disconnected from the community politics of Wynwood. During the 1990s a new crop of leaders including the Cuban priest of Wynwood's Catholic parish as well as Puerto Rican professionals who moved from New York and from the island, created new community organizations and became recognized by city officials and the news media as Wynwood's representatives. I will discuss some of the work of these new organizations below and in the next chapter. One of these organizations was the Puerto 
Rican Chamber of Commerce, formed in 1991. Another, the Puerto Rican CDC, was formed in Wynwood two years later under the direction of another Puerto Rican professional from New York. By 1999, when a new director took over the Puerto Rican CDC, she noted that as she started her work in the neighborhood and did not understand why the FTZ project had become "a real mess," she was clear that "it's something that everybody just shies away from."

\section{Faith-Based Activism against Disinvestment and "Blight"}

Noted earlier, in the 1980s the Catholic parish in Wynwood established satellite missions throughout the neighborhood to better reach residents and to increase its membership. By the late 1980s, the church became an important member of the countywide Faith-Based Activist Coalition (FBAC). In the next chapter I examine some aspects of the FBAC's broader, city- and county-wide work but here I focus on the emergence of the Wynwood Catholic Church and its Cuban head priest as a powerful force in the neighborhood.

As one reporter wrote in the late 1980s, "the inner city parish has turned political action into a tool of evangelization. That tool is the FBAC" (Rodriguez-Soto 1989, p. 7). It was described this way because in the late 1980s FBAC organizers canvassed the neighborhood in what they called a "listening process" to understand what problems Wynwood residents faced and which issues they would most likely support as social justice causes. With the Cuban priest as a key ally, the FBAC campaigned to increase building code enforcement and demolish abandoned houses in Wynwood. In March 1989, the FBAC held its first "accountability meeting" with city officials and more than 
350 residents at the Catholic parish in Wynwood. At the meeting, Wynwood leaders presented a list with images of 360 properties in the area that were vacant and littered with trash, abandoned buildings that had become "crack houses," or were otherwise in need of building code enforcement (Ibid).

Although it is not clear how many buildings were demolished as a result of the church's pressure, these actions contributed to the decrease in housing units noted earlier. By emphasizing the role of these demolitions in reducing the housing stock I do not mean to imply that "crack houses" are important assets to the neighborhood that should be preserved. But as a former FBAC organizer explained, knocking them down was one thing, monitoring the management of those properties was another challenge altogether.

It was easier to control a vacant lot [so that it] was kept clean than be dealing with a lot of the drugs, and a lot of the problems [in an abandoned building], especially for kids that have to walk distance from home to school. [But] it's very difficult [to monitor] because it costs a lot of money and resources to keep this type of campaign going on.

Of course, the FBAC's concern was ensuring that the properties were kept clean and drug-free. When in 1992 city officials devised a more rigorous code enforcement plan, the Cuban priest urged them to also include mechanisms for transferring properties to city or nonprofit ownership so that the outcome of their efforts is not just to produce vacant land.

It will be good... [for] the City Manager to bring us some kind of things that he can do with those empty properties... Because we are in favor of the strongest measure [of code enforcement] but we want also those empty lots to have something for them. We don't want empty lots in our city. We are willing to accept any... suggestions to make those affordable houses or whatever, you now, that can pay taxes. 
Ultimately, city officials passed stricter codes that streamlined their ability to place liens and foreclose on properties, but it was left up to Wynwood's CDCs to figure out how to develop affordable housing or propose alternatives on city-owned vacant lots. Although the FBAC organizers were aware of the potential threat of gentrification (as I discuss in the next chapter), it was not clear to them in the late 1980s and 1990s that by helping to clear land of abandoned buildings, the cost of redeveloping these properties was reduced (the "rent gap" enlarged). For this reason, the Alinsky tradition of neighborhood organizing that focused on short-term, practical objectives has been criticized for its lack of ideological vision and political analysis (e.g., DeFilippis 2004).

Another key initiative of the Catholic Church in Wynwood was to build a small chapel in the heart of the neighborhood, concretizing the envagelizing work of its roving missions. Regardless of whether residents believed it, the origin of the chapel was staged as a "miraculous" conception. One night in 1990 after parishioners expressed skepticism at the head priest's announcement of the project, a sheep appeared on the vacant, future site of the proposed church. As the Lamb of God is the central symbol on the shield of the Puerto Rican coat of arms, the Cuban priest announced it was a sign from God that the new chapel would be named for Puerto Rico. "And that lamb was there, nobody dared touch it," recalled Carlos Jr., who at the time worked at the PRES offices just down the block. "This [was] in a neighborhood where, you know, people would steal your tires while you're waiting at a red light."

The Puerto Rican Chapel was completed in 1994, after piecing together architectural designs, building materials and money from private donors. The designs 
were donated by renowned architects from the University of Miami and a small cohort of wealthy donors (most of whose identities were never revealed). The chapel project made the Catholic Church in Wynwood under the leadership of the Cuban priest a popular charity. A profile of a 1993 church fundraiser revealed a long list of powerful CubanAmericans, including the then-mayor and city manager (whose sister was treasurer of the church's fundraising department) (Landers 1993). The chancellor of the Archidiocese of Miami explained that the Wynwood Catholic Church "was the center point for Cubans at the beginning of exile. Most of the families [which] are the friends of [the church] went to school there, then moved on to other areas. Now they are coming back to help the people and the parish that helped them" (Landers 1993, p. 1J). ${ }^{111}$

Thanks in part to these relationships, the 1989 campaign to demolish "crack houses" and enforce building codes developed into a closer collaboration between the Wynwood Catholic Church and the city government. The Cuban priest was instrumental in the development of a new Community-Based Policing (CBP) system in Miami in 1992, modeled on the government participation efforts he led in Wynwood. At the March 1991, city meeting where the CBP system was approved, the City Manager credited the FBAC and its Wynwood support base as they "showed me that the only way we could deal with the problems of the community was out there in the neighborhoods," quoting the Cuban priest's approval of the new program when he said, "you have given a face to bureacracy. I can look at that guy and go and complain and maybe something will happen." The CBP system created what the city manager referred to as "mini city halls"

\footnotetext{
${ }^{111}$ The Mayor added, "my wife and I and many of our close friends, including a few doctors, find [the church's inner-city projects] to be one of the most important efforts in the city, in both the spiritual and community sense."
} 
inside of the neighborhoods to directly engage residents in issues of building code enforcement and permits, among other city services.

Ironically, the Cuban leaders who advocated for the CBP system also warned against the excesses of government. The Cuban city manager closed his March 1992 presentation of the new administrative infrastructure by reminding the commission that "President Eisenhower said that the best government is the government closest to the people, and that's simply what we're trying to do here." Moments later, the CubanAmerican Mayor interrupted the public comments to distinguish the CBP system from the communist neighborhood watch groups in Cuba: ${ }^{112}$

Let me just put in the record [that] the exchange has to with the characterization of the program as a committee of barrios which is something very, very distasteful to people in the Cuban community because it's something that was initiated by Castro to exert surveillance and to co-opt and otherwise oppress the people of Cuba and Mr. Urra has responded that he fought against that and that [the $\mathrm{CBO}]$ has nothing to do with that. There is no oppression here but there is order.

Even the Cuban priest from Wynwood was known for railing against the "imperialistic" schemes of heavy-handed government (Landers 1993), albeit in reference to City of Miami garbage dumps imposed on poor people's neighborhoods.

In some ways, the cautions against government "close to the people" were warranted. The creation of the CBP, while helping to make local government more responsive to poor neighborhoods in the 1990s, also became a form of closer social control at the neighborhood level. As I will examine in the next chapter, at the turn of the

\footnotetext{
${ }^{112}$ The Comité de Defensa de la Revolución or CDR created by Castro's government in 1960 are neighborhood watch groups often described as the "eyes and ears of the Revolution" in Cuba.
} 
21 st Century gentrification processes began to change the form and function of the neighborhood-based CBP offices, making them more responsive to speculative investors than long-time residents. Moreover, the rationalities and practices forged during the entrepreneurial turn of community-based organizations also shaped the way these organizations would engage with the unfolding gentrification processes.

\section{The Creation of the City of Miami Voting Districts}

At the height of the mobilization generated through the priest's leadership, a major change in the City of Miami political system undermined the potential power of the residential base of Wynwood. The fiscal crisis of the mid-1990s ${ }^{113}$ provoked a referendum to disincorporate the City of Miami and this, in turn, prompted sitting commissioners to propose a city commission district plan to replace the existing at-large voting system (see Branch 1997a, 1997b; Steinacker 2001). The referendum failed but voters approved a "five-seat plan" in September 1997 (Branch and Keating 1997;

Viglucci 1997). The resulting district system split Wynwood virtually in half, as Figure 4.7 below reveals. The political logic behind the boundaries that cross Wynwood - as expressed during several city commission meetings in July 1997 - was to unite the African-American strongholds of Liberty City and Overtown (District 5) and the largest Anglo-American voting blocs along the Upper East Side, Brickell and Coconut Grove (District 2).

\footnotetext{
${ }^{113}$ In 1996, a federal investigation of political corruption discovered that Miami had a \$68 million budget deficit, 25 percent of the overall city budget, causing rating agencies to immediately downgrade Miami's bonds, eventually to junk bond status (Garcia 1996; Dluhy and Frank 2002).
} 
The district plan was approved despite some initial concern and negotiation over the division of Wynwood. Notably, this concern did not come from community activists, organization leaders or any residents from Wynwood. The only two residents to criticize the impacts of the district plan on Wynwood lived in neighboring Allapattah and both commentators raised concerns in ethnic group terms, in line with the rhetoric that surrounded the larger debate over the future of the City of Miami (Steinaker 2001). At the city commission meeting on July 10, 1997, one Puerto Rican resident of Allapattah, a neighborhood known for its large Dominican population, was critical of both his fellow Puerto Ricans and commissioners for not being "fair" to all of the Hispanic "subgroups" in the creation of a plan that reinforced the tripartite (Black, White, Cuban) racial/ethnic structure of the city.

I have always attacked this commission, generally. But now I am going to attack my own people from the Puerto Ricans... Where are the Puerto Ricans? Why don't we have a district in companionship with the Dominicans? The Hispanics are... there are subgroups. So, if we are going to make this, we have to be fair to all the subgroups. ${ }^{114}$

Quoted below, the Cuban-American commissioner Hernandez was critical of a previous version of the plan that kept Wynwood intact by routing the boundary further east, along the FEC railway.

There is no way that you could connect Overtown to the African-American district on top without encompassing the Wynwood-Edgewater area. And I have to agree with Commissioner Plummer that the problem I have with that is that you are obviously not living up to the integrity of the Wynwood Edgewater area by

${ }^{114}$ Transcript of City of Miami Commission meeting, July 10, 1997. 
putting it into the African-American district. You are splitting it and I think you are kind of messing up with the actual integrity of that community. ${ }^{115}$

\section{Figure 4.7: Boundaries of the City of Miami Commission Districts and Wynwood}

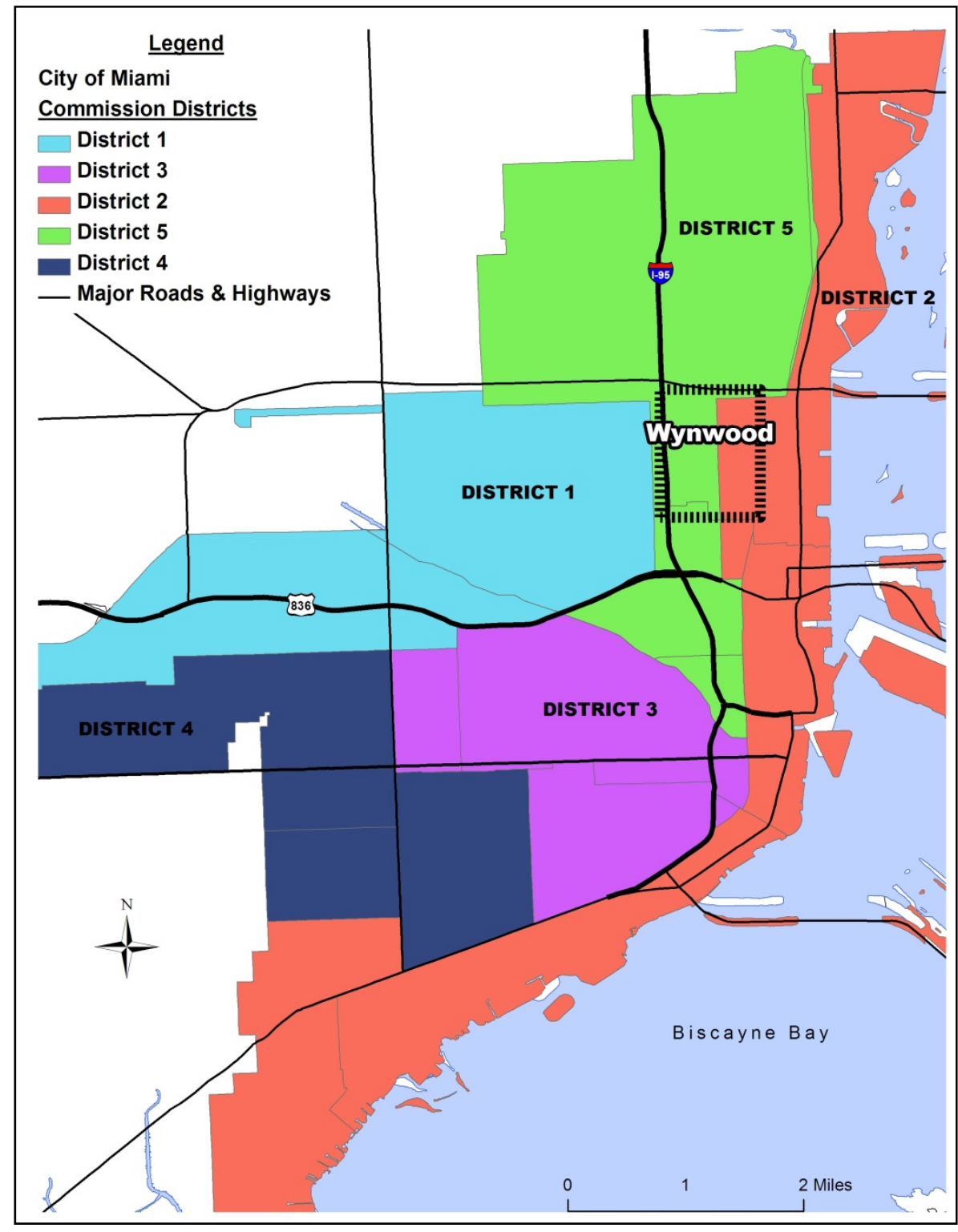

${ }^{115}$ Transcript of City of Miami Commission meeting, July 4, 1997. 
The decision to move the boundary further west into Wynwood did nothing to consolidate the Hispanic vote in the central corridor of the city. It is not entirely clear why the boundary between districts 2 and 5 was specifically routed along NW $2^{\text {nd }}$ Avenue, the central commercial corridor of Wynwood. Part of it likely had to do with the formula for allocating votes. If the boundary were moved east to keep Wynwood intact it would have added too many voters to the African-American corridor and, the resulting district would have been reduced along a different boundary. It is likely that AfricanAmerican leaders preferred to consolidate a black voting bloc instead of the mostly Hispanic area of Wynwood. Caught between majority white and majority black voting precincts, Wynwood's Hispanic vote was divided and apportioned almost evenly to each. Wynwood had not shown any substantial electoral power since the early 1970s, when Puerto Rican mobilization contributed to the Puerto Rican Democrats organization. In the mid 1990s, the Catholic Church seemed a potentially formidable force when it could mobilize hundreds and sometimes more than 1,000 Wynwood residents to "accountability meetings" with politicians. Yet neither the Wynwood Church nor the Faith-Based Activist Coalition spoke out against the districting plan, possibly because the growing number of recent Central American arrivals in Wynwood and the out-migration of upwardly mobile Puerto Ricans, Cubans and others, meant that fewer residents or parishoners were eligible to vote. Nevertheless, the head priest acknowledged that the new voting districts "sacrificed Wynwood" and made it the "rat's tail" in the city's electoral politics. Since then, he exaggerated, district commissioners "have never in their life stepped foot in Wynwood." 


\section{RATIONALITIES OF COMMUNITY-BASED ACTION}

By the early 2000s, as the City of Miami recovered from the 1990 s recession $^{116}$ and real estate markets were beginning to rebound, Wynwood emerged for the first time in its postwar history as a prime development interest and experienced rapid gentrification. In this chapter, I examine examples of the thinking and practice of community-based development in Wynwood during the 1990s and through the first decade of the 2000s. Of particular interest are two aspects of community politics: (1) the factors shaping the thinking and action of community-based organizational leaders and (2) the implications for how these organizations function as vehicles through which residents may engage in the politics that shape the built environment of the neighborhood. My interest here is not merely that community organizations in Wynwood were produced to be co-opted vestiges of previous generations of activism or ineffective in challenging the status quo or implementing some alternative development. The question is how this came to be: Why were these Wynwood organizations passive in the face of gentrification and even active in facilitating it?

These organizations shape resident participation in urban development by standing in as neighborhood representatives in political processes and by helping to inculcate residents (the constituents or "clients" of organizations) in ways of thinking and acting with respect to the politics of urban development. In this way, organizations help

\footnotetext{
${ }^{116}$ Noted earlier, in 1996 the City of Miami received a junk bond rating. The reduced bond rating increased the cost of financing redevelopment projects, resulting in increased austerity in subsequent city budgets, which encouraged the city to make greater use of alternative mechanisms such as Tax Increment Financing and tourist and parking taxes to finance inner city redevelopment (Garcia 1996; Miami Herald 1996; AP 1997; Cordle 2000; Rabin 2000; Dorschner and Corral 2001; Olkon 2001). As I will show in the case of the Midtown complex, the use of these financing schemes helped political and business elites circumvent or weaken public participation.
} 
to produce political subjectivies akin to what some have labeled the "new pragmatism" (Eick 2007, p. 270), a rationality that supports business initiatives and the local governments' growth agenda in neighborhood-level economic development projects.

The first section of this chapter focuses on the discourses and rationalities of action revealed in the development of the 1996 Wynwood Master Plan, which was a community-based planning exercise conducted as a partnership between the Catholic Church, the Puerto Rican Community Development Corporation and the University of Miami School of Architecture, and supported by a local bank and the City of Miami. This plan developed in the context of the neighborhood's leaders shift from demolishing to developing housing; from protesting disinvestment to proposing some alternative, a process which apparently led them to acknowledge and accept the political "realities" of urban development. The second section of this chapter seeks to further examine these leaders' thinking and action in the broader context of political activism and social justice advocacy in Miami during the mid-2000s, in some of which I was personally involved. I highlight the case of an initiative to create a more equitable Inclusionary Zoning (housing) policy in Miami-Dade County and I draw on other examples of how activists felt overwhelmed by the power of the wealth generated at the height of the 2003-2006 real estate bubble. In the subsequent chapter, I focus on three cases that exemplify the gentrification unfolding in Wynwood to explore how the ways of thinking and acting examined below shaped residents' and organizations' engagement with gentrification processes.

Recall that by the 1990s in Wynwood, non-Puerto Rican (or at least more diverse) leadership emerged through the local church campaigns to protest government neglect of 
the area and to demand services. Following the construction of the new Puerto Rican chapel, Fernando, the Cuban head priest of the Catholic Church, helped organize the formation of a new, Puerto Rican-led community development corporation (CDC) to provide assistance to small businesses and build affordable housing. The dissolving bonds of the neighborhood's decades-old Puerto Rican leadership and the previous Wynwood CDC's involvement in a protracted legal dispute (see Chapter 4) gave way to fresh crop of Puerto Rican professionals imported from the island and New York to manage existing agencies, found new organizations or otherwise inject fresh energy into the neighborhood's political relationships with government and the private sector. The new transition was not free of conflict as the Wynwood CDC claimed it was being sabotaged by the City of Miami's support of the new, competing CDC in the neighborhood. The new CDCs leaders sought to distance themselves from the Wynwood CDC and the negativity surrounding the Wynwood Free Trade Zone project. They were therefore much more likely to negotiate and partner with government officials and private developers. Indeed, from the 1990s onward, the neighborhood's new leadership, Puerto Ricans and otherwise, were decisively pro-development. Similar to the previous generation of leadership forged in the 1970s, which were enfranchised as service providers after rounds of protest, in the 1990s the neighborhood's leaders initiated the turn from protest activism to development implementation. An important and representative moment in this turn was the 1996 Wynwood Master Plan. 


\section{Community-Based Planning for the "Reality" of Gentrification}

Throughout the process of funding and building the Puerto Rican Chapel in Wynwood (Chapter 4), Fernando insisted that the group "do something more" for the neighborhood to enhance residents' sense of ownership. The general desire led to two specific initiatives - the formation of a new Puerto Rican CDC to assist small businesses, promote affordable housing development, and the initiation a neighborhood planning process in consultation with the University of Miami's Community Urban Design program. The CDC has provided homeowner counseling to low-income residents and sporadically implemented the City of Miami's commercial façade rehabilitation program, a source of financing to paint storefronts and fix awnings. As I will discuss below, it has been less effective in building affordable housing.

The Master Plan process, initiated in 1996 at the request of Fernando in collaboration with the Puerto Rican CDC, was supported by the City of Miami and Greater Western Bank (persuaded by the head priest to fulfill its Community Reinvestment Act obligations). ${ }^{117}$ It involved a week-long "charrette" including public meetings and private sessions for "neighborhood stakeholders" (residents, local business people, government officials, educators and civic and religious leaders). ${ }^{118}$ In the mid1990s gentrification was not evident but its potential was clear to the charrette leaders

\footnotetext{
${ }^{117}$ As part of his effort to pressure banks to invest in the neighborhoods of Wynwood and Allapattah, the Cuban priest organized a consortium of banks who supported the creation of low-income homebuyer workshops in 1994 (Ousely 1994).

${ }^{118}$ All meetings were held at the community center at Roberto Clemente Park.
} 
and some recently arrived art collectors and gallery owners. As the supervising architect explained, the charrette included a tour of one of world's largest private art collections. ${ }^{119}$

We actually all took a tour of the Rubell Collection... because we could understand that this was the first inroad of a future economy... And we understood that the potential game changers were the Nonprofit Arts Complex, ${ }^{120}$ revival of the $5^{\text {th }}$ Avenue [wholesale fashion district] area which was already a destination [where] people shopped and then, you know, the Rubell Collection. So [we chose these sites] in terms of economic activity or benefit for the whole area.

The resulting Master Plan document (WMP 1996) established a number of guidelines and objectives for Wynwood's redevelopment. In addition to design enhancements for the neighborhood's streets and edges, ${ }^{121}$ the Master Plan called for the preservation of historic structures, the creation of a public plaza ("Placita San Juan," see Figure 5.1 below) in the center of the residential area associated with Puerto Rican heritage, and the redevelopment of the FEC Rail yard (discussed in Chapter 4) into either a residential extension of Wynwood or an "arena alternative" designed as a civic and commercial space. The Master Plan also called for basic maintenance and preservation, particularly in terms of public space and affordable housing.

\footnotetext{
${ }^{119}$ According to its curator and several New York-based art journals and critics, the Rubells are among the 200 largest art collections in the world (Wallach 2001; Mason 2003).

${ }^{120}$ The Nonprofit Arts Complex [NAC] is funded through government grants, private donations, and mostly by renting studio space to artists at affordable rates.

${ }^{121}$ Such environmental designs differentiate between districts, which are thought to protect the identity of an area and help legitimize a group's claim to the place, according to architects.
} 
Figure 5.1: Proposed San Juan Plaza and Actual Development of the Site as a Parking Lot in 2008
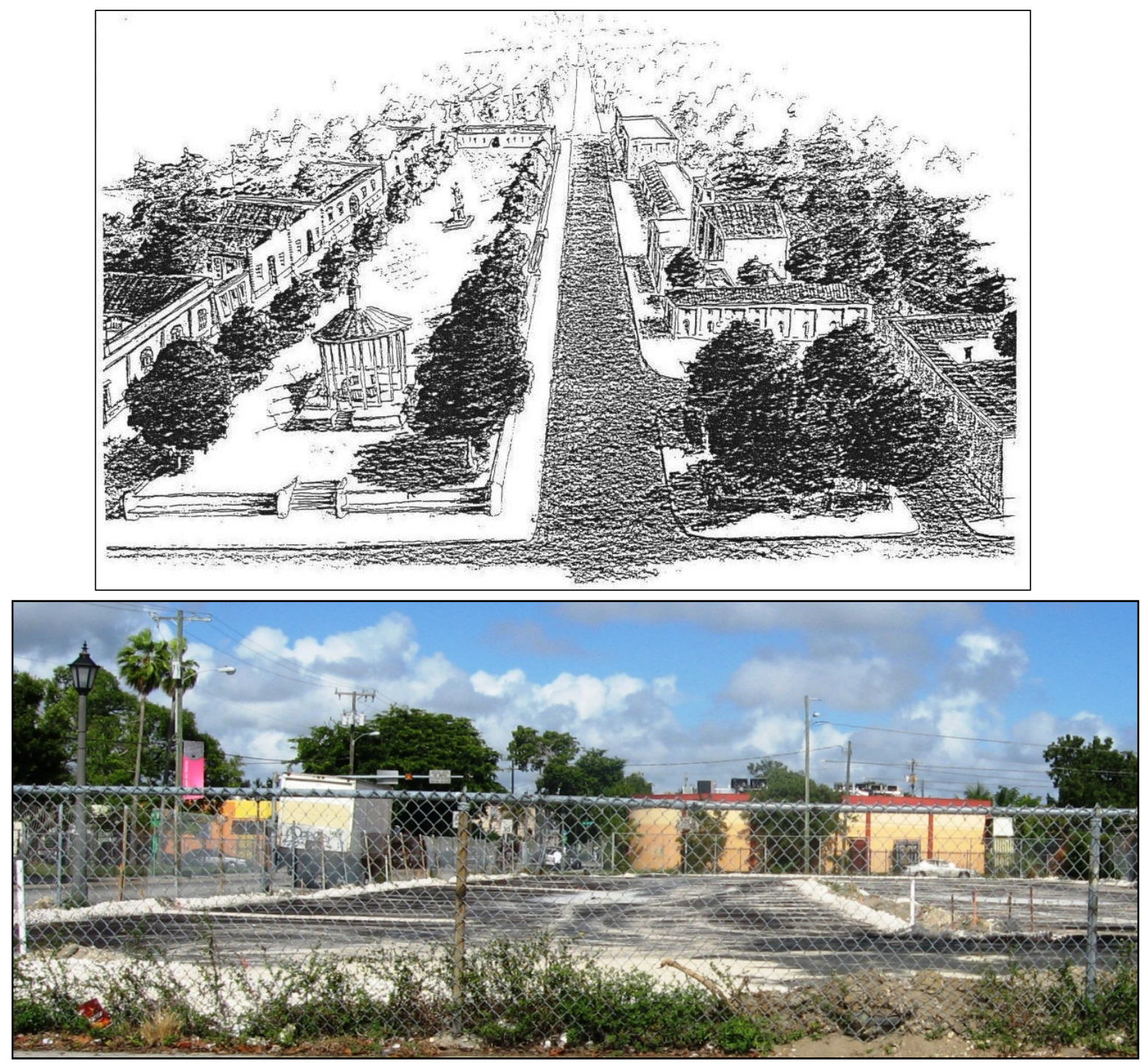

Source: The top image is of "Placita San Juan" from the 1996 Wynwood Master Plan (WMP, p. 19). It was envisioned along NW $2^{\text {nd }}$ Avenue across from the Puerto Rican chapel "to provide a civic space for informal activities and to serve as the symbolic center of the neighborhood." The bottom image is the author's photo of a parking lot built on the proposed plaza site in 2008. The black street lamp to the left is a part of the Master Plan explained by Carlos Jr., quoted below.

The 1996 Master Plan expresses the entrepreneurial policy orientation of the community-based organizations involved. In addition to suggesting conventional strategies to "combat the forces of deterioration," such as through building code 
enforcement and strategies to increase homeownership, the plan recommended that stakeholders "encourage controlled gentrification while protecting the rights of existing residents and businesses to thrive in place" (WMP 1996, p. 6). Although it cannot be known exactly what the plan's proponents were thinking in 1996, their reflections reveal a "practical" rationality in which gentrification and displacement were deemed acceptable as an outcome of "progress," or at least a preferable alternative to what they perceived as neighborhood disinvestment and decline. ${ }^{122}$ Moreover, the lack of implementation of those aspects of the plan which would have most benefited residents (as I will demonstrate below), such as the development of the central plaza or preservation and development of affordable housing (which inspired the creation of the Puerto Rican CDC), further shaped the leader's pragmatism. ${ }^{123}$

Carlos Jr., the son of a founding PRU member (Chapter 3), was chairman of the board of the Puerto Rican CDC when the Master Plan was conceived and emphasized the importance of symbolic preservation given the eventuality of change.

\footnotetext{
${ }^{122}$ As I will discuss below, such views were also shared by residents who opposed the claims of antigentrification activists working in Wynwood after 2005.

${ }^{123}$ Although not included in the Wynwood Master Plan, an example of the Cuban priest and the Puerto Rican CDC's struggle to implement community-based economic development was a case in which they asked the City of Miami for support to redevelop the aging minor league, Bobby Maduro stadium into affordable housing (MCC 4/25/1996). The project was ultimately released to an existing affordable housing developer from Hialeah (a working-class city in northwest Miami-Dade County controlled by Cubans) because the Puerto Rican CDC was thought to not have the capacity to construct the rental apartment complex (Skolnick 2001). This was a significant disappointment for the Cuban priest because he had been helping to coordinate various activities since 1993. He organized a consortium of banks who might be interested in financing the construction through the Puerto Rican CDC and coordinated a series of architectural charrettes. But the priest and the CDC needed support and approval from the City of Miami. Bobby Maduro stadium held sentimental value for Miami Cubans, not only because it was named for a Cuban ballplayer but also because it served as a camp for Cuban refugees. City commissioners, particularly the two Cuban politicians, Carollo and Hernandez, pushed for an "open" and competitive bidding process. This resulted in a second series of architectural drawings by a well-known Cuban architect at the University of Miami who proposed to preserve the symbolic stadium and develop a commercial complex surrounding it. Ultimately, commissioners ignored these plans too and chose the Hialeah company to build the "Stadium Apartments" while the stadium itself was demolished.
} 
We wanted up and down the neighborhood, that the lighting in Wynwood would be what we call in Puerto Rico guacaras, the old style street lamps... We envisioned a lot of the new development to look like Old San Juan where, you know, it would have courtyards [and] we were also encouraging the [historic] architecture... We knew that in the FEC railroad track area, where Midtown Miami is now, that was going to happen [eventually] [emphasis added]. But if it could happen in an organized way, then we wanted it to happen. And you know, we always were fighting for better services from the city and everything, but knowing in the back of our minds, hey, just like every other major city where huge development happens, gentrification comes along... So part of it was making sure, if that happens, that Wynwood in itself wouldn't lose its identity and wouldn't lose, you know, its heart.

His views reflect the thinking of the stakeholders in the 1996 planning process who led the main community organizations, which the City of Miami and private sector investors typically consulted about urban development projects in the neighborhood. ${ }^{124}$

However, the most influential figure in the neighborhood's organized political action throughout the 1990s was Fernando, the Cuban priest, particularly through his involvement in the Faith-Based Activist Coalition (FBAC), discussed in Chapter 4. He wields the kind of "pastoral power" that Foucault (1979b, p. 227) referred to as the "individualizing power," the power to shape the subjectivity of the individual through the "production of truths" that help people achieve not only eternal salvation but well-being

\footnotetext{
${ }^{124}$ In addition, as Carlos Jr. grew up in one of Wynwood's well-known Puerto Rican families and led several of the advocacy campaigns that preceded and coincided with the Master Plan process (such as the Save Our Schools campaign, discussed below), his views may have been influential among other neighborhood residents.
} 
on earth (Foucault 1982, p. 783). ${ }^{125}$ Or in the more reticent terms of Carlos Jr., "he comes in with the moral authority of the Catholic Church." 126

While Fernando supported revitalization via gentrification, he recognized that renters could be displaced. He hoped to insulate these residents from gentrification by increasing homeownership levels through founding a new Wynwood Puerto Rican CDC. However, the CDC proved incapable of protecting renters from gentrification. ${ }^{127}$ The only subsequent development project that fit into some of the Master Plan's guidelines is the new "Midtown Miami." While it had an integrated street grid, one of the plan's recommendations, Midtown lacked affordable housing for renters and homeowners. Other objectives in the Master Plan that failed to materialize include the preservation of historic bungalow homes used by low-income homeowners and renters and the development of public spaces to serve area residents. ${ }^{128}$

\footnotetext{
${ }^{125}$ The pastoral metaphor is particularly appropriate here. But that is not to say that Foucault's sense of "pastoral power" does not also apply to the leadership and work of other neighborhood organizations, for through the inter-personal relations of leadership and governance they are involved in the production and dissemination of truths and in organizational practice that reflects and applies those truths.

${ }^{126}$ Recall from Chapter 4 that one of the truths produced through the "miraculous" conception of the Puerto Rican chapel was that it was a sign of change and progress coming to the neighborhood and its poor residents who, "more than anyone, need beautiful churches" (Fernando the priest). It was his extraordinary influence in the lives of church members - rooted in trust - that led the Wynwood-based parish to become the most powerful organization within the county-wide FBAC in the 1990s. Indeed, when the Miami Catholic Archdiocese recently proposed to relocate the Cuban priest to another parish, hundreds of members protested and the proposal was scrapped.

${ }^{127}$ As I note below, the Puerto Rican CDC built a few lower-priced units for homebuyers but never developed or rehabilitated any rental properties. As with most CDCs elsewhere in Miami (recall from Chapter 4), CDCs in Wynwood have focused exclusively on promoting homeownership for low-income buyers instead of permanently affordable rental properties. This is also in keeping with Miami's history of urban renewal politics in which private home builders maintained a monopoly on rental housing development (see Chapter 2 and Mohl 1995, 2001a, 2001b).
}

${ }^{128}$ Another example is the Central "San Juan" Plaza, planned for a site occupied by an unused school playground and recently converted into a parking lot to serve a new school. 


\section{Figure 5.2: Diagram of Wynwood's Historic Buildings}

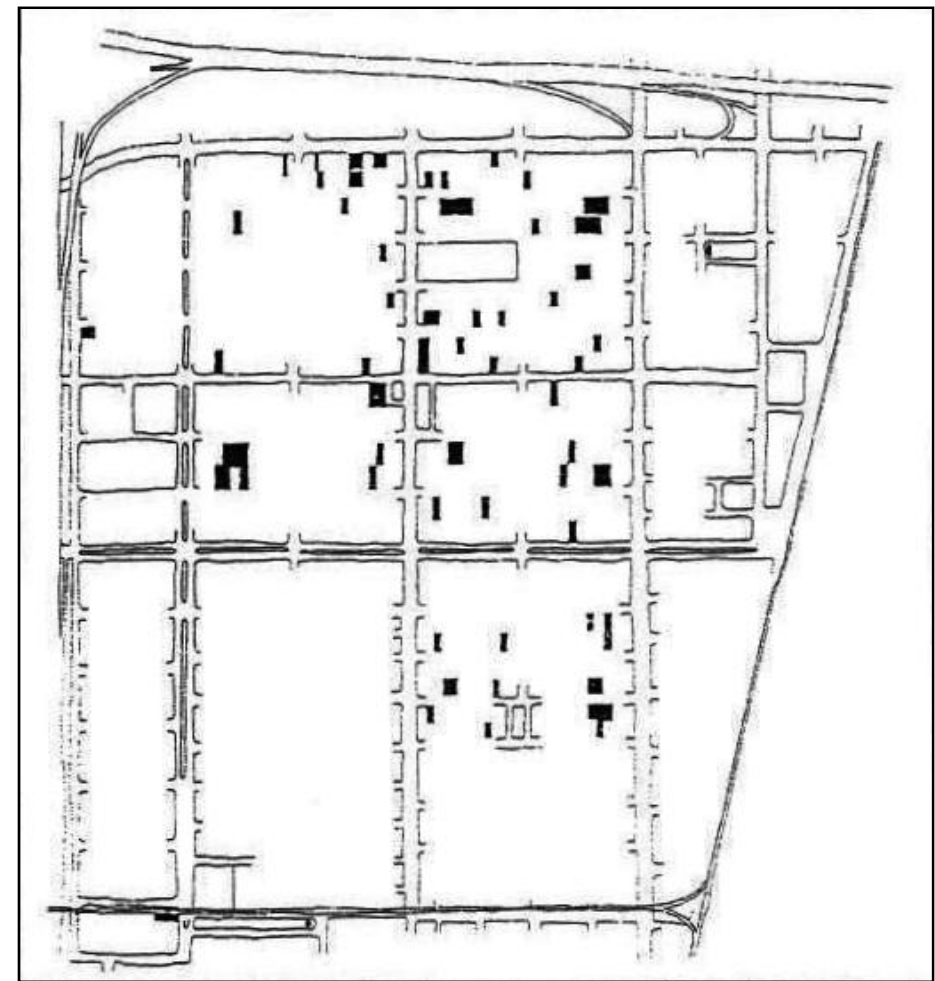

Source: Diagram from the 1996 Wynwood Master Plan (p. 9) that "shows the lots with historically significant and contributing buildings" which revealed that "much of the original Wynwood village is still standing."

The ongoing deterioration of historic buildings used and occupied by Wynwood's low-income residents is a clear example of the Master Plan's failings. The plan called for neighborhood leaders to "raise community consciousness about the value of historic buildings" (WMP 1996, p. 6), which to some extent was already evident in the preceding Save Our Schools campaign. ${ }^{129}$ The Master Plan made significant mention of several

\footnotetext{
${ }^{129}$ According to several respondents who were involved, the Save Our School campaign incorporated historic preservation as a tactic within the broader strategy to ensure that public schools remained in Wynwood. In 1988 the Save Our School committee was formed by a group of parents and staff from area service agencies (including Carlos Jr.) to press for an alternative to the County School Board's plans to close and demolish Robert E. Lee middle school because of its physical deterioration (Fisher 1988, 1989). The historic character of the school was cited among the reasons to save it but the $\$ 1$ million-priced
} 
dozen "craftsman bungalow" and mission-style homes built in the 1920s as well as two historic schools. Robert E. Lee School, "the single most important historical landmark in Wynwood" (Ibid, p. 21), was deemed too expensive to renovate by the Miami-Dade County School Board and demolished in 1995. Authorities did finance repairs to the façade of the Buena Vista Elementary School. ${ }^{130}$ However, there have been no efforts to preserve any of the other historic structures highlighted by the Master Plan's architects. ${ }^{131}$

renovation was deemed too expensive by the County School Board. It was eventually replaced with a new, Puerto Rican-named school in the same location but in the interim the school was closed for nearly a decade, angering families whose children were relocated to schools outside of the neighborhood (Ousley 1993a).

${ }^{130}$ The façade was preserved when the school was redeveloped in the mid-2000s into an all-boys prep school attended mostly by children from other parts of the county (Valdemoro 2007; Goodman 2008; McGrory 2010). While residents and long-time social workers in the area praised its preservation, it was County officials that independently made the decision to restore the facade.

${ }^{131}$ Although all of the neighborhood leaders I spoke to, including those Puerto Ricans who were active in the 1970s but not so much in subsequent decades, agreed that the old buildings should be preserved, they were divided over what names to give them. These divisions were usually along ideological lines. The more liberal leaders, for example, felt buildings should be named for Puerto Rican independence fighters (their views ultimately prevailed) while the more conservative valued U.S. historical figures such as Robert E. Lee. Although there is no evidence of outright conflict among Puerto Ricans or other neighborhood leaders over historic preservation, some of the older generation leaders did not participate because of these differences. 


\section{Figure 5.3: Images of Historic Bungalow Homes in Wynwood}
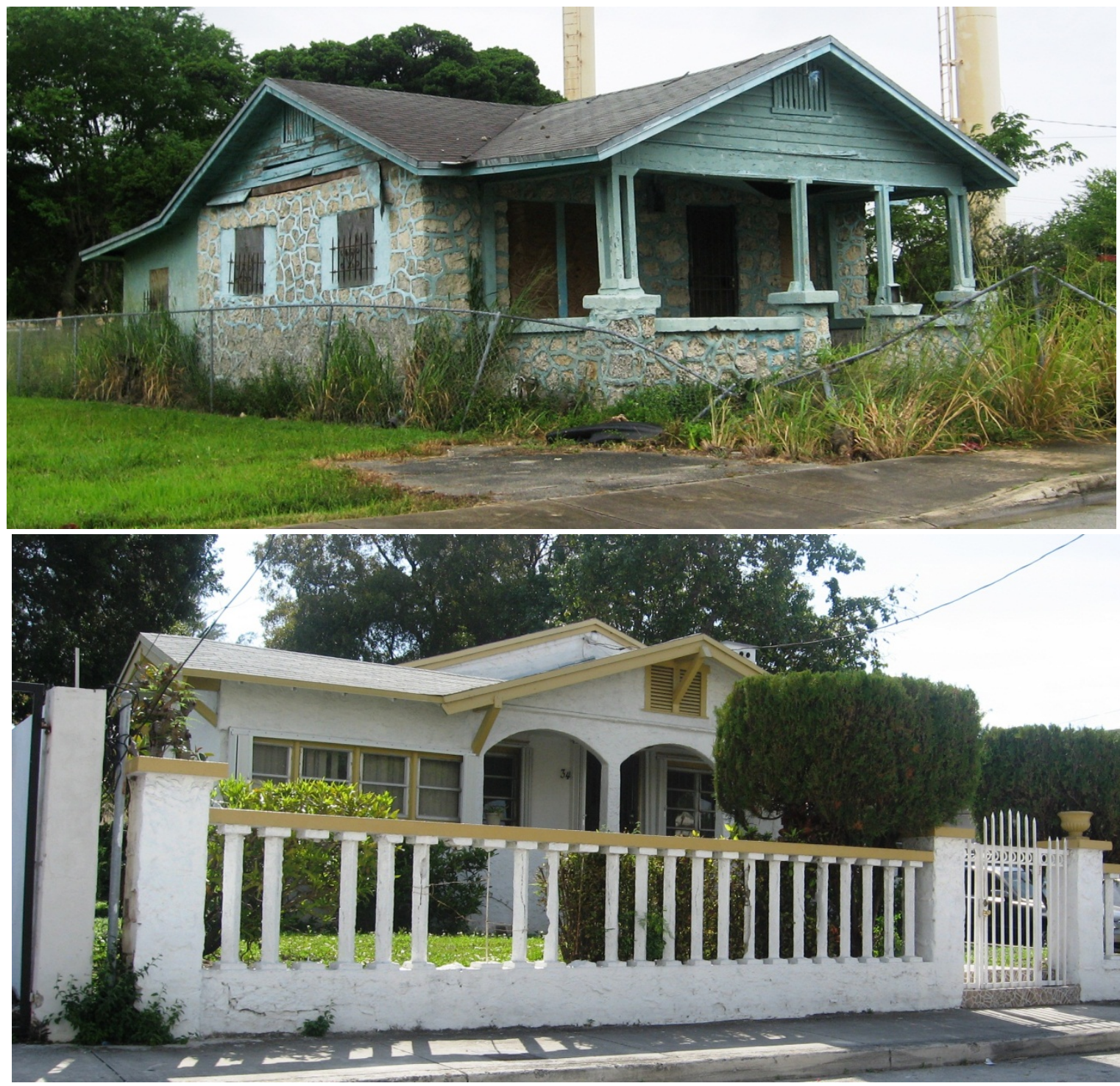

Source: Taken by author in December, 2010. Top image is of a boarded-up coral rock bungalow house purchased by an investment company in the early 2000s, located near the western edge of the Art District. Bottom image is of an inhabited bungalow in good condition in the heart of the residential section north of $29^{\text {th }}$ Street. Preservation of these buildings is left up to individual property owners, as there have been no government programs or organized efforts of communitybased organizations to systematically rehabilitate and preserve the old housing. 
The director of the Puerto Rican CDC, ${ }^{132}$ which developed merely 10 affordable, single-family homes (for ownership) between its inception in 1993 and 2010, admitted that developing housing that is affordable to Wynwood residents became virtually impossible after major investment in the neighborhood drove up property prices. ${ }^{133}$ (Figure 5.4 below depicts the growth of single family home prices between 2000 and 2005.) This was especially true for the historic "craftsman bungalow" homes in the neighborhood, the rehabilitation of which would price out existing residents.

We have tried to preserve the bungalow style, which is unique to Wynwood or to this area but they haven't been declared historic and really, honestly, we don't want it to be declared historic because historic becomes a whole different issue and it's very, very expensive to repair or replace historic.

\section{Recent corruption scandals at the Miami-Dade County Housing Authority (Cenziper}

2006; Pinzur 2007) ${ }^{134}$ combined with the collapse of housing market forced the Puerto

\footnotetext{
${ }^{132}$ The director since 1999, she was preceded by two directors.

${ }^{133}$ During the early 2000s, the Puerto Rican CDC partnered with Wind and Rain, Inc., a more experienced CDC based in Coconut Grove, to build five single-family homes scattered throughout Wynwood for sale to low-income families. The CDC used public subsidies to help families with incomes in the $\$ 20,000$ 's buy the homes priced between $\$ 120,000$ and $\$ 150,000$, "when those were available." At the height of the boom the definition of "affordable" housing "[went] up to $\$ 210-220,000$, which is the number that the county [sets]."

${ }^{134}$ Investigative reporting by the Miami Herald (Cenziper 2006, 2007; Pinzur 2007) revealed routine and widespread fraud at the Miami-Dade County Housing Agency in the use of subsidized housing funds during the late 1990s and early 2000s. More than $\$ 20$ million in assisted housing funds were stolen or squandered by housing agency administrators and well-connected contractors before the agency was placed under federal control. More corruption was found at the Miami-Dade County Empowerment Trust (Hiaasen and Grotto 2007), although not in the case of the five single-family homes built by the Puerto Rican CDC. The dubious investments approved by the EZ governing board, such as subsidizing parties and travel for celebrities during the MTV Music Video awards, took place during or after 2004. Until 2003 the chairperson of the Wynwood Neighborhood Assembly and Wynwood representative on the county-wide Empowerment Trust board was Rodrigo. The Wynwood member that replaced Rodrigo in 2004, Veldrin Freemon, never disclosed that she owned an employment agency that was funded by the EZ board to supply itself with office workers. Subsidized housing funding was frozen in the immediate aftermath of the scandal (2007-2008), as alluded to by the Puerto Rican CDC director. A new source of affordable housing finance arrived in the form of the Federal Neighborhood Stabilization (stimulus) program, but this money,
} 
Rican CDC out of the affordable housing business, at least temporarily. ${ }^{135}$ Moreover, the CDC's director revealed the way "the market" dictated her work. As investment flowed into Wynwood during the early 2000s, "affordable" took on a different meaning.

When we started we were very active in housing. But over time what has happened in Wynwood is, with all of the new investment in housing and all the talk with Midtown coming in, people started to invest in the area. The city was providing funds to build housing but there was, we didn't have the jobs, the infrastructure here wasn't what it should be for housing and to attract people back into the city.

Implicit in this statement is that the CDC did not have the power "to attract people back" to the area, unlike wealthier investors. The "people" she referred to are from lowerincome households that qualify for housing subsidies, as opposed to the wealthier consumers drawn to upscale developments. The CDC Director's statements affirm the pattern noted in Chapters 3 and 5 in which the policies of housing finance in Florida and Miami do not support affordable housing preservation and development nearly as much as they encourage private, market-rate housing development.

\footnotetext{
as with Low-Income Housing Tax Credits (Olorunnipa 2011a, 2011b), flowed to the largest CDCs in the county. As I discuss below, by 2010 and 2011 a tiny share of it was used by local governments' to cover budget deficits and was allocated to smaller CDCs for work such as façade rehabilitation and weatherization of old homes.

135 "We stopped building... because we were dependent on the housing authority and the housing authority underwent a lot of issues at the county, between the Feds getting involved and, you know, kind of cleaning up housing and stuff [for example, firing administrators indicted on fraud charges], a couple of years went by. On the tail end of that, there were other issues... with the banks with all the foreclosures and stuff. It just seemed housing is not the way to go right now."
} 


\section{Figure 5.4: Map of the Change in the Median Price of Single Family Homes in Census Block Groups, Wynwood and Vicinity, 2000-2005}

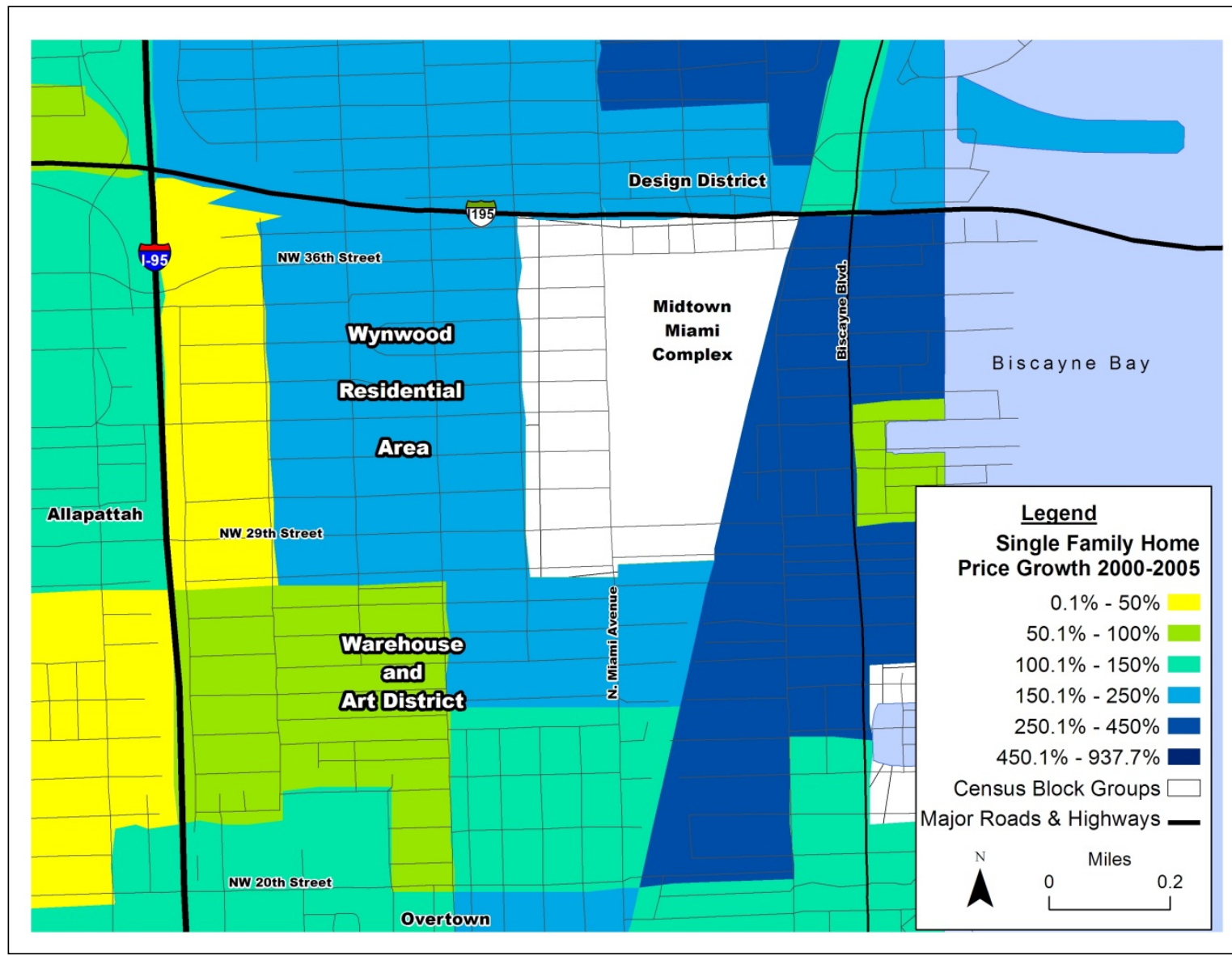

Note: Block groups colored white have too few data points for mapping, such as in the area of the Midtown complex, which was still under construction in 2005. Data from Miami-Dade Property Appraiser.

Between 2002 and 2006, the Puerto Rican CDC became increasingly involved in developing "live/work" loft apartments in order to remain productive in the context of the changing constituency of housing consumers and also out of a concern to protect recently arrived artists from future displacement. The Puerto Rican CDC never succeeded in building any live/work housing itself, but it did contribute to these developments in other ways. Its designation as a Community Based Organization by city and county 
government makes the Puerto Rican CDC eligible to receive not only community

development funding and other subsidies, it has also been granted government property to develop affordable housing. ${ }^{136}$ Although the property was never developed, the CDCcommissioned market research and architectural designs for a live/work building inspired a private developer to build a variation of the concept on adjacent land, setting a precedent in the neighborhood. ${ }^{137}$ In addition, the Puerto Rican CDC extended its prospective homebuyer counseling and financial assistance to the new artists who were moving into the neighborhood.

...Because with regard to the artists, some of them are magnificent and extremely talented but they're terrible managers of money. We have to work with them in the same exact way we would work with a family that's low-income trying to buy their first apartment or house. We needed to provide the same type of services and get them prepared to own, so what we figured was, OK, there has to be some kind of a product that we could offer them. And we worked with the Nonprofit Arts Complex and we did some studies throughout the community and we found out that if we created live/work environments we would be able to help them. And we worked with the County. This particular project we were working with the Empowerment Trust and we believed that if... we provided them the financial package they would be able to become stakeholders in what's going on.

The Puerto Rican CDC's shift toward artists leaves long-time residents with an even less effective vehicle for addressing their needs. The shift is also remarkable considering that one of the key findings of their market research on live/work lofts, as

\footnotetext{
${ }^{136}$ After the project was aborted, in 2008 the land - which includes 4 parcels next to the failed Wynwood Free Trade Zone (see Chapter 4) - was re-assigned by the county to the Puerto Rican Chamber of Commerce along with \$2.5 million in General Obligation Bond funding to develop "a multi-purpose facility to include rental gallery space, conference rooms, classrooms for neighborhood residents and students of two neighboring public schools, and office space for a community business enterprise program to assist with job creation" (MDCC 12/2/2008). In 2010, the Puerto Rican Chamber had received the support of the City Mayor addition to the area County Commissioner, and described the project as Casa Puerto Rico, a "cultural center and small business incubator" (PRCC 2010).

${ }^{137}$ Although this was the first newly built live/work loft building, this developer previously converted an existing manufacturing loft building into live/work studios.
} 
written by the Puerto Rican CDC's research consultants, was that area residents were concerned about the threat of gentrification (Urbana 2002). Although the bulk of the consultant's report focused on the strengths and limitations of building live/work loft buildings from a market-based perspective, it also included results from interviews, surveys and focus groups with more than 30 realtors, artists, developers, residents, community organization leaders and government officials. "The most pressing issue," stated the report, "was gentrification of existing businesses and residents" (Urbana 2002, p. 98). The report included the following quotes from a focus group held at the Wynwood Empowerment Zone (EZ) Neighborhood Assembly, the group that advises the MiamiDade Empowerment Trust on how to allocate federal EZ funding.

I think lofts may be a good idea but I have some reservations. I don't want people who already own property here to be driven out like they did in Overtown. I would like our community to stay intact. [...] Will residents be bought out? Will they have to move so that other people can benefit? Just be careful of gentrification. Many people don't have enough skills to take advantage of live/work lofts. This project will bring people from the outside. Will they be hiring people from the neighborhood? The concept is OK, just don't push the people here out.

- 35-year resident of Wynwood resident

What we need are multiple rooms for families. We need to help keep families here in the community. Lofts are nice, but they aren't practical. We have fixed space in this community. Lofts would cut the availability of housing. Is the first priority for artists? No, our families are the priority. These live/work lofts for artists don't meet our [Wynwood EZ Neighborhood Assembly] mission.

- Community organization leader ${ }^{138}$

\footnotetext{
${ }^{138}$ Despite the sentiment of this person that serving artists does not meet the EZ mission, the focus group that he or she participated in was part of research that was listed among the Empowerment Zone's "milestones" (U.S. HUD 2009). The research was likely to have been funded by the Empowerment Trust as well, since that was the source of the Puerto Rican CDC's administrative and project funding during the 2002-2003 period. Although I found no Empowerment Zone records indicating that funds had been
} 
I would be interested in knowing what kind of mixed use? Housing for artist is fine, but we don't have enough scattered [subsidized] housing. What kind of development will this be? We need to take care of the families. Artists are just one person. [...] I want to know the funding source of this project. Is it public money? [...] Don't limit it to ownership. We just want to build pride in our community, whether they own the property or not.

These residents' statements included in the Puerto Rican CDC's market research report highlight the contradiction of the agency's (and the Empowerment Trust's) strategy of supporting artists. During our interview, the CDC director did not mention gentrification and when I asked about it the conversation shifted to the expensive condos built at the Midtown complex. Her statements above suggest that she views artists as legitimate residents of the Empowerment Zone or at least as constituents of her organization.

The CDC director explained that her interest was not only in helping to prevent the eventual displacement of the artists - "we didn't want to lose them" - but it was also a way for her organization to capitalize on an opportunity. As she pointed out, the creation of the Art District "has helped Wynwood because that's when the local government started to pay attention to Wynwood." It is well-known that the vast majority of CDCs in the country operate within an organizational culture oriented toward "programmatic efficiency and organizational survival" (Newman and Lake 2006, p. 58; see also Gittell 1980; Stoecker 1997). Indeed, the current director had been invited to

specifically allocated for the Urbana Inc. research, a 2009 EZ annual report lists among its' "milestones" completed between April 2002 and December 2003: "Puerto Rican CDC to perform analysis of local demand for live/work residential units." In a separate section of the report, it states that the CDC was allocated $\$ 23,280$, which is listed apart from funding for the directors' administrative salary $(\$ 35,000)$ and project expenses to partner with the Coconut Grove-based firm to build five homes $(\$ 400,000)$. Moreover, this funding was provided with the stated purpose to help CDC "look for solutions to allow EZ residents of [Wynwood] to become homeowners." 
Miami from New York by her friend, Luis, director of the Puerto Rican Chamber of Commerce, to take over the Puerto Rican CDC in 1999 "when it was struggling" so that she could help "wind it down." But in doing so, "I realized, why are you closing this company? There's a lot of potential and you're owed money, not that you owe money." She was able to transform the agency's finances into "the green rather than in the red," after which she was told by Luis, "now that you saved it, you have to continue." The point is not that she is uncommitted to the purpose of community-based economic development but quite the contrary; within the entrepreneurial orientation of this field of work, recognizing the potential "that Wynwood could be the next SoHo of the eastern coast" is a key part of the job description. In this context, being a Puerto Rican professional is merely a part of one's employment qualifications; no longer the vital link to place- and ethnicity-based collective action.

The entrepreneurial orientation of community development is further illustrated by the most recent phase of Puerto Rican CDC's work. In 2011, the district commissioner funded the CDC to rehabilitate the homes of low-income, elderly residents in the neighborhood, a strategy supported by local and national policy shifts emphasizing "weatherization" of old homes. But again the Puerto Rican CDC's capacity is too limited to address the enormous need for rehabilitation that exists. The CDC director admitted that the most run-down homes are better left alone, so "we're not triggering a whole lot of other issues that really the program doesn't have [resources] to do."

Some of the houses are really bad. It's really tricky... None of us are in the business of putting anybody [out]. If you go into a home of that caliber... we'd have to condemn the property which then would [make] that family homeless. We just can't do that. So what happens is what we're initially going to start [with]... I 
would say it's modest but... focusing on making [homes] safe, like with decent, proper roof, proper windows, shutters, repair on the outside of the house to keep rats [out] and termite tenting. Things of that nature to kind of help. And all of them are going to have paint. We're going to include paint and all, because paint is like the cheapest fix and it really has an impact when you clean something up. So we're going to start with that and see, when we go into these houses, what can we really do inside.

She went on to explain that to "maximize the impact," the strategy would be deployed in a small cluster of homes surrounding Roberto Clemente Park. While these interventions are important, they are also crucially limited in that Wynwood has a great number of homes with severe structural problems in their walls and baseboards, electrical wiring and plumbing, problems far beyond the scope (in cost and effort) of the issues addressed by the CDC's rehab program. Therefore, the neediest homes (occupied by the poorest residents) will receive no attention, as the director makes clear, for revealing the extent of those deeper problems may cause their demolition.

Beyond the resource constraints of the CDC and the significant hardship faced by residents, these examples also reveal the market ideology that pervades "community development," something which has been noted throughout the country (e.g., DeFilippis 2004; Newman and Lake 2006; Thibault 2007). Most CDCs and especially Wynwood's Puerto Rican CDC work to achieve the "cheapest fix" not only because they operate with limited resources; but crucially because the concept of "neighborhood stabilization" inherent to the CDC movement (and its federal funding) is based on exchange value in the real estate market, not the use values to the occupant. As the logic goes, painting a building may marginally enhance the use value of a home but more importantly, it enhances the appearance of the street and the area, making Wynwood a more marketable 
neighborhood and thus improving the exchange value of the home. Thus, "maximize the impact" refers to area-wide property values, in which case it is important to paint homes in a cluster instead of scattered throughout the neighborhood. Existing homeowners in the particular area that comes to look "improved" may benefit financially if they sell their homes. But for renters and homeowners whose houses need more than a coat of paint, there is little if any benefit. Moreover, the preoccupation with individual houses reinforces the ideology of individual-level cost-benefit calculations. The larger point is that these cosmetic enhancements do nothing to help low-income renters remain in the area.

It is not surprising, then, that most of the hopes expressed in the 1996 Wynwood Master Plan and embodied by the formation of the Puerto Rican CDC remain unfulfilled. National and local politics as well as the funding for and rationality of community development practice ensure that gentrification and displacement cannot be "controlled." Nor is it remarkable that the Master Plan garnered little attention from public officials or developers, given that it was a small initiative carried out as a community service by the university's design team. ${ }^{139}$ Yet it proved a frustrating experience for the Catholic priest

\footnotetext{
${ }^{139}$ The architect in charge of this project, co-director of a renowned Urban Design firm and professor at a major private university in Miami, offered this explanation: "I think when we do [plans] here [at the university's community design department] it's different. [In contrast,] when [the firm] does it, somebody's investing a lot of money and asking us to make a plan that has economic sustainability. In other words, you can get started on it right away.... When we do stuff at the university... we don't expect that anybody's going to say, 'follow this plan,' because after all, we're not professionals here." The last reference is to the fact that the university architecture programs' community service typically involves students in surveying the site and making drawings. The Master Plan did not result in a final presentation to any public authorities. This architect nevertheless asserted that community design projects such as the Wynwood Master Plan may be implemented over a longer time period can be effective in other ways. "Sometimes you have to do things [many] times for people to really act on it... Many of us understood that plans are like guerilla warfare, you do it whether or not it's going to be official. It's out there [as] information and knowledge for people to use and if you've done a public process like a charrette, you've educated some people along the way."
} 
who catalyzed the initiative, leading him to wonder if he was involved in "charrettes or charades?" what is possible, the impacts of unfulfilled hopes and plans take on additional significance. If national and local politics adopted a fundamentally different approach, for example, devoting far greater resources to repairing homes or ensuring that rental and housing prices remained affordable to current residents, then gentrification could be controlled to a greater extent. But, to the long-term Puerto Rican and other residents of Wynwood, the Cuban priest and the Puerto Rican CDC, changing policy this dramatically is inconceivable and they can justifiably perceive gentrification as inevitable.

Since arriving in Wynwood, Fernando has been clear in his desire and efforts to physically revitalize the neighborhood for its existing residents, starting with the construction of the Puerto Rican chapel. ${ }^{141}$ But he has also "accepted the reality" that, given the aforementioned limitations to preserve affordable housing, neighborhood revitalization required an influx of wealthier people. After explaining that during the charrette process he advocated for the promotion of an art district to help "transform Wynwood, ${ }^{142}$ he addressed the more recent consequences of such a transformation. "Remember something: whether we like it or not, we have to accept the reality that the

\footnotetext{
${ }^{140}$ Although the head priest would not elaborate on the critique implicit in the humorous question, others involved in the charrette recalled that the priest expected the plan to be published somewhere and hoped a developer would implement one or more specific parts of it. Moreover, recall that this was not the first time he helped organize architectural charrettes. In the case of Maduro stadium, noted earlier, his efforts led to nothing.

${ }^{141}$ Despite its name, the chapels' membership is now mostly Central American.

142 "Wynwood has a gigantic potential. I would tell people [during the charrette] - we were talking about an arts district - why don't we convert [ $5^{\text {th }}$ avenue] into a boulevard and put modern sculptures all over it? We could do a cultural exposition, that is, [as a] suggestion for the art world, and transform Wynwood."
} 
redevelopment is displacement. ${ }^{, 143}$ Moreover, he concluded that it was not possible to prevent the displacement of residents (especially of tenants) through neighborhood political action given the nature of "this capitalist world we live in" and especially the transient and speculative patterns of property ownership in Wynwood. ${ }^{144}$ But beyond accepting the reality of a capitalist mode of change, the priest revealed how his perspective was shaped by specific ideas and experiences, including the territorial structure of the church's mission system, and the training he received during the FBAC's advocacy campaigns. ${ }^{145}$

Of course, I'm affected by the people who live here, that is, the affective attachments. [For example,] I'm screaming for this immigration reform because it would give [many of my members] representation. But while I want the best for my community, I also have to realize that I'm not Don Quijote, fighting against the windmills. The reality is that property owners are going to do [what they want]. This church, over time... the person that moves [to Wynwood] - I imagine that some of them will be Catholics and those I will have here [in my church]. The only thing that changes is the occupant of that house... they may or may not be of a higher level economically, but others will come... You have to respond to the problems of the territory. (emphasis added) Therefore, now my problem might be how to take care of the artists... [which is not] the Wynwood that I found [when I arrived in the 1980s]. And for that reason I think the best would be that someday I were not the pastor of this parish... [to] give way for another point of view.

\footnotetext{
${ }^{143}$ He said these emphasized words in English.

144 "I'll tell you why. In this capitalist world... if you're a homeowner, you want the maximum [investment] return. What would you do? 'No, out of my social solidarity I want to stay in Wynwood.' No! Because in addition [to the fact that] you're renting the place, maybe tomorrow [the opportunity to sell] gets away. In other words, one thing is theory and another is fact (he said this in English). If $80 \%$ of the neighborhood [residents are] not from the neighborhood and they [treat it] as an investment, then [the neighborhood's fate] is going to depend and fluctuate with the economic situation. As the neighborhood rises and suddenly the owners of these homes have to pay higher taxes... what do you do?"

${ }^{145}$ The territorial conception of the mission structure and the FBAC's campaigns were discussed in Chapter 4; here I explore the implications for the priests' thinking and action.
} 
Although on several occasions Fernando was critical of development projects that in his estimation offered few benefits to existing neighborhood residents, the above quote and other exchanges revealed that his political action was shaped by a "realistic" outlook rooted, in part, in the territorial mission structure he conceived ${ }^{146}$ and has implemented since the 1980s. His thinking was also shaped by his immersion in the FBAC. There he received training in a Congregation-Based Community Organizing (CBCO) model adapted from Saul Alinsky's brand of neighborhood organizing that emphasized fighting for what is winnable and immediately visible to residents (Chambers and Cowan 2003). As explained by Fernando, as well as the former director and the former lead organizer of the FBAC, ${ }^{147}$ advocacy campaigns are chosen on the basis of what residents say is affecting them combined with an analysis of what is "winnable, controversial and widespread." The first criterion has to do with perceived political opportunities and constraints. Controversial refers to whether the issue will generate sufficient interest from members, potential allies and the broader public. Widespread involves a measure of how many residents are affected by the issue and therefore have self-interest in addressing it.

The former FBAC activists agreed that gentrification, while a controversial and widespread issue at the height of the housing boom (according to what their members' told them), was challenging to confront because it was a highly complex issue with ambiguous solutions. That is, it was seen as unwinnable. Yet, as I will discuss in greater detail below, they differed in their analyses of the implications of this challenge; some

\footnotetext{
${ }^{146}$ Although the priest's interpretation was unique to Wynwood, the concept of mission churches used for evangelization dates at least as far back as Spanish colonization of the Americas. As he reminded me, "after all, the Catholic Church has always been territorial - it is responsible for a territory."

${ }^{147}$ Interviews with Adam, former director and Edwin, former lead organizer of the FBAC during 19962006.
} 
felt that gentrification must be addressed in smaller, perhaps indirect ways, while others felt the issue should be avoided altogether. As the leader of one of the most powerful components of the FBAC organization, Fernando felt it should be avoided altogether. His views may have been different, perhaps less conclusive, in the early 1990s, when he spearheaded efforts to increase homeownership levels and, he hoped, put residents in a better position to remain in the neighborhood as it gentrified. But the priest's attempted foray into housing issues in the 1990s and other experiences with city and county politics (that were not Wynwood-specific) taught him that it was difficult to mobilize residents around long-term and complex issues. ${ }^{148}$ The following is representative of various, similar reflections:

We have to be realistic. In other words, we have to choose things - and this is one of the things I learned. FBAC was a strong organization while it did things that were immediately visible. You cannot get into campaigns about things which [the results] are not visible. The best campaign we did was when we asked the City to knock down crack houses, that is, the abandoned houses. And people [could] see what the city did. Now the problem that was in the neighborhood is gone... When FBAC started to get involved in the education issue, where people no longer see what was being done and instead it was, 'go and work' and four people could see it but the majority of people did not see anything immediate, then it was a failure. These people cannot afford to wait. So this is what happens: they are discouraged. 'Why go to another meeting if we didn't get anything [last time]?' All those organizations ${ }^{149}$ if they do [things with visible, immediate impacts], good. But if what they want is to prevent what is inevitable, which is the change in the neighborhood, then as the scripture says, you're struggling in vain. ${ }^{150}$

\footnotetext{
${ }^{148} \mathrm{He}$ would not elaborate on his frustration with the kind of housing and urban development that he envisioned and led him to help create the Puerto Rican CDC. But others' accounts and his own avoidance of the subject suggest that his observation of neighborhood organization's inability to affect housing policy was disillusioning.

${ }^{149}$ Here he refers to more recent activists in the neighborhood, described below.

${ }^{150}$ He said, dando coces contra el aguijón, which literally means kicking yourself against the pricks.
} 
The FBAC took up education reform in the winter of 1995-1996, by asking the Miami-Dade County school system to adopt the "direct instruction" teaching method for reading, to improve reading levels in low-income schools (Mailander 1995, 1996). ${ }^{151}$ Although within a year the teaching method had been adopted in 12 schools on an experimental basis, the FBAC spent the next three years lobbying for the implementation of the program in the rest of the county's D- and F-graded schools, which led the group to also lobby the state legislature for increased funding for Miami-Dade County (Yee 2000). As a result, the legislature provided $\$ 2.3$ million of the $\$ 10$ million requested to boost the school system's implementation of the direct instruction system in 2001 (Lehman 2003). However, since individual schools had discretion over the whether to use the method in combination with or instead of other methods (such as the "whole language" model), the FBAC had to continually monitor individual schools while maintaining some pressure on the school board and superintendant (Rodriguez 2003; Santana 2003).

The former director of the FBAC (1996-2006), recalled that the priest's "personal involvement and how much time he spent on FBAC and FBAC issues was in continuous decline over the 10 years that I was there." The lead organizer of the FBAC between 1996 and 2008, who worked closely with inner city congregations and especially the Catholic Church in Wynwood, noted that Fernando "started to lose interest when they took on educational reform." According to the former FBAC organizer, the prolonged duration of the education reform campaign, and the diverse political targets involved (individual school principals, county school system officials, and state legislators), wore out and led to the Cuban priest "cooling off" from the FBAC's work. By 1999 the head

\footnotetext{
${ }^{151}$ Interviews with Adam and Edwin.
} 
priest assigned another priest to take the lead in the church's involvement in the issue campaigns. However, the former FBAC activists attribute his declining involvement not only to the "cooling off" effect of protracted campaigns but also to the priest's increasing workload within the parish. He spent several years planning and financing the construction of two new inner city churches ${ }^{152}$ to serve a growing parish, such that by the 2000s he was in charge of six churches in three neighborhoods. "To tell you the truth," the priest admitted, reflecting on his involvement in the FBAC, "it's been years that I'm not involved in the political questions of Wynwood. Now I have such a large parish and fewer people to help me... My problem is time." He also attributed tiring as he got older, since "at the beginning, you're capable of throwing yourself to the fire."

Although Fernando delegated another priest to work with the coalition, the former FBAC activists noticed that his steadily declining personal involvement was associated with the steadily decreasing mobilization of Wynwood residents for the campaigns. Adam, who directed the FBAC from 1997 to 2007, recalled that while Fernando was "personally involved and really wanted to, we... turned out 1,000 people just from the Catholic Parish alone. But without his active involvement, we might get 150, 200. That still made them one of the strongest congregations in our membership, but we always knew that if his heart were really in it, it could have been much larger."

\footnotetext{
${ }^{152}$ The first of these was the Puerto Rican chapel in Wynwood, which took nearly seven years to complete (see Chapter 4). The second has been a work-in-progress throughout most of the 2000s, costing almost $\$ 1.5$ million in construction and nearing completion as of this writing (Shoer-Roth 2010).
} 
The alternate priest assigned to work with the FBAC was simply not as effective at mobilizing residents, ${ }^{153}$ and by the turn of the 21 st Century the Catholic Parish was no longer the most powerful congregation within the FBAC. A Haitian church had become the largest inner city membership base and the growing influence of Haitians ${ }^{154}$ within the FBAC was reflected in the type of issues taken up in the annual campaigns, starting with issues that included the interests of both Latinos and Haitians. For example, in 1999 the FBAC sought improved treatment and services from the Immigration and Naturalization Service (INS), including INS information disseminated in Spanish and Kreyol (Lynch 1999). While immigration reform and the Dream Act remained at the forefront of FBAC activism in the early 2000s (issues primarily oriented toward Hispanic constituents), other campaigns sought to increase the number of Kreyol-speaking police officers and continued to demand improved treatment of Haitian asylum-seekers at the County’s Krome Detention Center (Casimir 1998; Santana 2003).

\footnotetext{
${ }^{153}$ Edwin, the former lead organizer, suggested that the alternate priest, as a subordinate within the parish hierarchy, was simply not powerful enough to mobilize as many members as the Cuban priest did. "Because remember that I can tell you, 'take this other [priest] to work with you,' but I'm delegating him. He has many other things to do. So the other priest could work with us a limited time, but he wasn't going to be the person in charge with the power to decide and delegate others." It is also likely that the alternate priest, a Dominican who had only begun working at Corpus Christi a short time before he was assigned to work with the FBAC, did not command the same respect, admiration and trust among members as the Cuban priest. Having worked in Wynwood since the 1980's, the head Catholic priest was admired by multiple generations and different Latino nationalities within the neighborhood.

${ }^{154}$ For example, one of the various ways in which the former organizer, Edwin, explained this to me was when he pointed out that the growing disengagement of the Cuban priest "did not affect [our overall turnout] because I still mobilized plenty of people from the Catholic Parish and other Churches, but there was a moment when the Haitian members started to become more numerous than members from Latino Churches." Adam, the former FBAC director, was clear: "Notre Dame d'Haiti became our biggest base in the city [by] 1999... They had some very similar issues, lots of synergy [with Latino Churches], but [also] some different ones. For example, we did a big campaign to get the City of Miami Police Department to hire more Kreyol speaking officers. Clearly, that was because Notre Dame wanted it. And we were intentionally trying to build our base in the Haitian community."
} 
The increased attention to injustices of special concern to Haitians does not mean that Hispanic issues were displaced. The FBAC's three annual campaign choices have almost always included a mix of "bread and butter" neighborhood issues (e.g., crime fighting, public services) and broad-based issues (e.g., education, transit, housing), along with a group- or neighborhood-specific issue (e.g., the struggle against the Port storage expansion in Wynwood). Rather, the tendency to take on larger-scale campaigns which appears to have demobilized the Catholic parish membership to some extent, both gave way to and coincided with the growth of Haitian influence within the FBAC. In many ways the experiences of the FBAC follow in the footsteps of classic examples of how the shift from mobilization through protest toward organizational advocacy and negotiation are demobilizing experiences (Piven and Cloward 1979), albeit played out in the context of contemporary issues and organizing models.

The contemporary context of organizing, combined with the Cuban priest's ideological dispositions noted above, helps to explain how and why by the time gentrification had emerged in Wynwood at the turn of the 21st Century, the priest and thereby the Catholic Parish were resigned to those "broader changes."

That was a point of tension and conflict between the priest and me and the other organizers at FBAC. He was much more resigned to those broader changes and not as interested in fighting them. I remember he really wanted us to just focus on the simpler, winnable, things in the neighborhood and didn't want us taking on these bigger fights. ${ }^{155}$

Furthermore, the FBAC organizers expressed frustration not only with the internal challenge (in terms of FBAC organizing capacity) of taking on the increasingly complex

\footnotetext{
${ }^{155}$ Adam, former FBAC director.
} 
issues of education, mass transit, and housing policy issues (including gentrification). But they also lamented the disillusionment and reluctance of some of their congregation leaders to take on urban development issues in the face of the growing intransigence of public officials at the height of the housing bubble's wealth. The next section examines the political climate affecting social justice campaigns on issues broader than Wynwood in order to understand how perceptions about Miami's "exceptional" and extremely "entrepreneurial" climate shapes how organizations and leaders think about what is possible, and thereby their choices of action.

\section{The Broader Political Climate of "Irresistible" Development}

The "bigger fights" referred to by Adam above included the education reform and mass transit campaigns that took place between 1998 and 2002, and also a housing policy campaign in 2006 which was a rare example of FBAC involvement in a county-wide urban development issue (as opposed to, for example, focusing on eliminating "crack houses" from the neighborhood). Although Fernando and the Catholic Parish were not involved, this last campaign is an especially illustrative example of the power of development interests in Miami during this period and the seeming inability of activists to impact the status quo. Although played out by actors at a political scale beyond Wynwood, a brief examination of the case helps understand why activists struggled to impact development processes at any scale, especially in Wynwood.

At the height of the housing boom in the mid-2000s, FBAC organizers were confronted by a paradox that forced them to make difficult choices. Many congregation members complained about gentrification pressures in their neighborhood, expressed in 
terms of rising rents, evictions and unequal public services (e.g., police protection favoring wealthier newcomers instead of existing, low-income residents). But activists struggled with how to wage an effective campaign against these issues, particularly how to balance the need to "win" with the importance of achieving something broad enough to benefit the diverse components of the FBAC's base (i.e., something worth winning). Its ultimate choice to take on a Miami-Dade County housing and development policy, deemed the Workforce Housing Ordinance in 2006, was shaped by its own capacity (or incapacity to do anything else) and a political opportunity that emerged in the wake of a corruption scandal at the Miami-Dade County Housing Authority (Cenziper 2006, 2007). Several other social justice organizations had also been prompted to act on this Ordinance because of this political opportunity (which they arguably helped create through neighborhood organizing that exposed the impacts of some the corruption) (McGrory 2006). Therefore, before briefly reviewing the experience of this collaborative effort and its implications for FBAC leaders, it is necessary to locate it within the context of the network of social justice organizations that was created during this period.

Nissen (2009) has termed this broader network of organizations as South Florida's "social justice infrastructure." ${ }^{156}$ A sub-section of the loose-knit network began meeting on a regular basis in 2005 (prior to the corruption scandal) to discuss how to

\footnotetext{
${ }^{156}$ See Nissen (2009) and Nissen and Russo (2006) for more of the history of these organizations prior to 2005. This author was a research assistant for one of the organizations during 2004 when some sporadic and informal meetings took place between the organizations that would later form the CBC. My field notes from 2004 documented the membership and contents of some of those meetings, including planning to obtain funds for future coalitional work.
} 
utilize the emerging political opportunities ${ }^{157}$ in order to address unequal urban

development in Miami. Along with Nissen, this author served as a research consultant to

the groups that were meeting, which eventually called themselves the Community

Benefits Coalition (CBC). ${ }^{158}$ Although no formal, coalitional campaign emerged, meeting

monthly for almost two years facilitated the maintenance of a mutually supportive

network which, on key occasions, collaborated to mobilize specific protest activities or

advocacy. ${ }^{159}$ One of those advocacy efforts was to intervene in Miami-Dade County's

attempt to pass a so-called Workforce Housing Ordinance, which I will now examine to

glean how this effort both shaped and reflected the FBAC leadership's thinking about

how to address housing and urban development issues at the height of the boom.

${ }^{157}$ When the "Community Benefits Coalition" (CBC) started meeting, several factors coincided to expose
social injustice in Miami and propel the group to collaboratively address inequalities: hurricanes Katrina
and Wilma had wreaked damage and exposed decades of inner city disinvestment; many of the coalitions"
activists were aware and/or had collaborated with Miami Herald reporters on the Housing Agency
corruption scandal; many of the organizations observed that the growing real estate wealth coincided with
growing neglect and punitive treatment (e.g., by police and welfare agencies) of low-income
neighborhoods. But perhaps the most immediate catalyst that brought the groups together was money. As I
will discuss later, not only were individual organizations being funded in 2005 at higher levels than ever
before, but a common funder invested in the collaborative space that was eventually constituted as the CBC.

${ }^{158}$ Despite the eventual name, some members of the CBC disagreed over whether it was an actual coalition, preferring instead to call it a "network" or even a "table" (see also Nissen 2009). Yet, with increased funding in 2007, the CBC hired a coordinator (instead of a group member volunteering to coordinate meetings) and established a website, giving the "Coalition" a public identity with which to take positions on different policy issues.

${ }^{159}$ The most cohesive collaboration that emerged from this network was the Emergency Housing Task Force. Made up mostly of the CBC's "base-building" organizations, the Task Force mobilized several protests at County Hall to demand criminal prosecutions and reparations for the public housing funds mismanaged and in some cases, embezzled by various corporations, non-profit organizations and government officials. Some CBC groups also worked together to challenge the County's Workforce Housing Ordinance, described here; to commission and publicize the finding of a study conducted by this author's research institute which contradicted the status quo of urban development in Miami; and to some extent, to coordinate and support each others' individual campaigns. The $\mathrm{CBC}$ initially hoped to collaborate on a central, unifying campaign that would use a referendum to pass a county ordinance requiring a variety of "extractions" or "community benefits" from large-scale development projects. But this effort never materialized and by 2008 the CBC meetings had ceased. 
In response to a Florida House Bill that required local governments to create landuse and zoning mechanisms to increase the supply of affordable housing, in 2001 MiamiDade County created a task force comprised of public officials and private developers to study inclusionary zoning policies and recommend an action plan to the County Commission (MDCC 7/24/2001). Inclusionary zoning (IZ) is a land-use regulation that requires development projects of a given size (typically the largest) to set aside a share of the project's total housing units for sale or rent to lower-income households, or to pay into an affordable housing trust fund instead. So as not to reduce developers' profit margins, IZ typically subsidizes the affordable housing set-aside by providing "bonus density," effectively allowing for the construction of a greater number of units to offset the reduction in profits from building smaller and cheaper units to satisfy the IZ regulation. Notwithstanding the challenges of defining (and ensuring) "affordability," the land use concept aims to link market forces to social needs. Although by 2002 MiamiDade's "Plan for an Enhanced Affordable Housing Program" was complete and the task force set about studying how to create IZ legislation (MDCC 1/29/2002; SFLCDC 2002), no legislation was proposed for another three years. In 2005, nearing the peak of the real estate bubble, the county created a new task force to re-examine IZ and propose legislation.

I was involved in several aspects of this renewed policy process. ${ }^{160}$ Along with representatives of some community-based organizations, I attended (as a university representative) a meeting at the County's Planning and Zoning Department where County

\footnotetext{
${ }^{160}$ In addition the examples of my involvement cited below, I participated in numerous public hearings and meetings and other correspondence of the activist coalition between September 2005 and December 2006 to determine strategy and actions for how to address the proposed IZ policy.
} 
officials and development industry representatives, including members of the Latin Builders Association, worked out key components of the proposed IZ policy. The policy's intent was to provide enough bonus density so that developers could, without sacrificing any profit margin, set aside a small fraction (5 to 15 percent) of a project's total housing units for families with incomes ranging between 65 and 140 percent of the county-wide median family income (County staff used the 2005 statistic, which was $\$ 46,350)$. The "upper tier" of the affordability range was chosen as the initial target around which to structure the proposed policy since the highest potential sales price was considered the easiest starting point for the development industry to create a "housing product." On the basis of advice from mortgage lenders, county researchers determined that a family with income at 140 percent of the median $(\$ 75,700)$ could afford to purchase a home for as much as $\$ 225,000$ or pay monthly rent up to $\$ 1,497$. Thus, during the meeting, the concern of planners and industry analysts was how much subsidy (bonus density) and which designs would produce housing that could be sold or rented for the aforementioned amounts. Industry representatives acknowledged that a "product type had not yet been developed" that might sell for less than $\$ 225,000$, or be affordable to families with incomes less than 140 percent of the median. In other words, at least initially, it seemed that implementation would focus on the most expensive possible "workforce housing" allowed under the IZ ordinance.

Following this meeting, I was involved in advocacy efforts to modify or defeat the proposed legislation, as analysts (including myself) and activists agreed that it would produce neither enough units nor housing at prices affordable to those who most needed it (Feldman and Nissen 2006; Haggman 2006). Affordable housing advocates were 
concerned that the passage of this ordinance, touted as an affordable housing policy, would preempt a potentially more progressive policy in the future. The FBAC invited me to present the findings of a policy paper critiquing the IZ policy to their membership during a church meeting in February 2006. The FBAC activists sought to inform members about the policy and request their attendance at an upcoming public workshop on a preliminary version of the ordinance where they could demand changes to the ordinance. Several dozen FBAC representatives attended the subsequent workshop in March of 2006 and spoke against the proposal, seeking specific changes. The following is representative of the discourse of the activist organizations that attended the workshop (MDCC 3/15/2006).

This is not affordable housing, workforce housing, inclusionary zoning... not middle-class housing. We can only afford to build a few hundred units for struggling professionals making $\$ 80,000$ a year? This shouldn't be so hard... There is a housing boom, there is abundance all around us and this is the best we can do for people's housing needs?

Instead of the wide range defined as between 65 percent and 140 percent of the median family income, opponents of the proposed IZ policy called for it to target multiple income tiers (e.g., to set aside a fraction of units for families with incomes at 6580 percent of the median) to ensure that some of the housing produced would be affordable to families at the lower end of the target income range. While affordable housing advocates opposed the potentially unaffordable outcomes, the IZ proposal was also opposed by major developers who felt it should not be mandatory. 
Social justice activists' pleas were ignored; developers' requests were incorporated. ${ }^{161}$ Ultimately, a voluntary IZ policy was passed that enacted the provision of bonus density as a way to subsidize "moderately-priced" housing (MDCC 2007a). Arguing that federal and state housing programs already existed to provide housing affordable to families with incomes up to 80 percent of the median income, ${ }^{162}$ the proponents of a voluntary IZ policy (including the sponsoring county commissioner) acknowledged the policy was not intended to produce housing for low-income people but rather represent "one of many tools" to diversify the cost and location of housing products (MDCC 1/25/2007b). What began in 2001 as a search for "an enhanced affordable housing program that promotes equitable distribution through inclusionary zoning” (MDCC 1/29/2002) ended as a subsidy for integrating \$200,000 apartments into developments with more expensive housing. Whatever its merits, IZ in Miami will not produce housing for poor people as it has elsewhere in the U.S., notably in some California cities where set-asides are mandatory (e.g. Mukhija et al. 2010).

The outcome of the IZ policy process in Miami was shaped by the timing of the legislation at the height of the real estate boom and by the extremely entrepreneurial orientation of policymaking in South Florida (as throughout Florida), where real estate

\footnotetext{
${ }^{161}$ For example, the IZ policy exempted developments over 200 units (high-rise projects), thus focusing mostly on lower- and medium-density projects which were the specialty of the builders who worked most closely with the County in crafting the legislation. This also made sense since the County opted not to pressure munipalities to implement similar IZ legislation, which is where the highest-density development tends to occur (such as in the City of Miami).

${ }^{162}$ Despite the apparent mismanagement in many of these housing subsidy programs (Cenziper 2006, 2007), public officials insisted that there was no need to enact additional policies since the existing affordable housing systems were adequate. Representative of this discourse was a 2007 Miami Herald editorial by the City of Miami Mayor, Manny Diaz, in which he said, "There is no crisis in housing... Mistakes were made and will be made, but we learn from and fix them. Does this amount to a crisis? Absolutely not."
} 
developers have historically overpowered neighborhood organizations and advocates of regulation. ${ }^{163}$ In 2005 , a Florida State University policy brief opined the IZ was unlikely to flourish in the state (West 2005, p. 2).

Inclusionary zoning succeeds where it is supported by organized groups, as it requires longstanding attention and focus to affect the distribution of housing. Local politics in Florida are fluid, reflecting the rapid population changes that occur in the state, making it difficult to sustain long-term organizations as are needed to maintain pressure for inclusionary zoning. By contrast, forces opposing the policy are well established and able to mobilize. In addition, the policy is most successful where growth rates are mild, as the market pressures that exist in areas with rapid growth, along with attendant pressures on local and state governments, render the policy difficult to enforce.

This logic may be especially applicable to Miami. As discussed in Chapter 4, Community Development Corporation projects in Miami struggled because they followed an entrepreneurial approach instead of relying on foundation and government grants to the extent that is typical in other parts of the country (see Von Hoffman 2001; Lowe 2006).

Moreover, the perception that Miami is not only exceptionally entrepreneurial but also a highly insular political climate, thereby resisting governance advice from outside, is frequently criticized by activists and reformers who work here. At one point during the IZ policy process, an e-mail discussion ensued within the activist coalition about an exchange between IZ opponents and the Cuban-American vice-chairman of the County Commission, in which a member of the former deemed the commissioner's views, "Miami exceptionalism." A part of the exchange, which took place in May of 2006, is illustrative of the perception of policymakers' intransigence and is worth quoting at

\footnotetext{
${ }^{163}$ However, later I will discuss how during the last housing boom a new coalition of middle-class neighborhood organizations partially and occasionally denied the advance of large-scale development through their neighborhoods.
} 
length. Here, an FBAC representative from a Jewish Temple tells of his experience with the commissioner. The response is from a public interest lawyer who supports several of the activist organizations and has practiced in Miami since 1992, longer than most of the activists have been in the city.

Jerry's message:

Yesterday, as Adam, Leticia, Father Mike and $\mathrm{I}^{164}$ were leaving the County [Hall], Pepe Diaz approached us. He showed his appreciation for our efforts on the workforce housing issue. He reminded us that he's a co-sponsor of the ordinance and gave me the impression that he wouldn't budge. When I asked about the fact that inclusionary housing ordinances had income tiers everywhere else, Diaz looked at me, an Anglo with a Kipah, and said that "it's that you don't understand Miami - we're different." When I insisted, he returned to this idea that I wasn't from Miami, (being Anglo and Jewish?) so I don't get it.

I think we need to present the question of how successfully tiers are used for a really just and inclusive housing policy and that it has nothing to do with the fact that Miami is different except perhaps that it is poorer than most. Diaz seems to think that Miami's ethnic or some other populational/statistical quirk makes the difference significant. Would you or Marcos or anyone else have a thought on how to refute this type of argument? Personally, I think his remarks were a kind of reverse discrimination.

Fred's response:

I have attached to this email a letter I sent to the Commissioners which has attached to it spreadsheets listing some of the many other jurisdictions who have inclusionary zoning. The Commissioners have been bombarded with this information. I think you have hit the nail on the head with this "Miami exceptionalism" argument. While other major cities and counties look to progressive ideas, Miami (both City and County) are incredibly insular refusing to look outside for ideas. There are many people that would love to help both the City and the County solve their housing problems but they continually hear that Miami does not need outside help. I have asked many to help with this and other issues and they continually say that while they are working with Cities and Counties throughout the state, Miami (city and county) just don't want help. What you heard was another voicing of that same idea. I don't think it can be combated solely by more information because it is deeper than information. It needs to be

\footnotetext{
${ }^{164}$ Adam was director of the FBAC; Leticia was an FBAC organizer; and Father Mike was the leader of a congregation in the inner city neighborhood of Overtown. Although Jerry's Temple was a member of the FBAC, his primary affiliation was as director of another inter-faith network that focused on worker justice. I witnessed the exchange described in the message. According to my field notes, the Cuban-American commissioner also said, "my opinion is that Miami is like no other place; our diversity if what makes us great, but that's also our Achilles heel."
} 
confronted as a problem in its own right - exactly as you stated it, a problem of insularity - Miami simply does not want ideas from outside. If we can confront and break through that wall, we open up the City and the County to a whole world of ideas that are just waiting to be utilized. (One initial opportunity might be the hiring of a new Housing Department Director - a progressive director with new ideas and open to working outside the bureaucracy could work wonders.)

Notwithstanding the identity- and place- politics implicit in the exchange (e.g., who are the real locals in Miami), many Miami activists (most of whom grew up outside of Miami), perceive the region to suffer from insularity in its governing regime (see also Steinacker 2002) in addition to being exceptionally entrepreneurial. In a separate conversation at the height of the housing boom and Miami's coalitional activism, Jerry hoped that activists and reformers would win something significant. Otherwise, he warned with some angst, "it's hard to not let this fatalism that envelops our community take hold again." His concern seemed well-founded as many within "our [social justice advocacy] community" became frustrated and discouraged by the extent to which unequal development seemed to rapidly outpace tangible "victories" or "extractions" 165 from development to benefit poor people.

The FBAC, which had in the past been able to change or resist policies that negatively impacted Wynwood, ${ }^{166}$ found that their power was much more limited during the 2000s and the height of the housing boom. Inside the neighborhood, as my analysis of major development projects will show, key community leaders and neighborhood organizations chose for practical or ideological reasons not to invest substantial time and

\footnotetext{
${ }^{165}$ Whereas activists often speak in terms of "victories," some community lawyers refer to the concessions provided by developers or public officials to low-income residents, racial minority groups or other social justice constituencies as "extractions."

${ }^{166}$ Such as shaping community-based policing systems and decisions about school construction, or rebuffing plans to expand the Port Authority's storage facilities in Wynwood.
} 
energy in opposing gentrification. In broader policy processes, such as the Workforce Housing Ordinance, their opposition and advocacy was ineffective. The former FBAC director, Adam, also noted how the organizations' typically impressive "people power" for affecting smaller, neighborhood issues seemed less effective.

I have this sense that in the great real estate bubble that occurred in the early and mid-2000s, you know, 2003 to 2007, my last several years there, that we, no matter how many people turned out, it didn't matter. That the economic power, the driving, the gentrification of Wynwood was more than we were able to compete with. That's how I felt in those years... that we were up against economically powerful forces that were more significant than the people power that we could muster... So as we tried to confront even simple issues, our members in Wynwood had the feeling that [government officials] don't want to fix any of the problems in the community because they want to drive people out so that the properties could be acquired dirt cheap and then demolished, redeveloped, you know, transformed, gentrified, etc. So we had this sense that, you know, whereas trash issues and crime and other neighborhood problems - it felt as though they were intentionally ignoring those things in order to force people out of their... [keep] property values low and force people out of the community.

Edwin noted that as he saw more and more conventional neighborhood organizations in Wynwood - CDCs, homeowner associations, and others - signing off as supporters of major gentrification projects, he became discouraged. "They were bought off; they let themselves be seduced [by financial concessions from developers]. ${ }^{167}$ As an organizer, there came a moment in which I felt frustrated because I saw these things, and when I took the decision not to recommend the topic of gentrification to the board of directors, I knew that FBAC did not assemble the conditions [necessary to win] and, in addition, the issue was not clear." Therefore, reasoned Edwin, "when you analyze gentrification, and you analyze the criteria for taking on a campaign, you realize that it's

${ }^{167}$ I will discuss these processes in subsequent sections. 
not winnable. That is why FBAC decided, for now, [that] we're not going to take any action."

The conditions that were necessary to take on gentrification included a clear definition of the specific issue that could be addressed by a social justice campaign, the support of the leadership of the FBAC's largest member organizations in gentrifying areas in order to mobilize member support, and an exploitable political opportunity (recall these criteria from earlier). Although some FBAC activists such as Edwin may have struggled to identify a clear issue, this problem was exacerbated by lack of support for the variety of options available to address gentrification. Indeed, in several U.S. cities "gentrification mitigation strategies" include a long list of specific media strategies, legal mechanisms, and other tactics for addressing specific aspects of gentrification, such as rising rents and evictions or large-scale gentrification projects subsidized by the property taxes of nearby low-income residents. But defined in such specific terms, campaigning against the gentrification "issue" was not likely to gain support from FBAC's institutional leaders who were reluctant to "oppose development," resigned to the "inevitable" neighborhood changes or in some cases, wholeheartedly supportive of progress even if it displaced some residents. The leadership in Wynwood, both among the FBAC's religious institutions as well as most conventional community organizations, was for practical or ideological reasons unopposed to gentrification. These conditions and especially the aforementioned "feelings" shaped the thinking and action of many activists in Miami at the height of the housing boom.

On the other hand, activists were not the only ones with a sense of powerlessness in the face of politics and business as usual. The sense that the forces of development 
overwhelmed community-based interests seemingly pervaded most settings of community-based, organizational action and politics, not just that of social justice activists. Over the winter of 2006-2007, the research institute where I worked conducted a series of focus groups with randomly selected "active voters" from a cross-section of Miami neighborhoods (Stepick and Feldman 2007). Among the participants were the leaders of some neighborhood organizations as well as unaffiliated, ordinary residents. We found that although people differed in their opinions about what to do, a broad array of residents - middle-class and poor, native and immigrant - believed that development was "out of control" and hurting their neighborhoods, and also that neighborhood-based interests had little to no influence in development policymaking and practice.

Residents clearly felt ignored and found public officials unresponsive, a sentiment which eventually made itself known at the polls with the election of a "neighborhoodfriendly" city mayor in 2009 in a campaign characterized by anti-incumbent voting (Rabin and Vasquez 2009). A notable community-based political development that was instrumental to the electoral shift was Miami Neighborhoods United (MNU), a coalition of homeowner associations representing several upper-middle class neighborhoods of mostly single-family homes. Although some of its member associations had previously been effective in resisting or weakening the advance of large-scale development, the coalition emerged largely in response to a city-wide rezoning policy known as Miami 21 which threatened to impose higher density zoning in or near MNU neighborhoods. 
According to the City planning director who helped design Miami 21 and is now in charge of its evolution as it is implemented: ${ }^{168}$

I think [through] Miami 21... all of these neighborhood activists [or] civic participants, to use a more neutral term, began to... cross-pollinate, inform one another of what their respective interests were, began to develop a fairly sophisticated view of what Miami as a city was, and began to find points in common and points of difference. And MNU has evolved into a very, sophisticated - I mean, I think that's the interesting paper to write, right? How MNU in a period of six years through the Miami 21 process became a coalition of neighborhood groups who garnered this very sophisticated understanding of how the city works and how they can influence government processes to further their interests.

Because of their substantial resources, including money, human capital (e.g., legal expertise) and social/political capital (e.g., comprised of current and former city officials), MNU garnered plenty of attention from policymakers and news media, including mention in more than 175 news stories between 2005 and 2011 (see e.g., Vasquez 2004; Leon 2007; Cave 2009). MNU was not only instrumental to the election of the new City mayor, noted above, but also introduced key amendments to the Miami 21 zoning plan, most of which have been accepted or are under consideration.

Two years later, in 2011, voters recalled the Miami-Dade County mayor and one commissioner in a historic referendum after these supported an increase in property taxes as well as major subsidies for private developers (Haggman and Brannigan 2011; Mazzei 2011). Though financed by a wealthy Anglo-American businessman, it was mostly Cuban-American voters who expelled the Cuban-American politicians they had previously elected (Mazzei 2011).

\footnotetext{
${ }^{168}$ It is worth noting that the City of Miami Planning Director, who in 2004 as zoning administrator resigned in protest because of an outsized development next to single-family homes, has the changed political environment to thank for his return to the city.
} 
In these ways, development politics and the housing boom and bust cycle provided a political window of opportunity, one which was partially exploited by the County recall advocates and neighborhood associations in the City of Miami. Other parts of the referendum, such as Miami-Dade County Charter reforms to enhance elected officials accountability to voters, were not as effective, as politicians were able to choose which reforms to put on the ballot (Brannigan and Haggman 2011). In any case, the charter reforms would have done virtually nothing to transform the inequalities inherent to the urban development system.

To the extent that corruption scandals and Housing Agency mismanagement at the height of the housing boom provided an opportunity to win reforms that might help low-income residents mitigate the impacts of unbridled and unequal development, social justice organizations mobilized individually and sometimes collectively win relatively minor reparations. Perhaps the most substantial concession won was in the case of the Liberty City-based Social Justice Center, which obtained one-for-one replacement of 850 public housing units demolished in a scandal-plagued HOPE VI redevelopment project after the original plan called for only a small fraction to be replaced. The collaborative efforts of the Emergency Housing Task Force described above, which coalesced in response to the widespread mismanagement, obtained $\$ 18$ million in budgetary commitments to low-income housing to partially make up for the more than $\$ 40$ million that were diverted. While such victories may make a real difference in poor people's lives if and when the funding is properly applied, the urban development systems remained basically unchanged and many of the victorious social justice organizations remain embattled with county and city government and private developers who as of this writing 
wish to carry out subsidized development projects without conceding to the organizations' demands. In other words, while small victories are important, development as usual continues. 


\section{CASE STUDIES OF 'UNSTOPPABLE' GENTRIFICATION}

To the extent that gentrification involves the constitution of a transformed living environment and a "new middle class" (Lees, Slater and Wyly 2008), the 2000s marked the consolidation of gentrification in Wynwood. Two key processes of urban development marked the onset and advance of gentrification of Wynwood. One is the Midtown Miami residential and commercial complex, which was shaped by two preceding planning processes, including the 1996 Wynwood Master Plan and the 20012003 FEC Corridor Plan, and was built between 2005 and 2007. The other is the creation and growth of the Wynwood Art District, formally established through a series of policies and institutions after 2006 but catalyzed and informally organized since the first art galleries arrived in the neighborhood in the 1990s. In addition to these processes, I examine the case of an activist campaign to address the deterioration and eventual reconstruction of the Community Center in Roberto Clemente Park. The first two cases are clear examples of gentrification while the community centers' deterioration and reconstruction reflected and symbolized the shifting balance of power in the neighborhood toward wealthier newcomers. Some community organizations supported some or all of the unequal redevelopment projects in Wynwood, readily admitting that inequality is an unchangeable "reality," while others lamented the unequal outcomes and criticized examples of gentrification but chose not to address them in action. While accepting gentrification as inevitable was not the case for every organization all of the time, these are nonetheless the predominant trajectories that emerged since the 1990s. 


\section{Case 1: The Midtown Miami Project}

By the end of 2007 the Midtown Miami complex was complete and its' corporate anchor tenants, such as Circuit City, Target, and Marshalls, among others, were setting up shop. The complex of 34-story residential towers and 4-story shopping centers mixed with ground-level retail outlets appears like a "new city" to many of the nearby, existing residents of Wynwood. A before-and-after birds-eye view of the complex, shown in Figure 6.1 below, reveals the emergence of a new street grid through the two-by-eight block district, contributing to the sense that urbanism was created from scratch. The following account of the creation of Midtown traces the role of neighborhood organizations in the process and the implications for neighborhood residents. The account also reveals how an array of legal techniques were invented to minimize accountability to both taxpayers and low-income residents, both of whom are the alleged beneficiaries of the public subsidies provided to Midtown. 
Figure 6.1: Aerial View of Midtown Miami Site, Before and After Redevelopment

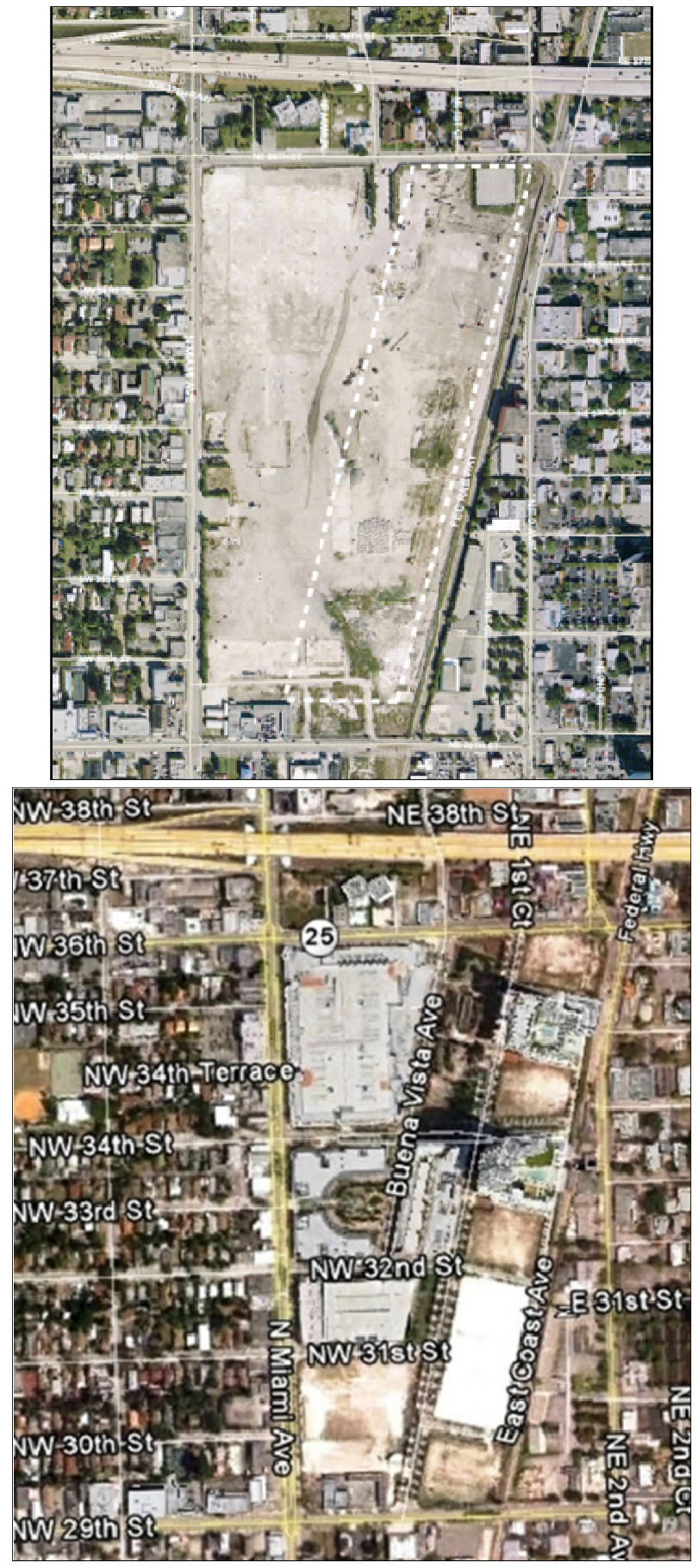

Source: Image of the empty Buena Vista rail yard from the City of Miami legislative package creating the Midtown Community Development District (City of Miami 2005); on the right, a Google Earth satellite image, 2010. 
A variety of specific legal, technical and political processes contributed to the public-private partnerships through which the Midtown complex was built. The most important of these processes included the Florida East Coast Railway (FEC) Corridor Redevelopment Plan, the creation of the Midtown Community Redevelopment Agency that enabled Tax Increment Financing (TIF district), and exemptions from key land use regulations within the process of obtaining a Major Use Special Building Permit (MUSP). ${ }^{169}$ These processes involved university researchers who conducted planning studies, corporate attorneys who lobbied for exemptions from zoning and other land use regulations, government officials who maneuvered complex regulatory techniques, selected neighborhood representatives who provided political support and, developers, architects and contractors who were responsible for executing the construction project within the frameworks established through the aforementioned processes. The costs of such processes as well as the redevelopment project itself totaled about $\$ 600$ million for the first phase built by 2007 , including upwards of $\$ 170$ million in direct and indirect subsidies from City and County taxpayers to two New York-based developers who partnered to build Midtown. ${ }^{170}$

Many people were able to claim some contribution to the projects' success, including people who were not involved in the specific processes mentioned above. The Catholic priest claimed that the emergence of the Midtown Miami complex, as an alternative to the abandoned Buena Vista rail yard, was made possible by his parishioners' activism in the 1990 s to prevent the creation of a storage facility in the rail

\footnotetext{
${ }^{169}$ I will also describe below how County and City government agencies applied for specific federal and state subsidies, some of which were unrelated to the FEC Planning, TIF district and MUSP processes.

${ }^{170}$ Total construction costs, including additional phases not yet built, were estimated at $\$ 1.2$ billion.
} 
yard (Glasgow 1994; Charles 1995b; Lynch 1996). Indeed, the expansion of port container storage at the rail yard would have most likely expanded the "dust storms" generated by truck traffic that residents complained about for years. Even if temporary, the Port's continued use of the site would have prolonged the environmental remediation needed to redevelop it, as it was designated an environmentally polluted "brownfield" after years of industrial use. Carlos Jr., who by the time of the FEC planning process was working as a policy advisor for the County Commissioner of the district containing Wynwood, also touted his role in "fighting the dust bowl" and noted that "all of this stuff that you see now [Midtown complex] happened after I left but... there were a lot of us that put the groundwork in for a long, long time, for stuff to happen."171

\section{Planning for the Florida East Coast Railway Corridor}

Nevertheless, a series of complex legal and quasi-scientific techniques, and specific political and planning processes initiated in the year 2000 made possible the conceptualization and development of Midtown. The city commission assembled a task force made up of government officials, business leaders, non-profit neighborhood organizations, and private developers to study and create a new master plan for the Florida East Coast (FEC) Railway corridor, which extends along the railroad tracks from the northern edge of Downtown to the northern boundary of the City of Miami (see Figure 6.2 below). Because it occupied such a large tract of undeveloped, inner city land, the Buena Vista rail yard on the eastern edge of Wynwood was a crucial component of

\footnotetext{
${ }^{171}$ The lead architect of the Wynwood Master Plan in which Carlos Jr. and the Catholic priest participated, said: "Our influence on Midtown, if any at all, was that we said, make a grid and make it part of the city... Eventually that happened in a different way than what we were suggesting but I think just the fact that some people started thinking about it in those terms early on was useful."
} 
the corridor and its' incipient redevelopment planning. The task force and its' subsequent research and planning (as with the research and plans of prior decades, e.g., see Chapter 4) was justified politically as a way to preserve and expand the light industrial uses along the corridor and thereby create jobs for city residents (MCC 2/10/2000). But the resulting plans' implementation, at least as of this writing, has consisted largely of upscale housing and retail consumption (especially in the case of the Midtown site), while industrial activity along the corridor continues to decline.

The City of Miami commissioned Florida International University (FIU) to lead and coordinate the research and planning efforts, which produced the first of several different redevelopment plans in 2002. Community participation was considered integral to the FIU-led planning research, which included a series of "community conversations" held across the three major neighborhoods comprising the FEC corridor, Wynwood, Edgewater and Little Haiti, in which residents and commercial stakeholders participated in the creation of redevelopment objectives and a vision statement for each area. To this end, two meetings and community mapping exercises were conducted and after drafting a plan, another meeting and follow-up correspondence was used to get more feedback. Indeed, as discuss below, much was made of the procedural aspects of the plan. 


\section{Figure 6.2: Boundaries of the FEC Corridor Study Area}

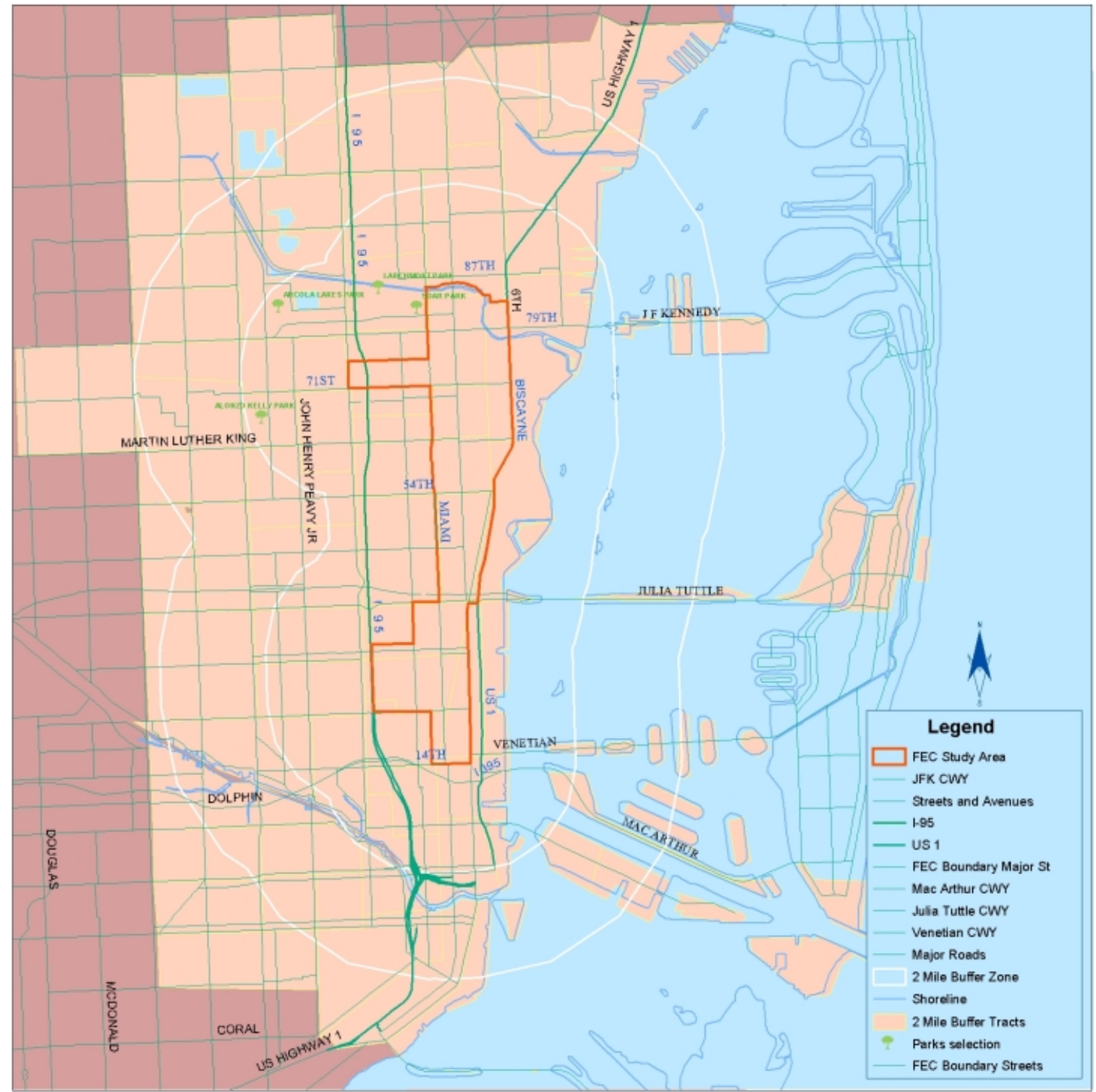

Source: City of Miami FEC Corridor Community GIS, from FIU GIS lab website (http://gislab.fiu.edu/gisrsal/frames/fec/home.html).

A wide and diverse representation from within and beyond the neighborhood attended these meetings- Felipe, the Puerto Rican leader from the 1970's who owned several properties in the area; more recent Puerto Rican leadership in community organizations; neighborhood residents; business owners ranging from art galleries to 
manufacturers and wholesale distributors; realtors and real estate developers; city and county politicians' advisors; the owner of an apartment building; and even the Governor of Puerto Rico. The concerns voiced at the Wynwood meetings related to the neighborhoods' physical deterioration and perceived lack of security; the need to create jobs and revitalize the real estate market; the extent of homeless persons attracted to the area's cluster of social service agencies; and the perceived lack of neighborhood participation among residents and businesses (FIU-MC 2001).

Although within a few years some residents voiced their opposition to ongoing redevelopment, especially the Midtown complex (Menendez 2005; Sohn 2005), the FIU project leader noted that during the 2001 community meetings the negative impact of gentrification "was something we were more concerned about than the people," an observation similar to that made by the lead architect of the Wynwood Master Plan in the mid-1990's. ${ }^{172}$ Similar to the 1996 plan, the apparent absence of concern over gentrification may have been a function of the mixed composition of the meetings, which apparently included a greater number of non-resident stakeholders compared to residents. ${ }^{173}$ Nevertheless, the lead researcher of the FEC plan explained his concern that

\footnotetext{
${ }^{172}$ Having done community design charrettes in Coconut Grove on several occasions, the lead architect of the 1996 Wynwood Master Plan reflected on her experiences to draw comparisons. "I think the main difference is that the West Grove [a historically Black neighborhood] has been conscious for more than a generation that it has to stave off gentrification. It's in a location and surrounded by people who would love to take over the real estate and so for a long time they've been very defensive about it... Now, up in Wynwood, there was no, there was nobody there or maybe there were, but very few people from six generations. It was a recent immigrant community. It was largely rental. There wasn't a lot of stakeholding, in a sense, in the community, the way there has been in the West Grove. So there wasn't same sense of either belonging, territory, or defensiveness that there was in West Coconut Grove." However, recall that the research commissioned by the Puerto Rican CDC (Urbana 2002) found a few members of the Wynwood Empowerment Zone Neighborhood Assembly who were opposed to the idea of artist lofts for fear of gentrification.

${ }^{173}$ Although only three neighborhood residents are identified in the list of 26 participants, there are three other names for whom no affiliation is provided, who may be residents. Anywhere from 3 to 6 out of 26
} 
speculative investment (some of the meeting participants were, in fact, such investors)

would not benefit existing residents:

We were only there six months, driving and walking around, hearing [people] saying, you know, 'the horse may be already out of the barn here.' Just because you don't see [gentrification] doesn't mean that this is not already happening. And sure enough, it was already happening. People were buying up stuff. Changes were starting to occur, not visible, but... so we tried to introduce some of this [concern], but it was also something that we obviously also took into consideration in the plan itself because we knew [that] economic opportunity has to come from within, not just people coming in, you know, outside developers, and taking advantage of the situation.

To enhance area residents' and merchants' sense of their stakes in the neighborhood, care was taken to help participants develop a deeper understanding of the imminent changes in Wynwood and the other neighborhoods where "community conversations" were held. Thus, much was made of participatory principles within the FEC Plan that laid the foundation for the eventual development of the Midtown Miami complex. Even the architect, Zyscovich, chosen as part of the planning team and later to design most of the Midtown Miami complex, was a proponent of "Real Urbanism," which, in contrast to the "New Urbanism" paradigm, argues that buildings must be designed "organically," according to the qualities and stakeholder preferences rooted in local context. ${ }^{174}$ "So our process," as the FEC project leader explained,

participants may have been residents. One of the resident-participants is someone I interviewed, who was a strong supporter of the eventual Midtown project in which he found employment as a security guard and was contracted personally by the developers to do odd-jobs. It should also be noted that, according to the project lead, many other residents participated outside of the meetings by joining along on the neighborhood walk and calling or writing letters to the research team after hearing about the project from others.

${ }^{174}$ According to Zyscovich (cited in Ottolenghi 2002), "I call it Real Urbanism because when someone does planning within a city, they need to take into account not only what it looks like, but how it came to be. The premise is simple: What we all want as human beings is to have an ever-increasing quality of life, 
was fairly nuanced and I made it very clear that we needed to develop a relationship with people in these communities... We knew going in there was a lot of cynicism and distrust based on past government efforts... So the thinking, even before we went in, [was that] we need to just have a conversation with people... to kind of figure out where they're at. You know, not just come in there with the flipcharts and the powerpoints... [but]... continually engage them, come back to them [with drafts], did we get it right? Show them, engage them in community mapping. Walking the neighborhoods with them, having them point out things. You know, really developing an understanding, but a mutual kind of understanding of building trust.

The approach taken to participation was a response to the project leaders' perception that city officials (in Miami and elsewhere) typically aim to satisfy the minimum criteria of "the statutory language relative to citizen participation - "we get the folks input, now we move on,' which is really contrary to what community development is all about in terms of building capacity within communities and neighborhoods.","175 Such "capacity building" discourse is rooted in the project leaders' background and expertise in Community Development practice, in which existing residents are supposed to be the focus and beneficiaries of investments. In this regard, the views of the FIU researcher were not closely matched to the city's interest ${ }^{176}$ as the task he was given was to draft a plan that was fundamentally about real estate development, however "organic,"

whatever that means at whatever state in life you are. If you are a poor person, for example, you want to own your own house one day and to have a more secure life. Urban life has the potential for that if it's done properly. 'Properly' means knowing where you are at and designing a way of life that corresponds to the characteristics of that place and is not artificial. It needs to be real, and "real" is diversity and things to do and places to go and creating strong neighborhood ties and community. I don't believe that those things are limited to small towns," in reference to the neo-conservatism of the "New Urbanism" design school which emphasized the traditional qualities of small towns.

\footnotetext{
${ }^{175}$ FEC project leader.
}

${ }^{176}$ On the other hand, he is employed by a university research institute that frequently gets local government contracts to do planning and other kinds of research, and was therefore a convenient choice for the FEC project. 
"authentic" or "sustainable" the physical design. The pairing of a community

development specialist to lead an economic redevelopment planning process apparently led to some "tension," according to the project leader, as he was pressured by city officials to shorten the community participation process. The city commissioner who sponsored the plan assigned oversight responsibilities to the Economic Development Department, instead of the Planning Department, which likely contributed to the tension between planning principles and the imperatives of real estate development.

Nevertheless, the project leader persisted in his approach to ensure that participants were "engaged from the beginning all through the process, then hopefully even when we're gone, they continue on, kind of the self-help kind of thinking."

Ironically (but not surprising, as I will explain below), the subsequent processes that led to the construction of the Midtown complex empowered a select group of neighborhood "stakeholders" to act in the name of Wynwood residents and, whatever their original intentions, ultimately "self-helped" themselves to lucrative relationships with the developers in exchange for the political manufacture of neighborhood support. This highly inequitable outcome was made possible, in part, by the claim the FEC Plan "was a huge public process," according to the deputy city manager, that "served to inform the city about what the residents wanted in that area... residential and retail on the property" (Sohn 2006a).

Although the FEC plan made a genuine effort to take residents concerns into account, it generated no enforceable commitments to residents which opened the way for development to proceed without implementing any of the industrial employment training and affordable housing strategies recommended both in the FEC plan and in subsequent 
plans integral to the creation of public-private partnership to build Midtown. (I will return to the political construction of "accountability" later.) For example, with regard to housing ${ }^{177}$ the FIU researchers recommended "using proposed zoning changes as a 'planning tool' for housing choice" (suggesting an inclusionary zoning type of policy), "creating new housing financing mechanisms" to support affordable housing construction and rehabilitation, and "sponsoring an affordable urban housing design competition" (FIU-MC 2002). None of these were implemented. ${ }^{178}$ The FIU project leader noted that the Plan's implementation "accomplished a lot" in terms of urban design and redevelopment guidelines, ${ }^{179}$ but "in the end, from my perspective, the thing that we didn't accomplish was affordable housing."

\section{The Governing Partnerships to Build Midtown}

The FEC process was the foundation of the planning that led to the construction of the Midtown Mall. The subsequent discussion will examine how the processes that led directly to the construction of Midtown evaded public and specifically neighborhood resident accountability as much as possible, partly by manufacturing "community participation" in specific ways and partly by devising innovative zoning designations that allowed the project to avoid key regulatory hurdles. My analysis of these processes draws

\footnotetext{
${ }^{177}$ They also recommended specific strategies for the retention and expansion of niche industries within the manufacturing sector and the creation of specialized job training programs to help local residents get jobs in these industries. As of this writing, these recommendations have not been implemented.

${ }^{178}$ Instead, as I noted earlier, existing community development funding was provided to the Puerto Rican CDC to build five single-family homes sold to low-income families. This small output represented a continuation of the status quo of affordable housing provision during the 2000 to 2008 period. Indeed, it allowed the CDC to meet objectives that had been established since the 1990's.

${ }^{179}$ The accomplishment most frequently cited by proponents of the FEC sites' redevelopment, including those who worked on the 1996 Wynwood Master Plan, was the creation of an integrated street grid.
} 
on interviews with a few neighborhood stakeholders, on my review of County and City commission meeting minutes and other government records and a study of these processes written by a public interest lawyer for a social justice organization considering a campaign against the Midtown project (Midtown Study 2006).

By the turn of the 21st Century, the Puerto Rican organizations and the local Catholic parish were largely disengaged from the political processes shaping Wynwood. At the crucial moment during the winter of 2003-2004 when, after decades of disinvestment, one of Miami's "flagship" redevelopment projects was set to transform the neighborhood, the only people to publicly ask about affordable housing and jobs for neighborhood residents was an African-American city commissioner and communitybased police officer who worked closely with area residents. Privately, others were critical of the public-private partnership that produced Midtown, and by 2006 different groups of residents spoke out against it.

Following the completion of the FEC Plan, in 2002 a New York-based investment partnership purchased the rail yard property for $\$ 35$ million and in 2004 sub-divided and re-sold the east and west partitions for $\$ 25$ and $\$ 38.5$ million, respectively, to the also New York-based developers. The original investment partnership retained control of the eastern portion under a new name, supported by additional investors once the development plans were in place. In other words, the original owners flipped the eastern half of the property to themselves as part of a new investment partnership. To carry out the more than $\$ 1$ billion in planned projects, the developers asked the City of Miami for assistance in the development of the street infrastructure, parking garages and a public plaza, totaling more than $\$ 170$ million. Specific planning and zoning processes were 
instrumental in facilitating the Midtown development receipt of subsidies with minimal public oversight and involvement.

According to the aforementioned legal analysis (Midtown Study 2006), "the Midtown Miami project has been able to proceed in its current form thanks to the elaborate and creative land use, zoning and permitting process underpinning it. ${ }^{" 180}$ Most important was the designation in 2003 by the City Commission of the site as a Regional Activity Center (RAC), a state-level land use designation, creating what the legal analyst termed a "sort-of hybrid building permitting process," of which only a select few exist throughout South Florida. What is crucial about the RAC is that it raises the threshold at which additional planning processes are triggered from 400,000 to 800,000 square feet of development (residential or commercial). Without this enhanced threshold, the scale of the combined projects on the single site by a single developer would have qualified as a Development of Regional Impact (DRI), required a Major Use Special Permit (MUSP) and a costly series of environment impact studies typically taking up to a year to complete. The DRI studies include an evaluation of the projects' impact on the existing supply of affordable housing and depending on the extent of the impact (see footnote below) developers may have to fund "affordable housing mitigation" efforts. In practice, because of the peculiar methodology used in these studies, no DRI study has ever found an affordable housing deficit, despite City and County planning studies that routinely

\footnotetext{
${ }^{180}$ This began in 2003 when the City of Miami created special zoning overlays, known as special districts SD-27.1 and SD-27.2, in order to amend the city land use ordinance and comprehensive plan and rezone the site from industrial and "general commercial" to higher-density residential and commercial uses.
} 
note such a deficit. ${ }^{181}$ Nevertheless, by avoiding the DRI studies that involve public hearings, the Midtown project avoided not only a costly and lengthy set of studies, but also one of the only mechanisms through which opponents could potentially intervene legally and/or politically (Midtown Study 2006). ${ }^{182}$

Furthermore, since the specific type of subsidy involved in the Midtown project “provide[s] little in the way of 'legal hooks' to get us into court” (Midtown Study 2006),

\begin{abstract}
${ }^{181}$ Since 1972 the state legislature has enacted a series of laws to implement a "coordinated system of state, regional and local planning" (Bennett 2004). The current version of the state's growth management system was established through regulatory measures passed in 1985, including a policy initiative that is especially relevant to the impacts of large-scale redevelopment projects in inner cities such as Miami: namely, Developments of Regional Impact (DRI). The DRI legislation requires state and regional review of development projects that are considered to impact more than one municipality, and established funding for Regional Planning Offices to conduct such reviews. Part of the review includes an analysis of whether the development "will favorably or adversely affect the ability of people to find adequate housing reasonably accessible to their places of employment" (Ibid, p. 5). The DRI review process includes, in addition to environmental and economic impact analyses, an affordable housing impact study with corresponding recommendations for local, regional and state planning advisory boards. However, DRI-related regulations pertaining to "urban infill" areas were recently weakened. Following the recommendations of the state's 2000 Growth Management Study Commission, the Florida legislature amended the 1985 Act to allow "concurrency requirements, except for transportation, to be waived in urban infill and redevelopment areas" (Bennett 2004, p. 2). The effect of this change is such that the DRI system is now only a review process, not strictly enforceable since local politicians can waive concurrency requirements such as the need to set aside affordable housing units if it is demonstrated that there is insufficient affordable housing to support demand. In Miami, for example, the Downtown DRI was modified to allow affordable housing that was required by DRI concurrency regulations to be built outside of the boundaries of the downtown DRI, defeating the purpose of "inclusionary" housing requirements. The downtown DRI was amended because developers argued that it had become too expensive or not profitable to build affordable housing near downtown. One part of the purpose of the DRI's affordable housing concurrency requirement is to offset the impact that major redevelopment projects have on surrounding property prices and the displacement of lower-income households. The other part is to make sure there is enough affordable housing for the incremental population that will be generated by the project itself. The broader purpose of "inclusionary" housing mandates is to reduce the segregation of city residents by income, a filtering process that happens primarily through the housing market. If affordable housing can be built anywhere within the city, instead of within the "impact zone" of major redevelopment projects, then the effect of the redevelopment projects is the same: displacement of lower-income households to areas where poverty is already concentrated. Like the Midtown case, these modifications could not be challenged since the state's concurrency requirements were weakened.
\end{abstract}

${ }^{182}$ Even if the methodology used by politically connected consultants to conduct DRI studies is faulty, the DRI processes prolong the development timeline, introduce more public hearings and allow for an appeal process for "aggrieved" members of the public to make their case against the provision of a MUSP. In Overtown, a DRI project was stopped by activists largely because of their lawsuit against the City of Miami in which they appealed the findings of an outdated environmental impact study (Sommereyns 2006; Viglucci 2006). 
the public interest lawyer referred his activist clients' to "potential points of leverage for the affected people of Wynwood in the political arena." Specifically, the infrastructure (streets, sewers, a massive parking garage) constructed to support the complex was financed through the sale of bonds backed by Tax Increment Financing (TIF) revenues (discussed below) - funding that is controlled by the board of the Midtown Community Redevelopment Agency (CRA, or TIF district), comprised of City of Miami Commissioners and did not require public hearings or approval. ${ }^{183}$ Had the project made use of federal or state subsidies, the public would have had greater opportunities to participate and intervene in the use of such funds. However, the developers specifically avoided the use of a federal Section 108 loan worth $\$ 20.5$ million, for example, because it would have required set-asides for low-income housing, guarantees and monitoring of local hiring, and additional public hearings and participation which may have delayed the project and potentially mobilized activists' or others to demand costly concessions (Midtown Study 2006). ${ }^{184}$ The exclusive reliance on bond proceeds backed by TIF revenues meant there were few legal mechanisms for public intervention.

\footnotetext{
${ }^{183}$ Indeed, a review of Midtown CRA board meetings (Midtown CRA 2005-2008) reveals typically one or two agenda items, no discussion, and an up-or-down vote approving the ongoing allocation of bond proceeds to the same projects. Below I will discuss the only purpose for which the Midtown CRA governing body exists, thereby clarifying the peculiar nature of this district.

${ }^{184}$ The aforementioned legal analysis described the Section 108 Loan (Midtown Study 2006, p. 8), issued by the U.S. Department of Housing and Urban Development (HUD), and the implications of its avoidance by the developers: "HUD's Section 108 Loan Guarantee Program provides federally guaranteed loans to CDBG recipients for large scale economic development projects. Recipients pledge their current and future CDBG grants as collateral and may borrow up to five times their CDBG yearly allocation (minus outstanding balance on previously funded 108 loans). The projects must further the objectives of the CDBG program. Based on the HUD eligibility category, the national objective, and the public benefit standard under which the County applied for the Section 108 loan, it would be required to 'document that at least 51 percent of the jobs will be held by, or will be available to, low- and moderate-income persons.' 24 CFR $\S$ 570.208(a)(4)(i)... In the spring of 2005, however, [the developers and the County] decided not to go ahead with the application. This is explicitly because it would have triggered an Environmental Impact Study, a process that could have taken a year to complete, which involves studying traffic, noise, historic
} 
These types of subsidies were made possible by the most inventive aspect of the projects' arrangements - the Midtown Miami Community Development District (MMCD) initiated and controlled by private developers as the only stakeholders in the district. The MMCD was created in 2003 and the Midtown Community Redevelopment Agency, a Tax Increment Financing (TIF) district, was created in $2005 .{ }^{185}$ The MMCD differs from a TIF district in that TIF district funds usually represent the potential property tax revenue from existing property owners that will be diverted toward private development (instead of public services). Tax Increment Financing districts are governed by public officials (whether existing elected officials or other appointed community leaders). But the MMCD's boundaries were drawn to encompass only the undeveloped Buena Vista rail yard, thus, involving only the set of Midtown developers. The site went from generating zero property tax revenue (as a publicly owned rail yard) to millions within a few years because of the redevelopment activity. ${ }^{186}$ The City of Miami therefore agreed with the developers' petition that they should be appointed, initially, to govern the

buildings... Because HUD Sec. 108 funds would have been the second most significant source of public funds provided to Midtown after [TIF], and because it would have been the only source of funds with relatively strong statutory/regulatory strings attached, the fact that Midtown Miami is not receiving such funds deprives us of what would have been a more straight-forward point of attack. (Most significantly, HUD money would have triggered a lengthy environmental review procedures under the National Environmental Policy Act, see 24 CFR 58 and 24 CFR 570.604, and would have required prevailing wage rates requirements under the Davis Bacon Act for construction financed in part by federal funds, see 42 USC 5310(a).)"

${ }^{185}$ TIF districts are created so that local governments can use future (projected) incremental property tax revenues to borrow money to fund the immediate costs of infrastructure and other projects within the TIF district. In other words, the rise in property taxes after the district is created is diverted from traditional authorities (e.g., schools, fire, police) to redevelopment activity.

${ }^{186}$ The TIF revenue increased to $\$ 300,000$ in 2006 and $\$ 3.9$ million by 2010 (CRA 2010). 
MCDD board, ${ }^{187}$ as they were the only property owner within the boundaries of the TIF district. Once projects were complete and condominiums purchased (or rented, as it turned out), these buyers and/or occupants would be eligible to form part of the MMCD board. ${ }^{188}$ Its sole purpose to was to establish an independent entity that could issue redevelopment bonds to the City and County, which then recycled the bond proceeds back into the TIF districts' redevelopment. The reinvestment process could not be initiated until the site was privately owned and acquired taxable value; thus, in 2005 the inter-local agreement between the MMCD, County and City established the Midtown Community Redevelopment Agency (CRA), that is, the TIF district governed by city commissioners. The TIF district has only one purpose - to pay the debt service on the bonds issued by the MMCD that existed within the same boundaries. ${ }^{189}$ In short - and this was a much celebrated point among city officials - the redevelopment district was self-financing through this circular shell-game of newly created taxing authorities (MDCC 1/27/2004, 2/8/2005; MCC 4/22/2004, 4/29/2004). The Midtown TIF district, unlike other CRA's in Miami and nationwide, was never intended to directly address poverty or affordable housing since its' boundaries and plans were drafted to exclude both of these "problems." 190 As a former CRA administrator put it, this makes the

\footnotetext{
${ }^{187}$ The MMCD's legal existence accomplished its' purpose. Thus, there was no need for board meetings and the creation of a board was merely a formality in accordance with Florida's special district regulations.

${ }^{188}$ This is not what happened, however. According to state of Florida audits, the MMCD's five-member Board of Supervisors continues to be made up entirely of the employees of the two developers.

${ }^{189}$ Until 2011, almost $\$ 100,000$ out of millions in TIF revenues was spent on the Midtown CRA's administration.

${ }^{190}$ Instead, the scientific justification for the TIF districts' creation (written by the same FIU researchers who conducted the FEC Plan) was the rail yards' dilapitaded and undeveloped conditions, referred as urban "blight."
} 
Midtown CRA "an aberration from what a CRA is supposed to be (enrich developers vs. improve blighted neighborhoods)" (Rollason 2007, p. 20). ${ }^{191}$

As there were no "legal hooks" for public intervention, the "political arena" was the only recourse for those who sought community input. At the April 2004 City Commission meeting in which the inter-agreement between the MMCD, City and County was approved, thereby establishing the financing plan for the project, proponents claimed that the Midtown developers were committed to a variety of specific investments to directly benefit Wynwood. These commitments were published in a series of memos between city officials (e.g., City of Miami 2004a), in a powerpoint presentation used to explain the project to City and County Commissioners in April of 2004 (City of Miami 2004b; MDCC 4/22/2004, 4/29/2004), and repeated verbally into the public record by different proponents throughout a series of public hearings (City of Miami 2004a, 2004b; MDCC 2004). Proponents of the project, including the city manager, deputy city manager, the sponsoring city commissioner and a community-based police officer, claimed that the developers had committed specifically to "minority participation" during construction, community outreach activities to ensure the participation of Wynwood residents during and after construction, and an "affordable housing program" described in significant detail (City of Miami 2004b). The housing program involved "making available" to the City of Miami 80 housing units from the eight condominium towers that the City could purchase using available housing subsidy programs; the claim that HSBC Bank had committed to provide mortgage financing for eligible (City of Miami-

\footnotetext{
${ }^{191}$ Rollason (the former CRA director who later became a columnist in a local newspaper) implied that the Midtown CRA, more than any other, was focused on enriching developers as it did nothing to directly "improve blight" in the surrounding Wynwood neighborhood. The least cynical interpretation would be that its' purpose was to finance the construction of the Midtown complex.
} 
approved) low-income homebuyers; developers' contribution of $\$ 5,000$ in closing costs for each of these units (for a total of $\$ 400,000$ ) as well as a $\$ 1$ million revolving line of credit to a local non-profit housing agency to acquire vacant parcels, condemned housing or other units to rehabilitate or build affordable housing within Wynwood or the surrounding neighborhoods.

The commitments were linked to the potential application for a U.S. HUD Section 108 loan. The complex financing plan described above was devised in less than two months and pushed through quickly at the city commission during the week of April $22^{\text {nd }}$, 2004, when a city commissioner complained that he had only one week to study the "the largest subsidy that we have ever given any developer." To which the sponsoring commissioner could only respond, "there's been a lot of changes in the way this structure's working, up to today... so this financing package, as you're looking at it, couldn't have come here a week ago." It was unanimously approved on April $29^{\text {th }}$ by the City and the County Commission and, as I will discuss below, even garnered an impressive but controversial showing of support from neighborhood residents who filled City Hall. During that final week the developers decided not to pursue the federal Section 108 loan, absolving them from the commitments that were nonetheless promised politically. ${ }^{192}$

\footnotetext{
${ }^{192}$ This was disappointing to the director of the Puerto Rican CDC, which stood to potentially benefit from the implementation of the proposed affordable housing program. Although she never made any public statements to this effect, during our conversation she argued that Midtown did not do enough for the community. "During the time that it was being developed, it was directly impacting the community in negative ways... I believe that when a big developer comes into town he has, the entity has to realize that these are side-effects of their investments. And they can't just say, oh well, that's their problem, not ours. I'm not saying that they were that casual with it but I don't think that they were as responsible about it as they could have been. And then, there was a lot of commitment to provide housing opportunities for local residents and that didn't happen. Well, it didn't have to be in the towers but there were so many lots around that they could have invested in building out some lots and helping out whether it was with loans or grants
} 
Thus, despite the detailed housing program proposed in 2004, since construction began the only benefits subsequently mentioned by proponents and other observers were jobs. All else was largely forgotten. The Miami Herald reported on developers' donation of thousands of dollars to charities and non-profit organizations in the area (Nahed 2004b; Swartz 2004), "positive interest in this community" and efforts to "inform Wynwood residents about job opportunities" (Ovalle 2004a), Wywnood Puerto Ricans' "first priority in getting jobs at Midtown Miami stores" (Ovalle 2004b), and so on (Ranta 2004). With one exception that I will return to below—-that of an investigative series in the typically NIMBY-oriented, ${ }^{193}$ Biscayne Boulevard Times (Sohn 2005, 2006a, 2006b) - press coverage either ignored the commitments made in public hearings by the projects' proponents or highlighted the aforementioned "job opportunities."

On the other hand, once construction began, news coverage increased of residents' and community organizations' complaints about the projects' unaffordable condos, its impacts on property taxes and rents, and speculative investment in the area surrounding the complex (Menendez 2005; Nahed 2005; Vasquez 2005; Viglucci and Haggman 2005; Sohn 2006a, 2006b; Morales 2008a). Such complaints have been dismissed by both political authorities and a small, select group of neighborhood stakeholders as "negativity" and anti-development ideology - responses recorded in some news coverage (e.g., Sohn 2005, 2006a, 2006b) and which I routinely discovered during

or something, but they got away with just doing like baseball team uniforms, plaques for this event, you know, little 'tsotchke' (a Yiddish term for small, insignificant item) stuff that in the size and magnitude of the project, I think they could have been a little more fiscally interested in the immediate area. They hired a security company [that employed local workers] that was part of the initial group and as soon as pretty much the job was done, they were fired and somebody else came in and, you know, just stuff that you say, I don't get it. Things like that disappointed me."

${ }^{193}$ NIMBY refers to "Not in my backyard" politics. 
my field research. But before I delve into my experience and analysis of the conflict that ensued between some residents, organizational leaders, activists and authorities, I will explain the context which shaped such conflict - the controversial process that led to an apparent upsurge of neighborhood support for Midtown in the spring of 2004.

In 2003 the community-based police officer for Wynwood single-handedly became the Midtown developer's community outreach program. Recall from Chapter 4 that in the 1990s the City of Miami devised an innovative community policing program implemented through neighborhood-level administrative units ("mini city halls") that housed a community-based police officer (CBPO) and integrated other city services, such as those of the building and solid waste departments. Bobby, of Puerto Rican parents, moved from New Jersey to become the CBPO for Wynwood in 1998 "because the Miami Police Department, by far, had the best community policing set-up.” Through his awardwinning community policing work between 1998 and 2003, ${ }^{194}$ Bobby grew close to neighborhood residents, developing and sometimes personally sponsoring a variety of neighborhood programs and became well-known as Wynwood's "guardian angel" (Nzinga-Ifateyo 1999).

In 2002, soon after the Midtown developers had purchased the land, they visited the community-based policing (CBP) office in Roberto Clemente Park to inquire about the processes for obtaining building permits. A conversation ensued in which the developers' told Bobby of some of their plans to build a shopping center and he explained that not only was he an expert in "crime prevention through environmental

\footnotetext{
${ }^{194}$ He was named community policing officer of the year in 1999 by the Miami Police Department.
} 
design" - something they should consider incorporating in their plans - but he had been working with neighborhood residents for years to help them get jobs. ${ }^{195}$

I had no intention of working for em'. I thought, 'that's a good contact.' And I said to them, 'gentlemen, if you need construction workers, I got a lot of people here, good people, that need jobs.' So the one guy, [Charlie], he's a really community oriented [developer], he was cool. Next thing I know, like 3 days later, they asked me out for lunch... I showed him all this [local press coverage]. Right there he goes, 'we'd like to be involved.' And you know, they just wrote out a check. [But] I would never take money. I'll say, 'make out a check to Athlete's Foot downtown, and I'll go pick up the stuff' [for the kids], you know what I mean? I would take the [neighborhood] kids camping and the top kids, I'd take them to North Carolina once a year. So [the developers] paid for the camping trip, the first fucking week! You know!? I took em' to [the Neighborhood Center], and they wrote out a check, stuff like that.

The developers did much more than that. Although they never entered into contractual obligations to hire residents or build affordable housing, they doled out hundreds of thousands of dollars. "They were smart," Bobby later reflected. Observing his enthusiasm and realizing the depth of his community connections, "they used me... they immediately started being real good to me." About two months later, as the story goes, the developers offered and Bobby accepted a job as chief of security for Midtown. According to Bobby, this happened just at the moment when he was feeling "very depressed" because he found out that not only was his promotion to sergeant becoming an increasingly distant prospect but the city "started reducing the CBP office and I saw everything... getting cut back." Meanwhile, he perceived that the recently hired Police Chief was promoting officers who were also new to the police force, adding insult to the

\footnotetext{
${ }^{195} \mathrm{He}$ explained why he was excited to hear about more job opportunities coming to the neighborhood: "Kids would always come to my CBP office and I would take them to Walgreens, McDonalds, or places, I would get kids jobs and I didn't have enough places to send kids. And I would go with the kid and say, cuz I knew the kid was a good kid, you know, and if you're the manager of Walgreens and the policemen walks in with you, yada yada..."
} 
injury of a protracted and uncertain promotion, despite earning accolades from within and outside the police department (Nzinga-Ifateyo 1998, 1999; Natale-Planas 1999; Muller 2003). He also explained that his bitterness and frustration was rooted in longer-standing disagreements with superiors. Whatever the circumstances, he noted a variety of "life pressures" shaping this key moment in his life. ${ }^{196}$ Noting his apparently extensive knowledge and close relations with Wynwood residents, Midtowns' developers "said to me, 'you know, you're really good with the community... we need a guy like you. Because those people don't know us.' So next thing I know, I'm having meetings, and I went out and I got them some real positive press" (e.g., Ovalle 2003, 2004a; Swartz 2004).

Whatever the case surrounding his exit from the Police Department, once he became security director for Midtown, Bobby was able to hire Wynwood residents as security guards, such as Hector, whose views and experience I discuss below. For a brief time, he was also able to get developers to give priority to neighborhood residents to operate a food truck for construction workers. He even tried to negotiate with the hiring managers at Target to give priority to neighborhood residents, but this effort was less successful since he and the developers' had little leverage over the retail tenants. He held some neighborhood meetings to let people know about job opportunities but he mostly relied on a network built over years of experience working closely with residents. ${ }^{197}$ In

\footnotetext{
${ }^{196}$ Among the dozen of my interview respondents who knew him, most opined that he was sincerely committed to community policing and helping Wynwood residents.

${ }^{197}$ I met Bobby at the 2010 annual Miami-Dade County Health fair hosted at the Puerto Rican clinic, where he was celebrating with other current and former Puerto Rican "leaders" at one time involved in the provision of services to Wynwood residents. Later we met for a roving interview that also included a stop by the offices of his security company. During our conversation in his security car, riding through the
} 
addition to thousands of dollars provided to fund Bobby's youth programs, Christmas celebrations and the continuation of other events he promoted as a CBPO, he negotiated a $\$ 200,000$ donation to the Puerto Rican child care organization (recall from Chapter 3), which used the funding to expand into a new facility in Little Haiti (Bobby continues to serve on the centers' advisory board).

The crucial piece of Bobby's community outreach - and what seemed to cause the indignation of a few neighborhood activists and other residents - was how he rallied support from a busload of elderly residents for the crucial City and County votes during April, 2004 to approve the financing package for Midtown. The Biscayne Boulevard Times' (Sohn 2005, 2006a, 2006b) series of investigative reports tried to get to the bottom of their headline question - "Did Midtown Bait Seniors' Support with Chicken Lunch?" Not surprisingly, there are many versions to the story of what happened on one seemingly fateful day (including questions about how fateful that day actually was). The basic facts are that Bobby picked up about 40 senior citizens with whom he apparently had a long-standing, trusting relationship, took them to the City Commission meeting, where they occupied several rows in the back of the room and stood up when asked to confirm their support for the project (MCC 4/29/2004). He also coordinated the attendance of some senior citizens from the nearby Little Haiti neighborhood as well as a smaller group of business owners from Wynwood. After dropping the Wynwood seniors back off at the neighborhood center, Bobby brought them all lunch from Kentucky Fried

streets of Wynwood, dozens of neighborhood residents stopped to talk with Bobby - for example, a teenager whose brother Bobby helped through drug addiction and an elderly Puerto Rican woman who sold him alcapurrias around the holidays. I ran into him again at the funeral of one of the neighborhoods' wellknown centenarians, accompanied by many other residents and service workers, at the local Catholic Parish. 
Chicken since, as he explained, they had to miss their daily lunch to attend the city meeting. ${ }^{198}$ Despite the variety of interpretations, Bobby's recollection speaks for itself:

Again, remember, I was in a state of mind that, these [developers] were the best thing since sliced bread. They were giving me money for the senior center Christmas Show. So I invited the seniors, 'would you like to go [to the city commission meeting]?' And the seniors do anything for a field trip. Cuz when I was a cop, I would take them every other week in the summer to watch a Marlins game. We were tight. Seeing, you know, I was taking care of their personal problems, they would call me, 'hey, my son is a junkie, he's coming to my house to steal,' you know, I would stay there all night with em' and wait til' the son comes home and put him in rehab. They were like my family, my extended family. And they loved me. They would see me, hug me and kiss me all the time. And then when I left, they cried. So when I needed, I wanted to take people to show that we were still not going to forget the seniors and... who knows, maybe the developers did set me up for this, but the bottom line was, truly in my heart, I believed we were doing the right thing.

Bobby later regretted leaving the police force to get involved with the developers not only because he was terminated but also because their generosity for the residents and organizations of Wynwood (or at least those referred by Bobby) dried up soon after the complex was built in 2007. Bobby argues that his insistence on local hiring, intensive community outreach, and "doing things right" caused him to fall out of favor with one of the developers who was increasingly concerned with curbing expenses. By then he had reached an agreement with his employers to form an independent security company, thereby making him their sub-contractor and easier to replace with another company. ${ }^{199}$

\footnotetext{
${ }^{198}$ Meanwhile, Bobby noted, the developers celebrated their accomplishment over dinner at a fancy restaurant. He insisted that they pay for the seniors' lunch.

${ }^{199}$ The private security company is based in Wynwood and provides security services to the Arts District, among other contracts. The Wynwood residents who worked at Midtown thus no longer work there.
} 
Whatever the exact circumstances and reasons ${ }^{200}$ Bobby's relationship with the developers came to an end.

It was also around this time that opponents of the project began to surface and Bobby's entanglement with the developers became a major point of contention, as opponents accused Bobby and complicit city agencies of manipulating neighborhood support for private real estate development. What most angered some of the neighborhoods' activists who opposed the Midtown project was, as one reporter put it (Sohn 2006b, p. 54), the feeling of being "betrayed, since no one from the city or county ever bothered to prepare them for the changes that the Midtown redevelopment would bring to their community."

\section{Discourses of Neighborhood, Community and Development}

One of activists most angered by the affair, the former director of the neighborhood's homeowner association, refused an interview, only telling me over the course of several brief encounters that she was pursuing an investigation into the city agencies responsible for informing residents about government affairs in the area. The homeowners association and its leaders contended that the Puerto Rican Neighborhood Center, where seniors gather daily to play dominos and eat lunch and the Community Action Agency (CAA) office, located in the same building, were complicit in the manipulation of seniors in 2004. A reporter's analysis of CAA meeting minutes seemed to confirm that the only information provided to the elderly residents about what they

\footnotetext{
${ }^{200} \mathrm{I}$ leave out the complex details of a story that includes tensions between the different developers and between Bobby and his employers over security services provided at different buildings that ostensibly led to his termination as security director.
} 
were "voting" for was a "watered-down version" of the facts of the Midtown project, and a presentation shown after key votes (Sohn 2006). Later I will return to the issue of how offices like the CAA and the Neighborhood Center become contested spaces amidst the politics of urban development that engulf their participants and service workers. This episode involving the elderly was divisive, pitting some of the neighborhood's few homeowners against others and contributing to a mistrustful environment of community politics.

In the course of my field research I found as many area residents who supported Midtown as those who opposed it. Those who supported the project may well have been influenced directly or indirectly by Bobby's community outreach, but like the neighborhood leaders involved in the 1996 Wynwood Master Plan, many were also predisposed to support new development. The words of a Wynwood homeowner who was part of the contingent of senior citizens that supported the project at the April 2004 City Commission meeting are illustrative and representative of others I spoke with. ${ }^{201}$ Our exchange, which begins with me probing a previous reference to a group of angry homeowners, is worth quoting at length.

Marcos: [The association] was upset about the Midtown project?

Eliza: Yes because it seems that in the newspaper it was written that that people that supported the project were paid to do so and I said, 'Too bad they didn't give me anything!' But that I know of, they never gave us anything and we did go the [City Commission] meeting because they took us from the Neighborhood Center. I even took some people in my car.

Marcos: Did you know you were going to support the project?

\footnotetext{
${ }^{201}$ In her native Guatemala, she was a registered nurse in the 1970s. Her relatively higher educational level and her professional experience having worked as a nursing assistant and therapist in a major Miami hospital for almost thirty years shape her views and ways of speaking.
} 
Eliza: Yes, they told us at the center that we were going to show support so they would build the center, this mall, that was by some people coming from New York, because they were going to give jobs to everyone in the neighborhood. That the first people that were going to work there were people from the neighborhood. ${ }^{202}$ I've never seen anybody work there - maybe 2, 3 or 4 people that got in to work as security, that's true, but other than that, I've never seen any employees that are from the neighborhood.

Marcos: You spend time over there?

Eliza: I always go to walk around, zapatear. To shop, not so much, but just to look... I like the stores. I know everyone over there. I think they already know me - I go in one door and out the other, just to pass the time.

Marcos: So you liked the shopping center idea?

Eliza: Fantastic. I thought it was very good because, first, it was supposed to give jobs to the people here, we knew it would bring good commerce here. We didn't have to spend money on bus fare or gasoline to go to another center and I thought also that they should bring a shopping center that has food, restaurants, and all that.

Marcos: After discussion about consumption, I ask: What about the impact on living costs?

Eliza: Well, the impact was bad to a certain extent because they raised property taxes because they said that this used to be catalogued not just as a residential area but as a zone of people with low incomes. When they started to bring [the shopping center], people started to buy and then taxes increased and the value of ours homes increased...

After discussion of her homes value, condition and how her social security payments are not enough to pay for needed maintenance, I ask if she thought to sell her house.

Eliza: No. Where am I going to find a place to sit and watch the birds? As my husband used to say. But the impact of the mall was substantial. Another impact that I've noticed also is that the police, I see that they take great care but almost always from $1^{\text {st }}$ Avenue toward the mall [one block from $1^{\text {st }}$ Avenue] because here on $2^{\text {nd }}$ Avenue I see all those little groups [hanging around] and I've known about a lot of robberies around here.

Eliza's discourse is representative of many residents and organizational leaders who position their views to be independent of anti-development rhetoric or what some call "negativity," and to be "realistic" about the costs and benefits of major real estate investment. Another example is that of Carmen, an undocumented Guatemalan

\footnotetext{
${ }^{202}$ Says this in English to emphasize that it was in the words of the projects' proponents.
} 
immigrant and long-time resident who regularly attends mass at the local Catholic parish, works as a janitor in an upscale interior design shop and briefly volunteered with a social justice organization that opposed Midtown. Noting that the Midtown project could have done more for the community, she opined that "it's too expensive for us but it brings cleanliness [to the neighborhood] and," stretching a big smile, said, "that's why I'm here."

Marta is a Cuban woman who has lived in Wynwood since the 1970s, married into a Puerto Rican family that owns two homes in the area and in the 1980s ran a small cafeteria a few blocks from her house. She has never wanted to participate in any organizational action against what she clearly perceives as a threat to the social fabric of her neighborhood (even though one of the leaders of the homeowner association does her husband's taxes). Marta noted that she was friendly with the leader of the homeowner association but simply dismissed "politics" as "a mess" to be avoided, seemingly resigned to the inevitability of things. Although she was not ideologically opposed to Midtown's "nice stores," its impact on neighborhood small businesses has led to her to believe that "then us poor people are relegated over here," "disappeared" from the section of the neighborhood where Midtown was built. Two of her favorite neighborhood hangouts, a well-known Puerto Rican grocery store and a cafeteria across the street from Midtown (the property belonged to Felipe, one of the long-time Puerto Rican leaders), closed because of rising rents and increased code enforcement.

According to several accounts, once the Midtown complex opened, Felipe raised the rent (doubled, according to some), forcing out the long-time Puerto Rican cafeteria owner and angering many long-time customers. Before it underwent renovations to 
accommodate a new arts-oriented business, it was rented by an Indian man who attempted to maintain it as a Latin cafeteria (keeping its Puerto Rican name). But he no longer allowed residents to hang out, play dominoes, or purchase beer without food, thus eliminating many of the practices established under the previous owner. The same happened to the Puerto Rican grocery store around the corner from Marta's house which also doubled as a cafeteria. In this case, not only did the rent rise, but building and "quality of life" code enforcement increased, such that one afternoon Marta's husband was arrested outside the store for allegedly drinking a beer without food. On a separate occasion, during a typical gathering in the improvised front terrace of the cafeteria, "a bus [police wagon] came and they took everybody because somebody had their beer hidden in a little bag. They took my brother-in-law, all my friends - a bus full of people!” She noted that the cafeteria owner subsequently received a "huge ticket" from the government. The store was located along the path of a new monthly "art walk" (which I will describe in the next section), bringing increased police attention to its patrons. While it is not clear exactly why the store closed, residents like Marta believe it is because of the extra police attention generated by the arrival of wealthier people, represented by Midtown and the Art District. "When the galleries came [to the neighborhood], before the [people would show up for art events] the police would come around for days to bother everybody and hit them with tickets [if they were caught drinking without food]. Since the galleries came, this got bad." Moreover, she resents that wealthy "tourists," such as those who consume alcohol publicly during the monthly Art Walk, are allowed to do what she and her friends are not. "You see the tourists - they carry beer in their hand 
without any paper [bag] or anything, and they (police) don't do anything. Why do people who are from here (the neighborhood) get locked up?"

When the Puerto Rican cafeteria closed, Marta, her husband and their friends lost their principal social lounge, a place that for years functioned as a neighborhood institution (see Sanchez-Jankowski 2008). Such was the importance of the small cafeteria and the good times enjoyed there, that a framed picture of its social scene hangs in her dining room (Figure 6.3). As Marta put it, "that was our social life. The whole world got together and saw each other. Now almost nobody sees each other because there is only one [cafeteria] left." What used to be a daily encounter decreased to only on the weekends and sometimes even less frequently, apparently because the only remaining cafeteria is farther from her house.

Figure 6.3: Photo of a Gathering of Friends at the Neighborhood Bodega

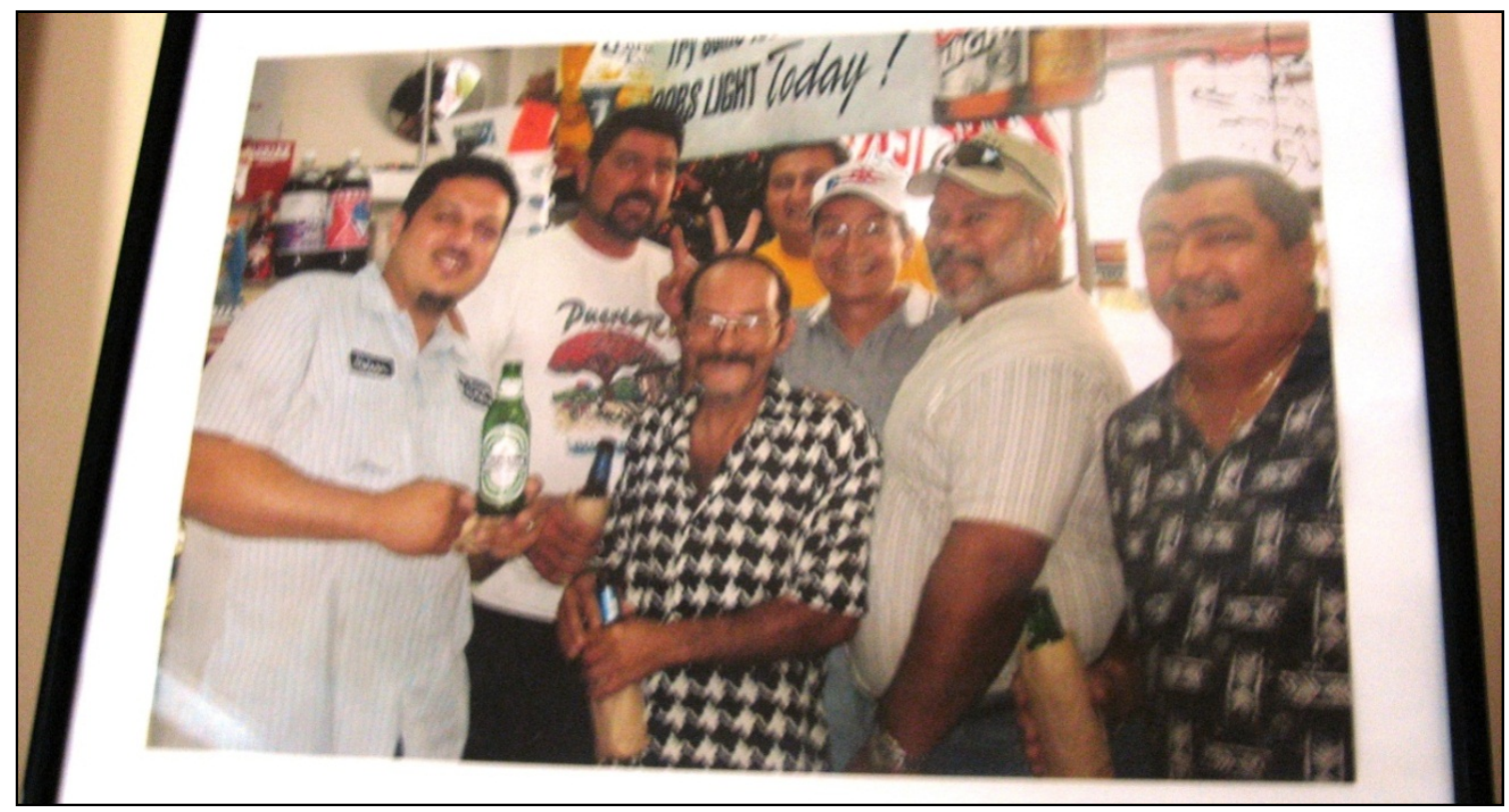

Source: Authors' photo during interview, December 2010. In Marta's dining room hangs a framed and matted photograph of family and friends at the grocery store and cafeteria around the corner from her house. Note how most men are holding beers covered by paper bags. 
As I will discuss later, she and other residents also resent the crush of art gallery patrons who descend on the neighborhood every month for the Wynwood "art walk" and once a year for the Art Basel festival, ${ }^{203}$ generating noise, trash (without additional city waste removal services) and crowded street parking. Yet, when pressed, she revealed that she was not ideologically opposed to the changes but rather felt they were too much, too fast, and thereby overwhelming. Moreover, although she complained about the lack of security in the neighborhood, she resented that her own social world had become the target of security forces. Since she clearly presented the Art District and her own neighborhood life as conflicting, antagonistic forces, I asked whether she thought she had to choose between investment and security, and her way of life. "Clearly," she asserted, with a wide-eyed look of surprise at my question, "I would rather have the cafeterias."

Figure 6.4: Image of Homes Belonging to Marta's Family

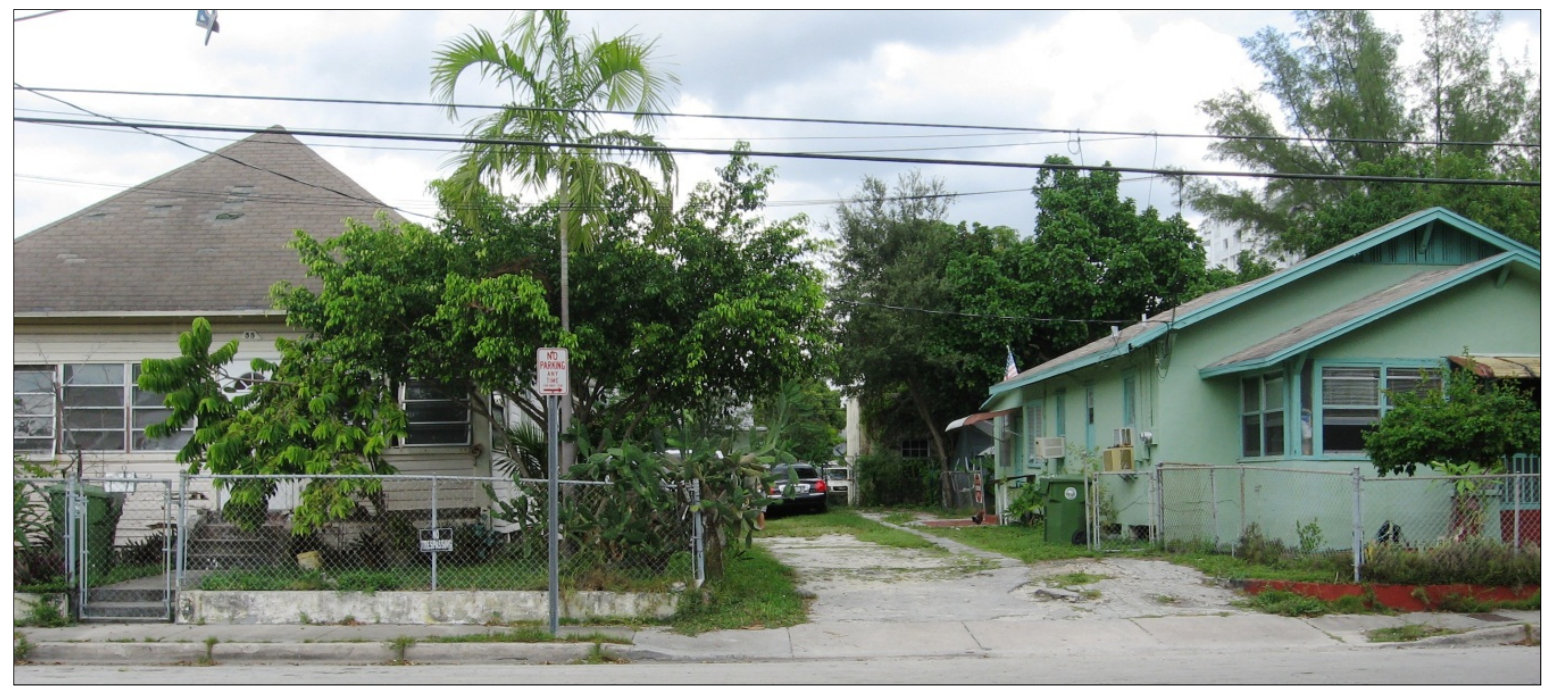

Source: Authors photo taken September, 2011. Marta's house (left), and that of her mother-in-law (right), carve out a social space where family and friends have gathered for decades. Both houses were built in the 1930s.

${ }^{203}$ For more information see www.artbaselmiamibeach.com. 
The few individuals involved in the political processes of the Midtown project tend to take more polarized positions. In at least two community meetings organized by neighborhood activists who tried to raise consciousness about gentrification, one of the neighborhood residents, hired by Bobby's security company, Hector, loudly insisted that not only had he personally benefited from Midtown, but argued that many others had benefited, too (although he cited none). One of these meetings was a community forum specifically about gentrification and another was a town hall meeting with an elected official about finding more funding for a neighborhood park (discussed later). Hector's voice was a rather important one as a long-time Puerto Rican homeowner who is known for his intense Puerto Rican pride (his house, inside and out, is practically a museum of Puerto Rican cultural memorabilia) and for having left a life of violence and vice in the 1980s to become the leader of a championship-winning little league baseball team in Wynwood. ${ }^{204}$ His support for Midtown has as much to do with the direct financial benefits he has enjoyed as a result of Midtown as his own prideful self-identity as someone who endured "the bad times" to experience "the good" in Wynwood.

Hector: You have the [arts] district. Now we got Midtown. I mean, you got famous restaurants.... I worked directly for one of the owners of Midtown. I do a yacht for him on Saturdays-the details, I wash it, I clean it. My wife do the interior. I travel with him. Anytime that he goes out in the boat, I do it... I mean, I do many, many things for him. He wants do a ... special occasion, I drive with him. I got a concealed weapon license. I got, G license, D license, I got chauffer license. You know, he uses me for his personal things. And since Midtown's here, Target, Ross, Pet supermarket, restaurants all over...

\footnotetext{
${ }^{204}$ Hectors' house, located on the northern edge of Roberto Clemente Park, has flagpoles in the front and back yard that wave the Puerto Rican and U.S. flags. During our interview, he spoke of his history as a former gang-member in the 1980's, involvement in the torching and looting of several stores during the 1990 riots, his turn-around as a mentor to troubled youth through the creation of the little league program in the 1990's, his recent relationships with Bobby and the Midtown developers, and conflicts with antiMidtown activists and other naysayers.
} 
Marcos: Is all this good for the community?

Hector: Oh, 100 percent yeah!. And whoever say no must be ridiculous. Now, you see, one of the things about the... that [anti-Midtown activist] group, I went to one meeting. I went real mad! Because they start talking [that] negativity about Midtown.

Marcos: What was the meeting about?

Hector: About the taxes, about how much the houses gonna raise, about how much this community gonna change when they do that... I said, 'What are you guys talking about? Do you want Wynwood to be like in the 80s?' And they was complaining, and this lady [who directs the local homeowner association but who] lives I don't know where in South Miami, that she don't live in no Wynwood, I said, 'Let me ask you a question, and I got three or four questions for you, in the front of these people here. First, do you live in Wynwood?' 'No.' 'Where you live?' 'Oh, I live somewhere...,' 'So how you gonna say what is good for my community?'

Although Hector's discourse represents one extreme of the polarized political environment surrounding the Midtown project, it reveals how key supporters of the project were able stake out positions "inside" the neighborhood as a way to discredit "outsiders." Although many residents critical of the project also live inside the neighborhood, most of the leadership of activist organizations does not, opening the way for the use of such delegitimizing tactics. Ironically, in one of our brief encounters, the woman Hector refers to above told me, "You have to actually be from this community. Anybody can come into the community to be the voice of the community," in reference to Bobby, the Midtown developers and others who supported the project and who did not live in the neighborhood. This woman lived in Wynwood briefly in the early 1990s, when she first moved to Miami from New York. Since then, she has worked a thrift store in the neighborhood. It is not clear whether such tactics were effective in limiting the power of Midtown's critics or whether they were simply used as a political justification for ignoring them, as such critics may not have been perceived as a threat by policymakers 
and proponents of redevelopment. Indeed, as Bobby told me (and had said to reporters years before), the naysayers were a small, unrepresentative group: "It wasn't a majority nor even the minority. I think at the very end [of the conflict] they had 12 people join. I've been in Wynwood for seven years, busting my ass. I've never even know who you are. Now you say you got this big homeowner association?" Or at least it appeared this way because, as I will examine in the next section, the critics were not united.

Although nothing will change Hector's mind about Midtown, the majority of the project's supporters, especially those who led neighborhood organizations, became disillusioned with the outcome of the Midtown project after Bobby was terminated as security chief. Puerto Rican organizational allies such as the Puerto Rican CDC and the Puerto Rican Chamber of Commerce were disappointed by how Midtown's developers reneged on their commitments to fund community programs, hire neighborhood residents and build affordable housing. The Chamber, which was cited by developers and politicians in 2004 as being a key supporter of the project, opined in its Spanish-language newspaper, La Opinion Puertorriqueña, in 2009, "The Midtown district benefits today from the initial support from the community of Wynwood without any commitment to return the support and resources to said community, which was simply used and discarded." It may be viewed as yet another lesson in why developers' promises must be secured by contractual agreements. This was precisely the fear expressed by a City Commissioner on April 22, 2004 the first time the financing package was discussed publicly. As he put it, "The problem with these gentlemen agreements is, when there's a disagreement, you can't find the gentlemen." Yet, by the following week, perhaps convinced that the developers would eventually obtain and use a federal funds requiring 
contractual commitments, the same commissioner said in voting for the project, "This stands on the threshold of being one of the greatest developments since Mr. Henry Flagler."

The Midtown case reveals the vulnerability of the devolution of certain kinds of power to neighborhood organizations, typically encouraged as the "self-help" solution to poor neighborhoods' problems (whether crime, addressed by the CBP office; housing, addressed by the CDC, etc.). These organizations may step into a void of political leadership (even when their functions are to provide services) or otherwise shape the environment for political leadership. In this case, their temporary co-optation into the arrangements of the governing regime helped ensure that whatever minimal opposition presented itself would have to contend with divisions among the neighborhood's stakeholders. Because some of the neighborhood's “own organizations” were used as part of the political strategy to obtain subsidies, the resulting level of mistrust engendered among its critics (the homeowner association) was so much that they were viewed as cynical naysayers by virtually all other organizations involved. This last point will become clearer as I examine the relationships between different stakeholders and organizations in relation to other redevelopment projects.

\section{Case 2: The Rise of the Wynwood Art District}

By the time the FEC Plan was published (City of Miami 2003), an art district had taken root in Wynwood. In 2003, a network of more than 30 galleries and arts-related spaces formed the Wynwood Art District Association (WADA) in order to pool resources and promote the district. They began publishing a map of venues (see below), designed 
and hung advertising banners throughout the neighborhood and organized promotional events. The slogan on their 2003 brochure read simply, “... at the intersection of contemporary culture and urban revitalization." By 2011, the association included more than 50 galleries and the map depicted more than 100 arts-related business and venues. The district has grown through the conversion of the area's boxy warehouses into galleries and related businesses either by developers or the gallerists. ${ }^{205}$ Whereas in other cities, arts-inspired revitalization movements were led by the artists themselves, sometimes as part of a broader social movement, in Wynwood gallerists and real estate developers led the movement, which succeeded only after an influx of resident artists.

In this section I describe the establishment and growth of the arts movement in the neighborhood and examine how its leaders increasingly penetrate and claim a place in the political territory of the neighborhood. In the first section I describe the uniquely entrepreneurial nature of the "Miami Model" of art appreciation at work in the transformation of Wynwood. In the remainder I study examples of two sets of processes that form a dialectic of "creative destruction" (Brenner and Theodore 2002; Swyngedouw 2003; Harvey 2007) shaping the neighborhood - the creation of the "social scene" that supports the arts economy and the removal of physical and social obstacles to neighborhood redevelopment.

\footnotetext{
${ }^{205}$ Gallerist refers to anyone who owns or runs an art gallery. The New York Times claims that the term emerged in the early 2000's (Glueck 2005). Gallerist was apparently in use in Wynwood's arts district by 2003 (Chang 2003; Kaplan 2003) and was certainly common parlance by the time I began field research in 2007. However, a gallerist may or may not also be an "art dealer." The latter refers to buying and selling among other dealers and collectors (the "secondary" market) while the former refers mainly to buying directly from artists and selling to gallery patrons (the "primary" art market).
} 
Figure 6.5: Image of a Typical Wynwood Warehouse Converted into an Art Gallery

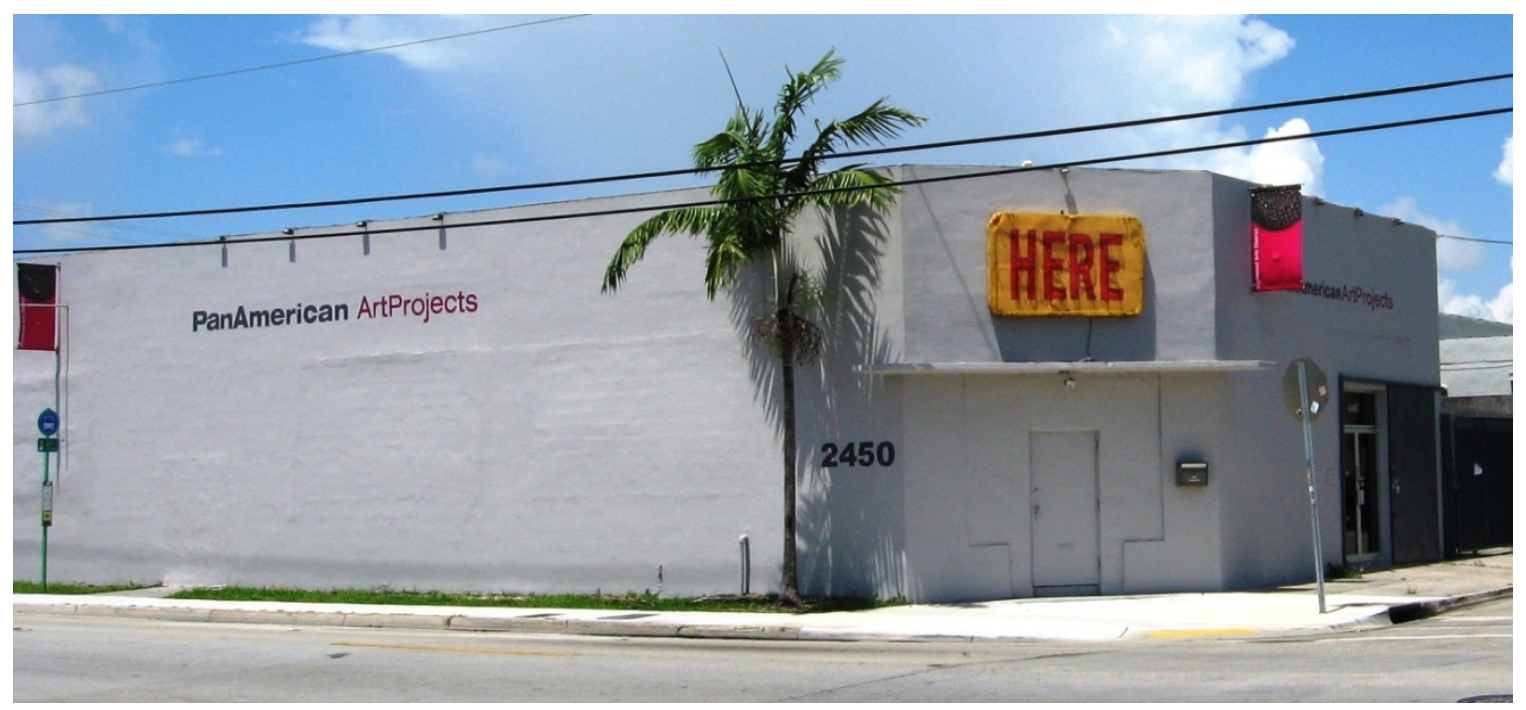

Source: Photo by author, June 2010. "HERE" is the title of painter Gustavo Acosta's exhibit, a series that traced the recent urban transformation of Miami.

The first inroads of an artist colony occurred in the 1980s through a single project, and this was perhaps the first and last project in Wynwood to be truly led by artists until the mid-2000s. In 1986 the Nonprofit Arts Center (NAC), a complex of more than fifty artist work studios, was established in a defunct baking factory by an organization of artists who were part of a larger group that worked at the former Grove House, a 1960sera artist cooperative in Coconut Grove that closed in 1981 (Blanchard 1982). The Grove House group divided; some artists established themselves in a gentrifying, more commercially-oriented strip of galleries in South Beach (Almashat 1985; Viglucci 1985). The other members of the Grove House cohort, because of their experience of displacement from Coconut Grove, ${ }^{206}$ were ideologically predisposed to purchasing and controlling their workspace and ended up in Wynwood, where a large complex like the

\footnotetext{
${ }^{206}$ The Grove House made way for a parking lot to serve the growing number of middle-class consumers. It was located in what is now the heart of the Grove's entertainment district along Main Highway.
} 
NAC was more affordable compared to sites in other neighborhoods. ${ }^{207}$ Located in the heart of the historically Puerto Rican section of neighborhood (NAC is number 5 on the map), even today the complex remains secluded from the burgeoning art scene in the warehouse district south of $29^{\text {th }}$ Street and along the edges of Wynwood. The renovation of the building was financed by City and County grants and loans, and operating income is generated through rents paid by artists. ${ }^{208}$

\section{Figure 6.6: Map of Galleries, Studios, Private Collections and Venues in the Wynwood Art District, 2003}

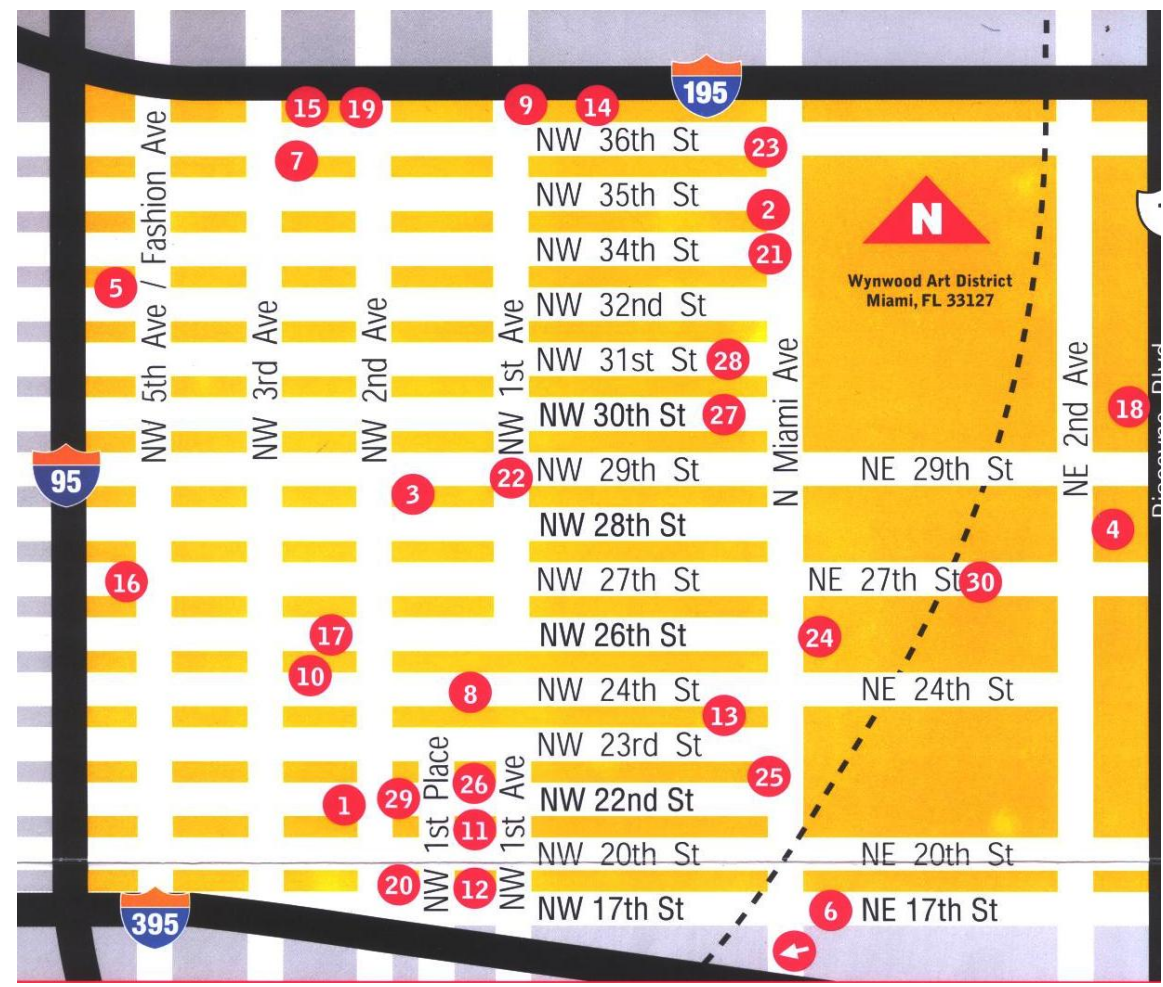

Source: From the 2003 brochure of the Wynwood Art District Association.

\footnotetext{
${ }^{207}$ This general account of a split among the artists, with some gravitating towards trendier, gentrifying South Beach while others sought a more secluded space that offered longer-term affordability, is confirmed by a few newspaper articles (Horn 1984; McCarthy 1985; Dunlop 1987) and my interview with the NAC director and staff.

${ }^{208}$ Today two-thirds of the NAC's budget comes from studio rents and the remainder from government grants and private donations.
} 
Although several long-time arts stakeholders believe that little-known artists probably worked in Wynwood before the NAC was established, the only recorded cases are that of the Cuban-born sculptor, Tony Lopez, who worked from 1958 until he died in 2011 in a studio on $36^{\text {th }}$ Street at the northern edge of Wynwood (Marquis 1987; Menendez 1994) ${ }^{209}$ and Miami born-and-raised artist, Purvis Young, who worked in Wynwood from the mid-1980s until his death in 2010 (Santiago and Burch 2010). ${ }^{210}$ There is no recorded history of other artists working in Wynwood until the NAC and not until the turn of the $21^{\text {st }}$ Century did an artistic enclave take root.

Wynwood's emergence as a site for artist workspaces and showrooms is linked to the evolution of real estate markets in other parts of Miami. As the Grove House artists were priced out of Coconut Grove, many resettled in South Beach but a sprinkling established the NAC. As South Beach gentrified and rents rose rapidly in the 1990s (see Table 6.1 below), art collectors and arts-oriented real estate developers began to move to the Design District, at the southeastern edge of Little Haiti, just northeast of Wynwood, and to Wynwood (Brennan 1993, 1994; Dietsch 1999; Chang 2003; Martin 2004; Donnelly 2006). ${ }^{211}$

\footnotetext{
${ }^{209}$ Lopez created innumerable monuments to Cuban heroes, a statue of the former U.S. congressman Claude Pepper, and other well-known pieces located throughout the Miami landscape and beyond (Ibid).

${ }^{210}$ Purvis Young, who died in 2010, was born in Liberty City and lived in Overtown, both historic AfricanAmerican neighborhoods in Miami. He made artwork from everyday things, including garbage.

${ }^{211}$ Art galleries and upscale commercial venues have also expanded along the Calle Ocho tourist district in the center of Little Havana, catalyzing the first wave of gentrification in the neighborhood occupied mostly by low-income residents (Gonzalez 2001; Shoer-Roth 2005; see also Feldman and Jolivet, forthcoming).
} 


\section{Table 6.1: Change in the Median Monthly Gross Rent in the Design District, South Beach and Wynwood, 1990-2000}

\begin{tabular}{|l|c|c|c|}
\hline Neighborhood & $\begin{array}{c}\text { 1990 Median } \\
\text { Monthly } \\
\text { Gross Rent }^{1}\end{array}$ & $\begin{array}{c}\text { 2000 Median } \\
\text { Monthly } \\
\text { Gross Rent }^{1}\end{array}$ & $\begin{array}{c}\text { 1900-2000 Change in } \\
\text { Median Monthly } \\
\text { Gross Rent }\end{array}$ \\
\hline Design District & $\$ 444.05$ & $\$ 522.70$ & $\$ 78.65$ \\
\hline Wynwood & $\$ 337.06$ & $\$ 447.00$ & $\$ 109.94$ \\
\hline South Beach & $\$ 399.29$ & $\$ 645.41$ & $\$ 246.12$ \\
\hline
\end{tabular}

Source: U.S. Census 1990, 2000.

Note: Data pertains to the following geographic units: One census tract that contains the Design District; two census tracts comprising Wynwood; South Beach reported here is five census tracts that make up South Beach's Flamingo Park neighborhood, which contains the Art Deco district.

${ }^{1}$ Includes utilities.

The first major collector to arrive in Wynwood was the Rubell family, whose case is also exemplary of the role of art collectors in the transformation of the built environment. "In six years," wrote the Miami Herald's art critic in 1997 (Gonzalez, p. 1L), "a family best known for their involvement in the New York art world and the redevelopment of SoHo, their art collection, and the exploits of Don's younger, late brother, Steve Rubell, co-owner of Studio 54 and successful hotelier, reinvented themselves as Miamians." Like many of the major art collectors and real estate developers now involved in Wynwood, in the 1980s and 90s the Rubells increased their fortunes by renovating historic Art Deco hotels (Sontang 1986; Kornbluth 1997). They were the first to move across the bay into Wynwood, when in 1993-1994 they converted a 40,000-square-foot, former Drug Enforcement Agency warehouse to store their collection of more than 1,000 pieces of contemporary art. ${ }^{212}$ In 2004 the Rubells bought a single-family home and two vacant lots on the street behind their warehouse to live

${ }^{212}$ At the same time, another South Beach development team, Craig and Scott Robins, began redeveloping buildings in the Design District, which was historically a center for interior and fashion design (Werne 1990; Ycaza 1993; Barry 1996). 
close to their collection. Given that they own residences throughout Miami, New York and elsewhere, it is not clear how much time they spend in Wynwood. But seeming to "live" next to their warehouse helps to authenticate their commitment to art and their position as "locals" in the neighborhood. Newspaper articles contributed to this authentication and the following excerpts from Hoban (2004, p. 1) and Martin (2004, p. 1A), respectively, are representative.

In addition, they're building a personal residence connected to the museum by a two-story library open to the public, epitomizing the public-meets-private Miami phenomenon. "We are simply coming as close to our art as we can," Mrs. Rubell says. "For us the art is our life, and it's impossible for us to separate the two. We have this passion, and we live inside the passion, and our particular paradigm of passion includes the public."

As the collection grew, they fantasized about living in a space big enough to house it all. Fantasy turns to reality as... the Rubells move into a house attached to their warehouse... That the occasional drunk comes around to scavenge scrap metal or that many people wouldn't be caught around there after dark doesn't worry the Rubells. "When we were deciding whether or not to buy the warehouse, I walked around," said Mera Rubell, sitting at the edge of the empty lap pool just put in behind her new house. "I found working people who took pride in their homes. I wasn't scared off. To the contrary. I'm an immigrant myself."

The other reason the Rubells need not be afraid-as the image below reveals - is because they secluded and fortified their house with concrete walls and steel doors, a sharp contrast to the short, chain-link fences draped in flowering bushes that border their neighbors' homes. Nevertheless, other than Brook Dorsch, who I mention below, such examples of live-in gallerists are idiosyncratic anomalies and function to authenticate the identity of the gallerist, not only as a passionate and "serious" patron of the arts but also, as I discuss later, as "pioneers" on the urban "frontier" represented by Wynwood. 


\section{Figure 6.7: Image of Fortification Surrounding the Rubell Residence next to their Wynwood Warehouse}

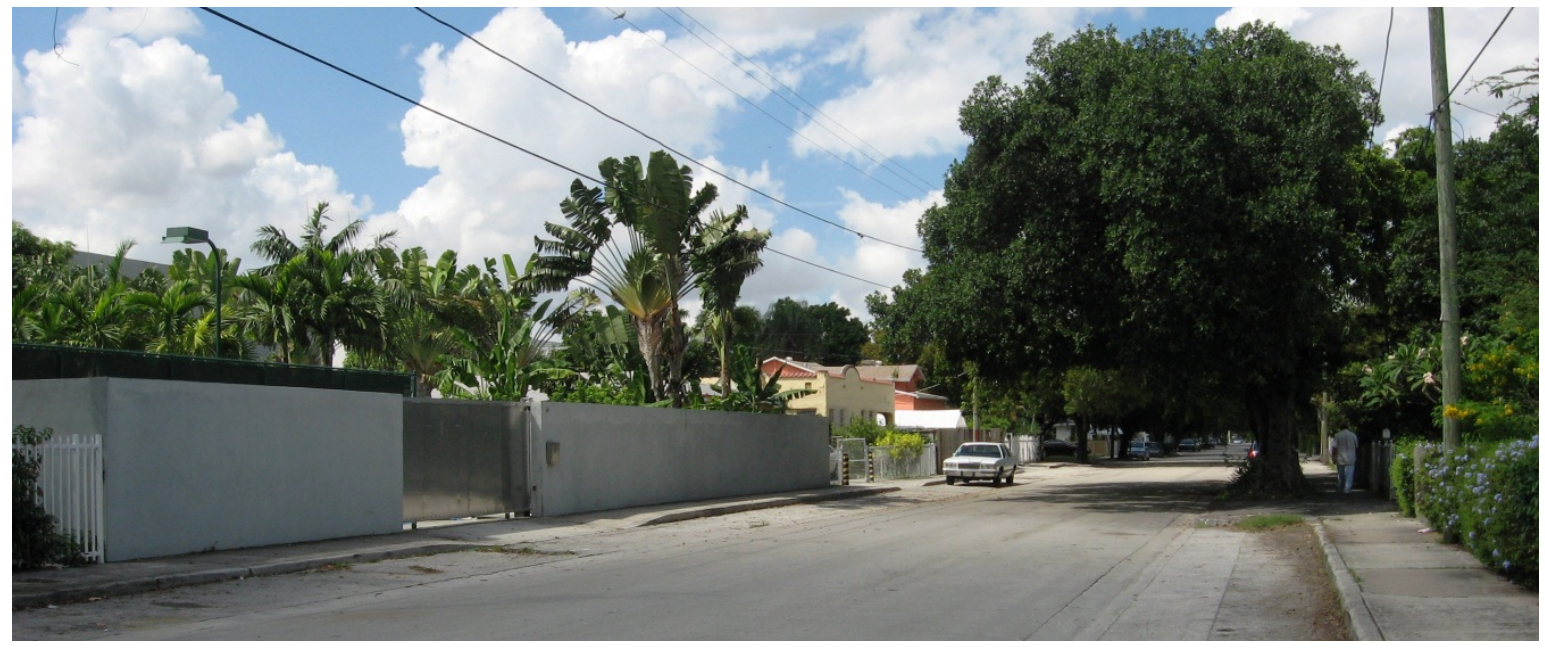

Source: Authors photo taken September, 2011.

Between 1998 and 2002 these pioneers were followed by other well-known New York collectors along with Miami-based collectors. Together they converted dozens of warehouses into gallery spaces. ${ }^{213}$ New York-based gallerist Bernice Steinbaum set up shop in 1998 on the northeast corner of the neighborhood that would soon face the Midtown complex across the street. Then several Miamians arrived. In 1999, Marty Margulies, a well-known housing developer from Miami, established his photography collection in a 35,000-square-foot, nondescript warehouse he purchased for $\$ 1$ million, and later enlarged by 10,000 square feet (Hoban 2004). In 2001, Brook Dorsch, known for his bohemian, risk-taking character and for throwing parties in his studio, moved his collection from southwest Miami to a 6,500-square-foot warehouse, which "he partitioned off [in] the back... to make himself a cavernous loft apartment, complete with

\footnotetext{
${ }^{213}$ Although I cite newspaper articles, the following was explained by interview respondents involved with the creation of the "arts scene" in Wynwood in the early 2000s.
} 
a sliding fireproof door" (Corral 2003, p. 1B). Dustin Orlando, another gallerist, contributed to the promotion of Wynwood's art scene by organizing parties (Cordovi 2002). Seldom mentioned as one of the influential, early stakeholders, the Miami Art Space (MAS) was established by Ofer Mizrachi in 2001 by retrofitting and fortifying a wooden warehouse built in 1925 in the middle of a residential street (see Figure 6.8 below). Steven, an acclaimed collector I interviewed who also manages the Miami office of a national foundation, set up shop in 2002 in a 9,500-square-foot warehouse shared by another well-known gallerist collector and university professor, Snitzer. Damien Boisseau, a French gallerist, opened a non-profit gallery to promote young, local artists in 2002 (Cohen 2002). Around the same time, Rosa de la Cruz, whose private collection, as with Steven, Rubell and Margulies, is considered a "de facto museum" (Sokol 2009; Austin 2010), moved her collection into a 28,000-square-foot building in the Design District in 2004. ${ }^{214}$

${ }^{214}$ A portrait of Rosa's mother-in-law painted by Salvador Dali is part of the collection (Ibid). 


\section{Figure 6.8: Image of the Colorful Wall Fortifying an Art Gallery Located on a Residential Street in Wynwood}

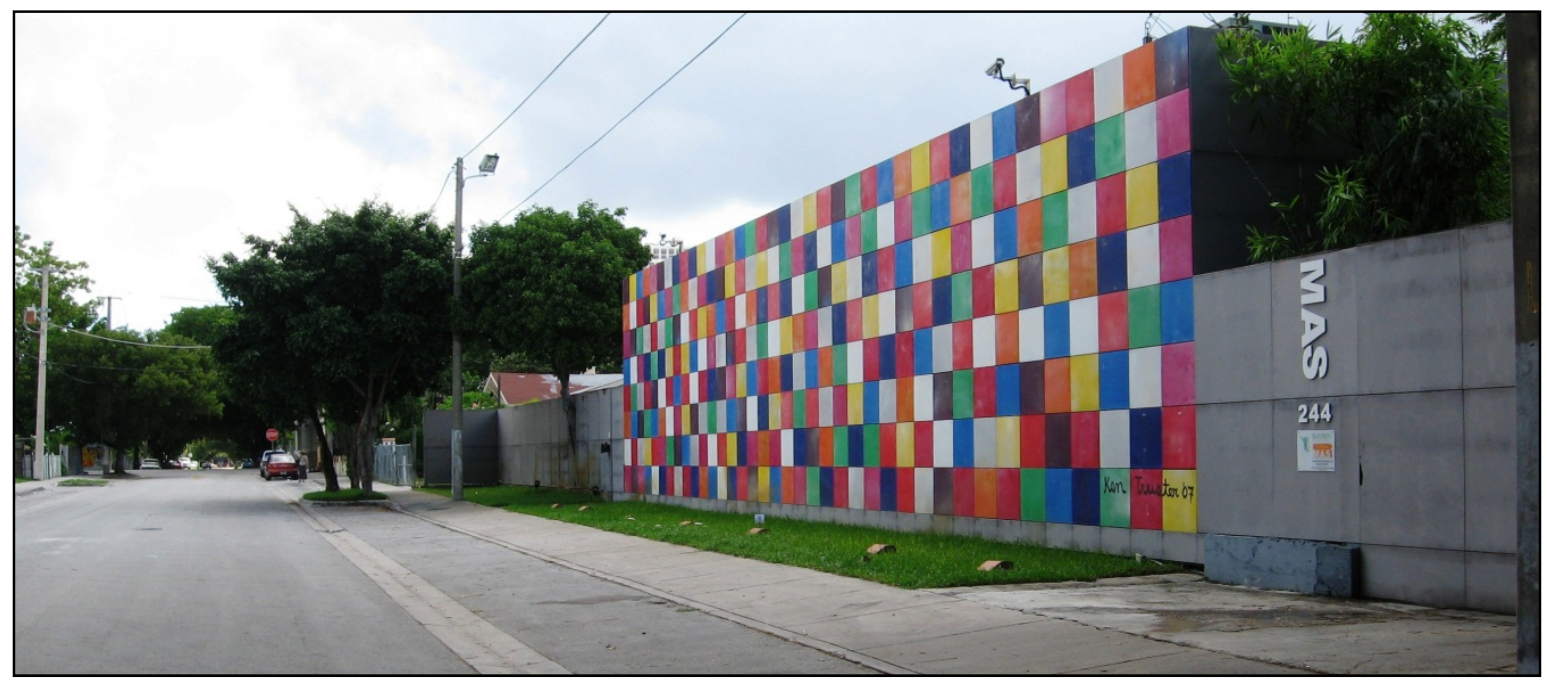

Source: Photo by author, September 2011. In 2001 Miami Art Space was established by retrofitting and fortifying an old warehouse, hidden by the wall topped with security cameras.

By the 2000s, real estate developers - whose work I will discuss later -began systematically converting warehouses into gallery spaces and redeveloping some of the multi-story factories into artist lofts. Concentrations of actual artists did not move to Wynwood in substantial numbers until after gallerists and developers had created the infrastructure for them (e.g., housing, consumption venues) - precisely the opposite of how artist-led gentrification was established nationally as a model of urban revitalization, notably in southern Manhattan (Zukin 1989) or in Chicago's Wicker Park neighborhood (Lloyd 2002, 2004). There is no evidence of a colony of artists who lived in Wynwood before the redevelopment boom of the 2000s. ${ }^{215}$

\footnotetext{
${ }^{215}$ According to the NAC director, a staff member, an artist and a former board member, even though artists are not allowed to overnight in their work studios, there is little enforcement and it does occur. However, no one could pinpoint exactly how often this happened.
} 
The illegal loft inhabitants of SoHo, the anti-establishment, "problematic social group of arts producers" and the activist organizations they created during the 1960s and 1970s in defense of artistic space (Zukin 1982, p. 424): none of these ever existed in Wynwood. ${ }^{216}$ In Wicker Park, the creation by artists of a cultural environment conducive to "creative work" in artistic fields became linked to economic redevelopment, thus leading Lloyd $(2002,2004)$ to term the environment, "neo-bohemia., ${ }^{217}$ While such an environment was created in Wynwood during the last 15 years, it was not led by artists living in the neighborhood and did not precede efforts to use "arts and culture" as vehicles for physical redevelopment. Gallerists' vision and endeavor to use Wynwood as a staging ground for the Arts - the creative moment of the "social scene," as some respondents and reporters called it - was catalyzed by the simultaneous arrival of "business people" 218 and the growth of a critical mass of collectors and other arts-related commercial venues at the turn of the $21^{\text {st }}$ century.

Nor were there in Wynwood during the 1980s and 90s the stereotypical "incumbent upgraders" of numerous gentrification case studies (e.g., Smith and Williams 1986; Lees, Slater and Wyly 2008), characterized by middle-class status, anti-suburban ideologies, or individuals otherwise interested in moving into an area to redevelop it

\footnotetext{
${ }^{216}$ It appears that similar groups existed in Coconut Grove in the 1960's and 70's, before being displaced and partially transplanted to South Beach, where an arts movement contributed to gentrification through historic preservation, exhibiting some similarities to what happened in SoHo around the same time (McCarthy 1982; Lawrence 1984; Donnelly 2006).

${ }^{217}$ His point, beyond describing ethnographically how it happened, was that while such "bohemian" environments have historically existed in disinvested, inner city districts, they are now systematically linked to physical redevelopment processes, drawing on Chicago as a paradigmatic case.

${ }^{218}$ The director of a government agency in Wynwood, whom I introduce below, referred to some real estate developers in this way to emphasize their business acumen for creating a social environment that would attract consumers.
} 
through their "sweat equity" investments (e.g., Smith 1986; Slater 2003). It would be a stretch to call the gallerists and collectors in Wynwood "incumbent upgraders," since at the end of the day they go home to another neighborhood, even another city. Observers' claims that it has become "South Florida's SoHo" (Cohen 2002; Hampton 2010) refer to the concentration of "creative industries" and artistic activity but the parallels to SoHo end there. Instead, Wynwood represents a newer model of arts-led gentrification, one that was already emerging in the 1980s (e.g., in London's Docklands) to capitalize on "the apparent success of a market phenomenon initiated from below" (Zukin 1989, p. 202) evidenced in Manhattan, San Francisco, and a few other places. As Zukin asserted in 1989, "SoHos are now made, not born, in culture-based economic redevelopment strategies" (Ibid).

Wynwood's claim that its artistic community is "from below" appears disingenuous given that the prime movers were outside wealthy arts collectors, real estate developers, art dealers and gallery owners. Nevertheless, news reporters and public officials parrot the arts and real estate entrepreneurs' self-identification as grassroots activists (e.g., Triff 2004; Iuspa-Abbot 2010), helping to legitimize the presence of a new community-based organization in Wynwood. As I will demonstrate in the following pages, the arts movement in Wynwood and, in particular, the Wynwood Art District Association (WADA) as its public and political representative, has mobilized and constructed a variety of operative scales through which to influence land-use policy only one of which is "from below." It operates simultaneously "from above" and at scales in between, working in and through existing city agencies (e.g., those with jurisdiction over specific corridors, "the neighborhood," the electoral district, municipal boundaries, 
etc.) as well as through vehicles and scales of its own creation. The Wynwood Art District Association has not only (re)defined the boundaries of Wynwood but, as I explain below, has created a sub-district where special administrative rules apply. The arts and real estate entrepreneurs redeveloping Wynwood, then, are both more than and distinct from the notion of "grassroots."

It is interesting to consider how and why these influential entrepreneurs and advocates of the arts movement in Wynwood (and Miami in general) believe their "movement" represents a new model of arts entrepreneurship related to the idea of action "from below" - what they call the "Miami Model."

\section{The "Miami Model" of Arts Entrepreneurship}

The Miami Model, as it has been dubbed by collectors and critics (Sokol 2009; Austin 2010), refers both to how art is collected and made accessible to the public, emphasizing the importance of private collectors as opposed to public museums in Miami's art consumption and appreciation. The Rubells are considered the pioneers of the Miami model because they were the first to install a collection of museum size and quality in a privately owned warehouse routinely accessible to the art-going public. According to one of the most articulate exponents, ${ }^{219}$ there are two basic, albeit interrelated elements of the so-called Miami model of arts-driven revitalization. One is historical, related to the young history of the Miami region and its public institutions. The other is political and economic, stemming from the power of real estate developers who

\footnotetext{
${ }^{219}$ Steven is the director of the Miami office of a major international philanthropic foundation and is a renowned art collector with a warehouse in Wynwood. He grew up in a northwest Miami neighborhood and attended the University of Miami.
} 
have also amassed acclaimed art collections, many of them quite recently. In Miami, many of these newly wealthy collectors made their real estate money in the relatively recent political and economic ascendance of Miami and Miami Beach (Sassen and Portes 1993; Nijman 1996, 1997). As a result, while public museums have yet to amass collections, privately owned collections are exhibited to the public in warehouses largely clustered in Wynwood, where individual collectors can purchase or rent museum-like space. Moreover, such privately-owned, "de facto museums" (Sokol 2009) often focus on contemporary art, since the market for "classics" is dominated by the world's most powerful public art institutions in New York, Paris and other major art centers (Zukin 1982, 1989). Steven, a philanthropic foundation director and major contemporary art collector described the Miami model:

It's a very unique situation here... to have private collections represented and available publically en masse. It happened because Miami is an untraditional town in terms of city organizations. When I grew up here as a boy, there were no museums. So when the group [of art collectors] that I was describing kept hoping for public spaces for private collections, began to collect [in the 1960s] - the typical model is a person of some wealth decides to collect art, doesn't know anything, gets picked up by a museum director and a museum curator, is taken to New York, the Vanderbilts, the Whitneys, taken to Europe to where the center of Art was. The museum director helped you buy a bunch of things, you became cultured, you know, and at the end you said, 'Thank you so much, I'd like to buy something from you, too.' Or 'thank you so much, when I die, you get all these things.' That's the standard - Philadelphia, Boston, New York, Chicago model... The Miami model is that there weren't those people here [to educate us] during that time period and so when we began collecting we all did it our own way. We ended up learning our own way. That's why the collections are so diverse and so different and so well thought of in the international art world - because these collections don't look like any other collections. Because [in Miami] there are not the same groups of people, the same group of educators. 
Moreover, Miami's unique situation has implications for its recently established public art museums. Public museums are typically established and grow through acquisitions from collectors, especially local collectors who want to promote arts appreciation in their city (the New York case is paradigmatic, e.g., Zukin 1982, 1989). In Miami public art museums have struggled, exemplified by doubts over the underconstruction Miami Art Museum to fill its walls with the highest quality art (Kaleem 2010; Sokol 2010). ${ }^{220}$ So because art museums succeeded the preeminent private collections, the former will have to "earn the trust of collectors," according to Steven, and when that eventually happens, the museums will grow "based upon bequest, upon [collectors] making decisions down the road," adding that "all the collectors are still pretty young." ${ }^{221}$ Second, in the short run, this has implications for public art consumption. As the foundation director put it, while public institutions "have to collect for posterity," to educate future generations,

these private institutions can be more idiosyncratic [and tend to] reflect a personal passion - that's not the same as a public institution. Public institutions have objects that become the community's objects. These [private institutions] are not the community's objects; they're the objects of the people that hold them. It's a different model. It won't be this way for ever. It's not about whether one model is good or bad, it's that there is a disagreement between when those objects will become public objects.

\footnotetext{
${ }^{220}$ Some major private collectors, such as Margulies (see Sokol 2010), have argued against public funding for the new Miami art museum.

${ }^{221}$ Interview with Steven, the foundation director and art collector.
} 
Depending on who you ask, about four of five private collections in Miami are considered to be world-renowned, "de facto" art museums. ${ }^{222}$ The Rubell collection mentioned above is one. The foundation director who I interviewed controls another major private collection, also housed in Wynwood. De la Cruz, Margulies, and perhaps a few other very wealthy families, all of whom house most of their art collection in Wynwood warehouses, round out the powerful players in Miami's art world and shape the highly privatized Miami Model. Although somewhat spatially clustered in Wynwood, the Miami Model's power structure is spread across the small group of private collectors, ${ }^{223}$ as opposed to the "art in the arms of state power" model represented by the Ford and Rockefeller families in New York since the 1960s (Zukin 1989). Private collectors are powerful in other cities such as New York, London or Paris, but unlike those cities, Miami has minimal state patronage for the arts. While state support for the arts was critical to artist-led gentrification in New York, for example, in Miami art collector-led gentrification is financed mostly by these wealthy collectors, most of whom are also developers. Yet, as I will discuss below, Miami's arts entrepreneurs do draw on government support in a different, less visible, more indirect fashion. The Miami Model has been advanced by a close alignment of developers and collectors who lobbied for

\footnotetext{
${ }^{222}$ The foundation director was careful to point that "we do not think of them as museums but [rather] public spaces for private collections. We have been very careful to name them that way. None of them are museums. They all do different things. Sometimes they have educational programs, sometimes they don't."

${ }^{223}$ Through their roles in major local and national Foundations and their close relationships with each other, Miami's top art collectors have worked together to make Miami an global center for contemporary art. "When people come to Miami for Art Basel [the annual international art festival, discussed below], they come every year to see those collections. It's a very important component of Art Basel. When we brought Art Basel here, that's one of the things that we all promised to do... that we [all] help in any way we could and one of the ways was to make those collections available during those festivals for people come to see. Those [visitors] make up 30,000 people over Art Basel week."
} 
specific "cultural" and urban development policies that facilitated the transformation of Wynwood into a privately controlled, but government abetted Art District.

\section{Art in the Arms of Real Estate Power}

If Miami's art scene is heavily shaped by a loose-knit network of a few very large private collectors whose "endgame is art" (Martin 2004, p. 1A), Wynwood's arts-driven real estate market is shaped largely by two developers who, conversely, are interested in how "art can make a neighborhood happen" (Ibid). Together these influential early stakeholders - collectors and developers - transformed Wynwood. By opening the private collections to the public, hosting parties in their warehouses and coordinating special monthly events with each other, the early promoters of Wynwood were instrumental in drawing a growing number of arts consumers to the neighborhood.

The developers were crucial not only for their business acumen - marketing, event organizing, and so on - but also because they control space and could cluster consumption in strategic areas. Between them, developers Goldman and Levine own more than 80 properties in Wynwood's warehouse district (see Figure 6.9 below), making them by far the largest property owners in the area. ${ }^{224}$ Each is considered a "kind of an artist [who] approaches real estate as an artist would approach art," according to the City Commissioner who represents the eastern half of the art district. Goldman made his name in the 1970s redeveloping SoHo's cast-iron manufacturing lofts into art galleries and "live/work" spaces for "creative types" in SoHo (Lees and Bondi 1995; Bernstein 2005;

\footnotetext{
${ }^{224}$ There is also a third major property owner who owns 20 properties in Wynwood, but he specializes in light manufacturing operations. According to my analysis of property records, after these three the next largest property owner in Wynwood - either north or south of $29^{\text {th }}$ street (mostly residential vs. mostly commercial, respectively) — holds no more than 10 properties.
} 
Pristin 2010). He has since been involved in the arts-oriented revival of other urban districts such as South Beach ${ }^{225}$ (Lacker 1986; Sontag 1986), Philadelphia’s Center City district (Flanagan 2000), the Fort Point Warehouse district in South Boston (Gregor 2006) and, most recently, Wynwood. In contrast to “developers [who] are knock 'em down, build 'em up guys" (Flanagan 2000, p. 4), Goldman and son claim to take a comprehensive approach to creating "an urban pedestrian environment" (Chang and Turner 2005, p. 1A), not only restoring and redeveloping buildings but selecting tenants to create a diverse consumption infrastructure, including art galleries, restaurants, boutiques and other commercial venues, in addition to creating a few of their own. However, the basic pieces of the consumption infrastructure were being established before the Goldman's first investment in the area in 2003.

${ }^{225}$ Goldman worked with Craig Robins, mentioned in note X above, in the redevelopment of South Beach. "The big story," said Robins in 2005 (Bernstein, p. 1), "is that the people who made South Beach... have now crossed the bridge." 
Figure 6.9: Map of Major Art District Property Owners and Selected Organizations and Government Agencies

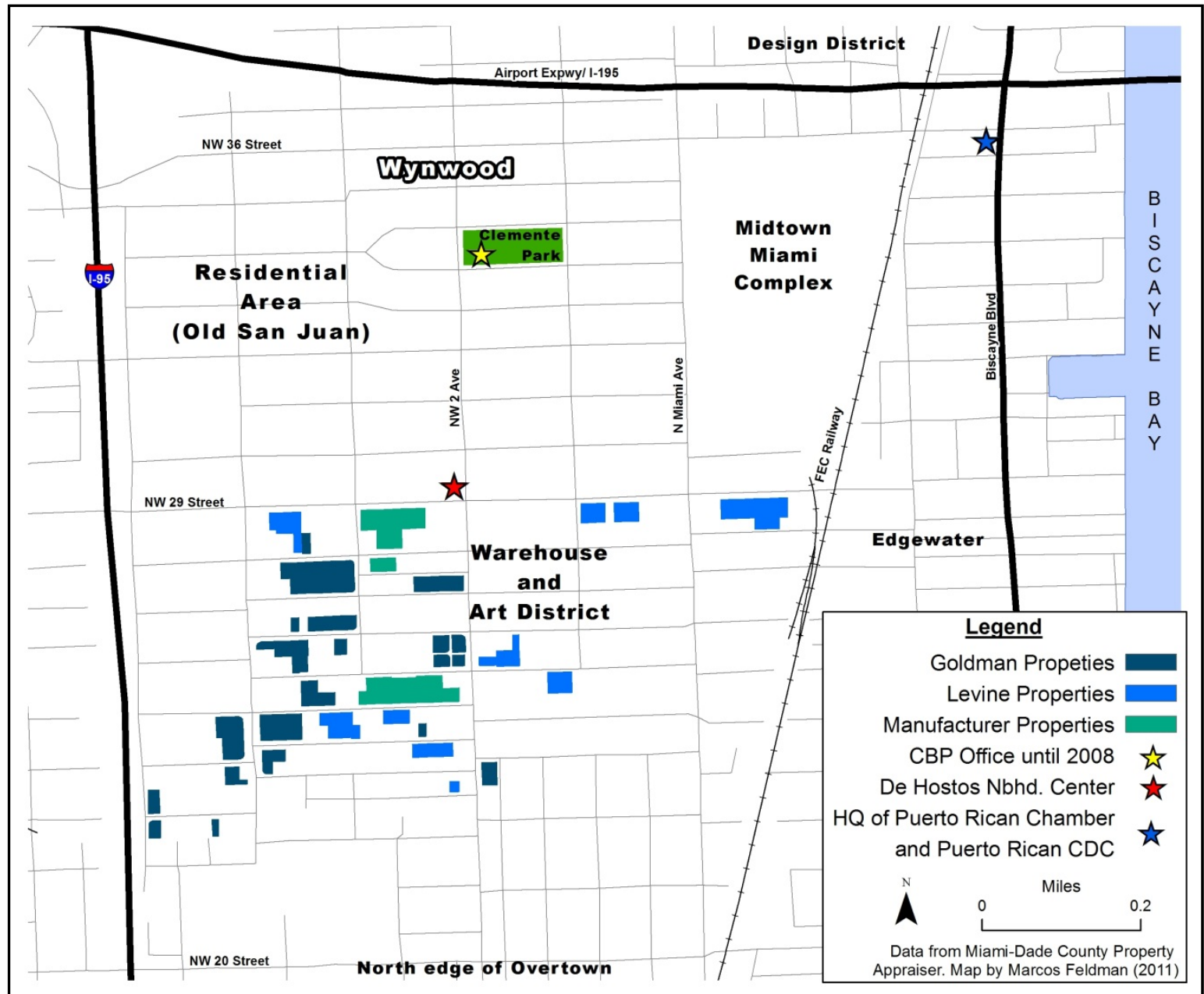

Levine, who also profited from investments in South Beach Art Deco rental apartments during the 1990s, started buying properties in Wynwood in 2001 with the idea of transforming them into live/work artist lofts, galleries or other supporting commercial venues. He also spent time promoting the area, which included giving other prospective investors tours of the neighborhood's "collection of nondescript facades with cherry 
filling. ${ }^{, 226}$ Part of his tour involved stopping by the Wynwood Community Based Policing (CBP) office located at Roberto Clemente Park to introduce prospective investors to Melissa, the CBP office administrator since 2000 who had become a key ally to Levine and other art district stakeholders. "He would bring them to the CBP office," said Melissa about the tours for "developers and people who were interested in the neighborhood," and "show [them] that there was engaged government and people who cared and who could help if you were an artist and, you know, artists aren't really into all this licensing and permitting stuff."

But the help provided by Melissa and the neighborhood's "mini city hall," as the CBP offices were initially nicknamed (see Chapter 4), went beyond basic licensing and permitting for new businesses. There were two crucial sets of processes in which the CBP office, as a conduit to work with government agencies, supported the budding Art District. One was by getting involved in the production of the social environment of arts and cultural consumption supporting economic revitalization - Lloyd's $(2002,2004)$ "neo-bohemia" in the Chicago neighborhood of Wicker Park ${ }^{227}$ or, as Melissa put it, "through the CBP office, I put my grain of sand to the creation of the scene [emphasis added]." The other was the close collaboration between the CBP office and Levine (and sometimes other developers) in the "quick and dirty work," as Levine put it, of neighborhood redevelopment; that is, to use another of Levine's phrases, the creation of a

\footnotetext{
${ }^{226}$ This is Levine's well-known marketing slogan, according to several respondents (including Levine), and repeated in brochures and websites. In addition to "talking the talk," noted Levine, he "walked the walk" by relocating his real estate office to a redeveloped Wynwood warehouse to help convince investors. Levine needed to lure other investors because, unlike Goldman, he did not have enough of his own capital to realize the extent of redevelopment that he wanted throughout the neighborhood.

${ }^{227}$ Although again, unlike the case of Wicker Park in Chicago, in Miami the "scene" was created mostly by gallerists, collectors and developers, who laid the groundwork for the eventual influx of artists.
} 
"clean canvas," implying processes of cleansing - demolition, homeless removal and other displacements. Taken together, these two sides of the coin of urban redevelopment - socio-cultural production and the displacement of "disorder" - have been referred to by way of Schumpeter's 1942 phrase, “creative destruction” (Brenner and Theodore 2002; Weber 2002; Swyngedouw 2003; Harvey 2007). The remainder of this chapter examines key examples of these processes in Wynwood since 2000, paying close attention to how they were implemented through collaborations between the Wynwood CBP office as a conduit to other city agencies, and the area's new developers and gallerists, as they endeavored to catalyze and grow an Art District.

\section{Creating the Scene: Artist Lofts and Artsy Parties}

In 2001, after buying nearly 20 properties, Levine's first loft redevelopment set the stage and served as an impetus for the district's promotion because, as Melissa put it, he then found himself "sitting on a lot of land." The retrofit of the 1924-built Terminal Fabrics ${ }^{228}$ manufacturing lofts was a public-private partnership of sorts because it required the City of Miami to facilitate new "live/work" land uses by, on the one hand, creating new county- and state-level zoning categories and, on the other hand, to look the other way in the meantime since it took years to establish those new categories.

So in $2001 \mathrm{I}$ built those lofts and the city didn't know what to make of them but they liked what I was doing and Manny Diaz [City Mayor, 2001-2009] said, 'Look Levine, here's Lourdes, she's the head of zoning. We're not quite sure how to classify you but we're going to leave you alone.' The problem was that that side of the street was zoned industrial and... they felt they had to re-write an

\footnotetext{
${ }^{228}$ Originally named the Seminole building when it was built, Terminal Fabrics was the name of the company that operated the apparel factory during the post-war years. The redeveloped live/work lofts became known as the Terminal Lofts.
} 
ordinance in order to make it kosher. So she wrote an ordinance that ended up never getting passed at the state level because the state wanted to add all of this gobbley-gook that she was not pleased with. But they just left me alone and told me that, anybody moving in there needed to get an occupational license for their space as a business. And if they slept there, so be it. ${ }^{229}$ They left it alone... because they shared the vision. My pitch to them was [that] the industrial manufacturing community... is no longer here and the few [remaining] won't be here in three years. [The City] agreed and, you know, manipulated the ordinance to facilitate what I wanted to do.

The three-story Terminal Lofts building is what began to draw comparisons between Wynwood and SoHo's manufacturing-turned-artist lofts. But this was one of the only multi-story manufacturing loft buildings in Wynwood - not enough to satisfy the potential demand for artistic "loft living," according to Levine. So in 2003, with help from a former City of Miami attorney, he started to build another four-story loft building from scratch. Wynwood Lofts was intended not only to continue to increase the supply of live/work lofts, but also because Levine wanted "the artists to be able to take an ownership stake in the neighborhood and not get forced out in gentrification.” Once again, "we had to go through a series of hopscotch from an industrial-zoned piece of land to get it zoned commercial with a special exception for residential, so we hired Lucia Dougherty," an attorney with Greenberg Traurig (who consulted for the Midtown developers) and formerly of the City of Miami and, as "she was the master of that universe, she got it rezoned." In the four months after the project was completed in

\footnotetext{
${ }^{229}$ Artists sleeping in their studios ("illegal studios" as they are known in Wynwood's art world) was widespread during the early 2000s, according to different gallerists, realtors and artists I spoke to. But the situation at the Nonprofit Art Complex and that of Levine's building were different because in the case of the NAC, the potential of losing its government funding if anybody was caught increased the risks. Levine was assured by city officials that nobody would enforce the zoning regulations as the City of Miami sympathized with his live/work vision for Wynwood. Until now, no artist has been caught sleeping in their studio at the NAC, at least not by government agency workers (nor is there any evidence of inspections or audits that focus on such behavior). But there were disagreements among NAC board members about whether the rules against sleeping in studios should be strictly enforced, apparently causing at least one board member to resign.
} 
November of 2006, rental prices per square foot in Wynwood increased from $\$ 200$ to \$300, according to realtors (Elkies 2007).

\section{Figure 6.10: Image of the Former "Terminal Fabrics" Factory Converted to Residential Lofts}

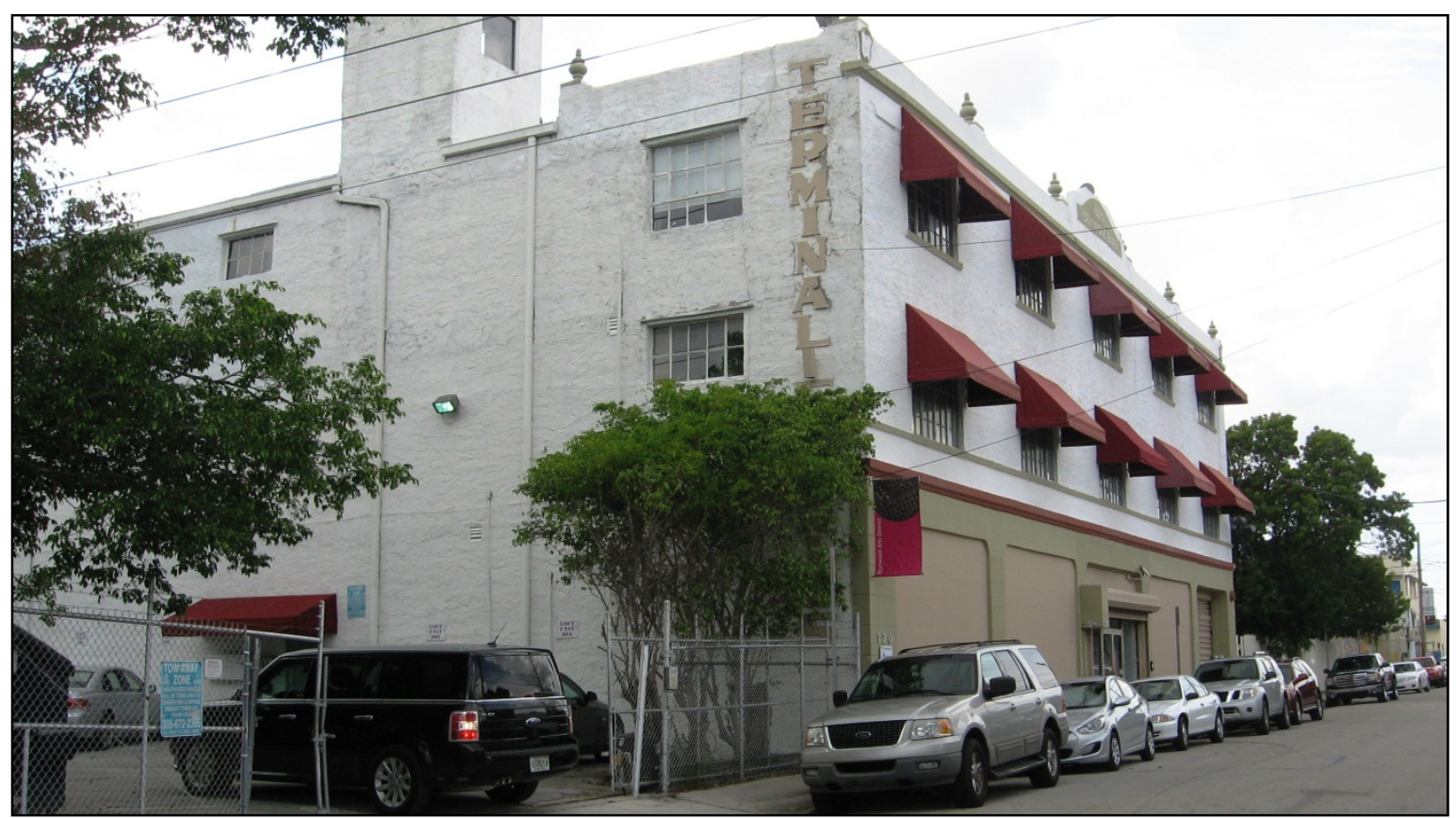

Source: Authors photo taken September, 2011. Incidentally, Marta lives on the same block.

While local government "for the most part has been very supportive over the 10 years that I've been [here]," Levine noted that the city was more helpful and cooperative during the early years of the housing boom compared to more recently, during the onset of recession, when bureaucratic officials seem to be trying to "justify their existence," suggesting that this is common across many cities.

This is not unlike other areas in the country. When they're [city agencies] desperate for change and new life, new blood to be pumped in, they pat you on the back and show you through. They let everything go and [say], "Do you what 
you gotta do." Once there's a certain level of success achieved, like when Midtown came in, all of a sudden it was "Levine who?" ... Now we're in a city that's financially crippled and there are inspectors [from] different departments that are trying to justify their existence so they're coming out [and] writing violations. I have spent honestly maybe $1 / 3$ of my time in the last 18 months [during 2009-2010] doing nothing but fighting the bureaucracy. Violations, getting zoning changes, use changes in spaces.

Just as he needed the support of investors and city agencies to create the Terminal and Wynwood life/work loft buildings, Levine worked with the CBP office, artists, gallerists and other area businesses to help fill them. Although their collaborations were actually intended to create a popular social environment in Wynwood ("the scene"), a crucial byproduct of this popularity was apartment sales. Melissa and Levine (independently) described how the idea emerged to create a series of roving parties eventually known as "Roving Fridays," a precursor to the existing Second Saturdays Art Walk - to promote the warehouse spaces to a broader audience, modeled on "the coolest" parties thrown on South Beach before "that scene" became a "place to be seen."230 Melissa recalled one of their frequent meetings:

It's Levine, Dustin Orlando, and me. Dustin Orlando... more of like an urban low-brow artist, very cool... was really one of the pioneers in getting cool people here. Levine was sitting on all this land, right? And I know about Code [building

\footnotetext{
${ }^{230}$ In addition to her career with the City of Miami - which more recently helped her get a job with a prominent consulting firm of former City of Miami Commissioners - Melissa was apparently a frequent party-goer on South Beach during the 1990s and, subsequently, in Wynwood when it became the "place to be" during the 2000s. "When I spent my 20s on Miami Beach," recalled Melissa, "the reason we loved it was because it was a frontier and it's where you went to be anonymous. The minute that I stopped really wanting to hang out on Miami Beach was when it became the place where you went to be seen. And that was a transition in Miami Beach... Now Wynwood is a similar thing," implying that when she was first involved in the roving parties of the early 2000s they were cool because they were largely unknown, compared to Wynwood's more recent acclaim, which was catalyzed by the first Art Basel festival in 2003. An indication of the turn in the Wynwood's [I presume you meant Wynwood and not M. Beach here.] broader popularity was when the neighborhood started to be consistently profiled by the New York Times' art and real estate writers in 2004 (Hoban 2004; Robin-Brandt 2004; Bernstein 2005; Tsui 2006; Chaplin 2008; Pristin 2010).
} 
permits and codes]. We were... starting to have a little feeling - you had Bernice Steinbaum and you had the NAC and you had Brook Dorsch and, you know, Brook Dorsch would throw these great parties and, Damien B, there's like a little something [potential with all these important gallerists in the neighborhood]. And Levine's like, "We need to figure out how to get people here at night."

Levine considered Brook "a tremendous inspiration. It was an [art] opening in his place in 2001 that put the light bulb on for me of what this neighborhood could be." After ruling out the idea of a night club, the group capitalized on Melissa's expertise. She reconstructed her thinking during that meeting.

I remember that the city has something like a temporary use permit that will let you do activities in your space that you don't have a certificate of use for, provided there's no safety issues. [The temporary use would be permitted] twice a year, for a period not to exceed two weeks each time. Right? So I said, well, if you keep it roving, you can rotate it through your property just one night a month, and he would rotate it through his properties. It's still how a lot of warehouses do their permitting for Art Basel [the annual international art festival, discussed below] - where a certificate of use doesn't exist for the activity that they're requesting; they're operating under a Temporary Use Permit.

The permit is issued twice a year per property, so if one person owns enough properties, he can get a permit for each property and rotate special events throughout them on a monthly basis. While it is not clear whether such creative permitting had ever been implemented in the City of Miami, Melissa's idea was nevertheless crucial to the creation of Roving Fridays. In addition, through her work in the CBP office she had relationships with businesses throughout Wynwood and Edgewater, such as the Bacardi Corporation, 
which began to support the monthly parties. ${ }^{231}$ And as Levine explained, this was good for sales.

The way we sold Wynwood Lofts was through our art parties. [During] Roving Fridays, back in 2002-2003, I would take whatever space I had empty [in one of my properties] and get 20 or 25 artists to come and hang works with a curator. We had a DJ. We had a band. We'd have Bacardi supply free booze for the whole night. And we would charge at the door, 5, 10 bucks, [which] would go to the artist for their troubles. Anything sold, the artist kept the money. And my whole intention was to get people used to coming here at night. To understand what the neighborhood could be. And it was very effective. We sold maybe 20 -some-odd of 36 units in that building just through those art parties, giving out brochures.

Despite their talent for promoting the neighborhood, this initial grouping of gallerists, businesses and a growing crop of artists were not effective at creating a permanent neighborhood association - the first attempt at the Wynwood Art District Association (WADA). "It never really gelled," opined Levine, because "the early galleries were a lot of under-capitalized young people. Nothing against them. They just weren't business people. Thank God for them because they really created the movement early on. I needed them to fill space." By the time I moved to Wynwood in 2006, Roving Fridays had evolved into "Second Saturdays" Art Walks and other neighborhood party circuits had developed. Before I describe the Art Walks, it is worth noting that there were some lesser-known groupings as part of the larger (and wealthier) social scene promoted by gallerists and developers.

I encountered one such lesser-known "scene" installed in a small storefront space known as Cornerstone Experiential Art, which in 2007 described itself as a "gallery and

\footnotetext{
${ }^{231}$ This way, the Friday parties could become more than "Levine with a cooler [full of] beers [and] hot dogs on the grill," as Melissa described the first edition.
} 
performance space" with a "purpose... to provide a nurturing venue for artists/humans to perform, experiment, grow, and unite" (website, www.myspace.com/cornerstonemiami). It was a relatively small and short-lived project (2005-2007). The five event organizers and main artists rented an apartment above the storefront venue (it was never clear exactly who lived there), which could accommodate no more than 60 or 70 people (40 was more comfortable). Weekend events, which were well enough attended to request a “donation” upon entry (typically $\$ 2-5$ dollars), helped pay for supplies. ${ }^{232}$ On weeknights, the regular artists and their friends gathered and experimented artistically. The space drew mostly college-aged people, including many who actually studied performing arts in different Miami universities (I heard about Cornerstone through friends at FIU). For many of these young people, Cornerstone was also seen as a different option to the other mainstay of alternative youth culture in Miami, Churchill's pub, the punk rock and "hipster"233 bar and music venue near the eastern edge of Little Haiti. At Churchill's, experimental, performing arts were relegated to an outdoor project, covered under a tent at the back of the property, known as "Theater De Underground." It was precisely those performers who took center stage at Cornerstone.

\footnotetext{
${ }^{232}$ The rent was paid mostly by one of the wealthier founders of the party who was a former $C N N$ en Español broadcaster "in a previous life," as he told me.

${ }^{233}$ Although hipsters are commonly associated with "indie rock" music, the term has come to refer to an increasingly diverse group of "counter-cultural" youth, described elsewhere (e.g., Lloyd 2006; Erlich and Bartz 2010).
} 


\section{Figure 6.11: Image of Cornerstone Experiential Art Scene in 2007}

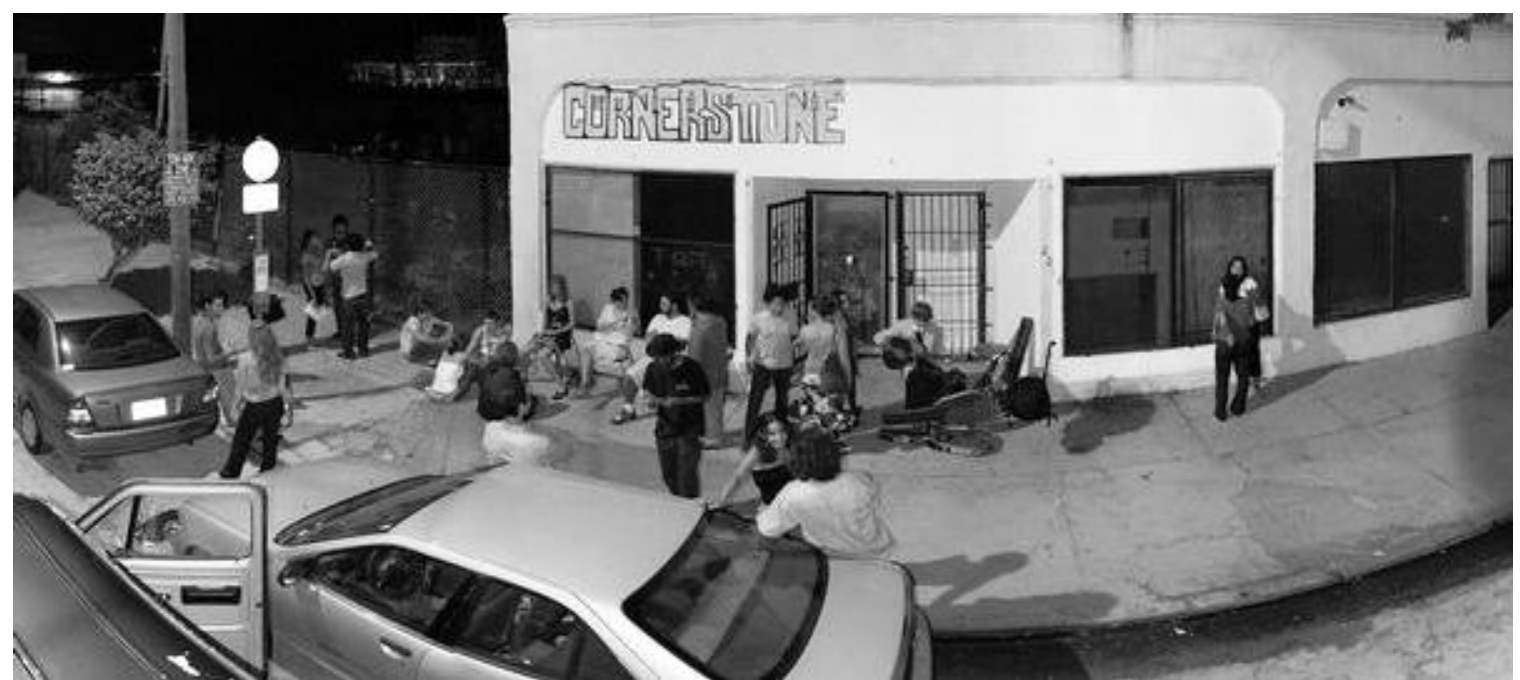

Source: Courtesy of a "Cornerstoner" photographer and the Cornerstone MySpace website (http://myspace.com/cornerstonemiami) where "all content is public." Photo dated April, 2007. Accessed August, 2011.

By the end of 2007, the venue closed when the building was sold. Cornerstone seemed to have played an important role in Wynwood's "arts movement" not only by providing a space for young performance artists to hone their talents but also because it inspired and facilitated artistic collaborations that have been sustained over the years. For example, Cornerstone routinely asked different artists, who benefited from the opportunity to perform, to host an "open mic" night each week. Catalina was a poet who regularly read at Cornerstone and eventually became a weeknight host. Her experience at Cornerstone gained her recognition as a good event organizer and expanded her artist network and fan base. After Cornerstone closed in 2008, Catalina initiated a weekly event in a Wynwood art gallery called "words and wine," which started as a poetry series and expanded to include all kinds of performance art. Since then, Catalina has established a new performance art series in Little Havana (a low-income, inner city Miami 
neighborhood), in addition to the Words and Wine parties. She was one of several former Cornerstone hosts and performers who, after its closing, went on to found their own events and/or advance their own artistic careers. Some Cornerstone performers have since played at major Miami concerts, recorded their first albums and even been featured on National Public Radio.

The Second Saturday Art Walks contrast Cornerstone's low-brow status but are in service to the same broader process of arts and neighborhood promotion. Initiated in 2004, the art walks are coordinated events that take place on the second Saturday of the month in which the vast majority of Wynwood galleries open to the public and typically serve wine and hors d'oeuvres (after the recession the latter were eliminated), and sometimes feature live bands or other performance art. During these events thousands of people descend on Wynwood from other parts of Miami, many revealing their social standing by the expensive cars they drive. Some people who arrive late and can't find parking close to the main cluster of galleries along NW $2^{\text {nd }}$ Avenue opt to secure their vehicles in the "safe parking" lots for $\$ 10$ and expend smaller fees to ride rickshaws to their gallery of choice. In 2011 , organizers initiated a shuttle service for $\$ 10$ to $\$ 15$, depending on the distance (the maximum distance is about 8 blocks) (Zimichi 2011). Most of these services are facilitated by Levine or Goldman, as they own the majority of the vacant land along the art walk corridor where the parking lots are located.

As I discuss in greater detail below, the monthly event has become a nuisance for some neighborhood residents as street parking and traffic becomes congested and they find the streets and sidewalks littered with garbage on Sunday mornings. In 2010, Levine made one of his empty lots available to food trucks and small merchants to sell their 
wares, drawing even more people to the already crowded art walks. By 2011, prominent gallery owner Bernice Steinbaum lamented that the "art walk has become dreadful" while another gallerist owner complained, "now you have stilt walkers and flame throwers and food trucks where people buy racks of barbecue they bring to eat in the gallery. It's turned into a total circus. It's chaos. The day after Second Saturday, the streets here look like a war zone because of all the litter" (De Jesus and Casuso 2011). As a result, some gallery owners began refusing to participate and have shifted their openings to other nights. What the "chaos" of the art walks has revealed is the fundamental difference (noted earlier) between gallerists' interests and that of real estate entrepreneurs - the former group's "endgame is art" while the latter primarily seek profits through real estate. 


\section{Figure 6.12: Images of "Safe Parking" Sign and Pedestrian Traffic during a Typical Wynwood Art Walk}

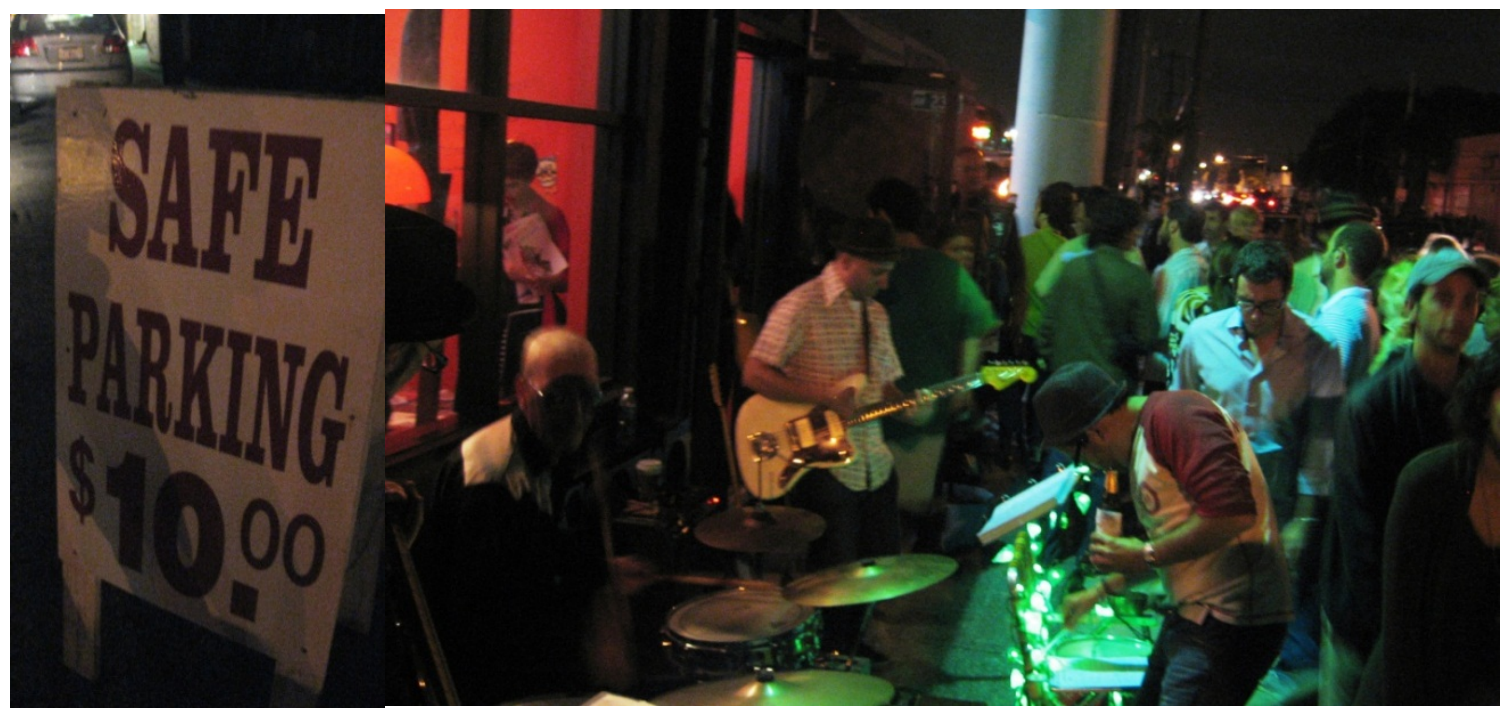

Source: Photos by author, December 2010. Foot traffic flows past the band on the sidewalk in front of an art gallery. For those who arrive late and have to park further away from the main cluster of galleries, "safe parking" costs $\$ 10$.

While Roving Fridays and later Cornerstone and the Art Walks helped draw attention to Wynwood from local Miami residents, one of the key events that put the neighborhood "on the map" internationally was the annual Art Basel Miami festival initiated in 2002 as a "sister exhibition" to the original festival held in Switzerland since 1970. The Miami edition then expanded through satellite fairs, the largest of which (outside of Miami Beach) has been held in Wynwood since 2003. The official Art Basel Miami fair draws an estimated 40,000 people during the week-long event (Wooldridge, Chang and Santiago 2010; Sampson 2010), although it is not known how many more are drawn by the satellite fairs in Wynwood, Downtown Miami and Coral Gables. It was the arrival of the Art Basel to Wynwood in 2003 that motivated the neighborhood's early promoters to form the association (WADA), publish a website and brochures, and create the first map of Wynwood galleries (recall Figure 6.6 above) (Chang 2003). 
The international exposure of Art Basel provided the impetus in 2007 for a series of coordinated graffiti projects known as Primary Flight (PF, see below). Graffiti has a long history in Wynwood as an art form, displayed in "tags"234 and murals, in addition to its traditional association as a territorial market for local gangs. Two prominent and longtime Miami graffiti artist who lead the annual PF projects explained that graffiti crews have been operating in Wynwood for decades, since at least the 1980s, but PF was transformative and unprecedented (globally, they claim) because it has raised graffiti to a fine art form. ${ }^{235}$ They also noted the contradictions of this transformation - similar to that highlighted in the recent documentary about Bansky, the legendary British graffiti artist (Banksy and Guetta 2010): namely, that graffiti, once commercialized, is stripped of precisely of that which makes it thrilling: "the adrenaline rush of doing something you're not supposed to do." In 2003, some of Wynwood's long-time graffiti artists (many of whom were in their 30s and employed in different professions) were invited by the owner of a decaying industrial property to use its walls to make a 550 -foot graffiti mural that would be clearly visible from interstate 95 (Martinez 2003). Other property owners followed this lead and by 2007 Tony Goldman got the idea to work with well-known local and international artists to coordinate a series of painting events and transform a huge swath of Wynwood walls into an "open air museum" and "the world's largest streetlevel mural installation" (PF website, www.primaryflight.com), giving "wings" to

\footnotetext{
${ }^{234}$ Tags are the artistic opposite of murals - the simple, spray-painted signature of the artist. There are different kinds of tags, some of which are intended to merely "represent" while others are meant to crossout or override the tags or art walk of rival crews. There is a complex of unwritten rules that govern the territorial world of graffiti (interview of the two PF co-founders and directors).

${ }^{235}$ Interview with two PF graffiti artists.
} 
Primary Flight. ${ }^{236}$ The PF organization devotes itself to hosting and coordinating projects among the world's best graffiti artists, including the London Police, ${ }^{237}$ Retna, ${ }^{238}$ and others, who descend on Wynwood in the week prior to Art Basel to re-paint the walls of Wynwood (having been painted the year prior). Started in 2007 with a little more than 20 artists, by 2010 the PF series involved more than 100 artists. Painting the entire exterior of buildings became known as "wrapping" walls in paint and during the recent Art Basel festival it was common to hear of project managers in charge of wrapping walls. One such project manager, Daniel, explained to me that his job was to find housing, paint and other supplies, mechanical lifts and, "basically, whatever they need" for the artists, including the most important part - establishing relationships with property owners willing to "donate" their walls. Rather than be centrally coordinated by the PF organization or by Goldman, most of the wide array of graffiti projects that are officially considered part of PF (e.g., included in the Art Basel Primary Flight Walls map) actually operate through a loose network of such project managers. ${ }^{239}$ During the 2010 PF series prior to Art Basel, I also met artists without project managers who operated largely on their own, by asking other artists where to get supplies and which building owners to approach about finding a wall to paint on (for some, it was "chaos," and their wall

\footnotetext{
${ }^{236}$ The arts news media has referred to the opening of PF projects as "spreading its wings" or "taking off," as well as telling the story of how PF "earned its' wings" (Roux 2010; Spinello 2011).

${ }^{237}$ Created in 1998, London Police is a network of mostly UK-based graffiti artists, not to be confused with the London Metropolitan Police. See www.thelondonpolice.com.

${ }^{238}$ Retna is a Los-Angeles based artist whose outdoor murals are known for looking like hieroglyphics as well as the use of historical and religious symbols and figures. See www.digitalretna.com.

${ }^{239}$ Interview with Daniel, graffit artist project manager. Not a graffiti artist himself, Daniel grew up on Miami Beach and was introduced to the art scene through his own profession as a night club DJ and party promoter.
} 
projects were delayed indefinitely for lack of support). In one case, a crew of three (two men from London and a woman from Paris) were supported by the sponsorship grant provided by Levi Jeans for the French woman's hotel expenses. ${ }^{240}$

\section{Figure 6.13: Image of the London Police Graffiti Crew Painting a Wall as part of the 2010 Primary Flight Project}

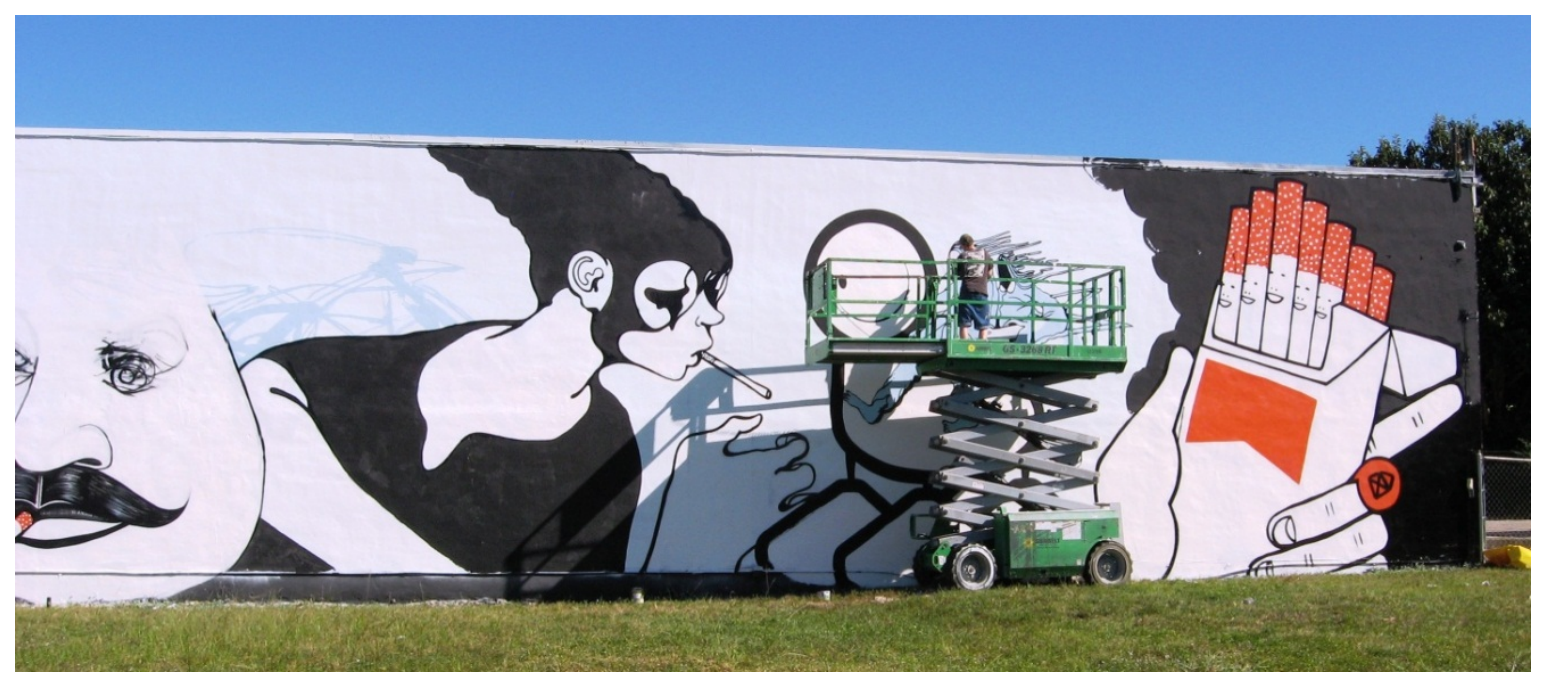

Source: Authors photo taken December ,2010. This version of the London Police crew included two British and one French artist.

Under the leadership of the Goldman family (Tony, Thea, and son, Joey), the Wynwood Art District Association (WADA) was re-created in 2008 as an effective business association that became increasingly influential in government policy processes. In 2010, it received a $\$ 100,000$ grant from the City of Miami in support of its operations as a neighborhood association (City of Miami 2010). As I will discuss below, the recreation and ascendance of WADA inserted it into city politics as another community

\footnotetext{
${ }^{240}$ Levi's also paid for her airfare but the British artists paid their own way. These were not starving artists. The French woman has a PhD in biology but had deserted an academic career for her love of painting and traveling. When asked about the quality of her traveling in Miami, she lamented that in a week she had "only seen giant walls" and, because of sponsorship arrangements, was boarding a flight out of Miami the following day.
} 
development organization, as its clout with local government crowded out other organizations.

While the original impetus for the 2003 edition of WADA was to promote the neighborhood as an art destination, the new edition of WADA focused on broadening the consumption base. Even though WADA did not have regular meetings during the interim years of 2005-2007, the website, art walk maps and other promotions continued to be published. The main order of business of the newly recreated WADA led by the Goldman was to lobby for the creation of the Wynwood Café District (Bojnansky 2008; Vasquez 2008). Technically a "cultural specialty district" under Miami's land use code, the Café District was an amendment to city's liquor license regulations to remove distance requirements between establishments that serve alcohol and thereby allow for the creation of a cluster of restaurants and bars. The specific Wynwood Café District established the boundaries within which up to 25 liquor licenses would be permitted according to the restricted distance requirements and waived parking requirements, which would have forced new restaurants to build or otherwise provide parking spaces. As reflected in Figure 6.14, the special district boundaries, expanded in 2011, were gerrymandered around the main cluster of galleries within the Art District south of $29^{\text {th }}$ Street and especially the Goldman properties. Indeed, Goldman submitted a map detailing plans for the properties his family owned as justification and assistance for the City Planning Department in drafting the ordinance (City of Miami 2008c). Goldman lobbied ${ }^{241}$ for this because they had plans to create two new restaurants along NW $2^{\text {nd }}$

\footnotetext{
${ }^{241}$ The Goldman's hired one outside lobbyist from a prominent law firm and registered two of their own employees (including son, Joey Goldman) as City of Miami lobbyists to support passage of the Café District Ordinance, according to the City's 2008 listing of registered lobbyists.
} 
Avenue, in the heart of the new district. The first new restaurant and bar, Joey's, opened in 2008 and a second, Wynwood Kitchen and Bar, opened in 2010. Another bar not owned by the Goldman's was opened around the same time within the district.

Figure 6.14: Map of the Wynwood Café District Boundaries as of February, 2011

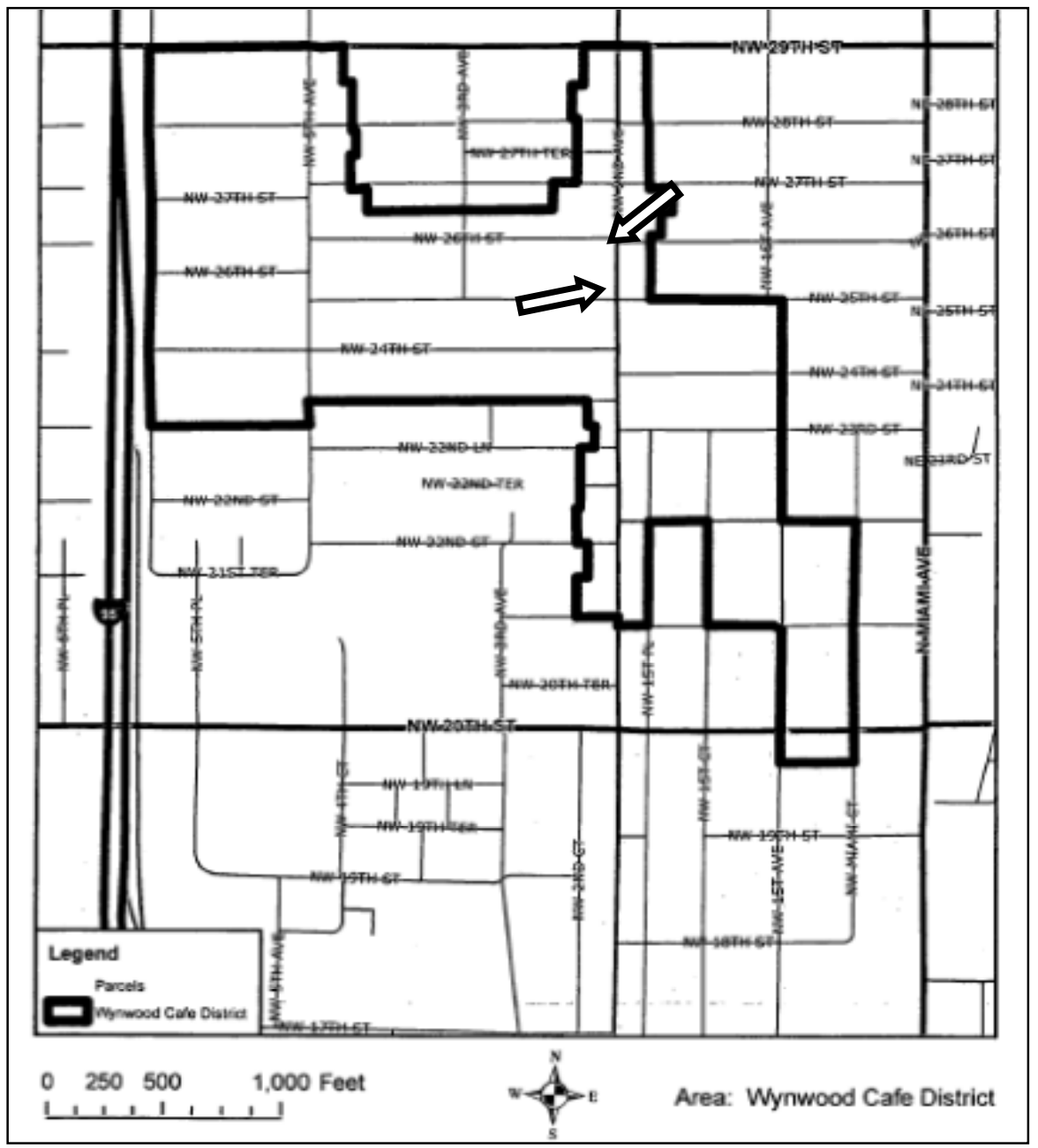

Source: From the City of Miami legislative archives, February, 2011. The section of Wynwood known as "Old San Juan" is located north of $29^{\text {th }}$ street (the upper limit of the map) and therefore excluded from the Café District. The arrows indicate the locations of the two Goldman restaurants (also see Figure 6.9). 
The creation of the Café District followed in the footsteps of other specialty districts in other City of Miami neighborhoods created with the same purpose. ${ }^{242}$ The Wynwood case, however, is unique because its creation and implementation were dominated by a single property owner - Goldman. There were hardly any opponents to the Café District. ${ }^{243}$ The owner of a "Southwestern-style" restaurant located on $36^{\text {th }}$ Street, outside of the proposed district boundaries, complained of the unfair competition that would result since he was only allowed to serve beer with food (City of Miami 2008a). However, his complaint was ignored and, as of this writing, he does not associate with WADA even though neighboring businesses do. ${ }^{244}$ None of the Puerto Rican or other small, Latino cafeterias, which have for years been harassed by the police and code enforcement for serving alcohol without food, ${ }^{245}$ voiced concerns about the ordinance, which also excluded them. (As I will show in a moment, they likely had no idea about it.) On the other hand, the city commissioner who represents the mostly African-American district, in which the majority of the Café District is located, insisted that the Goldmans conduct "community outreach" to obtain the support of other neighborhood stakeholders. A month before the final passage of the ordinance, she entered her concerns about the exclusion of Wynwood residents into the public record:

\footnotetext{
${ }^{242}$ The Calle Ocho Cultural District created in the Little Havana neighborhood in 2006, for example, allowed for more liquor-serving establishments along the popular tourist and consumption corridor in the symbolic heart of Cuban Miami.

${ }^{243}$ This is revealed in the City of Miami Commission meeting minutes from July, 2008.

${ }^{244}$ I heard this specific complaint in 2008 from the owner of Lost and Found Saloon when I ordered one of his micro-brews before having decided what I was going to eat.

${ }^{245}$ As I discuss elsewhere, patrons were sometimes fined and even arrested for drinking alcohol without food.
} 
While I am approving this on the first reading, I really expect for the City departments to really make sure that the community is very much involved in what [is] happening in that Wynwood area... There is a serious fear, a serious feeling of discomfort of them being pushed out further. So I really want to make sure those that are business owners within that area do whatever it takes to make sure the local organizations, the local associations, and the local groups are spoken to in those particular communities. It's extremely important... when this item comes back to us, we should have those residents, the folks that live in that area [and] that have businesses in that area out here supporting this particular issue. I also think that we need to... revisit the map [boundaries] because a certain portion of the community, the Wynwood residents that have been there for God knows how long are not even included in the new district plan... I just want it to be clearly understood that in order for you to have my support, which is the district Commissioner that represents most of that particular area... the Wynwood residents have to be involved and supporting it... This issue for me, you know, and not just in Wynwood, but Wynwood, Overtown, Little Haiti, and all of these areas where major development is happening, a lot of times these developments are happening in neighborhoods that are not considering the people that live there now... the Puerto Ricans, the Dominicans, Nicaraguans, all of these people are in my district that live in that particular area are not being considered when these major plans are being proposed.

A few weeks later, Goldman came back to the commissioner with 32 letters of support representing "a broad section of the Wynwood community" (City of Miami 2008a; see letters in Appendix). The letters were from 8 art galleries/museums, 4 community organizations, 16 business and property owners, and 4 residents (City of Miami 2008b). The 16 supporting business/property owners include clothing manufacturers and retailers, design studios, realty companies and property investors (many of whom own properties leased to art dealers), a used car dealership, an auto repair shop and an audio/video technology store. Of the 4 community organizations who wrote letters, one was WADA. The other three were Puerto Rican organizations - the Puerto Rican CDC, the Chamber of Commerce and the educational services organization (PRES, discussed later) located in the Puerto Rican Neighborhood Center. At the July City 
Commission meeting (2008a), the Puerto Rican Chamber claimed that two other Puerto Rican organizations - the health clinic and the senior center - were also in support. Of the four letters from residents, three are identical, typed templates signed by tenants whose addresses indicate they live in the same rental property north of $29^{\text {th }}$ street, in the "Old San Juan" section of the neighborhood. The remaining resident was hand-written by a tenant whose address was within Wynwood's warehouse district and the proposed Café District boundaries.

The letters reveal that the Goldman prepared templates for different categories ${ }^{246}$ of supporters (such as arts businesses, manufacturing businesses and Spanish-speaking residents) to edit, sign and submit to city policymakers. About half the letter writers left the template virtually unchanged. Some actually wrote original letters and a few made their support conditional (e.g., instead of 25, the number of licenses should be capped at 15). Every letter focused on the lack of pedestrian traffic in the Art District area during the day, and argued that foot traffic around restaurants would reduce crime. Some invoked Jane Jacobs' (1961) notion of "eyes on the street." About half of the letters noted the problem of the neighborhood's "desolate streets," such as the following paragraph, which was repeated in six letters:

The new influx of people will not only help my business, but also reduce crime. I truly believe that the desolate streets keep people away from the District. The new establishments will infuse life to an area that is on the verge of realizing its potential. The proposed Wynwood Café District will be the driving force in the area's success.

\footnotetext{
${ }^{246}$ The templates are detectable in the many letters that include exact copies of entire paragraphs, some of which I quote below.
} 
The other letters from area businesses were variations on the theme that new restaurant and bar patrons would fill the empty streets. The letters from residents were similar, although written in an awkward Spanish. The following translated paragraph comprised the three typed letters signed by residents who lived in the same Wynwood rental building.

We have received information about the opportunity to create cafés and restaurants in the Wynwood area, in which I am a resident of some years. I think that it will make [sic] a great opportunity as far as jobs are concerned, since it would create more pedestrian traffic in this area as well as the opportunity to combat crime, creating a greater future for our children.

Most of the 32 letters of support come from arts-related businesses, many of whom are part of WADA, or from other businesses and property owners who stand to gain from the increased "foot traffic." The major concern expressed by some of these businesses in newspaper articles, city commission meetings and even in some of the letters, was that the new Café District not usurp or otherwise crowd out the publicity of the original Art District. Once Goldman conducted outreach among the "community" of gallerists, these fears were assuaged (Morales 2008), as he clarified that the policy was not intended to create a competing slogan but to allow more liquor licenses within a concentrated area. ${ }^{247}$ Nevertheless, at the final hearing when the ordinance was approved, several long-time gallery owners in the area who ultimately supported the proposal wanted to state for the record that "we were here first" (City of Miami 2008a).

\footnotetext{
${ }^{247}$ No brochures, flyers or other propaganda for the "Wynwood Café District" have ever circulated, even though several restaurants and three bars now operate there.
} 
Regarding the Commissioner's concerns about consulting with "the people who

live there now," letters from four residents, none of whom are property owners, can hardly stand as evidence of significant resident support in a neighborhood of more than $5,500 .{ }^{248}$ So the commissioner's speech commending Goldman's outreach to the "whole community" during the final hearing seems contradictory:

[When this process started,] the biggest concern I had is that... the people that were born and raised in Wynwood that don't even know what's going on in the galleries most of the time are not being consulted with about what's happening in the area in which they grew up. I understand how [other gallery owners] can get on the microphone and say, 'you can't really call it a [new] district because... we had [the Wynwood Art District] before anybody else. [But] frankly, somebody had it before you had it, so those people need to be talked to. And I have to say that when I look at these letters... I commend you guys for getting those letters and making sure that there was serious outreach to the groups that really have the roots in the community. [But] my question becomes, how are we deciding where the map actually needs to go? ...I'm just going to give you an example and then I'm going to shut up because I can feel my Chairman breathing on my neck over here. NW $2^{\text {nd }}$ Avenue, which is a lot of small cafes all the way up to $36^{\text {th }}$ street, it seems as though the heart of Wynwood - I'm talking about the residents that were born and raised there - like they're not going to get any benefits out of it. [An administrative official explains that the map was created based on where the galleries are most concentrated] All right. That was my only comment, but I support it 100 percent. I'm glad that you guys are now making sure that the community, the whole entire community, is participating.

In between commending the Goldmans for their community outreach, the commissioner suggests that the small businesses on NW $2^{\text {nd }}$ Avenue that serve Wynwood's existing residents do not benefit from the proposed ordinance (which is actually the case). Goldman appears to have satisfied the city commissioner's request to include "the people that live there now" not because he reached out to four residents in

\footnotetext{
${ }^{248}$ According to the 2010 U.S. Census data for the two census tracts that comprise Wynwood. If we consider only the census tract where the Café District applies, the resident population is 1,212.
} 
two apartment buildings, but rather through private negotiations with the commissioner in which Goldman agreed to specific commitments that would enhance Wynwood residents' chances to benefit from the creation of the Café District. ${ }^{249}$ The most important of these commitments seemed to be "good faith efforts" to hire people from the neighborhood. ${ }^{250}$ When asked about these by a reporter, a spokesperson for the Social Justice Center, a relatively new activist organization in Wynwood, said that "if there is a true commitment to the community, there needs to be a 'community benefits agreement' ${ }^{251}$ with open consultation with residents, local businesses, and institutions" (Morales 2008), implying that "good faith efforts" are not enforceable and accountable to local residents.

The policy process that created the Café District is an example of how a new community organization has inserted itself into political territory in which decisions about Wynwood are made. The Goldmans and WADA make claims about what is good for the neighborhood and its residents. The Café District was the first moment when the gallerists were organized and mobilized to participate collectively in a policy process,

\footnotetext{
${ }^{249}$ The commissioner revealed that these negotiations too place at the second city commission meeting where the ordinance was approved.

${ }^{250}$ As stated, these included (1) working with an existing job placement program to hire "youths residing in Wynwood" as "ambassadors" of Wynwood during the Art Walks (i.e., hosts or ushers who help orient patrons) and to clean up after Art Walks; (2) participating in the Hospitality Institute Program managed by Miami-Dade College and the City's Community Redevelopment Agency, which links city residents with hospitality jobs; (3) "use good faith efforts to give preference in the hiring process to qualified residents of the City for non-construction jobs for each new business operated by Goldman Properties in this new district, with the goal of having Wynwood residents fill at least 25 percent of entry-level positions and 25 percent of managerial positions" and they promised to try to contract with qualified "local small businesses"; (4) attend "quarterly meetings of neighborhood businesses" hosted by the Puerto Rican Chamber of Commerce to address any concerns that arise in the neighborhood; (5) help the Chamber with the publication of an annual directory of businesses in Wynwood; (6) developer a security plan for the district; (7) meet with the Puerto Rican senior center to discuss the new ordinance with residents there.

${ }^{251}$ Community benefits agreements are contracts signed by community groups and a real estate developer that requires the developer to provide specific amenities or other concessions to a defined community. In exchange, the community groups will support her project at least not oppose it (see e.g., Baxamusa 2008).
} 
even though the Goldman's did most of the legwork. Moreover, WADA's organization occurred just at the moment when government agencies and services were contracting, increasing the competition to get city officials' attention. For example, during the last decade, the Wynwood Community-Based Policing (CBP) office gradually contracted, first by losing its public service aid, a key liaison between residents and government, and eventually when it was consolidated into the CBP office of neighboring Allapattah. ${ }^{252}$ This undermined the purpose of the CBP system to be a "mini city hall" inside of neighborhoods, reducing the distance between residents and city agencies. It also overwhelmed the CBP directors. As Levine put it, "it got lumped in with the Allapattah [CBP] office [where the director] is a wonderful guy but it's too much - you can't take a guy who has a big area called Allapattah and throw him into Wynwood and Edgewater and lump them together and not give him extra personnel." The current CBP office director said that responding to WADA and covering the rest of his terrain is overwhelming, noting that "I receive maybe three, four, five, six emails a week from [WADA]. So [we're] very close. Levine: he knows that he can just call me right away. Thea, ${ }^{253}$ they're all hooked up with me here.” When I saw him a few months later at a funeral for Elsa, the longtime Puerto Rican activist, and asked how he was doing, the CBP director let out a sigh and responded, "I'm always getting calls from WADA." He added that "Wynwood is the next South Beach" and therefore he is also inundated with calls from developers who need help with building permits. During our earlier interview

\footnotetext{
${ }^{252}$ In 2004 the Clemente Park Community Center, where the CBP office was located, was condemned and closed (which I will discuss below). The CBP officers and other staff worked out of trailers until 2008, when the CBP system contracted and Wynwood's CBP functions were folded into the Allapattah office more than 20 blocks away.

${ }^{253}$ Thea is Goldman's ex-wife.
} 
he explained that WADA is better able to deal with government retrenchment than the lower-income residents of Wynwood.

I think [by] removing the CBP office from there, groups like WADA do not suffer because, you know, we're a little further over here or over there, you know, but there is communication by email, by phone, and they're very aggressive. But definitely, Wynwood, you know, I'm seeing a great absence. Elsa [the long-time Puerto Rican activist] is already 101 years old, poor thing, she can't do what she used to do. And what I see going on in the neighborhood, I don't know... ${ }^{254}$ Definitely there is a lack of enthusiasm... not by the 'cultural part' [art district] of Wynwood but rather the residents that live there. We need something more.

As I will also examine in the next section, there is a widespread perception that Wynwood's residents are disengaged from government processes and, as the CBP director suggests, from taking care of their streets. Increasingly, organizations like WADA step into the space provided by such disengagement, to the point of literally cleaning the streets (see below), creating a "win-win situation" according to the CBP director. In the case of the WADA-CBP office relationship, the win-win situation refers to the fact that "the city is cleaner" and city agencies "have more control," as the director put it. In exchange for its assistance in securing the neighborhood, WADA is increasingly accepted and supported as one of Wynwood's community-based organizations.

The scene at a recent Town Hall meeting in May 2011 at Roberto Clemente Park revealed the shifting balance of neighborhood stakeholders. The meeting was called by the City Mayor to hear from Wynwood residents. But about half of the 30 attendees and the most vocal participants were realtors, developers and gallerists. Six were elderly residents who walked to the meeting. The rest were city staff, police and representatives

\footnotetext{
${ }^{254} \mathrm{He}$ was also referring to recent complaints from residents about a surge in heroin dealing along NW $2^{\text {nd }}$ Avenue.
} 
from neighborhood service agencies. A few days earlier, Levine had joked that he planned to attend "as an honorary Puerto Rican," but he did not attend. During the meeting the Mayor summarized in English and Spanish how his staff had solved a list of problems previously brought to his attention by residents. He then gave the speaking turn to four elderly residents who, each addressing the Mayor by his first name, complained about trash in the streets, drug sales on NW $2^{\text {nd }}$ Avenue, cars blocking their driveways, power lines caught between tree branches and other "quality of life" problems, as the Mayor described them. During these exchanges in Spanish between the Mayor and the elderly residents, the chatter increased among other meeting participants who grew restless, causing the Mayor to physically move closer and closer to the residents until he took a seat in the row in front of them. For the remainder of the meeting, different property owners south of $29^{\text {th }}$ Street raised their own concerns in English and even made some proposals. One commercial property owner suggested the city create a special taxing district to improve infrastructure and support the expansion of restaurants, to which the Mayor responded, "hey listen, if you wanna pay, I'll see you tonight." The mayor then projected his voice to the broader audience and said in Spanish, "If we have more business, we have more jobs. And if we have more businesses and more people coming to the area, the bad guys can't do what they do." Switching back into English, the discussion turned to crime prevention and a disagreement arose over the extent of city police protection. While the police commander for the area asserted that "policing the area is difficult to do with the current resources, outside of special events," Harold, a major commercial realtor in the Warehouse District and a former garment manufacturer, retorted, "You got to understand that because of the Arts District, taxes have gone up, 
values are up, so we're entitled to extra policing." Then Goldman, who arrived late, sought a consensus that would benefit WADA: "We cannot expect the city to do it all. We're proposing to be partners in watching out for crime. If you find $\$ 100,000$ in the next city budget, we have property owners [WADA] who will match it. We will supplement that with eyes on the street."255

The Town Hall meeting, the first held by the current City Mayor, was a microcosm of the changes in Wynwood. The spaces traditionally used by neighborhood residents, such as Clemente Park, increasingly become venues where art district stakeholders make claims to entitlements, such as increased police protection. Such claims ignore the fact that it requires capital to invest and raise property values; yet, investment and property value impacts are cited as the rationale for increased police protection. This logic slips into the argument that poor people, lacking the capacity to raise property values, may not be entitled to increased protection, too. But this contradiction is made to be invisible partly because meetings such as the Town Hall are conducted in Spanish and English. Some points are lost in translation. As I walked with the elderly residents back to their houses after the meeting, all expressed positive impressions of the art district stakeholders and agreed with the Mayor that they brought jobs and security to the neighborhood. As I discuss below, the extent to which such benefits are realized, and by whom, is highly uneven. This is especially true when it comes to security, as WADA hires private security services to patrol the Café District and related events.

\footnotetext{
${ }^{255}$ Since the city granted WADA the same amount in 2011, it seems likely they will do so again in 2012 (the Mayor confirmed as much at the end of the meeting).
} 


\section{Figure 6.15: Image of one of the Private Security Vehicles within the Wynwood Arts District Patrol}

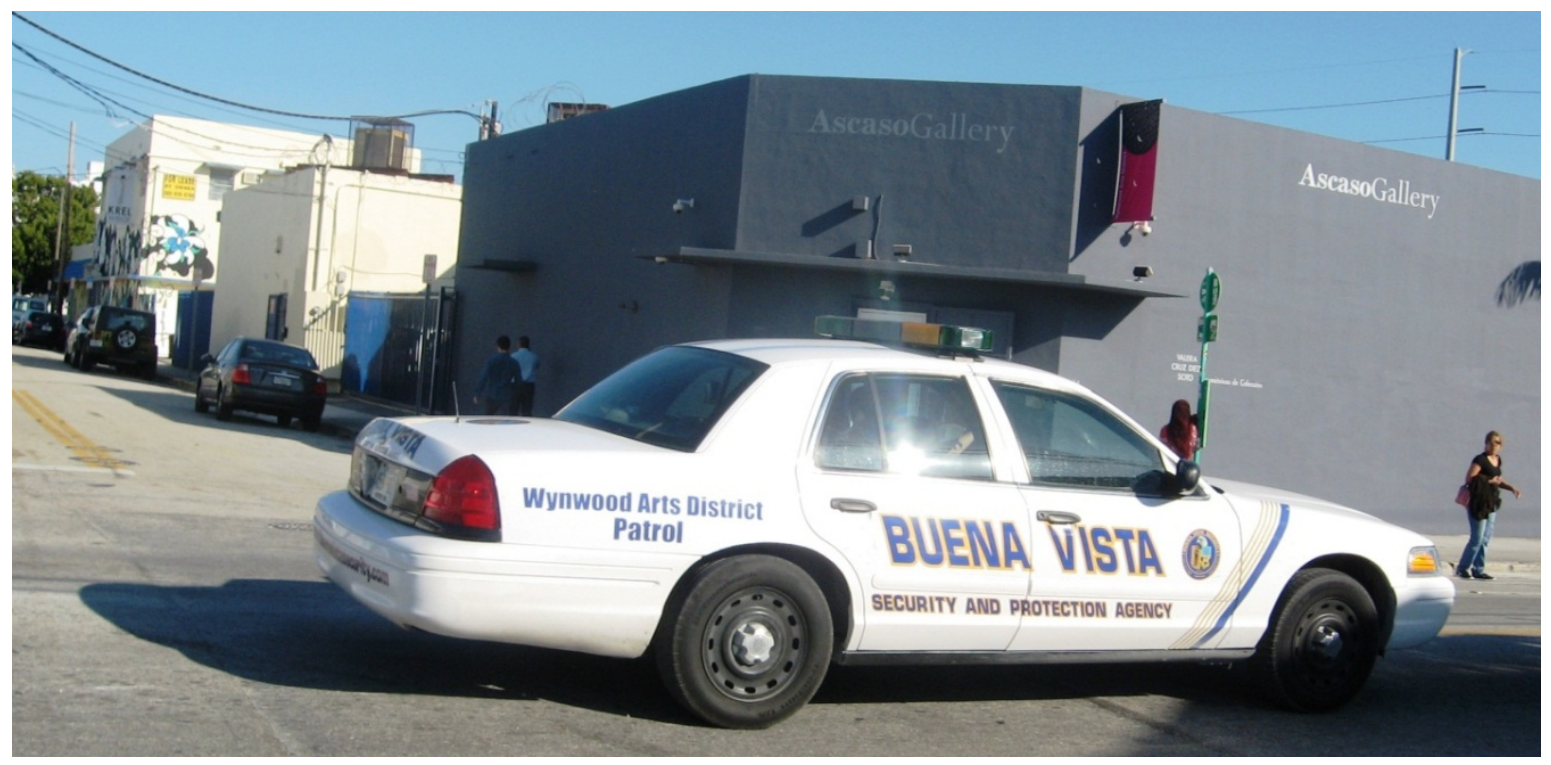

Source: Authors photo taken February, 2011.

Regarding direct economic benefits, there has been no monitoring or other followup research to evaluate the extent to which the Café District or even whether the broader Art District provides employment or other benefits to Wynwood residents. However, there are a few examples of gallerists and developers hiring locally and generating other economic benefits for local residents. The most obvious examples are residents who can be seen cleaning, painting and performing other handy work in the art district. George, who moved to Miami from Honduras about five years ago, is a handy man hired by and renting an apartment from Levine on the north edge of Wynwood. ${ }^{256}$ When I met him in December, 2010, he was painting over unwanted graffiti on the side of a warehouse but he also picks up garbage, patches roofs and other construction work. During the winter,

\footnotetext{
${ }^{256}$ Levine does not own the buildings that George cleans or rents an apartment in. George named him as the boss because that is who pays him and collects his rent. Levine's company provides property management services to commercial and residential property owners.
} 
the peak of the art season, George works from dawn until dusk (winter hours), five days a week at $\$ 100$ per day, paid in cash. As long as work is steady, he makes about $\$ 2,000$ a month, and splits the $\$ 735$ monthly rent for a 2-bedroom apartment with his brother and roommate. His only major expense other than rent is food, as he relies on a bicycle for transportation; most of what remains from his monthly income he sends to his wife and child in Honduras. Although he was earning more money working with construction crews before the economic recession set in, he claimed to live very comfortably in Wynwood and even insisted on staying in the neighborhood when his brother wanted to move closer to Biscayne Bay.

The Goldmans, Levine and gallerists have contributed to social service programs, particularly free art training for children. Levine listed the ways he has cultivated relationships, or at least a certain reputation, with existing residents.

The old-time residents have welcomed [us] because we helped the schools, which in turn helps the community. We do a lot of things for the Hartner Elementary School. I do an art show every year of the students' art work. I draped the back of Museo Vault [an art storage building he owns] with their art work. We put it up banner size and you can go by and read it - it says, created by the arts students of Hartner Elementary. The local CBP officer hits me up for money for turkeys every year at this time. I have an intern from the young men's preparatory academy three days a week after school. He's in $11^{\text {th }}$ grade. So we want to be part of the neighborhood. We don't want to be isolationists. We want to ingratiate ourselves to the neighborhood and we have. I think for that reason, the community has taken to us well. Chuck and his twin brother have grown up in Wynwood their whole lives. They do all my maintenance, anything for the association, hanging the banners, I hire them.

During my interview with Melissa, the former CBP office director, her voice began to tremble with emotion as she described how, during the creation of the graffiti murals known as Wynwood Walls, Goldman and some internationally renowned graffiti 
artists invited some children and teenagers from the neighborhood to paint with them. "Any millionaire can bring masters. Not all of them let the kids paint with them. It touched me so much." Thea Goldman who, together with her son, owns and manages Joey's restaurant, has raised money for the Lotus House thrift store and shelter (operated by Mrs. Margulies, of another art collecting family) to hire homeless women as street cleaners, initiating a program known as "Women of Wynwood." The women, who patrol two at a time, wear pink smocks as they push rolling garbage cans up and down NW $2^{\text {nd }}$ Avenue where they have been seen picking up trash. Yet, several residents I interviewed were critical of the Women of Wynwood because they do not believe they are neighborhood residents. One respondent, a man from the Canary Islands who owns and manages a rental property on the strip of $2^{\text {nd }}$ Avenue where the women clean, cited the fact that the women were Black (by which he meant African-American) as evidence they are not from the neighborhood (his own tenants are Haitian). He and others also questioned whether the work program is effective in cleaning the streets. For example, two sisters who live across the street from Clemente Park began to argue about the Women of Wynwood when I asked if the Art District had generated employment opportunities for neighborhood residents.

Sandra: [The Women of Wynwood] is about the only thing. I've seen them. Gema: Where? They were supposed to be working, cleaning around $30^{\text {th }}$ and $5^{\text {th }}$ Avenue. I saw this [piece of] wood sticking out from the sewer opening. You cannot even make a turn because that branch was just sticking out. And I'm like, 'what are these women waiting for?' And I remember telling them, 'look, that's been there for awhile.' What are [they] waiting for to get rid of it?

Sandra: I haven't seen them around. I know that once they come here to work, they disappear. You don't see where they go. I don't think they're from here. I think they just put the Wynwood [label] because they're doing their job here. 
Gema: They [the gallerists] don't give a damn, all they want is money. And then they want to take people's properties away from them. Because they wanted to take Jose's Fruit Stand for the gallery. They also wanted to take the corner house for a gallery.

Knowing that the Women of Wynwood are associated with major gallerists and developers, the sisters were highly skeptical about their work in the neighborhood, viewing it as an extension of the gallerists' penetration into the neighborhood's property market.

Stories about how gallerists have tried to "take over the neighborhood" abound in Wynwood. As I will explore in greater detail below, many residents complain of the increased automobile traffic, congested street parking (unlike wealthier neighborhoods, there are no residential permit parking zones in Wynwood) and the trash found strewn throughout the streets the morning after Art Walks or major art fairs. During 2008, a satellite art fair called Scope occupied Roberto Clemente Park during the week. Although it was criticized for the aforementioned reasons (added traffic, noise, garbage), and for tearing up the grounds of the park, many recalled that Scope had hired several neighborhood residents to set up and clean and had given away free passes to residents in the vicinity of the park. 


\section{Figure 6:16: Image of a Construction Site with a "No Hiring" Sign in Wynwood}

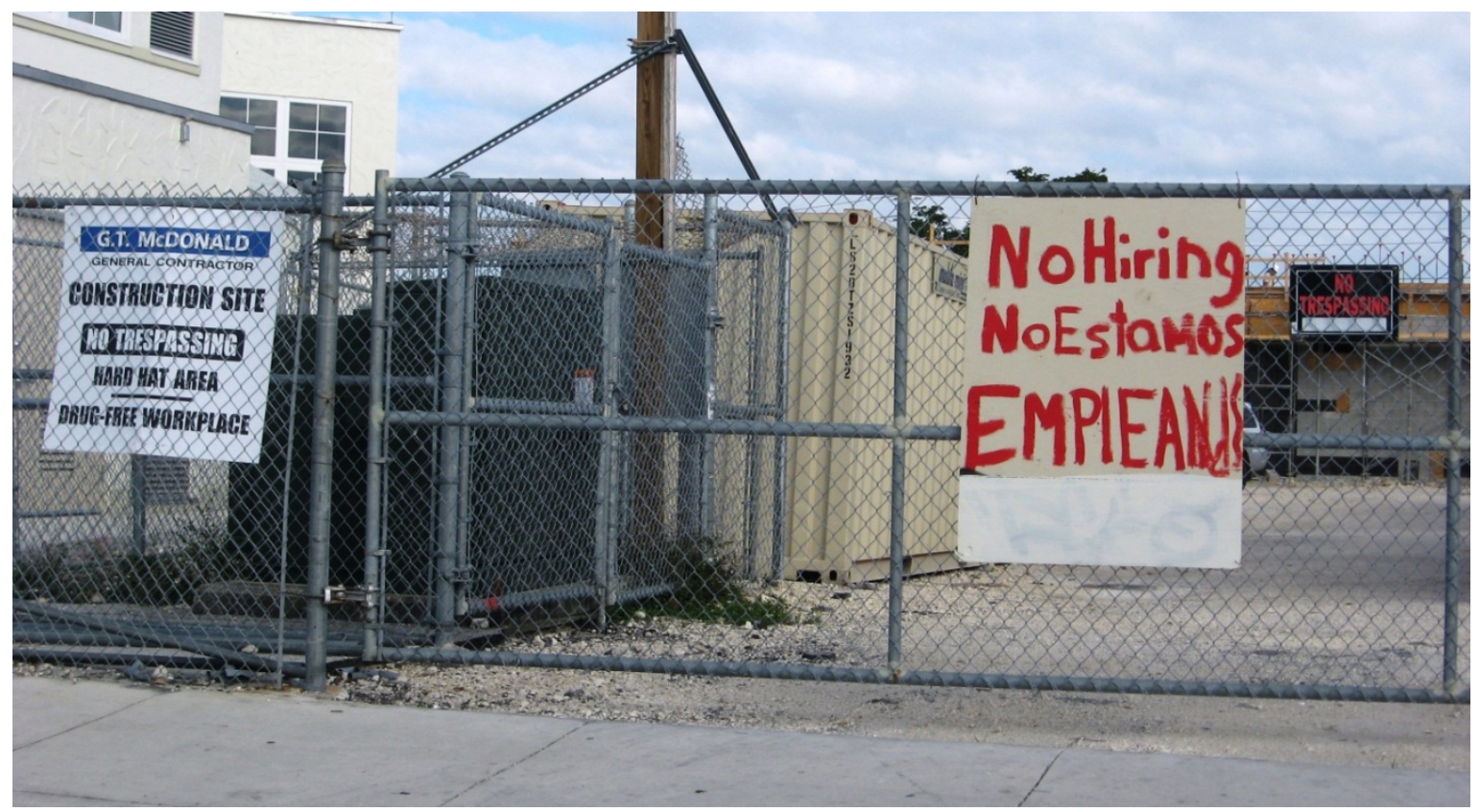

Source: Authors photo taken October, 2007. The need for work was apparently so great that a construction site in the center of Wynwood advised workers (in English and Spanish) not to bother applying.

The hiring of a few neighborhood residents to service Art District activities is clearly not a means of upward mobility. Even as a reliable source of income, the benefits of the "arts economy" for Wynwood residents are dubious. As was the case with the Midtown complex discussed previously, the few employment opportunities given to Wynwood residents within the "arts economy" function more as good community and public relations, particularly because of their impermanence. As for benefits to small business, described below, the arts economy pulses during brief periods of the year. Moreover, the relationship in which benefits accrue to workers and residents is hierarchical; residents and workers have little say in the process. This exclusion is especially true for the many Central American immigrants who live in Wynwood, even 
though some of them clearly benefit from jobs painting, cleaning and other handy work in and around the arts economy.

During pick-up soccer games at Clemente Park, I met other Central American immigrants who did similar work to George in the Art District. Their occupations were easy to deduce from the paint-spotted jeans they played in. Not all were as optimistic about the economic benefits of the art district as George. One man eventually quit working for the owner of a warehouse who had not paid him in three weeks, thereby surrendering his wages. ${ }^{257}$ For undocumented workers, confronting the boss would be unwise because, as another Costa Rican immigrant explained, "before the recession nobody asked for papers." He did not mean to suggest that art district employers ask for documentation but merely that the threat looms larger in a struggling economy, particularly as stories of deportation raids circulate in Wynwood. Sandra and Gema, the Puerto Rican sisters who have lived across the street from Clemente Park for more than 20 years, have seen and heard of many deportations.

Sandra: It's kind of sad what's going on because all this immigration thing going on, not having legal documents, a lot of houses are actually for rent now in Wynwood because people are being deported or the people are moving out [for fear of being deported]. What happens, unfortunately, I've met people personally where, OK, maybe you had a problem with your neighbor and that neighbor decided to get even with you, I will call immigration [authorities] and they will bust you. And I know someone from the corner of $34^{\text {th }}$ and $1^{\text {st }}$ Avenue, that they called immigration on them. And they took her. And if you asked [immigration authorities], they said, "Well, we received a call."

Gema: [It's] nothing new, unfortunately.

Sandra: My sister can tell you, I have a lot of Central American friends and some of them don't even have documents, and coming to Wynwood was very scary for them. When immigration [authorities] started picking up all these undocumented

\footnotetext{
${ }^{257}$ For more on the widespread problem of, and solutions to wage theft nationally and in Miami, see research by Bobo (2009) and Hernandez (2010), respectively.
} 
people, it was very tough, because they no longer wanted to come to the park and play soccer. We haven't been back here, you know, with the group that we used to have because they're afraid of, "oh, maybe somebody's going to call immigration." So that actually has messed us up [as a community]. I think the beginning of this year was one of the worst. I saw people at Jibarito [the Puerto Rican grocer], you know, immigration [authorities] going in there, asking for documentation of the employees. They actually deported, I think, they deported two women. They took them out of Jibarito because they didn't have papers.

Jose's Fruit Stand, mentioned above, was threatened not so much by gallerists but by the city's building code department, which in 2006 began citing him for not cleaning up the environmental contamination in the ground of the former gas station where he operates despite the fact that Jose has owned that property and operated the market there since $1989 .{ }^{258}$ However, the building across from Jose's Fruit Stand became home to artist studios in 2008 and prior to that was the subject of intense real estate speculation that disturbed the popular neighborhood beauty salon on the first floor. The building was owned by Felipe ${ }^{259}$ since the late 1970 s but sold in 2005 for $\$ 618,000$ to a developer with plans to undertake major renovations. The Argentinean owner of the beauty salon downstairs, who had been styling hair in the neighborhood since 1980, explained to me that her lease was not renewed and because her business depended on loyal clients, she had to seek another viable commercial space nearby. Several months later, after investing more than $\$ 5,000$ in her new venue, she realized that a contractor had installed the wrong plumbing and the City of Miami rejected her business license to operate the beauty salon. She then returned to her former landlord to ask about the status of the building, desperate to reestablish her business and generate some income. She was told that she could return

\footnotetext{
${ }^{258}$ This apparently happened in connection with complaints about the dumpsters full of decomposing produce from the homeowner who lives behind the Fruit Stand, according to several informants.

${ }^{259}$ Recall that he is the Puerto Rican businessman and former resident discussed in Chapter 3.
} 
but that should she would "need to be patient through all the renovations, that there was going to be crews and dust and trucks, and that I might even have to close a few days, once in awhile." Instead, in 2007, before any construction began, the economic downturn caused the developers to cancel their plans and sell the property to a gallerist for the same price. "So," she concluded, "the housing explosion cost me five thousand dollars," not including several months of lost business income.

\section{Figure 6.17: Image of the Argentinean-Owned Beauty Salon below an Artist Studio}

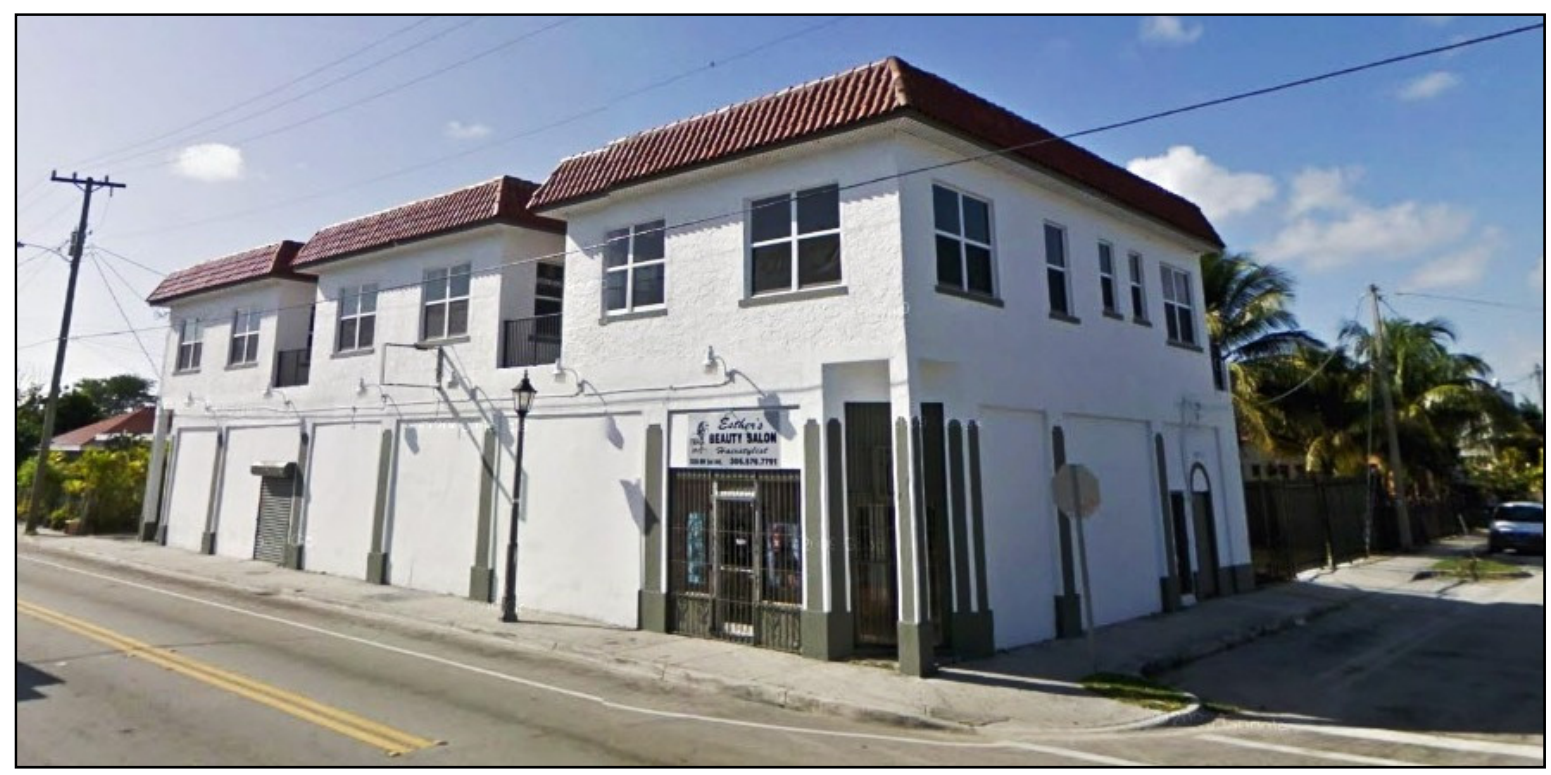

Souce: Google Street View image (2008). Across the street from Clemente Park and a popular Fruit Stand, the "white building," as it is known to some residents, is home to a popular beauty salon and, recently, an artist studio upstairs.

Further systematic research is needed to understand the extent to which neighborhood businesses that serve Wynwood residents benefit from the Art District and Café District. In brief conversations with the owners of four neighborhood business (two discount stores, two sandwich shops), an interview with a cafeteria owner and my own experience as a resident and patron of various restaurants, I found that the 
neighborhood's cafeterias and small businesses benefit in largely indirect and highly inconsistent ways, such as when the area is "cleaned up" during special events. For example, the Cuban-owned Enriqueta's sandwich shop, a very popular and cheap lunch spot on the eastern edge of Wynwood (most clientele do not live in Wynwood), reported that they made less money during art festivals and opted to close an hour earlier than usual ( $3 \mathrm{pm}$ instead of $4 \mathrm{pm})$. The owner of the most popular small eatery in the heart of Wynwood estimated that about half of his clients live in the neighborhood while the other half work nearby. He indicated that during the annual art festivals new customers who he believed to be art consumers - "Europeans," he thought, because of their accent stopped into his cafeteria for small items such as coffee, water or cigarettes. He noted that the only year this business was substantial was when in 2008 the Art Basel satellite fair, Scope, was held in Roberto Clemente Park, two blocks from his business. Two dollar store managers on the block had similar views, having benefited from spillover traffic in December of 2008, typical sales including cans of Coke, cigarettes, cigars or bottled water. All these business owners expressed that the main benefit of the growth of the Art District has been to help "clean up the neighborhood," even while acknowledging that police presence is greater during special art events and "they hardly do anything" during the rest of the year. Some restaurants seem to have no chance of drawing customers from the Art District events. I was walking east down $29^{\text {th }}$ Street during the 2010 Art Basel festival when I noticed the Central American manager of the Boricua Café, one of the few remaining Puerto Rican cafeterias in the neighborhood, learning out of the small coffee window yelling in her accented English, "Happy hour! Happy hour!" to no avail. Her cafeteria, located across the street from the Rubell Family Collection, was empty 
except for two children sitting at the back. With a shrug of her shoulders, she explained that tourists and art patrons never stop in, but she still tries. On the other hand, newly arrived merchants in the historically residential part of Wynwood north of $29^{\text {th }}$ Street, are keen to capitalize on the growth of arts patrons. A Bangladeshi man who bought and renovated a small Puerto Rican cafeteria along NW $2^{\text {nd }}$ Avenue explained that after "cleaning up the place," his first order of business would be to offer cheap, traditional Indian dishes and distribute a new menu to the galleries and artist studios south of $29^{\text {th }}$ Street. His only employee, a Puerto Rican woman who grew up in the neighborhood, acknowledged that the first Indian restaurant must be viewed as a sign of how Wynwood is changing. 


\section{Figure 6.18: Image of the Boricua Café, one of the few remaining Puerto Rican Cafeterias in Wynwood}

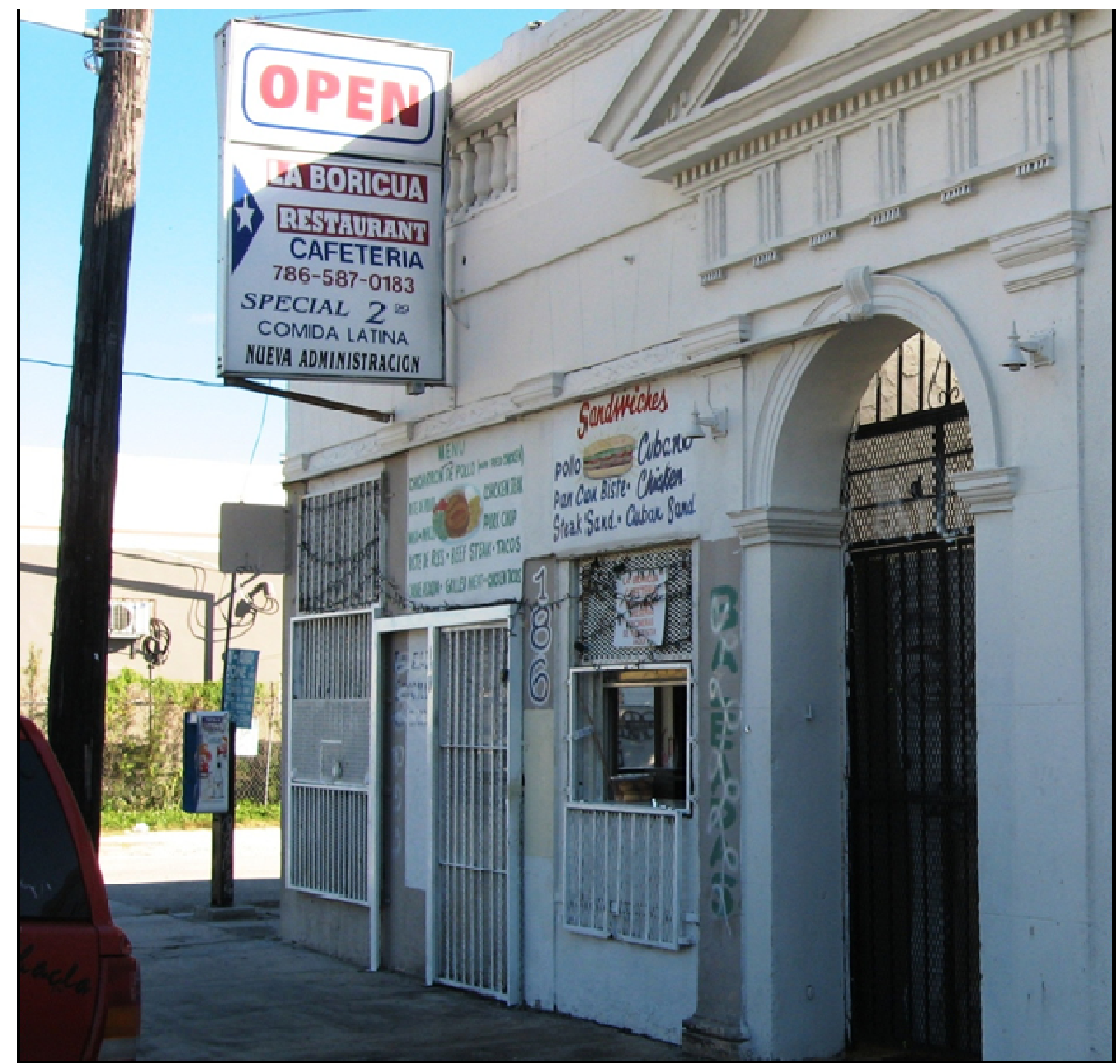

Source: Photo by author on a Saturday evening during Art Basel, December 2010.

These few examples are not meant to evaluate the extent of the costs and benefits to neighborhood residents and businesses of the growth of the Art and Café District in Wynwood. But they do suggest that the reality of the changing contours of the neighborhood does not match the rhetoric of an inclusive transformation (in which the "whole entire community" participates) espoused by the new Arts stakeholders, city officials and other enthusiastic proponents of the new Wynwood. More than this, however, the above examples of "cultural production" processes reveal the growing political clout of WADA and the "arts economy" in Wynwood. The arts sector's 
penetration into the political terrain of the neighborhood has proceeded not only by virtue of the production of events, boundaries, commerce, and so on. The creation of the Art District has also involved the removal of social and physical obstacles in order to enhance the profitability of investments.

\section{The Teamwork of Neighborhood Redevelopment}

Levine is known for saying that Wynwood is an ideal "clean canvas" for redevelopment (Del Campo 2006), a phrase parroted in newspaper articles and headlines (“Wynwood a Blank Canvas for Urban Renewal," Shepherd 2009). Wynwood has come to be seen this way because of the aesthetic qualities of large blank walls, which, once painted, transform the neighborhood into "the world's first outdoor museum" (Duran 2010). But Levine means more than blank walls and empty warehouses. He also refers to the political environment in which, as he says, "getting shit done" (see below) is made relatively easy. In Chapter 4, I described how the depopulation of Wynwood's warehouse district was carried out by a combination of the failure to implement economic development programs, public and private sector disinvestment from, and housing demolition. In the remainder of this section I examine examples of the more recent forces that have helped remove obstacles to the rooting and growth of an art district. It has also been made possible through collaboration with city agencies. The following is illustrative of such an example facilitated by the CBP office.

Levine: When I was new here, [Melissa] was invaluable at getting shit done. I'll give you an example. I had a building where the tenants were taking over the "asylum." They weren't paying me, they were selling drugs out of there, prostitution, and I did a quick and dirty analysis with my partner and said, you 
know, we should tear this fucking building down. We'll lose less money without them there. And this building was a big problem for the police. [It had] eight units. And the police were fed up. I called Melissa [and] said, "I want to tear the building down." She goes, "when?" I said, "As soon as possible." She goes, "Let me get [Joe Gonzalez] ${ }^{260}$ over, the policeman." The policeman comes over, he goes, "Levine, realistically, when?" I said, "a week from today." He said, "Great." I said, "I'm going to park a backhoe in front of the building tomorrow." I parked a backhoe, I told 'em [my tenants] (and he raises his voice as if yelling outside the building), "I'm tearing the building down. You're all going to have to fuckin' move." (He acts out their response.) "Fuck you! You're not tearing that building down. You're a joke. We're gonna keep this fuckin' building, buddy."

Marcos: Did you have to do a formal eviction?

Levine: Nothing. Parked the backhoe. The demolition guy pulled a permit. ${ }^{261}$ Took him five-six days to get the permit. I called Gonzalez, I said, "Joe, I got the permit." He goes, "Great, I'll be there in 20 minutes." We knocked on every door, told them to pack their shit and get out, that the demolition was starting in three hours. And they were like in disbelief, but with the policemen they had to listen. All eight of them were on the sidewalk with their worldly possessions. The guy started the backhoe up, started tearing into the building three hours later.

\section{Figure 6.19: Images of Vacant Lot where Housing was demolished by Levine}

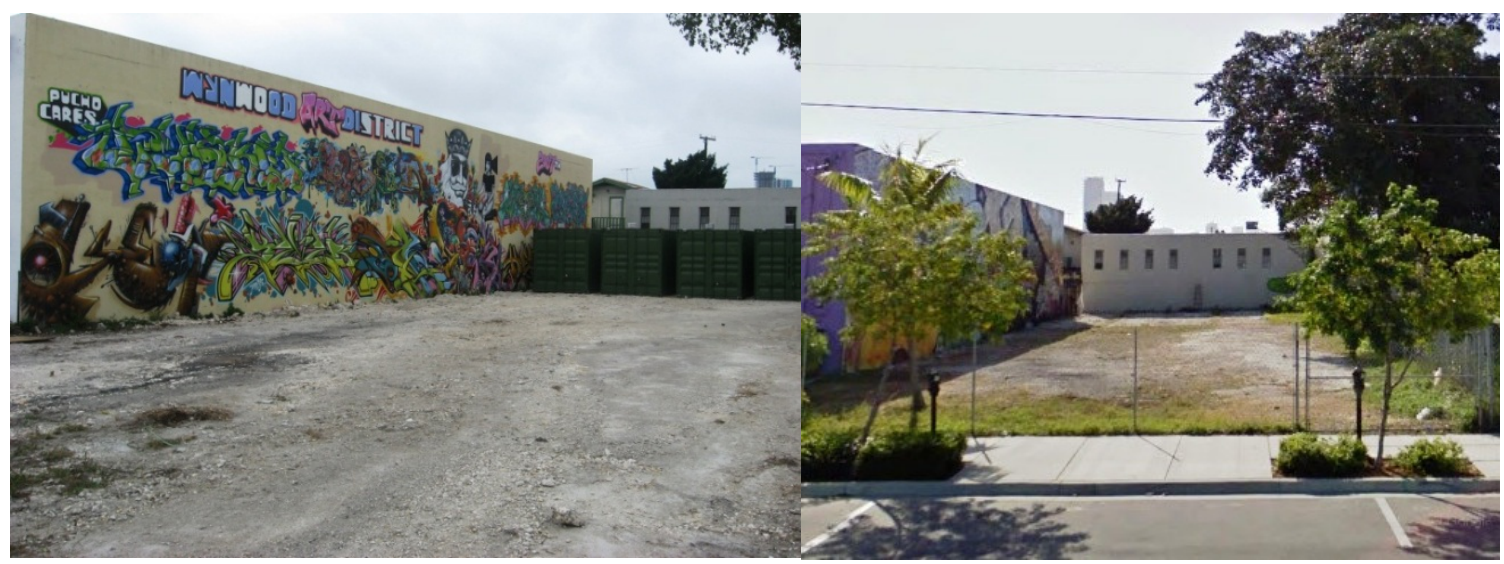

Source: One of the first photos I shot in Wynwood in 2008 (left) was of a mural facing the lot where Levine's building once stood. The image on the right, captured from Google Street View (2010), is of the entire property.

\footnotetext{
${ }^{260}$ Not his real name, this refers to the community-based policing officer for Wynwood - the same position held by Bobby who had moved on to become chief of security for the Midtown complex.

${ }^{261}$ He told me the exact location of the building, which I have omitted from this passage. Records from the City of Miami Building Department confirm the permit and "total demolition" of the building late in 2004.
} 
Similar to the Catholic Church leaders and members discussed earlier, the next generation of "pioneers" on the "urban frontier" of Wynwood endeavored to tear down dilapidated housing. Melissa proclaimed, "My first year here, we demolished 11 unsafe structures," and not only by working with Levine, but also at the behest of a neighborhood association in Edgewater that "did a lot of bulldozing of crack houses." Levine had many examples of "early Wynwood," when "you could do whatever you needed to do if you were bettering the neighborhood" because the local government was "desperate" for revitalization. "I was taking buildings full of animals and I was evicting 'em all, cleaning it up, rebranding it, repositioning it, bring in better tenants." The following example also reveals how such work sometimes went beyond dealing with tenants, with implications for neighborhood residents and the broader public. ${ }^{262}$

I had a bus stop in front of a building of mine, which shall remain site-less. The bus stop was a problem for me because the retailer in the space there on the corner was always being bothered by these people that wanted change, they would lean up against the building and block his windows, waiting for the bus. So on a weekend, we decided, we moved the fuckin' bus stop. We jack hammered the pole out of the ground. We moved it 50 yards west. Cemented it in. Moved the bench and by Monday, the bus started stopping up there. Problem solved.

As the neighborhood contains a concentration of thrift stores, soup kitchens and a major homeless assistance center and shelter, a major focus of the CBP office's work has been reducing or masking the presence of persons who are homeless in order to facilitate the construction of the image of an art district. Even though this continues to be one of gallerists and arts proponents major complaints, the current CBP officer is adamant that

\footnotetext{
${ }^{262}$ Although I could not confirm this example because he hid its' location, Melissa also independently made reference to the "bus stop" story.
} 
the "numbers have been drastically going down," although he had no idea where they

these individuals might have gone in the middle of an economic recession.

Melissa: There was a lot of homeless people around [the shelter] - a lot of encampments on those lots that nobody wanted back then. I remember across from where SoHo studios, there was an actual homeless house. They're very creative, obviously. They had little appliances. They had stuff like that. You know, and I had to go and take that out.

Marcos: How did you feel doing that work?

Melissa: It's hard. But you know what? Pushing forward a neighborhood is hard. Here's how I think about it. And I'm kind of weird. OK? And having kind of been exposed to it, this is how I can reconcile it. Do you remember the lands of like, fiefdoms and manors and all of that stuff? You had the people that lived within the manor. But then you had the people who lived in the forest, right? And they lived in the forest because they weren't happy with the rules of the manor or the fief. There you have it. We ain't got no forests. But we have ignored spaces and that's where those people gravitate to. Ignored spaces, frontier spaces.

It is not clear what the analogy accomplishes other than clarify the emphasis on interventions upon those who disobey rules. She later opined that people who do so, particularly in the case of homeless encampments, are drug addicts who have gone crazy. ${ }^{263}$ Here the imagery of the frontier individualizes the symptoms and causes of disorder, rationalizing interventions upon individuals. In Wynwood, asserted Melissa, "people, business men and women gotta have balls or they're not going to make it," noting that the typical characters in early Wynwood were "developer types and people who carry guns."

The pioneer character and the frontier concept pervade narratives of neighborhood gentrification (Lees, Slater and Wyly 2008). The pioneer on the urban frontier was longago exposed by researchers as a "myth," since "it is apparent that where the "urban

263 "I asked the cops once. I kept thinking, what comes first, the madness or the drugs? Unequivocally, they said: 'Drugs, homeless, madness.' [Marcos: But what comes before the drugs?] Oh well, I'm sure there's a whole bunch of... everybody's personal drama!" 
pioneers' venture, the banks, real-estate companies, the state or other collective economic actors have generally gone before" (Smith 1986, p. 18-19)." ${ }^{.264}$ Nevertheless, the myth persists and in the case of Wynwood, it is precisely these collective economic actors who consider themselves the pioneers operating on the frontier.

It was private sector, art, government, media, frontier. Wynwood is a frontier place. Anything can happen. You've got a big industrial part that doesn't have a lot of residents nitpicking about... you know, you've got a lot of renters, so you don't have a lot of people with the traditional stake in American civics. Right? So it's media, government, private sector, art and frontier. ${ }^{265}$

The mythical narrative survives, adapted to fit the well-resourced public-private partnerships of contemporary urban development, because "the imagery of frontier serves to rationalize and legitimate a process of conquest, whether in the $18^{\text {th }}-19^{\text {th }}$ century West or in the 20th-century inner city" (Smith 1986, p. 17). In this case, it is also clear that renters and people "without a stake" refer to the high proportion of immigrants in Wynwood. As Nijman (2011) has argued elsewhere, high rates of transience lead to low civic engagement in Miami. But as we see when contrasting Melissa's account to Marta's, below, the arguments about disengaged publics, "people without a stake" in their place in the world, function as a justification for ignoring them, removing the

\footnotetext{
${ }^{264}$ In particular, Smith (1986) noted "the importance of urban development to national and international recovery [in the 1980s, made] acutely clear in the enthusiastic language used by supporters of the urban Enterprise Zone, an idea pioneered by the Thatcher and Reagan administrations." It was precisely the Wynwood Neighborhood Assembly, the governing body for implementation of projects within the Empowerment Zone (EZ) in Wynwood, which was the historic remnant of the governments' long-standing interest in Wynwood's redevelopment. Under the Federal Enterprise Zone program, Empowerment Zones were local areas targeted for redevelopment within Enterprise Communities, which was the designation for municipalities such as Miami-Dade County, through which the federal funding was channeled. As discussed in Chapter 4, previous projects supported within the Zone - affordable housing construction, the Free Trade Zone - fell far short of expectations and potential. "[At] the beginning, that's what you had," recalled Melissa. "Those were the tools."

${ }^{265}$ Quote from interview with Melissa.
} 
remnants of their social life and redeveloping the spaces they once used into something else.

However, the use of the frontier rationality to implement redevelopment ebbs and flows. Even though Wynwood continues to have high poverty, crime and the presence of homeless persons, the frontier rationality seems to have softened. Levine was recently forced to evict a contractor who leased vacant land from him for use as a staging area for construction elsewhere in the city. After the contractor had leased the site for more than a year, residents' complaints prompted city code inspectors to investigate and ultimately cite Levine for lacking a permit and for improper storage of constructional materials in a residential neighborhood (Goyette 2011). The complaining residents owned and rented units in one of Levine's loft buildings, which reveals that the developers of artistic space

and its inhabitants do not necessarily have the same interests, and reinforces the point that artists may be in a vulnerable position when gentrification is led by developers in the name of artists. On the other hand, the frontier is not so empty; as more investors, consumer and residents come to occupy it, the political environment is also gradually transformed.

However, before there were either developers or artists, low-income workers and families lived in Wynwood. The next section explores the exclusionary pressures generated upon existing residents by the growth of the art district.

\section{$\underline{\text { Pressures of Exclusion and Displacement }}$}

Goldman and son have claimed that one of the unique characteristics of Wynwood, compared to other neighborhoods they have worked in, "was that the district 
could be redeveloped without displacing the surrounding Puerto Rican neighborhood" (Pristin 2010), having elsewhere referred to their work as "gentlefication" as opposed to gentrification (Triff 2005). The claim that there is something about Wynwood that makes it possible to avoid displacing residents seems to refer to the way the center of the historic Puerto Rican enclave is separated from the warehouse district by $29^{\text {th }}$ Street. In his interview with Triff (2005), Goldman explained his notion of "gentlefication."

Triff: Some people are scared of the bad aspects of gentrification: the displacement, the Gaps moving in, the homogeneity. We're a poor city with a nasty history of highway construction policies. ${ }^{266}$

Goldman: I think the arts community does need to come together almost as a community development group, and we would like to help and participate with that. We need a balance between the community vision and what you call the "romantic developer" vision. This shared vision needs to be built into the plan. I'm talking about a place that has a broad artistic base. Not gentrification, but "gentlefication," which would be a redefinition of the term. I introduced this idea to the National Trust [for Historic Preservation], this point of view that as you improve the quality of the buildings, you won't displace the people who have roots in the community. They provide sense of color, of diversity given by the embedded family. There needs to be a proactive approach with the community, because government will respond to what the community thinks it needs.

Although there is a clear emphasis on the need to work with and retain the "arts community," it is not clear whether these are also the people with "roots in the community," the embedded families that provide "color" and "diversity." Does this definition of the community that "government will respond to" also include Wynwood's low-income residents? Goldman's comment ambiguously conflates references to the darker skin color of the original residents and the colors of artists. The equally ambiguous concept of "gentlefication," as with "community," seems to suggest that displacement is

\footnotetext{
${ }^{266}$ Recall the history of the construction of the interstate highway system (I95, I395, I195) through Overtown, Wynwood and Allapattah from Chapter 2.
} 
avoided because the Goldmans are not demolishing and rebuilding the neighborhood but rather, they argue, enhancing its latent architectural and urban qualities, specifically in vacant buildings (former manufacturing warehouses).

However, such a claim seems to rest on a conceptualization of "direct" as opposed to "indirect" displacement (Marcuse 1986; Betancur et al. 1995) and therefore neglects the historical nature of exclusionary "pressures" generated by gentrification. Marcuse (1986) argued that residents may be displaced directly when landlords' actions force residents to move (e.g., rent increases or building deterioration) and indirectly when lowincome residents are prevented from moving in because of expensive (gentrified) living costs or a transformed socio-cultural environment in which they would feel marginalized. ${ }^{267}$ Davidson and Lees (2010, p. 400-401) note that the failure to account for exclusionary "pressures" has led many gentrification scholars "who search for the spatial moment of displacement [to] contradict themselves," such as the case they cite of Hamnett and Whitelegg (2007, p. 122): "Their arrival [gentrifiers] and the associated commercial gentrification have, however, significantly and probably irrevocably changed the social mix and ethos of the area which was dominated by social rented housing tenants. This [change] has not, however, been accompanied by significant residential displacement." "They have missed Marcuse," write Davidson and Lees (2010, p. 401), “for what they are describing is Marcuse's $(1985,1986)$ 'displacement pressure'.” I argue that so, too, have the Goldmans missed Marcuse. They have not directly displaced Wynwood residents as indeed their efforts have focused on re-developing former

\footnotetext{
${ }^{267}$ This applies to residents who already live in another house in the neighborhood as well as potential newcomers. In other words, the neighborhood is taken "off the market" for prospective residents with low incomes.
} 
manufacturing properties. However, by developing an upscale consumption infrastructure that contributes to escalating living costs and a transformed social environment in the neighborhood, they create "pressures" that exclude low-income residents and also shape residents' thinking about the place where they live. Consider again the example of Marta.

As hers is one of the few homes in the heart of the art district, along the path of the monthly art gallery walk and down the street from Levine's real estate office and Goldman's new restaurants, Marta is positioned to experience and describe how the exclusionary pressures operate. In addition to her experience of losing two neighborhood cafeterias and social lounges to rising commercial rents (discussed earlier), Marta lamented that "since the galleries arrived, this [area] is madness... the galleries have created un revolú." ${ }^{268}$ By madness (esa locura) she meant the many indications of a broader transformation - how, for example, during the crush of monthly art walks and the annual Art Basel festival, "the people [gallery patrons] are so dirty, they leave bottles, everything thrown there in front of people's houses."

When [the galleries] came over here, all of this happened, to remove bodegas, ${ }^{269}$ [and] everything here is now galleries. They'll [eventually] take this house for a gallery. There in front [of my house] a factory was emptied - gallery, everything is gallery, gallery, gallery! And when [people] come to the galleries you cannot even go out because there is such a huge traffic jam. There is no parking [for us] anywhere... Not a person can walk the streets! They get like this (she forms firsts with each hand and presses them together at the knuckles) of cars.

\footnotetext{
${ }^{268}$ Marta (who is Cuban) routinely uses Puerto Rican sayings, including "revolú," which refers to "revolution" but also to the notion of a mess, disorder or lacking organization.

${ }^{269}$ Since bodega refers to a grocery store, restaurant and social lounge, none of these individual terms would suffice as a translation.
} 
Not surprisingly, although she once visited the gallery two doors down and across the street from her house, she asserted that the art “doesn't matter to me at all, nor do I want to see it, because they're spoiling all of our [things]." As she does not read English, she did not understand the ironic message painted on that gallery's outer wall during the last Art Basel festival, which still reads, "remember that u're not doing it for money." When I translated the message for her into Spanish, she reacted angrily: "How shameless! They even brought their cars [over from Europe]."

Figure 6.20: Image of Message on the Wall of an Art Gallery that reads, "Remember that u're not doing it for money"

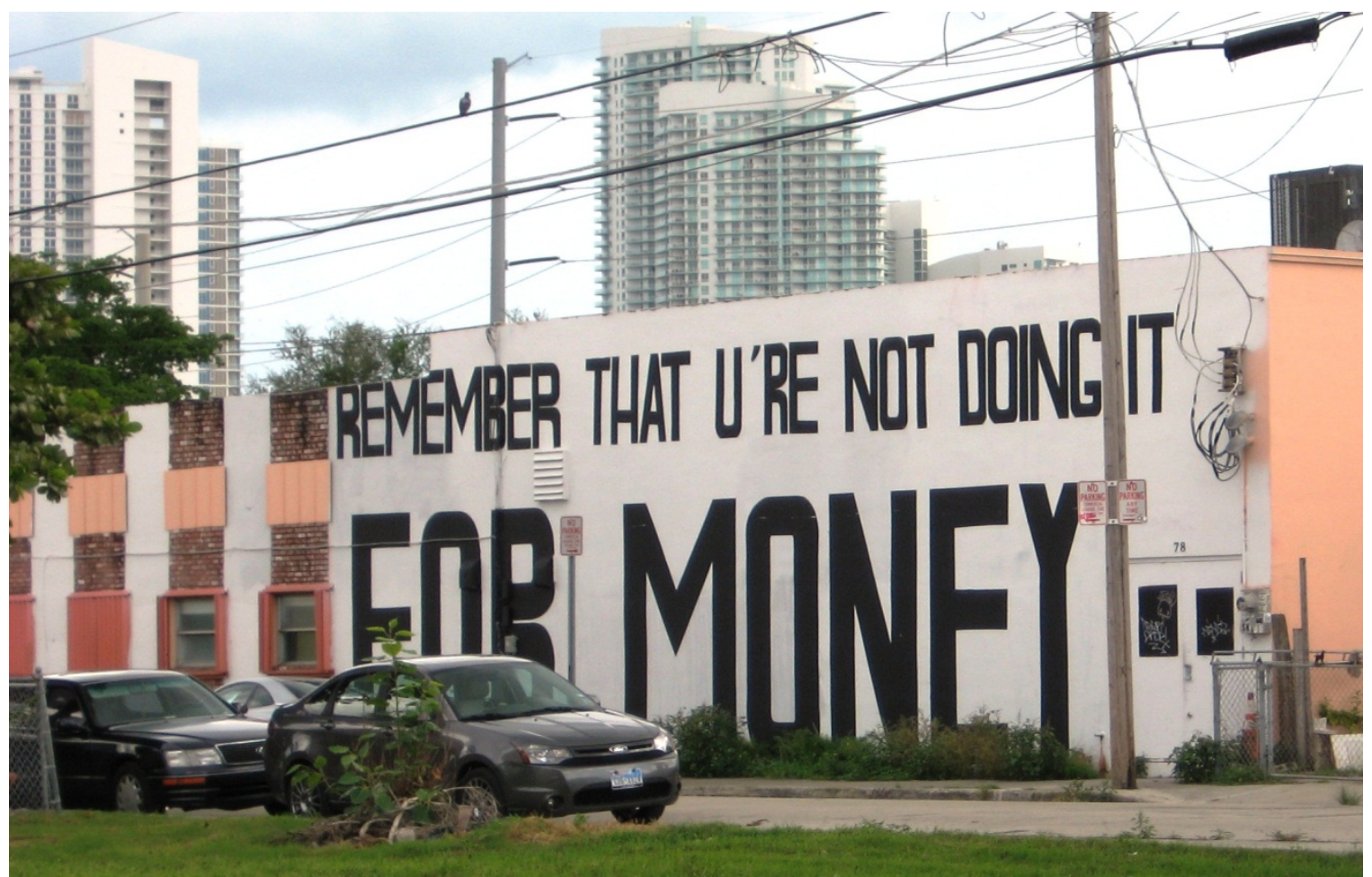

Source: Authors photo taken September, 2011.

Marta got increasingly agitated as I asked her how the growth of the art district makes her feel. As she responded, she sometimes made repeated, rapid flicks of her wrist 
through the air (leading with the back of her hand, as if swatting a fly), seeming to wish away the subject of our conversation, "that mess," represented by "all the galleries." But the translation into "mess" does not fully express what Marta meant by her use of the word "lio" (perhaps also "revolú" and "locura") in reference to "all of that" signified by the presence of galleries. ${ }^{270}$ Her reference to "ese lio" indicated her understanding that gentrification - albeit not termed this way by Marta - is not just a threat (trouble) but also something that one gets embroiled in, as it comprehensively shapes various aspects of neighborhood life: property ownership, living costs, the cultural environment, the everyday performance of street life, and so on.

The pressure of real estate speculation has also made her think about her family's role in the neighborhood as homeowners. Marta's family, who since 1993 has owned three neighboring properties, ${ }^{271}$ was invited to sell several times by investors who walked up to the house or left notes in the mail or taped to the front gate.

\footnotetext{
${ }^{270}$ About Midtown, for example, she said: "I like that [project] a little bit more [than the art galleries], but it also brought all of this lio." About the political conflicts between some neighborhood organizations and city agencies supportive of development projects, she was dismissive: "I don't get involved in that lio." The Spanish word "lio" refers to "mess" or "trouble" but also, as a verb, "liar" means to "wrap up," "involve," "complicate" and "confuse," making possible its' use to refer to a problem (un lio) that is encompassing and that one can become caught up or enveloped in.
}

${ }^{271}$ The cluster forms an L shape -two of the properties are next to each other while the third is on the next block north, directly "behind" Marta's house. While the third house is owned by Marta's late sister, her mother-in-law bought the other two homes for $\$ 14,000$ and $\$ 17,000$ in 1993. By 2007, similarly sized homes of varying conditions in Wynwood sold for between $\$ 150,000$ and $\$ 250,000$. Marta indicated that her mother-in-law had no plans to sell in the near future. Her mother-in-law had purchased the properties from the Hungarian woman who was her landlord since the 1970s and who also lived in the back of one of the partitioned homes. When the Hungarian woman sold the properties, Marta and her husband were living somewhere else in the neighborhood but were asked to move into the newly-empty house next door by Marta's mother-in-law, who felt alone after the Hungarian woman moved away. Eventually, she filled the back apartment where the former landlord lived with a Puerto Rican tenant who was friends with her son. In 2000, one of Marta's nephews arrived from Cuba to rent the partitioned one-bedroom apartment in the back of the house where she lives with her husband and daughter. Marta and her mother-in-law explained that it was important to rent to people they trusted, even though this meant charging less in monthly rent. For example, the Cuban nephew who is a limo driver paid Marta about $\$ 250$ monthly in 2003 and since then his rent has increased only in accordance with his income, such that in 2007 he paid $\$ 400$ for awhile 
Marta: Now we have these houses and they [would just] demolish and put up a building and it's all over [this life of ours]... They [who offer to buy our house] pressure us, because if they're interested in this little piece they will pressure you. [They tell us] that downtown is going to extend all the way over here. Have you heard this? This [area] just disappears.

Marcos: What I have heard is that they changed the rules so that they could build more stories.

Marta: But if I don't have any money? I only have this [one]-story [house]. Look at the condition it's in. It's more or less fixed up. But look at how ugly the outside is. I can't afford to fix it. How am I going to build 10 stories if I don't have [enough] for the bottom [one]?

Although not interested in selling her properties, the transformed housing market, represented by these "pressures," made her think in new and different ways. Ideas are introduced by speculators, for example, who promote the properties' profitability in relation to downtown expansion; or maybe by myself (or the presence of a new 10-story condo tower 2 blocks from Marta's house), contributing to her understanding (or at least articulation) that many of the neighborhood changes, such as high-rise zoning, are not beneficial to her. Moreover, in her expression that by selling her home and facilitating the ongoing transformation of the built environment, "it's all over," she seems to recognize that as a homeowner she is an important stakeholder in a way of life. In such ways, then, the various impacts felt by residents such as Marta are also more than impacts (i.e., unidirectional effects); they envelop residents in new considerations and contribute to

but is now paying only $\$ 350$ because the economic downturn affected his earnings. His rent included all utilities except gas for the oven he rarely uses. This price and arrangement is likely to be similar to the kinds of partitioned "efficiency" apartments rented among family and friends in other parts of Wynwood. But compared to typical real estate listings in the area (as low as \$500), that is, so-called arms-length transactions, the Cuban nephews' rent is very inexpensive, especially for the size of his apartment, which included a large bedroom (it used to be the master suite in the house before it was divided), full kitchen with a separate dining area, bathroom, and a living room in a converted (enclosed) porch, in addition to the back patio connected to the rest of the families' common space. In 2007, I paid $\$ 575$ for a smaller studio apartment a few blocks away from Marta's house, not including utilities. 
new ways of thinking about where they live. The multiplicity of impacts makes for a confusing "lio," one that Marta would rather not get involved in.

\section{Figure 6.21: Image of a New 10-story Condo Loft Building built in 2007 two blocks from Marta's House}

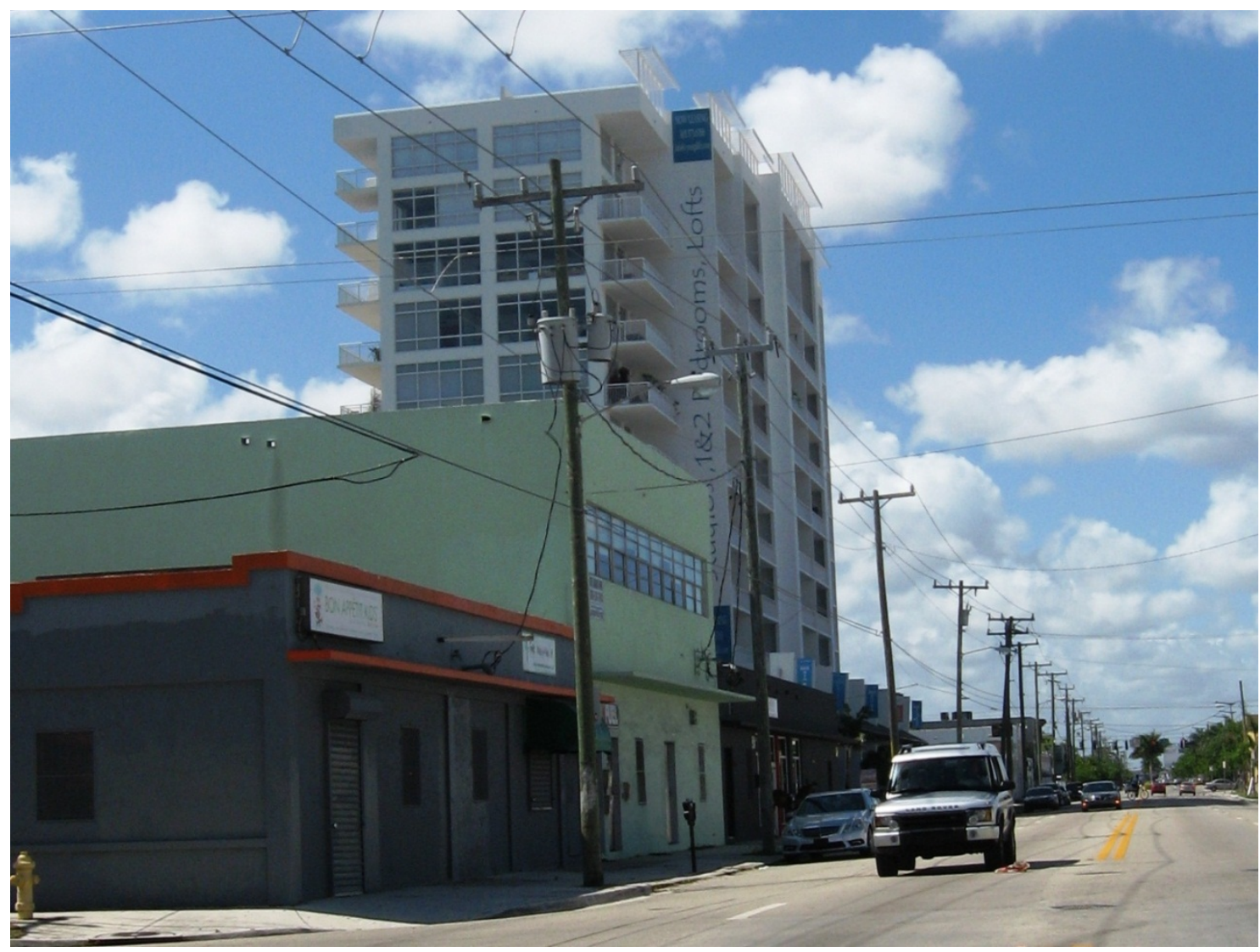

Source: Photo by author, November, 2010. The new building of live/work lofts, located two blocks north of Marta's house and one block south of the Midtown shopping complex, towers 10 stories above the typically low-rise structures of Wynwood.

Wynwood was produced as a frontier by a collective of political and economic actors who also constructed their own identities as pioneers willing to carry out the "quick and dirty" (Levine) work of "pushing a neighborhood forward" (Melissa). The conception of wealthy developers, collectors, gallerists and even government officials as 
grassroots activists in the redevelopment of the neighborhood is made possible by the Miami Model of art collection. Independent of tradition and government, Miami's powerful collectors have collaborated with real estate developers to remake Wynwood. One of the renowned practitioners of the Miami Model, Steven, is also the director of the Miami office of a national philanthropic foundation that supports a variety of the artistic and cultural projects remaking Wynwood, including large projects such as Primary Flight and smaller endeavors such as a poetry collective made up of artists affiliated with the former Cornerstone space.

A similarly networked assemblage of relations, albeit somewhat simpler to imagine and diagram, led to the creation of the Midtown complex. In this case, the political players involved were relatively fewer because two developers controlled the vast capacity to act (resources). "Partnership" was no less essential to the project's approval and development, although in the case of Midtown the partnership was primarily between city agencies and the developers. In both cases, complex legal and technical changes to planning and zoning policy were necessary to re-regulate (perhaps more appropriate than the term, deregulate) parts of the city to facilitate redevelopment. In the case of Midtown, more than a decade of "scientific" rationalization combined with the patron-client relations of the CBO office and neighborhood-level NGOs provided the basis for "community input." As with the Art District, the "mini city hall" represented by the $\mathrm{CBO}$ office was also essential to coordinating and implementing the "disciplinary normalization" (Foucault 2004, p. 56) of space through public and private policing and building code enforcement, in addition to the physical interventions constructed in the 1990s (see Chapter 4). 
Taken together, the network of power relations described above spans variegated geographies and social groups: the Wynwood Art District Association and its diversity of investors, merchants, artists and gallerists; neighborhood associations and nonprofit service providers; numerous city agencies; independent, artistic and entrepreneurial collectives; private security forces; and not to mention national foundations and multinational construction and finance corporations. Residents are also incorporated into these arrangements, typically through their relationships with the neighborhood-level service agencies which are mobilized and arranged by broader governing arrangements.

These ad-hoc policing and policymaking arrangements are what some scholars refer to as the "post-political" or "post-democratic" ethos of entrepreneurial urban governance because of how conflict is foreclosed in favor of processes biased toward consensus and accommodation (e.g., Purcell 2008, Swyngedouw 2011). As was evident in the case of planning processes that preceded the construction of Midtown, antagonistic perspectives are minimized and become less salient when meetings about the future of the neighborhood include more future investors and residents than current ones. In the case of the Puerto Rican CDC's shift to artist services, the director could ignore market research that found some residents feared gentrification because the research and planning itself was a privatized, unaccountable endeavor. Each public funding pool and the nonprofit agencies they fund has its own advisory board; any one of them can be mobilized in an ad-hoc, policymaking process. It is no wonder that Marta or other residents, who may know very little of what actually transpires in such governing arrangements (and between whom), views politics as a "lio" that she would rather not get enveloped in. This is not to say her social world is free of politics, of course; she is well 
aware of the exclusionary pressures transforming her social space, and the hypocrisy of the contradictions she perceives is both infuriating and alienating.

To help understand why community politics might alienate residents, the next section focuses specifically on an attempt to challenge the governing arrangements that produced and facilitated gentrification in Wynwood.

\section{Case 3: The Campaign to Take Back Roberto Clemente Park}

As developers converted Wynwood's warehouses into art galleries, the spaces of the northern, residential half of the neighborhood either fell into disrepair or closed, such as the cafeterias discussed earlier. The most dramatic example is that of Roberto Clemente Park Community Center, which in 2001 was slated for major renovations but eventually closed in 2004 and nearly succumbed to a terminate infestation that damaged nearby homes. Activists from the Social Justice Center (SJC), an organization based outside of Wynwood (see Figure 6.22 below), created a campaign to hurry along what eventually became a complete reconstruction of the center. Although activists achieved their larger objective to re-open the community center, the campaign was marked by the discord and divisions among the members of the Coalition to Take Back Roberto Clemente Park.

In this section I examine this episode of activism in defense of the neighborhood in the context of rampant gentrification. The case not only demonstrates how the neighborhood's history of community politics acquiesced to the local state's development interests and weakened the prospects of contesting or mitigating gentrification in Wynwood, but also reveals how contemporary social justice organizing interacts with 
established traditions of community politics, such as those practiced by Puerto Rican service organizations. As noted in the introduction, the purpose is not to critique the framework or practices of any single organization but to consider how the interaction of these organizations shape the political terrain in which gentrification unfolds.

Figure 6.22: Map of the Social Justice Center's location in Liberty City and near Wynwood

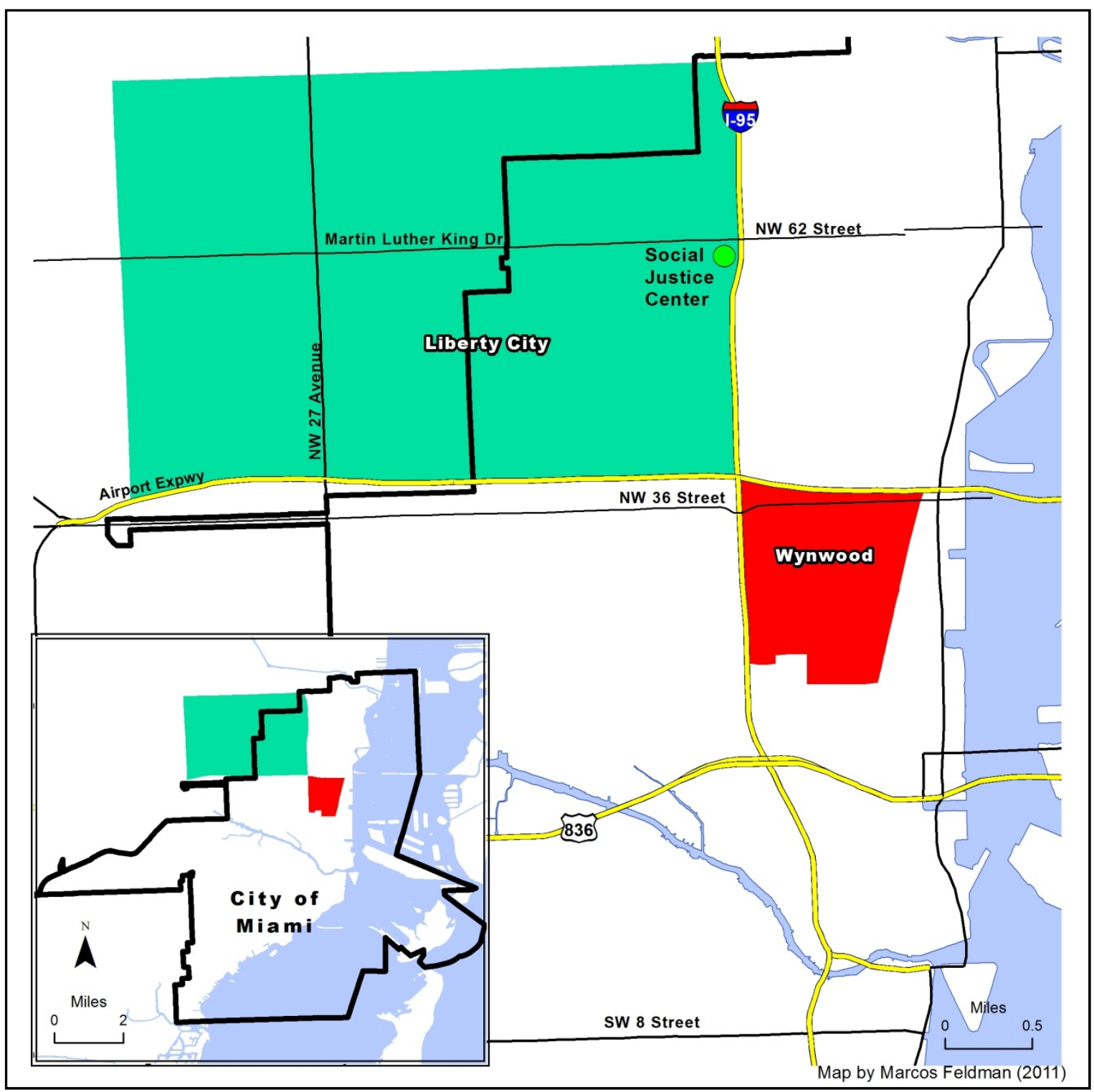


$\underline{\text { Wynwood's Community Center: Island of Decay in Seas of Renewal }}^{272}$

After Roberto Clemente Park was expanded in 1994 (see Chapter 4), the park received only minor upgrades during the next 10 years. ${ }^{273}$ Although in 2001 the city allocated \$1.1 million for various renovation projects including the park's community center as part of $\$ 255$ million county-wide bond package, by 2004 the community center was closed because its decaying roof was infested with termites. The allocation of funds and implementation of the program was mired in delays, as revealed in the minutes of several City Commission and Bond Oversight Board meetings where city commissioners vented their frustrations. ${ }^{274}$ The problem, as some argued in retrospect, was that in the rush to get the plan approved by voters, ${ }^{275}$ "the city didn't do much research on cost,"

${ }^{272}$ Writing about areas of New York and Chicago, Wyly and Hammel's (1999) article entitled, Islands of Decay in Seas of Renewal, charted the reversal of fortunes from the inner city conditions that led Berry (1985) to publish Islands of Renewal in Seas of Decay.

${ }^{273}$ From the City of Miami's $\$ 28$ million share of Miami-Dade County bond funds for parks, Clemente Park received a $\$ 28,400$ "facelift" to resurface basketball courts and replace doors on the community center (Herald Staff 1997; Kidwell 1998) and in 2004 a \$150,000 "splash park" for children was built (Nahed 2004).

274 The following remarks by a commissioner, annoyed by the ballooning costs of parks' projects initiated through no-bid contracts, is representative of the discord over the expenditure of the bond funds: "We now have \$34 million of no-bid contracts given to clients of the same lobbyist that now have \$17 million in change orders. That's not appropriate... Where is this money come from [to satisfy the change orders]? It's dipping into the interest earnings from the unspent money and all of that, [which] is drying up because we didn't spend the money within the three-year period and now we're on yield restriction. So we can't make interest earnings on the unspent money, and what happens? ... The building at Roberto Clemente is still closed. Two years. Screw up after screw up after screw up. Fix a roof; it's inundated with termites; now we've got to build a whole new building. We don't know when we're going to build it, don't know when that money's coming back to Roberto Clemente Park. We have a very active park there that our community wants to use. It was their community center. It was our CBP office. Our CBP officers [are] working out of trailers, but yet, we can increase 8.1 million in no-bid contracts by 15.3 million so that they now total 23.4 million [for a park and gymnasium in Little Havana].” (MCC 11/9/2006).

${ }^{275}$ According to Corral (2001) and Zeitlin (2008), the City of Miami rushed the bond referendum so that it would coincide (on the ballot) with a November runoff election as well as take advantage of the "environment of fear." Approved just after September 11, 2001, the bond package was pitched to voters as the "Homeland Defense/Neighborhood Improvement Bond." The Miami City Mayor Carollo refused to endorse the bond program arguing that "it's extremely deceptive" and "wrong to use the situation we have in our country today to try to get these bonds approved" (Corral 2001, p. 1B). 
according to the chairman of the Bond Oversight Board, while city officials cited unforeseen costs such as rapidly rising property prices (Zeitlin 2008). Although the oversight board allocated $\$ 300,000$ to Wynwood in June, 2004, for the renovation of the roof, a few months later city inspectors discovered that it was infested with termites and closed the building, prompting the need for updated cost estimates and design proposals from contractors. Armed with new estimates, in July, 2005, the Bond Advisory Board approved an additional $\$ 500,000$ for the reconstruction of the roof, bringing the total funds approved to more than $\$ 800,000$. While the center remained closed through 2005 , termites spread to nearby houses. ${ }^{276}$ When contractors began tearing off the roof in 2006, they saw that the termites had spread into the building's trusses. The community center would have to be rebuilt, which would cost at least $\$ 1.6$ million, twice as much as what was originally allocated. ${ }^{277}$ Services and activities (including the CBP office) previously housed in the center were moved into trailers while some recreational activities, such as the police baseball league organized by the Puerto Rican Chamber of Commerce, were cancelled because of insufficient space as well as the "embarrassment" of the dilapidated structure (Boyd-Barrett 2008; Morales 2008).

By 2008, an organized response to the park's deterioration emerged, led by a coalition of organizations, most of which are historically Puerto Rican social service agencies. The only non-Puerto Rican organization involved, the Latinos Unidos Grassroots Organization (LUGO), catalyzed the creation of the activist coalition, as I

\footnotetext{
${ }^{276}$ Interviews with several neighborhood residents and activists and the Clemente Park Manager.

277 A city audit would eventually find that the city's "due diligence" in previous inspections was "inadequate," concluding that over \$200,000 was "needlessly" spent on design plans and preliminary repairs (Igwe, Blake and Dobrev 2008).
} 
describe below. LUGO was an offshoot of the Social Justice Center (SJC), a communitybased organizing and strategy center founded and based since 1999 in the AfricanAmerican neighborhood of Liberty City. Until 2004, the SJC's work largely focused on organizing public housing residents against the neglect and deterioration of their housing, for inclusion in public housing redevelopment plans, and against punitive welfare reform practices. Organizing public housing residents led to the formation of SJC's first grassroots organization of mostly African-American women active in different housing and welfare rights campaigns. The SJC cultivates social justice leaders by offering training and political education programs in which members and staff analyze local injustices in order to link them to broader theories of gentrification, neoliberalism, white supremacy, and others.

LUGO grew out of the SJC's initial work in Wynwood during the summer of 2005, when organizers canvassed over 300 households to learn about residents' problems and needs. This entry into Wynwood was part of a broader conceptual restructuring of SJC to expand its power base beyond Liberty City and form an alliance between Blacks $^{278}$ and Latinos that might better challenge the status quo of urban development. According to the SJC executive director, "[W]e wanted to build power in Miami [beyond Liberty City], to figure out how we actually build a black-brown, multi-ethnic alliance." Thus, the SJC wanted to get closer to where gentrification was occurring in order to be able to resist or at least impact it, also realizing that gentrification would affect their traditional organizing base. The SJC director recalled:

\footnotetext{
${ }^{278}$ Includes African-Americans as well as Jamaicans, Haitians and others of Afro-Caribbean descent.
} 
We had started to already see by 2002,2003 , the bubble, the cranes... the gentrification impacts of the building boom. So we had [for years] been biting around just... public housing in Liberty City. Even in Liberty City which was further out from where the center point of the building boom was, the ideology of the boom was moving towards... previously unmarketable areas, [now] being targeted for market rate [housing].

The SJC director emphasized the importance of adopting and articulating a broader strategy in order to attempt to match the power of developers and others in the urban growth coalition ${ }^{279}$ who "declared a vision for the city, the county, and the region, that was all-encompassing and broad, putting forward a vision for everybody." As an African-American neighborhood, Liberty City is too socially and politically remote to impact the broader systems shaping urban revitalization in the City of Miami, where a majority of residents are Hispanic. SJC leaders also recognized that Liberty City was geographically distant (recall Figure 6.22) from the perceived "center point" of the housing boom and therefore would not (by itself) be an effective platform for framing alternative ways of thinking about and implementing urban development. However, the expansion of SJC's campaign work into Wynwood was not the only strategic choice made to address unequal urban development; it was part of a broader strategy that incorporated new tactics beyond base-building, i.e., organizing a base of support among residents for a given cause. As the SJC director explained, in contrast to the organization's traditional work in Liberty City in which "you build a base [of support] in an area, you have a campaign and then you project... communication about that fight," by 2004 he felt that the organization needed to "have a visionary coalition that speaks to

\footnotetext{
${ }^{279}$ As in other U.S. cities (see Logan and Molotch 1987; Jonas and Wilson 1999), Miami's pro-growth coalition is made up of elected officials and business elites, including those from the finance, real estate, tourism and mass media sectors.
} 
what progress in the region looks like beyond... your particular neighborhood interests [and] beyond where we may or may not have base building."

The SJC thought that residents and organizational leaders in Wynwood might make strong allies in campaigns to challenge the status quo of urban development in Miami. In contrast to Cuban-Americans, who are generally perceived to be politically conservative $^{280}$ (Portes 2005; Girard and Grenier 2008), particularly compared to the SJC's critique of neoliberal urban development, Hispanics in Wynwood were thought to be more ideologically compatible with the work of the SJC.

Our sense was that [given] the perceived politics around the Cuban population, that Central Americans and Puerto Ricans, Caribbeans, Latinos, would be a much better, natural partner with the African-American community to build a progressive, working class political block... Wynwood was the area that was closest and most well-known... for being a Puerto Rican stronghold, but increasingly Central American too. (SJC director)

As the former organizing director, Frank, also explained, the organization's AfricanAmerican members were prepared for this transition though the SJC's political education programs, in which "people started saying, 'Hey, the history of Puerto Ricans, we can relate to that. The racism that they ran across, the economic injustices they faced, the colonialism of the U.S. in Puerto Rico."” Frank recalled that once members began

\footnotetext{
${ }^{280}$ Many social justice activists in Miami, such as those at the SJC, perceive the Republican party voting patterns and anti-communist exile ideology of many Cuban-Americans as a sign that they are less likely to support U.S. social justice movements. However, Cuban-Americans' political practice has been more complex, such as in the case of the Miami Community Coalition for a Living Wage (Nissen 2000). Although advocates of the Miami-Dade County Living Wage Ordinance expected Cuban-American Republican politicians to be staunch opponents, these turned out to be not only the most receptive but were key sponsors of the successful ordinance. Grenier (1992) previously noted the strength of the CubanAmerican labor movement in Miami and militancy of many of its members.
} 
spending time in Wynwood and getting to know residents, the extent of poverty and physical disrepair in the area was "revelatory" for members who "started to identify" with the hardship of living in such conditions. In addition to cultivating a sense of common cause among Blacks and Hispanics, the expansion of the SJC into Wynwood after 2003 was part of a larger organizational restructuring that requires elaboration.

Between 1998 and 2008 "the Miami area... changed from being relatively underdeveloped in terms of social justice activism into a relatively active locale" (Nissen 2009, p. 163). The SJC is at the forefront of the growth of a "social justice infrastructure" in Miami, made up of faith-based groups, neighborhood and labor organizers, unions, advocacy organizations and a research institute, among others (Nissen 2004; Nissen and Russo 2006; Nissen 2009). In recent years it has spearheaded various coalitions (Gittel, Ferman and Price 2007), ${ }^{281}$ expanded its work beyond neighborhoods to regional campaigns, and founded a new organization to carry out state-wide electoral and legislative advocacy. The SJC receives more in foundation grants than any other social justice organization in Southeast Florida. According to data from the Foundation Center, ${ }^{282}$ the amount of grants the SJC received annually increased from $\$ 160,000$ in

\footnotetext{
${ }^{281}$ In addition to the Ford Foundation report cited here, which relies on self-reported coalition activities of various social justice organizations in Central and South Florida, I have observed and sometimes participated in the SJC's coalitional work during my tenure at the university-based research institute, noted in Chapter 5.

${ }^{282}$ The Foundation Center, a philanthropic support and research organization (see www.foundationcenter.org), produced a database that includes grants of more than $\$ 10,000$ awarded by the 1,000 largest national foundations. Only discretionary funding from local community foundations is included. The SJC receives relatively little from local foundations (over 8 years, less than $\$ 70,000$ in numerous small grants, according to annual reports from two Miami-based foundations) and little in private donations.
} 
2002 to $\$ 410,000$ in 2005 to nearly $\$ 1$ million in $2009 .{ }^{283}$ It had quickly become the largest social justice organization in Miami doing community organizing work, ${ }^{284}$ and this growth was transformative. The SJC diversified its strategies and tactics, not just its geographic focus, to include media/communications work (or "strategic messaging"), coalition building and policy advocacy by 2005 . Since then, it has diversified further to address and participate in other geographic and political scales of work, such as electoral turnout, state-level legislative advocacy and national networks of social justice action. Examining the nature of this different work is beyond the scope of this research. But I draw on the context of the organization's transformation to understand the implications of these multiple scales and dimensions of political work on community politics in Wynwood. The beginning of this expansion and transformation is the context in which the SJC entered Wynwood, formed the grassroots organization LUGO, and participated in the campaign to "save" Roberto Clemente Park, from 2005 to 2008. Further organizational transformations during the 2008-2009 period shifted the SJC's campaign work away from Wynwood (and from other neighborhood-based campaigns, to a large extent), as I will discuss below.

One way in which the SJC's work expanded beyond specific neighborhood cases at the same time as it entered Wynwood was to implement a regional communications campaign (the "air war," as the SJC have described it) to publicize the negative impacts

\footnotetext{
${ }^{283}$ This is not the same as their annual operating budget. The awards reported by the Foundation Center are spread over several years and sometimes divided among several organizations working within a coalition or on a campaign led by the SJC.

${ }^{284}$ The social justice organization doing similar work (community organizing/base-building) that was funded at comparable levels until the FBAC (discussed in Chapter 5) with a budget of more than $\$ 400,000$ in 2006. However, with the departure of its' director the FBAC struggled to raise funds during the 20072009 period and has not fully recovered as of this writing, according to its' former staff who stay abreast of the FBAC progress.
} 
of gentrification. To this end, in 2005 the SJC launched the campaign, Regional Equity for Neighborhoods and Tenants (RENT), which included town hall meetings in AfricanAmerican, Haitian and Latino neighborhoods (including Wynwood), press conferences and other events to draw media attention (Jeffers 2005; Sohn 2005; Vasquez 2005), and the presence of SJC staff and members at key public policy hearings to speak out against gentrification. SJC also created and sold posters and T-shirts with the RENT logo and the message, "Gentrification Stops Here," in English, Spanish and Haitian creole.

Figure 6.23: Image of the Social Justice Center's Anti-Gentrification Poster

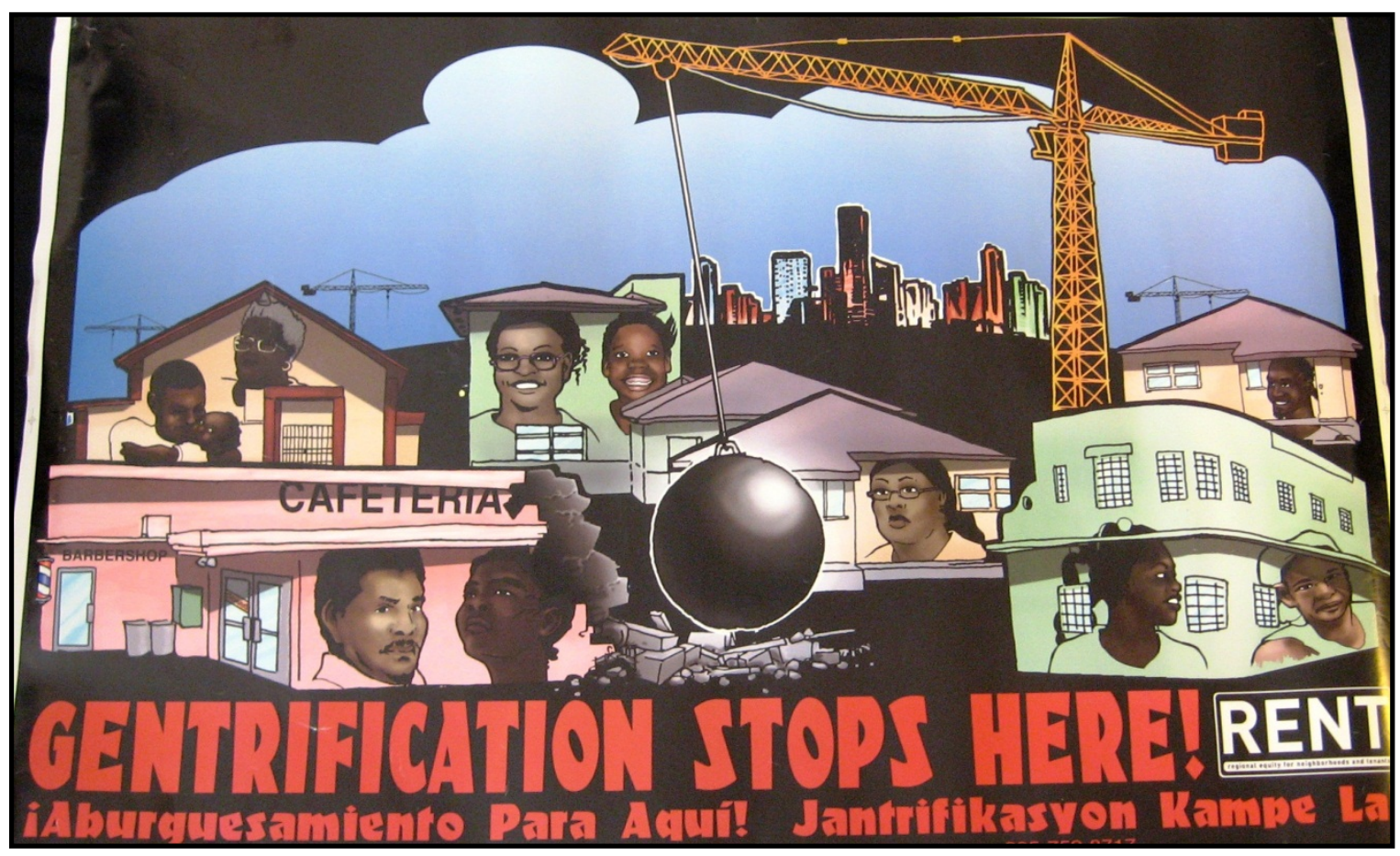

Source: Authors photo of the SJC's poster which reads, in three languages, "Gentrification Stops Here!" The same image was used for T-shirts and flyers. 
The SJC staff organizers spent the second half of 2005 and most of 2006 recruiting Wynwood residents and integrating them into existing campaigns, including RENT and other campaigns related to the mismanagement of public housing funds discussed in Chapter 5. In 2006 they formed the Wynwood Anti-Gentrification committee, which carried out protests in Wynwood linked to the broader campaigns of the SJC. That September, for example, as part of the SJC's countywide "fill the vacancies" campaign, Wynwood residents and SJC organizers rallied in front of a public housing structure that had been shuttered for several years because of physical disrepair. They hung a banner that read "Housing Now" from the fence enclosing the housing project, located half a block from the rising Midtown complex. The first public mention of the new grassroots organization, LUGO, came in the announcement of a second protest in front of the same housing project January of 2007 (Phelan 2007).

In September of 2007 the SJC announced it was launching a campaign to renovate and re-open the Clemente Park Community Center. The SJC executive director explained why the organization made the community center, and not Midtown, its major campaign in Wynwood:

We had considered... the biggest glaring thing to take on was Midtown. But we didn't feel like at that time that we had the established base or... the coalition relationships to be able to take on... a huge power in Midtown. We went back and forth about it a lot. I still think, should we have just taken a few people and taken it on? [Given] such a big fight for that neighborhood, we didn't feel that we had been established enough to be able to [be] the leading voice of that fight. So we did the [more modest] work and kept building the relationships... with them [Puerto Rican service organizations] and other people to try [and] take on smaller things... We can start preserving the neighborhood and cultural institutions that are anchors for the existing community, [such as] Roberto Clemente Park... If we do that well, then we can earn our keep... as neighborhood champions, rather than... landing in Wynwood to fight [Mayor] Manny Diaz on Midtown. 
Frank, SJC'S former organizing director, raised another point. Building alliances within the neighborhood was crucial to organizer's work in Wynwood, he said. 'Let us build it on this smaller scale [because] if difference is going to come up, let that difference arise before we get in over our heads." Moreover, the choice to address the community center may have been unavoidable because of the nature of the problem. By the time LUGO decided to take on the park campaign, it was an issue that many different groups were affected by or cared about and could be united around. It was also too obvious to ignore.

\section{Figure 6.24: Image of the Clemente Park Community Center, Condemned and Closed, with Midtown Condo Building in the Background}

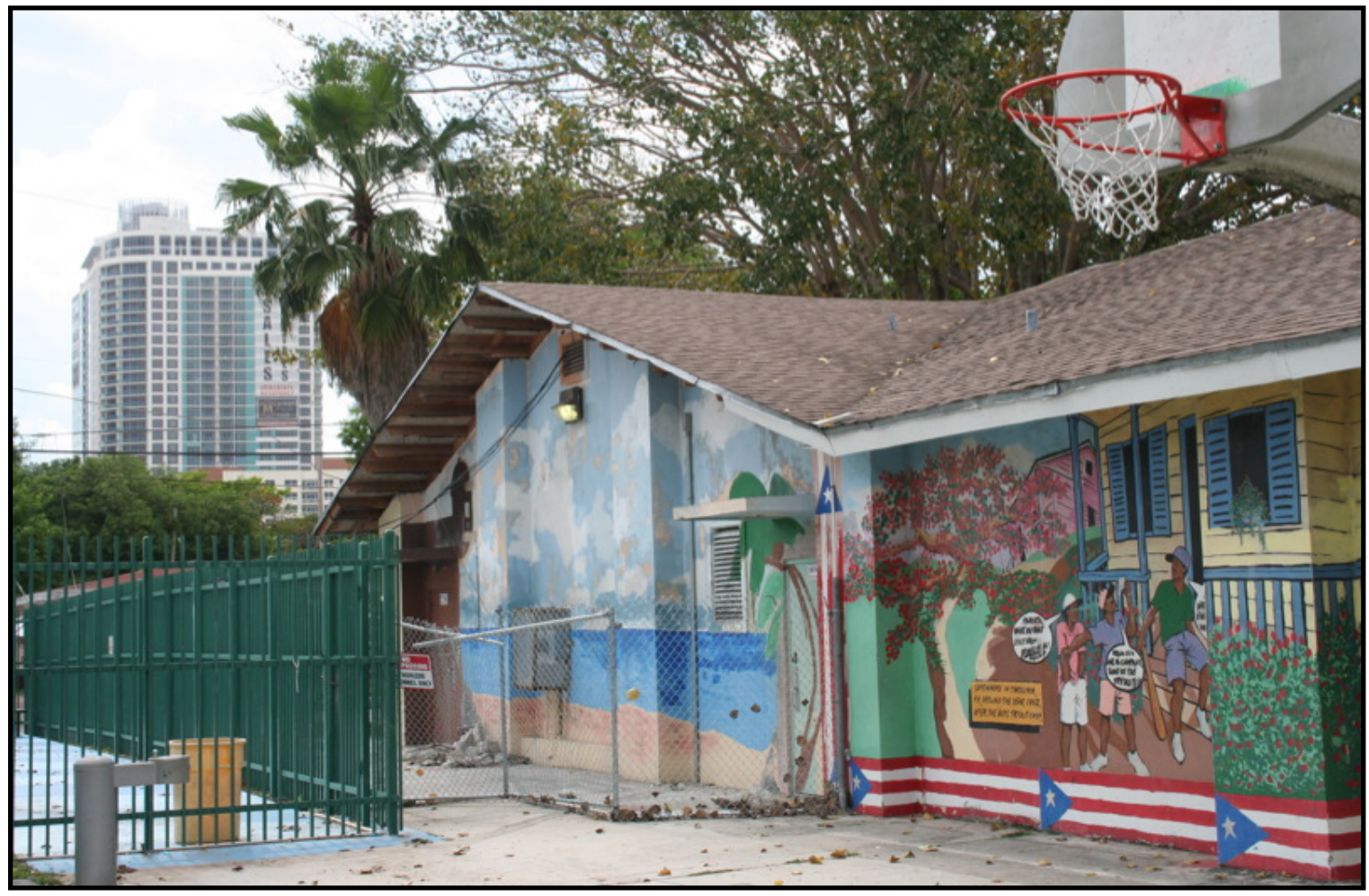

Source: Photo taken by the SJC in May, 2008, posted on their photo sharing website. 
During the last months of 2007, SJC and LUGO collected more than 1,000 signatures to petition the city district commissioner to expedite the reconstruction of the community center as well as agree to a list of other "community benefits" from the project, such as local hiring and additional amenities. SJC organizers convened neighborhood meetings to generate support and publicize their actions. In December, 2007, they requested the participation of the city commissioner in a "community accountability" meeting held at the Wynwood Baptist Church. ${ }^{285}$ About 40 people attended, including six LUGO resident-leaders. ${ }^{286}$ Teresa, an SJC organizer, explained to residents the list of "demands" ${ }^{\prime 287}$ that were being presented to the city commissioner and placed the neglect of the park in the context of "fighting against gentrification." "Everyone is trying to sell Wynwood as the next thing for the artists," she asserted. "But what about the needs of the people that already live here?" As the city commissioner arrived (late) with two assistants and settled into the back row of wooden church pews, he was given headphones and a receiver by an SJC volunteer to listen to the translation she provided in English. A few residents stood to speak but rather than address the park's problems or the activists' demands, they began a polarized debate about the Midtown

\footnotetext{
${ }^{285}$ The SJC never found strong allies in the neighborhood Churches. Noted in a previous chapter, the Catholic church did not oppose them but neither did priests actively support LUGO. The same was true for other churches, including the Baptist church, other than offering the building for a neighborhood meeting on this particular occasion.

${ }^{286}$ I assisted with translation for the mostly Spanish-speaking audience.

${ }^{287}$ The demands included, as written: (1) A community led process with public meetings that allow for community participation in decisions including the following: facility design, programs for youth and adults, community space, environmentally sustainable development; (2) expedite the construction process; (3) ensure local residents are given opportunity for job training and placement on this project; (4) continue to meet with LUGO after the February 9th Town Hall to address concerns regarding gentrification; (5) ensure immediate and long term funding for the Community Center and explore funding options from moneys generated from Midtown Miami.
} 
project (see also previous cases in this chapter). ${ }^{288}$ Moments later the commissioner took the stage and was presented the list of demands through the translation equipment. Ignoring Teresa's instructions to respond "yes or no" to the demands, the commissioner abruptly removed the headphones and scolded the activists for their tactics. "Where I come from in Brooklyn, good manners say that you don't make demands, we make requests." ${ }^{289}$ Noting that he "could have easily approved a cheaply built [center] but I wanted to give you a community center deserving of Roberto Clemente Park," he explained that he was looking for an additional $\$ 1.2$ million. "Now I am prepared to answer your questions." Ultimately, the commissioner seemed to agree to most of what the activists wanted. ${ }^{290}$ Over the next few months the SJC and LUGO attended city agency meetings and convened other reunions in the neighborhood to try to shape the final plans for the new center.

But in March 2008, the SJC and LUGO decided to create a coalition and escalate their protests when they realized that the requests of neighborhood residents and

\footnotetext{
${ }^{288}$ A man spoke about the "hypocrisy" of the "politicians and investors" who "offered pretty designs" in the Midtown project "but now they're building a parking lot." (Midtown amounted to more than a parking lot. He may have perceived it this way because he did not care for any of the rest.) He concluded that "if you don't vote, you don't have the right to benefit." The Puerto Rican leader of the neighborhood homeowner association (even though she did not currently live in the neighborhood) listed several critiques of the Midtown project in a brief, carefully thought out statement. "They gerrymandered the political districts [to build Midtown] and they're not fulfilling promises. They don't hire local people in Midtown. Meanwhile, our costs are rising." Hector, whose views were discussed in Chapter X, argued in favor of Midtown: "Just because Midtown comes doesn't mean it's going to give [specific] things to the community. It brings generally good things to the community."

${ }^{289}$ His translator's Spanish version of the message was, "it's very important to have dialog."

290 "Of course the community should participate in the conception of the new Community Center." Regarding the timeline for reconstruction, the commissioner retorted that "this is not a yes or no demand. It will take between 24 and 30 months to complete the whole process," adding that he would expedite it as much as possible. Regarding local and minority hiring, the commissioner argued, "I can't legally require contractors to hire particular people. I can make a request of contractors to hire from the neighborhood and usually with city contracts they are willing to do this request."
} 
organizations were largely ignored by city officials. During a meeting organized by city officials at the De Hostos Neighborhood Center, residents and representatives of several neighborhood service organizations packed a conference room to express what they would like to see at the park: a library, pool, gymnasium, improvements to the baseball field and some kind of museum or memorial to Roberto Clemente (Boyd-Barrett 2008). But toward the end of the meeting they learned that they were providing input to a plan that would not change. Instead of finding more money, the city had reduced the size of the proposed community center by 3,000 square feet (Boyd-Barrett 2008; Zeitlin 2008b). ${ }^{291}$ The SJC announced its opposition to the city plan in a March $21^{\text {st }}$ letter to the editor of El Nuevo Herald (LUGO 2008). "The community should decide what type of facility it wishes to see built," read the letter. "The city is making excuses to not provide more funding to the community while focusing the money in projects ${ }^{292}$ that hurt the community" (Ibid).

As a new organization in the neighborhood, the SJC joined forces with existing neighborhood organizations in order to increase pressure on city officials. Faced with intransigent city officials who refused to seek additional funding or redesign the project, various neighborhood organizations were motivated to join the coalition. The most important of these was a Puerto Rican-led educational services organization (PRES,

\footnotetext{
${ }^{291}$ At a March meeting, city officials told residents and activists that they had increased the centers' size to accommodate a "reading room" to serve as a library. But this was done by eliminating the plans for a gymnasium. It seemed to activists that city officials had substituted the library request for a gymnasium because the former was cheaper.

${ }^{292}$ The letter refers to $\$ 619$ million in city and county subsidies for a new baseball stadium for the Florida Marlins, arguing that the project benefits developers and "well-off people" but not low-income city residents (LUGO 2008).
} 
hereafter). ${ }^{293}$ The history of PRES in the neighborhood since 1982 facilitated the incorporation of other service organizations. In addition to the SJC and PRES, the Coalition Recupera Tu Parque Roberto Clemente ("Recover Your Park") included several Puerto Rican service organizations - the Puerto Rican Chamber of Commerce, the Puerto Rican Child Care (PRCC) organization and the De Hostos Senior Center. Members included Orlando, a Puerto Rican long-time resident who ran the park's softball league, and Miriam, a Puerto Rican commissioner of a wealthy municipality in northeastern Miami-Dade County. These organizations and individuals shared a desire to help the neighborhood and protect an important Puerto Rican symbol in Miami. Furthermore, PRES' and the Senior Centers' interest in expanding services at the new center were also likely related to the threat of their own displacement from the nearby De Hostos Center. By 2008, half of this neighborhood center had been vacated and closed because of disrepair and was slated for major renovations (as of this writing, the designs have been finalized but funding for reconstruction is still unavailable). The PRES director recruited Miriam to the coalition because she was a graduate of the PRES program. Meanwhile, the Chamber's director was involved in the park's baseball programs with Orlando.

Although the SJC-written vision statement that was approved by other organizations emphasized the role of gentrification, coalition members avoided rhetoric that they thought was too radical or militant throughout the process of meeting, planning and carrying out public actions. The April 2008 vision statement stated:

\footnotetext{
${ }^{293}$ PRES is a well-known, national educational services organizations (e.g., tutoring, school clubs, dropout prevention) formed by Puerto Rican activists in New York and Puerto Rico in the 1970s.
} 
We are fighting to ensure that the community is controlled by those who live in it. We believe it is those most affected by gentrification who can see the best ways to fight these system and should lead the way. Furthermore, we believe it is critical for those most affected to unite with other sectors in the fight for selfdetermination and progressive development in our communities.

Gentrification and fighting the system were never specifically mentioned in the two coalition meetings I attended (out of four that were scheduled). As I discuss below, disagreements over messaging were a common source of friction between coalition members. An invitation for a May press conference, only a month after the previous communication mentioning gentrification and "the system," focused on the neighborhood's share of public investments:

We have been waiting for the reconstruction of the Dorothy Quintana Community Center for over three years now. The City of Miami recently approved a plan to spend billions of dollars to construct, among other things, a new stadium for the Marlins, a Port Tunnel, and a Streetcar that will run through downtown and to Midtown. Now, the Recover YOUR Roberto Clemente Park Coalition has come together to present a petition to City officials voicing the concerns and hopes of the neighborhood for a Community Center and a park that will honor the legacy of Roberto Clemente.

Press coverage of the event repeated similar statements from different participants, including the SJC staff and LUGO members. But the coalition fragmented in the three months following the press conference. Some coalition members had been invited to a series of meetings with the City Mayor's staff and other city officials to reconsider the reconstruction plan. Specifically, the SJC was not invited to a key final meeting in August. But the SJC organizers showed up anyway, arriving without their resident members. They were not allowed in the meeting room at City Hall where most of 
the neighborhood's major Puerto Rican organizational stakeholders were already inside.

According to Teresa, one of the organizers:

Frank and I went representing LUGO. That day we did not take any of our members with us because, to cap it all, Leticia got sick, Denise had to work. It was really a bad day to bring members because nobody could make it. However, [we] went to the meeting and when we arrived, Paul [the PRES director] totally denied us entry.

She went on to explain that the PRES director's justification for not letting them in to the meeting was because it was "for community members only." The three were standing in the partially open doorway of the meeting room. Then, Teresa said, "Frank got crazy."

He even told them they were going to die, basically. He said everything. He called Paul a traitor. So after that impression, I imagine they viewed us as crazy, no? But that's Frank's style and I think it was fair because he was super angry because they were throwing away all of my work and they appropriated it [for themselves].

Later, Frank reflected that the problem was "not only political difference and whose side you're on, but there's a question of process." "We potentially could have some allies, tactical allies, who have differences with us [but] we had a dialog [and] we had understandings [with PRES]." He reasoned that "there was obviously conversations going on prior to that [between the Mayor's office and the PRES director] to get him [the PRES director] at the table, that we weren't privy to, and he was at the final table." One of the people in the conference room during the August meeting was a PRES administrator who felt that the conflict in the coalition stemmed from the SJC's “approach.” When I interviewed her in 2010 she reflected: 
With the whole thing with Roberto Clemente Park, we were trying to work together with [LUGO] and... I'm not sure [about] the incident that happened but there was an incident between Paul and... ummm, LUGO and so we don't work with them in that capacity anymore. It's related to their approach... there's a time and place for everything and you can be militant or progressive or whatever you want to call it when the time calls for it. And then there is also - especially when you are part of an organization like ours -[a] politically correct approach that you have to take. And so they weren't, from my understanding, as willing to work with us and understand that perspective. And they disrespected Paul in a very public form.

A few days after the fateful August meeting, the SJC and LUGO members held a protest in the park. About 20 people spread around the basketball courts with large signs that read "no dirty deals," "community process," "clean play" and a quote from Roberto Clemente: "I always try to lead the clean life." Unlike previous events that were covered by The Miami Herald, the only reporters on the scene were from Spanish-language television. In September, as the center was being demolished, the SJC sent an email update to supporters reporting that "community demands for the park have not been met" and lamenting the "hard lessons" learned after "the head of PRES struck a backroom deal with the politicians and claimed to represent the community that [was] locked out of the meeting."

Later, the SJC and LUGO organizers attended or, as they put it, "crashed the party" of the official groundbreaking ceremony. They had not been invited nor did they appear in the official photo of city leaders and the directors of Puerto Rican service organizations holding shovels against the dirt. ${ }^{294}$ Eliza, a neighborhood resident and former LUGO member who attended the press conference, recalled that a Cuban-

\footnotetext{
${ }^{294}$ They did not appear on the photo shown in news stories or on the city website, but they did take their own photos holding shovels to the dirt, as city officials looked on.
} 
American city commissioner from the district representing Little Havana "asked Teresa [the SJC organizer] why she was involved when in reality she didn't belong there," to which Teresa apparently responded that she was helping the neighborhood. Regardless of how accurately Eliza remembered the exchange between Teresa and the Little Havana commissioner, such stories (recall also Hector, Sandra and Gema) reveal how residents are attuned to the fluidity of the construct of "belonging" and its manipulation during specific conflicts in order to include and exclude people.

City officials announced that the new center would cost $\$ 1.8$ million (up from the previous $\$ 1.2$ million allocated), include a large multi-purpose room ("a social hall for community and family functions"), a children's play area, a computer lab, an arts and crafts room, and a fitness center. Paul, the PRES director, said, "We want it to be more than just a recreation building. It should have services for the elderly and a child-care program" (Morales 2008, p. NW13). At that time, and still as of this writing, there are no public records or any other evidence indicating that the coalition organizations that provide some of these services will be granted office space in the new center. ${ }^{295}$

The final weeks of that summer, when PRES seemed to break ranks with the SJC, clearly indicates there had been tensions within the coalition during the previous months. Pedro, a former LUGO member and Puerto Rican resident of Wynwood, noticed that during the coalition process LUGO and PRES seemed to be "at war with each other."

There were many battles [between them]. Some people would talk [negatively] about the SJC, other talked about PRES. Instead of everyone together hammering the commissioners - no, some went through this door and others went through

\footnotetext{
${ }^{295}$ There was no mention of these services or any other specific programming during the public hearings in which the cost increases and design specifications were approved, nor in any of the supporting documents.
} 
another door. What they had was an internal fight to say, 'Oh, they did that [community center] because of me!' And I think whoever does that, does a disservice to the neighborhood.

Miriam, one of the original coalition members, stopped participating when her advice "on how to word communications both verbally and in writing... was not heard." She reflected on the coalition experience:

The group [SJC] was well organized in terms of that representation, but we were not very well organized in terms of message. There appeared to be a struggle from the get-go... What I remember most was discord over messaging... There also appeared to be a power struggle as to who was in charge, and that is never good in a "coalition."

Former LUGO members agreed with the SJC's interpretation that they had been betrayed by PRES, which, according to some, sought all along to take credit for the coalition's work. Eliza, ${ }^{296}$ for example, who was involved in some coalition meetings and "would go with the big signs to protest," opined that "after [the campaign was over] it appears like the ones who fixed all that was PRES when in reality it was... LUGO that called all the people and asked PRES to help out." Sandra, a former LUGO member who lives across from the park, was explaining "the tensions" she noticed between PRES and LUGO when her sister, Gema, interrupted: "Those were two rabid dogs!" "Yeah, it was kind of a big tension there," acknowledged Sandra, reluctantly. "Because to be honest, LUGO came up with the idea about the park. We - Teresa, walked through the neighborhood, she got people walking, signing the petition.,297

\footnotetext{
${ }^{296}$ As I will discuss below, Eliza eventually chose to disassociate herself from LUGO.

${ }^{297}$ Mauricio, an elderly, Costa Rican immigrant and current LUGO member, explained what happened in one of the early coalition meetings in his typically polite style. "That was when people got upset [with
} 
Despite the discord, coalition members I spoke with thought that the outcome of the community center was a worthy improvement, even if the final project did not incorporate everything that the coalition asked for. ${ }^{298}$ After several change orders, the center's cost increased from the original $\$ 1.2$ allocated to $\$ 1.8$ million in 2009 , then to \$2.9 million in 2010. Paul, the PRES director, hoped that Art District developers would contribute to the cost of the community center project (Morales 2008b), ${ }^{299}$ but the extra funding came from the Obama administration's first stimulus package (City of Miami $11 / 28 / 2008$ ). When it was finally built in 2010 , the new center included a reading room, an exercise room with treadmills and weight machines, a computer lab, a large multipurpose room, and offices for the park manager and other city employees. The front lounge has two large display cases sparsely populated with Roberto Clemente memorabilia.

Paul]. That is when a lady told him a bunch of things, and he got upset, too. But they told him the truth. Because he had not lifted a finger to create all this and now he was trying to own everything. That wasn't fair because people had done a lot of work to accomplish [the coalition]. But he didn't like it [so] he left and said, 'ok, I'm not needed here.' Later he came back but that time it was not that we had to do everything he said." Other current LUGO members had similar perspectives, such as that of Wilma, who recalled that at the meeting "with the old people and the government... they called PRES but not us," adding that PRES got credit in newspaper articles for coalition work that LUGO had actually carried out.

\footnotetext{
${ }^{298}$ Those who acknowledged that the park lacks a pool, indoor gymnasium, library and other things that were requested by residents, also expressed views akin to, "you can't have everything you ask for." Some residents I spoke with are not happy about new fees to use the fitness room, the application of which appears to be a trend at other parks in low-income neighborhoods amidst the city's growing budget deficit (Sanchez 2010). A few others have complained that there is not enough parking. The City issues a waiver so that the new center could be built with 11 less parking spaces than required by its' zoning code (City of Miami 11/13/2008).

${ }^{299}$ The City of Miami had enough funding from the Neighborhood Improvement Bonds to finance the demolition but a shortfall delayed construction until April, 2009, several months after it was demolished (City of Miami 4/29/2009). Since during the summer of 2008 Goldman had promised to contribute funding "to the community" north of $29^{\text {th }}$ street in exchange for passage of the Café District ordinance, the head of PRES mentioned this at the groundbreaking ceremony as the reason why Goldman should help finance the shortfall for the new center's reconstruction (Morales 2008b).
} 
At the grand opening of the community center in October, 2010, the SJC claimed the reconstruction as a victory. ${ }^{300}$ Wearing their typical yellow T-shirts, LUGO members stood silently throughout the press conference and held up large signs that read, "Justice for Wynwood.” It was fitting that these messages were written on the back of SJC posters leftover from the 2005 RENT campaign, emblazoned with the message, "Gentrification Stops Here," as if to not only "reclaim" the community center (as they wrote in their press release) but to also reclaim the rhetoric that was compromised in the work of the coalition. LUGO members told El Nuevo Herald (the only press at the opening), "we're here because we've been in this struggle for five years" (Sanchez 2010a).

The coalition was vulnerable to breaking apart or, at least, breaking away from the SJC for several reasons, reflected in the aforementioned tensions over messaging. The Puerto Rican service organizations were funded by the government whose plans they opposed. This made them more willing to negotiate and compromise with the Mayor's office. These organizations also had a stake in the new center's office space. As noted earlier, the De Hostos Center is slated for major renovations, ${ }^{301}$ which will displace its current service organization tenants. The Senior Center and its' lunch program has been assured temporary space at the new center during these renovations, but there is no indication that PRES, which occupied the most office space in the De Hostos building,

\footnotetext{
${ }^{300}$ In the official communication of the event via their website on October 28,2010 , the SJC wrote that, "Now, 3 years later, Roberto Clemente Park is once again the heart of Wynwood. We won a community center, with computer lab, fitness center, and afterschool program and a ballroom."

${ }^{301}$ Half of the De Hostos Center is closed because of structural deterioration. As I learned at a January 2011 neighborhood meeting, the City of Miami has yet to allocate funding for the demolition and reconstruction but the reconstruction plan and designs for the new neighborhood center are complete. The shell of the old building will be preserved but the interior will be rebuilt into office space for the service agencies that now operate there. A third floor will be added to the current two-story design in order to incorporate a library, something which the Coalition to Save Clemente Park had asked for.
} 
will be accommodated in the newly built community center. ${ }^{302}$ Although the SJC suspects that PRES and PRCC may have been promised office space during private meetings, it remains to be seen whether the allegedly promised concessions are actually given.

Unlike previous decades, during the 2000s there were no leaders clamoring for attention in Wynwood. The Puerto Rican service organizations had long become accustomed to conventional avenues of negotiating for funding, largely limited to lobbying at City or County Hall. During the 1980s and 90s, the Catholic Church revived the art of protest in Wynwood under the influence of the FBAC, and sometimes built alliances with service organizations to attain neighborhood objectives (e.g., the Save Our School campaign). But by the 2000s, at the height of the housing boom, the faith-based protest activity largely receded from Wynwood and, as I discussed earlier, the FBAC in general found it increasingly difficult to win concessions from government during this period. Therefore, the Puerto Rican service organizations in Wynwood needed a new organization like the SJC to generate the protest activity that might compel a greater response from public officials.

For the service organizations, getting back to the negotiating table was all that they wanted, as this resumed the conventional politics of community-based service funding that had broken down under the pressure of a development boom that consumed the city's administration. As discussed earlier, during the early 2000s, the CBP office had become a sort of "community outreach" extension of developers. CBP office

\footnotetext{
${ }^{302}$ There are no records, such as in memorandums between city agencies, minutes of city hall meetings or legislative actions that indicate which services and organizations may use the new center's office space.
} 
administrators devoted increasing time and energy to facilitating the growth and operation of the Art District. Community-based policing itself was transformed under the influence of the Midtown developers, as years of "serving" and "protecting" could be leveraged into political support for the new development project. In the terms of urban scholars, in this moment Wynwood experienced "the fundamental difference between a politics of income redistribution and a politics of growth" (Hall and Hubbard 1996, p. 153-174). The prolonged closure of the park's community center confirmed and reflected these transformations. Notably, service organizations were doing nothing to change this, even though some may have been frustrated by the situation. The director of PRES, considered by some colleagues a militant and outspoken leader, ${ }^{303}$ never spoke at the city commission meetings or other public hearings about the condition of the community center until 2008, when he partnered with the SJC. The Chamber president asked for updates on the project in his role on the Neighborhood Improvement Bond advisory board. But not until the SJC mobilized residents to speak out during town hall meetings did any of the service organizations publicly express their own disappointment, creating the conditions for an alliance. Even though the objectives of the coalition were expressed in terms of tangible outcomes for the community center, in practice the resumption of negotiation between Puerto Rican organizations and city officials seemed to end the collaboration between the SJC and the other coalition members.

\footnotetext{
${ }^{303}$ For example, the Carlos Jr. who was assistant director of PRES programs in Wynwood, referred to Paul as the "bad cop" in their lobbying partnership. "It was the whole good cop, bad cop thing. He'd be the bad cop and I'd come in and be the good cop and do the negotiating kinds of things and get programs for the kids or get the city to understand that you can't walk all over Wynwood and not expect people to call you on it." He went on to point out that Paul "was part of the young lords movement back in Rochester, New York... from the early 60s [when] you had to confront people in order to get things done." Nevertheless, he explained that because "the circumstances have changed and... the people in power also understand that [they] just can't keep neglecting the neighborhood," militant tactics are no longer the most appropriate or effective for working with government.
} 
It is not clear if and when the service organizations would have been invited to negotiate the terms of the community center reconstruction; or, even, if and when the community center would have been rebuilt without the pressure generated by the SJC. Moreover, the pressure created by the SJC may not have been limited to the mobilizations and protest in Wynwood. The City of Miami preferred not to deal with the SJC for other reasons. During the 2000s, the SJC had challenged the Mayor's administration on many issues and the summer 2008 negotiations over the community center coincided with the SJC's involvement and leadership in new national alliances of activists and major protests against the Diaz administration. The broader context requires some elaboration, as the SJC's involvement in more radical protest activities, independent of the coalition, became a source of friction within the coalition.

During the winter of 2007-2008 the SJC helped create a national alliance of social justice organizations known as the Right to the City Alliance (RTTC) to advocate and lobby for specific national urban policies as well as support the city- or neighborhoodspecific campaigns of its member organizations. A regional sub-section of the alliance was created to represent South Florida, comprised of the SJC and two other South Florida social justice organizations. The creation of the national RTTC has been written about elsewhere (Goldberg 2008; Gladora 2009; Horlitz and Vogelpohl 2009), but some key aspects are relevant to understanding the processes of gentrification in Wynwood.

The formation of the RTTC represents a shift in urban social justice organizations that once exclusively addressed neighborhood problems toward multi-dimensional social movements that are rooted in, but "transcend the local" (DeFilippis, Fisher and Shragge 2009, p. 40), including building alliances between organizations or constituencies at 
various political and geographic scales. The basis for this shift lies in the critique that urban social justice movements were not "scaling" their work to match the forces they were confronting: "Unlike the fiscal system [supporting unequal urban development], the urban and peri-urban social movements of opposition, of which there are many around the world, are not tightly coupled; indeed most have no connection to each other" (Harvey 2008, p. 37). The last decade has seen a trend among social justice activists toward the construction of social justice alliances across neighborhoods, cities, regions, states and even countries (Goldberg 2008; Smith and Guarnizo 2009; Sugranyes and Mathivet 2010). The RTTC is an example of the "coupling" of diverse social justice organizations with the aim of transforming urban development systems within the United States. The RTTC leaders describe it as "a national movement for urban justice, human rights and democracy," which, "in the process [is] building new ways to work and organize," including "new ways to build reciprocal knowledge and common cause between locally based organizations and networks" (RTTC Funder's Guide 2008, pp. 34). The alliance is organized flexibly to address a variety of injustices at different geographic and political scales, from state education policies to national housing policy to local and regional issues. Flexibility is facilitated by a network structure as opposed to a more rigid single organization or coalition. The RTTC created regional and national working groups, and specialty groups to address specific injustices across different locations, such as environmental degradation or disaster recovery. One of the RTTC's first major coordinated actions was a "March on the Mayors Conference" in Miami, which took place the same summer of the community center reconstruction negotiations at City Hall. 
Miami hosted the U.S. Conference of Mayors in June 2008, months before the leadership of this institution would be passed to Miami Mayor, Manny Diaz. The Mayors' Conference is not only an annual meeting but a national lobbying organization for urban policymakers. Therefore, the conference was also seen as an opportunity for activists from Miami and elsewhere to publicize their policy demands on the streets and mobilize neighborhood residents around a variety of urban policy issues. The RTTC held its own two-week long conference, dubbed the People's State of the City Conference, at the downtown campus of Miami-Dade College. It was attended by more than 30 activist organizations from across the country whose leaders organized various planning meetings, festivities and a "people's summit" made up of educational workshops for members and supporters about why a national alliance was needed and what policy reforms it sought. The conference culminated in a protest march, fashioned as a "New Orleans Jazz Funeral March," from the edge of a controversial redevelopment project in Overtown to the hotel where the Mayor's Conference was taking place (Hargot and Torter 2008; Wakefield 2008). More than 300 protestors from organizations representing seven urban regions (San Francisco, Washington D.C., Los Angeles, New Orleans, New York, Boston/Providence and Miami) marched for an hour in the rain, under the shelter of black umbrellas that read, "Take Back the City." Protestors also carried cardboard funeral boxes and 6-foot tall skeletons inscribed with the names of different urban problems, such as "privatization," "gentrification," "deportations," "police harassment," "racism," and so on - props which symbolized activists' desire to end these urban injustices. 
Figure 6.25: Image of Protests Convening in Front of the Mayors Hotel during the "March on the Mayors Conference"

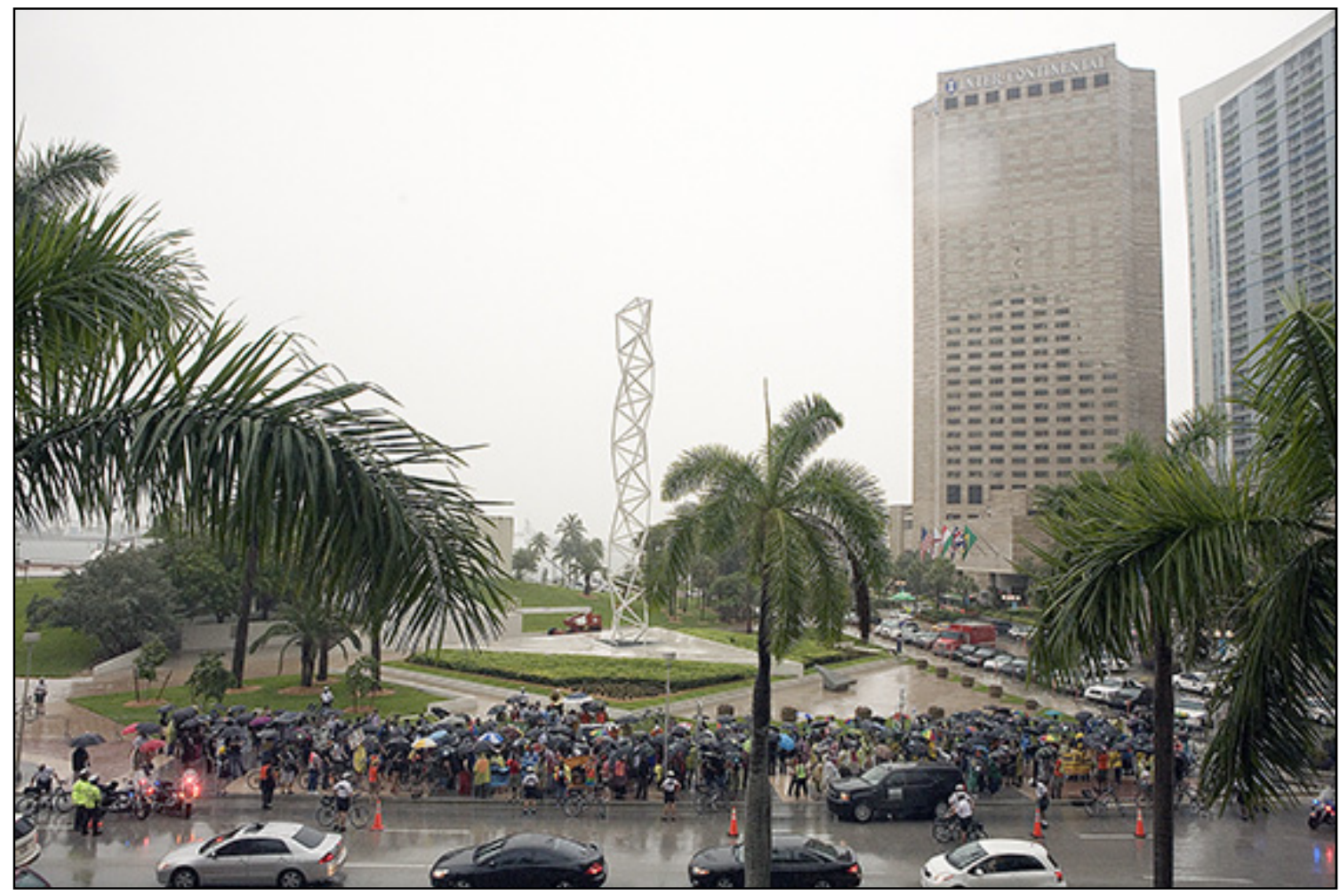

Source: Photo from June 2008, courtesy of Carlos Miller's (2008) online article available at: http://www.pixiq.com/article/march-on-the-mayors-protest-proceeds-through-downpour

The SJC's lead role in both the RTTC and the 2008 "March on the Mayors" clearly identified them as opponents of the Miami Mayor's urban policies at the same period that the Coalition to Recover Clemente Park was beginning to negotiate concessions with the Mayor's office. Their opposition in 2008 was not the first time the SJC had challenged the Miami Mayor (e.g., the 2005 RENT campaign). However, the SJC's leadership role in the RTTC protests, in addition to the prior oppositional campaigns, may have made the Mayor's office even more reluctant to deal directly with it. The SJC director argued that what the city gained from the "backroom deals" negotiated with PRES “was not having to deal with us." Moreover, the SJC's 
autonomous work during the summer of 2008 increased frictions within the fragile coalition, ${ }^{304}$ although SJC staff members do not believe that it caused the coalition's fragmentation. The other organizations' disapproval of the SJC's autonomous work ${ }^{305}$ merely reflected and confirmed the fragility of the coalition rooted in ideological and political differences. The service-providing organizations funded by local government were apparently more willing to compromise on the coalition's broader objectives in order to meet the needs of their individual organizations.

\section{Neighborhood Organizing as part of Social Movement-Building}

The case of the coalition to re-open the community center revealed the challenges not only of organizing in relatively new terrain, i.e., Wynwood for the SJC, but also highlighted the challenge of building alliances in Wynwood within a social movementbuilding project that integrates neighborhood organizing as one of a diverse array of strategies implemented across different geopolitical scales. As the SJC's then-lead organizer, Frank, explained, "we believe that we will not achieve the power we need to bring out about the fundamental changes that are necessary unless alliance building is a fundamental part of our strategy," adding that it was therefore crucial to learn lessons

\footnotetext{
${ }^{304}$ In response to my question about the coincidence of coalition work and RTTC protests, the SJC director noted that compromise within the coalition became "tricky." "Compromise gets tricky because the coalition doesn't want you to do your own autonomous work and wants you to compromise in the coalitions work. So we both built the coalition... staffed it, respected its consensus. Did the work for it, succumbed to what it was willing to agree to even if we didn't agree, but they also then didn't want us to do our own work. Because they didn't want us to increase our relative power within the coalition or to have our own work impact them in the coalition. And so I think that's where we had to insist, we will respect you in the coalition but we have the right to continue to have our own voice, our autonomy, et cetera."

${ }^{305}$ Another segment of the SJC's autonomous work was the Galeria del Barrio, a photography exhibit (subtitled, "This is Wynwood") that took place during the Art Basel festival December, 2008, held in an art gallery in the Wynwood Art District. LUGO members from Wynwood took pictures of their neighborhood as a way to highlight the social environment that existed before the arrival of the Art District.
} 
"when it [alliance building] fails." Frank alluded to some of these lessons through rhetorical questions about whether more could have been done to build alliances with small businesses. "What are we doing to not just build with [PRES] but with the small businesses and the small business formations [such as the Chamber of Commerce]? Can we build a tactical alliance and, if not, are there subsets of [that formation] we need to be building with or is it a tiny little sector of the businesses that [can] have unity with us?"

Alliance building is increasingly seen by activists and scholars as a way to build power to the scale of the political and economic forces driving unequal urbanization - the problem emphasized by Harvey (2008) and others (DeFilippis, Fisher and Shragge 2010). But there are questions as to the durability of such networks and whether "smaller, weaker organizations federated through flexible networks can accomplish more than large, strong organizations weakly federated with each other" (Nissen 2009, p. 164). ${ }^{306}$ Across South Florida, the "constantly shifting constellations of alliances that so far have not shown great organizational stability" (Nissen 2009, p. 166) may eventually be effective through repeated collaboration and/or during moments of political opportunity (such as a particular state election or legislative cycle), or even by eventually settling on a more permanent formation. The RTTC South Florida region organizations or the more

\footnotetext{
${ }^{306}$ Nissen examined the work of the CBC "coalition" formed in Miami between 2004 and 2008, discussed in Chapter 5, and concluded that "the evidence from the local Miami scene and/or the national scene gives scant verification for the belief that [the network] will be a stable or permanent form of interaction" (2009, pp. 165-166).
} 
recent state-wide alliance, Florida New Majority, ${ }^{307}$ may represent more durable formations, but are still too new to judge.

Scholars of community organizing and movement-building have highlighted the need to balance flexible alliance-building with longer-term investment in grassroots organizing, widely recognized as the most important and labor-intensive aspect of movement-building (e.g., Dreier 1996; Goldberg 2008; DeFilippis, Fisher and Shragge 2010). Grassroots organizing seems especially important in the context of South Florida, where social justice organizations such as the SJC are relatively young and have small residential bases of support. On the other hand, this may also make alliance-building crucial, as small bases of support can be pooled to build larger, more powerful constituencies during specific campaigns. At the same as the SJC was building an alliance to Take Back the Park, they were also involved in canvassing operations to Take Back the Vote and RTTC actions to Take Back the City and later became involved in state-wide alliances to affect legislative processes. The SJC's former lead organizer, who now works for the national RTTC, reflected on the challenge of balancing these different projects:

When we started the SJC we kind of glorified [grassroots organizing] to the degree that we didn't see the significance of communications strategy, alliance building, etc, beyond the significance of base building and leadership development. I think what dynamic you see happening now is not any lessening of the significance and importance of base building and leadership development... [But] with that said, there's tensions as we've gone through processes [of] deepening [our] understanding of the different aspects of movement building. One example is, we've learned that no matter how powerful you get locally, there's a lot of forces at work nationally, that need to be addressed and one strong, locally

\footnotetext{
${ }^{307}$ In 2009, the SJC created Florida New Majority (FNM), an independent organization to mobilize voters in support of "progressive" policies in Florida. Although FNM is formally independent from the SJC, at the time of my field research the two organizations shared office space, staff and other resources.
} 
based organization can't address that. This understanding led to the SJC back in around, starting 2006, to start investing some time and energy in connecting with other local organizations that believe in aggressive organizing on the ground, direct action, similar to what Alinksy would say, but also believes in ideology and understanding the root causes of problems and importance of leadership development and political education. We reached out to them and ultimately the result was birthing a national alliance. With that reorientation there's always a tension: Well, we got to invest in that, but at the same time, you know, we can't let go of the bread and butter of the movement, which is [organizing]. It's a real tension, because you only have so much capacity... Now, one way we resolve some of that tension is we go out and get more resources. So you'll see our commitment to every move, whether it be the birth of RTTC or the birth of Florida New Majority, you see an increase in our budget and our staff. So it's not like, oh my God, no one's working in Wynwood or Liberty City... We have new staff. But I say all that to say... there's a real tension there always around capacity and the need to always build the base, focus on leadership development, but at the same time, realizing the importance of other aspects of building the movement.

Indeed, through 2010 the SJC's presence in Wynwood continued through its outreach work in relation to broader campaigns (e.g., voter mobilization) but also through the creation of a weekly walking group to promote exercise and health among Wynwood residents. However, the SJC's work in Wynwood, despite the formation of LUGO in 2007-2008, was not to create a neighborhood-based organization or to conduct long-term, neighborhood-based organizing. Mobilization around the Clemente Park community center was a way to integrate Latino residents from Wynwood into the SJC's broader goal of "movement-building."

Without sufficient history and credibility in Wynwood, the SJC had to build alliances to implement a social justice campaign on neighborhood issues. Given the existing organizations in Wynwood, an anti-gentrification campaign could not be the basis for such an alliance. Although the SJC clearly positioned itself as an opponent to gentrification through its "strategic communications" work (e.g., the "Wynwood Anti- 
Gentrification Committee"), it did not seek to address gentrification as manifest in a specific development project. In this way, the SJC, like other organizations that have worked in Wynwood (whether social justice or service organizations), chose not to directly address gentrification as a complex of processes manifest in specific projects or policies. It opted instead to publicize the problem, perhaps in the hopes that in the future residents might be more receptive to supporting a specific anti-gentrification campaign. Minimally, the goal was to "make gentrification a counter-message to progress," as the SJC director explained, "so that we were successful at having gentrification become a household name." The strategy chosen was that of "visibilizing what the development was coming on top of and giving voice to those communities, which meant that we started doing work - but it wasn't really base-building work - in Wynwood and Little Haiti and Opa-Locka and a bunch of places, really being able to put out a frame and a message to visibilize those communities and having activities and tactics that put them as the counter-balance to the [downtown] development coalition."

While framing gentrification may have been the broader movement-building strategy - and appears to have been effective in terms of publicizing the issue in the broadcast media and within the neighborhood ${ }^{308}$ - neighborhood residents used existing frames to interpret events which sometimes complemented and at other times conflicted with the SJC's framing of political action. Although the SJC linked the neglect of the community center to gentrification, the coalition campaign to re-open it fit into the

\footnotetext{
${ }^{308}$ Indeed, much of the debates and discord surrounding the value of the Midtown complex was centered on gentrification - whether new wealthy investors and residents are more of a cost or benefit to existing residents. These debates took place in the Town Hall meetings organized by the SJC and between organizational leaders and stakeholders who came into contact with the political processes catalyzed by the SJC.
} 
neighborhood's history of struggle against disinvestment, including protest-based campaigns that led to the creation of service agencies, demolition of abandoned housing, resistance to environmental pollution, and so on. "They don't care about Wynwood" or "the police don't do anything" are typical remarks from Wynwood residents who believe that local government is not responsive to their neighborhood. Note that the antigentrification narrative used by the SJC at the outset of their alliance-building gave way to more moderate claims about collective consumption - demands for government services added to the place-based narrative of Puerto Rican honor ("a park deserving of Roberto Clemente's name"). The recent community center campaign resonated with residents' sense that politicians ignore Wynwood until residents mobilize to make demands. However, the view that political action in Wynwood should target city government also suggests that some Wynwood residents are unlikely to agree with or even understand the community center campaign as did the SJC: as part of a broader strategy for achieving political change in the Miami region or across U.S. cities - that is, for bringing about the "right to the city" for all low-income city-dwellers.

Although almost all of the Wynwood residents I spoke to expressed appreciation for the SJC's work, several also suggested their limited presence would necessarily result in limited impacts on the status quo of urban politics that affect the neighborhood. For example, Sandra's opinion was typical of a small group of residents who were involved in or supported the community center campaign but have not remained with LUGO as dues-paying or otherwise active ${ }^{309}$ members. "I think that it's a shame, in a way, that you have people from your own community that could fight for justice, like Teresa is doing,

\footnotetext{
${ }^{309}$ I explain membership requirements and categories below.
} 
and that someone else has to come from outside ${ }^{310}$ to do it. But at least she's doing

something," added Sandra. She then agreed with her sister that the neighborhood will not be able to defend or even express itself in the face of development pressures "unless that [internal] pissing contest stops," referencing the divisions and competition between coalition leaders.

Others were more critical of the SJC's lack of presence in the neighborhood and particularly of its apparent departure from the perceived aim of increasing their membership base in the neighborhood. Wilma, who was still participating in SJC protests in Miami when I interviewed her in $2010,{ }^{311}$ argued that "The membership is declining and I would like to increase it, but they [the organizational staff] did not want to support me in that." ${ }^{\text {12 }}$ Pedro, a former LUGO supporter mentioned earlier, argued that the SJC's small membership base resulted from its lack of commitment to the neighborhood.

Look, I say this because I belonged to them [LUGO], I say it with some pain. When you pretend to be an organization to lead a neighborhood, so that in the neighborhood people can see a difference, you have to be immersed in the neighborhood. So I can't put an office in Broward to fight for Wynwood or for Little Havana, I have to be there! Not just say, 'Now I represent Wynwood.' Here [in Wynwood] there is a widow who does not have anything to eat - nobody will know that and it won't show up in the newspaper but it is my problem with the organization. 'Let's get some soup together and go visit her in the afternoon.'

\footnotetext{
${ }^{310}$ This part was said in Spanish: "y que tenga que venir de afuera otra persona."

${ }^{311}$ Wilma explained that she was initially attracted to the SJC's housing campaigns because she was herself struggling to get into a subsidized apartment, but also because she was angry about the mismanagement of the public housing system (Cenziper 2006, 2007). When we met at the SJC offices in 2010, she asked me for help with the use of a fax machine in order to obtain a government-subsidized phone service for the public housing unit she had recently moved into after years on the public housing wait list.

${ }^{312}$ While a certain degree of confidence may not have been placed in Wilma's leadership abilities, other Wynwood residents such as Mauricio have been elected to the Grassroots Leadership Council and feel highly supported by the SJC as well as their member-peers. Mauricio was not concerned about the size of LUGO membership, asserting that in the near future they would be developing new campaigns which would draw more members and supporters.
} 
Here no organization does that. Here the organizations appear - and I say this with anger (con coraje, in the original Spanish) - when the press is around. You know, here in Wynwood there are a bunch of problems! There is an incredible drug problem. And nobody cares about that!

Pedro is clearly exaggerating, as the SJC's office (2 miles from the edge of Wynwood) is not in Broward County and it continues to maintain a limited presence in the neighborhood. ${ }^{313}$ Although as a member Pedro participated in some of the SJC's other campaigns and is aware of how Wynwood fits into the SJC's broader movement-building strategy, his primary concern was the extent to which any organization claiming to represent Wynwood spent time and energy building and sustaining relationships in the neighborhood. ${ }^{314}$ He asserted the same critique of the Puerto Rican service organizations, opining that they spent too much time in their offices instead of on neighborhood streets recruiting and helping residents. While he recognized that the "galleries are coming on top of the neighborhood" instead of "lifting up the community to the level of the galleries," Pedro was not critical of the Puerto Rican service organizations for their willingness to support, or at least, reluctance to oppose gentrification.

The point here is not to analyze the SJC's membership and leadership development or residents motivations for affiliating (or not) with the SJC but rather to highlight how some residents expectations of community political practice are at odds with the SJC's broader and shifting approach, which I elaborate on below. The ways in

\footnotetext{
${ }^{313}$ They do this through the exercise groups mentioned earlier and have occasionally organized fundraisers for residents in need of different things (e.g., food, funeral ceremonies).

${ }^{314}$ Like Wilma, Pedro has fond memories and feelings toward SJC staff and members, even though he disagrees with their tactics. He is mentioned on the SJC website as someone who developed political skills through their organization before moving on to become involved in immigration reform campaigns. But as the SJC's work appeared to become increasingly distant from Wynwood, Pedro became less involved with the SJC.
} 
which political organizing and action was framed by the SJC as compared to by some neighborhood residents, including the current and former LUGO members cited above, reveal differing expectations and assumptions about organizational practice. Wynwood's history includes many service organizations but little sustained, neighborhood organizing and collective action. Moreover, residents who have participated in the activism of Wynwood's service or faith-based organizations in prior decades became accustomed to these organizations' strategies and practices. Service and faith-based organizations have tended to be either accomodationist or otherwise become partners in relationships with government and developers. They have also been continually present as "caretakers" in the neighborhood. The more confrontational practices of the SJC and their more limited presence in the neighborhood was a different mode of operation than what residents were accustomed to.

The SJC had neither set out to build a mass organization in Wynwood nor is it singularly focused on grassroots organization as the only way to create social change. The organization's grassroots council is made up of six members, half AfricanAmericans and half Latinos. ${ }^{315}$ Membership in LUGO, which grew to 16 people in 2008 , required payment of annual dues of $\$ 24$ (reduced to $\$ 20$ in 2010) in addition to other commitments. ${ }^{316}$ The SJC draws on the tools of grassroots "base-building" (community organizing) as just one strategy for "building the movement," which also includes

\footnotetext{
${ }^{315}$ The SJC staff, including executive director, organizers, communications team, researchers and clerical staff, number 8 . Sometimes duties and roles are shared and interchangeable.

316 The SJC has two general categories of membership, which can be described as full and partial. The former includes members who not only agree ideologically with the mission of fighting racial and economic justice (demonstrated by signing a membership form), participate and/or take leadership of specific organizing tasks (phone banking, door-knocking), and pays their membership fee. Some residents, such as Elsa who lived in Wynwood, paid the membership fee and made other donations (clothes, kitchenware) even though she participated in hardly any SJC/LUGO events.
} 
"strategic communications," alliance-building and the creation of flexible networks of individuals to achieve specific, limited objectives. They use intensive leadership development (political education and organizational skills training) to create a small but capable and deeply motivated cadre of grassroots leaders. ${ }^{317}$

The importance of grassroots organizing in the broader work of the SJC seems to ebb and flow as the organization becomes more multi-dimensional. Or more precisely, the reasons for grassroots organizing, and thereby the geographic focus and intensity of organizing, shifts with broader movement-building strategies.

After building the small LUGO membership between 2005 and 2008, the organization restructured away from neighborhood-specific "bases" and campaigns (e.g., in and from Liberty City and Wynwood) in the next two years, and toward a united grassroots leadership. In this 2010 restructuring dubbed "We Are One," the SJC transformed neighborhood-specific campaigns into geographically broader but issuespecific committees, including: Work and Housing; Women and Youth; and Citizenship. An SJC organizer explained that the "main purpose [of this restructuring] is that there should not be campaigns by neighborhood [and] separated by race, which is really how we were functioning, but instead to integrate the campaigns." Thus, "We Are One" was also a process of "internal organizing" (as another SJC organizer put it) or intramembership relationship building between longtime African-American members and the

\footnotetext{
${ }^{317}$ Intensive political education appears to be a tool used by social movement organizations (SMOs) since at least the 1970s to overcome to non-ideological orientation of Alinsky-style neighborhood organizing, criticized for not developing residents' understanding of the root causes of the injustices they faced. As a result, many neighborhood organizations settled for "getting what they could," a modus operandi of "neighborhood protection," but did nothing to change the broader structuring of inequality that caused their problems in the first place (Stoecker 1997; DeFilippis 2004). Intensive political education focuses on the deep-rooted causes of injustice and the long-term strategies needed to create structural change so that participants will be better prepared and more willing to invest in longer-term campaigns.
} 
new, Hispanic LUGO members. The expansion of the grassroots base through LUGO and its integration with the previous membership base was not free of tension, as both current and former staff and members have attested. ${ }^{318}$ During the process of constructing new scopes and scales of activism, some members left the organization, not entirely accepting the broader objectives of the SJC, while the new campaigns recruited new members (e.g., RTTC electoral canvassing or mobilization around state-wide legislative issues). LUGO's membership is illustrative. Its founding members (16 partial, 10 full members) were from Wynwood and Allapattah, but the broader scope of more recent campaigns attracted new members from Little Havana and the cities of Hialeah and Opa-Locka. While some "Black-Brown" relationships have been developed and stabilized within the leadership structure, there is also some turnover and transience. ${ }^{319}$

\footnotetext{
${ }^{318}$ Some current and former SJC staff have lamented, for example, how integrating Latino residents from Wynwood into the organization's leadership structure, formerly dominated by members from Liberty City, created tensions between members. One staff organizer expressed that she would prefer not to be assigned the painstaking work of leadership development because it sometimes involved mediating disputes between Black and Latino members over seemingly insignificant things, such as what type of food to order for events (e.g., traditionally Latin or African-American cuisine). Another organizer pointed out long-standing beliefs about racial/ethnic relations in Miami had to be addressed in building relations ("a multi-racial, multi-ethnic base") across boundaries that, in the popular imagination, were zones of conflict. She noted that a Puerto Rican member from Wynwood had "a rich language against the Cubans even though I see her with some Cuban friends." But more importantly, SJC staff encountered conflict between Blacks and Hispanic members, such as African-American members who "may say things like, 'Latinos are taking our jobs" or Latinos who fear violence in African-American neighborhoods, among other things. A Mexicanborn SJC organizer noted that it took some of the African-American organizers more than a year to realize that she was not Cuban - a misunderstanding that is perhaps unique to Miami's history of inter-ethnic conflict. As Frank put it, there were "different levels of consciousness, different levels of unity" among the various grassroots members. To help build unity between African-American and Hispanic members, organizers developed educational workshops within the "circle of consciousness" process that focused on race relations in the unique context of South Florida, such as one titled, "Black, Brown and Sunny." It focused on the exploitation involved in the different migration histories of Bahamians, Jamaicans and various Caribbean and Central and South American nationalities - cases representing the ancestral backgrounds of different SJC members, who shared their own experiences of migration and discrimination.

${ }^{319}$ In addition to leadership turnover for reasons of strategic disagreements, a member's death or other personal life changes, in some cases immigrant status, influences the duration of their membership. For example, Mauricio, an elderly man who is part of the grassroots council, has for the last two years been weighing his return to his native Costa Rica, at the urging of his kids who argue he has no need to continue working or to live without stability - adequate wages or health insurance in the U.S. "Well, I'll think about
} 
The SJC continues to be involved in state-wide campaigns that involve mobilizing already-established grassroots bases (including those of ally organizations throughout the region) toward legislative advocacy. But, at least of this writing, there has been some winding down of campaigns through the national networks, such as the RTTC. The SJC appears to be shifting back to community organizing and recruitment, although not specifically on a neighborhood basis. In 2010, the grassroots council's citizenship committee began a campaign to pressure county and city government to create an immigrant ID card acceptable to local law enforcement authorities, banks and other institutions as a way to protect undocumented immigrants from deportations. The immigration ID campaign includes organizing residents in neighborhoods with a large share of recent immigrants, including Little Havana and Allapattah.. ${ }^{320}$

The increasingly multi-scalar and changing strategies for social movementbuilding are sometimes lost on residents who, while generally supportive of the SJC, have also expressed concern that base-building is declining in importance.

\section{Discussion: Community Organizing, Movement-Building \& Gentrification}

The SJC-led coalitional campaign to re-open the community center was a means not only to improve the building, but also to recruit and develop "conscious" grassroots members to help build the SJC organization and participate in broader strategies for

it" - he recounted a recent phone conversation with his son in December, 2010 - "it's that I have a commitment to an organization that doesn't want me to leave, so I don't know what to do yet, but it's most likely that I'll leave soon, maybe at the end of the year [2011]."

${ }^{320}$ This geographic focus developed not only because these are areas with many undocumented immigrants (as there are many similar neighborhoods throughout Miami-Dade County), but particularly because many of their grassroots members live and/or have connections to these particular neighborhoods. These neighborhoods are part of their turf. 
political change. The tensions between radical and pragmatic ideologies of change made the coalition unsustainable. To work with Wynwood's Puerto Rican service organizations, the SJC needed to temporarily adopt a more practical rhetoric devoid of attacks on gentrification or "the system." Adopting a more practical rhetoric enabled a workable coalition that pressured the government to rebuild the community center more quickly. But the end result was compromised, as the City ignored additional concessions demanded by different neighborhood stakeholders. The SJC recognized that in the future it will have to build more effective alliances, seeking a greater diversity of partners and supporters. But beyond the tactics of alliance-building, the case of the community center coalition in Wynwood raises other questions about the multi-dimensional, movementbuilding approach. One question has been raised in the literature with regards to the effectiveness of flexible networks for building a durable base of support for progressive political change (Nissen 2009). Another question is: what is the function of neighborhood-based, social justice organizing - essential to resisting gentrification within the expanding political strategies of movement-building?

In some ways, the campaign to re-open the community center was reminiscent of previous mobilizations in Wynwood for neighborhood services; but in more ways, the campaign represents a new kind of neighborhood organizational practice in Wynwood.

Like previous cases - the formation of the Puerto Ricans United and service organizations in the 1970s and faith-based activism to "clean up" the neighborhood in the 1980s and 1990s - the community center campaign focused on obtaining some kind of service from the government, what Castells (1983) referred to as the politics of “collective consumption." Never did grassroots organizing in Wynwood give rise to 
radical political demands. In addition, all episodes of grassroots mobilization were catalyzed and supported by professional activists who worked but did not live in the neighborhood. In these two ways - the role of outside activists and the absence of radical politics emanating from the grassroots - Wynwood is a microcosm of the history of neighborhood organizing found in many U.S. cities. In other ways the neighborhood exhibits the limitations of neighborhood organizing in the contemporary "neoliberal" urban context (Goldberg 2008; Shepard 2010).

Even in some other U.S. cities, where neighborhood residents are more ideologically predisposed to radical proposals to ameliorate injustices, neighborhoodbased movements have often fragmented along ideological lines (e.g., radical vs. pragmatic) or else settled on a pragmatic strategy that resulted in co-optation by government sponsors and/or narrowed objectives (Castells 1983, pp. 106-137; Fainstein 1987; Heathcott 2005). ${ }^{321}$ These effects - fragmentation, co-optation, narrow vision - are thought to be a function of the transformed urban political context in the latter half of the $20^{\text {th }}$ Century, "shifts... that have dulled the political edge of organizing" (Fisher and Shragge 2000, p. 1). In the wake of the 1999 "anti-globalization" protests in Seattle, activist scholars were calling for "the community movement [to] reconsider its shift to a politics of moderation and collaboration. It needs to reinsert more protest” (Ibid, p. 2). Others have called for organizers and activists to broaden their vision to better match the

\footnotetext{
${ }^{321}$ A recent analyst and former community organizer, while calling for renewed neighborhood organizing, noted that Alinksy-style neighborhood organizing "failed to build permanent institutions that could connect for city, state, and national action, go deeper into local power structures, and do more than win concessions from the powers-that-be. Alinsky himself observed that the life span of one of his organizations was five years; after that it was either absorbed into administering programs (rather than building people power) or died" (Miller 2010).
} 
globalized economic forces that affect urban neighborhoods (Harvey 2010). ${ }^{322}$ In the U.S. some argue that focusing on the metropolitan region is most effective way to affect the distribution of resources in cities (Benner and Pastor 2008), while others advocate political organizing at local, state and national levels (DeFilippis, Fisher and Shragge, 2010).

One of a few recently created social justice alliances across U.S. cities, ${ }^{323}$ the RTTC seeks "to develop a common frame and approach to unify our diverse struggles for housing, social wages, public space, and culture" (www.righttothecity.org). South Florida differs from other RTTC regions in that its labor movement is relatively weak and social justice organizations are young (Nissen and Russo 2006; Nissen 2009). In addition, with a few exceptions, Republican politicians and conservative political organizations dominate much of state and local politics (Colburn and De Haven-Smith 1999; Stepick et al. 2003; Mormino 2005; Girard and Grenier 2008; Shell-Weiss 2009). ${ }^{324}$

It was precisely this combination of forces, together with Florida's importance in national elections - made clear during the 2000 Florida recount (New World 2005) - that led progressive political organizations and liberal philanthropic foundations to invest heavily in the state during the last decade. This investment is evident in the emergence

\footnotetext{
${ }^{322}$ In Urban Activism in a Downsizing World, Heathcott (2005, p. 289) writes: "Perhaps the days of broad social vision are over. Indeed, in a world fragmented by consumer capitalism and market imperatives, social struggle has become increasingly piecemeal, dislodged from overarching ideological agendas in favor of pragmatic, winnable tactics or identity politics. It may be the case that broad social visions were only conceivable in an era marked by broad social compact, where mass institutions such as immigrant churches and synagogues, labor unions, and the Democratic Party shaped common agreements about the nature of working class civic life and the form of citizenship in a democratic order."

${ }^{323}$ Other alliances include the Domestic Workers Alliance and the Partnership for Working Families, which also incorporate scholars cited in this text (e.g., Theodore, DeFilippis, Pastor).

${ }^{324}$ A majority of Miami-Dade County voters chose the Democrat in the 2004 and 2008 elections, and many elected officials (regardless of party affiliation) have support from major labor unions.
} 
between 1999 and 2005 of the main organizations in South Florida's "social justice infrastructure" (Nissen 2009) and also in major funding initiatives. Two prominent examples were the Ford Fund for Community Organizing (FCO) "Second Phase" investments from 2004 to 2007 (Gittel, Ferman and Price 2007) ${ }^{325}$ and the New World Foundation's New Majority Fund (since 2005) and Social Justice Infrastructure Funders program (2006-2007), "a learning community of program officers from various foundations" established to coordinate investments in Florida (New World 2005, 2007). ${ }^{326}$ Similar to New World's investments, "the extension of the [Ford] FCO into Florida" was seen as a way of "augmenting the state's organizing infrastructure," particularly by helping existing organizations "to scale up their activities and effectively collaborate" as well as reduce intra-organizational competition for grants (Gittel, Ferman and Price 2007, p. 109). The Ford investments were specifically designed so that "besides organizing to increase their capacity to address the concerns of their constituencies, the community organizations in Florida must make a concerted effort to work together to be more effective in some policy areas" (Ibid, p. 109-110). For its part, the New World Foundation sought to support what it envisioned as "new majority structures" (New World 2005, p. 13):

New majority structures are civic alliances; they may emerge within one umbrella organization or in a looser consortium of complementary organizations. They are alliances with organizing capacities that connect and integrate multiple constituencies, expanding the core and reaching the new. The most common structures are labor-community-interfaith collaborations, though several have

\footnotetext{
${ }^{325}$ The Second Phase added Denver and Central and South Florida to the list of FCO locations.

${ }^{326}$ While these were some of the earliest foundations that emphasized alliance-building and the creation of regional and state-wide infrastructures for political change, several other major foundations also invested in south and central Florida since 2005.
} 
been initiated by social service providers and advocates. They are also multi-issue alliances with applied research and policy capacities, and they create common agendas that are pro-active and escalating. They coordinate their activities through strategic planning, and also through intensive civic leadership development across their constituencies.

Although several foundations have invested in South Florida, the visions espoused by Ford and New World most aptly characterize the direction that the funding and organizing strategies have taken during the last 10 or more years. While many of these community-based organizations were born in the late 1990 s or early 2000 s, it is only with the support of major national foundations (on which they are virtually entirely dependent) that South Florida's social justice organizations, especially the SJC, have been able to move beyond "the limits of local organizing" (Cloward and Piven 2004; DeFilippis, Fisher and Shragge 2010). In theory, this permits them to avoid the either/or choice of local vs. extra-local (state, national) organizing. ${ }^{327}$

However, in practice, local vs. extra-local organizing seems to be an ongoing "tension" and strain on organizational capacity, as the SJC's former organizing director made clear. Not all community organizers value the broader aspects of movementbuilding in the same way, either. In 2010, Sheila, the former director of Activists in Defense of Overtown (ADO), another social justice organization that addresses

\footnotetext{
327 "At first glance," wrote Cloward and Piven (2004, p. xii-xiii) in the forward to a well-known community organizing manual (Staples 2004), "the juxtaposition of local organizing with the nationalization and internationalization of economic and political power appears to render local efforts weak or even futile. There are two typical responses by organizers. One is to turn to efforts to build national instead of local organization. The other is to call for the decentralization of economic and political decision making so as to make it accessible to local organizations. Neither strategy stands up to scrutiny. If the solidarities and leverage that underlie the possibilities of popular power are yielded by the local institutions in which ordinary people play important roles, then popular power can only be organized locally. Concentrating on the development of the formal apparatus of a national organization is no substitute for the mobilization of these local resources. At best, national organization can encourage the spread of local protests and perhaps coordinate them, but they are not themselves a source of much influence. At worst, efforts to build national organizations become an exercise in illusion."
} 
gentrification and participates in the RTTC alliance, was more critical of the funding that has supported a reorientation of organizing toward electoral mobilization.

I think funding in the last three years made a big shift to an investment in electoral politics and, so then that sucked a lot of money out of [other] things in order to for people to invest in electoral politics. It got framed as two things: we can actually have change if we have someone we want in office, and the other thing being, this is how we get to scale on base building. Because then you have influence and increasing power and this is going to help build organizations. Right? For me, the jury is out on both. I'm remaining kind of quiet because maybe I'm wrong, but the work that I've seen on the doors [to mobilize people for elections after 2008 or state legislation] is not moving people. They're not committing to doing a fuckin' thing. It still to me says, all you have to do is just go vote on November... It's important to have better candidates in there... but I think if we're saying that we're about radical change, then that's not the end game.

As a close ally and collaborator with the SJC (particularly through the RTTC in which they both participated), the former ADO director recognizes that electoral mobilization is not the only aspect of the SJC's shift into broader, movement-building work. The difference for the Overtown organization is that it lacks the funding ${ }^{328}$ and therefore capacity to balance electoral mobilization with the need to "hold down" its territory in Overtown, a neighborhood perpetually threatened by gentrification from all directions - the expanding downtown district to the southeast, the University of Miami medical complex to the west and the Wynwood Art District immediately north. ${ }^{329}$

\footnotetext{
${ }^{328}$ According to the former director, ADO's budget grew to more than $\$ 300,000$ around 2007, "plummeted" by about $25 \%$ in 2009 and has since rebounded somewhat. Other than support to be part of the RTTC Alliance, the Overtown organization has not received funding from the foundations supporting FNM or other regional- and state-level political organizing.

${ }^{329}$ In addition to their work to stop or modify specific redevelopment projects on the edge between Downtown and Overtown, ADO has most recently (2010-2011) sought to obtain concessions (e.g., jobs and job training) for Overtown residents from the University of Miami's expanding Medical Complex, specifically a new, partly subsidized BioTech laboratory, abutting the eastern edge of Overtown (Vasquez 2010). As of this writing, the first facility of the two-part project has been built while ADO continues to
} 
Electoral organizing "is not something I would not do at all," reasoned Sheila, "but it's certainly not going to be my main squeeze... where for four months, that's all I'm doing." 330

The SJC's ability to expand into a broader array of issue areas (e.g., state legislation, voter mobilization, federal stimulus advocacy) may be partly a function of having achieved a partial resolution to the original issue around which the organization was created - a federal HOPE VI project to demolish and redevelop an 850-unit public housing complex in Liberty City. Although the project was eventually demolished, the SJC's organizing combined with the exposure of fraud and mismanagement at the Public Housing Agency (Cenziper 2006, 2007; Pinzur 2007), pressured the county into an agreement to replace all of the demolished units, which was not part of the original redevelopment plan (Phelan 2007; Wakefield 2007). Since 2007, its role has been largely to continue to apply pressure and oversight to ensure that former residents are given jobs and housing. This reduced role has freed up some of its capacity to do other work. But the SJC's ability to "attach their wagon to the national work," as the ADO director put it, also partly results from the combination of the effective work of its staff in cultivating a

pressure for a written agreement to provide more tangible benefits to Overtown residents (Scott 2011; Vasquez 2011).

${ }^{330}$ The former ADO director does see the value of the RTTC Alliance, however. "[The RTTC] gives them [members] clout. Many times when I would say, in the local struggle, we're part of Right to the City, and there's seven major cities out there who are in this same fight that we have resource and access to, and that the March on the Mayors, all these people come, right? That kind of access to help you win your local fight - it doesn't mean you're going to win some big national thing and that we're going to have rent control across the nation or we're going to change public policy next week. I mean, that's the hope but it does help move [locally], and it gives you access, it gives you information, you meet new people, you have the training, it is what helps build local groups... I was totally down with Right to the City - my initial thought, though, was, 'oh, this is some thinking that's critical to help us understand gentrification more politically and to help deepen the analysis for our membership.' But then the other side of me was like, this is a fuckin' opportunity we need to cash in some money, you know, and so of course we're going to jump on the band wagon. It turns out that it was the right thing, and we got so much more out of it." 
positive reputation nationally ${ }^{331}$ as well as building relationships with funders during the key window of opportunity opened by the 2008 Obama campaign. ${ }^{332}$

The tension between neighborhood and broader scales of political action is not only evident in the distribution of organizational capacity, however; it is also observable in member recruitment. While experienced practitioners warn to guard against membership stasis, what are the perils of high membership turnover? With each new campaign, the SJC gained new supporters and members. At the same time, when the scale and scope of organizing constantly shifts from the neighborhood to the city to the state and beyond, some members are demobilized and disengaged. The Faith-Based Activist Coalition experienced this when Wynwood's Catholic Parish leadership gradually lost interest as FBAC campaign objectives shifted beyond the neighborhood's particular interests. There is some evidence of the same taking place with LUGO, as some members and supporters became uninterested in the broader movement-building project. The question is not whether losing members is itself a negative outcome, for the former LUGO members I spoke with all came away from their experience with a more critical analysis of political processes. Even if they criticized the SJC and opted out of

\footnotetext{
${ }^{331}$ This positive reputation is evident not only from my own observations of SJC staff members during meetings with funders, but also from the perceptions of colleagues in the social justice movement, including activists and academics. For example, at the March, 2011, Urban Affairs Association conference, I asked a panel of scholars discussing the potential of contemporary urban activism, what they thought of the challenges of scaling up organizing and advocacy to state and national levels while trying to maintain local-level organizing in cities and neighborhoods. The respondent, a member of the national RTTC and prominent urban sociologist, asserted that challenging as it may be, there was no other way to build a movement without building power "vertically" to affect policy across multiple levels of government. Having identified myself as from Miami, he added that the SJC was among a handful of organizations nationally at the forefront of this type of work.

${ }^{332}$ Sheila noted how the 2008 Obama campaign provided financial opportunities for social justice organizations to move into electoral work, which, in turn, helped savvy organizational leaders such as the SJC's director build and strengthen relationships with foundations.
} 
formal membership, they are closer to being allies than enemies of the SJC and may prove to be key supporters in future campaigns.

Instead, the question is whether and how this multi-scalar, multi-issue movementbuilding model can build membership faster than it turns over, thus allowing the slow and steady growth of a cadre of neighborhood-based leadership, albeit spread across diverse sites in Miami and perhaps Florida. A key challenge highlighted by the examples from Wynwood stems from the ways in which residents are accustomed to the rationalities and practices of community politics embedded in the neighborhood's institutional history. The experience of successes and failures in the past may lead residents to have expectations and assumptions about political organizing and action that differ from those of contemporary social justice activists, and may dampen efforts to build alliances and leadership in the neighborhood. Organizers may confront, for example, an environment in which the failures of established CBOs and CDCs to achieve change or implement development has narrowed the political frames available for mobilizing people. The potential for misunderstanding may be heightened in the particular case of attempts to resist gentrification in the context of contemporary approaches to social movementbuilding.

The complexity of gentrification exemplifies the challenge of linking local and extra-local political action. Gentrification is felt by people at the neighborhood level and affects very few neighborhoods within a metropolitan area - typically the poorest, inner city neighborhoods. While neighborhood-level mobilization is the source from which political pressure may be generated against specific, inequitable development projects, mobilization from one or more neighborhoods within a single city is insufficient to affect 
the broader regional, state and national level housing and land use policies facilitating gentrification (Lees, Slater and Wyly 2008; Wacquant 2008). Political advocacy at multiple levels as well as alternative development practices are needed to more permanently alter the way the costs and benefits of development are distributed (Benner and Pastor 2008, 2011). Such are the insights that informed the creation of the RTTC Alliance and which may inform and animate political action in Miami in relation to one or more of the many sites where gentrification is unfolding. ${ }^{333}$

Yet, the "tension" articulated by the SJC's former organizing director between "the need to always build the base" and "the importance of other aspects of building the movement" is accentuated in the case of gentrification of because of the nature of the injustice - gentrification not only advances a complex of harmful urban development practices (e.g., rental-to-condo conversions, upscale residential and commercial development, and the associated rise in evictions and punitive policing, etc.) but also implies the absence of beneficial ones, such as affordable housing and residents' control over land use patterns (e.g., community land trusts, housing cooperatives, etc.). In other words, it requires not only preventing but also proposing and implementing, at least in order to more fundamentally reform urban development. Although gentrification is not

\footnotetext{
${ }^{333}$ A few recent social justice campaigns have taken a multi-scalar approach to the organizing, albeit in limited ways. A labor-community coalition launched a campaign in 2006 to protect mobile home parks from demolition and redevelopment that included not only organizing residents to improve park conditions prevent the closure and sale of parks, but also lobbying and advocating at County Hall and, most recently, the state legislature to obtain policy changes. Currently, the organization is working with consultants to figure out how to help residents to collectively purchase and renovate mobile home parks. In contrast, SJC's broader, movement-building work is not linked together in a singular campaign. The SJC's work within the RTTC and state-wide legislative alliances address a variety of specific issues (e.g., accountability in federal stimulus spending or state unemployment compensation reforms) but these efforts are not integrated with the SJC's local work in Miami. In fact, the various strains of work are led by formally independent organizations (the SJC and the national and state-wide alliances), even though SJC leads the work of these other two entities in Florida and South Florida.
} 
unique in this respect, ${ }^{334}$ it is different than other social justice causes taken up in recent years, such as living wage campaigns that focus on passing specific legislation, which can be (and have been) won without a mass base of support. ${ }^{335}$ Political organizing that focuses on passing a particular law or halting a specific pattern of abuse (e.g., wage theft) need not be limited to a singular strategy; passage of the living wage may also be a stepping stone to building a social movement that seeks not only to curb abuses but propose new labor and even development policies. ${ }^{336}$

The key difference, at least in the context of Miami's rapid urban growth and progrowth political climate, is that it is extremely difficult to oppose development without also advancing an alternative. As discussed previously, the pressure for growth was unrelenting, which led activists to avoid opposing gentrification projects unless the political conditions were ideal. Among neighborhood residents the debate was also polarized as growth vs. no-growth (recall Hector's pro-Midtown plea: “do you want to go back to what we had before!?”). Moreover, stopping a gentrification project and advancing a more equitable proposal requires more than a large base of support, most of which is likely to come from neighborhoods affected by gentrification; but as the Clemente Park case demonstrates, this support has to be local in order to reduce the

\footnotetext{
${ }^{334}$ This duality applies to different injustices associated with "development," such as pollution associated with industrial growth, and is especially pronounced in areas experiencing rapid growth. During periods of growth, when many people are interested in the potential to profit from development, opposition to specific projects typically lead to polarized debates of growth vs. no-growth. Opponents are pressured to envision viable alternatives.

${ }^{335}$ In Florida it was passed because of advocacy efforts (without a mass support base) and sympathetic policymakers (Nissen 2000).

${ }^{336}$ This is precisely the strategy of the Partnership for Working Families, a national alliance of social justice organizations that work in several political arenas (industrial policy, urban development, etc.) through the mechanism of labor organizing.
} 
possibility that activists are construed as illegitimate outsiders. Because gentrification is by definition a neighborhood problem, to challenge development practices at the local level requires a groundswell of local support. Gentrification may be the quintessential social justice issue in which both the localism that stirs masses of people and the policy advocacy that is more distant from them are indispensable to "winning." 


\section{CONCLUSION}

My dissertation has examined, through historical analysis and ethnographic methods, how gentrification is produced to be uncontested by organized groups and the implications for neighborhood residents. In the remainder of this chapter I reiterate the key empirical findings of this research through a reflection on how the creation and formation of these governing arrangements is made possible through spatial, material and discursive practices of "place-making," particularly the "flexibilization” (Fraser 2003; Lepofsky and Fraser 2003; Cox 2004) and redefinition of place-based "community."

Many analysts have located the disappearance of conflict from urban politics in the proliferation of processes dubbed "community." On the one hand, this refers to the specific field of "community development" and the transformation of its "logics" under the aegis of urban entrepreneurialism (Jennings 2004; Newman and Lake 2006; Kirkpatrick 2007; Thibault 2007). As was the case with Wynwood's oldest community organizations, "the politics of identity and difference that energized the community development movement of the [1970s] has been replaced by an accommodationist politics in which the celebration of difference is antithetical to the dynamics of urban capital investment, the exchange-value denomination of urban neighborhoods, and the operational requirements of bureaucratized community development institutions" (Newman and Lake 2006, p. 45). The ethnic politics that inspired the creation of Wynwood's Puerto Rican organizations was subdued when these organizations were integrated in the community development funding and social service system. Their bureaucratic enfranchisement turned political energies inward, leading to internal divisions that weakened organizational cohesion and leadership. By the 1990s, to the 
extent that Wynwood's Puerto Rican organizations celebrated difference, it was for largely symbolic purposes, such as the naming of streets and buildings after Puerto Rican independence philosophers or the installation of San Juan-inspired street lamps (guacaras). In the context of the burgeoning Art District, the Puerto Rican CDC created to support local small businesses and build affordable housing for existing residents shifted its' orientation in the 2000 s to begin to serve artists and help create and implement a vision for live/work artist housing in the neighborhood, despite some residents' and other stakeholders' fears about gentrification. The CDC's shift was perhaps unsubstantial in terms of the impact of their work on the built environment since the Puerto Rican CDC did not actually build artist housing (though others did, following the CDC's lead), but their shift represented a weakened capacity to serve existing residents and exemplifies the transformation of the neighborhoods' political terrain under the pressures of gentrification.

But beyond representing the collapse or weakening of what appeared once as a potentially opposition politics, the evolution of community development organizations should be understood as productive of community-based governance. Analysts have drawn attention to "how particular locales become envisaged as communities in order to facilitate the mandates of the postwelfare state" (Fairbanks 2007, p. 112). Notions of "community voluntarism," service, and self-help are posited as an "unequivocal good in American political culture that distrusts government and exalts the individual" (Katz, 2001, p. 165). Yet, researchers may actually find, as Maskovsky (2006, p. 93) did in the case of a gentrifying neighborhood in Philadelphia, that 
It is the very inclusion of African American residents in the new devolved institutions of urban governance - and, notably, the insistence that they participate in a diverse, not a black, community - that produces a new sense of racial inequality and new forms of class division in the new inner city. In this regard, it is the very social construct of community - the sublime ideal and enabling condition of neoliberal governance - that disrupts the relation of significant segments of the urban population to governmental authority and creates new patterns of inequality.

In Wynwood, too, the inclusion of residents is part of the creation of exclusionary governance arrangements. In the name of community participation the Midtown developers used the CBP office as the conduit through which they could manufacture political support. The $\$ 200,000$ spent to support the Puerto Rican child care agency and other thousands for neighborhood service programs represented a tiny fraction of the $\$ 170$ million in subsidies and unknown hundreds of millions in profits the developers are actually earning. More important were the unaccountable processes through which these governing arrangements and payments were made between the developers, Bobby and city officials in conversations and meetings that left no public record revealing how the choices were made prior to the official political resolution documented in City Commission meeting transcripts. Residents waved silently from the back row as developers and Bobby assured politicians of the benefits to "the community."

The fallout from these processes was divisive, pitting the neighborhood association leaders against the CBP office, the directors of the Senior Center and the facilitating Community Action Agency (CAA). In 2010, the homeowner association director was voted out of her position as CAA board chairperson in elections organized by a new CAA coordinator who sought to "change [the] negative environment [that took 
hold] for a very long time, ${ }^{, 337}$ generated by the association directors' persistent criticism of the CAA for its' role in facilitating the political support for Midtown. The newly elected chairperson is a fraud investigator who worked as a police officer in Wynwood in the 1990s. Although the leader of the homeowner association continues to attend the CAA meetings, she does so to keep watch over the processes of community participation.

Local government has been instrumental in these changes in other, largely unintended, although perhaps not unforeseeable ways. The neighborhood-based CBP office, the hallmark of a nationally renowned community-based policing system devised in the 1990s to be the "government closest to the people," has, ironically in the Miami context, become a crucial instrument of social and political control. Despite years of critical service provided to residents - building code enforcement, permitting and certifications, coordinating neighborhood services, and helping poor residents in myriad other ways - under the pressure of gentrification, Wynwood's "mini city hall" became a highly malleable conduit through which developers and investors could manipulate the micro-processes of "street-level bureaucracies" (Proudfoot and McCann 2008) and neighborhood service agencies to help transform the neighborhood. Control over these administrative offices and their government service networks has been wrested, at least temporarily, from the residents whose activism in the 1990s was the impetus for their creation in the first place.

Symbolic of the contradiction between the reality of gentrification and the discourse of inclusive partnership was Levine's teasing reference to himself as an honorary Puerto Rican as he considered attending the Mayor's Town Hall meeting at

\footnotetext{
${ }^{337}$ Interview of Wynwood CAA coordinator.
} 
Roberto Clemente Park. Without knowing the history and context behind the statement, it can seem as a benign and even charming endearment that reflects his desire to ingratiate himself to his new neighbors, to form a diverse partnership for "pushing a neighborhood forward," as Melissa put it. But despite working out of an office down the block from Marta, these two are worlds apart in many other ways. The presumption of partnership in the face of such distance is not the problem, per se, as difference is arguably inherent urbanism (Lefebvre 2003[1970]). Rather, the problem is in the constitution through such partnerships of a political space called "community" that is exclusionary and unaccountable to residents.

Research on gentrification has in many ways been at the forefront of this critical understanding, for gentrification entails the establishment of new spatial and political practices for the "new middle classes" returning to inhabit the city (Zukin 1989; Bridge 1995, 2001; Butler 2004; Ley 2003; Davidson 2007). Case studies of the activities of gentrifiers reveal how new residents and real estate investors aggressively manipulate building code enforcement and other "street-level bureaucracies" (e.g., Goode Bryant 2005; Proudfoot and McCann 2008), policing and security forces (e.g., Merry 2001; Herbert 2008, 2011; Beckett and Herbert 2010) or other regulatory systems to implement their vision for the neighborhood. In Wynwood the new art district association has increasingly dominated political relations between the neighborhood and city government, and newcomers such as artists and gallerists have increasingly become the beneficiaries of government and nonprofit services.

These changes are made possible by a redefinition of "community," or through processes that make place-membership flexible and redefine-able. Lepofsky, Fraser and 
colleagues (Lepofsky and Fraser 2003; Fraser et al. 2003; Fraser 2004; Fraser and Kick 2007) have examined "community building projects" in terms of their effects beyond the amelioration of poverty (through the provision of social services) on the political terrain of the city.

Community-building initiatives occur in an increasingly globalized context, providing opportunities for stakeholders other than residents to promote certain productions of space and place and that urban restructuring and the development of inner-city neighborhoods may be viewed as arenas where developers, realtors, lending institutions, and a host of other private ventures extract profit and instigate a particular vision of the city. (Fraser et al. 2003, p. 417)

Moreover, Fraser and Lepofsky (2003) argued that "the reconstruction of the local" through the spatial practices of community building may be understood as a shift in the meanings of belonging and citizenship. Thus, community-building initiatives represent

a shift in the meaning of citizenship from being primarily guaranteed as a status (although a status dependent on certain performative acts) to being primarily guaranteed as a performative act (although still only accessible to those of a certain status). In moving toward the performative, the notion of flexibility takes on importance and does the ideological work to reframe who can be a citizen, what a citizen can do and how citizenship is important to claim one's right to the city and the production of that space.

The place-making practices were evident in the variety of individuals and groups who claim to be of, or speak on behalf of Wynwood, usually in contradistinction to others. Residents such as Hector who want to discredit the critics of gentrification or specific projects such as Midtown challenge naysayers legitimacy as neighborhood representatives with questions about where they live, how long they have been there, and what they have done for "the community." Other residents emphasized the skin color of 
the Women of Wynwood or the association with arts entrepreneurs to discredit this program for providing jobs to people from "outside" of Wynwood. Even the former City Mayor (1973-1985) asserted that "the so-called leadership of the community, none of them lived in Wynwood." Yet, living in Wynwood is not a requirement for governing in the neighborhood. The Mayor's remarks reflect the way the "political and economic elites... have prioritized certain forms of civic engagement over others" (Fraser 2005, p. 439), such as those "contemporary reconfigurations in the relationships of civil society, state and market [that are] conductive to supporting the spread of market forces in areas... beyond the reach of capital" (Mayer 2003, p. 109).

The so-called Miami model of private art museums may also be viewed as a hyper-entrepreneurial gentrification strategy in which wealthy collectors who double as real estate developers have been portrayed as the grassroots "community" that government must increasingly respond to and engage with. The "lash-up of organizations, practices, [and] institutional logics" (McQuarrie 2010, p. 239) produced by these stakeholders have not only transformed the relationships between government, the market and "civil society" actors and organizations in Wynwood, but the emergence of this new community politics has materially and politically displaced existing neighborhood residents. This displacement occurs through, not despite, the discourses and practices of partnership and inclusion in which some residents become involved.

Many residents and organizational leaders perceptions and engagement with gentrification processes are shaped by the "false choice" of gentrification and displacement or a return to the political and economic neglect of the past (Wacquant 1997; Jennings 2004; Slater 2009). This false choice between deprivation or displacement 
came to be perceived as real through decades of efforts at community-based selfgovernance. Each turn toward a new way of building "community" in order to accomplish "development" led practitioners closer to the market logics of gentrification and away from the kinds of political and economic changes needed to give residents more control over the future of their space and place in the city. Each respondent, from Rodrigo and Felipe to the leaders of the Catholic Church and the Puerto Rican CDC and even recent social justice activists articulated a clear sense of the limitations of their actions to change the politics of urban development. Perhaps the most dramatic expression was that of the Catholic priest who, despite assembling considerable "people power" at the height of his involvement in the FBAC, came to view the struggle for alternative urban development in Wynwood as "struggling in vain" or, as he put it even more dramatically in Spanish, dando coces contra el aguijón, which amounts in theological terms to the sense of futility in resisting the will of God.

The discourses and practices of Wynwood's community organizations help explain the problem I noted at the outset - "why most often the property sector works unopposed" (Gottdiener 1994, p. 227). It is not sufficient to say that residents, community organizations or activists are overwhelmed by the power of real estate investors and the governing arrangements they work through. Since the 1970s, the "citizen" and the "community" have become increasingly responsible for managing their space and place in the world, and the proliferation of programs to advance this community-based responsibility have transformed community politics (Chaskin and Abunimah 1999; DeFilippis 2004). Governing must happen in the neighborhood even though the resources for implementing policy decisions - particularly in the case of 
Wynwood - are not located there. This leads to the situation noted above in which "residents' rights to the city become based more on what they do as active citizens than who they are as urban neighborhood residents" and "as residency status loses significance with increased attention placed on civic participation... non-resident stakeholders... gain legitimacy in their claim to place-making rights" (Lepofsky and Fraser 2003, p. 132). This was especially clear in the growth of the Wynwood Art and Cafe District and the growing power of WADA.

But while this growth in "performative" and "flexibile" citizenship empowers non-resident stakeholders, it also transforms the rationalities and practices - the selfconduct - of existing residents and community leaders who participate in the new and evolving forms of community-based governance. The insights of Foucault's notion of "governmentality" and the "conduct of conduct" are useful here (Foucault 1979, 2004). In the context of the retreat of the state from welfare provision and the expansion of flexible, performative citizenship, it is easy to lose sight of government, increasingly extended over multiple sites and process through the forces that shape self-government within the "community." As Fairbanks (2011, p. 2557) writes,

The concept of governmentality allows us to see how devolution, retrenchment and the withdrawal of the state do not constitute merely a retreat from public space, but rather enact a set of interrelated political strategies designed to redistribute the disciplines of governance throughout the interstices of the social body. In this light, we can consider the question of whether an increasingly privatised or decentralised state is any less governmental and regulatory than its counterpart at the high water mark of Fordism.

The City of Miami agencies and the government's community organization partners in Wynwood reveal a variety of ways in which regulation is not removed but 
merely decentralized, reconfigured and internalized by neighborhood-based actors. Whether CDC leaders or neighborhood residents or the staff of service organizations, many of the respondents I interviewed asserted that there was a "proper" way of maintaining relationships to local government that precludes "negativity." A key condition for participating in the various processes of service provision and urban planning is managing and minimizing oppositional politics. Organizational actors come to embrace this through the experience of their failures and successes in different community development projects.

Crucially, it is not only nonprofit managers such as Rodrigo or those at PRES and the Puerto Rican CDC who have become convinced that they cannot and must not fundamentally challenge the politics of urban development; social justice activists in Miami across a range of organizational ideologies and tactics have also concluded that resisting gentrification is not possible given the present context and resources. This is not unique to Miami, although the effects of this choice may be pronounced since there is a less established history of anti-growth activism (with the perhaps notable exception of activists in Overtown). Nevertheless, social justice activists across the globe have increasingly embraced social movement approaches that do not necessarily prioritize or privilege "the local," instead seeking to build multi-local and flexible networks in response to and to capitalize on the opportunities afforded by transformation of governance itself. If non-residents become increasingly able to shape the built environment of residents, then activism may come to be managed by non-residents as well. As the director of the SJC put it, developers felt they "had a right" to put forth a 
"vision for the whole region" regardless of where they lived; activists must respond accordingly.

Amid the shifting tactics of social justice struggles, however, how can we keep sight of the broader questions about democracy? While compelled to "win" against the forces of unequal development, how can our response not merely recreate the governance processes in which the right to participate is determined by the willingness to perform in certain ways, potentially excluding neighborhood residents? In a place such as Miami where people come and go often, and few have been here for long (Nijman 2011), we must pay careful attention to the potential for governance to be transformed into a arrangement of place-based performance between non-residents, or at least ask how and why residents are not involved. 


\section{REFERENCES}

Addie, Jean-Paul D. 2009. Constructing Neoliberal Urban Democracy in the American Inner-City. Local Economy 24 (6-7):536-554.

Aguirre, B. E., Kent P. Schwirian, and Anthony J. La Greca. 1980. The Residential Patterning of Latin American and Other Ethnic Populations in Metropolitan Miami. Latin American Research Review 15 (2):35-63.

Almashat, Mayade. 1985. Gallery's Move South Boosts Colony Spirit. The Miami Herald, Neighbors MB, January 31, 6.

Andrews, Sharony. 1991. Wynwood Merchants Welcome Trade Zone. The Miami Herald, Neighbors NC, November 24, 3.

Ash, Agnes. 1964. Filling the Sweet Teeth of the Prairie Called Allapattah. The Miami News, History, June 14, 15.

Ash, Clarke. 1967. Middle Ground in the Slums. The Miami News, May 18.

Associated Press. 1997. Zero Hour Nears For 'Poor' Miami. The Orlando Sentinel, Local \& State, April 8, C1.

Atkinson, Rowland and Gary Bridge, ed. 2005. Gentrification in a global context: the new urban colonialism. London; New York: Routledge.

Austin, Tom. 2010. Private spaces - Local collections add another dimension to Miami's art scene. The Miami Herald, December 1, AB14.

Balmaseda, Liz. 1989. A Worn-Down Neighborhood Houses Hope. The Miami Herald, Living Today, February 5, 1989, 4g.

Balsameda, Liz. 1982. Crime Crushes Dreams for City Park. The Miami Herald, Local, June 20, 1 B.

Banksy, Thierry Guetta. 2010. Exit through the Gift Shop. Paranoid Pictures, 87 minutes, released March 5. United Kingdom, United States.

Barry, Andrew, Thomas Osborne, and Nikolas Rose, eds. 1996. Foucault and political reason: liberalism, neo-liberalism, and rationalities of government. Chicago: University of Chicago Press.

Barry, John. 1996. Miami Art \& Design Village The Miami Herald, Home \& Design, March 24, $1 \mathrm{H}$. 
Baxamusa, Murtaza H. 2008. Empowering Communities through Deliberation The Model of Community Benefits Agreements. Journal of Planning Education and Research 27 (3):261-276.

Beckett, Katherine, and Steve Herbert. 2010. Penal Boundaries: Banishment and the Expansion of Punishment. Law \& Social Inquiry 35 (1):1-38.

Begley, Jaclene, Caitlyn Brazill, Vincent Reina, and Max Weselcouch. 2011. State of New York City's Subsidized Housing. Furman Center for Real Estate and Urban Policy, New York University, and the Institute for Affordable Housing Policy. September. Available from http://furmancenter.org/files/publications/Ship_Final.pdf

Benner, Chris, and Manuel Pastor. 2011. Moving On Up? Regions, Megaregions, and the Changing Geography of Social Equity Organizing. Urban Affairs Review 47 (3):315-348.

Bennett, Michael S. (Senator). 2004. Interim Project Report: Review Of Florida's Growth Management Policy. Committee on Community Affairs. The Florida Senate. Available at http://www.leg.state.fl.us/data/Publications/2005/Senate/reports/interim_reports/p df/2005-117ca.pdf.

Bernstein, Fred A. 2005. A Founder of SoHo Has Another Vision for Miami. New York Times, Real Estate, January 16, 1.

Berry, Brian J.L. 1985. Islands of Renewal in Seas of Decay, in The New Urban Reality, edited by P. E. Peterson. Washington D.C.: The Brookings Institution.

Betancur, John J. 2002. The Politics of Gentrification: The Case of West Town in Chicago. Urban Affairs Review 37 (6):780-814.

Betancur, John J., Michael Leachman, Anne Miller, David Walker, and Patricia A. Wright. 1995. Development without Displacement Task Force Background Paper. Chicago, IL. The Nathalie P. Voorhees Center for Neighborhood and Community Improvement, University of Illinois at Chicago. June. Available from http://tigger.uic.edu/ pwright/dwd.html.

Blanchard, Brian. 1982. '60s Grove House Torn Down. The Miami Herald, Neighbors SW, September 12, 15.

Blanchard, Louise. 1966. Urban Renewal: Displaced Persons Parley Due. The Miami News, Front, August 5, 4A. 1970. Second officer of Model City quits here. The Miami News, Front, November 13, 1A, 4A. 
Bobo, Kimberley A. 2009. Wage theft in America: why millions of working Americans are not getting paid-and what we can do about it. New York: New Press: Distributed by W.W. Norton \& Co.

Bockmeyer, Janice L. 2003. Devolution and the transformation of community housing activism. The Social Science Journal 40:175-188.

Boddy, Martin, and Christine Lambert. 2002. Transforming the city Post-recession gentrification and re-urbanisation. ESRC Centre for Neighbourhood Research, United Kingdom. Available from British Library Document Supply Centre, http://www.opengrey.eu/item/display/10068/474583.

Bojnansky, Erik. 2008. A Restaurant Comes to Wynwood. Biscayne Boulevard Times, November.

Bonilla, Frank, and Ricardo Campos. 1981. A Wealth of Poor: Puerto Ricans in the New Economic Order. Daedalus 110 (2):133-176.

Boswell, Thomas, and Angel Cruz-Báez. 1997. Residential Segregation by Socioeconomic Class in Metropolitan Miami: 1990. Urban Geography 18 (6):474-496.

Boyd, Michelle. 2008. Defensive Development: The Role of Racial Conflict in Gentrification. Urban Affairs Review 43 (6):751-776.

Boyd-Barrett, Claudia. 2008. City Says Residents' Input Is Too Late. The Miami Herald, Neighbors, March 16, 3NE.

Branch, Karen. 1997a. Commissioners Choose 5-Seat Plan. The Miami Herald, Local, July 4, 1 B.

_ 1997b. Ballot Issues To Alter City's Power Web. The Miami Herald, Local, September 3, 1B.

Branch, Karen, and Dan Keating. 1997. City's Abolition Found Favor In Six Precincts. The Miami Herald, Local, September 6, $1 \mathrm{~B}$.

Brannigan, Martha, and Matthew Haggman. 2011. Miami-Dade charter reform: Is something better than nothing? The Miami Herald, May 8.

Brennan, Fran. 1994. Renters Paying Price of Restoration. The Miami Herald, Neighbors $\mathrm{MB}$, September 1, 3 .

Brenner, Neil, and Nik Theodore. 2002. Cities and the Geographies of "Actually Existing Neoliberalism". Antipode 34 (3):349-379. 
Bridge, G. 1995. The space for class? On class analysis in the study of gentrification. Transactions of the Institute of British Geographers 20 (2):236-247.

Bridge, Gary. 2001. Bourdieu, Rational Action and the Time-Space Strategy of Gentrification. Transactions of the Institute of British Geographers 26 (2):205216.

—. 2007. A global gentrifier class? Environment and Planning A 39 (1):32-46.

Brownstein, Cheryl. 1980. José Molina: de Radical a organizador de la comunidad. El Miami Herald, Enero 26.

Bussey, Jane. 1996. Wynwood Trade Zone Project Draws Skepticism Proposed Rents May Be Too High And Loan In Limbo. The Miami Herald, Business, December $15,1 \mathrm{~A}, 1 \mathrm{~F}$.

- 2003. White Flag Waved In Trade-Zone Battle. The Miami Herald, Business, January $29,1 \mathrm{C}$.

Butler, Tim. 2004. The middle class and the future of London, pp. 269-286 in City matters: competitiveness, cohesion and urban governance, edited by M. Boddy and M. Parkinson. London: The Policy Press.

Cabán, Pedro. 1994. Puerto Rico: National Security, Economic Growth and Colonialism. Journal of the Caucus for a New Political Science 30-31:191-216.

Cahill, Caitlin. 2006. "At Risk”? The Fed Up Honeys Re-Present the Gentrification. Women's Studies Quarterly 34 (1-2):334-363.

- 2007. Negotiating grit and glamour: Young women of color and the gentrification of the Lower East Side. City \& Society 19 (2):202-231.

Cantero, Araceli. 1976. Puertorriquenos de Miami celebran tradiciones. The Voice, XVIII, June 18, 21.

Casimir, Leslie. 1998. Miami Police Will Add Haitian-American Officers. The Miami Herald, Neighbors NC, March 5, 3.

Castells, Manuel. 1983. The City and the Grassroots: A Cross-Cultural Theory of Urban Social Movements. Berkeley, CA: University of California Press.

Cave, Damien. 2009. After Years of Development, Miami Ponders Whether the Good Outweighs the Bad. The New York Times, Front, November 22, 22.

Cenziper, Debbie. 2006. House of Lies. The Miami Herald, Special Report, July 23.

- 2007. Developer used funds for art, Dade says. The Miami Herald, March 2. 
Cenziper, Debbie Oscar Corral and Larry Lebowitz. 2007. City's affordable housing program in crisis. The Miami Herald, Front, June 2.

Chambers, Edward T., and Michael A. Cowan. 2003. Roots for radicals: organizing for power, action, and justice. New York; London: Continuum.

Chang, Daniel. 2003. Here Comes The Neighborhood. The Miami Herald, Tropical Life, November 30, 2003.

Chang, Daniel, and Elisa Turner. 2005. New Museum Expected To Boost Arts District. The Miami Herald, Front, September 23, 1 A.

Chaplin, Julia. 2008. In Miami, the Beach Party Moves Indoors. New York Times, Travel, February 3.

Charles, Jacqueline. 1995a. Foreign Trade Zone Lifts Hopes In Wynwood. The Miami Herald, Neighbors NC, February 19, 3.

Charles, Jacqueline. 1995b. Port Facility Fuels Protests in Wynwood. The Miami Herald, Neighbors NC, January 12, 3.

Chaskin, Robert J., and Ali Abunimah. 1999. A View from the City: Local Government Perspectives on Neighborhood-Based Governance in Community-Building Initiatives. Journal of Urban Affairs 21 (1):57-78.

City of Miami. 1949. Dwelling Conditions in the two Principal Blighted Areas. Planning Board. Slum Clearance Committee, Dade Community Health Department. Available at the Urban/Regional Collection, Florida International University Reference Library.

- 1961. A comprehensive Analysis of Miami's Neighborhoods: Phase II Report of the Miami Comprehensive Plan. Planning and Zoning Board. Available at the Urban/Regional Collection, Florida International University Reference Library.

1965. Community renewal program phase I: extent and nature of city-wide blight conditions. Planning Department. Available at the Urban/Regional Collection, Florida International University Reference Library.

_ 1967. Community Renewal Program Final Report. Planning Department. Available at the Urban/Regional Collection, Florida International University Reference Library.

- 1976a. Neighborhood Survey. Prepared for the City of Miami Planning Department by Hunter Moss and Company. February. Available at the Urban/Regional Collection, Florida International University Reference Library. 
1976b. Miami comprehensive neighborhood plan, 1975-1985. Prepared by Wallace, Roberts \& Todd, Urban and Ecological Planners, and the City of Miami Planning Department. October. Available at the Urban/Regional Collection, Florida International University Reference Library.

. 1979. Garment Center/ Fashion District Redevelopment Plan. Planning Department. July. Available at the Urban/Regional Collection, Florida International University Reference Library.

1982. The revised Miami comprehensive neighborhood plan. Planning Department. Supported by the Florida Local Government Comprehensive Planning Act Assistance Fund. Available at the Urban/Regional Collection, Florida International University Reference Library.

_. 1990. Wynwood Safe Neighborhood Improvement District Plan. Planning Department. May. Archives of the City of Miami Clerk.

1996. Wynwood Community Development Target Area: Neighborhood Planning Program 1994-1996. Planning Department. Available at the Miami-Dade Public Library.

2004a. April 27 Memorandum: Resolution regarding Interlocal Agreement and a "Finding of Necessity Study" for the creation of a Community Redevelopment District. From City Manager to Mayor and City Commissioners. Archives of the City of Miami Clerk.

- 2004b. The Midtown Miami Project: A Catalyst for Economic Revitalization. Department of Economic Development. Presentation at April 22 meeting of the Miami City Commission. Archives of the City of Miami Clerk.

2005. March 24 Resolution (R-05-00211) and Legislative Package creating the Midtown Community Redevelopment Agency. City of Miami Commission. Archives of the City of Miami Clerk.

. 2008a. Map of Goldman Properties Wynwood District: Item PZ10, April 24 meeting agenda. Planning Department. Archives of the City of Miami Clerk.

- 2008b. Letters of Support: Item PZ10, April 24 meeting agenda. Planning Department. Archives of the City of Miami Clerk.

. 2008c. October 29 Application for Special Exception Permit: Community Center at Roberto Clemente Park. Department of Capital Improvement Projects and Planning and Zoning Department. Project B-30172A. Archives of the City of Miami Clerk. 
- 2008d. November 12 Ordinance: Economic Stimulus Expedite Legislation. Department of Capital Improvement Projects. File Number 08-01316. Archives of the City of Miami Clerk.

- 2009. City of Miami Begins Construction of Community Center at Roberto Clemente park. Press Release, Office of Communications, April 29.

Clemente, Deirdre. 2007. Made in Miami: The Development of the Sportswear Industry in South Florida, 1900-1960. Journal of Social History Fall:128-148.

Cloward, Richard A., and Frances Fox Piven. 1975. The politics of turmoil; essays on poverty, race, and the urban crisis. New York: Vintage Books.

- 2004. Foreward, in Roots to Power: A Manual for Grassroots Organizing, edited by L. Staples. 2nd Edition. Westport, Connecticut; London: Praeger.

Cohen, Howard. 2002. Wynwood Swinging. The Miami Herald, March 19, 2002.

Colbert, Haines. 1957a. Puerto Ricans in Miami: A Debatable Issue. The Miami Daily News, Cover, April 22, 1A, 5A.

_ 1957b. Miami's Puerto Ricans: Law Pay Goes with Talking Little English. Miami Daily News, Cover, April 23, 1A, 7A.

-1957c. Native Customs or Crimes, Puerto Rican Debate is Hot. The Miami Daily News, Cover, April 24, 1A, 2A.

— 1957d. Miami's Puerto Ricans: Education Helping Solve Problem of Big Islander Population Here. The Miami News, Cover, April 25, 1A, 4A.

Colburn, R. David, and Lance De Haven-Smith. 1999. Government in the Sunshine State. Gainesville: University Press of Florida.

Colon, Yves. 1984a. Colon Quits As Wynwood EDC Director. The Miami Herald, Neighbors NW, June 3, 3.

- 1984b. Former Wynwood Manufacturing Plant May Become New Home For Art Colony. The Miami Herald, Neighbors NW, May 20, 6.

Columbia Law Review. 1966. Citizen Participation in Urban Renewal. 66 (3):485-607.

Connolly, Nathan. 2006. Colored, Caribbean, and Condemned: Miami's overtown district and the cultural expense of progress, 1940-1970. Caribbean Studies 34 (1):3-58. 2009. Timely innovations: planes, trains and the "whites only" economy of a Pan-American city. Urban History 36 (Special Issue 02):243-261. 
Cordovi, Adriana. 2002. Artists Reviving Loft Life. The Miami Herald, Local, April 6, 2B.

Corral, Oscar. 2001. Critics Say City Signs Exploit Terrorism. The Miami Herald, Local, October 30, $1 \mathrm{~B}$.

—. 2003. Artists Work And Reside In An Enclave They've Created In This Old Miami Area. The Miami Herald, Local, January 12, $1 \mathrm{~B}$.

Cosco, Joseph. 1986. Merchants Move To Revive `Melting-Pot` Neighborhood. SunSentinel, Local, April 13, 15B.

Cox, Kevin R. 2004. Globalization, the class relation and democracy. GeoJournal 60:3141.

Crampton, Jeremy W., and Stuart Elden, eds. 2007. Space, knowledge and power: Foucault and geography. Aldershot [u.a.]: Ashgate.

Cress, Doug. 1996. His Tower Of Power. Los Angeles Times, July 27.

Crouch, Paul. 1949. Miami Chosen Center for Latin Red Network. Miami Daily News, Cover, May 9, 1A, 7A.

Croucher, Sheila L. 1999. Ethnic Inventions: Constructing and Deconstructing Miami's Culture Clash. The Pacific Historical Review 68 (2):233-251.

Cruz, Humberto. 1974. Miami's Puerto Ricans live West Side Story: They resent Cubans, fear Blacks. The Miami News, Cover, August 2, 1A, 3A.

Cummings, Scott, and Mark Glaser. 1985. Neighborhood participation in community development: A comparison of strategic approaches. Population Research and Policy Review 4 (3):267-287.

Davidson, Mark. 2007. Gentrification as global habitat: a process of class formation or corporate creation? Transactions of the Institute of British Geographers 32 (4):490-506.

Davidson, Mark, and Loretta Lees. 2010. New-build gentrification: its histories, trajectories, and critical geographies. Population, Space and Place 16 (5):395411.

Dávila, Arlene. 2004. Empowered Culture? New York City's Empowerment Zone and the Selling of El Barrio. The ANNALS of the American Academy of Political and Social Science 594:49-64.

Davis, Ann. 1992. Health Center Makes 'A New Start' Wynwood Clinic Puts Years of Feuds And Vandalism Behind. The Miami Herald, Local, November 6, $1 \mathrm{~B}$. 
Davis, Mike. 1992. The L.A. Inferno. Socialist Review 22 (1):57-80.

Daytona Beach Morning Journal. 1958. Dade County Council on Community Relations to Solve Problems of Puerto Ricans. August 8.

De Jesus, Carlos Suarez, and Jorge Casuso. 2011. Wynwood's Second Saturday circus. Miami New Times, March 10.

De Vise, Daniel. 2004. Ragtag Avenue. The Miami Herald, Metro \& State, December 5, $1 \mathrm{~B}$.

DeFilippis, James. 1999. Alternatives to the "New Urban Politics": finding locality and autonomy in local economic development. Political Geography 18 (8):973-990.

-2004. Unmaking Goliath: Community Control in the Face of Global Capital. New York and London: Routledge.

- 2008. Paradoxes of community-building: community control in the global economy. International Social Science Journal 59 (192):223-234.

DeFilippis, James, Robert Fisher, and Eric Shragge. 2009. What's left in the community? Oppositional politics in contemporary practice. Community Development Journal 44 (1):38-52.

-2010. Contesting community: the limits and potential of local organizing. New Brunswick, N.J.: Rutgers University Press.

Del Campo, Deserae. 2006. Midtown, loft projects transform Wynwood into vibrant district. Miami Today, January 19.

Deleuze, Gilles. 1992. What is a dispositif? pp. 159-165 in Michel Foucault Philosopher, edited by T. Armstrong. London: Harvester Wheatsheaf.

DeSena, Judith N. 2006. "What's a Mother to Do?" Gentrification, School Selection, and the Consequences for Community Cohesion. American Behavioral Scientist 50 (2):241-257.

Diaz, Manny. 2007. There is no crisis in housing. The Miami Herald, Editorial, June 11, A17.

Dietsch, Deborah K. 1999. Redesigning The District. Sun-Sentinel, Arts \& Leisure, August 22, 1D.

Dluhy, Milan, Keith Revell, and Sidney Wong. 2002. Creating a positive future for a minority community: Transportation and urban renewal politics in Miami. Journal of Urban Affairs 24 (1):75-95. 
Dluhy, Milan J., and Howard A. Frank, eds. 2002. The Miami fiscal crisis: can a poor city regain prosperity? Westport, Conn.: Praeger.

Donnelly, Jeff 2005. The Art Deco District of Miami Beach: What Really Happened? Paper read at American Studies Association annual meeting, November 4, Washington, D.C.

Dorschner, John, and Oscar Corral. 2001. Miami Back In Financial Health after Near Disaster. The Miami Herald, Front, December 15, 1A.

Downs, Anthony. 1970. Uncompensated Nonconstruction Costs Which Urban Highways and Urban Renewal Impose upon Residential Households, pp. 69-114 in The Analysis of Public Output, edited by J. Margolis: National Bureau of Economic Research.

Dreier, Peter 1996. Community Empowerment Strategies: The Limits and Potential of Community Organizing in Urban Neighborhoods. Cityscape: A Journal of Policy Development and Research 2 (2):121-159.

Duany, Jorge. 1992. The Census Undercount, the Underground Economy and Undocumented Migration: The Case of Dominicans in Santurce, Puerto Rico. U.S. Census Bureau Evaluation Report. Available from http://www.census.gov/srd/papers/pdf/ev92-17.pdf

- 2000. Neither White nor Black: The Politics of Race and Ethnicity among Puerto Ricans on the Island and in the U.S. Mainland. Paper presented at The Meaning of Race and Blackness in the Americas: Contemporary Perspectives. Brown University, Providence, Rhode Island, February 10-12.

- 2002. Mobile Livelihoods: The Sociocultural Practices of Circular Migrants between Puerto Rico and the United States1. International Migration Review 36 (2):355-388.

Duany, Jorge, and Félix V. Matos-Rodríguez. 2006. Puerto Ricans in Orlando and Central Florida, Policy Report: Vol. 1, No. 1. New York. Centro de Estudios Puertorriqueños, Hunter College (CUNY). Spring. Available from www.centropr.org.

Dulchin, Ben. 2003. Organizing Against Gentrification, Fighting the Free Market: The Displacement-Free Zone Campaign. Social Policy 34 (2/3):29-34.

Dunlop, Beth. 1987. Old Bakery Rises Again For the Arts. The Miami Herald, January $11,1 \mathrm{~K}$.

Dunn, Marvi. 1997. Black Miami in the Twentieth Century. Gainesville, FL: University Press of Florida. 
Duran, Jose D. 2010. BooksIIII Bischof: Street Vendor. Miami New Times, November 25.

Ehrlich, Brenna, and Andrea Bartz. 2010. Stuff hipsters hate: a field guide to the passionate opinions of the indifferent. Berkeley, CA: Ulysses Press.

Eick, Volker. 2007. Space Patrols--The New Peace-Keeping Functions of Nonprofits: Contesting Neoliberalism or the Urban Poor?, pp. 266-290 in Contesting neoliberalism: urban frontiers, edited by H. Leitner, J. Peck and E. S. Sheppard. New York, London: Guilford Press.

Eisinger, Peter K. . 1988. The rise of the entrepreneurial state : state and local economic development policy in the United States. Madison, Wisconsin: University of Wisconsin Press.

El Mundo. 1952. Hay un arrabal de boricuas en Miami. February 16, 9. 1957. Boricuas en Miami: Problema Principal son Braceros, no Propietarios o Negociantes. April 29.

Elkies, Lauren. 2006. Wynwood: Projects grow in Miami art hub - District's galleries, artist studios and museums attracting condo, retail developers. Accessed February 14, 2011 at www.therealdeal.net.

Fainstein, Susan S. 1987. Local Mobilization and Economic Discontent, pp. 323-342 in The Capitalist City: Global Restructuring And Community Politics, edited by M. P. Smith and J. R. Feagin: Blackwell Publishers.

Fainstein, Susan S., and Norman I. Fainstein. 1978. National Policy and Urban Development. Social Problems 26 (2):125-146.

- 1985. Economic Restructuring and the Rise of Urban Social Movements. Urban Affairs Review 21 (2):187-206.

Fainstein, Susan S., Norman I. Fainstein, and P. Jefferson Armistead. 1983. Bureaucratic Enfranchisement under the Community Development Block Grant Program. Journal of Urban Affairs 5 (2):123-139.

Fainstein, Susan S. and Clifford Hirst. 1994. Urban social movements. Piscataway, N.J.: Center for Urban Policy Research.

Fairbanks, Robert P. 2007. The Political-Economic Gradient and the Organization of Urban Space, pp. 102-117 in Handbook of Community Movements and Local Organizations, edited by R. A. Cnaan and C. Milofsky: Springer US.

- 2011. The Politics of Urban Informality in Philadelphia's Recovery House Movement. Urban Studies 48 (12):2555-2570. 
Feagin, Joe R. and Michael Peter Smith. 1987. Cities and the New International Division of Labor: An Overview, pp. 3-34 in The Capitalist City: Global Restructuring And Community Politics, edited by M. P. Smith and J. R. Feagin: Blackwell Publishers.

Feldman, Marcos. 2007. The State of Miami’s Housing Crisis: Housing Affordability Problems in One of the Country's Least Affordable Housing Markets. Miami, FL. The Research Institute on Social and Economic Policy, Florida International University. November 9. Available from www.risep-fiu.org.

Feldman, Marcos, and Violaine Jolivet. forthcoming. "Eyes on Little Havana": Gentrification and the Securitization of Space in the Heart of Miami. Political Geography (submitted August, 2011 and under revision).

Feldman, Marcos, and Bruce Nissen. 2006. Workforce Housing and Miami's Affordable Housing Needs: Issues and Policy Options. Miami, FL. Research Institute on Social and Economic Policy, Florida International University. February. Available from www.risep-fiu.org.

Feldstein-Soto, Luis. 1983a. Jose Mendez Defiende Su Barrio De Wynwood. El Nuevo Herald, Frente, September 22, 3.

- 1983b. New Development Chief Hopes to Harmonize Wynwood Voices. The Miami Herald, Neighbors NW, December 29, 2.

- 1984. Hopes Of Poor Vanish With Activist. The Miami Herald, Local, March $10,1 \mathrm{~B}$.

- 1990. Many Elements Combined to Fuel Outburst. The Miami Herald, Front, December 5, $1 \mathrm{~A}$.

Fisher, Luchina. 1988. Drive To Save School Gears Up. The Miami Herald, Neighbors NE, December 8, 18.

- 1989. Parents Lose Fight For Neighborhood School. The Miami Herald, Local, April 27, 4B.

Fisher, Robert, and Eric Shragge. 2000. Challenging Community Organizing. Journal of Community Practice 8 (3):1-19.

FIU-MC. 2001. Reported notes from Wynwood Community Conversations: March 24, Roberto Clemente Park, and May 1, De Hostos Senior Center. Miami, FL. Florida International University Metropolitan Center. Available from FIU-GIS laboratory, http://gislab.fiu.edu/fec/ 
- 2002. FEC Corridor Strategic Redevelopment Plan. Miami, FL. Prepared for the City of Miami by Florida International University Metropolitan Center. May. Available from http://gislab.fiu.edu/fec/

Flanagan, Barbara. 2000. On the Streets With: Tony Goldman - Writing a New Philadelphia Story. The New York Times, House \& Home, April 6, 4.

Florida Grand Jury. 1986. Dade County's Department of Housing and Urban Development, pp. 1-26 in Final Report of the Grand Jury. The Circuit Court of the Eleventh Judicial Circuit of Florida in and for the County of Dade. Fall Term. Available from Miami-Dade Office of the State Attorney, http://www.miamisao.com/publications/grand_jury/1980s/gj1985f4.pdf.

Foote Jr., Cornelius. 1983. Sewing Class Has A Common Thread: Jobs. The Miami Herald, Neighbors NW, September 4, 3.

Foucault, Michel. 1977. Discipline and Punish. Londgon: Allen Lane. 1979. 'On governmentality'. Ideology and Consciousness 6:5-21. 1979b. Omnes et Singulatim: Towards a Criticism of Political Reason, in The Tanner Lectures on Human Values, delivered at Stanford University, October 10 and 16: The Tanner Humanities Center, University of Utah.

- 1982. The Subject and Power. Critical Inquiry 8 (4):777-795.

- 2009. January 25, 1978, pp. 55-86 in Security, territory, population: lectures at the Collège de France, 1977-78, edited by M. Senellart, F. Ewald and A. Fontana. New York: Picador/Palgrave Macmillan.

Foucault, Michel, Graham Burchell, Colin Gordon, and Peter Miller, eds. 1991. The Foucault effect, studies in governmentality: with two lectures by and an interview with Michel Foucault. Chicago: University of Chicago Press.

Fraser, Nancy. 2003. From Discipline to Flexibilization? Rereading Foucault in the Shadow of Globalization. Constellations 10 (2):160-171.

Fraser, James. 2004. Beyond Gentrification: Mobilizing Communities and Claiming Space. Urban Geography 25 (5):437-457.

Fraser, James, and Jonathan Lepofsky. 2004. The uses of knowledge in neighbourhood revitalization. Community Development Journal 39 (1):4-12.

Fraser, James C., Jonathan Lepofsky, Edward L. Kick, and J. Patrick Williams. 2003. The Construction Of The Local And The Limits Of Contemporary Community Building In The United States. Urban Affairs Review 38 (3):417-445. 
Freeman, Lance. 1999. A Note on the Influence of African Heritage on Segregation. Urban Affairs Review 35 (1):137-146.

- 2006. There goes the 'hood: views of gentrification from the ground up. Philadelphia: Temple University Press.

Galster, George, and Anna M. Santiago. 1994. Explaining the Growth of Puerto Rican Poverty, 1970-1980. Urban Affairs Review 30 (2):249-274.

Ganapati, Sukumar, and Howard Frank. 2008. Good Intentions, Unintended Consequences: Impact of Adker Consent Decree on Miami-Dade County's Subsidized Housing. Urban Affairs Review 44 (1):57-84.

Garcia, Manny. 1996. Rating for Municipal Bonds Sinks. The Miami Herald, Local, November 5, $1 \mathrm{~B}$.

—. 1998. Three Jailed In New Scandal. The Miami Herald, Local, November 3, 1 B.

Garland, David. 2001. The culture of control: crime and social order in contemporary society. Chicago: University of Chicago Press.

Gaston, Mauricio, and Marie Kennedy. 1987. Capital Investment or Community Development? The Struggle for Land Control by Boston's Black and Latino Community. Antipode 19 (2):178-209.

Geolytics, Inc. Neighborhood Change Database, 1970-2000. Accessed April, 2011. Available from Florida International University GIS Laboratory.

George, Paul S. 1978. Colored Town: Miami's Black Community, 1896-1930. The Florida Historical Quarterly 56 (4):432-448.

George, Paul S., and Thomas K. Petersen. 1988. Liberty Square, 1933-1987: The Origins and Evolution of a Public Housing Project. Tequesta XLVIII:53-68.

Gibbs Knotts, H., and Moshe Haspel. 2006. The Impact of Gentrification on Voter Turnout. Social Science Quarterly 87 (1):110-121.

Giddens, Anthony. 1991. The constitution of society: outline of the theory of structuration. Cambridge: Polity Press.

Gilbert, Craig. 1984. Panic Buttons Ready If Push Comes To Shove. The Miami Herald, Local, November 18, 2B.

Girard, Chris, and Guillermo J. Grenier. 2008. Insulating an Ideology: The Enclave Effect on South Florida's Cuban Americans. Hispanic Journal of Behavioral Sciences 30 (4):530-543. 
Gittell, Marilyn. 1980. Limits to Citizen Participation: the Decline of Community Organizations. Beverly Hills, CA: Sage Publications.

Gittell, Marilyn, Barbara Ferman, and Charles Price. 2007. Assessing Community Change: An Evaluation of the Ford Foundation's Community Organizing Initiative Volume II, 2004-2007. New York. Howard Samuels Center, The Graduate Center, CUNY. Available from http://www.howardsamuelscenter.org/reports/FordEvalVolII.pdf.

Gladora, Christopher. 2009. A Right to the City: Building a Los Angeles Tenant Union, MA Thesis, Department of Urban Planning, University of California Los Angeles, Advisor Jacqueline Leavitt.

Glasgow, Kathy. 1994. Power to the Parish: Father Jose Luis Menendez of Wynwood takes the church to the people and the people to the streets. Miami New Times, January 26.

- 2007. Dreams and Dead Ends. Biscayne Boulevard Times, Neighborhood Correspondents: Liberty City, May, 22.

Glass, Ian. 1967. Exiles - The Tragedy's Changing Face. The Miami News, Cover, April 4, 1A, 5A.

Glueck, Grace. 2005. Old Business, New Name: Behold the Gallerist. The New York Times, December 24.

Goldberg, Harmony. 2008. Building Power in the City: Reflections on the Emergence of the Right to the City Alliance and the National Domestic Worker's Alliance. Journal of Aesthetics and Protest: 2008 Convention Protests, Movement and Movements. Available from http://inthemiddleofthewhirlwind.wordpress.com/building-power-in-the-city/

Gonzalez, Fernando. 1997. Family Treasures. The Miami Herald, Arts, June 8, 1 I.

González, Gaspar. 2001. What Art Thou, Little Havana? Viernes Culturales is transforming Calle Ocho -- but into what remains a big question. Miami New Times, September 27.

González, José Luis Colón. 2008. Jorge Font Saldaña: un hombre para todos los tiempos. San Juan, P.R.: EMS Editores: Fundación Luis Muñoz Marín.

Goode Bryant, Linda 2005. "Law Is Life!": Flag Wars, Local Government Law, and the Gentrification of Olde Towne East. Fordham Intellectual Property, Media \& Entertainment Law Journal 16:715-723.

Goodman, Allison. 2008. All-boys public school to open in fall. The Miami Herald, Neighbors, August 10, 8GR. 
Gotham, Kevin Fox. 2005. Tourism Gentrification: The Case of New Orleans' Vieux Carre (French Quarter). Urban Studies 42 (7):1099-1121.

Gotham, Kevin Fox and William G. Staples. 1996. Narrative Analysis and the New Historical Sociology. The Sociological Quarterly 37 (3):481-501.

Gottdiener, Mark. 1994 (1985). The social production of urban space. 2nd ed. Austin: University of Texas Press.

Goyette, Jared. 2011a. Residents want construction site shut down due to noise, dust. The Miami Herald, Open Media Miami, April 6.

- 2011b. Developer asks contractor to vacate property after resident complaints, Commissioner Dunn apologizes. The Miami Herald, Open Media Miami, April 7.

Gregor, Alison. 2006. A SoHo for the South Boston Waterfront. The New York Times, Business, December 27, 6 .

Grenier, Guillermo, and Alex Stepick, eds. 1992. Miami Now! Immigration, Ethnicity and Social Change. Gainesville, FL: University of Florida Press.

- 2002. Miami: Ethnic Succession and Failed Restructuring, pp. 135-150 in Unravelling the rag trade: immigrant entrepreneurship in seven world cities, edited by J. Rath. Oxford: Berg.

Grenier, Guillermo J., and Max Castro. 2001. Blacks and Cubans in Miami: The Negative Consequences of the Cuban Enclave on Ethnic Politics, pp. 137-157 in Governing American Cities: Interethnic Coalitions, Competition, and Conflict, edited by Michael Jones-Correa. New York: Russell Sage Foundation.

Griffin, Larry J. 1993. Narrative, Event-structure Analysis, and Causal Interpretation in Historical Sociology. American Journal of Sociology 98 (5):1094-1133.

Grosfoguel, Ramon. 2003. Colonial Subjects: Puerto Ricans in a Global Perspective. Berkeley, CA: University of California Press.

Hackworth, Jason, and Neil Smith. 2001. The changing state of gentrification. Tijdschrift voor Economische en Sociale Geografie 92 (4):464-477.

Hackworth, Jason. 2002. Post-recession gentrification in New York City. Urban Affairs Review 37:815-43.

Haggman, Matthew. 2006. Housing Plan Questioned. The Miami Herald, Metro \& State, February 28, 1B.

Haggman, Matthew, and Martha Brannigan. 2011. Alvarez, Seijas appear headed for ouster. The Miami Herald, March 5. 
Hale, Fraser, and Dillon Aerial Photography. 1965. Aerial Photos of Interstate 95 Construction. The Miami News, Front, January 27.

Hall, Tim, and Phil Hubbard. 1996. The entrepreneurial city: new urban politics, new urban geographies? Progress in Human Geography 20 (2):153-174.

Hamnett, Chris, and Drew Whitelegg. 2007. Loft conversion and gentrification in London: from industrial to postindustrial land use. Environment and Planning $A$ 39 (1):106-24.

Hampton, Adele. 2010. Wynwood: South Florida's SoHo: Miami Herald Video available at http://www.miamiherald.com/video/?genre_id=4275\#.

Hancock, David. 1992. Jose Molina: Un Arduo Regreso A La TV. El Nuevo Herald, Frente, November 3, $1 \mathrm{~B}$.

Handros, Nicolette. 1973. New drug program will serve Puerto Rican community here. The Miami News, April 5.

Hargot, Angie, and Ben Torter. 2008. Conference Crashers: Protesters crash the U.S. Conference of Mayors to mourn the loss of our cities to special interests, gentrification and poverty. The Miami SunPost, June 26.

Hartman, Chester. 1964. The Housing of Relocated Families. Journal of the American Institute of Planners 30 (4):266-286.

- 1971. Relocation: Illusory Promises and No Relief. Virginia Law Review 57 (5):745-817.

Harvey, David. 1973. Social Justice and the City. Baltimore, MD: Johns Hopkins University Press.

- 1975. The Geography of Capitalist Accumulation: A Reconstruction of the Marxian Theory. Antipode 7 (2):9-21.

- 1985. The Geopolitics of Capitalism, pp. 129-163 in Social Relations and Spatial Structures, edited by D. Gregory and J. Urry. New York: St. Martin's Press.

- 1989. From Managerialism to Entrepreneurialism: The Transformation of Governance in Late Capitalism. Geografiska Annaler 71 (B):3-17.

- 2007. Neoliberalism as Creative Destruction. The ANNALS of the American Academy of Political and Social Science 610 (1):21-44.

- 2008. The Right to the City. New Left Review 53 (September-October). 
2010. Organizing for the Anti-Capitalist Transition. Talk given at the World Social Forum in Porto Alegre, Brazil: Available at http://davidharvey.org/2009/12/organizing-for-the-anti-capitalist-transition/.

Heathcott, Joseph. 2005. Urban Activism in a Downsizing World: Neighborhood Organizing in Postindustrial Chicago. City \& Community 4 (3):277-294.

Herbert, Steve. 2008. Contemporary geographies of exclusion I: traversing Skid Road. Progress in Human Geography 32 (5):659-666.

- 2011. Contemporary geographies of exclusion III: To assist or punish? Progress in Human Geography 35 (2):256-263.

Herbert, Steve, and Elizabeth Brown. 2006. Conceptions of Space and Crime in the Punitive Neoliberal City. Antipode 38:755-777.

Hernandez, Cynthia S. 2010. Wage Theft in Florida: A Real Problem with Real Solutions. Miami, FL: Research Institute on Social and Economic Policy, Florida International University. Available from www.risep-fiu.org.

Hernandez, Evelyn. 1984. High Fashions, Low Fortunes. The Miami Herald, Neighbors NE, April 8, 24.

Hiaasen, Scott, and Jason Grotto. 2007. Breach of trust: Created to fight poverty, the Miami-Dade Empowerment Trust squandered millions of dollars on insider deals, pet projects and bad loans. The Miami Herald, Special Report, September 30.

Hirsch, Arnold R., and Raymond A. Mohl. 1993. Urban policy in twentieth-century America. New Brunswick: Rutgers University Press.

Hoban, Phoebe. 2004. ART - 7BRs, OcnVu, WrldClass Art. The New York Times, Arts and Leisure, March 14, 1.

Horlitz, Sabine, and Anne Vogelpohl. 2009. Something Can Be Done! - A Report on the Conference 'Right to the City. Prospects for Critical Urban Theory and Practice', Berlin November 2008. International Journal of Urban and Regional Research 33 (4):1067-1072.

Horn, Laurie. 1984. Alternative Arts May Get More Space. The Miami Herald, Amusements, April 30, 6C.

Huxley, Mario. 2008. Space and Government: Governmentality and Geography. Geography Compass 2 (5):1635-1658.

Igwe, Victor, Lewis Blake, and Elena Dobrev. 2008. Audit of Capital Projects Funded with Homeland Defense, Neighborhood Improvements, Capital Projects and Infrastructure Improvements Bond Proceeds and Other Funding Sources - Phase 
No. 3, Audit No. 08-010. Office of the Independent Auditor General. City of Miami. January 16. Archives of the City of Miami Clerk.

IJURR (AbdouMaliq Simone, Ed.). 2008. Debate on Gentrification. International Journal of Urban and Regional Research 32 (1).

Inclan, Hilda. 1972a. Latins here undergoing awakening. The Miami News January 31, $3 \mathrm{~A}$.

- 1972b. Flexibility makes Latin coalition a reality now within Dade group. The Miami News, August 16.

—. 1973a. Resigning upsets Latins. The Miami News, April 2.

- 1973b. Community Relations Board hears pleas: Improve Services, Latins ask. The Miami News, May 3, 16A.

- 1974a. Power struggle stymies Latin clinic. The Miami News, Metro, January 24, $5 \mathrm{~A}$.

- 1974b. Clinic director back; chairman to quit. The Miami News, Metro, March 7, $5 \mathrm{~A}$.

- 1976. Enchanting or Enchanted? The Miami News, Miami Al Dia, 7A.

Iuspa-Abbott, Paula. 2010. Tony Goldman. Daily Business Review, June 28.

Jacobs, Jane. 1961. The Death and Life of Great American Cities. New York: Random House.

Jager, Michael. 1986. Class definition and the esthetics of gentrification: Victoriana in Melbourne, pp. 78-91, in Gentrification of the city, edited by N. Smith and P. Williams. Boston: Allen \& Unwin.

Jeffers, Jason. 2005a. City Breached Business Deal, Judge Finds. The Miami Herald, April 21, 3NH.

- 2005b. Communities Out To Fight Gentrification. The Miami Herald, Neighbors, September 18, 2005, 3NH.

Jennings, James. 2004. Race, Politics, and Community Development in U.S. Cities. The ANNALS of the American Academy of Political and Social Science 594 (1):171194.

Jessop, Bob. 2007. From micro-powers to governmentality: Foucault's work on statehood, state formation, statecraft and state power. Political Geography 26 (1):34-40. 
Johnson-King, Terry. 1969. Exile Aid Agency Folding. The Miami News, Cover, January 22, 1A, 10A.

Jonas, Andrew E. G. and David Wilson, ed. 1999. The City as Growth Machine: Critical Reflections Two Decades Later. Albany, N.Y.: State University of New York Press.

Josephs, Lawrence. 1984. Is South Beach The Next Grove? The Miami Herald, Neighbors, March 25 1984, 3.

Judd, Dennis R. 1988. The Politics of American Cities: Private Power and Public Policy. 3rd ed: Harper Collins.

Kaleem, Jaweed. 2010. MAM's new man. The Miami Herald, Tropical Life, August 15, $1 \mathrm{M}$.

Kaplan, Steven. 2003. Miami on the Brink. Miami Art Exchange, February 26.

Katz, Michael. 2001. The Price of Citizenship: Redefining the American Welfare State. New York, NY: Henry Holt.

Keith, Michael. 2009. Figuring city change: understanding urban regeneration and Britain's Thames Gateway, pp. 75-92 in Regenerating London: Governance, sustainability and community in a global city, edited by R. Imrie, L. Lees and M. Raco. London and New York: Routledge.

Kidwell, David. 1998. Ex-Officers Who Fatally Beat Man Still Free Plans For Community Remain Unfulfilled. The Miami Herald, Local, December 27, 1B.

Kirkpatrick, L. Owen. 2007. The Two "Logics" of Community Development: Neighborhoods, Markets, and Community Development Corporations. Politics Society 35 (2):329-359.

Konicki, Steve. 1982. U.S. charges 50 companies with underpaying workers. The Miami News, Local, November 11, 5A.

Kornbluth, Jesse. 1997. Is South Beach Big Enough For Two Hotel Kings? The New York Times, Style Desk, February 16, 53.

Kranish, Michael. 1982. Is Future In The Past? Deco Advocates Think So. The Miami Herald, August 29, 1982.

Lacher, Irene. 1986. SOBE. The Miami Herald, Amusements, August 31, 1K.

Landers, Peggy. 1993. Prayer, And Power, For the Poor: An Inner-City Priest Teaches The Faithful To Lift Up Their Voices For Their Own Rights. The Miami Herald, Living, September 5, 1J. 
Lees, Loretta, and Liz Bondi. 1995. De-Gentrification and Economic Recession: The Case of New York City. Urban Geography 16 (3):234-253.

Lees, Loretta, Tom Slater, and Elvin K. Wyly. 2008. Gentrification. New York: Routledge/Taylor \& Francis Group.

Lefebvre, Henri. 1976. The survival of capitalism: reproduction of the relations of production. London: Allison \& Busby.

_. 2003 [1970]. The Urban Revolution. Translated by Robert Bononno: University of Minnesota Press.

Lehman, Gigi. 2003. The Faithful Among Us. The Miami Herald, Living, May 10, 2E.

Leon, Hortense. 2007. Miami 21 generates confusion. Florida Real Estate Journal, September 7 .

Lepofsky, Jonathan, and James C. Fraser. 2003. Building Community Citizens: Claiming the Right to Place-making in the City. Urban Studies 40 (1):127-142.

Levy, Diane, Jennifer Comey, and Sandra Padilla. 2006. In the Face of Gentrification: Case Studies of Local Efforts to Mitigate Displacement. The Urban Institute. March 17. Available from http://www.urban.org/url.cfm?ID=411294

Ley, David. 2003. Artists, Aestheticisation and the Field of Gentrification. Urban Studies 40 (12):2527-2544.

Lloyd, Richard. 2002. Neo-Bohemia: Art and Neighborhood Redevelopment in Chicago. Journal of Urban Affairs 24 (5):517-532.

- 2004. The Neighborhood in Cultural Production: Material and Symbolic Resources in the New Bohemia. City \& Community 3 (4):343-372.

- 2006. Neo-Bohemia. New York: Routledge.

Logan, John R. and Harvey L. Molotch. 1987. Urban fortunes: the political economy of place. Berkeley: University of California Press.

Low, Setha M. 1997. Urban Fear: Building the Fortress City. City \& Society 9 (1):53-71.

Lowe, Bob, and R.A. Zaldivar. 1983. Lax Code Enforcement Helped Create Slums. The Miami Herald, Front, May 25, $1 \mathrm{~A}$.

Lowe, Jeffrey S. 2006. Rebuilding communities the public trust way: community foundation assistance to CDCs, 1980-2000. Lanham, MD: Lexington Books.

Lynch, Marika. 1996. A Parish's Quest Fulfilled. The Miami Herald, Local, June 16, 1 B. 
- 1999. Activists Hand In Grievances. The Miami Herald, Local, October 6, 4B.

Maass, Harold. 1993. Office Building to Give Clinic New, Bigger Home. The Miami Herald, Neighbors NW, March 25, 6.

MacLeod, Gordon. 2011. Urban Politics Reconsidered: Growth Machine to PostDemocratic City? Urban Studies 48 (12):2629-2660.

Mailander, Jodi. 1995. Church Group Aims To Raise Test Scores. The Miami Herald, Local, December 13, $1 \mathrm{~B}$.

- 1996. School Board Agrees To Allow Phonics Reading Instruction. The Miami Herald, Local, December 12, 1B.

Maldonado, Edwin. 1979. Contract Labor and the Origins of Puerto Rican Communities in the United States. International Migration Review 13 (1):103-121.

Mantler, Gordon Keith. 2008. Black, Brown and Poor: Martin Luther King Jr., The Poor People's Campaign and Its Legacies. PhD Dissertation, Department of History, Duke University.

Marcuse, Peter. 1986. Abandonment, gentrification, and displacement: the linkages in New York City, pp. 121-152 in Gentrification of the city, edited by N. Smith and P. Williams. Boston: Allen \& Unwin.

Marquis, Christopher. 1987. Tony Lopez: Una Obra De Amor. El Nuevo Herald, Frente, June 28, 15.

Martin, Lydia. 2004. Art And Commerce Mix In A Revived Wynwood. The Miami Herald, Front, November 28, 1A.

Martin, Leslie E. 2007. Fighting for Control: Political Displacement in Atlanta's Gentrifying Neighborhoods. Urban Affairs Review 42 (5):603-28.

Martinez, Draeger. 2003. Project Turns Into A Reunion For Graffiti Artists. The Miami Herald, Neighbors NC, June 22, 3NC.

Marwell, Nicole P. 2004. Privatizing the Welfare State: Nonprofit Community-Based Organizations as Political Actors. American Sociological Review 69 (2):265-291.

Maskovsky, Jeff. 2006. Governing the "New Hometowns": Race, Power, and Neighborhood Participation in the New Inner City. Identities: Global Studies in Culture and Power 13 (1):73-99.

Mason, Brook S. 2003. Art among the gators. Financial Times, Weekend - Collecting, December 6, 9. 
Massey, Douglas S., and Brooks Bitterman. 1985. Explaining the Paradox of Puerto Rican Segregation. Social Forces 64 (2):306-331.

Massey, Douglas S. and Nancy A. Denton. 1993. American Apartheid: Segregation and the Making of the Underclass. Cambridge, MA: Harvard University Press.

Mayer, Margit. 2003. The onward sweep of social capital: causes and consequences for understanding cities, communities and urban movements. International Journal of Urban and Regional Research 27 (1):108-130.

Mazzei, Patricia. 2011. To win recall, Mayor Alvarez may need to appeal to new groups. The Miami Herald, February 28.

McAdam, Doug, John D. McCarthy, and Mayer N. Zald, ed. 1996. Comparative Perspectives on Social Movements: Political Opportunities, Mobilizing Structures, and Cultural Framings. Cambridge, UK: Cambridge University Press.

McAdam, Doug. 1999. Political process and the development of Black insurgency, 19301970. 2nd ed. Chicago: University of Chicago Press.

McCarthy, Kathy. 1982. Deco building is haven for artists, creative tenants. The Miami News, July 30.

1985a. Workers Face Crisis of Learning a New Career While a Community Suffers Without Them. The Miami Herald, Neighbors NW, May 16, 8.

— 1985b. Old Bakery Gives Rise To Artists' Marketplace. The Miami Herald, Neighbors SW, February 21, 18.

McGrory, Kathleen. 2006. Activists: Punish Crooks, Aid Renters. The Miami Herald, Metro \& State, August 9, 1 B.

- 2010. Single-sex schools prosper -- if you can get kids to go. The Miami Herald. December 11, A1.

McQuarrie, Michael. 2010. Nonprofits and the Reconstruction of Urban Governance: Housing Production and Community Development in Cleveland, 1975-2005, pp. 237-268 in Politics and partnerships: the role of voluntary associations in America's political past and present, edited by E. S. Clemens and D. Guthrie. Chicago; London: University of Chicago Press.

McQuarrie, Michael, and Nicole P. Marwell. 2009. The Missing Organizational Dimension in Urban Sociology. City and Community 8 (3):247-268.

Melendez, Edgardo. 2003. Puerto Rican Politics in the United States: Examination of Major Perspectives and Theories. Centro Journal XV (I):9-39. Available at http://www.centropr.org/documents/journals/Melendez.pdf. 
Menendez, Ana. 1994a. Little Havana Building Plans Spark Hopes. The Miami Herald, Neighbors CT, July 24, 1994, 3.

—. 1994b. A NEW TREND? The Miami Herald, June 12.

1994c. Sculptor Preserves The Many Faces Of Cuba His Works Can Be Found All Over Dade. The Miami Herald, Neighbors KE, July 7, 1.

- 2005. Building Boom Pushing Out Many Residents. The Miami Herald, Metro $\&$ State, August 6,1B.

Merry, Sally Engle. 2001. Spatial Governmentality and the New Urban Social Order: Controlling Gender Violence through Law. American Anthropologist 103 (1):16.

Mesa, Blanca. 1990. In The Grove Village Losing Charm, Style Residents Fear. The Miami Herald, HOME \& DESIGN, November 11, 5J.

Miami City Commission. 1917. March 15 Meeting Transcript. Archives of the City of Miami Clerk.

— 1975. March 12 Meeting Transcript. Archives of the City of Miami Clerk.

—. 1977. November 10 Meeting Transcript. Archives of the City of Miami Clerk.

—. 1979. July 23 Meeting Transcript. Archives of the City of Miami Clerk.

— 1980. June 26 Meeting Transcript. Archives of the City of Miami Clerk.

- 1980. October 9 Meeting Transcript. Archives of the City of Miami Clerk.

— 1981. December 10 Meeting Transcript. Archives of the City of Miami Clerk.

- 1981. October 7 Meeting Transcript. Archives of the City of Miami Clerk.

—. 1982. January 14 Meeting Transcript. Archives of the City of Miami Clerk.

—. 1982. July 29 Meeting Transcript. Archives of the City of Miami Clerk.

- 1983. January 28 Meeting Transcript. Archives of the City of Miami Clerk.

_ 1983. June 9 Meeting Transcript. Archives of the City of Miami Clerk.

- 1983. September 29 Meeting Transcript. Archives of the City of Miami Clerk.

_ 1990. June 7 Meeting Transcript. Archives of the City of Miami Clerk.

_. 1991. January 10 Meeting Transcript. Archives of the City of Miami Clerk. 
1993. October 14 Meeting Transcript. Archives of the City of Miami Clerk.

_ 1995. Transcript of Closed Meeting, February 9: Wynwood Community Economic Develompent Corporation, Inc., et al., vs. City of Miami, et al. Archives of the City of Miami Clerk.

—. 1996. April 25 Meeting Transcript. Archives of the City of Miami Clerk.

- 2000. February 10 Meeting Transcript. Archives of the City of Miami Clerk.

- 2004. April 22 Meeting Transcript. Planning and Zoning Department. Archives of the City of Miami Clerk.

- 2004. April 29 Meeting Transcript. Archives of the City of Miami Clerk.

_ 2006. December 14 Meeting Transcript. Department of Planning and Zoning. Archives of the City of Miami Clerk.

-2006. November 9 Meeting Transcript. Archives of the City of Miami Clerk.

_ 2008. July 24 Meeting Transcript. Planning and Zoning Department. Archives of the City of Miami Clerk.

- 2008. June 26 Meeting Transcript. Planning and Zoning Department. Archives of the City of Miami Clerk.

- 2008. November 13 Meeting Transcript. Archives of the City of Miami Clerk.

—. 2009. April 29 Meeting Transcript. Archives of the City of Miami Clerk.

Miami Herald Staff. 1983. Activist in Wynwood Dies. The Miami Herald, Local, December 9, 3C.

- 1996. Around Dade Miami Bond Rating Cut To Junk Level. The Miami Herald, Local, December 3, 2B.

- 1997. Safe Neighborhood Parks Bond Program. The Miami Herald, Neighbors NW, September 14, 14.

—. 1998. Another Housing Mess. The Miami Herald, Editorial, August 10, 10A.

Miami-Dade County. 2006. Surtax Cash Flow Analysis. Miami-Dade Housing Agency Development and Loan Administration. September 1. Available at http://wwwstage3.miamidade.gov/manager/library/DLAD-Attachments.pdf.

Miami-Dade County Commission. 2001. July 24 Resolution (R-870-01) requiring the County Manager to identify, research and visit jurisdictions of best practices for 
the purpose of developing an affordable housing policy. Miami-Dade County Legistlative archives, http://www.miamidade.gov/govaction.

2002. Plan for an Enhanced Affordable Housing Program. January 29 Meeting Agenda Item. Miami-Dade County Legislative archives, http://www.miamidade.gov/govaction.

2004. April 27 Resolution (R-377-04) approving Interlocal Agreement among the City of Miami, Miami-Dade County and Midtown Miami Community Development District for the Midtown Miami Project. Miami-Dade County Legislative archives, http://www.miamidade.gov/govaction.

. 2005. February 8 Resolution Declaring Certain Geographic Areas of the City of Miami to be a Slum and Blighted Area and Finding of Need for Creation of a Community Redevelopment Agency. Miami-Dade County Legislative archives, http://www.miamidade.gov/govaction.

2006. March 15 Meeting Transcript. Miami-Dade County Legislative archives, http://www.miamidade.gov/govaction.

. 2007a. Ordinance (07-05) establishing Workforce Housing Development Program. Passed January 25. Miami-Dade County Legislative archives, http://www.miamidade.gov/govaction.

—. 2007b. January 25 Meeting Transcript. Miami-Dade County Legislative archives, http://www.miamidade.gov/govaction.

- 2008. December 2 Meeting Transcript. Miami-Dade County Legislative archives, http://www.miamidade.gov/govaction.

Midtown Study. 2006. Memorandum: Summary of Preliminary Research on Community Extractions from Midtown Miami. Prepared for the Social Justice Center by Volunteer Public Interest Lawyer. February.

Miller, John C. 1978. The Emigrant and New York City: A Consideration of Four Puerto Rican Writers. MELUS 5 (3):82-99.

Miller, Mike. 2010. Alinsky for the Left: The Politics of Community Organizing. Dissent 57 (1):43-49.

Mohl, Raymond A. 1995. Making the Second Ghetto in Metropolitan Miami, 1940-1960. Journal of Urban History 21 (3):395-427.

1999. "South of the South?": Jews, Blacks, and the civil rights movement in Miami, 1945-1960. Journal of American Ethnic History 18 (2):3(3). 
- 2001a. Whitening Miami: Race, Housing and Government Policy in TwentiethCentury Dade County. The Florida Historical Quarterly 79 (3):319-345

- 2001b. Elizabeth Virrick and the "Concrete Monsters": Housing Reform in Postwar Miami. Tequesta LXI:5-37.

- 2004. Stop the Road: Freeway Revolts in American Cities. Journal of Urban History 30 (5):674-706.

Mollenkopf, John H. 1975. The Post-War Politics of Urban Development. Politics and Society 5 (3):247-295.

Molotch, Harvey 1976. The City as a Growth Machine: Toward a Political Economy of Place. American Journal of Sociology 82 (2):309-330.

Moore, Marilyn A. 1981. Garment firms resist plan to legalize at-home work. The Miami News, Local, May 23, 4A.

Morales, Laura. 2008a. Area residents aim to resist displacement. The Miami Herald, NE4, February 3.

- 2008b. Park improvement plan opposed. The Miami Herald, Neighbors, June 1, $3 \mathrm{NE}$.

-2008c. Landowner aims to assuage district critics. The Miami Herald, Neighbors, July 31, 10NE.

- 2008d. Demolition begins at Wynwood's Quintana Center. The Miami Herald, northwest, September 18, NW13.

Mormino, Gary. 2005. Land of Sunshine, State of Dreams: A Social History of Modern Florida. Gainesville, FL: University Press of Florida.

Morris, Christine. 1983. Wynwood Needs United Leadership. The Miami Herald, Neighbors NW, September 11, 14.

Mukhija, Vinit, Lara Regus, Sara Slovin, and Ashok Das. 2010. Can Inclusionary Zoning Be An Effective And Efficient Housing Policy? Evidence from Los Angeles and Orange Counties. Journal of Urban Affairs 32 (2):229-252.

Muller, Eli. 2003. Residents Clash With Police Chief Over Crime. The Miami Herald, Neighbors NE, August 3, 3N.

Musibay, Oscar Pedro. 2011. Wynwood land plan is in the works. South Florida Business Journal, July 1.

Nahed, Aldo. 2004a. Water Park Opening Delights Community. Miami Herald, March 4. 
—.2004b. Rally Shows Unity Against Drugs. Miami Herald, August 15.

Natale-Planas, Donna E. 1999. Wynwood neighborhood resource officer held a DARE graduation ceremony Thursday at Eneida M. Hartner Elementary. The Miami Herald, Neighbors NC, May 9, 3NC.

Nellius, Dick. 1964. Metro, Road Engineers In 'Shotgun Wedding'. Front, July 13, 1B.

New World. 2005. Building the New Majority: the New World Foundation Perspective. New York. The New World Foundation. September. Available from http://www.newwf.org.

- 2007. Social Justice Infrastructure Funders. New York. The New World Foundation. March. Available from http://www.newwf.org.

Newman, Kathe. 2004. Newark, Decline and Avoidance, Renaissance and Desire: From Disinvestment to Reinvestment. The ANNALS of the American Academy of Political and Social Science 594 (1):34-48.

Newman, Kathe, and Robert W. Lake. 2006. Democracy, Bureaucracy and Difference in US Community Development Politics since 1968. Progress in Human Geography 30 (1):44-61.

Nijman, Jan. 1996. Breaking the Rules: Miami in the Urban Hierarchy. Urban Geography 17 (1):5-22.

- 1997. Globalization to a Latin Beat: The Miami Growth Machine. The ANNALS of the American Academy of Political and Social Science 551 (1):164-177.

2011. Miami: Mistress of the Americas. Philadelphia: University of Pennsylvania Press.

Nissen, Bruce. 2000. Living Wage Campaigns From a "Social Movement" Perspective: The Miami Case. Labor Studies Journal 25 (3):29-50.

- 2009. "Social Justice Infrastructure" Organizations as New Actors From the Community: The Case of South Florida. Journal of Community Practice 17:157169.

Nissen, Bruce and Guillermo Grenier. 2001. Local Union Relations with Immigrants: The Case of South Florida. Labor Studies Journal 26 (1):76.

Nissen, Bruce and Monica Russo. 2006. Building a Movement: Revitalizing Labor in Miami. WorkingUSA 9 (1):123-139.

Nzinga-Ifateyo, Ajowa. 1998. Wynwood Officer Helping to Organize Community. The Miami Herald, Neighbors NC, March 5, 3. 
_ 1999. Top Cop: Wynwood 'S `Guardian Angel'. The Miami Herald, Neighbors NC, January 7, 3.

OGPRUS. 2006. The Records of The Offices of the Government of Puerto Rico in the United States, 1930-1993: Finding Aid. Archives of the Puerto Rican Diaspora. Centro de Estudios Puertorriqueños, Hunter College, CUNY. October 18. Available from Available at www.centropr.org.

Ojito, Mirta. 1995a. Edificio De Clínica Es La Culminacion De Un Sueño. El Nuevo Herald, Locales, August 1, 3A. 1995b. 'Yes, We Did It!' The Miami Herald, Local, July 22, 1B.

Olkon, Sara. 2001. Miami Imposes Hiring Freeze, Eyes Cuts. The Miami Herald, Front, July 13, 1 A.

Olorunnipa, Toluse. 2011a. Building boom in affordable housing underway in South Florida. The Miami Herald, April 18.

— 2011b. As rents soar, 'affordable' housing is anything but. The Miami Herald, June 11.

Ottolenghi, Hugo H. 2002. Miami architect Bernard Zyscovich says pleasant, stable neighborhoods can "ascend" by concentrating on quality of life. Daily Business Review, October 10.

Ousley, Ivette. 1993a. Help for Forgotten Wynwood. The Miami Herald, Neighbors NE, November 21, 1993, 1B.

Ousley, Yvette. 1993b. Wynwood Agency, City Clash Over Paperwork, Board The Miami Herald, Neighbors NC, September 19, 3.

. 1994. Seminar Helps Residents Buy First Home. The Miami Herald, Neighbors NC, March 10, 3.

Ovalle, David. 2003. Developer Is Ready To Help Clean Up Abandoned House. The Miami Herald, Neighbors NE, October 2, 3N.

—.2004a. Project Offers Hope For Jobs. The Miami Herald, Neighbors NE, April 4, $3 \mathrm{~N}$.

- 2004b. Wynwood's Puerto Rican Character Fading. The Miami Herald, Metro \& State, October 24, 2004, 1B.

Padilla, Felix M. 1987. Puerto Rican Chicago. Notre Dame, Ind.: University of Notre Dame Press. 
Pena, Gus. 1974. Catholic Center - Cubans, Puerto Ricans share cultures. The Voice, August 30.

Phelan, Joseph. 2007a. January 24 Rally in the Face of the Monster! Latino Communities Join in Battle Over Gentrification: Midtown Miami is eating Wynwood. Social Justice Center event flyer.

- 2007b. Report from the HUD Takeover Town Hall. People's Tribune, October. Available from http://www.peoplestribune.org/PT.2007.10/PT.2007.10.7.html.

Pinzur, Matthew I. 2007. Tentative Deal Made On Housing Takeover. The Miami Herald, Metro \& State, September 28, $1 \mathrm{~B}$.

Piven, Frances Fox, and Richard A Cloward. 1979. Poor people's movements: why they succeed, how they fail. New York, N.Y.: Random House.

Polk, R.L. and Company. 1976. Profiles of change: 1973-1975. Detroit, MI. Prepared for the City of Miami. Available from Urban/Regional Collection, Florida International University Reference Library.

Porter, Bruce, and Marvin Dunn. 1984. The Miami riot of 1980: crossing the bounds. Lexington, Mass.: Lexington Books.

Portes, Alejandro. 2005. The Cuban-American Political Machine: Reflections on its Origins and Perpetuation, pp. 187-206 in Changes in Cuban Society since the Nineties, edited by L. B. Joseph S. Tulchin, Mayra P. Espina Prieto, Rafael Hernández, with Elizabeth Bryan. Washington, DC: Woodrow Wilson International Center for Scholars.

Portes, Alejandro, and Ramon Grosfoguel. 1994. Caribbean Diasporas: Migration and Ethnic Communities. Annals of the American Academy of Political and Social Science 3:48-69.

Portes, Alejandro, and Alex Stepick. 1985. Unwelcome Immigrants: The Labor Market Experiences of 1980 (Mariel) Cuban and Haitian Refugees in South Florida. American Sociological Review 50 (August):493-514.

-1993. City on the Edge: The Social Transformation of Miami. Berkeley, CA: University of California Press.

Portes, Alejandro and Ruben G. Rumbaut, ed. 1990. Immigrant America: A portrait. Berkeley and Los Angeles: University of California Press.

Pristin, Terry. 2010. A SoHo Visionary Makes an Artsy Bet in Miami. New York Times, Business, March 31, 6. 
Proscio, Tony. 1992. Korean Firms Are Already Settling In. The Miami Herald, Local, January 28, 1B.

Proudfoot, Jesse, and Eugene McCann. 2008. At Street Level: Bureaucratic Practice in the Management of Urban Neighborhood Change. Urban Geography 29 (4):348370 .

Puerto Rican Chamber of Commerce. 2010. Chamber Celebrates Guayabera Night. Chamber News Update, December.

Purcell, Mark. 2008. Recapturing democracy: neoliberalization and the struggle for alternative urban futures. New York: Routledge.

Rabin, Charles. 2000. Miami's Bond Rating Given A Boost In Status. The Miami Herald, Local, December 12, 1B.

Rabin, Charles, and Michael Vasquez. 2009. Anti-incumbent feeling colors race. The Miami Herald, Metro \& State, October 18, 1B.

Rabinow, Paul, and Nikolas Rose, eds. 2003. The essential Foucault : selections from the essential works of Foucault 1954-1984. New York: New Press.

Ranta, Sherri C. 2004. Midtown Miami isn't there yet, but its security force is. Miami Today News, February 19, 9.

Reed Jr., Adolph L., ed. 1999. Without Justice for All: The New Liberalism and Our Retreat from Racial Equality. Boulder, CO.: Westview Press.

Reynolds, Don. 1953. Sur de Florida 'tiene problema puertorriquenho. El Mundo, February $12,5$.

Roberts, Jack W. 1954a. Dade Acts To End Horror Of Puerto Rican Camps. The Miami News, February 18, 1A, 8A.

_ 1954b. Brautigan to Questeion Arriving Puerto Ricans: Capitol Shooting Spurs Check Here. Miami Daily News, Cover, March 4.

- 1954c. Miami Puerto Rican Housing is Probed. Miami Daily News, Cover, March 25, 1A.

—. 1954d. Puerto Rican Labor Reform Program Set. Miami Daily News, April 18.

- 1954e. Port Linked to Racket in Farm Labor. The Miami News, Cover, November 8, 1A, 9A.

- 1981. Puerto Ricans could join the river flowing here. The Miami News, March 20. 
Robertson, Edith. 1969. Can't Live On Plans, Negroes Say In Criticism of Renewal Lag. The Miami News, Front, January 10, 1A, 2A.

Robin-Brandt, Pamela. 2004. Miami: The Art of Seeing and Being Seen. New York Times, Escapes, November 26, 1.

Robinson, Tony. 1995. Gentrification and Grassroots Resistance in San Francisco's Tenderloin. Urban Affairs Review 30 (4):483-513.

Rodriguez, Ana. 1979. Centro San Juan de Puerto Rico Celebra Festival: Preparando a los Niños para el Mañana. The Voice XXI, June 22 (17).

Rodríguez, Clara E. with Joseph Monserrat. 2000. Puerto Rican Immigrants and Migrants: A Historical Perspective. Americans All, A National Education Program. Available from http://www.americansall.com/PDFs/02-americansall/9.9.pdf.

Rodriguez, Elliot. 1979. Wynwood is Miami's 'Little San Juan'. The Miami News, Lifestyle, December 31, 1B, 2B.

Rodriguez, Ketty. 2003. Prometen Una Mejoría En La Educación Pública. El Nuevo Herald, Panorama, March 30, 38A.

Rodriguez-Soto, Ana. 1989. Political Action: Helping parishioners build pride, gain in evangelization, pastor says. The Voice, April 15, 7, 20.

Rollason, Frank. 2007. No More Perpetual Poverty: Yes, it's possible to win the fight against blight, but not the old-fashioned way. Biscayne Boulevard Times, October.

Roman, Ivan. 1987. Wynwood Seeks Its Identity. The Miami Herald, Neighbors NW, November 15, 10.

- 1988a. Clinic To Return To Wynwood Roots Health Center Outgrows Its Headquarters. The Miami Herald, Neighbors NC, February 4, 3.

- 1988b. Wynwood Area Preserves Flavor Of Old San Juan. The Miami Herald, Local, December 23, 1D.

- 1989. Battle Over Money Splits Wynwood Area. The Miami Herald, Neighbors Ne, January 8,12 .

Roux, Caroline. 2010. Dissenters transform the art showcase. Financial Times, November 26.

RTTC. 2008. Building Local, Regional, and National Movement for Urban Justice and Democracy: A Funder's Guide. The Right to the City Alliance. November. Available from www.righttothecity.org. 
Ruben, Matt, and Jeff Maskovsky. 2008. The Homeland Archipelago: Neoliberal Urban Governance after September 11. Critique of Anthropology 28 (2):199-217.

Sala, Caridad, and Sarah E. Eaton. 1987. Buena Vista East Historic District Designation Report. Planning and Zoning Department. City of Miami. Ordinance No. 10213 (01/22/87). Available at www.ci.miami.fl.us.

Sampson, Hannah. 2010. Art Basel draws a crowd, and hotels are selling out. The Miami Herald, December 1.

Sanchez, Melissa. 2010a. Se disparan tarifas en piscinas públicas. El Nuevo Herald, Frente, November 12, $1 \mathrm{~A}$.

- 2010b. Inauguran moderno centro comunitario en Wynwood. El Nuevo Herald, October 14.

Santana, Sofia. 2003. Activist Group Maps Strategies for Coming Year. The Miami Herald, Local, March 30, 3B.

Santiago, Fabiola, and Audra D.S. Burch. 2010. An eye that captured beauty in the rough. The Miami Herald, Front, April 21, 1A.

Sarasota-Herald Tribune. 1955. Puerto Rican Indicted for Murder at Miami. March 4.

Sassen, Saskia and Alejandro Portes. 1993. Miami: A New Global City? Contemporary Sociology 22 (4):471-477.

Schutt, Russell K. 1999. Investigating the social world: the process and practice of research. Thousand Oaks, Calif: Pine Forge Press.

Scott, Alec. 2011. Residents remain hopeful for community benefits. South Florida Times, July.

SFLCDC. 2002. Miami-Dade Inclusionary Housing Task Force Issues Report. South Florida Community Develoment Coalition. June 12. Accessed March 2, 2011 from InfoFax Archive: http://www.floridacdc.org/infofax/020612.htm.

Shell-Weiss, Melanie. 2009. Coming to Miami: A Social History, Sunbelt Studies. Gainesville, FL: University of Florida Press.

Shepard, Benjamin. 2010. Responding to Harvey: It's all about organizing. Interface: a journal for and about social movements 2 (1):287-297.

Shepherd, Terence. 2009. Wynwood a blank canvas for urban renewal. The Miami Herald, Editor's Note, January 5. 
Shimberg Center. 2007. Rental Market Study. Prepared for Florida Housing Finance Corporation by the Shimberg Center for Affordable Housing, University of Florida. September 14. Available from http://flhousingdata.shimberg.ufl.edu/docs/2007RentalMarketStudy.pdf.

Shoer-Roth, Daniel. 2005. 'Adios' For Little Havana? The Miami Herald, Business Monday, October 10, 2005, 4G.

- 2010. Church for South Florida's Peruvian community takes shape in Allapattah. The Miami Herald, August 7.

Sidlo, Steve. 1979. City May Alter Garment District. The Miami Herald, Local, August 7, 1B, 2B.

Silva, Helga. 1976a. Garment industry starts to look threadbare. The Miami News, Front, September 13, 1A, 4A.

_ 1976b. Union label rare in garment trade. The Miami News, Front, September $15,5 \mathrm{~A}$.

Skolnick, Ethan J. 2001. A Baseball Dream Ending With Stadium's Demolition Bobby Maduro To Give Way For Housing. The Miami Herald, Front, May 24, 1 A.

Slater, Tom. 2003. Comparing Gentrification in South Parkdale, Toronto and Lower Park Slope, New York City: A 'North American' Model of Neighborhood Reinvestment? Paper 11. Center for Neighbourhood Research (April). Available from http://www.neighbourhoodcentre.org.uk.

- 2006. The Eviction of Critical Perspectives from Gentrification Research. International Journal of Urban and Regional Research 30 (4):737-757.

- 2008. 'A Literal Necessity to be Re-Placed': A Rejoinder to the Gentrification Debate. International Journal of Urban and Regional Research 32 (1):212(12).

- 2009. Missing Marcuse: On gentrification and displacement. City 13 (2-3):292311.

- 2010. Still missing Marcuse: Hamnett's foggy analysis in London town. City 14 (1-2):170-179.

Smith, Michael Peter, and Luis Eduardo Guarnizo. 2009. Global Mobility, Shifting Borders and Urban Citizenship. Tijdschrift voor economische en sociale geografie 100 (5):610-622.

Smith, Neil. 1986. Gentrficiation, the frontier, and the restructuring of urban space, pp. 15-34 in Gentrification of the city, edited by N. Smith and P. Williams. Boston: Allen \& Unwin. 
- 1996. The new urban frontier: gentrification and revanchist city. London; New York: Routledge.

- 2002. New Globalism, New Urbanism: Gentrification as Global Urban Strategy. Antipode 34 (3):427-450.

- 2008. On 'The Eviction of Critical Perspectives'. International Journal of Urban and Regional Research 32 (1):195(3).

Smith, Neil, and Peter Williams, eds. 1986. Gentrification of the city. Boston: Allen \& Unwin.

Sohn, K. Lee. 2005. Wynwood Historic Homeowners' Association Wants to Stop Midtown Miami. Biscayne Boulevard Times, December.

- 2006a. Discriminatory Participation - Midtown Miami: City Denies Cutting Wynwood Residents Out of Loop. Biscayne Boulevard Times, News, May, 18.

- 2006b. Per-Duped - Did Midtown Bait Seniors' Support with Chicken Lunch? Biscayne Boulevard Times, News, June, 1.

Sokol, Brett. 2009. Heads Up: Rehousing a Miami Collection. The New York Times, November 29.

- 2010. The New Miami Art Museum Rises. Ocean Drive Magazine, Culture, December.

Sommereyns, Omar. 2006. Survey Says: City Attorney Agrees to Conduct Environmental Survey for Crosswinds Project. Miami SunPost July 21.

Sontag, Debbie. 1986. New Yorkers Buying Deco. The Miami Herald, Neighbors MB, May 18, 3.

Spinello, Anthony. 2011. Miami, We Have Lift-Off: How the World's Largest Curated Street Level Art Event, Primary Flight, Earned Its Wings. Dirty Magazine, August 28.

St. Petersburg Times. 1952. Five Murdered by Puerto Rican. May 13.

Stearns, Frank F., and R.E. Smalley. 1955. Map of Miami annexations, dis-annexations \& re-annexations. City Planning and Zoning Board of Miami. City of Miami. Available at Miami-Dade Public Library System.

Steinacker, Annette. 2001. Prospects for Regional Governance: Lessons from the Miami Abolition Vote. Urban Affairs Review 37 (1):100. 
- 2002. The Use of Bargaining Games in Local Development Policy. The Review of Policy Research 19 (4):120-153.

Stepick, Alex, Guillermo Grenier, Max Castro and Marvin Dunn. 2003. This Land Is Our Land: Immigrants and Power in Miami University of California Press.

Stepick, Alex, and Marcos Feldman. 2007. Miami Voter Dispositions Towards the Development 'Boom' and Economic Policy. Research Report. Miami, FL. Research Institute on Social and Economic Policy, Florida International University. May 1. Available from www.risep-fiu.org.

Sterne, Richard S. 1965. Social Problem Levels in City of Miami: An Analysis of Social Problem Indices And A Delineation of Problem Areas. Prepared for City of Miami Community Renewal Program by Welfare Planning Council of Dade County. City of Miami Planning Department Library.September. Available at Urban/Regional Collection, Florida International University Reference Library.

Stoecker, Randy. 1997. The CDC Model Of Urban Redevelopment: A Critique and an Alternative. Journal of Urban Affairs 19 (1):1-22.

Sugranyes, Ana, and Charlotte Mathivet, eds. 2010. Cities for All: Proposals and Experiences towards the Right to the City: Habitat International Coalition, HIC.

Sullivan, Daniel Monroe, and Samuel C. Shaw. 2011. Retail Gentrification and Race: The Case of Alberta Street in Portland, Oregon. Urban Affairs Review 47 (3):413432.

Swanstrom, Todd. 1999. The nonprofitization of United States housing policy: dilemmas of community development. Community Development J 34 (1):28-37.

Swartz, Brandy. 2004. Kidco Trying To Make Do After Cuts. The Miami Herald, Neighbors NC, June 3, 1NC.

Swyngedouw, Erik, and Maria Kaïka. 2003. The making of 'glocal' urban modernities: exploring the cracks in the mirror. City 7 (1):5-21.

_ 2011. Interrogating post-democratization: Reclaiming egalitarian political spaces. Political Geography, forthcoming (online August 31).

The Miami News. 1921. The Miami News, Society - wedding announcements, May 11.

—. 1921. Classifieds: Real Estate, April 1. 1921. Classified: Real Estate, October 25. 1923. Society - Wedding Announcements, July 10. 
—. 1927. Classified: Real Estate, September 1.

- 1956. Puerto Rican chooses state prison over return to the island. Miami's Whirligig, December 1.

—. 1961. Shouts Won't Clear Miami's Slums. Letters, February 1, 10A.

—. 1967. Avenue to Lose 4-Block 'Leg'. January 21, 8A.

_. 1970. Faces of Miami. Conversation Page, October 19.

-1973. Keep this case open. Editorial, January 18, 10A.

The Voice En Espanol. 1964. Fructifica la Primera Misión Para Hispanos: Aumenta la Asistencia a Misa y Sacramentos. October 2.

The Voice. 1971. Religious Programs, Ch. 4, WTJV: Wynwood Community Project will be the topic of the clergy panel this week, February 12, 10.

- 1975. Puerto Ricans celebrate patron's feast June 29 at the San Juan Center. June $20,2$.

Thibault, Robert E. 2007. Between Survival and Revolution: Another Community Development System is Possible. Antipode 39:874-895.

Triff, Alfredo. 2004. Out with the Old: Artists are helping to revitalize Miami, but danger looms ahead. Miami New TimesJuly 8.

_ 2005. Designing Wynwood: Developer Tony Goldman has made a big investment in a small neighborhood. Miami New Times, March 10.

Tsui, Bonnie. 2006. Art? In This Neighborhood? The New York Times, Surfacing Miami, November 26.

Turner, Robyne S. 1999. Entrepreneurial Neighborhood Initiatives: Political Capital in Community Development. Economic Development Quarterly 13 (1):15-22.

U.S. Census Bureau. 1977-1997. Number of Establishments by Employment Size Class, County Business Patterns. Data request provided April 29, 2011 by U.S. Census Bureau staff.

- 1977-1997. Number of Establishments by Employment Size Class, Zip Code Business Patterns. Data request provided April 29, 2011 by U.S. Census Bureau staff.

1980. Census Tract Tables: Ratio of Income to Federal Poverty Level. Available at Florida International University GIS Laboratory. 
U.S. Civil Rights Commission. 1974. Counting the Forgotten: The 1970 Census Count of Persons of Spanish Speaking Background in the United States. A Report of the U.S. Commission on Civil Rights. April. Available from http://www.law.umaryland.edu/marshall/usccr/documents/cr12sp22970.pdf.

U.S. HUD. 2009. Annual Report: Miami-Dade County Empowerment Zones/ Enterprise Communities. Office of Community Planning and Development. RC/EZ/EC Performance Measurement System, U.S. Department of Housing and Urban Development. Available at http://www5.hud.gov/urban/perms/printReport.asp?report=1147.

United Methodist Church. 1972-1974. Wynwood Community Project, in Archives of the United Methodist Church, Race and Religion Commission, Minority SelfDetermination Grants. Records provided electronically May, 2011 by archive librarian.

Urbana. 2002. Live/Work Market Analysis for the Wynwood Entrepreneurial Cluster. Prepared for the Puerto Rican CDC by Urbana Research and Consulting, Inc. May. Provided by the director of the Puerto Rican CDC, December 2010.

Valdemoro, Tania. 2007. Renovated school moves up in class. The Miami Herald, Neighbors, February 18, 3NE.

Vasquez, Michael. 2004. Homeowners Unite Against Developers. The Miami Herald, Metro \& State, June 12, 2 B.

. 2005. Group Forms To Battle Gentrification. The Miami Herald, Metro \& State, August 12, 2005, 4B.

- 2008. Miami commission approves Wynwood cafe district. The Miami Herald, Miami-Dade, July 25.

- 2011. UM biotech building nears completion, as protests grow. The Miami Herald, March 22.

Vasquez, Michael R. 2010. Groups protest UM biotech center in Overtown. The Miami Herald, December 10.

Vaughan, Chris. 1983. Clinic Politics. The Miami Herald, Neighbors NE, November 24, 20.

Veciana, Ana. 1979. Fashion District splits seams, seeks growth. The Miami News, Front, June 27, 4A.

Viegas, Michelle S. 2005. Community Development and the South Beach Success Story. Georgetown Journal on Poverty Law and Policy 12 (3):389-408. 
Vigdor, Jacob L. 2002. Does Gentrification Harm the Poor? pp. 133-182 in BrookingsWharton Papers on Urban Affairs. Washington, D.C.: Brookings Institution.

Viglucci, Andres. 1985. Mall Gives Artists A Home. The Miami Herald, Living Today, March 8, 1B.

—. 1991. Power Struggle Grips Model Clinic For Poor. The Miami Herald, Front, June $17,1 \mathrm{~A}$.

- 1997. Abolition Attempt Crushed Miami To Be Run By Strong Mayor. The Miami Herald, Front, September 5, 1A.

—. 1998. Nonprofit agency had role in vote collections. The Miami Herald, April 5.

- 2006. Conflict Slows Overtown Project. The Miami Herald, Metro \& State, August 7, 1B.

—. 2007. Making Good On A Bad Deal. The Miami Herald, Front, October 15, 1A.

Viglucci, Andres, and Matthew Haggman. 2005. High-rises, high hopes. The Miami Herald, May 22.

Von Hoffman, Alexander 2001. Divergent Strategies: Edison Gardens and Tacolcy Economic Development Corporation, Miami, Florida. Fannie Mae Foundation Practice Report: Fuel Lines for the Urban Revival Engine. Fannie Mae Foundation. January. Available from http://www.communitywealth.org/pdfs/articles-publications/cdcs/report-vh_case-studies.pdf.

Wacquant, Loïc. 1997. Three Pernicious Premises in the Study of the American Ghetto. International Journal of Urban and Regional Research 21 (2):341-353.

- 2007. Territorial Stigmatization in the Age of Advanced Marginality. Thesis Eleven 91 (1):66-77.

- 2008. Relocating Gentrification: The Working Class, Science and the State in Recent Urban Research. International Journal of Urban and Regional Research 32 (1):198-205.

Wakefield, Rebecca. 2007. Someone Oughta Pay. Miami Sun Post, January 18.

- 2008. The People's Mayors - As the nation's mayors converge on Miami this week, activists plan a funeral march fit to wake the dead. Miami SunPost, June 19.

Wallach, Amei. 2001. In Miami, a Hot Spot of Art, the Temperature's Rising. New York Times, Arts and Leisure Desk, September 16, 33. 
Weber, Rachel. 2002. Extracting Value from the City: Neoliberalism and Urban Redevelopment. Antipode 34 (3):519-540.

Weber, Rachel, Marc Doussard, Saurav Dev Bhatta, and Daniel McGrath. 2006. Tearing The City Down: Understanding Demolition Activity In Gentrifying Neighborhoods. Journal of Urban Affairs 28 (1):19-41.

Werne, JO. 1990. Design District The Sequel. The Miami Herald, Home and Design, August 5, 1990, 1J.

West, Ryan. 2005. Inclusionary Zoning: Is it Right for Florida? Policy Brief. DeVoe L. Moore Center, College of Social Sciences, Florida State University. Issue 17: November. Available from http://www.fsu.edu/ p policy/materials/PolicyBrief17.pdf.

Williams, Verne O. 1967. Sky-High Over Dade. The Miami News, April 20, 8C.

Wilner, Isaiah. 1999. Renewal Project Falls Apart Miami In Dispute Over Money, Land. The Miami Herald, Local, August 9, 1B.

Wilson, David, and Dennis Grammenos. 2000. Spatiality and Urban Redevelopment Movements. Urban Geography 21 (4):361-370.

Wilson, William Julius. 1996. When Work Disappears: The World of the New Urban Poor. New York: Alfred A. Knopf, Inc.

Winsberg, Morton D. 1979. Housing Segregation of a Predominantly Middle Class Population: Residential Patterns Developed by the Cuban Immigration into Miami, 1950-74. American Journal of Economics and Sociology 38 (4):403-418.

- 1983a. Changing Distribution of the Black Population: Florida Cities, 19701980. Urban Affairs Review 18 (3):361-370.

- 1983b. Ethnic Competition for Residential Space in Miami, Florida, 1970-80. American Journal of Economics and Sociology 42 (3):305-314.

Woodlieff, Katie E. 2006. Does Race Really Matter? Dimensions of Housing Inequality in Miami. Paper read at American Sociological Association Conference, August 10, Montreal, Quebec, Canada.

Wooldridge, Jane, Daniel Chang, and Fabiola Santiago. 2007. High Culture. The Miami Herald, Front, December 6, 1A.

Wyly, Elvin K, and Daniel J. Hammel. 1999. Islands of Decay in Seas of Renewal: Housing Policy and the Resurgence of Gentrification. Housing Policy Debate 10 (4):711-771. 
Wynwood Master Plan. 1996. University of Miami Center for Urban and Community Design, with the Puerto Rican CDC. Sponsored by Greater Western Bank. Copy provided by the director of the Puerto Rican CDC, December, 2010.

Ycaza, Cindy. 1993. Born Again. The Miami Herald, Neighbors NE, June 17, 16.

Yee, Ivette M. 2000. Group Lobbies Support For Phonics Program. The Miami Herald, Local, February 13, 2B.

Zeitlin, Janine. 2008a. Parks Bond Languishes: Miami leaders scared voters into approving a \$255-million bond that's gone nowhere. Miami New Times, February 7.

- 2008b. Withering in Wynwood. Miami New Times, March 27.

Zimichi, Fatima. 2011. The Second Saturday art walk has a new shuttle - but is it too expensive? The Miami Herald, Open Media Miami, May 26.

Zukin, Sharon. 1982. Art in the Arms of Power: Market Relations and Collective Patronage in the Capitalist State. Theory and Society 11 (4):423-451.

- 1989. Loft living: culture and capital in urban change. New Brunswick, N.J.: Rutgers University Press. 


\section{APPENDIX: WYNWOOD CAFÉ DISTRICT LETTERS OF SUPPORT}

Note: Letters have been modified to protect the confidentiality of respondents.

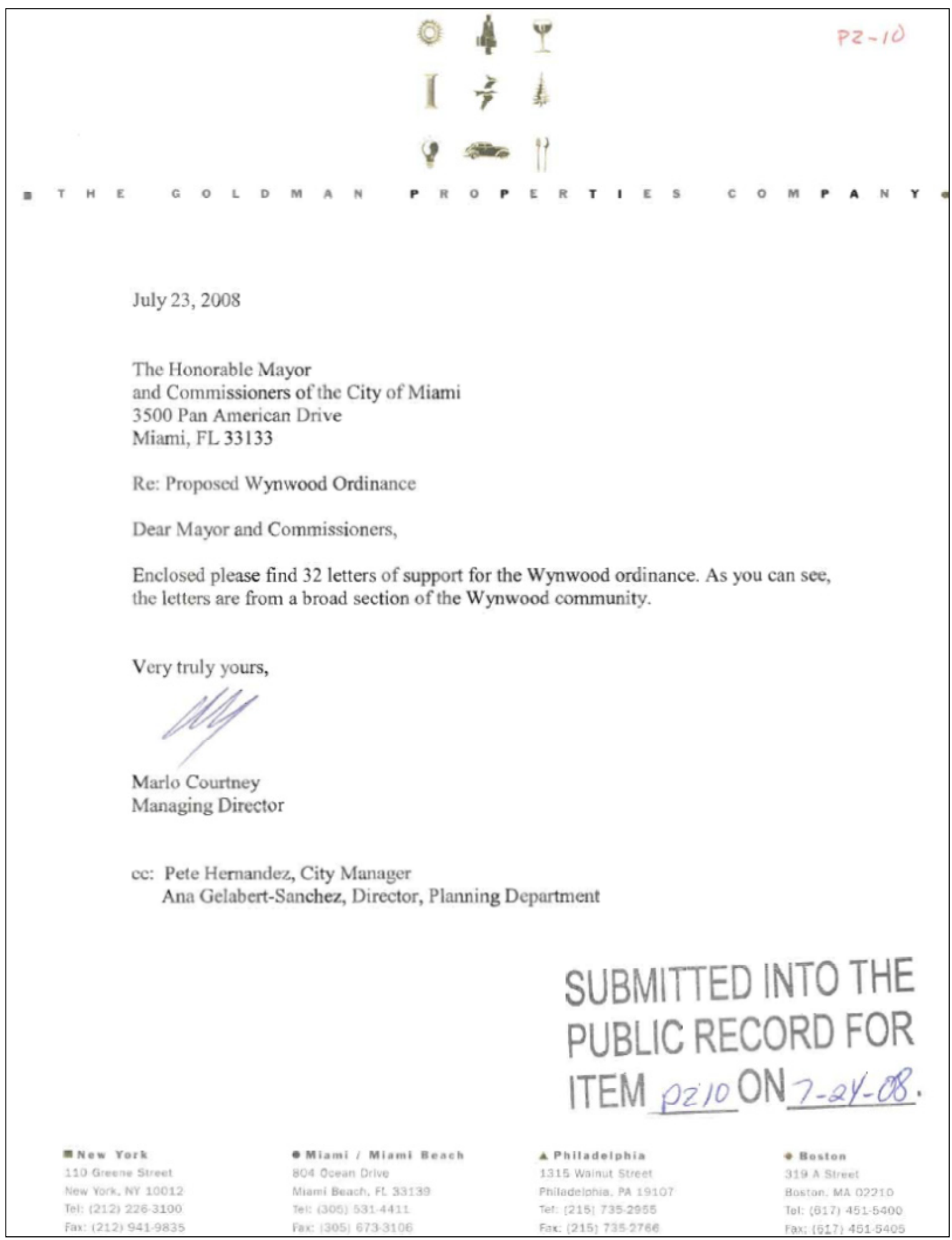




\section{Letters of Support for Wynwood Ordinance}

\section{Table of Contents}

\section{Community Groups}

1. Puerto Rican Educational Services (PRES)

Avenue, Miami, Florida 33137

2. Puerto Rican Chamber of Commerce (Luis De Rosa, President) 3550 Biscayne Blvd, Suite 306, Miami, FL 33137

\section{Puerto Rican CDC}

$$
\text { Avenue, Miami, Florida } 33127
$$

4. Wynwood Art District (Executive Board) Brook A Dorsch (Owner - Dorsch Gallery) Claire Breukel (Executive Director - Locust Projects) Nina Johnson (Owner and Director - Gallery Diet) Jose Diaz (Diana Lowenstein Fine Arts) Issac Pereiman (Dot 51)

\section{Residents}

5. Jorge Corcho 335 N.W. $28^{\text {th }}$ Street, Miami, Florida 33127

6. Alejandrina E. Herrera 321 N.W. $32^{\text {nd }}$ Street, Miami, Florida 33127

7. Keira Castro 321 N.W. $32^{\text {nd }}$ Street, Miami, Florida 33127

8. Pamela Diaz. 321 N.W. $32^{\text {nd }}$ Street, Miami, Florida 33127

\section{Galleries/Museums}

9. MOCA-Museum of Contemporary Art (Bonnie Clearwater, Director and Chief Curator)

770 N.E. $125^{\text {th }}$ Street, Miami, Florida 33161

10. Praxis (Pablo Dona, Gallery Director) 2219 N.W. $2^{\text {nd }}$ Avenue, Miami, Florida 33127

11. Gallery Diet (Nina Johnson, Director and Owner) 174 N.W. $23^{\text {rd }}$ Street, Miami, Florida 33127 
12. Milou Gallery (Perry Milou, Director and Owner) 17 N.W. $36^{\text {th }}$ Street, Miami, Florida 33127

13. Art Rouge Gallery (Ivdia Velazquez, Project Manager) 46 N.W. $36^{\text {th }}$ Street, Miami, Florida 33127

14. Pan American Art Projects (Carolina Marquez, Registrar) 2450 N.W. $2^{\text {nd }}$ Avenue, Miami, Florida 33127

15. Baez Fine Art (Elizabeth Baez) 4100 N.E. $2^{\text {nd }}$ Avenue, Miami, Florida 33137

16. Ignacio Gurruchaga Photography (Ignacio Gurruchaga) 175 N.W. $22^{\text {nd }}$ Street, Miami, Florida 33127

Business Owners/Operators/Property Owners

17. Lehman Pipe and Plumbing Supply (Dennis Jay Lehman, President) 230 N.W. $29^{\text {th }}$ Street, Miami, Florida 33127

18. Trendy Studio (Enrique Lopez, Owner) 194-196 N.W. $24^{\text {th }}$ Street, Miami, Florida 33127

19. Windsor Capital Corporation (Alex Torres, Property Owner and Landlord) 1441 Brickell Avenue, Suite 1001, Miami, Florida 33131

20. Maria Moreno, Inc. (Francisco Kim, Owner) 2545 N.W. $5^{\text {th }}$ Avenue, Miami, Florida 33124

21. Karine Rousseau Design Studio (Karine Rousseau, Owner) 250 N.W. $23^{\text {rd }}$ Street, Suite 209, Miami, Florida 33127

22. David Wek (Property Owner) 2801 N.W. $3^{\text {rd }}$ Avenue, Miami, Florida 33127

23. London Motors, Inc. (Fernando Camargo, Owner) 2390 N.W. $2^{\text {nd }}$ Avenue, Miami, Florida 33127

24. Adriana Fashion (Edson Han, Owner) 2801 N.W. $5^{\text {th }}$ Avenue, Miami, Florida 33127

25. Mizrach Realty Associates (Larry Mizrach, President) 2399 N.W. $2^{\text {nd }}$ Avenue, Miami, Florida 33127

26. Victor Ballestas, Inc. (Victor Ballestas, President) 500 N.W. $24^{\text {th }}$ Street, Miami, Florida 33127 
27. Harold's Paint and Body Repair (Harold Coqmard, Owner) 2151 N.W. $3^{\text {rd }}$ Avenue, Miami, Florida 33127

28. Better Products International, Inc. (Peter Hsu, Owner) 295 N.W. $27^{\text {th }}$ Avenue, Miami, Florida 33127

29. Blandon Ornamental Iron (Raul Blandon, Owner) 2730 N.W. $2^{\text {nd }}$ Avenue, Miami, Florida 33127

30. Las Tias (Esther Percal, Owner and President) 2834 N. Miami Avenue, Miami, Florida 33127

31. Aurix (Mario A. Puig, Owner) 345 N.W. $24^{\text {th }}$ Street, Miami, Florida 33127

32. P \& S Property Management, Inc. (Owner) 560 N.W. $29^{\text {th }}$ Street, Miami, Florida 33127

Submitted into the public record in connection with item PZ.10 on 07-24-08

Priscilla A. Thompson City Clerk 


\section{Puerto Rican \\ Priscilla A. Thompson \\ Educational \\ Services (PRES) \\ Organization \\ a Investment in Latino Youth \\ E 2 ${ }^{\text {ad }}$ Ave. Miami, Florida $33137-3161$ (305) 576-8494 Fax (305) 576-6217 \\ Youth Leadership Development and Outreach Programs \& Charter Schoois}

July 21,2008

The Honorable Mayor, Commissioners, and City Manager of the City of Miami

3500 Pan American Drive

Miami, FL 33133

Re: Proposed Wynwood Ordinance - Wynwood Café District

To the City of Miami City Commission:

As a leading community organization in Wynwood, PRES , Inc., has been an advocate for social advancement of the Wynwood residents. We have a thorough understanding of the community needs and believe that this ordinance is beneficial for both residents and business owners.

The new food and beverage establishments will substantially increase the number of visitors in the area and help eliminate blight, desolate streets, and crime by creating a pedestrian friendly environment. In addition, the establishment of such businesses will assuage development employment opportunities that will benefit the community.

As a member of the Wynwood community, we strongly support this city initiative and encourage its adoption.

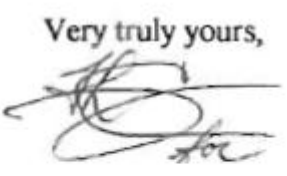

President \& CEO

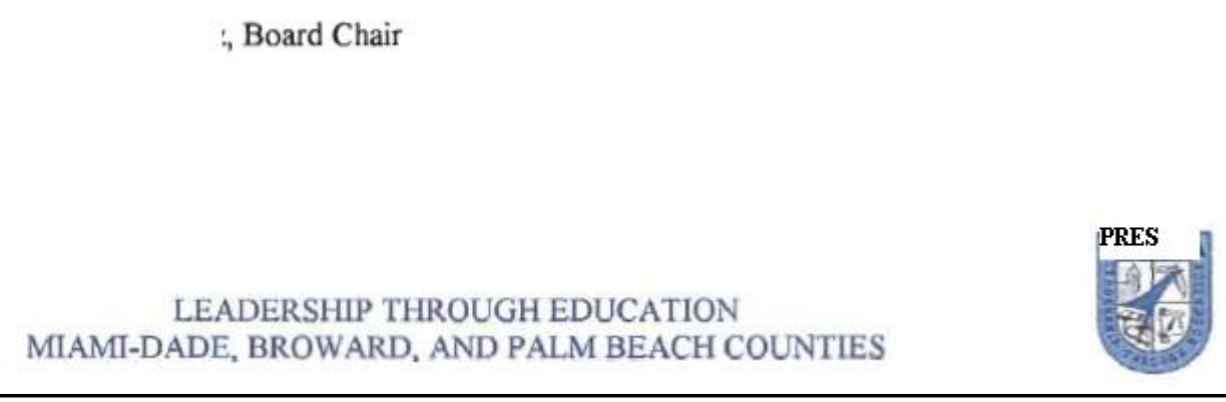




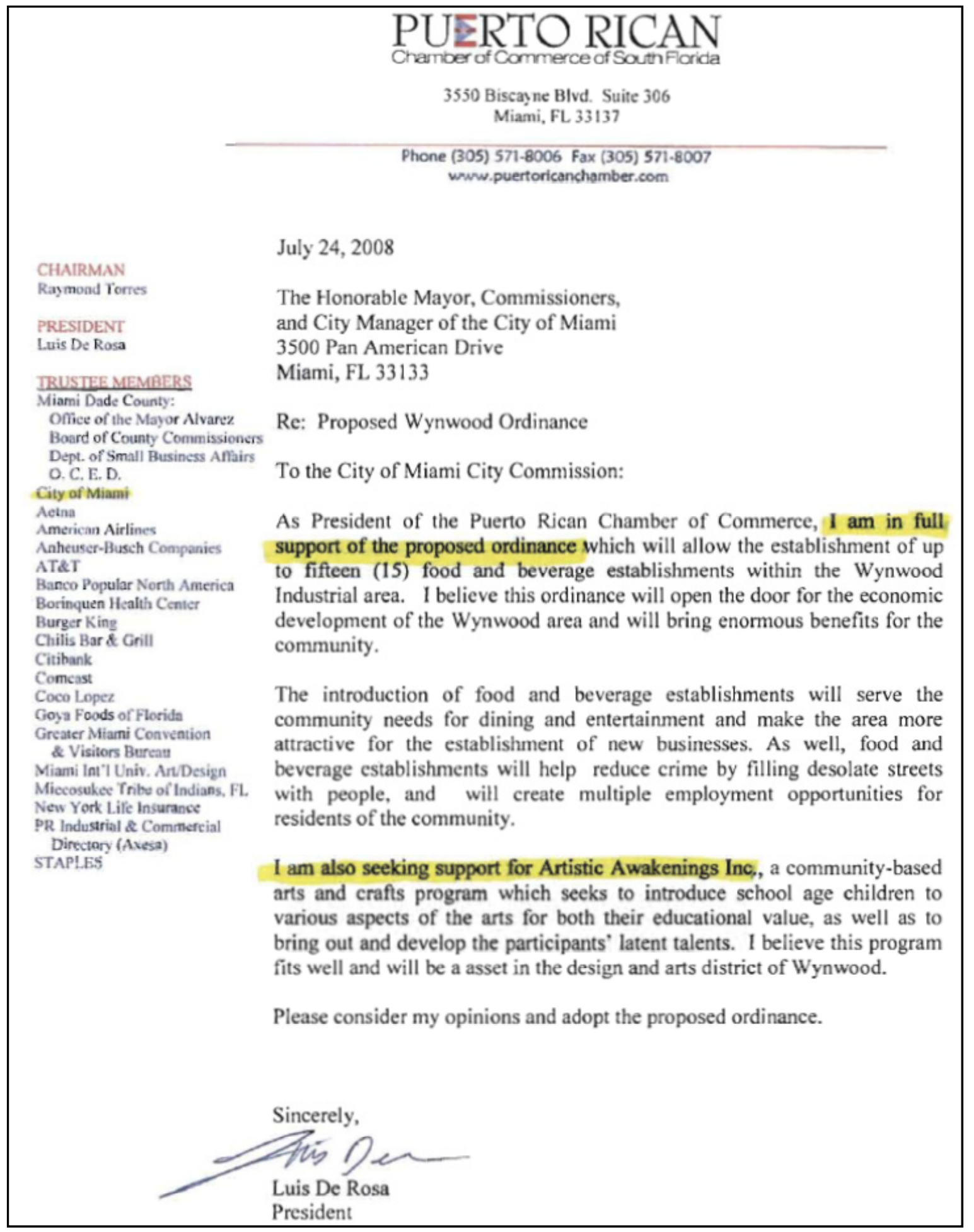




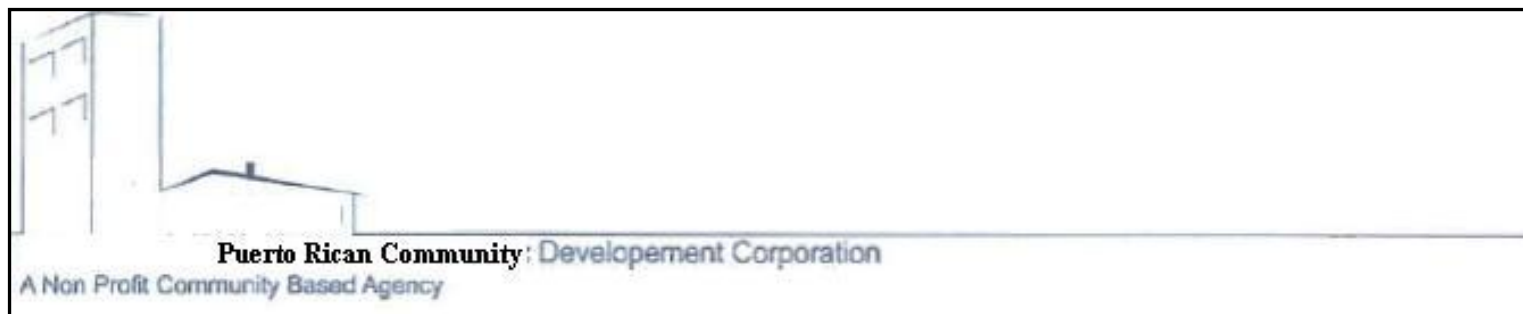

July 17,2008

The Honorable May, Commissioners, And City Manager of the City of Miami 3500 Pan American Drive Miami, Florida 33133

Re: Proposed Wynwood Ordinance - Wynwood Café District

To the City of Miami City Commission:

As Executive Director of the Puerto Rican Community Development Corporation, I am directly involved in the business and residential affairs of the Wynwood area. 1 have been working in Wynwood for over 15 years and 1 know what the area needs to realize its potential.

The Wynwood Café District will play a vital role in bringing economic vitality to an area that has long been economically flat lined. The new establishments will make Wynwood a destination for locals and tourists alike. The restaurants and cafes will keep people in the area, thereby increasing commerce throughout the gallery district and fashion district. The influx of people will replace the dark, desolate streets thereby reducing crime. The ordinance provides the sparks that this area desperately needs.

The ordinance will also benefit the resident of the community. The restaurants and cafes will create both skilled and non-skilled jobs for local residents. Right now, Wynwood residents must drive or take public transportation to work in the hospitality sector. The new establishment will provide many new opportunities for the Wynwood's residents.

As a member of the Wynwood community, $I$ ask that the commission please adopt this important initiative.

Sincerely, 

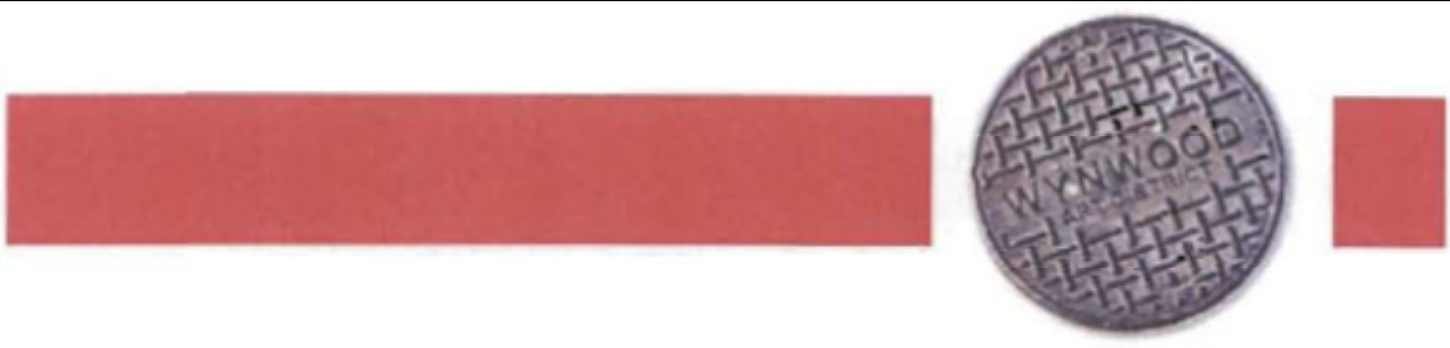

\section{Executive Board}

Brook A Dorsch

Ciare Breukel

Nina johnson

Jose Diaz

Isaac Pereimain

July $22^{\text {nd }}, 2008$

To whom it may concern,

The Wynwood Art District, the association was established in 2001 and currently has more than 50 members located within Miamis Wynwood neighborhood, which is larger than the area proposed by the ordinance. The Wynwood Art District organization consists of Galleries, Museums, Collections, Non-profit Art Studios and Artist's Studios.

The Executive Board supports the newly proposed Wynwood Ordinance only if the district designated does not use the name "Wynwood Art District." A designation such as the "Wynwood Café District" has our support. We feel it is important to recognize an area within the overall Wynwood Art District as a restaurant and bar friendly area to increase the amount of viable foot traffic in the neighborhood. The new influx of people will help to reduce crime therefore infusing new life into this culturaliy rich area of the city.

Not only as tenants and property owners in the area but as the executive board members of the Wynwood Art District we ask that you consider our opinions and adop: the proposed ordinance.

Sincerely.

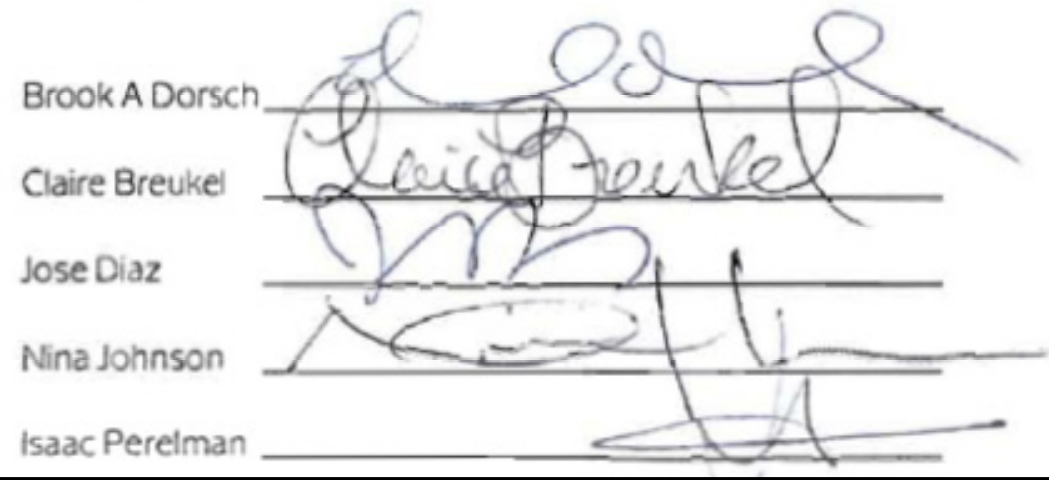


22 de Julio de 2008

Para: Comisionados de Miami

Hace varios años que vivo en wynwood, cerca de los almacenes. El area esta bien abandonada y es peligroso salir de noche porque no hay ningun tipo de actividad en la calle. Creo que la idea de traer restaurantes a la zona es muy buena porque va a haber mas gente en la calle y sitios donde comer y salir a caminar. Tambien van a haber mas trabajos para los residentes.

Como residente apoyo que se apruebe esta ordenanza.

Gracias.

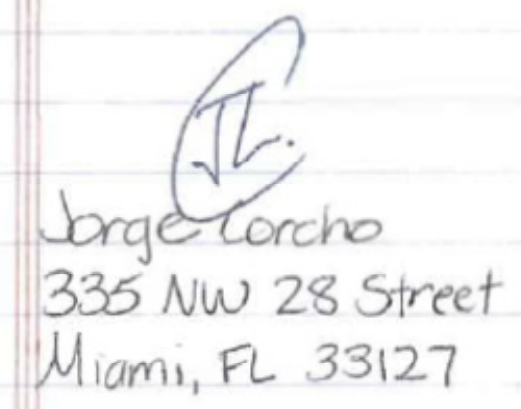


21 de Julio 2008

Atención Comisionados de Miami:

Hemos recibido información sobre la oportunidad de crear cafés y restaurantes en el área de Wynwood, en cual soy residente por algunos anos.

Creo que va hacer una gran oportunidad en cuanto trabajo concierne, llaque crearía mayor trafico peatonal en esta área al igual que la oportunidad de combatir el crimen creando un mayor futuro para nuestros hijos.

Agradeciendo de antemano la atención brindada,

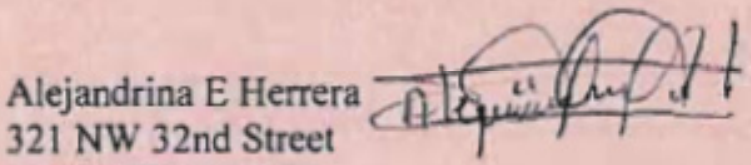

Miami, Fl 33127 
23 de Julio 2008

Atención Comisionados de Miami:

Hemos recibido información sobre la oportunidad de crear cafés : restaurantes en el área de Wynwood, en cual soy residente por algunos anos.

Creo que va hacer una gran oportunidad en cuanto trabajo concierne. llaque crearia mayor trafico peatonal en esta área al igual que la oportunidad de combatir el crimen creando un mayor futuro para nuestros hijos.

Agradeciendo de antemano la atención brindada.

$$
\text { keita castro }
$$

Keira Castro

321 NW 32 Street

Miami, Fl 33127 
22 de Julio 2008

Atención Comisionados de Miami:

Hemos recibido información sobre la oportunidad de crear cafés y restaurantes en el área de Wynwood, en cual soy residente por algunos anos.

Creo que va hacer una gran oportunidad en cuanto trabajo concierne, llaque crearia mayor trafico peatonal en esta área al igual que la oportunidad de combatir el crimen creando un mayor futuro para nuestros hijos.

Agradeciendo de antemano la atención brindada,

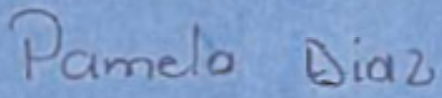

Pamela Diaz

321 NW 32 Street

Miami, F1 33127 


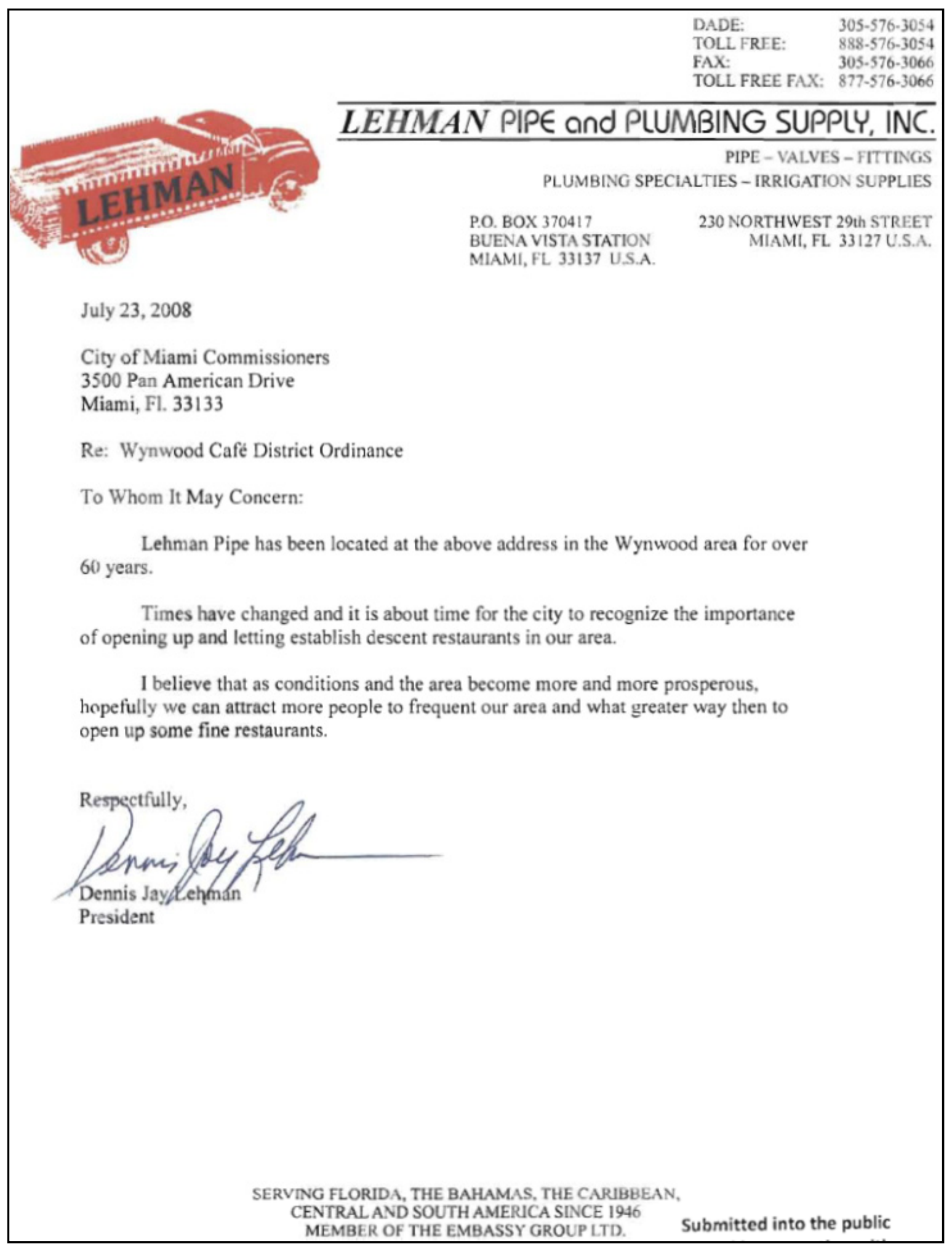




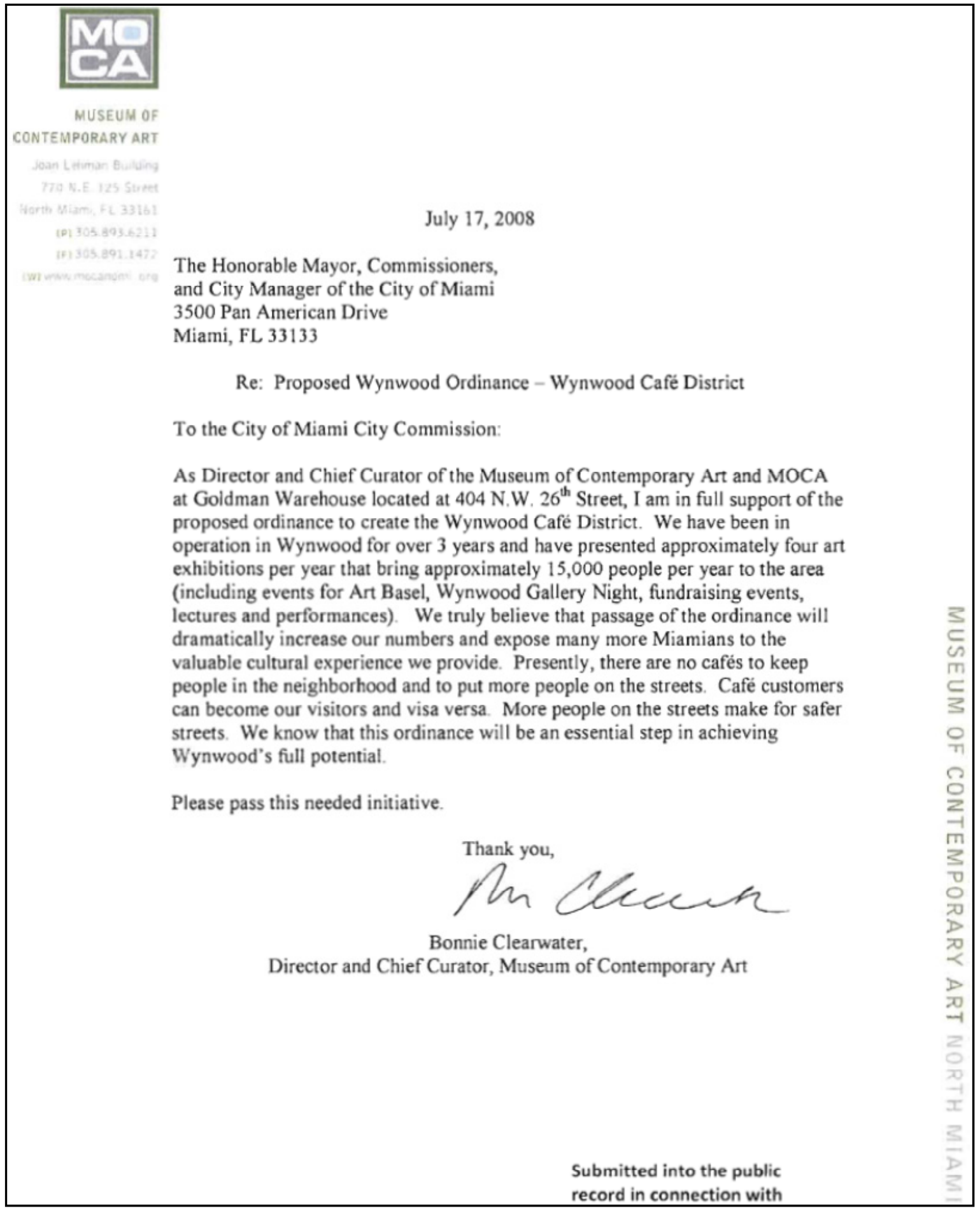




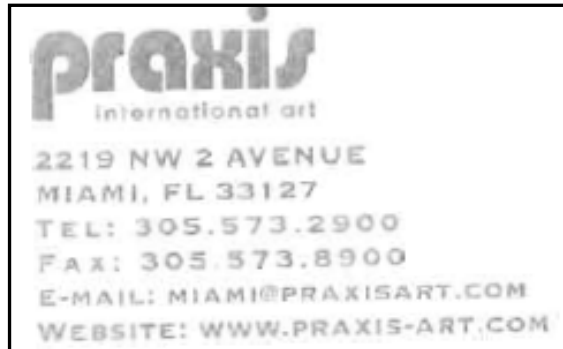

Juily 21. 2008

The Honorable May or. Commissioners.

and City Manager of the City of Miami

3500 Pan American Drive

Miami, FL 33133

\section{Re: Proposed Wynwood Ordinance - Wynwood Cafë District}

To the City ol Miami City ('ommission:

As gallery director in the Wynwood Art District, I am in full support of the proposed ordinance. The Wynwood Café District will fuel the area and the art community as a whole. Right now, pedestrian traffic rarely passes b: my gallery unless it is during Second Saturdays. The new cafés and restaurants will substantially increase the number of people in the area and incruse the amount of time these visitors stay.

The new influx of people will not only help my business and expose my gallery. but also reduce crime. I truly believe that the desolate streets keep people away from the District. The new establishments will infuse life to an area that is on the verge of realizing its potential. The proposed Wynwood Café District will be the driving force in the areas success.

As a tenant and gallery director in the $\mathrm{W}_{\text {ynuwood Arts District. please consider my }}$ opinions and adopt the proposed ordinance.

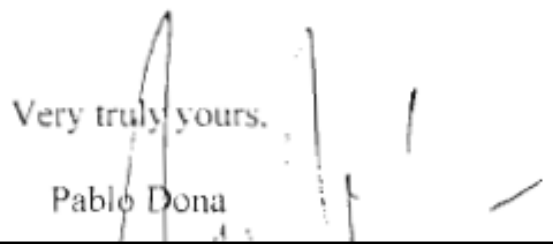


July 23,2008

\section{To Whom It May Concern:}

As a tenant and business owner in Wynwood I am writing to state my supyort for the proposed "Tlynwood Café" District." I feel that the lack of peclestrian tralfic is one of the main causes of crime in the neighborhood and am certain that restaurants, bars, and cafes will help to bring additional viable foot traffic to the neighborhood. We need businesses that will help create and sustain a lively atmosphere in the ncighborhood.

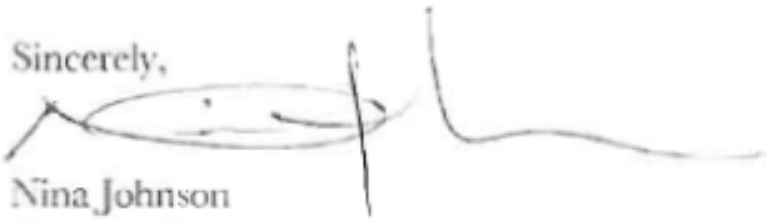

Director/Owner

Gallery Dicı 
The Honorable Mayor, Commissioners, and City Manager of the City of Miami 3500 Pan American Drive Miami, FL 33133

FROM MILOU GALLERY PERRY MILOU DIRECTOR $17 \mathrm{NW} 36^{\text {THI }}$ STRLEET MIAMI FLORIDA 33127

THIS LETTER IS WRITTEN WITH THE HIGHEST REGARDS IN FAVOR OF SUPPORTING GOLDMAN PROPERTIES PROPOSED ORDINANCE OF DEVELOPING "THE WYNWOOD CAFÉ DISTRICT!"

GOLDMAN PROPERTIES HAS A LONG OUTSTANDING NATIONAL. REPUTATION OF VISIONARY TALENTS IN DEVELOPING PLIGHTED URBAN Z.ONES INTO INCREDIBLE LIVING/RETAIL NEIGHBORHOODS. WYNWOOD'S UNTIMATE SUCCESS DEPENDS GREATLY ON THIS SOLE CONCEPT!

MILOU GALLERY FULLY SUPPORTS THE NEW ORDINANCE NAMING "THE WYNWOOD CAFÉ DISTRICT"

PERRY MILOU

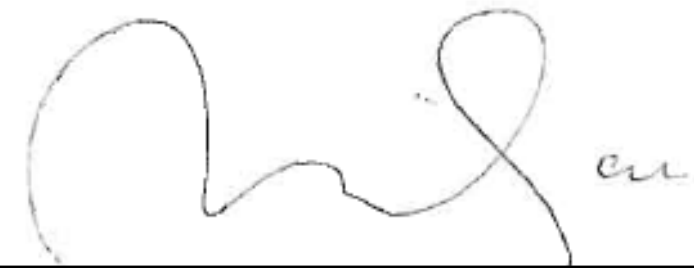




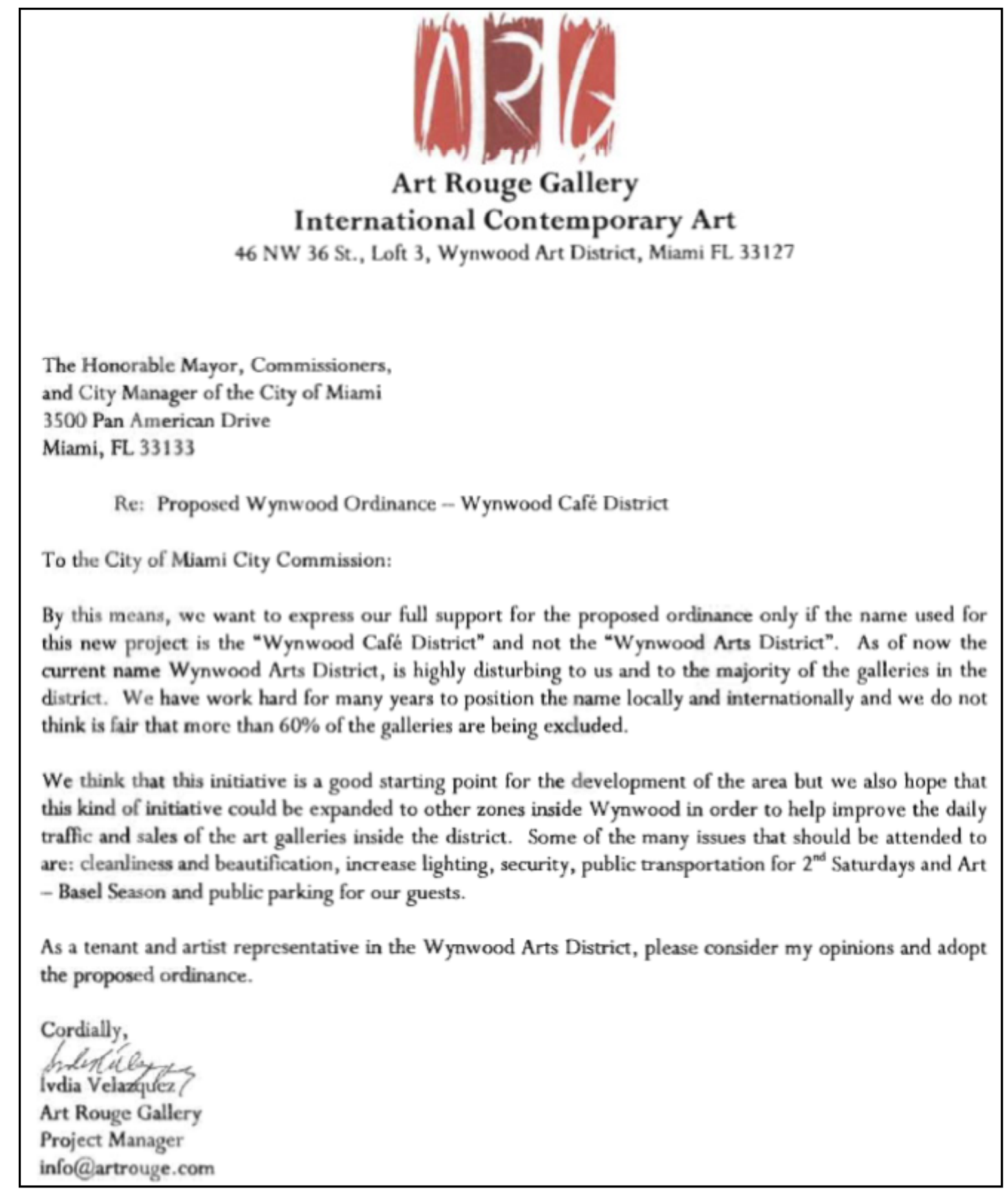




\section{PanAmerican ArtProjects}

2450 NW 2nd Avenue Miami, FL 33127

t. 305.573 .2400

f. 305.573 .0720

miami@panamericanart.com www.panamericanart.com

To Whom It May Concern:

On behalf of the working team at Pan American Art Projects, we are in full support of the Wynwood Café District ordinance. We feel that the Wynwood area would greatly benefit from the opening of more restaurants, as it would draw in a greater crowd and provide close locations for those of us that work within the vicinity.

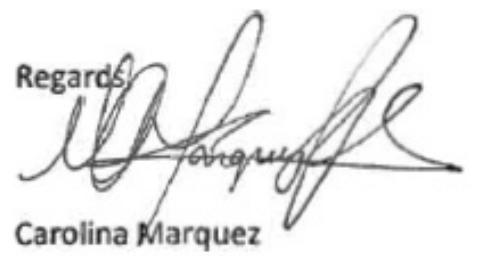

Registrar 


\section{July 17,2008}

The Honorable Mayor, Commissioners, and City Manager of the City of Miami 3500 Pan American Drive

Miami. FL. 33133

\section{Re: Proposed Wynwood Ordinance - Wynwood Cafẻ District}

To the City of Miami City Commission:

As an artist and a community activist, I have a unique perspective on the Wynwood Area. I am not only an artist, but I also volunteer my time to help local youth organizations such as ASPIRA. The proposed Wynwood Café District will greatly aid both of my passions, art and the development of teenage youth.

From the Art perspective, the creation of cafés and dining establishments will bring new visitors to the area, exposing them to the various Art studios and galleries that are blossoming in the warehouse district. Further, with the influx of visitors, more artists will view the area as a great place to exhibit their art, thereby creating a mutually beneficial relationship.

The new cafés and eateries will also provide great employment opportunities for the area's youth. Currently, the residents of Wynwood must leave the area to find empioyment. The Wynwood Café District will create jobs for these residents and increase the overall vitality of the cultural gem that is Wynwood.

Artists and residents alike will both benefit from this ordinance. Please consider my opinions as an artist and activist.

Very truly yours,

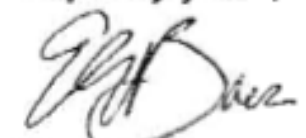

Elizabeth Erazo Baez 


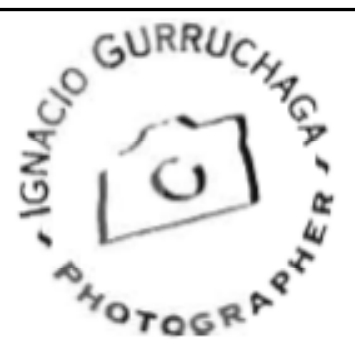

July 21. 2008

The Honorable Mayor. Commissioners.

and City Manager of the City of Miami

3500 Pan American Drive

Miami, FL 33133

Re: Proposed Wynwood Ordinance - Wynwood Café District

To the City of Miami City Commission:

As an photographer in the Wynwood Art District. I am in full support of the proposed ordinance. The Wynwood Café District will fuel the area and the art community as a whole. Right now, pedestrian traffic rarely passes by my gallery unless it is during Second Saturdays. The new cafés and restaurants will substantially increase the number of people in the area and increase the amount of time these visitors stay.

The new influx of pcople will not only help my business and expose my art. but also reduce crime. I truly believe that the desolate streets keep people away from the District. The new establishments will infuse life to an area that is on the verge of realizing its potential. The proposed Wynwood Café District will be the driving force in the areas success.

As a tenant and artist in the Wynuood Art\$ District, please consider my opinions and adopt the proposed ordinance.

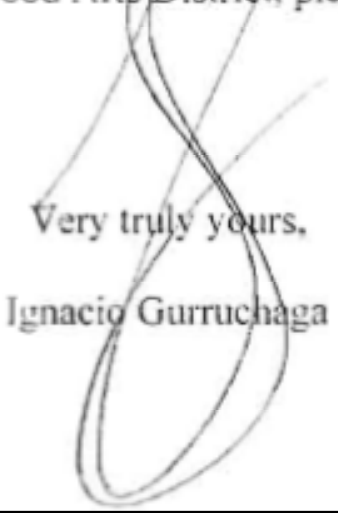


July 23,2008

The Honorable Mayor, Commissioners, and City Manager of the City of Miami 3500 Pan American Drive Miami, FL 33133

\section{Re: Proposed Wynwood Ordinance - Wynwood Café District}

To the City of Miami City Commission:

As a business owner in the Wynwood Art District, I am in full support of the proposed ordinance. The Wynwood Café District will fuel the area and the art community as a whole. The new cafés and restaurants will substantially increase the number of people in the area and increase the amount of time these visitors stay.

The new influx of people will not only help my business, but also reduce crime. I truly believe that the desolate streets keep people away from the District. The new establishments will infuse life to an area that is on the verge of realizing its potential. The proposed Wynwood Café District will be the driving force in the area"s success.

Due to a prior business engagement I will not be able to attend the meeting, however, as a business owner in the Wynwood Arts District, I trust your will consider my opinions and adopt the proposed ordinance.

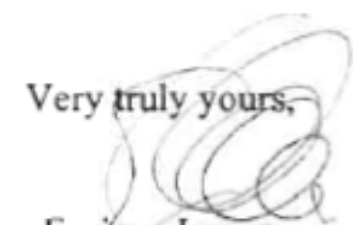

Enrique Lopez

Trendy Studio. LLC

194-196 NW 24 Street

Miami. FL 33127 


\section{$\bigvee_{\text {Windsor Capital }}$}

July 21, 2008

Major Diaz and City of Miarni Commissioners

3500 Pan American Drive

Miami, FL 33133

Re: Proposed Wynwood Ordinance

To whom it may concern:

As a property owner in the Wynwood Art District, Windsor Capital owns the property located at $143 \mathrm{NW} 23^{\text {rd }}$ Street, I am in full support of the proposed ordinance. The Wynwood Café District will fuel the area and the community as a whole. Right now, pedestrian traffic rarely passes by our tenant's showroom/gallery space unless it is during Second Saturdays. The new cafés and restaurants will substantially increase the number of people in the area and increase the amount of time these visitors stay.

The new influx of people will not only help our tenants business, but also reduce crime and increase property values. I truly helieve that the desolate strects keep people away from the District. The new establishments will infuse life to an area that is on the verge of realizing its potential. The proposed Wynwood Café District will be a driving force in the areas success.

As a property owner and Landlord in the Wynwood Arts District, I strongly support the proposed ordinance.

Very truly yours,

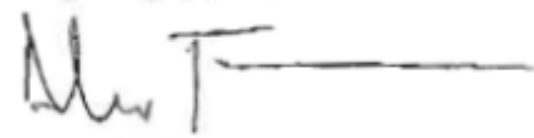

Alex Torres

Windsor Capital 


\section{Maria Morena Inc.}

$2545 \mathrm{NW} 5^{\text {th }}$ Avenue - Miami Florida 33124

July 17,2008

The Honorable Mayor, Commissioners,

and City Manager of the City of Miami

3500 Pan American Drive

Miami, FL 33133

\section{Re: Proposed Wynwood Ordinance - Wynwood Café District}

To the City of Miani City Conmission:

I've been doing business in the Fashion District for about 17 years, since 1991 and I've scen may businesscs opening and closing around here but one thing that always bothers me is that for 17 years there hasn't been one descent place to have lunch or coffee. My business depends on walk in customers and unfortunately some of them will just cone in for their purchases and leave back where they came from.

I believe the Wynwood Café District will make a tremendous difference in this area. It will be extremely convenient for the people who travel from outside the United States because most of them don't want to spend money in rental cars taking taxicabs. These customers don't have any idea where they could go for a decent restaurant where they could have a good meal. There are a few cafes in the neighborhood but they are not very clcan. We always need to take our customers to have lunch or discuss business at places that would take us at least 20 minutes drive.

I an sure the Café District will make a huge difference for all of us. It will also bring more people out to our business. Sales will go up for sure with more people out and besides that crimes will go down with more people walking around our business.

As a business owner I hope you take this consideration for this definitely needed ordinance. I am sure it will make not only better for the commụnity but also for our district.

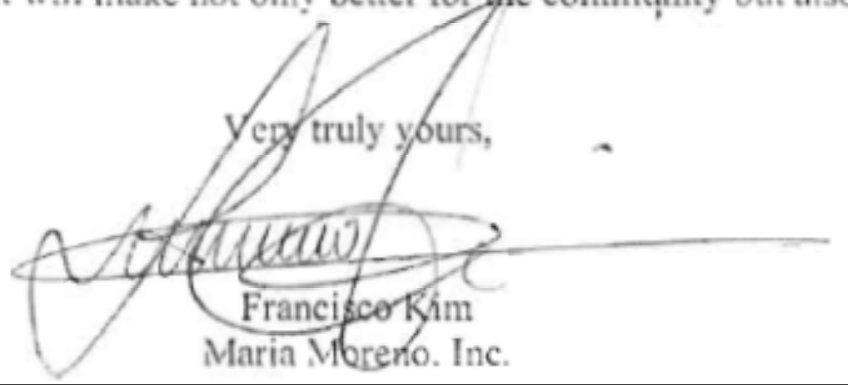




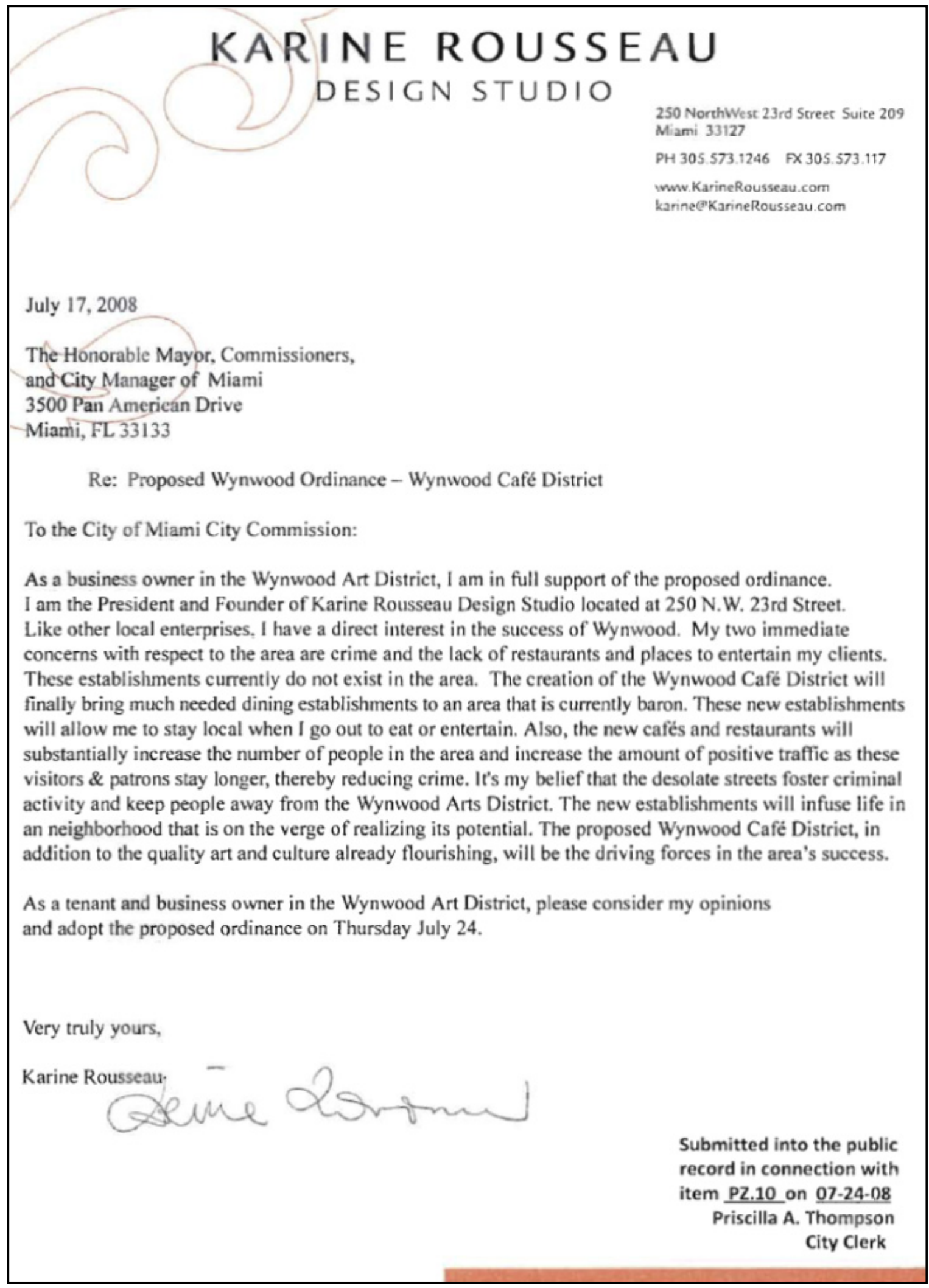




\section{DAVID WECK \\ 2801 N.W. $3^{\text {rd }}$ Avenue \\ Miami, FL 33127 \\ Telephone (305) 573-0163 Fax (305) 576-3964}

July 23,2008

City of Miami Commissioners

3500 Pan American Drive

Miami, FL 33133

RE: Wynwood Café District Ordinance

Dear City of Miami Commissioners:

I am a businessman and owner of several properties in the Wynwood area who employs 150 persons here. We have been in the area for 20 years, and are pleased with the progress thus far.

It would be an excelient development to allow cafés and restaurants to be established in Wynwood to make it more popular not only for our own community, but to attract people from all over, and make it a beautiful and safe place.

I am very fond of Wynwood, and I am in support of this cafe district ordinance.

Please make it happen!

Thank you very much,

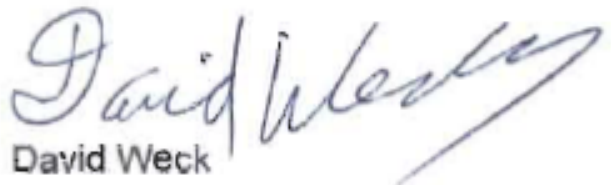




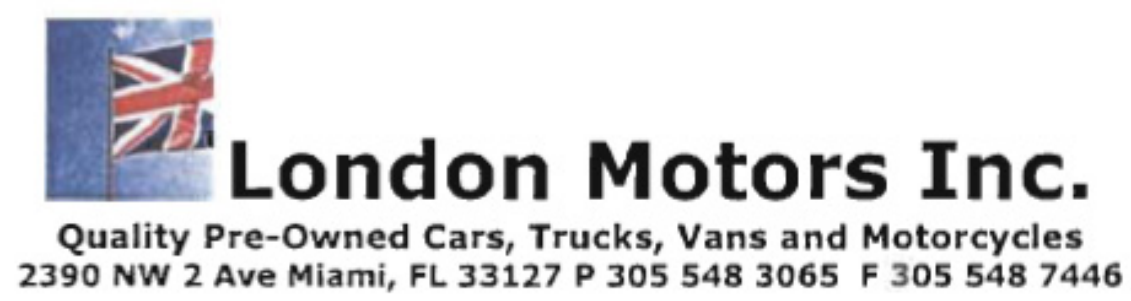

July 21,2008

Mayor Diaz \& City Commissioners

Re: Wynwood Ordinance

Dear: Mr. Diaz \& City of Miami Commissioners:

I currently own and operate a car dealership in the Wynwood area. The area is thriving with new galleries and businesses but still lacks food and beverage establishments. My employees as well as my customers need to drive away from the area to have breakfast and lunch since there are no restaurants and cafeterias in the nearby. I am also forced to close my business early due to the lack of traffic and pedestrian activity in the early evening hours.

I believe that the creation of restaurants and cafeterias will bring new customers and visitors to the area and will benefit all existing businesses. Increasing the amount of pedestrians will also help to reduce crime and vandalism as well.

I strongly support this ordinance and hope the city approves it.

Thanks,

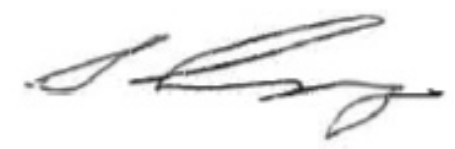

Fernando Camargo

London Motors

$2390 \mathrm{Nw} 2$ Ave

Miami, Fl 33127 


\section{ADRIANA FASHION}

2801 NW $5^{\mathrm{TH}}$ Avenue - Miami Florida 33127

July 17,2008

The Honorable Mayor, Commissioners, and City Manager of the City of Miami

3500 Pan American Drive

Miami, FL 33133

Re: Proposed Wynwood Ordinance - Wynwood Cafe District

To the City of Miami City Commission:

As a business owner in the Fashion District, I an well aware of the benefits and shortcomings of the Wynwood area. My business survives on return customers who come to the area for the sole purpose of visiting my store. They drive in and drive out, never staying in the area or visiting other businesses.

The Wynwood Café District will change the trend mentioned above. The establishment of cafés and restaurants will bring more visitors to the area, hence exposing more people to the stores in the Fashion District. The additional foot traffic will greatly cnhance our exposure and the sales of our goods. Further, as a business owner in the area, my biggest concern is the prevalent crime. I am confident that this ordinance will bring more people to the streets, thereby making a safer more energized environment.

As a business owner in this area for several years, plcase take my opinions into consideration. Please adopt this much needed ordinance, not only for the businesses, but for the greater good of this community.

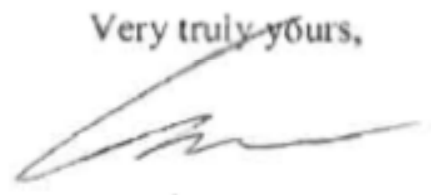

Edson Han

Adriana Fashion 


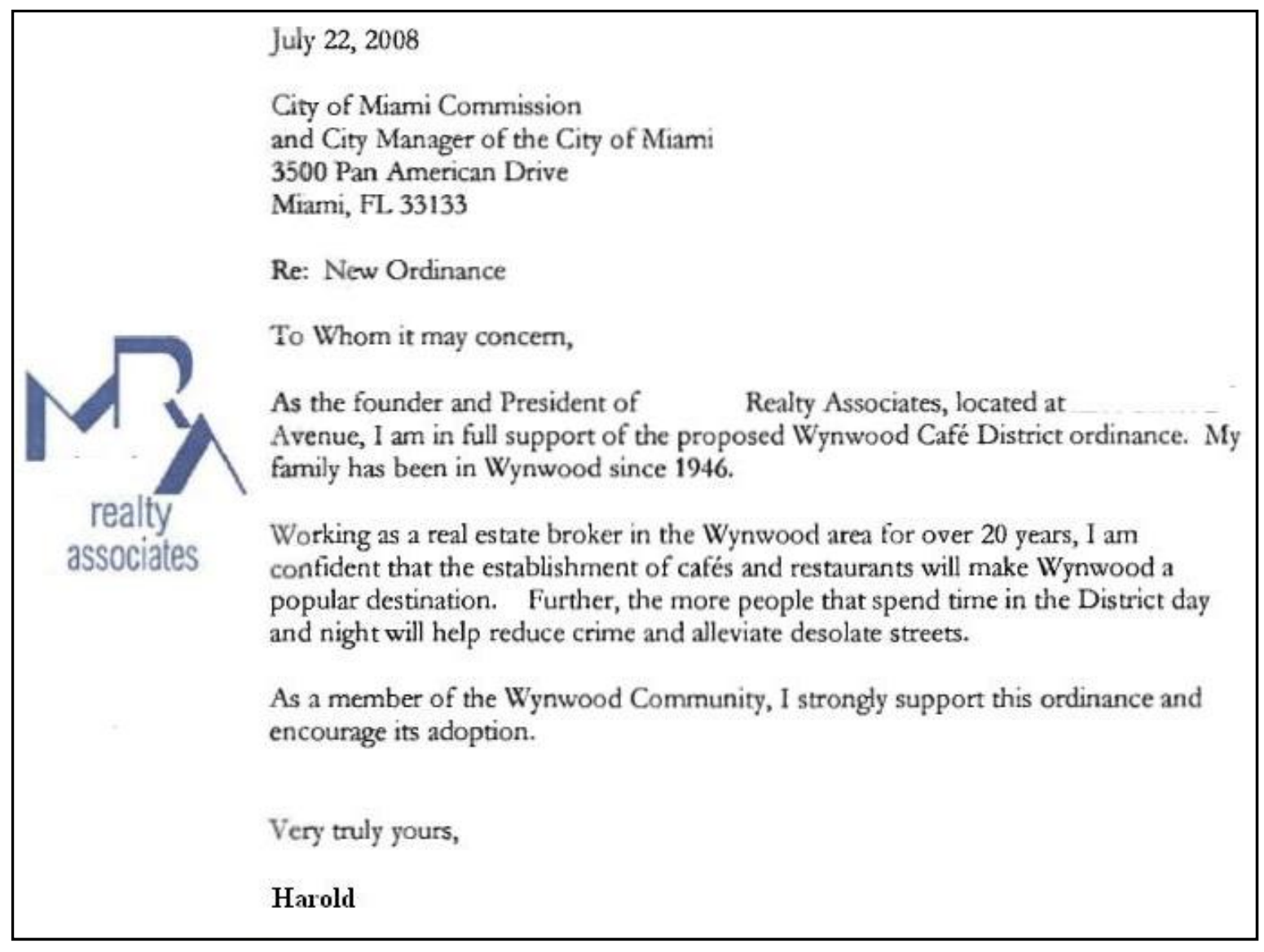




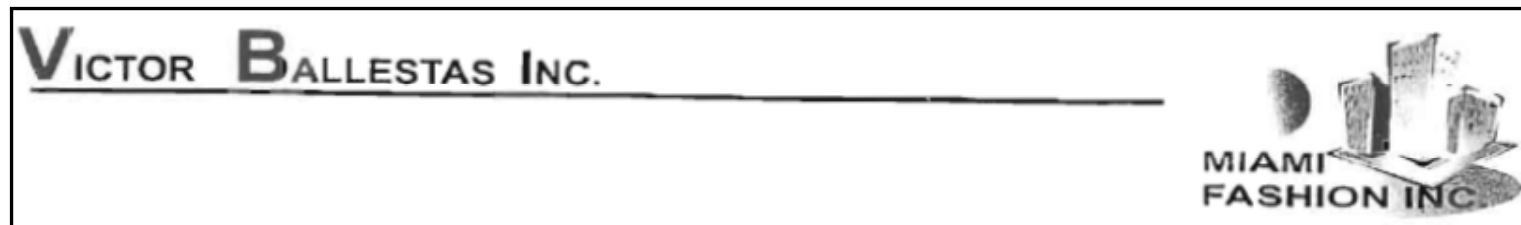

July 23, 2008

City of Miami commission

and City Manager of the city of Miami

3500 Pan American Drive

Miami, FL 33133

Re: New Ordinance

To Whom It May Concern,

As president of Miami Fashion Inc, located at 500 NW $24^{\text {th }}$ Street, I am in full support of the proposed Wynwood Cafe District ordinance.

In the past few years Wynwood has changed for the better. But, I think we are lacking of places to eat and enjoy leisure time. Please approve the ordinance in order to improve much more the area and reduce crime.

Very truly yours

Victor Bailestas

President 
am

2151 NW $3^{\text {rd }}$ Avenue Miami, Florida 33127

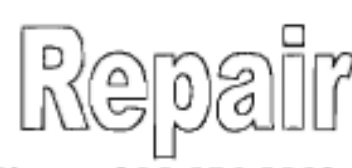

Phone: 3055768993

July 18,2008

City of Miami Commissioners

3500 Pan American Drive

Miami, FL 33133

Re: Wynwood Café District

To Whom It May Concern:

I have owned and operated my body shop business in Wynwood for many years and have seen how the area has changed for the better over the past few years. Unfortunately the area is still desolated most of the time since most businesses close early. Also there is no place to eat!

As a property and business owner I support this ordinance. Please approve this ordinance.

Thanks,

Harold Coqmard

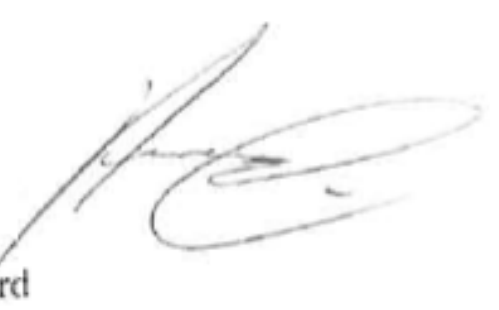

Owner 


\section{Better Products International Inc. 295 NW $27^{\text {th }}$ Street \\ Miami, FL 33127 USA}

Tel: 305-573-9361 Fax: 305-573-9360

July 23, 2008

City of Miami Commissioners

3500 Pan American Drive

Miami, FL 33133

Re: Wynwood Cafe District ordinance

To Whom It May Concern:

I have been doing the wholesale business in the Wynwood area for over 10 years, and often been asked " where is the place to eat" by my customers? Since there are no much choice in Wynwood, so the customers just leave the area and go somewhere to spend the money!

As a business owner I support this ordinance and encourage its adoption.

Sincerely;

Peter Hsu

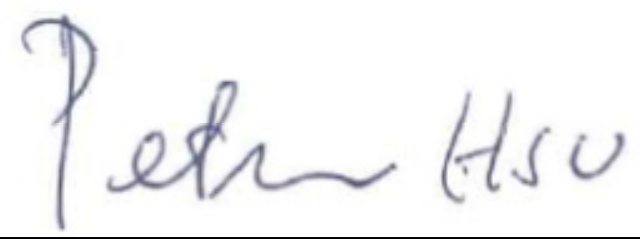


July 22,2008

City of Miami Commissioners

3500 Pan American Drive

Miami, FL 33133

New Ordinance

To whom it may concern,

As owner of Blandon Ornamental Iron, I will like to express my full support for the propose Wynwood Café District ordinance. I believe the area is in dire need for this type of business because it will bring life, traffic, jobs and safer streets. I sincerely believe this new ordinance is a win win for all.

Yours Truly

Raul Blandon 


\section{LAS TIAS \\ 2834 NN. Miami Ave. \\ Miami, $F[33127$}

City Of Miami Commission

July 23,2008

City Manager City of Miami

3500 Pan American Drive

Miami, Florida 33133

RE: $\quad$ Proposed New Ordinance for Wynwood District

Dear Commissioners and City Manager,

As the owner and President of Las Tias, located at 2834 North Miami Avenue, I am in full support for the proposed Wynwood Café District Ordinance. I have been a business owner as well as a property owner in the district for the past 4 years.

I am very confident that the establishment of cafes and restaurants will make the Wynwood District a much more popular and desirable destination. Further, the more people that spend time in the District will help reduce crime and alleviate desolate streets.

As a member of the Wynwood Community, I strongly support this ordinance and encourage its adoption.

Best regárds,

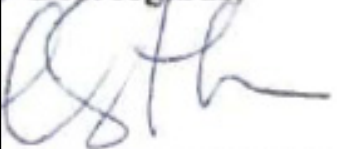

ES'THER PERCAL 
July 22.2008

City of Miami Commissioners

3500 Pan American Drive

Miami, FL 33133

Re: Wynwood Café District

To: Whom It May Concern:

I have owned and operated an Audio and Video Company in Wynwood for a couple of years and have seen how the area has changed for the better over the past few years. Unfortunately, the area is still desolated.

I am confident that the establishment of cafes and restaurants will make Wynwood a popular destination. Also, the more pop:lated the community is, the better community we will have.

As a property owner in the Wynwood community, 1 support this ordinance and encourage its adoption.

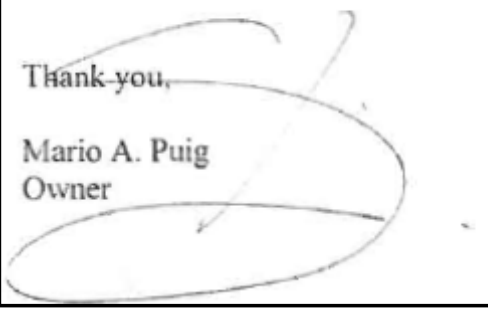




\section{P\&S Property Management INC \\ 560 N.W. $29^{\text {th }}$ St. Miami, FL. 33127}

July 23, 2008

City of Miami Commissioners

3500 Pan American Drive

Miami, FL 33133

Re: Wynwood Café District

To Whom It May Concern:

I have owned the above real estate and operated my shoe whole sale tusiness in Wynwood for many years and have seen how the area has changed for the better over the past few years. Unfortunately the area is still desolated most of the time since most businesses close early and 1 had closed my shoe whole sale business few months ago. Also there is no place eat!

As a property and business owner I support this ordinance. Please approve this ordinance.

Thanks,

P\&S Property Management LNC Owher 
VITA

\section{MARCOS FELDMAN}

2011

2006-2011

2009, February

2005, December

2004-2005

$2003-2004$

2002, December
Dissertation Year Fellow

Florida International University

Miami, Florida

Doctoral Candidate in Global and Sociocultural Studies

Florida International University

Miami, Florida

Research Associate, Research Institute on Social and

Economic Policy (RISEP)

Florida International University

Miami, Florida

Principal Investigator, Participatory Action Research, The impacts and implications of mobile home park redevelopment on residents and their communities. Sociological Initiatives Foundation, \$15,000.

M.A. Comparative Sociology

Florida International University

Miami, Florida

Research Assistant, Miami Workers Center

Miami, Florida

Teaching Assistant in Sociology and Anthropology

Florida International University

Miami, Florida

B.A. Sociology

University of Illinois

Urbana-Champaign, Illinois

\section{PUBLICATIONS AND PRESENTATIONS}

2011, July

2011, June
Feldman, M. and Jolivet, V. forthcoming, Eyes on Little Havana: Gentrification and the Securitization of Space in the Heart of Miami (under review, Political Geography).

Book Review of Cassanello, R. and Shell-Weiss, M. Eds. (2009) Florida's Working Class Past: Current Perspectives 
2011, March

2010, October

2010, March

2009, June

2008, April

2007, November

2007, March

2007, March on Labor, Race, and Gender from Spanish Florida to the New Immigration, in Labor Studies Journal, Vol. 36, No. 2.

Inter-Ethnic and Inter-Organizational Relations in a Gentrifying, Immigrant Gateway Neighborhood in Miami, Florida. Paper presented at the Urban Affairs Association annual meeting, New Orleans, LA.

'Eyes on the Street': Ethnicity, Class, and Surveillance by Neighborhood Organizations in Little Havana, Miami. Paper presented at Race, Ethnicity and Place conference of the American Geographical Society, Binghamton, NY.

Mobile Home Parks under Pressure of Redevelopment: A Participatory Survey Research Project. A research report of the Research Institute on Social and Economic Policy, Miami, FL.

The Miami Case of Urban Planning and Housing Policy. Presented with Alex Stepick at "Local Policy Responses on Integration: A Transatlantic Knowledge Transfer Project," sponsored by the German Marshall Fund and the Swiss Forum for Migration and Population Studies, Berne, Switzerland.

The growing divide: Income inequality and its effects on Florida's families, with Emily Eisenhauer, Bruce Nissen, and Yue Zhang. A research report of the Research Institute on Social and Economic Policy, Miami, FL.

Contingent urban neoliberalism: the attempt and failure of the Workforce Housing Ordinance in Miami-Dade County. Paper presented at American Anthropology Association annual meeting, Washington, D.C.

Neighborhood Organizing in Miami: The Importance of Latinos in the Struggle for the City. Paper presented at United Association for Labor Education annual meeting, National Labor College, Silver Springs, Maryland.

How are Displaced Scott-Carver Residents Faring? The Aftermath of HOPE VI Public Housing Redevelopment in Miami. A research report of the Research Institute on Social and Economic Policy, Miami, FL. 